Hans Lauge Hansen

\title{
Litterær erfaring og dialogisme
}

Museum Tusculanums Forlag Københavns Universitet [e-bog 2006] 
Litterar erfaring og dialogisme

e-bog

(C) Museum Tusculanums Forlag, 2006

ISBN-13: 978-87-635-0620-5

ISBN-10: 87-635-0620-3

Uændret gengivelse i PDF format af bogen:

Littercer erfaring og dialogisme

(C) Museum Tusculanums Forlag og forfatteren, 2005

Omslag: Pernille Sys Hansen

Forlagsredaktion: Julie Bjørchmar

Layout og sats: Forlagsbureauet / Ole Klitgaard

Sat med Sabon

Trykt hos Narayana Press, Gylling

isbn 87-635-0195-3

Udgivet med støtte fra

E. Lerager Larsens Fond

Landsdommer V. Gieses Legat

Forskningsrådet for Kultur og Kommunikation

Museum Tusculanums Forlag

Njalsgade 94

dk-2300 København S

www.mtp.dk 


\section{INDHOLDSFORTEGNELSE}

\section{INTRODUKTION 9}

\section{DEN SEMIOTISKE BAGGRUND I5}

Semiologi og semiotik I 5

Charles Peirces semiotik I 8

Peirces fænomenologi 20

Peirces tegnbegreb 2I

Semiotikkens discipliner og tegnets betydningsdimensioner 27

Begrebet 'grund' 30

Træstruktur eller rhizom 34

Semiosis som dialog 39

Mikhail Bakhtins tegnbegreb 44

Dialogismebegrebet hos Bakhtin 49

Jurij Lotmans begreb om tekstlig asymmetri 52

Jurij Lotmans semiosfærebegreb 55

Den litterære diskursorden 58

Faircloughs interdiskursivitetsbegreb 60

Litteratur som imaginær erfaringsdannelse 6I

\section{SUBJEKT OG ERFARING 65}

Charles Peirce: subjektet som tegn 66

Subjektets selvrefleksion 72

Narrativ identitet hos Paul Ricœur og Jerome Bruner 76

Narrativ identitet hos Bruner 80

Kritik af de narrative identitetsteorier $8 \mathrm{I}$

Subjektet hos Bakhtin 83

Subjektet hos Lotman 87

Psykostrukturen som tegn 89

Kritikken af psykosemiotikken: det radikalt decentrerede subjekt 92

Det dialogiske subjekt 93

Det kulturelle subjekt IO2

Subjektets imaginære erfaringsdannelse 107 
III. ÆSTETISK ERFARINGSDANNELSE

I LITTERÆRE TEKSTER II9

Læseprocessen som semiotisk proces I2 I

Tekstens æstetiske strategi I 22

Den umiddelbare interpretant I 29

Begrebet om det æstetiske hos Peirce I30

Den emotionelle, energetiske og logiske interpretant I34

Den æstetiske erfaring i læseprocessen I $42^{2}$

Det morfosyntaktiske niveau: Roman Jakobsons parallelismer I43

Pablo Nerudas »Digt nummer tyve " I46

Kærlighed og erindring I47

Den selvreferentielle læsning I49

Sangens semiotik I 52

Det semantiske niveau: Paul Ricœur og Paul Henle: metaforen I 53

Rafael Albertis »Togstation Syd « I 59

Det pragmatiske niveau: Bakhtins polyfoni, kronotop

og intertekstualitet I64

Dialogen mellem 'autor' og fiktiv person: polyfoni 165

Tekstens traditionsrelaterede dialog med de genrebestemte

kronotoper 168

Tekstens intertekstuelle dialog med andre tekster I7I

Manuel Vázquez Montalbáns »El premio « I77

Tekstens stemmer I79

Urskovskronotop og krimigenre i 8 I

Den intertekstuelle dialog med litteraturteorien I 86

Æstetiske træk ved den umiddelbare interpretant $\mathrm{I} 88$

\section{ETISK ERFARINGSDANNELSE I LITTERATUR 193}

Fiktion mellem indekser og objekter I94

Tekstens designative referencer 197

Udfyldningen af tekstens tomme pladser 198

Præfiguration, konfiguration og refiguration 204

Talen som 'ideologeme' og læserens etiske ansvarlighed 2I3

Teksten som erindring, aktualiseret ikon og model til selvforståelse 222

Referencen i dialogisk forståelse 226

Antonio Muñoz Molinas »Sefarad « 233

Tekstens stemmer som ideologemer 234

Fiktion, historie og opfattelsen af Europa 237

Læserens ansvarlighed og teksten som etisk erfaring 24I 


\section{LITTERATUR OG LOGISK ERFARINGSDANNELSE 245}

Fra individuel læsning til litterær offentlighed 246

Kanon og kulturel selvrefleksion 249

Litteratur og videnskabelig erkendelse 255

Kriterier for videnskabelighed 26I

Metafiktion som diskursregulerende selvreference 267

Selvreferencen og det æstetiske 27I Jorge Luís Borges' fortællinger 274

Fiktion og selvreference 277

Cervantes' "Don Quijote" 278

Dannelse: teksten som model i læserens identitetskonstruktion 283

Antonio Muñoz Molinas »Beltenebros« 284

VI. GLOBALISERING, FREMMEDSPROG OG LITTERATUR 293

Globalisering af semiosfæren 294

Krisen på fremmedsprogsstudierne 302

Sprogfagenes selvforståelse og videnskabelige paradigmer 305

Litteraturstudierne på fremmedsprogene 3 I I

Humanioras interkulturelle udfordring 3 I 4

Opgøret med tekstens autonomi og 'metodegørelsen'

af kontekstrelationen 3 I 8

Faglighed og tværfaglighed 320

VII. LITTERATURLISTE 323 
Copyright (C) Museum Tusculanums Forlag 2006

Til Birgit og Tais

Litterær erfaring og dialogisme, E-bog 2006

ISBN-13: 9788763506205

ISBN-10: 87-635-0620-3 


\section{INTRODUKTION}

Hvorfor læser vi litteratur, og hvordan kan vi beskrive de erfaringer, som udspringer af den litterære praksis? Hvad er det vi kan lære af de litterære tekster, og hvorfor er det nu lige at litteraturen står så centralt placeret på en række humanistiske fag, ikke mindst på fremmedsprogsfagene, som udgør min egen 'hjemmebane'? Sådanne fundamentale spørgsmål har været styrende for arbejdet med denne bog, og selv om de på ingen måde kan siges at være nye for litteraturteorien, er det min overbevisning at det konkrete udgangspunkt, som denne bog tager såvel teoretisk som praktisk, gør, at både spørgsmål og svar stilles og gives på en anderledes måde end det ofte sker.

Bogens praktiske udgangspunkt har at gøre med, at jeg de sidste fem til seks år været optaget af de moderne fremmedsprogs aktuelle krise og fremtidige udvikling. Fremmedsprogsstudierne er, såvel i Danmark som i udlandet, ramt af en krise, der omfatter såvel optag, økonomi og selvforståelse, idet det traditionelle filologiske videnskabsparadigme, der lå til grund for deres etablering i starten af det tyvende århundrede, har mistet sin legitimitet. Denne krise er lige så uheldig som den er paradoksal, al den stund den øgede globalisering stiller krav om et øget beredskab af fremmedsproglige kompetencer bredt i vores samfund. Som repræsentant for de moderne fremmedsprog i Det Humanistiske Fakultetsråd på Københavns Universitet har jeg forsøgt tage dette problem op til behandling i forskellige sammenhænge. Jeg har således arrangeret konferencen Changing Philologies i samarbejde med Danmarks Humanistiske Forskningscenter i februar 2002 (bogudgivelse på Museum Tusculanums Forlag, august 2002), jeg har fungeret som leder af 'Sprogfagenes Identitetsprojekt 200I-2002' (Hvidbogen for de moderne fremmedsprog udkom på Romansk Institut, KU, 2002) og jeg har fungeret som netværkskoordinator for Sprog- og Kulturnetvarket, der i perioden 20022004 samlede omkring Ioo forskere fra fremmedsprogsuddannelserne ved de højere læreanstalter i Danmark. Et resultat af dette arbejde foreligger bl.a. med bogen Disciplines and Interdisciplinarity in Foreign Language Studies, der udkom i august 2004 på Museum Tusculanums Forlag.

I diskussionen af sprogfagenes fremtid har jeg selv arbejdet for at styrke en tværfaglig og kulturteoretisk tilgang til studiet af sprog, historie og litteratur, som kan etablere vores institutionelle enheder omkring et fælles studieobjekt, teksten. Personligt har jeg forfægtet en strategi for fremmedsprogene, som består i at redefinere det filologiske videnskabsparadigme i retning af det vi har kaldt en 'ny kulturfilologi' - en tværfagligt baseret tilgang til studiet af sprog, historie og litteratur, der tager kulturstudierne 
som deres fælles omdrejningspunkt. Dette skift muliggøres af tre 'vendinger' som har præget humanvidenskaberne i de sidste IO-I 5 år: den pragmatiske vending inden for sprogvidenskaben, den kulturelle vending inden for litteraturvidenskaben og den sproglige vending inden for historie- og kulturforskningen. I mit eget bidrag til Changing Philologies har jeg udlagt dette som et samlet epistemologisk skift i retning af en dialogisk baseret forståelse af forholdet mellem sprog, viden og verden.

Det er imidlertid vigtigt, at arbejdet med at gentænke grundlaget for fremmedsprogsfagene i lyset af den globaliserede senmodernisme ikke kun bliver ført på et overordnet niveau, men også bliver taget op så at sige 'indefra' i hver af vores discipliner (litteratur, sprogvidenskab, historie osv.), hvor vi ud fra en diskussion af egen faglighed kan sikre os faglig og saglig grund under fødderne. Personligt mener jeg, at den pragmatiskfunktionelle tilgang til litteraturstudierne giver et interessant bud på hvorfor den æstetiske dimension ikke står i modsætning til en kulturanalytisk orienteret litteraturbeskæftigelse, men tværtimod snarere danner forudsætning herfor.

Bogens teoretiske udgangspunkt består således $\mathrm{i}$ at anlægge en dialogisk-semiotisk tilgang til litteraturstudiet, og i den forbindelse har jeg især interesseret mig for de mulige forbindelseslinjer mellem den amerikanske filosof Charles Sanders Peirce (I839-I9I4) og den russiske litteraturkritiker Mikhail Mikhajlovitj Bakhtin (I895-I975). Indskrivningen af kendte og anerkendte litteraturteoretiske erkendelser i en dialogisksemiotisk kontekst åbner muligheden for at anlægge en reelt tværfaglig tilgang til litteraturstudierne, som bryder med dogmet om den autonome tekst, der sammenkæder studiet af litteraturen med forståelsen af kultur og historie, og som samtidig arbejder bevidst med det sprog, hvoraf litteraturen udspringer. Forstået inden for en Peirce-semiotisk ramme vil læserens æstetiske erfaring danne forudsætning for den etiske erfaring, som igen udgør forudsætningen for den logiske erfaringsdannelse. Det har imidlertid hele tiden været vigtigt for mig at understrege, at bestræbelsen på at redefinere sprogfagenes epistemologiske grundlag ikke skal forstås som et felttog hverken for eller imod bestemte teoretiske retninger, men tværtimod skal begribes som et åbent felt af forskellige teoretiske tilgange, der kan reetablere en frugtbar tværfaglighed på fremmedsprogsstudierne, og som kan etablere vores institutionelle enheder omkring et fælles studieobjekt.

Brugen af en Peirce-inspireret semiotik i studiet af litteratur er ikke i sig selv noget nyt, om end det heller ikke er et område som har fundet et stabilt ståsted $\mathrm{i}$ form af et etableret forskningsfællesskab. Folk som Michael C. Haley, John K. Sheriff og Victorino Tejera har givet endog 
meget forskellige bud på hvordan en Peirce-orienteret semiotisk teori kan anvendes på studiet af litteratur, og mit bud adskiller sig fra alle disse indbyrdes forskellige behandlinger på flere måder. John K. Sheriff har i sin bog The Fate of Meaning (1989) beskæftiget sig med forholdet mellem den litterære reception og litteraturvidenskaben, hvilket også tages op af Victorino Tejera, men ellers beskæftiger alle de nævnte bidrag sig udelukkende med studiet af teksten og dens umiddelbare reception. Heroverfor har jeg haft en ambition om at se på hele den litterære praksis fra forfatterens kreationsproces over læserens reception til kritikkens videnskabelige behandling, hvorved jeg adskiller mig fra alle de tre nævnte. Jørgen Dines Johansen har med sin Literary Discourse (2002) givet et seriøst bud på et autoritativt værk, der kan markere et udgangspunkt for et forskningsfællesskab som anlægger et bredt analytisk blik på hele den litterære praksis, og Dines Johansens grundlæggende forståelse af Peirces dialogiske semiotik og den litterære diskurs ligger da også til grund for denne bog. Til gengæld adskiller mit bidrag sig fra Dines Johansen i kraft af et teoretisk fokus, der i stedet for at sammenkæde semiotikken og psykoanalysen forsøger at sammentænke Peirces pragmatisme med Paul Ricœurs hermeneutik, med Mikhail Bakhtins sprogfilosofi og med Jurij Lotmans kultursemiotik. Koblingen til Bakhtin er tidligere behandlet af Augusto Ponzio, men hovedsageligt i en rent sprogfilosofisk og ikke specifikt litterær kontekst.

Bogen indledes med en introduktion til den almene semiotiske teori, hvor der lægges vægt på at diskutere det dialogiske princip hos primært Charles Peirce, men med vigtige sideblik til hhv. Bakhtin og Jurij Lotman. Der introduceres til tegnbegrebet og niveauet er i det hele taget intenderet således, at alle med en humanistisk basisviden og en interesse for emnet skal kunne være med. Afsnittet afsluttes med kort at berøre litteraturens funktioner som selvstændig diskurs.

Kapitel II, Subjekt og erfaring, tager fat på spørgsmålet om hvordan vi kan begribe det subjekt, som udgør grunden for den litterære erfaringsdannelse. Subjektsbegrebet gennemgås igen primært ud fra Peirce, men med vigtige sideblik til Bakhtin, Paul Ricœur og Jurij Lotman. Sigtet er at etablere rammerne for en forståelse af subjektet som en dialogisk og narrativ størrelse, hvilket vil tillade at foretage en semiotisk beskrivelse af erfaringsdannelsen, herunder erfaringsdannelsen i de imaginære erfaringsprocesser som sættes i gang af litteraturen.

Kapitel III, Æstetisk erfaringsdannelse i litteratur, er det første af tre kapitler der behandler den imaginære erfaringsdannelse i litteratur ud fra Peirces opdeling af de normative videnskaber i en æstetisk, en etisk og en logisk beskrivelse. Den semiotiske beskrivelse af den æstetiske erfarings- 
dannelse udlægges som en dialogisk relation imellem emotionelle, hændelsesmæssige (energetiske) og logiske interpretanter, og denne overordnede beskrivelse udmøntes i en gennemgang af bl.a. Roman Jakobsons parallelismer (morfosyntaks), Paul Ricœurs begreb om den levende metafor (semantik) og Bakhtins dialogisme og polyfoni-begreb (pragmatik). Der er ikke tale om en egentligt receptionsæstetisk tilgang, der ville være henvist til at arbejde med empiriske læserundersøgelser - i stedet baserer afsnittet sig på Umberto Ecos forestilling om at enhver tekst har en indskrevet tekstlig 'strategi'. Tekstens betydning bliver herefter at forstå som et betydningspotentiale, der skal realiseres i læseprocessen i overensstemmelse med de indskrevne strategiske forudsætninger (hos Peirce den umiddelbare interpretant). Hvert af underafsnittene (Jakobson, Ricœur og Bakhtin) følges op med en eksemplificerende analyse og afsluttes med nogle overvejelser over de æstetiske momenter i den narrative subjektskonstruktion.

Kapitel IV, Etisk erfaringsdannelse i litteratur, ser på hvordan den konkrete læser tilegner sig teksten og bruger den som model for at forstå sig selv og sin egen livsverden bedre. Hvor den æstetiske erfaringsdannelse bliver studeret som et betydningspotentiale i teksten, dér skal den konkrete læsehandling forstås som en hændelse, hvorigennem teksten opnår en reference til en omverden. Tekstens reference udgør et komplekst problem for litteraturkritikken, al den stund det både involverer spørgsmålet om hvordan og i hvilket omfang teksten kan læses som havende en potentiel reference til dens oprindelige kulturelle og historiske kontekst, og spørgsmålet om hvordan læseren tilegner sig teksten som havende en reference til hans eller hendes egen livsverden. Først igennem den hermeneutiske tilegnelse, hvor en konkret læser tilskriver teksten en personligt tilegnet 'mening', tilskrives teksten en etisk betydningsdimension. Udgangspunktet for beskrivelsen af det hermeneutiske problemkompleks findes hos Paul Ricœur, hvis begreber om konfiguration og refiguration fra Temps et récit (I983-85) relateres til Peirces betydningsniveauer for den umiddelbare og den dynamiske interpretant. Igen finder vi altså den litterære erfaring udmøntet i en dialogisk relation, denne gang mellem teksten som strategisk tilrettelagt potentiale (den umiddelbare interpretant) og som aktualiseret reference (den dynamiske interpretant). I beskrivelsen af læserens aktive deltagelse i konstruktionen af det fiktive univers trækkes på Wolfgang Isers virkningsæstetik, og i beskrivelsen af læserens brug af teksten som model til forståelse af sin livsverden trækkes på Jurij Lotmans kultursemiotik. Kapitlet afsluttes med en eksemplarisk læsning af den spanske forfatter Antonio Muñoz Molinas roman Sefarad. 
Som det måtte være fremgået kombinerer jeg bogens eksplicitte kompositionsprincip for kapitlerne III-V, dvs. gennemgangen af den æstetiske, etiske og logiske erfaringsdannelse i den litterære praksis, med tre forskellige epistemologiske betydningsniveauer, som Peirce har beskrevet med begreberne den umiddelbare, den dynamiske og den finale interpretant. I den forbindelse vil jeg understrege, at denne kombination er et valg jeg har truffet, og ikke en logik som teorien sætter. Jeg har således valgt hovedsageligt at behandle gennemgangen af æstetikken med udgangspunkt i teksterne som et betydningspotentiale i sig selv - et epistemologisk betydningsniveau der svarer til Peirces umiddelbare interpretant, og i gennemgangen af den etiske erfaringsdannelse har jeg valgt at knytte an til diskussionen af teksternes reference til en livsverden i den konkrete læsning - et betydningsniveau, hvor Peirce taler om dynamiske interpretanter. Med denne kombination af to forskellige struktureringsprincipper kan man sige at jeg bevidst gør vold på teorien i fremstillingslogikkens interesse. Der er naturligvis altid tale om såvel en æstetisk, en etisk som en logisk betydningsdimension på alle tre interpretantniveauer, men en sådan gennemgang ville have resulteret $\mathrm{i}$ en meget omstændelig struktur og en tre gange så lang tekst. Den valgte opbygning af bogen ville imidlertid ikke have kunnet lade sig gøre, hvis jeg f.eks. havde valgt at behandle teksternes æstetiske karakter ud fra en empirisk baseret receptionsæstetik, eller teksternes etiske betydningspotentiale ud fra en immanent tekststrategisk synsvinkel. I Peirces terminologi ville disse tilgange omhandle æstetisk betydningsdannelse på niveauet for den dynamiske interpretant og etisk betydningsdannelse på niveauet for den umiddelbare interpretant.

Hvad angår bogens Kapitel V, Litteratur og logisk erfaringsdannelse, betyder valget af denne fremgangsmåde, at behandlingen af den logiske erfaringsdannelse i den litterære proces kombineres med det betydningsniveau som Peirce karakteriserer som den finale interpretant. Den finale interpretant skal forstås som et grænsebegreb, en tendens som sociale fællesskaber tenderer mod at etablere som en vane i Peirces forstand, og som forskningsfællesskaber ligefrem stræber efter at etablere. Den finale interpretant nås aldrig $\mathrm{i}$ ultimativ forstand, men er reelt og virkeligt til stede i den måde vi etablerer intersubjektive 'vaner' på i den litterære praksis. Tendensen til at etablere finale, logiske interpretanter i den litterære praksis behandles ud fra tre forskellige aspekter: de konkrete læseres dialog med den dagsaktuelle offentlighed om det som de har læst, udkrystalliseringen af et sæt af paradigmatiske værker over tid i en form for kanon samt denne kanons inddragelse i de sociale institutioner og endelig litteraturkritikkens etablering af et forskningsfællesskab baseret 
på videnskabelige kriterier og traditioner. Efter ganske summarisk at have berørt hvert af disse niveauer, afsluttes kapitlet med en behandling af den litterære diskursordens tematisering af sin specifikke egenart i form af metafiktionen. Begrebet metafiktion udlægges som en diskursregulerende selvreference. Ligesom alle andre diskurser indeholder den litterære diskursorden et selvrefleksivt element, ja måske er den litterære diskurs det diskursive register hvori selvrefleksionen er klarest og stærkest markeret. Dette skyldes dels litteraturens generelle funktion, som jo til dels netop er at reflektere over såvel individuelle som kollektive subjekters betingelser for at være eller blive subjekter, dels skyldes det at litterære tekster er æstetiske objekter, som i høj grad selv kaster opmærksomheden tilbage på deres egen form. Teorien om metafiktionen som diskursregulerende selvreference søges illustreret gennem læsningen af tre litterære tekster af hhv. Jorge Luis Borges, Miguel de Cervantes og Antonio Muñoz Molina.

Bogen afsluttes med et sidste kapitel, Globalisering, fremmedsprog og litteratur, hvor jeg præsenterer nogle overvejelser over fremmedsprogsstudiernes nuværende situation i vadestedet mellem det traditionelle filologiske videnskabsparadigme og et nyt kulturvidenskabeligt eller interkulturelt paradigme samt litteraturfagets placering i den forbindelse.

Afslutningsvis vil jeg gerne takke lektor Steen Jansen fra Romansk Institut ved Københavns Universitet, lektor Anne Magnussen fra Institut for Historie og Kultur ved Syddansk Universitet samt min kone, lektor Birgit Eriksson på Center for Æstetik og Kultur ved Århus Universitet, for gode diskussioner og værdifulde kommentarer. 


\section{DEN SEMIOTISKE BAGGRUND}

\section{Semiologi og semiotik}

Semiologi og semiotik betyder begge dele noget i retning af 'studiet af tegn'. Menneskets optagethed af tegnene går helt tilbage til før antikken, men især med det 20 . århundredes indsigt i sprogets centrale betydning for den menneskelige erkendelse har semiologien eller semiotikken udviklet sig til en af de centrale videnskabelige discipliner, naturligvis først og fremmest inden for humaniora, men i stigende grad også inden for andre videnskabelige grene såsom socialvidenskab, naturvidenskab og medicin. Begreberne semiologi og semiotik anvendes desværre ofte uden skelnen mellem de forskelle som eksisterer mellem de to forskellige hovedretninger, som har præget udviklingen af moderne videnskabsteori inden for human- og samfundsvidenskaberne i det 20 . århundrede: Ferdinand de Saussures (I857-I9I3) sémiologie og den amerikanske filosof Charles S. Peirces ( I 839-I9I4) semeiotics. Desværre, fordi den manglende skelnen kommer til at underbetone de store forskelle der i virkeligheden er tale om. Peirces semiotik tager afsæt i en tradition som går helt tilbage til antikken, og som udvikler sig gennem store europæiske tænkere som John Locke, Johann Heinrich Lambert, Jospeh Wronski og Bernhard Bolzano. Heroverfor lader det til, at Saussure slet ikke kender denne tradition, men selv sætter sig som mål så at sige at opfinde sin egen semiologi (Jakobson I979, I 24). Hvor Peirce i overensstemmelse med traditionen tager udgangspunkt i filosofien og fænomenologien, dér tager Saussure udgangspunkt i studiet af sproget. Hvor Peirce studerer sproget i dets sociale interaktion, $\mathrm{og}$ forstår den symbolske betydning som en betydning der vokser frem igennem vaner - dvs. gennem iterativ brug over tid - der sætter Saussure sig for at studere sproget som en kode - dvs. et synkront og arbitrært sæt af regler. For Peirce bliver studiet af sproget blot et element blandt andre i beskrivelsen af både naturens og menneskenes brug af tegn, 'semiosis', og derfor er Peirces semiotik bredere orienteret, og bedre udrustet til at studere andre typer af semiosis end den rent logisksproglige, f.eks. billeder, film eller historiske begivenheder, og dermed er den også bedre egnet til at beskrive samspillet mellem sådanne fænomener og sproglige tekster.

En af Saussures vigtigste landvindinger, som førte til oprettelsen af den moderne lingvistik som en videnskab, bestod $\mathrm{i}$ at indføre en skelnen imellem 'diakron' og 'synkron' sprogvidenskab. Indtil Saussures banebrydende forelæsninger i starten af forrige århundrede havde den videnskabe- 
lige beskæftigelse med sprog først og fremmest bestået i studier af sprogets historiske udvikling (diakroni). Den opgave, som Saussure stillede sig selv og den moderne lingvistik, var at give et bud på hvordan man kunne beskrive ét sprogs særlige egenart på et givet tidspunkt. Over for den traditionelle sproghistorie insisterede Saussure altså på en synkron og komparativ sprogvidenskab.

Inden for den synkrone sprogvidenskab skelnede Saussure imellem to forskellige aspekter af sproget, som han kaldte hhv. sprogsystemet ('langue') og sprogbrugen ('parole'). Sprogsystemet er den række fastlagte koder, der giver sproget dets konstante betydning, f.eks. ordenes betydning, samt forskellige grammatiske regler for hvordan ord kan føjes sammen til sætninger. Sprogsystemet sikrer således, at vi overhovedet kan forstå hinanden når vi taler sammen, og at vi også kan forstå det, som historien har overleveret os i form af tekster. Heroverfor definerer Saussure sprogbrugen som de konkrete og enkeltstående ytringer, som vi bruger når vi kommunikerer med hinanden: samtaler, avisartikler, litterære tekster osv. osv.

Der er for Saussure tale om et vekselvirkningsforhold mellem disse to aspekter af sproget, idet sprogsystemet hele tiden bliver modificeret og fornyet igennem sprogbrugen, men den egentlige, videnskabelige beskæftigelse med sproget må, ifølge Saussure, tage udgangspunkt i en beskrivelse af sprogsystemet. De strukturalistiske arvtagere til Saussures tænkning, som f.eks. den danske lingvist Louis Hjelmslev, mente ligefrem at sprogbrugen var alt for kaotisk og vilkårlig til at kunne danne basis for en videnskabelig beskrivelse. Derfor har den strukturelle forskningstradition efter Saussure først og fremmest udviklet sig som et studium af sprogsystemet.

Heroverfor tager Peirces semiotik udgangspunkt i studiet af hvordan tegn bruges til at kommunikere med, altså det som Saussure betegnede som sprogbrugen. For Peirce indgår alle tegn, når de bruges til at kommunikere med, i dialogiske relationer med andre tegn. Vi kommunikerer nemlig altid ind i en sammenhæng, en kontekst, som i forvejen er ladet med betydning, med andre tegn. Hver gang vi siger eller skriver noget, siger eller skriver vi op imod noget, som har været sagt, skrevet eller i det mindste ment før. På den måde produceres tegn og tekster altid på baggrund af andre tegn og andre tekster, og de retter sig altid frem imod deres egen fortolkning.

De to forskellige teoretiske udgangspunkter resulterer i to forskellige definitioner af hvad et tegn er. Saussure forstår et 'tegn' som en konventionel enhed af en lydlig figur (signifiant) og et idémæssigt indhold (signifié), hvorfor studiet af tegnene ofte kommer til at koncentrere sig om 
de koder eller konventioner som knytter indholdet til udtrykket. Heroverfor definerer Peirce et 'tegn' som en treleddet relation imellem en tegnbærer (reprasentamen), det som tegnet henviser til (object) og tegnets fortolkning i form af et nyt tegn (interpretant). Denne tegndefinition lægger mere op til at studere den proces, hvorigennem tegnet tilskrives sin betydning. Det skal vi vende tilbage til nedenfor. Det vigtige på dette sted er blot at betone, at disse grundlæggende forskelle i opfattelsen af hvad et tegn er, også sætter sig igennem i den praktiske anvendelse af teorierne, f.eks. inden for litteraturvidenskaben. Hvor strukturalismen typisk ville lede efter nogle faste betydningsstrukturer i afgrænsede og udvalgte samlinger af tekster (f.eks. et værk, et forfatterskab, en periode, en genre), dér vil en Peirce-orienteret semiotik typisk fokusere på samspillet mellem teksten og dens fortolkning i en bestemt kontekst.

De to semiotiske traditioner har haft en vidt forskelig receptionshistorie i det tyvende århundredes europæiske åndsliv. Saussures tegnbegreb kom i første omgang til at ligge til grund for den strukturalistiske tilgang til så vidt forskelige områder som lingvistik, litteraturvidenskab og antropologi (f.eks. Hjelmslev, Greimas, Barthes og Lévi-Strauss), og siden blev den et 'negativt' forlæg for diverse poststrukturalistiske retninger (f.eks. Foucault, Lacan, Derrida, Barthes). Således mener jeg, at en stor del af den poststrukturalistiske fokuseren på tekstlige fraværserfaringer og dekonstruktion af stabile betydningsindhold kan tilbageføres til problemet med at anvende et af Saussure afledt tegnbegreb, konstrueret med henblik på analyse af langue, på tekster i deres funktion af parole. Peirces pragmatisk orienterede tegnbegreb, konstrueret med henblik på studiet af tekster i deres funktion som sprogbrug, blev derimod hovedsageligt kendt i en europæisk kontekst gennem Charles Morris' forenklede pragmatik samt gennem Roman Jakobsons forsøg på at sammentænke de to sprogfilosofier. En lignende bestræbelse finder vi hos Umberto Eco, der med Lector en fábula og The Role of the Reader er en af dem, som i høj grad sætter Peirces semiotik til diskussion i en europæisk sammenhæng. Men det er først fra engang i firserne og frem at interessen for Peirce for alvor begynder at brede sig herhjemme, samtidig med at også Mikhail Bakhtin og Jurij Lotman bliver navne, der samler en stadig større interesse omkring sig. Det er derfor min hypotese, at mange af de spørgsmål af både tekstanalytisk, fortolkningsmæssig og kulturkritisk karakter, som har været gjort til genstand for den poststrukturalistiske metafysik, med fordel kan gentænkes inden for rammerne af en pragmatisk og funktionel semiotik.

En lignende bestræbelse på at udvikle en realistisk, funktionel og dynamisk semiotik har inden for de seneste årtier udviklet sig i spændingsfeltet mellem den kognitive lingvistik og René Thom samt Jean Petitots 
katastrofeteori. ${ }^{1}$ I en dansk sammenhæng udgør Center for Semiotik ved Århus Universitet, med Per Aage Brandt som hovedfigur, det centrale knudepunkt for denne udvikling. På trods af høj grad af sammenfald i bestræbelsen på at bryde med strukturalismens forestilling om tegnets immanente betydning og at udvikle semiotikken som et studium af betydningstilskrivelsen som en dynamisk proces, har jeg valgt ikke i videre omfang at inddrage denne retning, for klarere at kunne fokusere på aksen Peirce, Bakhtin og Lotman.

\section{Charles Peirces semiotik}

Som naturvidenskabsmand studerede Peirce tegnene som en del af en mere generel videnskabsteori. Han problematiserede empirismen, som dominerede hans tid, altså opfattelsen af at 'sandheden' kan afledes direkte af vores umiddelbare registreringer af forhold i verden, fordi han indså, at mennesket aldrig har en direkte og uformidlet adgang til virkeligheden. Vores forhold til verden er filtreret igennem den måde hvorpå vi ser og forstår verden, og derfor er det påvirket af de forventninger som udspringer af vores personlige og kulturelle horisont. Og for Peirce var semiotikken en integreret del af et mere omfattende videnskabsteoretisk paradigme, som kortfattet kan illustreres med nedenstående diagram:

Ikke-normative videnskaber:

- Matematik

- Fænomenologi

i. Firstness (CP I.302-32I $)^{2}$

ii. Secondness (CP I.322-336)

iii. Thirdness (CP I.337-49)

Normative videnskaber:

i. Æstetik (CP 5.I29)

ii. Etik (CP 5.I29)

iii. Semiotik / Logik (CP 5.I29)

\footnotetext{
${ }^{1}$ I antologien Kognitiv semiotik finder man en glimrende introduktion til denne særlige retning inden for semiotikken: Bundgaard, Egholm og Skov (red.), 2003.

${ }^{2}$ I referencerne til Peirces Collected Papers anvender jeg den annotation som er blevet alment accepteret inden for Peirceforskningen, hvor CP henviser til Collected Papers, tallet før punktum til bindet og tallet efter punktum til paragraffen. Citaterne fra Collected Papers er citeret efter den elektroniske version redigeret af Charles Hartshorne, Paul Weiss og Arthur Burks og udgivet af Harvard University Press. Dog har jeg tilladt mig at foretage en standardisering af Peirces mange forskellige typer fremhævelser (versaler, fed, understregning, kursiv osv.), som alle er blevet til kursiv.
} 
I. Tegnet i sig selv. Pure grammar eller morfo-syntaks ${ }^{3}$

a. Kvalitegn / tone (CP 4.537)

b. Sin-tegn / token (- " -)

c. Legi-tegn / type (- " -)

2. Tegn og objekt. Logic proper eller semantik
a. Ikon
b. Indeks
c. Symbol

3. Tegn og interpretant. Pure rhetoric eller pragmatik

a. Rhem / term (CP 2.250)

b. Dicent sign / proposition (CP 2.25I)

c. Argument /argument (CP 2.252)

i. Abduktion / hypotese (CP 2.270)

ii. Induktion (CP 2.269)

iii. Deduktion (CP 2.267)

Peirce skelner mellem de normative og de ikke-normative videnskaber ud fra forståelsen af begrebet norm »in the sense of a pattern which is copied « (CP I.586). Der er altså ikke tale om normativitet forstået som en forskrift eller lignende, men blot det at de normative videnskaber beskæftiger sig med beskrivelsen af en vane- eller mønsterdannelse gennem iterativ forekomst over tid. Med Peirces egne ord drejer de normative videnskaber sig om $»$ the science of the laws of conformity of things to ends « (CP 5.I29). Heroverfor består de ikke-normative videnskaber af matematikken, der handler om udarbejdelse og observation af rent imaginære konstrukter, og fænomenologien, eller 'faneroskopien' som Peirce kalder den, der beskæftiger sig med studiet af alt det, som præsenterer sig for the mind. De normative videnskaber er beskæftiget med » the laws of conformity of things to ends « (CP 5.I 29), og disse ends kan nu varieres i forhold til deres fænomenologiske karakter. Æstetikken beskæftiger sig således med at studere "those things whose ends are to embody qualities of feeling " (CP 5.I29), etikken tager sig af studiet af »those things whose end lie in action« (CP 5.I 29), mens logikken, eller

\footnotetext{
${ }^{3}$ I stedet for Peirces betegnelser pure grammar, logic proper og pure rhetoric foreslår jeg at bruge betegnelserne morfosyntaks, semantik og pragmatik. Jeg er heri inspireret af Charles Morris' terminologi, som er langt mere udbredt end Peirces, selv om dennes tænkning ligger til grund. Morris skelner mellem syntactics, semantics og pragmatics, men da studiet af tegnet i sig selv både må indeholde undersøgelsen af formdannelse og kombinatorik, vil jeg foreslå betegnelsen morfo (form) syntaks (kombinatorik). Den morfosyntaktiske analyse dækker altså i denne fremstilling en langt bredere semiotisk disciplin end begrebet dækker inden for den strikt grammatiske terminologi, ikke mindst fordi Peirces tegnbegreb jo omfatter mange andre typer tegn end de sproglige.
} 
semiotikken, handler om »those things whose end is to represent something « (CP 5.I29).

\section{Peirces fænomenologi}

Peirces fænomenologi består $\mathrm{i}$ en bestræbelse på at beskrive de mest fundamentale og samtidig mest elementære betingelser, der bestemmer menneskets møde med og opfattelse af verden. Peirce beskriver menneskets møde med verden ud fra tre fundamentale kategorier, som han kalder 'førstehed', 'andethed' og 'tredjehed' (firstness, secondness og thirdness). Disse fænomenologiske kategorier elaboreres løbende gennem Peirces forfatterskab, men må anses for at være fuldt udviklede omkring I 885 . Kategorierne ligger til grund for hele hans filosofi, herunder hans semiotik, hvilket indebærer, at alle hans semiotiske begreber opdeles og underopdeles i treheder.

Førsteheden er den rene kvalitet i sig selv, farven rød f.eks., som i bevidstheden (mind) modsvares af en ren følelse. Et sådant uafgrænset univers af ren kvalitet eller ren følelse kan ikke eksistere i den ydre verden, men kan kun bestå som rene muligheder (maybes). For at begrebsliggøre førsteheden må vi tænke på den som »ren natur eller som en kvalitet, der i sig selv er uden dele, uden nogen træk og ikke legemliggjort « (Peirce I994, 35). Det er i det følgende citat bemærkelsesværdigt i hvor høj grad Peirce søger til poetiske og ligefrem metaforiske udtryk for at udtrykke førstehedens karakter:

The idea of the absolutely First must be entirely separated from all conception of or reference to anything else; for what involves a second is itself a second to that second. The First must therefore be present and immediate, so as not to be second to a representation. It must be fresh and new, for if old it is second to its former state. It must be initiative, original, spontaneous, and free; otherwise it is second to a determining cause. It is also something vivid and conscious; so only it avoids being the object of some sensation. It precedes all synthesis and all differentiation: it has no unity and no parts. It cannot be articulately thought: assert it, and it has already lost its characteristic innocence; for assertion always implies a denial of something else. Stop to think of it, and it has flown! What the world was to Adam on the day he opened his eyes to it, before he had drawn any distinctions, or had become conscious of his own existence, that is first, present, immediate, fresh, new, initiative, original, spontaneous, free, vivid, conscious, and evanescent. Only, remember that every description of it must be false to it (CP I.357).

Hvis førsteheden består i ren mulig væren, så består andetheden i aktuel eksistens. Det er tingenes og begivenhedernes eksistenskategori, og består i såkaldt duale relationer: »Det møder os i kendsgerninger som relation, 
tvang, virkning, afhængighed, nægtelse, hændelse, virkelighed, resultat « (Peirce 1994, 79). Andetheden er vores møde med den konkrete virkelighed, der yder os modstand, døren der binder f.eks, og det er vores viljesbestemte eller driftstyrede anstrengelse, rettet mod denne modstand.

Just as the first is not absolutely first if thought along with a second, so likewise to think the Second in its perfection we must banish every third. The Second is therefore the absolute last. But we need not, and must not, banish the idea of the first from the second; on the contrary, the Second is precisely that which cannot be without the first. It meets us in such facts as Another, Relation, Compulsion, Effect, Dependence, Independence, Negation, Occurrence, Reality, Result. A thing cannot be other, negative, or independent, without a first to or of which it shall be other, negative, or independent. [...]

We find secondness in occurrence, because an occurrence is something whose Existence consists in our knocking up against it. A hard fact is of the same sort; that is to say, it is something which is there, and which I cannot think away but am forced to acknowledge as an object or second beside myself, the subject or number one, and which forms material for the exercise of my will $(\mathrm{CP}$ I. 358$)$.

Tredjeheden medierer endelig mellem de to første kategorier ligesom et midterstykke forbinder en begyndelse og en slutning. Medieringen udgøres af regelmæssighed eller lovmæssighed, der i form af en vanedannelse (habit) får det konkrete til at slå om i noget alment.

By the third, I mean the medium or connecting bond between the absolute first and last. The beginning is first, the end second, the middle third. The end is second, the means third. The thread of life is a third; the fate that snips it, its second. A fork in a road is a third, it supposes three ways; a straight road, considered merely as a connection between two places is second, but so far as it implies passing through intermediate places it is third (CP I.337).

For Peirce handler tredjehed således om generalitet og begrebsdannelse, en tankens lov, hvorfor det klareste udtryk for tredjehed er det repræsentative princip, tegnets princip.

\section{Peirces tegnbegreb}

Peirces semiotiske grundopfattelse vinder i løbet af hans liv i både dybde og rækkevidde, men er samtidig præget af en høj grad af integritet (Jakobson I979, I20). Ikke desto mindre varierer Peirces definition af tegnet noget over tid, som det også fremgår af Robert Martys glimrende samling af 76 forskellige bud på en definition fra Peirces hånd (Marty, 
internetartikkel på Arisbe). ${ }^{4}$ En repræsentativ udgave finder vi f.eks. i CP I.54I:

A representamen is a subject of a triadic relation $T O$ at second called its object, for a third, called its interpretant, this triadic relation being such that the representamen determines its interpretant to stand in the same triadic relation to the same object for some interpretant (CP I.54I).

Et tegn kan således igen deles op i komponenter: for det første tegnet i sig selv, som Peirce også kalder et 'repræsentamen', for det andet 'objektet' som tegnet refererer til, og for det tredje 'interpretanten', som er et nyt tegn der fortolker det første og hvis relation til objektet er den 'samme' som repræsentamenets. Når jeg f.eks. fortæller (repræsentamen) min ven om en fælles bekendts fortrædeligheder (objekt), kan jeg med rimelighed forvente at min ven producerer en mental forestilling om hvad der er hændt vores fælles bekendt (interpretant). Det er værd at lægge mærke til at Peirce i denne definition understreger den determinative rolle repræsentamenet har i forhold til genereringen af interpretanten som et nyt tegn ${ }^{5}$. At der er tale om en form for determination betyder ikke at der er tale om en fuld og hel identitet imellem repræsentamen og interpretant; som vi skal se nedenfor mener Peirce at der ved oversættelsen mellem repræsentamen og interpretant kan tilføjes nye betydningsdimensioner som får tegnet til at 'vokse' (se s. 33). Når han taler om determination skal det snarere forstås på den måde, at interpretanten ikke kan genereres som et nyt vilkårligt tegn. Min ven kan f.eks. kende andre sider af vores fælles bekendt, hvilket gør det muligt for ham at se andre implikationer af den fortalte historie, men min ven må vide, hvem den omtalte person er, ellers siger min historie ham intet, eller meget lidt. Interpretanten bliver efterfølgende udgangspunkt for at generere et nyt tegn når min ven kommenterer min historie eller stiller uddybende spørgsmål, eller evt. blot forholder sig tavs. Dette nye tegn bliver selv genstand for en fortolkning, dvs. det bliver selv repræsentamen, når jeg skal forstå den måde hvorpå min ven reagerer på min historie. Derved produceres der en ny interpretant, og der opstår en i princippet uendelig kæde af tegn som tolker tegn, en uendelig semiosis. ${ }^{6}$ Grafisk kan vi repræsentere processen som en

\footnotetext{
${ }^{4}$ http://members.door.net/arisbe/.

${ }^{5}$ Denne definition fra Peirces Lowell Lectures, Lecture III (1903) er repræsentativ for det store flertal af hans definitioner, idet den netop understreger det determinative forhold mellem repræsentamenet og interpretanten.

${ }^{6}$ Begrebet 'uendelig semiosis' er ikke Peirces eget, men en oversættelse af Umberto Ecos betegnelse semiosis ilimitada (I975, afsnit 2.7.3), der imidlertid er en meget præcis begrebsliggørelse af det dynamiske aspekt i Peirces forståelse af tegnenes interaktion.
} 
trekantsrelation, der med omvendingen af interpretanten til et nyt repræsentamen eller tegn gentager sig i det uendelige.

\section{Repræsentamen}

$\Delta$

Objekt

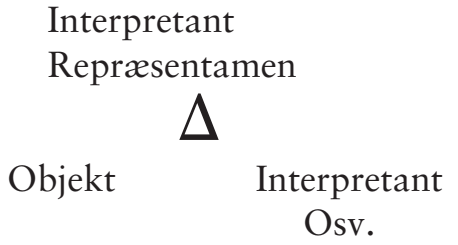

Tegnet, min fortælling, repræsenterer objektet, vores fælles bekendts fortrædeligheder, men ikke på nogen simpel måde. Der er således ikke tale om at tegnet henviser direkte til den skinbarlige 'virkelighed' eller 'realitet', altså min ven i kød og blod. For min ven vil min historie om vores fælles bekendt være min udlægning (repræsentation) af vores bekendts fortrædeligheder og ikke dennes fortrædeligheder i sig selv. Derfor indfører Peirce en skelnen mellem to aspekter af objektet: et 'umiddelbart' - og et 'dynamisk' objekt:

[W]e have to distinguish the Immediate Object, which is the Object as the Sign itself represents it, and whose Being is thus dependent upon the Representation of it in the Sign, from the Dynamical Object, which is the Reality which by some means contrives to determine the Sign to its Representation (CP 4.536).

Det umiddelbare objekt er at forstå som objektet reproesenteret af tegnet i sig selv, en betydningsdimension som kun eksisterer i kraft af selve denne repræsentation (min fortælling om vores bekendts fortrædeligheder), mens det dynamiske objekt er at forstå som den realitet der så at sige genererer eller determinerer hele tegnprocessen (de hændelser som vores fælles bekendt faktisk har været ude for). Tegnet repræsenterer således kun objektet $i$ en bestemt henseende, og overlader dermed andre aspekter af det dynamiske objekt til at generere yderligere semiotiske processer. Når vi taler om et bestemt sagsforhold, f.eks. den universitetsreform som regeringen gennemførte i 2003 , så kan vi tale om den som en del af forskningsminister Helge Sanders politiske portefølje og vurdere den i lyset af hans personlige karriere, vi kan tale om den som lovgrundlag for universitetslovsinstitutionerne, og det kan vi gøre enten set fra studenterside, fra forskerside, fra underviserside eller fra administrativ side osv. osv. Hvert af disse afspekter af universitetsloven er konstrueret diskursivt, og 
de må derfor betragtes som umiddelbare objekter. De udgør altså forskellige måder hvorpå selve 'tegnet' fokuserer det dynamiske objekt (universitetsreformen i alle dens egenskaber). Det dynamiske objekt må derfor siges at ligge uden for tegnet, fordi det ikke kan repræsenteres udtømmende af tegnene. Der vil altid være nye måder at diskutere og forstå en politisk reform, som aktuelt, historisk, politisk eller socialt fænomen. Og det dynamiske objekt er netop dynamisk, fordi den aktuelle virkelighed hele tiden fremprovokerer nye diskurser, nye måder at fokusere verden på. Det er dog værd at bemærke at der ikke er noget naivt over Peirces forhold til den ontologiske status af dette dynamiske objekt, hvilket fremgår af et andet og senere citat om de to aspekter af objektet:

We must distinguish between the Immediate Object, - i.e. the Object as represented in the sign, - and the Real (no, because perhaps the Object is altogether fictive, I must choose a different term, therefore), say rather the Dynamical Object, which, from the nature of things, the Sign cannot express, which it can only indicate and leave the interpreter to find out by collateral experience (CP 8.3 I4).

Det er interessant hvordan Peirce i dette citat karakteriserer objektet som "altogether fictive", hvilket vil sige at han altså ikke nærer nogen forestilling om en ontologisk 'ren' realitet, ubesmittet af vores semiotisk medierede forhold hertil. Den enkelte diskurs kan ikke rumme dette dynamiske objekt i al dets kompleksitet, men den enkelte fortolker heraf (som ikke er det samme som interpretanten, der netop er determineret af den konkrete diskurs) kan tilnærme sig en forståelse af det dynamiske objekt gennem collateral experience, dvs. gennem andre erfaringer med objektet.

Hvor Peirces beskrivelse af tegnet gør det nødvendigt at tale om to forskellige objekter, gør hans beskrivelse det logisk at tale om (mindst) tre forskellige typer af interpretanter. Hans mest kendte og anvendte begreber, den umiddelbare, den dynamiske og den finale interpretant, skelner mellem tre forskellige indholdsaspekter et tegn kan antage: det kan have karakter af et muligt betydningsindhold, det kan være noget der rent faktisk sker helt aktuelt eller det kan være en alment antaget eller videnskabeligt bevist sandhed. Jørgen Dines Johansen giver i Dialogic Semiosis en fremstilling af interpretantproblematikken hos Peirce, hvor han udlægger indholdet af denne som et spørgsmål om interpretanternes informationsmæssige indhold, gående fra » minimal state of information « i den umiddelbare interpretant der er tilknyttet makrotegnets fulde betydningspotentiale, over dets aktualisering i en læsning i den dynamiske 
interpretant til »the maximal state of information « $\mathrm{i}$ den intersubjektive og tendentielt ideale betydning i den finale interpretant (Johansen I993, I 62 ff.). Peirces dynamiske objekt modsvares således på interpretantsiden af den finale interpretant. Ifølge Dines Johansen er der imidlertid endnu ikke opnået klarhed omkring den indbyrdes relation mellem de forskellige sæt af begreber som Peirce selv lancerede i beskrivelsen af interpretantfunktionen (Johansen I993, I66). Dette forhold er også bekræftet af Joseph Ransdell på internettets Peirce-diskussionsliste:

[W] hat baffles me most are the two seemingly distinct trichotomies of the interpretant: on the one hand, the immediate, dynamical, and final; on the other the emotional, energetic, and logical. As you probably know, there has been a good deal of dispute about what the relationship is, with no consensus forming on that, as far as I know (Joseph Ransdell på internettets Peircediskussionsliste d. 25/( $\left.2000^{7}\right) .^{8}$

Hvor Joseph Ransdell antager at de to trikotomier måske skal forstås som synonyme, mener jeg at kunne argumentere for at Peirces skelnen mellem den umiddelbare, den dynamiske og den finale interpretant beskriver tegnets tre forskellige værensmodi (betydningspotentiale, aktualiseret betydning og vanemæssig betydning), mens hans skelnen mellem den 'emotionelle', den 'energetiske' og den 'logiske' interpretant vedrører forskellige kognitive aspekter af tegnets tolkning (følelsesmæssig oplevelse, overraskelse og tilskrivelse af logisk betydning). Forstået på den måde ville hver af de første kunne underopdeles i hver af de andre, og omvendt. Det vil jeg vende tilbage til i forbindelse med Peirces behandling af begrebet om det æstetiske (se s. I30). I første omgang vil det imidlertid være hensigtsmæssigt blot at koncentrere fremstillingen om den første interpretant-trikotomi. Peirce siger selv herom:

In regard to the Interpretant we have [...] to distinguish, in the first place, the Immediate Interpretant, which is the interpretant as it is revealed in the right understanding of the Sign itself, and is ordinarily called the meaning of the sign; while in the second place, we have to take note of the Dynamical

\footnotetext{
${ }^{7} \mathrm{http}: / / \mathrm{members}$.door.net.arisbe/mem/people/peirce-1/peirce-1.htm.

${ }^{8}$ Listen over Peirces forskellige inddelinger af interpretanterne er lang og udredningsarbejdet ville blive en kompliceret og lidet frugtbar proces. Ud over de ovenfor nævnte interpretantkategorier refererer Dines Johansen således til Peirces skelnen mellem essential, informed og substantial interpretant, til hans skelnen imellem den logiske interpretants første, anden og tredje interpretant som igen opdeles i higher og lower interpretants. Endelig refererer Johansen til Peirces skelnen mellem intentional, effectual og communicational interpretants, som vil blive taget op igen i forbindelse med semiosis forstået som kommunikation og dialog nedenfor (Johansen I993, I62-I82 samt 2002, 42 ff.).
} 
Interpretant which is the actual effect which the Sign, as a Sign, really determines. Finally there is what I provisionally term the Final Interpretant, which refers to the manner in which the Sign tends to represent itself to be related to its Object. I confess that my own conception of this third interpretant is not yet quite free from mist (CP 4.536).

Den umiddelbare interpretant definerer Peirce her som »the right understanding of the Sign itself «. Der er to elementer i denne definition, som det er værd at understrege. For det første er der tale om »the right understanding ", altså en udlægning af tegnet som i et eller andet omfang må kunne verificeres gennem en slags filologisk kontrol af tegnets betydning. Augusto Ponzio mener derfor at den umiddelbare interpretant er »fixed by use and tradition " (Ponzio I990, 200). For det andet er der tale om »the Sign itself «, hvilket får Dines Johansen til at mene at det gælder »the interpretability that a sign has before it gets an interpreter " (Johansen I 993, I 66). Som førsteheden inden for interpretanterne repræsenterer den umiddelbare interpretant "[T]he significative power of the sign in itself [...] a possible field of signification " (Johansen I993, I69). Som sådan foreslår Dines Johansen at den europæiske strukturalisme »might be regarded as the study of the immediate interpretants " (Johansen I996, 338), ganske vist ikke forstået som tegnets mere eller mindre objektive betydning som den ville tage sig ud ifølge strukturalismens selvforståelse, men netop som beskrivelsen af et betydningspotentiale.

Den dynamiske interpretant beskriver Peirce som »the actual effect which the Sign, as a Sign, really determines «. Som andetheden inden for interpretanterne er der tale om fortolkning forstået som en konkret hændelse, hvorfor Dines Johansen da også understreger, at den dynamiske interpretant udgør »the actual interpretation « (Johansen I993, I69). Augusto Ponzio forbinder på sin side dette hændelsesaspekt af tegnets betydning med begrebet om den uendelige semiosis:

Considered in relation to both the dynamical interpretant and dynamical object $[\ldots]$ for Peirce $[\ldots]$ the sign could never be something repetitive. Each time it is taken up, it makes its appearance in a new semiotical act. This causes the sign to be continually renewed, so that its interpretant is never established once and for all: this is the Peircean principle of unlimited semiosis [...] (Ponzio I990, 257).

Begrebet om den 'finale' interpretant er i det ovenfor bragte citat fra CP 4.536 ikke præcist udlagt, og Peirce er selv klar over dette. Han konkretiserer imidlertid sidenhen begrebet således: »[T]he Final Interpretant, [...] is that which would finally be decided to be the true interpretation if 
consideration of the matter were carried so far that an ultimate opinion were reached « (CP 8.I 84). Den finale interpretant bliver i denne forståelse resultatet af en i princippet uafsluttet semiosis. På den baggrund definerer Dines Johansen den finale interpretant som »[t]he interpretation that would be agreed on after unlimited research « (Johansen I993, I67), altså en tendens i retning af en enighed inden for et givet forskningsfællesskab på et givet tidspunkt.

Den finale interpretant er til at få øje på i enkle spørgsmål, såsom f.eks. tyngdeloven og planeternes bevægelser omkring solen, men på mere komplekse spørgsmål, som f.eks. fortolkningen af kunstneriske og litterære værker, vil den finale interpretant kun kunne registreres som en række bestræbelser af forskellig karakter på at nå frem til en stabil og intersubjektiv forståelse af de givne værker og deres kulturelle betydning. Jeg mener således at man må skelne mellem forskellige niveauer i tendensen til at etablere finale interpretanter, forstået som stabile vanemæssige fortolkninger, som må beskrives specifikt inden for hvert afgrænset emneområde. Således ville man kunne betragte læsernes indbyrdes samtaler om de litterære værker samt den dagsaktuelle, offentlige kritik af samme som et første skridt i retning af dannelsen af en almindelig konsensus eller en final interpretant. Andet skridt kunne være etableringen af en litterær kanon der også sætter sig spor i uddannelsesinstitutionernes pensumlister, og et sidste led kunne være den litteraturvidenskabelige praksis, der på grundlag af teoretisk reflekterede tilgange forsøger at forhandle sig frem til bestemte fortolkninger af litterære værker, forfatterskaber, perioder, genrer og stilretninger.

Peirces skelnen mellem den umiddelbare, den dynamiske og den finale interpretant vil som et strukturerende princip ligge til grund for kapitlerne III, IV og V. Behandlingen af den umiddelbare interpretant i Kapitel III vil blive koblet til en diskussion af værkets æstetiske strategi, behandlingen af den dynamiske interpretant i Kapitel IV vil blive sammenkædet med gennemgangen af værkets etiske implikationer, og behandlingen af den finale interpretant i Kapitel V vil blive koblet til diskussionen af litteraturkritikken som videnskab og som forvalter af den kulturelle arv. På dette sted skal vi imidlertid videre med Peirces tegnbegreb og dets hermeneutiske og dialogiske aspekter, som efterfølgende vil blive diskuteret i forhold til andre teoretikere fra det 20. århundrede (Bakhtin og Lotman).

\section{Semiotikkens discipliner og tegnets betydningsdimensioner}

Som det fremgår af diagrammet på side i 8 , opdeler Peirce studiet af tegnene i tre discipliner. Studiet af tegnet i sig selv kalder han grammatik (pure grammar), hvorved han forstår "what must be true of a representa- 
men in order to embody any meaning « (CP 2.229, I 897). Studiet af forholdet mellem tegnet og dets objekt kalder han logik (logic proper), hvorved han forstår »the formal science of the conditions of the truth of representations « (ibid.). Endelig kalder han studiet af tegnet og dets interpretanter retorik (pure rhetoric), hvorved han forstår »the laws by which in every scientific intelligence one sign gives birth to another, and especially one thought brings forth another « (ibid.). I det følgende vil jeg imidlertid anvende de begreber som Charles Morris har foreslået for de samme relationer, og som har haft større internationalt gennemslag. Med Morris kan vi opdele analysen af tegnet i et morfosyntaktisk, et semantisk og pragmatisk plan. I stedet for Peirces pure grammar taler Morris ganske vist om syntactics, men da studiet af tegnet i sig selv både må indeholde undersøgelsen af formdannelse og kombinatorik vil jeg foreslå betegnelsen morfo (form) syntaks (kombinatorik).

Inden for hver af disse tre analytiske planer opdeler Peirce tegnet i tre typer. På det morfosyntaktiske plan opdeles tegnet i sig selv i 'kvalitegn', 'sin-tegn' og 'legitegn'. Kvalitegnet er en ren kvalitet der fungerer som tegn, som f.eks. når det samme ord, skrevet i hånden eller på tryk, opfattes forskelligt. Sin-tegnet, som Peirce også kalder token, er et konkret optrædende tegn, som når et ord, der optræder flere gange på en side, betragtes som forskellige tegn, mens legitegnet, som Peirce også kalder type, er tegnet forstået som en almen lovmæssighed, som f.eks. når et ord, der optræder flere gange på en side, kun betragtes som ét tegn.

På det semantiske plan opdeles tegnet i 'ikoner', 'indekser' og 'symboler'. Dette er Peirces mest kendte deling af tegnet, og den som har vundet mest udbredelse inden for analyse af kunst og litteratur. Ikoner er tegn, der refererer til det objekt som de betegner i kraft af at besidde nogle af de samme egenskaber, altså ved i en vis forstand at ligne objektet. For Peirce dækker ikonicitetsbegrebet i sig selv - ikke overraskende - over tre forskellige typer af ikonicitet i andre tegn end de rene ikoner, heriblandt i sprogets symboler. Peirce kalder tegn af denne type hypoicons. I en kompakt og ofte citeret passage udlægger han relationen mellem de tre typer således:

Those (representamens) which partake of simple qualities, or First Firstnesses, are images; those which represent the relations, mainly dyadic, or so regarded, of the parts of one thing by analogous relations in their own parts, are diagrams; those which represent the representative character of a representamen by representing a parallelism in something else, are metaphors ( $\mathrm{CP} 2.227)$.

Peirce opererer således med typerne image, diagram og metaphor, som 
bygger på hhv. simpel lighed, analogi og »en parallelisme i noget andet «. Michael Cabot Haley nævner følgende eksempler for at illustrere de tre typer inden for en sproglig diskurs (Haley I988, 28, 40 og 77):

- »That baby has creamy skin «.

- »That executive is the cream of the company «.

- "[The stars are] diamonds trembling through and through « (citeret fra Keats: »Epistle to my brother George «).

Forskellen mellem de to første sætninger udlægges af Haley som forskellen mellem den kvalitative lighed, karakteristisk for the image, $\mathrm{i}$ » that baby has creamy skin « (babyhudens blødhed, den hvide hud, duften af mælk), og diagrammets rent analogiske relation $i$ »that executive is the cream of the company ", hvor betydningen etableres i kraft af relationen mellem fire elementer: lederens forhold til andre medarbejdere er som forholdet mellem mælk og fløde i en flaske. Denne relation kan bringes på formel således: \{executive : others in the company :: cream : milk in a bottle\}.

De to ikonicitetsformer indgår endelig $\mathrm{i}$ en dialogisk interaktion $\mathrm{i}$ metaforen, der således kan siges at mediere mellem kvalitativ lighed og analogisk relation, idet forholdet mellem stjernerne (som aldrig ekspliciteres) og diamanter bygger på en optisk lighedsrelation (twinkle/glitter), mens udtrykket trembling som billede på lysets virkning forudsætter en analog læsning inden for to forskellige sanseområder: det optiske og det kropsligt-taktile: \{sparkling: light :: trembling : motion\}. Det er ligheden i den optiske sanseerfaring med diamanter og stjerner, deres glimten og changering, der gør det muligt at forstå det som en 'skælven', dvs. at den kvalitative lighedsrelation ekspliciterer den indholdsmæssige relation mellem de parvist relaterede elementer i den analoge relation. Men i modsætning til diamanternes 'døde' glitren er stjernernes glimten 'levende', dvs. at forskellen på analogiens domæner forklarer forskellen på $\mathrm{x}$ og x' i lighedsrelationens kvalitative ligheder.'

Indekser er tegn der peger tilbage på deres objekt ved at være påvirket af det (nærhed, del-helhed, deixis osv.). Blandt indekserne skelner Peirce mellem på den ene side 'ægte' indekser, eller reagents, der forbinder tegnet direkte til en realitet således som vejrhanen eller fodsporet, og på den anden side de såkaldt degenererede eller afledte indekser, designations,

\footnotetext{
${ }^{9}$ Eksemplet er Haleys, men udlægningen af metaforen som en mediering af de to ikonitetsformer er min. Denne udlægning af Peirces metaforbegreb kunne med fordel diskuteres i lyset af Anthony Jappy, der går ind i diskussionen af metaforen som syntese af image og diagram, men alligevel ikke når ud over beskrivelsen af metaforen som en ren analogiform (Jappy I996, 25 I257).
} 
som er tegn der refererer til positioner i teksten/tegnet selv såsom sprogets pronominer. Endelig er symboler tegn, der refererer til deres objekt i kraft af en vanemæssig association af ideer, således som vi kender det fra sprogets brug af historisk forankrede 'koder' i form af semantisk betydning og grammatiske relationer.

På det pragmatiske plan skelner Peirce mellem 'rhemer', 'dicente tegn' og 'argumenter'. Rhemer er tegn, som forstås som rene muligheder, som f.eks. betydningen af et enkelt, løsrevet ord, f.eks. betydningen af ordet 'menneske' isoleret. Dicente tegn er tegn som er sat ind i en kontekst, som når det løsrevne ord sættes ind i en sætning: »Aristoteles er et menneske ". Endelig dannes argumentet når flere dicente tegn føjes sammen i en logisk og argumentativ struktur med præmisser og konklusion, som vi f.eks. finder den udtrykt i den klassiske syllogisme: »Alle mennesker er dødelige / Aristoteles er et menneske / Aristoteles er dødelig «.

Det er vigtigt at understrege, at tegnene i konkret kommunikativ brug ikke kan kategoriseres som værende enten det ene eller det andet, men at f.eks. ikoniske, indeksikale, symbolske og argumentative betydninger lejrer sig oven på hinanden i de kommunikative processer. Den semiotiske analyse handler således ikke om at kategorisere tegn (her har vi et ikon, her et indeks osv.), men om at forklare hvordan bestemte betydninger (interpretanter) genereres af tegnet.

\section{Begrebet 'grund'}

Den vel nok mest udbredte af Peirces tegndefinitioner er den, som vi finder i CP 2.228. Denne definition fra I 897 adskiller sig ironisk nok fra de fleste andre på to måder. For det første indebærer denne definition ikke et determinativt forhold mellem repræsentamen og interpretant, og for det andet introducerer den begrebet 'grund' (ground) som ellers kun optræder uhyre sporadisk i Peirces skrifter. Definitionen lyder som følger:

A sign or representamen is something which stands to somebody for something in some respect or capacity. It addresses somebody, that is, creates in the mind of that person an equivalent sign, or perhaps a more developed sign. That sign which it creates I call the interpretant of the first sign. The sign stands for something, its object. It stands for that object, not in all respects, but in reference to a sort of idea, which I have sometimes called the ground of the representamen. 'Idea' is here to be understood in a sort of Platonic sense, very familiar in everyday talk (CP 2.228).

Peirce nævner her tegnets grund som endnu en instans i bestemmelsen af tegnet ved siden af de tre tidligere nævnte aspekter af tegnet: repræsentamenet, objektet og interpretanten. Det kunne således se ud som om der 
pludselig indgår fire elementer i tegnbegrebet, men det er ikke tilfældet. Peirce præciserer nemlig umiddelbart efter at det er repræsentamenets forhold til de andre tre instanser som er bestemmende for semiotikkens tre discipliner beskrevet ovenfor: »In consequence of every representamen being thus connected with three things, the ground, the object, and the interpretant, the science of semiotic has three branches « (CP 2.229). Det er disse vi ovenfor har kaldet morfosyntaks, semantik og pragmatik. Forstået således er grunden altså den instans som bestemmer tegnets betydning i relation til sig selv på det morfosyntaktiske niveau, idet denne disciplin »has for its task to ascertain what must be true of the representamen used by every scientific intelligence in order that they may embody any meaning " (ibid.).

Begrebet grund er imidlertid et omdiskuteret begreb blandt Peirceforskere, fordi det, som nævnt, kun optræder sporadisk som en videnskabelig term strictu sensu hos Peirce, og primært i hans tidlige tekster. Der er derfor grund til at antage at andre af hans begreber, herunder først og fremmest interpretant-begrebet, i de senere tekster udvikler sig til at indeholde de indholdsmæssige aspekter som grunden tidligere brugtes til at udtrykke. Når jeg alligevel føler at der er særlig grund til at opholde mig ved dette begreb, er det fordi det ekspliciterer nogle af de aspekter ved semiosen, som gør Peirces semiotik åben over for koblinger med hermeneutisk orienterede fortolkningsteorier.

I CP 2.228 hedder det, at tegnet ikke repræsenterer objektet »in all respects, but in reference to a sort of idea, which I have sometimes called the ground of the representamen «. Tegnet refererer ikke til objektet på en almen eller generel måde, men konkret og specifikt i form af et umiddelbart objekt, og denne konkrete og specifikke måde at fokusere objektet på er bestemt af tegnets grund. Det vælger jeg at udlægge sådan, at begrebet grund udgør en slags betydningsmæssig stabilisator, der giver tegnet en given grund at etablere referencen på. Hvis vi f.eks. ønsker at skelne noget fra noget andet, må vi specificere i hvilken henseende der er tale om lighed og forskel (størrelse, farve, vægt osv.), som i denne henseende bliver at betragte som sammenligningens 'grund'. I den forstand er grunden en abstraction/prescission (CP I.55 I og I.353), som Anne Marie Dinesen foreslår at forstå ud fra gestaltpsykologiens skelnen mellem figur og baggrund. Altså: vi er kun i stand til at skelne figuren fordi den skiller sig ud fra en baggrund / vi er kun i stand til at se at to røde ting ligner hinanden fordi vi er enige om, at forudsætningen for sammenligningen er at vi fokuserer på objekternes farve og abstraherer fra alt andet. Forstået som en sådan 'baggrund' som tegnet producerer sin reference på, vil grunden kunne forstås som den kæde - eller de kæder - 
af forudgående tegnprocesser omkring det samme objekt, som det nye tegn tager som sin forudsætning. Dvs. snakker vi om en ældre roman, vil de tidligere læsninger af romanen og af forfatterskabet, der konstituerer den tradition som en given analyse bygger på, udgøre denne analyses grund. Selv om Peirce holder op med at gøre opmærksom på grundbegrebets karakter af videnskabelig term tilknyttet tegnfunktionen i sig selv, fortsætter han med at anvende ordet i netop denne betydning.

Man kan således sige, at tegnenes betydning for Peirce udgøres af den vane som historisk er dannet over tid i forståelsen af tegnene gennem deres brug:

[A] sign cannot denote an object not othervise known to its interpreter, for the obvious reason that if he does not already know the Object at all, he cannot possess these ideas by means of which alone his attention can be narrowed to the very object denoted. [...] A Sign necessarily has for its Object some fragment of history, that is, of history of ideas (Peirce, MS 849. Citeret efter Marty, nr. 56).

Den dimension af tegnets betydning, som udgøres af de kulturelt og historisk determinerede forudsætninger som en given fortolkning foretages ud fra, vil jeg således foreslå at betegne som tegnets grund. Men hvis grunden udgøres af de fortolkningsmæssige forudsætninger som er gældende idet et givet objekt på et givet tidspunkt determinerer produktionen af et givet tegn, så betyder det også, at det vil være muligt at definere grunden i relation til hvert af de netop skitserede interpretantniveauer.

På niveauet for den umiddelbare interpretant har vi at gøre med de almene betingelser for betydningsdannelsen overhovedet. På ordniveau gælder det de associative mønstre, der som former stabiliserer sprogenes historiske udvikling, mens det på niveauet for hele litterære værker handler om de genreforventninger som determinerer en given læserforventning. Grunden fungerer her som den vanemæssige baggrund, hvorpå en given udtryksform (signifiant) henviser til en given indholdsform (signifié) i noget der ligner Saussures forstand (dvs. en diskontinuitet i en kontinuert udtrykssubstans). Muligheden for på dette sted at anvende Saussures begreber udspringer af at der på niveauet for den umiddelbare interpretant ikke er tale om henvisning til et konkret objekt, men kun om muligheden for en reference. Og fordelen ved at indsætte Saussures begreber $\mathrm{i}$ en sådan peirceansk ramme ville være, at den strukturelle relation mellem udtryk og indhold i udlægningen af Saussures tænkning bliver gjort afhængig af grunden som historisk / kulturel stabilisator / 
variabel. ${ }^{10}$ At Peirce faktisk mente at den historiske dimension i tegnets tilblivelseshistorie indgår som en gyldig faktor i bestemmelsen af tegnets betydning, fremgår af hans berømte udsagn om at »symboler vokser «:

[E]very symbol is a living thing, in a very strict sense that is no mere figure of speech. The body of the symbol changes slowly, but its meaning inevitably grows, incorporates new elements and throws off old ones (CP 2.222).

Med den organiske vækstmetafor bliver der indført en historisk dimension i tegnets og tegnkodens tilblivelse i kraft af vanen, og det er denne dimension som $i$ visse af Peirces tidlige skrifter ekspliciteres i form af begrebet grund.

På niveauet for den dynamiske interpretant finder vi på grundens sted hermeneutikkens sammenstød eller sammensmeltning (Gadamer) af erfaringshorisonter. I konkret og praktisk kommunikation afstikker eller determinerer ethvert tegn en interpretant, som produceres på den samme grund som determinerede produktionen af tegnet. I mange tilfælde, som f.eks. ved direkte samtale, vil tegnets grund være sikret i kraft af den situationelle kontekst og samtaleparternes mulighed for at forhandle og justere på talens forudsætninger. Men idet sproget bliver til skrift, sker der en løsrivelse af teksten fra dens situationelle, historiske og kulturelle kontekst. Idet der sker en tidsforskydning mellem produktionen af tegnet og den aktuelle fortolkning, som hvis vi f.eks. skal læse og diskutere en bog skrevet for 500 år siden, sker der en glidning mellem grund og umiddelbart objekt. Det står klart at vi ikke længere kan fortolke teksten ud fra de samme kulturelle og historiske forudsætninger som var gældende, da den blev skrevet. Der sker nu (mindst) to ting: for det første sker der det, at dele af de forudsætninger som tidligere var indeholdt $\mathrm{i}$ grunden glider ned og bliver en del af det umiddelbare objekt. I det tilfælde læser vi bogen som et tegn for sin tid og for de kulturelle normer osv., som var gældende på affattelsestidspunktet. For det andet sker der det, at efterfølgende læsninger danner tradition og bliver til en ny grund, som nye læsninger må forholde sig til. Vil vi forsøge at sætte os ind $\mathrm{i}$ hvordan bogen er blevet læst på det tidspunkt hvor den blev skrevet, dvs. respektere den grund som bogen er skrevet ud fra, så må vi gøre vores filologiske hjemmearbejde og sætte os ind i den historisk-kulturelle kontekst. Den hermeneutiske tilgang til tekster beskæftiger sig med at denne bestræbelse aldrig lykkes fuldt ud. Og Peirce lader til at være enig:

\footnotetext{
${ }^{10}$ Nedenfor vil jeg i en kort ekskurs forfølge denne tråd, idet jeg tager diskussionen op mellem Charles Peirce og Louis Hjelmslevs strukturalistiske begreb om tegnet forstået som enheden af to funktiver.
} 
It is requisite then, in order to show what we are talking or writing about, to put the hearer's or reader's mind into real, active connection with the concatenation of experience or of fiction with which we are dealing, and, further, to draw his attention to, and identify, a certain number of particular points in such concatenation. If there be a reader who cannot understand my writings, let me tell him that no straining of his mind will help him: his whole difficulty is that he has no personal experience of the world of problems of which I am talking, and he might as well close the book until such experience comes (CP 3.4 I9).

Det er altså i et vist omfang modtagerens egne personlige erfaringer som skal udgøre det materiale som forståelse bygger på. Ricœur siger det på den måde, at læseren, for at tilskrive teksten en egentlig mening (og ikke bare en logisk/sproglig betydning), må foretage en 'appropriering' af teksten, dvs. investere sine egne erfaringer med de tilhørende kulturelle og historiske værdisæt og normer. Fortolkningen repræsenterer derfor et sammenstød af kulturelle horisonter (tekstens og læserens), og teksten opnår først en mening for en læser i den forstand Ricœur kalder for en 'metaforisk sandhed', når læseren formår at fusionere tekstens historiske og kulturelle horisont med sine egne livsverdensbaserede erfaringer. Alt dette vil jeg vende tilbage til i Kapitel IV, som omhandler teksternes referentielle funktioner.

På niveauet for den finale interpretant vil begrebet grund hovedsageligt henvise til forskningsfællesskabernes mere eller mindre ekspliciterede teoretiske forudsætninger som danner udgangspunkt for etableringen af en tradition. Det vil jeg vende tilbage til i Kapitel V, men først skal vi kort se på nogle af de konsekvenser som det pragmatiske tegnbegrebs åbning over for hermeneutikken har for den semiotiske forståelse af sproget. Dette vil tage form af en modstilling af Hjelmslevs strukturelle lingvistik og Umberto Ecos udlægning af Peirces pragmatiske semiotik.

\section{Trcestruktur eller rhizom}

Den danske sprogforsker Louis Hjelmslev har i sin glossematik videreudviklet Saussures lingvistik på både indholds- og udtryksplanet i strukturalistisk retning, og derfor kan en modstilling af Hjelmslevs udgave af semiologien med Peirces semiotik bidrage til at klargøre forholdet mellem de to traditioner. Ifølge Hjelmslev består tegnfunktionen af to funktiver, indholdsform og udtryksform, som svarer til Saussures signifié og signifiant. Forholdet mellem disse to funktiver er, ifølge Hjelmslev, karakteriseret ved arbitraritet og solidaritet $\mathrm{i}$ den forstand at der er fuldstændig vilkårlighed mellem koblingen af udtryksform og indholdsform, mens der er absolut solidaritet mellem de elementer som indgår i den strukturelle 
konfiguration af hhv. udtryksform og indholdsform (Hjelmslev i 943, 30).

Det at der er fuldstændig vilkårlighed mellem koblingen af udtryksform og indholdsform indebærer, at det afhænger af et givet sprogs arbitrære kode om man kalder det samme individ a girl, eine mädchen, una muchacha eller en pige. Men omvendt vil hvert enkelt sprogs karakter være bestemt af hvordan sprogsystemet (langue hos Saussure) kombinerer sprogets mindste betydningsbærende elementer i en række binære relationer, der tilsammen danner en struktur eller en kode. På udtryksplanet viste Saussure hvordan fonemerne som de mindste, betydningsbærende elementer etablerede sig med en række distinktive træk, der gør det muligt at knytte forskelligt indhold til forskellige udtryk: forskellene mellem de danske ord "pige ", "pege «, "page " og "puge " kan således, hvad angår indholdsformen, reduceres til de distinktive træk der adskiller fonemerne 'i', 'e', 'a' og 'u' (fortunge/bagtunge, åben/lukket osv.). Tilsvarende kan man, ifølge Hjelmslev, beskrive indholdsplanet strukturelt ved at kortlægge de mindsteelementer som indgår i indholdsformen. Hjelmslevs teoretiske projekt repræsenterer således, i endnu højere grad end Saussures, en søgen efter sprogets immanente og systematiske strukturer, som styrer et givet sprogs udtryksformer og indholdsformer samt kombinationen imellem dem.

Hjelmslevs idé om en strukturel beskrivelse af sprogets indholdsplan blev videreført af Algirdas Julien Greimas, der med sin Sémantique structurale (I966; da. overs. I974) introducerede begrebet 'sem' som betegnelse for det mindste betydningsbærende element på indholdsplanet. Tager vi igen ordet "pige « vil det have en hel række fælles betydningselementer med ordet »dreng «: » menneskelighed «, » barnlighed « osv. Men de to ord vil adskille sig på ét punkt, nemlig semerne »maskulinitet « over for »femininitet «. Den strukturelle semantiks påstand er således at man kan beskrive indholdsformen ved systematisk at beskrive hvordan semerne indgår i binære relationer og hierarkiske strukturer:

\begin{tabular}{|c|c|c|c|}
\hline \multicolumn{4}{|c|}{ MENNESKE } \\
\hline \multicolumn{2}{|c|}{ BARNLIG } & \multicolumn{2}{|c|}{ VOKSEN } \\
\hline $\begin{array}{c}\text { MASKULINITET } \\
\text { dreng }\end{array}$ & $\begin{array}{c}\text { FEMININITET } \\
\text { pige }\end{array}$ & $\begin{array}{l}\text { MASKULINITET } \\
\text { mand }\end{array}$ & $\begin{array}{c}\text { FEMININITET } \\
\text { kvinde }\end{array}$ \\
\hline
\end{tabular}

Hvert lag i hierarkiet udgør en semantisk akse hvorudfra den semiske opdeling etableres. Den øverste akse i eksemplet kan man kalde »art «, den næste »alder « og den sidste »køn «. Selve strukturen ligner et træ vendt på hovedet, med stammen for oven og forgreninger nedad, hvorfor den ofte kaldes en 'træstruktur'. 
Selv om det var hverdagssproget der udgjorde det materiale som var genstand for Hjelmslevs arbejde, var det egentlige sigte med hans studium at konstruere en teori som kunne levere en konsistent og udtømmende beskrivelse af enhver tekst, givet dens tilhørsforhold til et bestemt system (op.cit. 9). Og en sådan beskrivelse ville, ifølge Hjelmslev, alene vedrøre den sproglige form:

[U]den om denne form, med funktion til den, foreligger et ikkesprogligt emne, den såkaldte substans. Medens det tilkommer lingvistikken at analysere den sproglige form, vil det lige saa selfølgeligt tilfalde andre videnskaber at analysere substansen (op.cit. 70).

Derfor vedrører analysen af det sproglige tegn eller den sproglige ytring alene selve sprogformen og de mulige syntagmatiske kombinationsmønstre og har derfor intet at gøre med sætningens eller tegnets mening, der vedrører det han kalder indholdssubstansen (op.cit. 3 I og 5 I). Hjelmslev betegnede denne mening eller indholdssubstans som 'tanken selv' (ibid.) og han henførte studier heraf til psykologien, fænomenologien og fysikken.

Hvor Hjelmslevs glossematik alene var koncentreret om beskrivelsen af sprogets form, dér er Peirces semiotik også orienteret mod udforskningen af den kommunikative mening, eller indholdssubstansen i Hjelmslevs terminologi. Hjelmslevs beskrivelse af indholdsmeningen som »tanken selv « bekræfter, at den peirceanske semiotik må forstås som en teoretisk udfoldning af forholdet mellem form og substans hos Hjelmslev. Skulle vi omvendt forsøge at placere Hjelmslevs strukturalistiske tegnbegreb i forhold til Peirces komplekse, semiotiske teori, har vi ovenfor været inde på at Hjelmslevs tegnfunktion, kombinationen af de to funktiver til et betydende tegn, må forstås som den grund, hvorpå den umiddelbare interpretant etablerer sin fortolkning. Denne udlægning følger i store linjer Jørgen Dines Johansens position over for f.eks. Ellen van Wolde, der ser det umiddelbare objekt som sammenligneligt med Hjemlslevs indholdsform. ${ }^{11}$

Endelig skal det påpeges at Hjelmslev selv var bevidst om nødvendigheden af at afgrænse sit tegnbegreb, dvs. tegnet forstået som en funktion bestående af to funktiver, over for andre, mere ikoniske tegnrelationer byggende på lighedsprincippet. I hans ret sene bog Sproget kan man således læse følgende refleksion:

\footnotetext{
${ }^{11}$ Ellen van Wolde skriver at »the immediate object is comparable to Saussure's signified or to Hjelmslev's and Greimas's content form « (van Wolde I996, 34I), hvorimod Dines Johansen anfører at den europæiske strukturalisme »might be regarded as the study of the immediate interpretants « (Johansen I996, 338).
} 
Om noget ligner eller ikke ligner noget andet, afhænger ganske af, ud fra hvilket synspunkt man anstiller sammenligningen: noget ligner aldrig noget andet $\mathrm{i}$ almindelighed, men noget ligner noget andet $\mathrm{i}$ en bestemt henseende [...] (Hjelmslev I963, 47).

Parallellen mellem dette citat og Peirces definition fra 2.228, citeret ovenfor, er slående. Her understreger Peirce at tegnet netop ikke kan stå for sit objekt » in all respects « men kun kan repræsentere dette i relation til det, han kalder "a sort of idea, which I have sometimes called the ground of the representamen «. Og lige så slående finder vi Hjelmslevs bemærkning om at forestillinger af denne karakter kun kan regnes for en del af sprogbrugen, »til sprogbygningen hører de i hvert fald ikke " (op.cit. 46). Disse sammenfald i formuleringer antyder at det evt. kunne være muligt at bruge resultaterne fra en strukturalistisk tilgang til lingvistikken inden for rammerne af en peirceansk baseret semiotik, men at dette må gøres med den største varsomhed og altid under hensyntagen til at den strukturelle beskrivelse af tegnsystemet, eller sprogbygningen som Hjelmslev kalder det, vedrører beskrivelsen af tegnets potentielle betydningsmuligheder sådan som de er determineret på niveauet for den umiddelbare interpretant i Peirces semiotik. ${ }^{12}$

I sin Tratado har Umberto Eco foreslået at forstå de to forskellige opfattelser af et tegns indhold som forskellen på et ordbogsopslag og beskrivelsen i en ideel og altomfattende encyklopædi (Eco 1977). Hvor ordbogsopslaget giver en kort og koncis definition, svarende til den strukturelle semantiks træstruktur, dér giver encyklopædien os, ideelt set, en beskrivelse af alle de kontekster dette tegn har indgået i, og ville kunne tænkes at komme til at indgå i i fremtiden. For kun ved at beskrive ordet i den konkrete kontekst for dets brug, kan vi forstå dets konkrete betydning.

I et forsøg på at skildre ideen om betydningsdannelsen som en uendelig semiosis grafisk, griber Eco tilbage til Ross M. Quillians model over den semantiske erindring, som han kalder 'model Q': » Model Q består af en mængde indbyrdes sammenvævede knuder, som er forbundet til hinanden gennem forskellige associative relationer " (Eco 1977, 193. Min oversættelse). Ifølge denne model kan ethvert tegn betragtes som en type, dvs. et encyklopædisk opslag, som interpretanterne bliver tokens i forhold til. Hvert token kan derefter etableres som ny type og så fremdeles i en uendelig semiosis (for en beskrivelse af disse begreber hos Peirce, se s. 28).

\footnotetext{
${ }^{12}$ Et fuldstændig tilsvarende forhold gør sig gældende i Mikhail Bakhtins beskrivelse af forholdet mellem langue og parole: "With respect to real utterances and real speakers, the system of a language is purely potential «(Bakhtin I986, I I 8). Se afsnittet om Bakhtins tegnbegreb senere i dette kapitel (se s. 44 ff.).
} 
Denne model er, ifølge Eco, så kompleks, at den ikke retfærdigt ville kunne skildres grafisk, og dårligt nok i form af en tredimensionel model. Selv giver Eco forskellige bud på metaforer for en repræsentation af koden: en æske med små magnetiske metalkugler som alt efter omstændighederne kan antage forskellig konstellation, men ikke alle konstellationer (Eco 1977, I96) eller en labyrint af form som et vidt forgrenet rodnet uden centrum og med en kaotisk struktur, hvor hvert punkt er forbundet med et optimalt antal af andre punkter (Eco I983, $80 \mathrm{ff}$.).

Som inspiration for dette billede henviser Eco til Gilles Deleuze og Félix Guattaris beskrivelse af 'rhizomet'. Et rhizom er et kaotisk og layrintisk rodnet uden centrum, og uden en klar afgrænsning af indre og ydre. I rhizomet kan ethvert punkt forbindes med et hvilket som helst andet punkt, og det er ikke muligt at lave en samlet beskrivelse af det - ikke mindst fordi det ændrer form over tid (ibid.). Med afsæt i denne metafor beskriver Eco det semiotiske univers i fem punkter (op.cit. 83-84):

- It is structured according to a network of interpretants.

- It is virtually infinite because it takes into account multiple interpretations realized by different cultures.

- It does not register only 'truths' but, rather, what has been said about the truth or what has been believed to be true as well as what has been believed to be false and legendary.

- Such a semantic encyclopedia is never accomplished and exists only as a regulative idea.

- Such a notion of encyclopedia does not deny the existence of structured knowledge.

Ifølge Eco betyder denne komplekse beskrivelse af koden som en encyklopædisk labyrint eller et rhizom at vi, i stedet for én kode der sammenknytter koderne ${ }^{13}$ i udtryk og indhold, må opfatte betydningstilskrivelsen som en række samvirkende koder eller subkoder af forskellig styrke, som kun tilsammen, og med udgangspunkt i sprogets diskursive realisation, producerer betydning. Hvor strukturalismens træstruktur i sin intention er stabil, logisk ordnet og konsekvent, dér er rhizomet som semantisk struktur kaotisk og flydende, idet vi fra en hvilken som helst position kan bevæge os i hvilken som helst retning, afhængig af den

\footnotetext{
${ }^{13}$ Eco ( I977) skelner mellem egentlige tegnkoder og det han kalder 'S-koder' eller systemer. En S-kode er en systematisk ordning af et kontinuum af fænomener eller tilstande, begge mentale eller fysiske, der gennem den relative position i systemet udpeger visse elementer som relevante og andre ikke. Fonemernes distinktive træk og semernes binære strukturer kan være eksempler fra hhv. udtryks- og indholdsplanet på sådanne S-koder. Ifølge Eco forbinder en egentlig tegnkode to eller flere S-koder, således at betydningstilskrivningen ikke længere kun er relativ, men absolut i den forstand, at den ene S-kode tilfører den anden selvstændig anden betydning.
} 
konkrete situation hvori sproget bruges. Først i den diskursive realisation aktiveres lokale udsnit af det encyklopædiske potentiale, hvilket vil sige at det er konteksten, såvel den tekstuelle som den ekstratekstuelle, der gør modtageren i stand til at opstille den semantisk-pragmatiske ramme, som tillader ham at selektere i det kaotiske potentiale.

\section{Semiosis som dialog}

Som det vil være fremgået er Peirces opfattelse af semiosis grundlæggende processuel og dialogisk, idet tegnet defineres som en treenighed af repræsentamen, objekt og interpretant. Interpretanten er selv et nyt tegn, der etablerer sig som et repræsentamen, der igen determinerer en ny interpretant og så fremdeles. Semiosis er således bundet til en processuel udspændthed i tid, og dynamikken er kommunikativ og dialogisk. Det er imidlertid vigtigt at slå fast, at dialog-begrebet her skal forstås som en metafor for den processuelle tegnudveksling, der ikke nødvendigvis er bundet til den menneskelige kommunikation og bevidsthed. Semiosis, eller tankevirksomhed og -udveksling gennem tegn, er for Peirce noget, som gennemsyrer hele den fysiske verden:

Thought is not necessarily connected with a brain. It appears in the work of bees, of crystals, and throughout the purely physical world; and one can no more deny that it is really there, than that the colors, the shapes, etc., of objects are really there $(\mathrm{CP} 4.55 \mathrm{I})$.

Dette synspunkt, som overbevisende er blevet fulgt op af folk som f.eks. Thomas Sebeok, Jesper Hoffmeyer og Claus Emmeche, forstår naturens processer i billedet af den menneskelige kommunikation. Den nærliggende anklage for antropomorfisme tager Peirce selv roligt. Han anser det ikke for et problem at tolke den fysiske og biologiske verdens processer $\mathrm{i}$ begreber afledt af den menneskelige tænkning, al den stund den menneskelige tænkning selv er en del af den samme semiosis som præger naturens verden. Ganske vist er den menneskelige tænkning den højest udviklede og mest selvstændiggjorte form for semiosis verden endnu har kendt, men selv de mest elementære biologiske processer kan forstås igennem tegnets tredelte relation (Peirce 1976). Derfor er også selve den den menneskelige tænkning underkastet den samme dialogiske form: »It should never be forgotten that our own thinking is carried on as a dialogue $($ CP 5.556).

Opfattelsen af tænkningen som værende dialogisk i sin form kan føres tilbage til antikken, hvor bl.a. Platon forfægtede et lignende synspunkt i de sokratiske dialoger, men vi skal frem til Peirce omkring skiftet til det 
tyvende århundrede før denne indsigt knyttes sammen med en almen semiotisk teori om betydningsdannelsen. Og selv for Peirces vedkommende ser det ud til at selve dialog-metaforen først optræder i den senere del af hans skrifter, dvs. fra omkring århundredeskiftet og frem, selv om hans tegnbegreb fra starten kan siges at have indeholdt den dialogiske relation. Den menneskelige tænkning bliver fra dette tidspunkt og frem beskrevet som en indre dialog mellem forskellige instanser af det menneskelige subjekt:

[T]hinking always proceeds in the form of a dialogue -- a dialogue between different phases of the ego -- so that, being dialogical, it is essentially composed of signs, as its matter, in the sense in which a game of chess has the chessmen for its matter ( $\mathrm{CP} 4.6)$.

De kultursemiotiske implikationer af det dialogiske subjektsbegreb vil blive taget op i Kapitel II. På dette sted skal vi nøjes med at konstatere, at tænkningen som fortløbende proces, ifølge Peirce, i sig selv er dialogisk organiseret, og at hans bredt anlagte semiotik gør det muligt for ham at se tænkningen som en dialogisk udveksling mellem tegn af forskellig observans og erkendelsesform:

All thinking is dialogic in form. [...] Consequently, all thinking is conducted in signs that are mainly of the same general structure as words; those which are not so, being of the nature of those signs of which we have need now and then in our converse with one another to eke out the defects of words, or symbols. These non-symbolic thought-signs are of two classes: first, pictures or diagrams or other images (I call them Icons) such as have to be used to explain the significations of words; and secondly, signs more or less analogous to symptoms (I call them Indices) of which the collateral observations, by which we know what a man is talking about, are examples (CP 6.338).

Selv om den menneskelige tænkning hovedsageligt foregår i sproglige termer, forestiller Peirce sig at det er nødvendigt, at den sprogligtsymbolske diskurs suppleres med ikoniske og indeksikale betydningsindhold, og at denne udveksling mellem forskellige tegnformer antager dialogens karakter.

Jørgen Dines Johansen har i bogen Dialogic Semiosis foretaget den hidtil mest gennemgribende udlægning af Peirces semiotik ud fra en overgribende dialogisk forståelse, og har i den forbindelse udviklet den semiotiske pyramide som en modellering af kommunikationsprocessen på dialogisk-semiotisk grundlag (Johansen I993, 245 ff. og igen 2002, 54 ff.). I stedet for blot at lade tegnrelationen mellem repræsentamen, objekt og interpretant repræsentere i form af en traditionel trekantsrelation, 
kombinerer Dines Johansen denne tegnrelation med positioner fra Peirces skelnen mellem den intentionelle, den effektuelle og den kommunikative interpretant:

There is the Intentional Interpretant, which is a determination of the mind of the utterer; the Effectual Interpretant, which is a determination of the mind of the interpreter; and the Communicational Interpretant, or say the Cominterpretant, which is the determination of that mind into which the minds of utterer and interpreter have to be fused. This mind may be called the commens (Peirce 1977, I95).

Dines Johansen mener nu at denne skelnen lader sig kombinere med Peirces skelnen mellem den umiddelbare, den dynamiske og den finale interpretant. Ifølge Dines Johansen forudsætter den intentionelle interpretant den umiddelbare, mens den effektuelle er en specificering af den dynamiske interpretant. Den kommunikative interpretant er imidlertid forskellig fra den finale interpretant, idet dét, som parterne i en dialog måtte enes om, ikke nødvendigvis er det sidste ord som kan siges om den sag (Johansen 2002, 46-47). ${ }^{14}$ Fordelen ved at kombinere de to trikotomier er indlysende al den stund det tillader en sammentænkning af tegnets elementære betydningsrelation med kommunikationsprocessens agenter, om end den uens relation positionerne imellem (forudsætning, inklusion og divergens) skæmmer billedet.

Det kan desuden diskuteres hvorvidt Dines Johansens udlægning af Peirces kommunikative cominterpretant eller commens i Literary Discourse er helt dækkende. Dines Johansen slår fast at der på ingen måde er tale om en mysticisme, men om en mulighed for logisk konklusion på en dialog forstået som en rationelt organiseret proces (inferential process), hvilket ideelt set vil sige noget i retning af en forskningsmæssigt tilrettelagt undersøgelse. Derfor slår Dines Johansen da også til lyd for, at »nothing guarantees the attainment of the cominterpretant in dialogue [...] although it would be strange to deny its possibility « (Johansen 2002, 48). Kominterpretanten bliver en slags konsensus som i visse tilfælde kan opnås på baggrund af en systematisk tilrettelægning af dialogen, og med en rent lokal rækkevidde. Heroverfor fastslår Peirce selv i den citerede tekst, at »no object can be denoted unless it be put into relation to the object of the commends " (Peirce 1977, 197). Dermed antydes at kominterpretanten er af almen karakter og kan forstås som noget i retning af et semiotisk rum, evt. svarende til Lotmans begreb om semiosfæren (se

\footnotetext{
${ }^{14}$ I Dialogic Semiosis sammentænker Jørgen Dines Johansen disse to interpretantkategorier med the essential, informed og substantial interpretant (Johansen I993, I7 I ff.).
} 
nedenfor s. 55). Dette aspekt af kominterpretanten er imidlertid heller ikke helt fremmed for Dines Johansen, idet han selv anfører, at begrebet peger på at vi »inescapably belong to an indefinite number of systems and processes of signification while we, at the same time, make up our own unique system " (Johansen 2002, 47).

Det som jeg imidlertid ønsker at forfølge på dette sted, er den måde Dines Johansen understreger tegnudvekslingens dialogiske karakter ved at kombinere tegnbegrebets elementære kategorier (repræsentamen eller tegn, objekt og interpretant) med positionerne i den traditionelle kommunikationsmodel, afsender, meddelelse og modtager (Jakobson I98I, bd. III, 22). Dines Johansen kombinerer de to registre på en sådan måde, at relationerne falder sammen i tegnet / meddelelsen og adskiller sig i fire distinkte positioner i pyramidens bund (Dines Johansen I993, 246):

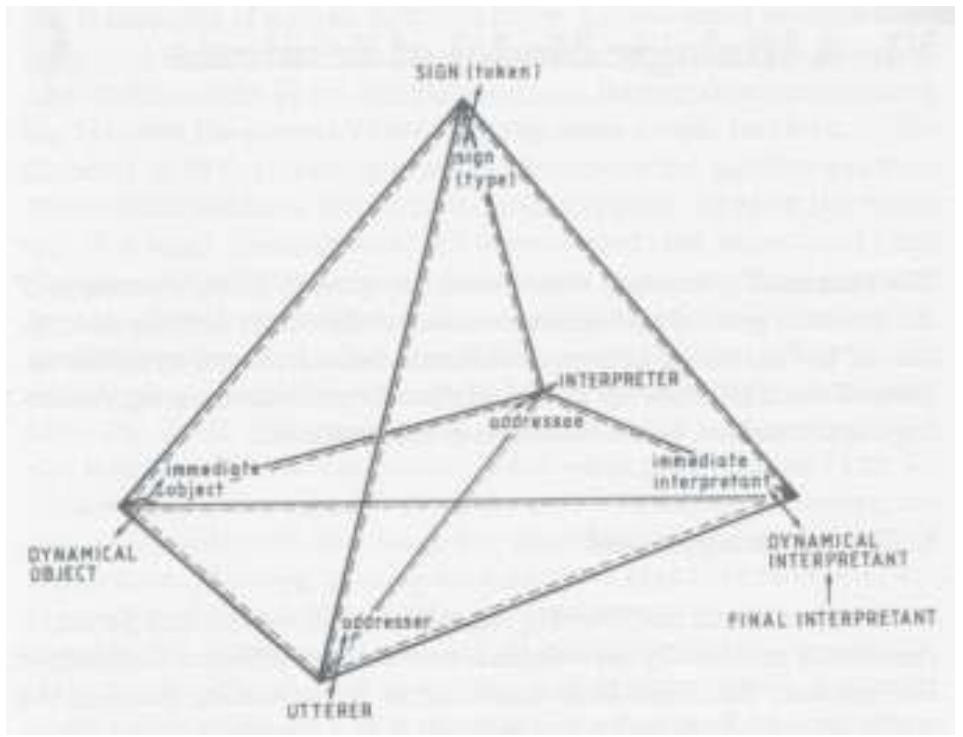

En styrke ved modellen er, at den inkorporerer en skelnen mellem to kommunikative niveauer, svarende til Peirces skelnen mellem det umiddelbare og det dynamiske niveau i både objekt- og interpretantkategorien. Dines Johansen skelner således mellem det, han kalder the adresser, som er den måde afsenderen er diskursivt konstrueret i teksten, og the utterer, som er den empiriske afsender af kød og blod. På tilsvarende måde skelner han mellem the adressee, der svarer til modtagerpositionen som 
den er konstrueret af teksten, og the interpreter, der modsvarer den empiriske læser. Vi har således at gøre med en model som ikke bare sammentænker Peirces tegnbegreb og Jakobsons kommunikationsmodel, men som netop derigennem skaber teoretisk grundlag for at operere med kendte litteraturvidenskabelige distinktioner, såsom distinktionen mellem forfatter og implicit fortæller, mellem Wolfgang Isers begreber læser og implicit læser (Iser I980) eller mellem Umberto Ecos begreber empirisk forfatter og modelforfatter, empirisk læser og modellæser (Eco, I98 I). Skulle man kritisere modellen for noget, måtte det være for at udkrystallisere eller 'fryse' et moment af den løbende dialogiske proces som et fragment, dvs. for at den ikke skildrer den dynamiske omvending af interpretanten i et nyt tegn som igen bliver udgangspunktet for en semiotisk relation. Denne kritik retter sig imidlertid eksklusivt mod modellen som grafisk repræsentation, da Dines Johansen i sin tekst vedholdende understreger dette forhold.

På trods af at Peirces tegnbegreb grundlæggende er processuelt og kommunikativt defineret, og at dialog-metaforen især i Peirces senere skrifter kommer til at indtage en så central placering som den gør, så tager Peirce imidlertid ikke selv skridtet til at generalisere metaforen til et begreb. Begrebet 'dialogisme' reserveres hos Peirce til en meget mere specifik funktion, nemlig som betegnelse for en bestemt type argument, dvs. en logisk operation som, modsat syllogismen, består i at aflede to konklusioner af en enkelt præmis:

[A]ny argument may be resolved into arguments, each of which has one premiss and two alternative conclusions. Such an argument, when complete, may be called a dialogism (CP 3.I72).

Selv om Peirces semiotik har haft en afgørende indflydelse på den teoretiske hovedlinje som præger hele denne bog, vælger jeg ikke at følge ham i denne udlægning af dialogisme-begrebet. Men på linje med Dines Johansen vælger jeg at forstå hele Peirces tænkning som værende grundlæggende dialogisk, og jeg vil forsøge at bruge dialogisme-begrebet til at knytte forbindelseslinjer mellem Peirces semiotik og andre semiotiske tilgange, som, op igennem det tyvende århundrede, har anvendt dialogmetaforen på en tilsvarende måde i beskrivelsen af de kommunikative former, først og fremmest Mikhail Bakhtin og Jurij Lotman. 


\section{Mikhail Bakhtins tegnbegreb}

Der er intet som tyder på at Charles Peirce og Mikhail Bakhtin havde noget kendskab til hinanden. Peirce døde i I9I4, altså inden Bakhtin overhovedet begyndte at skrive, og så vidt vides kendte Bakhtin heller ikke noget til Peirce - i hvert fald skriver han ikke noget om det. Formentlig har han haft kendskab til Peirce gennem Roman Jakobsons skrifter, men jeg har ingen konkrete indikationer på det. På trods af deres forskellige udgangspunkter har de to tænkere tilstrækkeligt mange teoretiske forudsætninger til fælles, til at kunne berige hinanden indbyrdes. At udfolde denne hypotese for alvor er en spændende udfordring, som måtte involvere begge tænkeres teorikomplekser i deres helhed, og som følgelig falder noget uden for denne bogs rammer. Dette arbejde er imidlertid allerede $\mathrm{i}$ et vist omfang påbegyndt af italieneren Augusto Ponzio, og selv om jeg ikke til fulde deler hans noget relativistiske tilgang, vil jeg i det følgende støtte mig til hans resultater i et vist omfang (Ponzio I990, I995 og I998).

Bakhtins sprogfilosofi tager afsæt $\mathrm{i}$ en diskussion af Saussures landvindinger inden for lingvistikken og af de senere fortolkninger heraf. Det gælder ikke mindst den russiske formalisme som Bakhtin selv havde tæt inde på livet, men også de strukturelle lingvister der koncentrerede deres arbejde eksklusivt om beskrivelsen af langue eller sprogsystemet. Over for denne, i Bakhtins terminologi 'traditionelle' lingvistik, argumenterer han selv for nødendigheden af at studere det levende sprog, parole eller sprogbrugen. Og som studieobjekt er dette 'sprog i brug' fundamentalt anderledes end sprogsystemet, da sproget opfattet som kommunikativ handling er at forstå som nyt og enestående hver gang processen gennemløbes - også selv om det handler om læsningen af skrevne tekster, der som fysisk objekt betragtet må siges at være det samme: »The reproduction of the text by the subject is a new, unrepeatable event " (Bakhtin I986, I06). Bakhtin beskæftiger sig altså med sprog som led i en kommunikativ handlen, og på dette punkt ligger hans sprogfilosofi tæt op ad Charles Peirces semiotik, som vi har set også studerer tegnene i deres kommunikative brug. Tzvetan Todorov går så langt som til at udnævne Bakhtin til pragmatikkens grundlægger, en betegnelse som ellers ofte bruges om Peirce (Todorov I984, 24).

Som talens mindstelement udpeger Bakhtin diskursen eller ytringen, the utterance: ${ }^{15}$ »The real unit of speech communication: the utterance "

\footnotetext{
${ }^{15}$ Bakhtin bruger på russisk ordet vyskazyvanie, som i de engelske oversættelser jeg har været henvist til at konsultere oversættes med utterance. Men, som Rigmor Kappel Schmidt gør
} 
(Bakhtin I986, 7I). Hvad Bakhtin gør her, er ikke blot at modstille den traditionelle lingvistiks mindste betydningsenheder, morfemerne, med mere komplekse, makrosekventielle størrelser som sætninger, men at modstille studiet af sproget som system (langue), dets morfologi og syntaks mv., med sproget som et kommunikativt instrument (parole). Således modstiller han sætningen og ytringen som tilhørende hvert sit register: "the sentence as a unit of language, as distinct from the utterance as a unit of speech communication « (op.cit. 73). Det er med andre ord måden objektet betragtes på og ikke karakteren af det studerede objekt, der skaber forskellen mellem sproglige sætninger og diskursive ytringer: »[D]iscourse, that is, language in its concrete living totality, and not language as the specific object of linguistics (Bakhtin I984, I8I).

Hos Bakhtin finder vi således også pragmatikkens forestilling om at sprogets betydning altid er lejret i en historisk-kulturel kontekst. Denne kontekst er imidlertid også selv af først og fremmest sproglig karakter, båret af sprogets historiske, kulturelle og sociale funktion i form at noget som kunne minde om Lotmans semiosfære (se herom s. 55):

The word in language is half someone's else's. It becomes 'one's own' only when the speaker populates it with his own intention, his own accent $[\ldots]$ adapting it to his own semantic and expressive intention. Prior to this moment of appropriation the word does not exist in a neutral and impersonal language [...], but rather it exists in other people's mouths, in other people's contexts, serving other people's intentions: it is from there one must take the word and make it one's own (Bakhtin I98 I, 293-94).

Man skal ikke lade sig vildlede af den engelske oversættelse af det russiske ord slovo til the word. Med udtryk som the word eller living speech henviser Bakhtin altid til sprogbrugen, og altså hverken til det enkelte ord alene, eller til talen over for den skriftsproglige kommunikation. Således er betydningen af citatet, at sproget, når vi bruger det i vores konkrete, daglige kommunikation, altid er præget af den stabilitet, som den kulturelle tradition eller semiotiske vane har forlenet det med. Ved visse lejligheder ekspliciterer Bakhtin denne betydningsstabilisator i form af billedet af en tredje og upersonlig deltager i samtalen, der nærmest står over de dialogerende:

opmærksom på, kan utterance eller det danske 'ytring' ikke rumme alt det som Bakhtin henregner til vyskazyvanie, hvorfor Kappel Schmidt foretrækker at tale om 'udsigelse' (Schmidt 2003, I IO, 70n.). For mit eget vedkommende foretrækker jeg at anvende begrebet 'ytring', både fordi utterance er blevet internationalt anerkendt uden for russisktalende kredse af Bakhtinforskere, men også fordi termen 'udsigelse' har sin egen fastlagte betydning som litteraturvidenskabeligt begreb. 
Each dialogue takes place as if against a background of the responsive understanding of an invisibly present third party who stands above all the participants in the dialogue $[\ldots]$ the aforementioned third party is not any mystical or metaphysical being $[\ldots]$ he is a constitutive aspect of the whole utterance $[\ldots]$ (Bakhtin I986, I26-27).

Men samtidig med at den historiske brug af sproget forlener det med en betydningsmæssig stabilitet eller semiotisk vanedannelse, så er sprogbrugen altid konkret og specifikt tilknyttet en diskursiv udsigelsesposition: "All languages of heteroglossia [...] are specific points of view on the world « (Bakhtin I98I, 29I). I en vis forstand kan man sige at Bakhtin opfinder diskursbegrebet og grundlægger principperne for diskursanalysen, blot kalder han de normsæt, som fungerer som regulerende og formgivende principper for diskurserne, for 'talegenrer'. Talegenrerne taler / skriver sig altid ind i bestemte sociokulturelle sammenhænge eller institutioner, og hver epoke, hver kultur og hver social sammenhæng har sin måde at forme de diskurser, som indgår i dem, hvorfor der i enhver sammenhæng tales distinkt og genkendeligt:

All words have the 'taste' of a profession, a genre, a tendency, a party, a particular work, a particular person, a generation, an age group, the day and hour. Each word tastes of the context and contexts in which it has been lived its socially charged life; all words and forms are populated by intentions (Bakhtin I98 I, 293).

Det er endvidere diskursens udspring i en konkret, kommunikativ handlen der giver den dens referentielle rettethed: »Each utterance is characterized primarily by a particular referentially semantic content " (Bakhtin I986, 84). Sætningen, dvs. sproget forstået som et rent studieobjekt revet bort fra dets kommunikative funktion og løsrevet fra dets kontekst, har ingen referentiel mening, kun strukturel betydning. Men i kraft af sprogets nedsænkning i den kommunkative brug, tager det også farve af afsenderens forhold til det omtalte: »Thus, the utterance, its style, and its composition are determined by its referentially semantic element (the theme) and its expressive aspect, that is the speaker's evaluative attitude toward the referentially semantic element in the utterance" (Bakhtin I986, 90).

På alle disse punkter er der overensstemmelse mellem Bakhtins diskursbegreb og Charles Peirces tegnbegreb, men de to adskiller sig i kraft af Bakhtins polemiske forhold til Saussures lingvistik, der binder hans egne undersøgelser til tekster konstrueret på baggrund af sproglige tegn. Man kan sige at dette 'negative' udgangspunkt ikke tillader ham at udvide 
tegnbegrebet ud over det rent sproglige tegn i teoretisk forstand, om end hans udvidede tekstbegreb også omfatter andre typer af kreative udtryk:

[I] f the word 'text' is understood in the broad sense - as a coherent complex of signs - then even the study of art (the study of music, the theory and history of fine arts) deals with texts (works of art) (Bakhtin I986, I03).

Her kommer Peirces fænomenologisk baserede tegnbegreb ind som en frugtbar åbning af diskursbegrebet i forhold til andre typer af kommunikative sammenhænge og udtryk: visuelle, auditive, kropslige, gestiske tegn osv. Peirces semiotik har, som jeg har været inde på, rødder i hans almene videnskabsteoretiske filosofi og kosmologi, hvilket giver den en, om muligt, større bredde og et større udsyn end Bakhtins. Men Peirces afsæt i I 800 -tallets naturvidenskabelige tradition giver samtidig hans tænkning et lidt optimistisk 'sten-på-sten' perspektiv for videnskabelige fremskridt. Heroverfor understreger Bakhtin diskursernes modsætningsfyldthed og indbyrdes konflikt, også de videnskabeliges, og han betoner diskursernes sammenhæng med de sociale og kulturelle forhold som de udspringer af. For Bakhtin er sproget, forstået som diskursive ytringer i kommunikativ handlen, altid unikt og nyskabende, og altid snævert forbundet med en værdimæssig stillingtagen:

An utterance is never just a reflection or an expression of something already existing and outside it that is given and final. It always creates something that never existed before, something absolutely new and unrepeatable, and, moreover, it always has some relation to value (Bakhtin I986, I19-20).

Bakhtins fokus på diskursen adskiller således hans sprogbegreb fundamentalt fra den strukturelle lingvistiks interesse for de gentagelige lovmæssigheder og knytter sproget sammen med kulturelle praksisformer og sociale institutioner. Denne forskel mellem en søgen efter det gentagelige og en søgen efter det unikke er ikke kun et spørgsmål om valg af studieobjekt, men vedrører et grundlæggende epistemologisk spørgsmål om hele den videnskabelige praksis' mål: sandheden.

It is an unfortunate misunderstanding (a legacy of rationalism) to think that truth can only be the truth that is composed of universal moments; that the truth of a situation is precisely that, which is repeatable and constant in it (Bakhtin I993, 37).

For Bakhtin er al videnskabelig søgen efter sandhed, inklusive hans egen sprogfilosofi og litteraturkritik, således indskrevet i nogle historiske og 
kulturelt bestemte magtforhold, som det er nødvendigt at medtænke i behandlingen heraf. Kritikken rammer, naturligt nok, først og fremmest den forudgående 'traditionelle' lingvistik og stilistik:

Linguistics, stylistics and the philosophy of language that were born and shaped by the current of centralizing tendencies in the life of language have ignored dialogized heteroglossia [...] For this very reason they could make no provision for the dialogic nature of language, which was a struggle among socio-linguistic points of view, not an intra-language struggle between individual wills [...] (Bakhtin I98I, 273).

Begrebet 'heteroglossia' er for Bakhtin både et historisk og et normativt begreb, dvs. det er rettet både mod en beskrivelse af sproget som sådan (filosofisk) og mod den empiriske beskrivelse af en bestemt kulturel sprogbrug. Begrebet kan referere til forekomsten af forskellige nationalsprog, sociolekter, registre, talegenrer osv., som kombineres dialogisk i en given diskurs. Således peger Bakhtin på at tilstedeværelsen af heteroglossia altid afspejler sameksistensen af socio-ideologiske modsætninger mellem nutid og fortid, mellem fortidens forskellige epoker og mellem nutidens socioideologiske grupperinger og tendenser osv., idet de alle repræsenterer en synsvinkel på verden (se også nedenfor Kapitel IV, s. 2 I 3 ff.). Når Bakhtin kritiserer den traditionelle stilistik for at ignorere eksistensen af de heteroglotte relationer, mener han at stilistikken erstatter analysen af romanens stilistiske orkestrering af historisk og kulturelt specifikke måder at bruge sproget på med beskrivelsen af én bestemt forfatters sprog. Stilistikken analyserer med andre ord en af romanens diskurser (typisk fortællerens), som om den var repræsentativ for romanen som helhed:

Equally in both cases, style is understood in the spirit of Saussure: as an individualization of the general language (in the sense of a system of general language norms) (Bakhtin I98I, 264).

Det, som Bakhtin anser for at være den traditionelle stilistiks største begrænsning i behandlingen af de analyserede tekster, er at den reducerer det litterære værk til et selvstændigt mikrosystem svarende til sprogsystemet. Derved forhindrer den traditionelle stilistik at man får greb om værkets indre dialogiske relationer mellem forskellige typer af sprogbrug:

The system comprising an artistic work was thought to be analogous with the system of language, a system that could not stand in a dialogic interrelationship with other languages (Bakhtin I98I, 273-74). 
Det, som kritiseres her, er bl.a. den strukturalistiske tilgang til litteraturstudierne, der overtager forestillingen om et bagvedliggende lukket system fra lingvistikken og applicerer dette på det litterære værkbegreb:

From the point of view of stylistics, the artistic work as a whole - whatever that whole might be - is a self-sufficient and closed authorial monologue, one that presumes only passive listeners beyond its own boundaries (Bakhtin I98 I, 274).

Den reduktion, som den strukturelle tilgang indebærer, reducerer teksten til en monologisk diskurs, hvorved tekstens iboende dialogiske spil på forskellige stemmer og deres indbyrdes forhold går tabt. Og det er denne betydningens grundlæggende dialogiske karakter der optager Bakhtin, hvad enten han beskæftiger sig med sprogfilosofi, litteraturkritik eller videnskabsteori. Det skal vi vende tilbage til nedenfor.

\section{Dialogismebegrebet hos Bakhtin}

Vi har ovenfor været inde på, hvordan Bakhtin på den ene side tager sit udgangspunkt i forståelsen af det sproglige tegn i Saussures to-delte tegnbegreb, og hvordan han på den anden side gør op med den strukturelle lingvistiks optagethed af sprogkoden for at fokusere på det han kalder den levende diskurs. Hvad der måske ikke har været tilstrækkeligt betonet indtil nu er at sprogbrugen, eller diskursen, også for Bakhtin altid er dialogisk i sin orientering:

The dialogic orientation of discourse is a phenomenon that is, of course, a property of any discourse [...]. Only the mythical Adam, who approached a virginal and as yet verbally unqualified world with the first word, could really have escaped from start to finish this dialogic inter-orientation with the alien word that occurs in the object (Bakhtin I98I, 279).

Sproget har altid allerede været brugt om verden, det er $i$ verden forud for den konkrete diskursive italesættelse af verden, og dermed er sproget også præget af den sociale og historiske formningsproces, som det har gennemløbet. Som Michael Holquist påpeger, adskiller Bakhtins sprogopfattelse sig på dette punkt fra Saussures. Hvor Saussure skelner mellem sprogbrugen som knyttet eksklusivt til den individuelle sprogbruger og sprogsystemet som knyttet til både individet og det sociale, dér søger Bakhtin at skildre det man kunne kalde en kulturel eller social dimension i sprogbrugen (Holquist I990, 45).

Det forhold at ingen ytring fremstår som jomfrueligt ny, men altid indgår $\mathrm{i}$ en dialogisk relation til det som har været ytret tidligere om 
samme emne, kalder Bakhtin at der altid er et 'fremmed ord' $i$ objektet. De fremmede ord i objektet er altså diskurser som har været talt og skrevet om det omhandlede emne forud for den givne kommunikation. I denne forstand er tegnets betydning altid intertekstuelt bestemt. Ethvert tegn, enhver tekst, medtager altid andre, forudgånde tekster som en del af deres reference (Todorov I984, 60). Bakhtin siger herom at sprogbrugen er dialogisk rettet bagud mod fortiden. Men sprogets dialogiske karakter er dobbelt, for ud over at være bagudrettet, er det også rettet fremad mod fremtiden.

[The word] encounters an alien word not only in the object itself: every word is directed toward an answer and cannot escape the profound influence of the answering word that it anticipates (Bakhtin I98 I, 280).

I vores konkrete sprogbrug er afsenderen altid opmærksom på den kommunikation som har gået forud omkring det emne der tales eller skrives om, hvorfor han eller hun uundgåeligt tilrettelægger diskursen retorisk med sigte på at anticipere modtagerens fremtidige reaktion. Tilsvarende er modtagerens tolkning af diskursen, ifølge Bakhtin, altid kun at betragte som første skridt i formuleringen af et svar:

Thus, all real and integral understanding is actively responsive, and constitutes nothing other than the initial preparatory stage of a response (in whatever form it may be actualized). And the speaker himself is oriented precisely toward such an actively responsive understanding [...] Moreover, any speaker is himself a respondent to a greater or lesser degree. He is not, after all, the first speaker, the one who disturbs the eternal silence of the universe (Bakhtin I986, 69).

Bakhtins forståelse af dialogismen på tegnniveau ligger meget tæt op ad Peirces forståelse af tegnets indhold som oversættelsen af tegnet med et andet tegn i en uendelig semiosis (Holquist, 50). Peirce opererer således med den samme kommunikative rettethed i tegnet som Bakhtin, om end han som oftest formulerer sig på et mere overordnet plan: »If the series of succesive interpretants comes to an end, the sign is thereby rendered imperfect, at least " (CP 2.303), eller: »If the series is broken off, the Sign, in so far, falls short of the perfect significant character " (citeret efter Marty, definition nr. I3). Derved leder den dialogiske forståelse af tegnudvekslingen med nødvendighed frem til at semiosis bliver knyttet dialogisk til både fortid og fremtid som et moment $\mathrm{i}$ den i princippet uendelige kæde af tegntolkninger, der karakteriserer såvel verdens livsformer som menneskenes italesættelse heraf: 
$[\mathrm{A}] \mathrm{n}$ utterance is a link in the chain of speech communication, and it cannot be broken off from the preceding links that determine it both from within and from without, giving rise to unmediated responsive reactions and dialogic reverberations (Bakhtin I986, 94).

Den fortsatte dialogiske tegnudveksling i og omkring verden er imidlertid ikke at forstå som en ligegyldig og konsekvensløs plapren, men en semiosis drevet frem af en erkendelsesinteresse omkring verden. Verden er for såvel Bakhtin som Peirce et i semiotisk forstand dynamisk sted, og diskurserne $i$ og omkring verden er drevet frem, eller med Peirces ord ligefrem determinerede, af verdens påkalden sig en forståelse. Når vi taler, taler vi om verden, sproget refererer $t i l$ verden og giver os i et eller andet omfang en viden om verden, om end denne viden ikke nødvendigvis er entydig og monologisk.

The direct word, as traditional linguistics understands it, encounters in its orientation toward the object only the resistance of the object itself (the impossibility of its being exhausted by a word [...]), but it does not encounter in its path toward the object the fundamental and richly varied opposition of another's word. No one hinders this word, no one argues with it.

But no living word relates to its object in a singular way: between the word and its object, between the word and the speaking subject, there exists an elastic environment of other, alien words about the same object, the same theme $[\ldots]$

Indeed, any concrete discourse (utterance) finds the object at which it was directed already as it were overlain with qualifications, open to dispute, charged with value, already enveloped in an obscuring mist - or, on the contrary, by the 'light' of alien words that have already been spoken about it (Bakhtin I98I, 276).

Hvis Bakhtins måde at skelne mellem word og object forstås i lyset af Peirces skelnen mellem det umiddelbare- og det dynamiske objekt, kan man sige at så længe vi befinder os på niveauet for den umiddelbare interpretant, finder tegnet kun »the resistance of the object itself (the impossibility of its being exhausted by a word [...]) «, mens der på niveauet for den dynamiske interpretant melder sig en helt ny dimension i Bakhtins måde at anskue tingene, som vi ikke finder hos Peirce: »the fundamental and richly varied opposition of another's word «. Som vi har set er sprogbrugen for Bakhtin altid involveret i konkrete praksisformer og sociale institutioner, som igen er forankret i politiske magtrelationer. Derfor er diskursen altid distinkt genkendelig i kraft af sin form, og derfor er semiosis ikke en neutral eller rent abstrakt kategori, men at forstå som social interaktion: 
The relationship to other's utterances cannot be separated from the relationship to the object (for it is argued upon, agreed upon, views converge within it), nor can it be separated from the relationship to the speaker himself. This is a living tripartite unity. But the third element is still not usually taken into account. And even when it has been taken into account (in analysis of the literary process $[. .$.$] the special nature of relations toward other utterances as$ utterances, that is, towards semantic wholes, has remained disclosed and unstudied (Bakhtin I986, I22-23).

Bakhtins opfattelse af sprogets dialogiske karakter er filosofisk set baseret på en fænomenologisk tankegang, der har såvel eksistensfilosofiske som epistemologiske og videnskabsteoretiske implikationer. I bogen Dialogism formulerer Michael Holquist det således:

Dialogism, like relativity, takes it for granted, that nothing can be perceived except against the perspective of something else: dialogism's master assumption is that there is no figure without a ground. The mind is structured so that the world is always perceived according to this contrast (Holquist I990, 2 I-22).

Bakhtin kritiserer både formalismen, den traditionelle stilistik og strukturalismen for at reducere den analyserede tekst til en monologisk diskurs, hvormed han mener at tekstens iboende dialogiske spil på forskellige stemmer og deres indbyrdes forhold går tabt i læsningen. Vi skal i de følgende kapitler vende tilbage til nogle af disse problemstillinger og udfolde beskrivelsen af det dialogiske princip, men på dette sted vil det være hensigtsmæssigt at følge gennemgangen af tegnbegrebet til dørs med en kort behandling af Jurij Lotmans forståelse af de kommunikative processers komplekse asymmetriske relationer og hans indsættelse af den isolerede kommunikationsproces i en kulturelt-semiotisk kontekst, 'semiosfæren'.

\section{Jurij Lotmans begreb om tekstlig asymmetri}

Ligesom Bakhtin bygger Jurij Lotman i udgangspunktet sin semiotiske teori på Saussures binære tegnbegreb, idet han i de tidlige skrifter definerer tegnet som bestående af relationen mellem tegn og betegnet, eller mellem tegn og kode (Lotman I976, 46). Men hans position kan alligevel ikke bare karakteriseres som værende strukturalistisk, idet han ikke blot interesserer sig for tegnets og kodens (læs: betegner og betegnets) strukturelle organisering i teksten, men anlægger et funktionelt syn på kunsten (op.cit., 47 og 53). Imidlertid ser han tilsyneladende ikke selv i de 
tidlige tekster at disse to præmisser er $\mathrm{i}$ indbyrdes konflikt. Når det alligevel må hævdes at de er det, skyldes det det forhold, at der ikke opereres med en reference i Saussures binære tegnbegreb, kun en indholdsmæssig position som Saussure illustrerede med skakbrikkens valør. Til gengæld indser Lotman at han med sit funktionelle syn på litteraturen får de litterære tekster til at optræde dynamisk, dvs. han ophæver alle de statiske distinktioner, som den strukturelle tegnopfattelse foreskriver som virksomme for det almindelige sprog. I sine senere tekster betragter Lotman således også relationen mellem tekst og læser som en dialogisk relation, hvor læseren bidrager aktivt til etableringen af tekstens betydning:

A text behaves like a partner in dialogue: it re-orders itself (as far as its supply of structural indeterminacy allows) in the image of the readership. And the reader responds likewise, using his or her informational flexibility for the restructuring which will draw him or her closer to the world of the text (Lotman I990b, 80).

I sin senere produktion går Lotman derfor også ind i en kritik af de teoretiske forudsætinger bag Saussures eksklusive interesse for den sproglige kode som garanten for den effektive kommunikation:

For a fairly complex message to be received with absolute identity, conditions are required which in naturally occurring situations are practically unobtainable: addressee and addresser have to have wholly identical codes, i.e. to be in fact semiotically speaking a bifurcation of the same personality, for a code includes not only a certain binary set of rules for encoding and decoding a message, but also a multi-dimensional hierarchy (Lotman I990b, I3).

Her ser vi hvordan Lotman ikke længere betragter modtagerens semiotiske kompetence som en stabil, binært organiseret sproglig kode, men også inddrager et multidimensionelt netværk af betydningsrelationer, som udgør den baggrund fortolkningen foretages på. Afsender og modtager er ikke i besiddelse af den samme 'kode' eller semiotiske kompetence. Udtrykt i Umberto Ecos terminologi kan man sige at afsender og modtager ikke har banet nøjagtig de samme stier gennem rhizomet, den encyklopædiske labyrint der karakteriserer individets semiotiske kompetence, hvorfor, nu igen med Lotmans ord, »the identity of the transmitted and received text is relative " (ibid.). Der opstår en grundlæggende asymmetri i den dialogiske udveksling, som er basis for sprogets kreative funktion. Argumentet, som Lotman udfolder i begreber hentet fra oversættelsesdisciplinen, forløber som følger: en symmetrisk relation mellem afsender og 
modtager ville betyde at en oversættelse af tekst I til tekst 2 ville resultere i en tekst identisk med tekstI, hvis vi oversatte den tilbage igen. I virkelighedens verden vil vi imidlertid få en ny tekst3. Og grunden til det er at den asymmetriske relation mellem afsender og modtager indebærer at tekster ikke bare reproducerer en én gang fastlagt betydning, men hele tiden genererer ny betydning.

Et af de områder, hvor den asymmetriske relation gør sig stærkest gældende, er i oversættelsen mellem det, som Lotman karakteriserer som de diskrete og de non-diskrete diskurser. Lotman anser disse to typer af diskurser for at være konstituerende for den menneskelige bevidsthed:

[T]here are at least two essentially different ways of reflecting the world and working out new information [...] within one consciousness there are as it were two consciousnesses. The one operates as a discrete system of coding and forms texts, which come together like linear chains of linked segments. In this system the bearer of meaning is the segment (= the sign), while the chain of segments $(=$ the text) is secondary. In the second system the text is primary [...]. This text is not discrete but continuous (Lotman I990b, 36).

Der eksisterer en oplagt parallel mellem Lotmans teori om de kontinuerte og diskontinuerte diskurser og Peirces forestilling om at den menneskelige tænkning foregår som en dialogisk udveksling mellem symbolske, ikoniske og indeksikale tegn. Men hvor Peirce taler om en sådan dialogisk relation som en refleksionsform i subjektets indre dialog med sig selv, dér taler Lotman om hele tekster af forskellig karakter. De tekster, som i Lotmans beskrivelse er opbygget af diskrete og lineært segmenterede elementer, er i vid ustrækning at forstå som symbolske tekster i en peirceansk terminologi. Bag Lotmans non-diskrete og kontinuerte diskurser, hvor betydningen bliver båret af tekstens helhed, finder vi alle de komplekse og kunstneriske udtryk, spændende lige fra litterært billedsprog over maleriets canvas til scenerummet eller filmlærredet, som i vid udstrækning kan sammenlignes med Peirces ikoniske tegn. Der er dog to afgørende forskelle. For det første er Peirce opmærksom på forskellen mellem to forskellige typer af non-diskrete diskurser eller tegn, nemlig ikoniske og indeksikale tegn, og for det andet anser Peirce udvekslingen mellem de forskellige tegntyper for at være relativt uproblematisk, mens der for Lotman er tale om en fundamental asymmetri imellem de to diskursformer, og derfor også tale om en grundlæggende uoversættelighed. Men idet den menneskelige bevidsthed hele tiden udveksler information mellem de to niveauer, er der tale om en permanent betydningsgenererende dialog der konstant skaber ny mening kulturelt, historisk, diskursivt, socialt osv. 


\section{Jurij Lotmans semiosfærebegreb}

Som vi var inde på ovenfor, har Lotman en forestilling om at ny betydning udspringer af de semiotiske systemers asymmetri og genereres gennem den kulturelle praksis' dialogiske oversættelser fra en type diskurs til en anden:

Dialogue presupposes asymmetry, and asymmetry is to be seen first, in the difference between semiotic structures (languages) and second, in the altering directions of the message-flow (Lotman I990b, I 43).

Det enkelte subjekt er på den ene side præget af en indre dialog mellem diskrete og kontinuerte diskurser, og på den anden side præget af sin egen kultur, historie og sociale tilhørsforhold, der har formet subjektets diskursive register og semiotiske system. Desuden er subjektet aktivt dialogerende i forhold til den omgivende verdens kakofoni af forskelligartede og hybride diskurser, der igen virker tilbage på udviklingen af de semiotiske systemer selv: "semiotic systems are in a state of constant flux " (Lotman I990b, I 5 I). Dette komplicerede system kan ikke repræsenteres af en simpel kommunikationsmodel, og selv ikke den semiotiske pyramide slår til her; i stedet må der, ifølge Lotman, anlægges et holistisk syn på de kommunikative processers samspil med de kulturelle formationer.

Ifølge Lotman er det et fællestræk ved både Saussures og Peirces traditioner at de tager udgangspunkt i 'det atomare', dvs. i den isolerede tegnrelation eller den enkelte tegnudvekslingsproces, hvilket giver disse traditioner et problem $\mathrm{i}$ forhold til at forstå de semiotiske systemer og diskurser i deres komplicerede samspil (Lotman I990a, 288). Vi har imidlertid allerede været inde på, hvordan Charles Peirces semiotik er forankret i en overgribende fænomenologi og kosmologi, som de enkelte tegnprocesser ikke kan forstås uafhængig af, jf. også hans begreb om the commens. Således fortæller Lotmans synspunkt muligvis mere om, at hans kendskab til Peirce formentligt går over hans læsning af Charles Morris og evt. Roman Jakobson, end det siger noget om Peirces semiotik. Men baggrunden for overvejelsen, hensynet til at den enkelte kommunikative proces skal indsættes eller 'nedsænkes' i et generelt semiotisk 'rum' for at blive forstået i sin kompleksitet, er frugtbar:

[I virkeligheden] gives der slet ingen tegnsystemer som fungerer helt præcist og funktionelt entydigt $\mathrm{i}$ isoleret form [...]. De fungerer kun fordi de er involveret $i$ et bestemt semiotisk kontinuum (Lotman I990a, 288. Min oversættelse). ${ }^{16}$

\footnotetext{
${ }^{16}$ Teksten lyder således på tysk: "[In der Wirklichkeit kommen] keine Zeichensysteme vor, die völlig exakt und funktional eindeutig und in isolierter Form für sich allein funktionieren [...]. Sie funktionieren nur, weil sie in ein bestimmtes semiotisches Kontinuum eingebunden sind «.
} 
Lotman foreslår at anvende begrebet 'semiosfære' som en metafor til beskrivelse af denne proces af konstant semiotisk udveksling og oversættelse mellem forskellige typer diskurser og flux mellem semiotiske systemer. Semiosfæren er, ifølge Lotman, at betragte som semiosis' mindsteenhed. Det er hverken tegnet eller det enkelte sprog, men deres samvirken $i$ en semiosfære som på én gang er resultatet af og forudsætningen for kulturel udvikling (Lotman I990b, I 25).

Semiosfærebegrebet er inspireret af den russiske naturvidenskabsmand V.I. Vernadskijs begreb om 'biosfæren' (Lotman I990a, 289 og I990b, I 25). Ifølge Vernadskij kan biosfæren betragtes som en levende organisme, der har udviklet sig over millioner af år, og som inkluderer hele hydrosfæren, atmosfæren op til ca 30 kilometers højde og jordskorpen ned til ca. to til tre kilometers dybde, hvor der endnu er levende bakterier at finde. Inden for denne biosfære lever alle organismer i indbydes interaktion og afhængighed, og med menneskenes udvikling af en dominerende, forstandsbaseret kommunikation har der, ifølge Vernadskij, udviklet sig det, han kalder en 'biosfære' (Lotman I990a, 289). Analogt til Vernadskijs begreb om biosfære foreslår Lotman at forstå semiosfæren som et semiotisk kontinuum eller rum, gennemstukket af forskellige heterogene diskurser og praksisser, der på trods af deres forskellighed står $i$ indbyrdes dialogisk relation og udveksling. I modsætning til Vernadskijs biosfære, der har en materiel-rumlig eksistens, er semiosfæren en abstrakt størrelse, men det gør den ikke mindre reel. Og parallelt med Peirces begreb om the commens udgør semiosfæren for Lotman et rum som er nødvendigt for at de semiotiske processer kan udspille sig: »Kun inden for et sådant rum er det muligt for de kommunikative processer at udspille sig og at skabe ny information " (Lotman I990a, 289. Min oversættelse). ${ }^{17}$

Lotmans semiosfærebegreb har mange ligheder med Umberto Ecos beskrivelse af det semiotiske univers som en encyklopædisk labyrint, men hvor Ecos rhizom er en abstrakt metafor for hvordan den uendelige semiosis kan begribes, dér er Lotmans semiosfære langt mere konkret knyttet til de sociale og kulturelle formationer. Hvor rhizomet i princippet er en uafgrænset og uafgrænselig labyrint uden centrum, dér er semiosfæren organiseret omkring et centrum og struktureret omkring en skelnen mellem det indre og det ydre, hvorfor et af de helt centrale begreber i dens konstitution bliver 'grænsen'. Semiosfærens centrum er struktureret omkring dens mest udviklede og bedst strukturerede tegnsystem, dvs. i første række de naturlige sprog, men alle andre former for strukturerede tegnsystemer i kommunikativ brug indgår i dialog dermed. Det semiotiske

${ }^{17}$ Teksten lyder således på tysk: »Nur innerhalb eines derartigen Raumes ist die Realisierung kommunikativer Prozesse und die Herausbildung neuer Information möglich «. 
systems højeste form for strukturel organisering er, ifølge Lotman, dets selvbeskrivelse, som kan tage form af f.eks. grammatikker, lovsamlinger, litteraturhistoriske afhandlinger eller etnologiske beskrivelser af kulturelle vaner og riter. Sådanne selvbeskrivelser udgør en centripetal dynamik og styrker semiosfærens sammenhæng, hvorved den får modstandsdygtighed over for de udefrakommende impulser og centrifugale kræfter, men samtidig bliver denne selvbeskrivelse selv en del af semiosfærens forandring. Ofte er det et regionalt sprog eller kulturelt udtryk som bliver gjort til genstand for beskrivelsen af semiosfærens helhed: »A partial grammar of one cultural dialect becomes the metalanguage for description of culture as such « (Lotman I990b, I28).

Semiosfæren er imidlertid, som nævnt, ikke en homogen helhed. I modsætning til Peirces forestilling om betydningernes forankring og pragmatiske stabilisering i et overgribende og mere eller mindre homogent commens, er semiosfæren at forstå som et heterogent rum, præget af asymmetriske relationer og større eller mindre grad af uoversættelighed, sprog og diskurser imellem. Således er forholdet mellem centrum og periferi præget af asymmetri, ligesom semiosfæren som helhed er gennemstukket af forskellige sprog og diskurser, der tjener hvert sit partielle formål (r990b, I28).

The structure of the semiosphere is asymmetrical. Asymmetry finds expression in the currents of internal translation with which the whole density of the semiosphere is permeated. Translation is a primary mechanism of consciousness. To express something in another language is a way of understanding it. And since in the majority of cases the different languages of the semiosphere are semiotically asymmetrical [...] then the whole semiosphere can be regarded as a generator of information (Lotman I990b, I27).

Hvis vi forstår semiosfæren som det semiotiske aspekt af en given kultur, kan man sige at i kulturer præget af interkulturel åbenhed og dialog vil oversættelserne hen over semiosfærens indre og ydre grænser medføre en tilgang af ny information og nye impulser som gør, at kulturen er i stadig udvikling og under permanent ombrydning. Semiosfærens grænser bliver i sådanne tilfælde (fler)sproglige filtre, der tillader udveksling mellem heterogene segmenter af den samme kultur, eller lader 'tekster' forfattet på sprog, der ikke tilhører den givne semiosfæres kerne, trænge ind $\mathrm{i}$ semiosfæren i form af oversættelser og dermed bidrage frugtbart til kulturens udvikling. Grænsen bliver et åbent semiotisk felt for indhøstning af ny erfaring og kulturel berigelse.

I kraft af grænsedragningerne bliver semiosfæren i bund og grund bestemt i forhold til det den ikke er, hvorfor der nemt opstår et behov for 
at konstruere forestillingen om det ydre eller den 'anden' som et stereotypt, truende og desorganiseret kaos - Lotman nævner her de antikke kulturers konstuktion af forestillingen om 'barbarerne' og bevidsthedens konstruktion af forestillingen om det ubevidste (Lotman I990a, 293). I sådanne kulturelt lukkede og intolerante miljøer ændrer grænsen karakter og bliver til en demarkationslinje, hvis funktion bliver at sikre marginaliseringen af den anden. Dermed bliver Lotmans grænsebegreb et interessant udgangpunkt for interkulturelle studier, der ønsker at fokusere på den dynamiske og processuelle udvikling af kulturelle identiteter i dialogisk sam- og modspil (Gustafsson 2003). Og som eksemplet med bevidsthedens konstruktion af det ubevidste som en fremmed anden viser, tøver Lotman ikke med at korrelere semiosfærens grænsebegreb med en semiotisk forståelse af den individuelle personlighed, hvorved der opstår en interessant mulighed for at studere samspillet mellem den individuelle semiotiske subjektskonstruktion og bredere kultursemiotiske og kulturhistoriske processer af kollektiv karakter. Det skal vi vende tilbage til nedenfor (se s. IO2 ff.).

Som en metafor for et øjebliksbillede af en semiosfære nævner Lotman museet. Man skal forestille sig en udstillingshal, fyldt med genstande fra forskellige perioder og ledsaget af inskriptioner på såvel kendte som ukendte sprog, samt instruktioner for at afkode dem. Hertil kommer museets vejledende plancher, skriftlige tourguider og regler for publikums opførsel. Og endelig kommer de besøgende gæster, guiderne og kustoderne. Forestiller man sig alt dette på en gang har man et øjebliksbillede af en semiosfære (Lotman, ibid.).

\section{Den litterære diskursorden}

Inden for semiosfærens overgribende ‘økosystem' betragter Lotman litteraturen som et særligt semiotisk system, hvis repræsentation bygger på andre repræsentationer. Lotmans udgangspunkt er at sproget i sig selv udgør et system, hvorigennem vi repræsenterer verden, et såkaldt modelling system, og idet litteraturen for Lotman leverer repræsentationer af denne sproglige repræsentation af verden bliver litteraturen et secondary modelling system. Hermed mener han at litteraturen udgør en særlig form for diskurs, en enhed der konstitueres mellem niveauet for den enkelte ytring på den ene side og den overgribende semiosfære på den anden, og denne enhed er altså karakteriseret ved at tage den sprogligt diskursive praksis som sin genstand, eller 'objekt' i Peirces forstand. I dette syn på litteraturen er han inspireret af Bakhtin, der ligeledes betragter litterære 
tekster som images of language, altså mere eller mindre ikoniske afbildninger af social, diskursiv praksis.

Peirce har i langt mindre grad tematiseret litteraturen som en selvstændig social diskurs, men det er vigtigt i udgangspunktet at slå fast, at tegnsystemerne, også for Peirce, hænger sammen i stadig større, overordnede enheder, forstået på den måde at de enkelte tegn, rhemerne, knyttes sammen til sætninger, eller dicente tegn, og disse knyttes sammen til argumenter (deduktive, induktive og abduktive). Og argumenterne knyttes videre sammen i det, som han kalder diskurser:

[D]iscourse consists of arguments, composed of propositions, and they of general terms, relative and non relative, of singular names, and of something that may be called copulas, or relative pronouns, etc. according to the family of speech that one compares the discourse to (MS 939, I905, 27. Citeret efter Johansen 2002).

For både Bakhtin og Lotman eksisterer der altså nogle diskursive enheder mellem den enkeltstående, sproglige ytring og den overgribende semiosfære, men hvordan beskriver vi litteraturens funktion i den forbindelse?

Fiktionslitteratur er, ifølge Dines Johansen, at forstå som en diskursiv praksis, adskilt fra øvrige diskursive praksisformer gennem de særlige konventioner eller vaner som knytter sig til den. Dines Johansen tager i definitionen af diskursbegrebet udgangspunkt i Jürgen Habermas' definition, der forstår det som en teknisk term knyttet til den kommunikative handlen, og nærmere bestemt som en form for talehandling rettet imod opnåelse af konsensus, eller skabelse af en 'cominterpretant' eller commens i den snævre udgave af dette begreb hos Peirce (Johansen 2002, 47). I Literary Discourse skildrer Dines Johansen diskursens placering inden for den kommunikative handlen forstået som en social handlen på denne måde (Johansen 2002, 84):

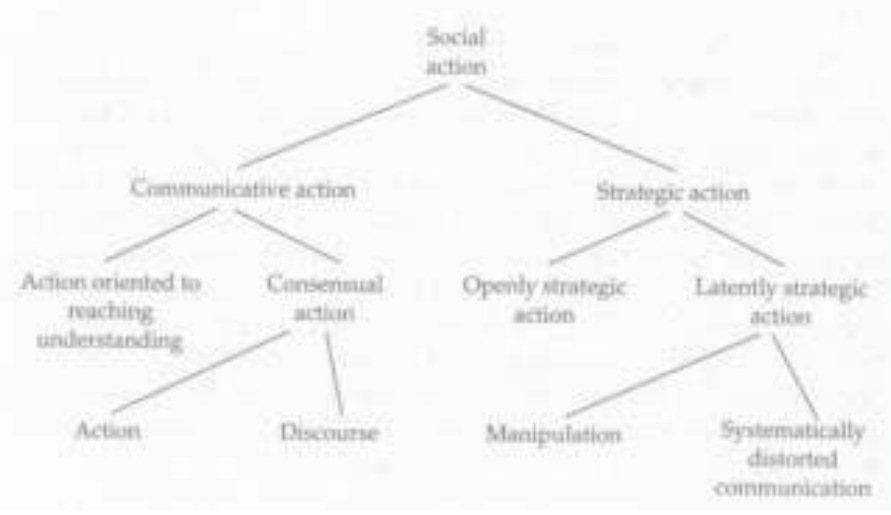


If. Johansen karakteriseres selve det diskursive felt af fem diskursive formationer, hvoraf kunsten eller litteraturen udgør den femte, den mimetiske. De øvrige er den teoretiske (religiøst-filosofiske), den tekniske, den praktiske og den historiske diskurs. Den litterært mimetiske diskurs, som bl.a. karakteriseres ved at være i stand til at mime de andre diskurser, kendetegnes, ifølge Johansen, af fem træk, som oftest, men ikke nødvendigvis alle sammen på en gang, indgår i det som vi betragter som litteratur: fiktionalitet, poeticitet, eksemplaritet, poetisk frihed og kontemplativitet (Johansen 2002, 97):

I. Fiktionalitet.

De litterære tekster refererer som oftest til et univers som er ontologisk forskelligt fra det univers, som vi er fysisk og kropsligt til stede i.

2. Poeticitet.

I litterære tekster finder man ofte et i høj grad motiveret forhold mellem udtryk og indhold, hvor metrum, rim, rytme og forskellige tematiske og kompositoriske mønstre giver et yderligere betydningslag i teksten.

3. Eksemplaritet (Dines Johansen kalder det inquisitoriality).

Romaner og fortællinger handler oftest om konkrete begivenhedsforløb der undersøger livets og/eller samtidens store spørgsmål, hvilket giver dem en form for eksemplaritet, der igen foranlediger etisk refleksion og argumentation hos læseren.

4. Poetisk frihed (Dines Johansen kalder det license).

Forfatteren af den litterære tekst står med en anden uforpligtethed over for relationen mellem tekst og verden som følge af opfattelsen af kunstens autonomi i forhold til samfundet. Forfatteren kan f.eks. anlægge flere indbydes forskellige perspektiver og knytte an til forskellige værdisæt.

5. Kontemplativitet.

Også læseren står i et frit og kontemplativt forhold til kunsten eller litteraturen. Dette betyder ikke at der ikke eksisterer en relation mellem litteraturen og læserens livsverden, men at relationen er af en anden karakter end for de andre diskurser.

\section{Faircloughs interdiskursivitetsbegreb}

Over for Habermas' diskursbegreb tager Norman Faircloughs kritiske diskursanalyse afsæt i Michel Foucaults diskursbegreb. Foucault forstår diskurser som bestemte måder at konstruere viden om verden på, men han bruger det på flere forskellige niveauer samtidig: som overbegreb for alle ytringer, som afgrænsende begreb for en gruppe af ytringer eller en reguleret praksis for et afgrænset antal af ytringer. Med udgangspunkt i den sidste af disse betydninger forstår Fairclough enhver form for diskursiv praksis som en underkategori af anden social praksis, og den enkelte diskursive ytring forstås som en instantiering af en overgribende diskursorden. Diskursordenerne er for Fairclough strukturelle enheder der 
er knyttet til de sociale institutioner, og som ligger 'under' de konkrete diskursive hændelser og strukturerer disse. Diskursordenerne er reguleret af en række komplekse og modsætningsfyldte elementer, som har at gøre med genrespecifikke træk: de subjektspositioner det er muligt at indtage i diskursen, det retoriske register, den intertekstuelle regulering osv. (Fairclough I992, 68 ff.). Diskursordenerne er hele tiden under forhandling i takt med udviklingen i de sociale praksisformer, og de konkrete tekster gennemskæres hele tiden af forskellige diskurser tilhørende forskellige diskursordener. I kraft af dialogen mellem diskurser og diskursordener sættes disse regulerende elementer til diskussion, hvorved de også kan undergå forandring. Dialogen med de diskursregulerende elementer bliver således for Fairclough en slags intertekstuel dialog som han kalder 'interdiskursivitet' eller constitutive intertextuality. Denne form for intertekstualitet adskiller sig fra det, han kalder manifest intertextuality (her støtter han sig på Bakhtin) ved at den »extends intertextuality in the direction of the principle of the primacy of the order of discourse " (Fairclough, op.cit. 85).

Det greb, som er nødvendigt for at relatere Faircloughs interdiskursivitetsbegreb til de litterære studier, er at betragte hele den litterære praksis, omfattende kreation, produktion, distribution og reception af litteratur, som en diskursiv social praksis, etableret med sin egen diskursorden tilknyttet den litterære institution. Den litterære institution må forstås som en del af en mere omfattende kunstinstitution, som fra I 80o-tallet og frem, i overensstemmelse med det borgerlige samfunds selvforståelse, har etableret sig som en særlig sfære for fri og uhildet æstetisk kontemplation af det rent menneskelige (Bürger I984, 35 ff.). Som et sådant konstrukt mellem ideologi og social praksis er den litterære institution en realitet, hvilket tillader os at konstruere den som en selvstændig diskursorden. Med udgangspunkt i Faircloughs diskursbegreb kan vi udpege tre elementer, som regulerer den litterære diskursorden (idet vi holder Dines Johansens fem kriterier i baghovedet): for det første giver litteraturen læseren en æstetisk oplevelse eller erfaring, for det andet åbner litteraturen nogle imaginære frirum eller mulige verdener vi som læsere bruger som modeller til at organisere vores erfaringer, og for det tredje bruger vi denne modellering til at se og forstå både os selv og vores livsverden anderledes eller bedre.

\section{Litteratur som imaginær erfaringsdannelse}

Anskuet på denne måde vil den litterære kreation kunne begribes som forfatterens forsøg på at forstå sig selv og sin verden bedre. Dette betyder ikke at forfattere altid skriver om sig selv og deres egen verden, selv om 
det også ofte forekommer. Snarere skal de fiktive universer, som åbnes i kraft af den kreative skrivning, forstås som forfatterens iscenesættelse af eksperimenter med erfaringsdannelse i en mulig verden, hvorved det eller de fiktive subjekter kommer til at fungere som identifikationspunkter for det skrivende og/eller læsende subjekt. Psykologen Jerome Bruner formulerer litteraturens funktion således i efterskriftet til sin bog Actual Minds, Possible worlds:

I have tried to make the case that the function of literature as art is to open us to dilemmas, to the hypothetical, to the range of possible worlds that a text can refer to. I have used the term 'to subjunctivize' to render the world less fixed, less banal, more susceptible to recreation. Literature subjunctivizes, makes strange, renders the obvious less so, the unknowable less so as well, matters of value more open to reason and intuition. Literature in this spirit, is an instrument of freedom, lightness, imagination, and yes, reason. It is our only hope against the long grey night (Bruner I986, I 59).

Det skrivende subjekt gennemløber en imaginær erfaringsdannelse, som $i$ et andet semiotisk omløb inviterer læseren til at gentage en tilsvarende, om end ikke identisk, proces. Lotman ser ligefrem læserens arbejde med teksten som en asymmetrisk omvending af den kreative akt: » The reader repeats this process [kreationsprocessen, $\mathrm{HLH}]$ in the opposite direction, passing from the text to the intention " (Lotman I990b, 78), men tilføjer umiddelbart herefter at der også her er tale om asymmetrisk proces, hvilket jo så indebærer en kreativ aktivitet fra læseren: »their relationship to the text is asymmetrical " (ibid.). Hvor læseren ser teksten som en afsluttet struktur, er den for forfatteren i konstant udvikling. Samtidig bringer læseren »his or her own personality, his or her own cultural memory, codes and associations, to bear on the text « (op.cit. 79), og disse erfaringer er altid forskellige fra forfatterens. Forfatterens skriveproces fungerer med andre ord som en interpretant af det sprogligt medierede forhold mellem hans eget 'selv' og hans omverden, men så at sige iscenesat $i$ en kulisse med mere eller mindre fiktive personer og tid/rum-koordinater i form af en possible world. Dines Johansen formulerer dette således:

[I]t must not be forgotten that the source of the immediate object of a fictional text is not a dynamical object, but an author who on the basis of his experiences, i.e., by being himself influenced by dynamical objects, but also by other texts representing fictional universes, offers a certain vision that only exists by virtue of his text (Johansen I998, I86).

Teksten bliver til som en skriftsproglig interpretant af forfatterens erfaringer af såvel livsverdensbaseret som litterær karakter. Forfatterens 
livserfaringer er langt hen ad vejen i forvejen sprogligt konstruerede, og den litterære diskurs kan således med Bakhtin forstås som et image of language, en ikonisk repræsentation af diskursiv praksis. Som et ikon er litteraturen radikalt åben for fortolkning, hvorfor den litterære diskursorden for læseren fremstår som det, vi med Lotmans betegnelse kan kalde et secundary modelling system. Men forfatterens livserfaringer indeholder også dimensioner, som endnu ikke er blevet verbaliserede, og som altså først 'oversættes' til en sproglig diskurs i skriveprocessen. Og selve verbaliseringen udgør en mediering af disse erfaringer, således at de efterfølgende ikke længere er de samme erfaringer, både på godt og ondt. Hvad de mister i umiddelbarhed, vinder de i refleksion. Patricia Waugh citerer John Barth for følgende iagttagelse i romanen The End of the Road:

$[T]$ o turn experience into speech - that is to classify, to categorize, to conceptualize, to grammatize, to syntactify it - is always a betrayal of experience $[\ldots]$ but only so betrayed can it be dealt with at all and only in so dealing with it did I ever feel a man alive and kicking (Waugh I984, 75).

Dette aspekt af litteraturens og kunstens funktioner, der handler om den fortolkende mediering af erfaringsmaterialet, finder man formuleret på forskellig måde hos flere af de kritikere, som vil blive inddraget nedenfor. Således tager Wolfgang Iser afsæt i en tilsvarende funktionel relation, som han fokuserer ud fra relationen mellem tekst og læser. Iser koncentrerer sig om at beskrive den konkrete læsehandling som en proces, og på den baggrund konkluderer han, at "this does not necessarily mean that such a process is to lead to the enlightenment and reeducation of the reader " (Iser I978, 2 I I). Relationen er altså ikke så enkel, at læseren blot tilegner sig tekstens positivt formulerede argumenter; tværtimod er tekstens kommunikative budskab hovedsageligt negativt artikuleret, hvorfor læseren selv må udfylde tekstens 'tomme pladser'. Og samtidig er det netop denne aktive deltagelse i betydningsproduktionen som sikrer at læseprocessen resulterer i en udvidelse af læserens eget erfaringsrepertoire: "a defamiliarized world is incorporated into the reader's store of experience " (Iser op.cit. 22 I). Læserens gentagelse af forfatterens erfaringsdannelsesproces er således ikke en positiv eller identisk gentagelse, al den stund læseren ikke gentager forfatterens erfaringsdannelse eller reproducerer hans intentio. Tværtimod skaber læseren sine egne imaginære erfaringer med teksten som redskab. Forstået på denne måde bliver litteraturen, og kunst i det hele taget, at betragte som ikoniske tegn, dvs. privilegerede rum, hvorindenfor læseren kan foretage imaginære eks- 
perimenter med kulturelle erfaringer: » This means that works of literature become individualized models for the contemplation of the human condition at a given time and place « (Johansen, op.cit. 294). Det, at litterære værker får model-karakter i den forstand at læseren kan lære noget om livsbetingelserne i det samfund som omgiver ham/hende, betyder at litteraturen får en dannelsesmæssig funktion. Dette perspektiv formulerer Umberto Eco i billedet af barnets leg:

It [fiction] offers us the opportunity to employ limitlessly our faculties for perceiving the world and reconstruction the past. In playing, children learn to live, because they simulate situations in which they may find themselves as adults. And it is through fiction that we adults train our ability to structure our past and present experience (Eco I994, I3I).

Denne iscenesatte eller imaginære dannelsesproces må forstås som en mimet gentagelse af subjektets almene konstitutionsproces, hvorfor det vil være hensigtsmæssigt i udgangspunktet at opridse nogle hovedtræk for en semiotisk forståelse af den proces, der ligger til grund for subjektets erfarings- og identitetdannelse. Paul Ricœur beskriver ligefrem litteraturens funktion som et laboratorium for etisk stillingtagen:

Literature is a vast laboratory in which we experiment with estimations, evaluations, and judgements of approval and condemnation through which narrativity serves as a propaedeutic to ethics (Ricœur I992, II 5).

Som et sådant etisk laboratorium er læserens forventning til den litterære diskurs at de enkelte tekster vil have en almen eller eksemplarisk værdi, som ligger ud over tekstens eget partikulære univers, og som læseren vil kunne bruge til at forstå mere om sin egen livsverden. Og idet læseren læser teksten på denne måde, fremtræder den ikke længere som et vanedetermineret symbolsk tegn, men antager karakter af et åbent, diskontinuert og betydningsgenererende ikon. 


\section{SUBJEKT OG ERFARING}

Menneskets beskrivelse af sig selv som subjekt udgør et spejl til forståelsen af, hvordan mennesket, i forskellige perioder og under indtryk af forskellige idéhistoriske strømninger, har forstået sig selv og forholdet mellem menneske og verden i det hele taget. Hvor det menneskelige subjekt både i klassikken og middelalderen fandt sit fundament i en overgribende teologisk forklaringsramme, dér installerede Descartes' cogito det rationelle subjekt knyttet til den rene refleksion, der som ideal kom til at ligge til grund for oplysningstænkningens menneskeforståelse. Det sekulariserede selv opstod således som et både homogent og selvbevidst selv, der kom til at ligge til grund for den liberalistiske og individualistiske ideologi, og som igen udmøntede sig i den romantiske forståelse af subjektivitet og identitet som transcendentale og essentielle størrelser. Anthony Cascardi siger det på denne måde: »the emergence of a secular subject reflects the process by which the transcendent authority of religious ideals came to be replaced by a series of increasingly normative social practices, bound together by the newly formed 'subject' of rational discourse " (Cascardi I992, I27). Heroverfor betød de moderne teoriers undergravning af den menneskelige rationalitet (Marx, Nietzsche, Freud, Foucault), at subjektet ikke længere kun kunne betragtes som en bevidst og selvbevidst enhed. I stedet underminerede forskellige processer af ubevidst, social-magtrelateret og/eller sproglig karakter subjektets tidligere suveræne position. Som Christensen og Meyer formulerer det i introduktionen til deres antologi The Modern Subject: "A century after the proclamation of the 'death of God', the human subject seems to have expired altogether « (Christensen \& Meyer I996, 5).

Inden for litteraturfaget indebar det 20 . århundredes modernistiske interesse for de bagvedliggende bevidsthedsstrukturer et opgør med den biografiske metode der havde domineret århundredet før. Dette var i sig selv et fremskridt, men samtidig var der en tendens til at barnet røg ud med badevandet i den forstand, at det kreative subjekt nu kun blev opfattet som en diskursivt konstrueret position (Foucault 1969) eller en funktion afledt af selve skriveprocessen (Barthes I977). Med de antisubjektivistiske strømningers tilbagetog de sidste ro til I 5 år er det imidlertid et spørgsmål om ikke subjektet som en handlende størrelse (agens) igen er blevet aktuelt? Siden I980'erne er subjektsproblematikken i hvert fald blevet et emne som er taget under behandling af både psykologer, filosoffer, litterater og historikere, der alle ud fra deres tilgang har rejst spørgsmålet om, hvordan vi beskriver den diskursive konstruktion af 
personlig og kulturel identitet. Og inden for litteraturvidenskaben betyder det at vi igen må rejse spørgsmålet om forfatterens tilstedeværelse - ikke som en naiv biografisme, men netop som en teoretisk reflekteret overvejelse over subjektets erfaringsrepræsentation og identitetskonstruktion. I det følgende vil begrebet 'identitet' blive forstået som et både kulturelt og tekstligt fænomen (processen der konstruerer identiteter), og ikke som et hverken etnisk, racemæssigt, nationalt eller på anden måde selvstændigt fænomen, med egen ontologiske væren.

Det moderne subjekt udgør grunden for al moderne erfaringsdannelse i den forstand, at mennesket i det moderne samfund gives en række valgmuligheder, der sætter individet fri fra det traditionelle samfunds statiske rodfæstethed og forudbestemte skæbne (Nielsen 200I). Menneskets individuelle frisættelse i det senmoderne samfund problematiserer forholdet mellem individ og kollektiv, mellem subjekt og samfund. Fra og med etableringen af det moderne bliver subjektet det problematiske udgangspunkt for erfaringsdannelsen, såvel individuelt som kollektivt, kropsligt som semiotisk. Og litterært. Derfor handler de forskellige typer af litterær erfaringsdannelse, hvad enten de er æstetiske, etiske eller logiske, om 'dannelse' af subjektet som en socialt og kulturelt handlende størrelse. Og derfor er afklaringen af, hvordan det menneskelige subjekt kan forstås, af helt afgørende betydning for denne fremstillings videre progression.

I det følgende vil jeg, på baggrund af den semiotiske tilgang som har præget gennemgangen i Kapitel I, argumentere for en semiotisk forståelse af subjektet, hvor subjektet først og fremmest begribes som en kommunikativ størrelse, udspændt mellem de kommunikative processers afsenderog modtagerpositioner. Der er tale om en både semiotisk og dialogisk subjektsopfattelse, idet kommunikationsprocessens dobbelthed og dialogiske dynamik så at sige er indbygget i subjektets 'indre' måde at processere erfaring på. Anskuet på denne måde bliver subjekt og erfaring til to gensidigt forudsættende begreber, idet man med Dines Johansens ord kan sige at »subjectivity is not bound up with individuality but with the articulation of experience" (Johansen 2002, 239).

\section{Charles Peirce: subjektet som tegn}

Peirce gjorde aldrig selv det menneskelige subjekt til genstand for et systematisk studium, men alligevel optog problematikken ham gennem det meste af hans forfatterskab. De til dato mest interessante behandlinger af Peirces syn på den menneskelige subjektsdannelse er Vincent Colapietro 
I989, Augusto Ponzio I990 og Norbert Wiley I994, hvoraf kun Colapietro giver sig af med en egentlig gennemgang af Peirces egne forestillinger om selvet og subjektet, mens både Ponzio og Wiley foretager fortolkende læsninger, der kombinerer Peirce med hhv. Mikhail Bakhtin og George Herbert Mead.

I den følgende fremstilling har jeg ladet mig inspirere af Wileys opdeling af subjektets konstitutionsproces i tre generalitetsniveauer: et niveau for subjektets identitetskonstruktion, et niveau for selvets erfaringsbearbejdning og et niveau for kommunikativ interaktion. I stedet for, som Wiley, at beskrive en bagvedliggende eller inkluderende struktur vil jeg beskrive subjektet på dets mest generelle niveau som en spatio-temporal proces, en mediering mellem fortid og fremtid, der danner baggrund for selvets møde med verden. Mødet mellem ego og non-ego er et spørgsmål, Peirce kommer tilbage til igen og igen som et grundlæggende forhold $i$ hans forståelse af mennesket som et semiotisk væsen. I selvets møde med verden, nonego, akkumuleres subjektets erfaringer i form af en række vanemæssige hverdagsforklaringer og handlemønstre, der igen danner baggrund for subjektets kommunikative handlen. Man kan sige at den semiotiske dynamik på et mere alment niveau står i et dialogisk forhold til processerne på de mere konkrete niveauer, hvorfor der finder et indbyrdes, processuelt flow sted imellem de tre níveauer, en dialog som er i konstant udvikling. Subjektet er ikke noget én gang givet, men en proces under permanent konstruktion eller regeneration på alle niveauer.

Peirces udgangspunkt for at bestemme det menneskelige subjekt er at »man is a sign «. Denne noget sælsomme udtalelse, som de fleste vel ville vælge at forstå mere eller mindre billedligt, insisterer Peirce på at forsvare i bogstaveligste forstand. I en relativt tidlig forelæsning fra perioden I 866-68 skriver han således:

But is there not this difference [between man and sign, HLH]? Man's feelings are perceptions, he is affected by objects. He sees, hears, etc. A word does not. Yes; that is true, but perception, plainly, depends upon having an animal organism and therefore there is here no further difference beyond the obvious two mentioned at first. Yet even here, there is a correspondence between the word and the man. Perception is the possibility of acquiring information, of meaning more; now a word may learn. How much more the word electricity means now than it did in the days of Franklin; how much more the term planet means now than it did in the time [of] Hipparchus. These words have acquired information; just as a man's thought does by further perception. But is there not a difference, since a man makes the word and the word means nothing which some man has not made it mean and that only to that man? This is true; but since man can think only by means of words or other external symbols, words might turn round and say, You mean nothing which we have not taught 
you and then only so far as you address some word as the interpretant of your thought. In fact, therefore, men and words reciprocally educate each other; each increase of a man's information is at the same time the increase of a word's information and vice versa. So that there is no difference even here (CP $7.587)$.

Jeg har valgt at bringe et langt citat på dette sted, da jeg mener at passagen er helt essentiel for at begribe Peirces forståelse af forholdet mellem menneske og sprog. Det er nok muligt, at han forsøger at provokere med den direkte sammenligning mellem menneske og tegn, og andre steder uddyber Peirce da også selv kroppens betydning for den menneskelige bevidsthed. Ikke desto mindre er den pointe, han går efter at understrege her, helt central: sproget er ikke bare en neutral beholder for det kommunikerede indhold, men tilføjer selv ny substans til det kommunikerede, og denne substans er kulturelt og historisk specifik. Sproget udvikler sig i snæver interaktion med den historisk kulturelle kontekst, jf. Lotmans semiosfærebegreb ovenfor, hvorfor Peirce bruger en organisk metafor for denne proces. Han siger at »symboler vokser « (CP 2.222). En tilsvarende sprogfilosofisk opfattelse finder vi hos Jorge Luis Borges, f.eks. i fortællingen om Pierre Menard, hvor fortælleren kommer med den irrationelle påstand at Pierre Menards genskrivning af Cervantes' Don Quijote er indholdsmæssigt meget rigere end Cervantes' originale tekst, selv om den ord til andet er magen til. Påstanden bygger på det synspunkt, at den socialhistoriske og kulturelle udvikling fra det I7. til det 20. århundrede har tilført sproget en ny og større indholdsdimension, hvorfor vi i dag kan læse ting ind i romanen som det var umuligt at læse ind i den på Cervantes’ tid. Dette svarer jo ganske til Peirces betragtning i det anførte citat: » how much more the word electricity means now than it did in the days of Franklin «.

I Peirces udlægning bliver mennesket endvidere at betragte som et tegn, fordi det, ved at rette sin opmærksomhed mod det, som det ikke er, nonego, refererer til verden som et tegn:

A man denotes whatever is the object of his attention at the moment; he connotes whatever he knows or feels of this object, and is the incarnation of this form or intelligible species; his interpretant is the future memory of this cognition, his future self, or another person he addresses, or a sentence he writes, or a child he gets (CP 7.59I).

Forstår vi med Peirce det menneskelige subjekt som et tegn, kan man overordnet sige at mennesket refererer til objektet for dets opmærksomhed, dvs. verden eller den kulturelle 'anden', og at interpretanten af denne 
tegnproces er en fremtidig udgave af dette subjekt, hvor erindringen om mødet med verden eller denne anden lejrer sig som en erfaring. Men, som Colapietro påpeger, er det nødvendigt at forstå Peirces opfattelse af det menneskelige subjekt i et udviklingsperspektiv. Colapietro skildrer selv en udvikling i Peirces syn på mødet mellem ego og non-ego over - mindst tre faser, og den følgende udlægning vil i store træk følge denne opdeling.

I Some Consequences of Four Incapacities ( I 868) formulerer Peirce dét, som Colapietro kalder hans 'negative' definition af det menneskelige 'selv' som en fra andre afgrænset enhed. Synspunktet er, at barnet, gennem konkrete erfaringer med at komme galt af sted når det ikke følger de voksnes råd, må erkende, at andre ved mere om verden end det selv. Derved erkendes også "a self in which this ignorance can inhere « (CP 5.233 , I 868). Tilsvarende erkender barnet også sit eget selv gennem fejlslutninger, hvorfor »ignorance and error are all that distinguish our private selves from the absolute ego of pure apperception « (CP 5.235, I 868). I denne tidlige fase er mennesket, i Peirces formulering, selv et tegn:

[W] henever we think, we have present to the consciousness some feeling, image, conception, or other representation, which serves as a sign. But it follows from our own existence [...] that everything which is present to us is a phenomenal manifestation of ourselves. This does not prevent its being a phenomenon of something without us, just as a rainbow is at once a manifestation both of the sun and of the rain. When we think, then, we ourselves, as we are at that moment, appear as a sign (CP 5.283).

Ifølge Peirce optræder alt, hvad der er nærværende for den menneskelige kognitive opmærksomhed, som en fænomenisk manifestation af mennesket selv i den forstand, at vi kun er i stand til at opleve verden som noget andet end os selv. Selvet bliver et tegn (ego), der henviser til verden som et ikke-selv (non-ego), for et nyt selv, der skal mediere imellem de to. Herved bliver selve den menneskelige eksistens at forstå som en dialog mellem ego og non-ego, dvs. en kæde af uendelige tegnprocesser:

For, as the fact that every thought is a sign, taken in conjunction with the fact that life is a train of thought, proves that man is a sign; so, that every thought is an external sign, proves that man is an external sign (CP 5.3 I4).

I subjektets konstitutionsproces er dette man/sign udgangspunkt for repræsentationen af en given identitet, forstået på den måde at subjektet etablerer sig som en relativ consistency i forhold til det, som det ikke er: alteriteten, verden. Men da den verden, som subjektet konfronteres med, 
hele tiden er omskiftelig og i udvikling, bliver subjektet selv en tendentielt ustabil størrelse, som hele tiden må diskutere de nyindhøstede erfaringer i forhold til de værdier og normer, som er opstået på baggrund af tidligere erfaringer. Ved 'erfaring' forstår Peirce ikke en hvilken som helst hændelse eller tildragelse, men noget som får subjektet til at tænke sig selv og sit forhold til verden på en anderledes måde. I en godt nok noget senere tekst fra 1905 definerer Peirce erfaring på følgende måde: "It is the compulsion, the absolute constraint upon us to think otherwise than we have been thinking that constitutes experience " (CP I.336). Dannelsen af subjektets kulturelle identitet tager derved form ved, at subjektet foretager en fortolkning af sit eget selv (ego) i forhold til ikke-selv (non-ego / alterity). Denne fortolkning udspiller sig som en dialog mellem det, som subjektet (ego) historisk set repræsenterer af forudgående erfaringer, og de nye erfaringer som høstes i mødet med non-ego eller alteriteten.

Subjekt (Ego)

$\Delta$

Altertitet (Non-ego) Erfaring

Der er heller ikke i denne model tale om en statisk struktur, men om en dynamisk proces som hele tiden regenererer sig selv. Således må ego forstås som en form for ureflekteret væren, et I/Self, hvis semiotiske grund er baseret på subjektets hidtidige erfaringshorisont, manifesteret i form af kulturelle værdier og normer. Mødet med non-ego opstår i subjektets aktuelle konfrontation med sin omverden, der tager form af den 'anden', mens dannelsen af subjektets identitetsstruktur således hele tiden regenereres som nye erfaringer. I kraft af denne proces ser subjektet sig selv som stående i opposition til det, som det ikke er, men samtidig sker der det, at det ser sig selv profileret gennem den 'anden'.

I det som Colapietro kalder Peirces anden fase, og som han tidsfæester til omkring I 890'erne, er Peirce optaget af de større linjer i sin evolutionære kosmologi. I denne fase betones ikke blot det enkelte individs sammenhæng med det omgivende samfund, men det omgivende samfund fortolkes også 'mentalistisk' som en personlighed. Dette skal forstås på den måde at forskellige kulturelle enheder, ifølge Peirce, tenderer mod at udvikle den samme form for kontinuitet i måden hvorpå tanker opstår og udvikles. I en tekst fra I 892 beskriver Peirce den menneskelige personlighed i positive termer som "some kind of coordination or connection of ideas « (CP 6.I 55), og han præciserer at denne samordning implicerer »a teleological harmony in ideas, and in the case of personality this teleology is more than a mere purposive pursuit of a predeterminate end; it is a 
developmental teleology «(CP 6.I 56). I Peirces anden fase er det menneskelige subjekt således ikke en én gang given størrelse, men en proces under stadig udvikling med et åbent og ikke-determineret fremtidsperspektiv, der rummer mulighed for nyudviklinger: »Were the ends of a person already explicit, there would be no room for development, for growth, for life; and consequently there would be no personality « (CP 6.I 57$)$.

Denne position er for så vidt ikke i modstrid med den tidligere, negativt definerede opfattelse. Forskellen på de to er, at hvis mennesket betragtes som et isoleret individ vil det kun kunne defineres negativt, men idet det forstås i dets samspil med andre, bliver det muligt at tilskrive det et positivt element i dets særlige »samordning af ideer ", samt i den retning som disse udstikker for en fremtid. Og heri ligger igen parallellen til den almene forståelse af tegnet: »A sign cut off from its future interpretants is a sign denied the possibility of realizing its essence; that is, the possibility of being a sign " (Colapietro I 989, 77). For at det menneskelige subjekt kan realiseres positivt, må det derfor være et kommunikerende subjekt, der udtrykker sig i, og interagerer med, det omgivende samfund.

Colapietros pointe er nu at disse to lettere divergerende opfattelser af subjektet, en negativ, semiotisk opfattelse og en positiv, mentalistisk opfattelse, forenes i den tredje og sidste fase af Peirces tænkning, som Colapietro relaterer til Peirces skrifter fra omkring århundredeskiftet og frem. I artiklen » The Logic of Elements « fra I 898 forsøger han sig igen med at definere den menneskelige personlighed. Hvor han tidligere, som refereret ovenfor, forstod personligheden som en slags samordning af ideer, ser han omkring århundredeskiftet personligheden som udmøntet $i$ en »enhed af vaner«:

[E]ach personality is based upon a 'bundle of habits', as the saying is that a man is a bundle of habits. But a bundle of habits would not have the unity of self-consciousness. That unity must be given as a centre for the habits (CP $6.228)$.

Denne beskrivelse af personlighedens formning omkring et centrum kunne umiddelbart lyde som endnu en romantisk variant af det essentialistiske subjekt. Når dette imidlertid efter min mening ikke er tilfældet, skyldes det at Peirces position er formuleret semiotisk og dialogisk. Subjektets egenart forstås som 'vaner', der udspringer af en erfaringsbaseret dialog med forskellige andre, aktuelle og kommunikative instanser af det samme subjekt, som igen bliver udgangspunktet for subjektets selvrefleksion. Og her skal vi huske på, at netop vanebegrebet (habits) ligger til grund for 
symbolet som tegnkategori hos Peirce. Subjektet konstruerer altså sig selv som et tegn baseret på semiotiske vaner, og subjektets enhed er ikke på forhånd givet som en spirituel præmis, men er resultatet af subjektets kamp for at skabe sammenhæng og mening.

\section{Subjektets selvrefleksion}

Gennem sin individuelle livshistorie udvikler hvert enkelt subjekt en måde at se og forstå sig selv og verden på, der samtidig udgør et beredskab for fremtidig handlen. Subjektets 'grund' for handlen udgøres således af en beholdning af semiotiske vaner, og gennem subjektets dialog med sig selv udvikles eller 'vokser' dette sæt af vaner i retning af en enhed, der giver det dets særegne personlighed. "When one reasons, it is that critical self that one is trying to persuade; and all thought whatsoever is a sign, and is mostly of the nature of language « (CP 5.42I, min fremhævning). Over for det kritiske selv står en uspecificeret instans, som Peirce blot benævner som et upersonligt 'man' (one), der forsøger at argumentere med udgangspunkt i de aktuelle tildragelser, som subjektet bliver konfronteret med i en omskiftelig verden. Colapietro navngiver denne instans som et innovative self, og definerer det som en udfordring af disse vaner (Colapietro I989, 93). I en anden tekst fra I909, tidligere citeret i Kapitel I, formulerer Peirce det samme således:

All thinking is dialogic in form. Your self of one instant appeals to your deeper self for his assent. Consequently, all thinking is conducted in signs that are mainly of the same general structure as words; those which are not so, being of the nature of those signs of which we have need now and then in our converse with one another to eke out the defects of words, or symbols (CP 6.338).

Forholder vi disse to dialogerende instanser af subjektet til modellen udarbejdet på baggrund af ego / non-ego / erfaring - strukturen ovenfor, finder vi en relation hvor det kritiske selv, som en repræsentation af de allerede erhvervede habits, refererer til de indtrædende aktuelle eller mulige hændelser ${ }^{18}$ som værende noget 'andet', for et innovativt selv, der bliver locus for genereringen af nye erfaringer.

\footnotetext{
${ }^{18}$ Det at potentielle, dvs. imaginære, hændelser eller tildragelser kan spille en rolle i subjektets udvikling af egen personlighed, vil blive uddybet nedenfor i forbindelse med subjektsdannelse og litteratur.
} 
Kritisk selv

Tilegnede vaner

$\Delta$

Aktuelle eller

Innovativt selv

mulige hændelser

Nye erfaringer

Forholdet mellem det innovative og det kritiske selv er dynamisk i den forstand at dialogen kan omsættes i habit changes, dvs. revisioner af de hverdagsforklaringer og tillagte handlemønstre, som et givet subjekt lægger til grund for sine umiddelbare handlinger. I kraft af dialogen mellem disse to instanser foregår der således løbende en rekursiv ${ }^{19}$ behandling af subjektets eksisterende vaner, og i kraft af denne kritiske revision bliver det menneskelige subjekt $\mathrm{i}$ besiddelse af en udviklet grad af selvkontrol og autonomi. I den første af hans Lowell Lectures fra 1903 skriver Peirce:

Reflection upon these rules, as well as upon the general ideals behind them, has a certain effect upon his [man's, HLH] disposition, so that what he naturally inclines to do becomes modified. Such being his condition, he often foresees that a special occasion is going to arise; thereupon, a certain gathering of his forces will begin to work and this working of his being will cause him to consider how he will act, and in accordance with his disposition, such as it now is, he is led to form a resolution as to how he will act upon that occasion (CP I.592).

Det kritiske selv repræsenterer nogle grundlæggende eksistentielle idealer, ud fra hvilke den givne personlighed har tillagt sig rækken af vaner, forstået som hverdagsforklaringer og handlemønstre, udviklet på baggrund af dennes opvækst og hidtidige livserfaring.

Reflecting upon these ideals, he [man, HLH] is led to intend to make his own conduct conform at least to a part of them - to that part in which he thoroughly believes. Next, he usually formulates, however vaguely, certain rules of conduct. He can hardly help doing so. Besides, such rules are convenient and serve to minimize the effects of future inadvertence and, what are well-named, the wiles of the devil within him (CP I.592).

\footnotetext{
${ }^{19}$ Begrebet 'rekursion' anvendes i den betydning Jerome Bruner giver det: »the process whereby the mind or a computer program loops back on the output of a prior computation and treats it as a given that can be the input for the next operation " (Bruner 1986, 97).
} 
Habit-changes kan over tid føre til, at selve de eksistentielle idealer tages op til revision: »In addition to these [...] self-criticisms of single series of actions, a man will from time to time review his ideals « (CP I.599). Således bliver subjektets evne til selvfortolkning, selvkritik og selvkontrol det måske væsentligste træk ved den menneskelige rationalitet (Colapietro I989, I IO-I I I).

Den menneskelige selvrefleksion er indgånde behandlet af Norbert Wiley, der ser den som et særligt aspekt af den grundlæggende selvrefleksion, der præger alle semiotiske processer: »the semiotic stream of communication not only goes out to the audience or listener, it also goes back, reflexively, to the speaker " (Wiley I994, 27). I bogen The Semiotic Self kombinerer Norbert Wiley Peirces og Meads elementære modeller for tankens indre dialog. Wiley fortolker Peirces dialog mellem et kritisk og et innovativt selv som en dialog mellem et $I$ og et fremtidigt billede af dette selv, som Wiley døber et you. Heroverfor beskriver Mead subjektets dialog med sig selv som en dialog mellem I og me, hvor me skal forstås som en fortidig eller tidligere udgave af $I$. Hvor Peirces dialog peger frem, rækker Meads dialog altså tilbage, mens Wileys selvstændige greb består $i$ at kombinere de to modeller i en treleddet struktur for selvet, der består i en relation mellem $I$, me og you, mellem nutid, fortid og fremtid.

Subjektets indre dialog erstatter ikke erfaringsdannelsen og dialogen med omverdenen, men supplerer den. Idet $I$ repræsenterer subjektets i dets nutidige, semiotiske handlen (tænken/talen), så tager denne second-order refleksion form af en henvendelse til det fremtidige you om et fortidigt $m e$, der indtager objektets plads. Wiley skelner mellem tre generalitetsniveauer i beskrivelsen af subjektet, som han kalder 'struktur', 'identitet' og 'tegn' (op.cit. I4). De tre niveauer er indbyrdes inklusive, således at forstå at strukturen i sig indeholder identiteten, som i sig indeholder tegngivningen. De konkrete forbindelser mellem niveauerne er imidlertid ikke klargjort, og 'struktur'-betegnelsen, som Wiley bruger om relationen mellem $I$, you og me gør det vanskeligt at se hvordan interaktionen finder sted. Men selv om det refleksive element er en del af al semiotisk aktivitet, er der forskel på om selvrefleksionen er gjort til diskursens centrale topic eller ej. Wiley skelner derfor mellem referentielle first order signs og selvrefleksive second order signs: " First order signs, meanings of reflexive acts are about ordinary objects. In contrast, those of the second order are about other signs, meanings or reflexive acts « (op.cit. 83). Det er således vigtigt for Wiley at understrege, at der er tale om to forskellige processer, som ganske vist er særdeles tæt sammenknyttede: på den ene side en referentiel first order stillingtagen til en konkret situation eller generering af en konkret erfaring, og på den anden side en selvreferentiel second 
order diskussion af de eksisterende handlemønstre og de etiske eller moralske værdiforestillinger, som ligger bag. Over tid, og ved gentagne revisioner, kan der endvidere blive tale om en revurdering af disse bagvedliggende idealer.

Som model for denne selvrefleksive proces, hvor selvet anvender second order signs til at reflektere over sig selv, opstiller Wiley en trefløjet relation mellem $I$, you og me der lader sig repræsentere i en trekant. Her diskuterer et nutidigt jeg sin egen fortidige fremtræden $(m e)$ i forhold til en fremtidig repræsentation af sig selv, der således kommer til at fungere som interpretant for det nutidige selv:

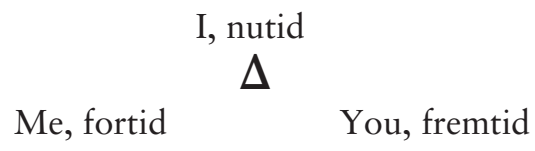

Som Colapietro gør opmærksom på, kan det imidlertid være hensigtsmæssigt at skelne mellem to instanser i det nutidige $I$, som Peirce kaldte det 'kritiske selv': På den ene side har vi idealerne som genererer hele beholdningen af 'vaner', og på den anden side har vi selve den instans, som indgår i dialogen omkring de potentielle eller aktuelle tildragelser. Colapietro trækker i denne forbindelse på DeWitt Parker, der i Experience and Substance (Ann Arbor, Univ. of Michigan Press, I94I) skelner mellem to instanser i selvet: matrix self og focal selves. Matrix-selvet er at forstå som "that complex of habits that represents both a summation of the past and an orientation toward the future ", og på baggrund af hvilket der udspringer diverse fokale repræsentationer af selvet (Colapietro I 989, 94). Mindst én af disse repræsentationer udgør den enhed eller kontinuitet hvorpå matrix-selvet er dannet, mens de andre er knyttet til de indtrædende tildragelser. Forholdet mellem det kritiske selv og det innovative selv, mellem I og you, bliver med dette udgangspunkt at forstå som en dialog mellem to focal selves: "thinking always proceeds in the form of a dialogue - a dialogue between different phases of the ego « (CP 4.6, I 906). Men som baggrund, eller 'grund', for denne dialog finder vi matrix-selvet, forstået som »the ultimate logical interpretants of prior semiotic processes « (Colapietro I989, 94).

Ifølge den senere Peirce udvikles det menneskelige subjekt, som vi har været inde på, ikke til en distinkt personlighed i et tomrum. De kulturelle idealer og værdier er grundlæggende rodfæstet i subjektets historiske, kulturelle og sociale sammenhæng, og det menneskelige subjekt er kun positivt bestemt i forhold til denne sammenhæng. I de tidligere citerede Lowell Lectures fra 1903 formulerer Peirce det således: 
These ideals, however, have in the main been imbibed in childhood. Still, they have gradually been shaped to his personal nature and to the ideas of his circle of society rather by a continuous process of growth than by any distinct acts of thought (CP I.592).

Anskuet på denne måde bliver det menneskelige subjekt at betragte som en kulturel konstruktion, et tegn eller en tekst, hvis betydning afhænger af den kontekst, hvori den aktualiseres. Jerome Bruner udtrykker den konstruktivistiske opfattelse af selvet som en tekst således:

I think of Self as a text about how one is situated with respect to others and toward the world - a canonical text about powers and skills and dispositions that change as one's situation changes from young to old, from one kind of setting to another. The interpretation of this text in situ by an individual is his sense of self in that situation. It is composed of expectations, feelings of esteem and power, and so on (Bruner I986, I30).

Det menneskelige subjekt bliver at forstå som en tekstlig konstruktion, og det erfaringsmateriale som indgår i denne konstruktion er hovedsageligt af narrativ karakter.

\section{Narrativ identitet hos Paul Ricœur og Jerome Bruner}

I Time and Narrative beskæftigede Paul Ricœur sig med tidsbegrebet og narrativerne som en måde (den eneste) at menneskeliggøre tiden eller gøre tiden forståelig for menneskene: »time becomes human time to the extent that it is organized after the manner of a narrative; narrative in turn, is meaningful to the extent that it portrays the features of temporal experience " (Ricœur I983 I, 3). I den forbindelse udviklede han begrebet 'narrativ identitet' (hhv. personlig og kulturel) som et svar på spørgsmålet om hvorvidt der fandtes en erfaringsstruktur, der kunne integrere de to store klasser af narrativer: historieskrivning og fiktionsfortælling. Kun ved at etablere en forløbsmæssig ramme (begyndelse, midte, slutning) og forbinde handlingens hændelser og begivenheder til antropomorfe agenter (personer, karakterer) der spiller bestemte roller i forhold til hinandens projekter (aktanter), er det, ifølge Ricœur, muligt for det menneskelige subjekt at skabe kausale sammenhænge og give historien mening - såvel individuelt og kollektivt. I bogen Oneself as Another fortsætter Ricœur denne tråd, men nu ud fra intentionen om at få beskrevet begrebet om den personlige identitet mere præcist, et begreb som også kun giver mening inden for en temporal forståelsesramme ( I 990, I I 4-I 5). Begrebet 
om narrativ identitet bliver her et analytisk redskab til at mediere fortidsrettet beskrivelse (description) til fremtidsrettet, etisk baseret handlingsanvisning (prescription) for subjektet.

Ricœur knytter identitetsproblemet til spørgsmålet om at være genkendelig som den 'samme', altså det at have en vis identitetsmæssig stabilitet over tid. Samtidig skelner han mellem to sider af dette at være den 'samme', der på en gang dækker det som han kalder sameness (latin: idem) og selfhood (latin: ipse). Hvad vil det sige at noget er det 'samme'? Er to ens ord på en side det samme ord? De ligner hinanden, men er forskellige entiteter.

Den første type lighed, sameness, har, ifølge Ricœur, både en numerisk og en kvalitativ identitet knyttet til sig. Vi siger i almindelig sprogbrug om to fremtrædener af en genstand som benævnes med det samme substantiv, at de er 'én og samme ting': » the same thing twice, $n$ times « (Ricœur I990, I I 6). Samtidig siger vi også om to jakkesæt der ligner hinanden fuldstændig, at de er de samme. I den forstand at ligheden bruges som udgangspunkt for at samle de enkelte, fremtrædende fænomener til en kategori eller et begreb, kan vi sige at Ricœurs sameness eller idem-identitet har en affinitet til Peirces type-begreb (se s. 28), men samtidig er udgangspunktet for sammenligningen en rent kvalitativ eller ikonisk lighed, hvilket understreger kvalitegnets inklusion i Peirces type.

Den anden type lighed, selfhood eller ipse-identitet, er mere kompleks at begribe i semiotiske termer. Umiddelbart peger Ricœurs eksempel med de to ens ord på en side, der i kraft af deres ipse-identitet er forskellige størrelser, på Peirces token-begreb (op.cit). Men denne udlægning kompliceres af, at den omhandlede genstand er et levende væsen som udvikler sig over tid. Er jeg, i en alder af 50 år, den 'samme' som den lille lyshårede purk, som startede i I. klasse i I960? Mellem Hans i I960 og Hans i 2005 er der hverken lighed eller konceptuelt sammenfald. Vi hedder ganske vist det samme, men det er der så mange andre der også gør, hvilket heldigvis ikke gør os til én stor Hans. Man kunne derfor meningsfuldt spørge hvad det er der gør, at jeg normalt anser de to udgaver af Hans for at være én og den samme? Her træder et støttebegreb i værk for den kvalitative identitet, som Ricœur kalder uninterrupted continuity. Det, der for Ricœur gør Hans i 1960 og Hans i 2005 til én og samme person, er altså det forhold at vi er forbundet gennem en ubrudt evolutionær udvikling over tid. Og den eneste måde at begribe tiden, at gøre den menneskelig, er, ifølge Ricœur, ved at fortælle den.

Ricœur efterlyser herefter nogle principper som kan forklare hvad det er, der giver os denne identitetsmæssige stabilitet over tid, og han opstiller to modeller, der kan opsummeres i udtrykkene: Character og keeping 
one's word. Den sidstnævnte kategori kalder han også selfconstancy. I det følgende skal vi kun beskæftige os med karakterbegrebet, men keeping one's word går senere hen og bliver interessant at diskutere i en Bakhtinsammenhæng. Ricœur forstår begrebet 'karakter' som »the set of lasting dispositions by which a person is recognized ", hvorefter disse dispositions defineres som hhv. habits og acquired identifications (op.cit. I2I). Vanerne giver den personlige karakter sin historiske dimension, men samtidig tenderer vanebegrebet mod at overlejre den forandring, der faktisk gik forud for vanens etablering som vane med vanens stabilitet over tid. Derfor tenderer ipse mod at præsentere sig selv som idem, og en persons karakter kan således, ifølge Ricœur, betragtes som værende sammensat af et sæt af vaner eller personlighedstræk, der igen er at betragte som tegn. Parallellen til Peirce er oplagt, om end ikke ekspliciteret:

Each habit formed this way, acquired and become a lasting disposition, constitutes a trait - a character trait, a distinctive sign by which a person is recognized, reidentified as the same - character being nothing other than the set of these distinctive signs (Ricœur I990, I2I).

Det andet element i karakterens dispositions som Ricœur nævner, er det sæt af identifikationsmodeller, som subjektet bruger til at identificere sig med: Bestemte rollemodeller eller helte gennem hvem værdier, normer og idealer bliver tilegnet, både på et individuelt eller personligt plan og på et kollektivt eller kulturelt plan. Ricœur siger at det er gennem denne identifikation, at det fremmede (the other) indgår i konstruktionen af det 'samme' (same) (Ricœur I990, I2I). Det, at genkende sig selv $i$ noget andet, bidrager til at erkende dette andet i os selv. Subjektets identifikation med heroiske figurer viser subjektets tilegnelse af andethedens værdier som sine egne, hvorved et element af loyalitet og trofasthed følger med, både over for den højere sag i det heroiske plot, og over for det at opretholde subjektets egen karakter som den samme. Her går den personlige identitets to poler (idem og ipse) helt op i hinanden, idet det ikke er muligt at tænke en persons idem-identitet (altså hans kvalitative egenskaber og karaktertræk) uden at tage hans ipse-identitet i betragtning (hans singulære eksistens som et subjekt med en historie). Parallellen til Umberto Ecos beskrivelse af semiosis som en dialogisk relation imellem type og token i en rhizomatisk, labyrintisk struktur ligger ligefor (se herfor s. 37 ff.). Denne proces kan ses som en parallel til den proces der foregår ved den semiotiske vanedannelse omtalt ovenfor, idet det fremmede og nye internaliseres gennem erfaringen, hvorved det annuleres som andethed. På denne måde stabiliseres subjektets præferencer, stillingtagen 
og vurderinger på en måde, som ikke er det Freud'ske overjeg fremmed (Ricœur I990, I22). Og i denne konstruktionsproces indtager fortællingen, eller narrationen, en dynamisk position:

The dialectic of innovation and sedimentation, underlying the acquisition of a habit, and the equally rich dialectic of otherness and internalisation, underlying the process of identification, are there to remind us that character has a history, which it has contracted [...]. It is then comprehensible that the stable pole of character can contain a narrative dimension, as we see in the uses of the term 'character' identifying it with the protagonist in a story. What sedimentation has contracted, narration can redeploy (Ricœur I990, I22).

Fortællingens dynamiske rolle i identitetskonstruktionen kan udfoldes både på et individuelt og et kollektivt plan. På det kollektive plan fremhæver Ricœur Fernand Braudels L'Identité de la France som et værk, der udpeger en række distinktive træk ved den franske nationale identitet som Braudel knytter sammen med geografiske og historiske forhold, uden hvilke opregningen af sådanne træk ville kunne anvendes i den mest skadelige udgave af forestillinger om national identitet (Ricœur I990, I23).

På det individuelle plan sammenligner Ricœur subjektets identitetsarbejde med den hermeneutiske cirkel. Hvis det enkelte individ skal tilskrive sit eget liv mening i dets helhed, må dette liv først konstrueres narrativt som en helhed - det må tilskrives narrativ enhed. Fortællingens rolle er her i mindre grad blot det at kæde de begivenheder sammen som udgør personens liv, men snarere at stå for en værdimæssig vurdering af personens handlinger knyttet til disse begivenheder og derigennem værdsætte personen:

As for the term 'narrative unity', the aspect we are emphasizing here is less the function of assembling-together, performed by the narrative at the summit of the scale of praxis, than the connection the narrative makes between estimations applied to actions and the evaluation of persons themselves (Ricœur I992, I78).

Idealet om 'det gode liv', dvs. de idealforestillinger og fremtidsdrømme, vi gør os, om hvad et fuldt og rigt liv er, bliver den 'grund', i peirceansk forstand, som hver enkelt af os vurderer vores egen livsfortælling på baggrund af. Og det er denne selvfortolkning som, ifølge Ricœur, ikke er uden lighedspunkter med den hermeneutiske cirkel:

[B]etween our aim of a 'good life' and our particular choices a sort of hermeneutical circle is traced by virtue of the back-and-forth motion between 
the idea of the 'good life' and the most important decisions of our existence (career, love, leisure, etc.). This can be likened to a text in which the whole and the part are to be understood each in terms of the other (Ricœur I992, I79).

\section{Narrativ identitet hos Bruner}

Psykologen Jerome Bruner udvikler sin kognitive konstruktivisme parallelt med Paul Ricœurs narrative subjektsfilosofi. I bogen Possible worlds, Actual Minds skelner Bruner mellem to grundlæggende forskellige kognitive måder at konstruere vores tilgang til verden på: den paradigmatiske eller logisk-scientistiske og den narrative. Ifølge Bruner er det den menneskelige psykes væsentligste opgave at knytte perceptionens mangfold af indtryk sammen til meningsgivende helheder, der kan danne udgangspunkt for handlen og som kan lagres i erindringen. Og i denne proces spiller den narrative sekvens en afgørende, strukturerende rolle. Bruner overtager begrebet 'perfink' fra David Krechs med henblik på at karakterisere enheden af tre funktioner som normalt holdes adskilt:

$[\mathrm{P}]$ erceive, feel and think at once. They (people) also act within the constraints of what they 'perfink'. We can abstract each of these functions from the unified whole, but if we do so too rigidly we loose sight of the fact that it is one of the functions of a culture to keep them related and together in those images, stories, and the like by which our experiences is given coherence and cultural relevance (Bruner I986, 69).

Selve erfaringsdannelsen bliver således ordnet narrativt: »det, der ikke indplaceres i en narrativ sammenhæng vil forblive kaotisk og vil i øvrigt heller ikke blive bevaret i hukommelsen som udgangspunkt for erindring « (Køppe I 998, 28). Det 'narrative' eller 'narrationen' skal her forstås som »ordningen af størrelser i en tidsmæssig orden « (Køppe, op.cit. 27). Narrativerne er, ifølge Bruner, ordnet ud fra en række grammatiske kategorier, såsom:

- Agent: handlinger udført af en agent rettet mod et mål

Sekventiel orden: linearitet

口 Lovmæssighed: kanoniserede regler for kommunikation

口 Perspektivisme: mening fremstilles af nogen.

Hvert af disse punkter modsvarer hver især velafgrænsede og velbeskrevne aspekter af narratologien og litteraturvidenskaben. Hvor de to første åbenlyst refererer til de strukturelle narratologiske aktantrelationer og forløbsanalysen, vil de to sidste kunne forstås som relateret til genrespørgsmålet og udsigelsesanalysen. Men hvorom alting er, for Bruner 
forudsætter fortællingen en række betingelser, inden for hvilke handlingen kan tilskrives betydning og dermed danne afsæt for generering af erfaring:

Stories define the range of canonical characters, the settings in which they operate, the actions that are permissible and comprehensible. And they provide, so to speak, a map of possible roles and of possible worlds in which action, thought and self-definition are permissable (or desireable) (Bruner op.cit. 66).

Menneskets forudbestemte forventninger virker regulerende eller direkte styrende for hvordan den erfaring tolkes, som subjektet indhøster i samspillet med verden; Peirce ville her tale om vaner, mens en litteraturkritiker ville tale om genrer. Men dermed er det også sagt at der, for Bruner, ikke eksisterer nogen 'oprindelig' verden som ligger forud for, eller som ikke er underkastet menneskets kulturelt bestemte syn på den: » The world of appearance, the world we live in, is created by mind « (op.cit. 96). I beskrivelsen af denne kulturelt bestemte konstruktion af verdener trækker Bruner på Nelson Goodman, ifølge hvem der ikke eksisterer en verden som er mere 'virkelig' end andre. Der er med andre ord ingen ontologisk privilegeret verden (ibid.) og ingen erfaring fri af en forudgående 'teoretisk' forventning (op.cit. I Io). ${ }^{20}$

For Bruner rummer de narrative strukturer ikke bare et sæt af imaginære erfaringer, som vi bruger til at udvikle vores psykiske beredskab og udvikle vores 'selv', de udgør ganske enkelt den ene af de to diskursive modi hvorigennem vi overhovedet kan forstå os selv og vores verden. Selv om vores omverden kan forklares videnskabeligt og kausalt, har vores omverden ingen betydning for os, før vi lægger de narrative strukturer ned over den. Vi tænker således os selv og vores forhold til verden i narrative strukturer, og litteraturen bliver i forlængelse heraf at forstå som en af de måder, hvorpå vi kan konstruere modeller til forståelse af vores egen verden.

\section{Kritik af de narrative identitetsteorier}

I artiklen »The Dialogics of Narrative Identity « kritiserer Jennifer De Peuter mange af de teorier om konstruktion af narrativ identitet, som har set dagens lys siden I980'erne. Kritikken er rettet mod bl.a. Jerome Bruner, og går på at han og andre narrative identitetsteoretikere fasthol-

\footnotetext{
${ }^{20}$ Det skal bemærkes at Goodmans radikale konstruktivisme strider mod Dines Johansens hypotese om at et af de træk, som adskiller litteratur (den mimetiske diskurs) fra andre diskursive formationer, er at den refererer til et univers som er ontologisk forskelligt fra det, vi er fysisk til stede i. På trods af at nogle af Bruners synspunkter inddrages, fortsætter Dines Johansens definition med at have gyldighed for resten af fremstillingen.
} 
der et centraliseret og homogent subjektsbegreb med rødder i Descartes og Rousseau (de Peuter 1998). Kvaliteter såsom kontinuitet, kohærens, enhed og autenticitet har fungeret som de idealer, derigennem de sidste par hundrede år har styret vores, dvs. den vestlige/europæiske kulturs forståelse af subjektivitet og identitet, og de genfindes i nærmest identisk form i en række af de narrative tilgange til identitetsspørgsmålet. Selv om de konstruktivistiske tilgange altså erstatter det romantiske subjekts transcendentale essentialitet med fortællingens tekstlighed som den kerne, hvorom subjektets identitet opbygges, så fastholder de, ifølge de Peuter, centrale dele af den traditionelle vestlige tænkning ideologiske ballast: »By reconciling opposing tendencies, traditional narrative theory turns dispersion into synthesis and the unintilligible into coherence through the monologues of authorship « (de Peuter I998, 40). Ved at privilegere integrationen af værdier og livsperspektiver i et homogent subjekt kommer hovedparten af de narrative teorier til at udgrænse det fragmenterede og modsigelsesfyldte. I bedste fald bliver de begrebet som modstande der skal overkommes, og i mere ekstreme tilfælde bliver de ligefrem diagnosticeret som sygelige tilstande.

For både Paul Ricœur og Jerome Bruner gælder, at de på linje med de kritiserede teoridannelser ser narrativerne som redskaber til at konstruere subjektet som en stabil, selvidentisk enhed over tid, der grundlægges på en række værdier, normer og idealer, tilegnet på såvel et individuelt eller personligt som på et kollektivt eller kulturelt plan. I den forstand kan man sige at de Peuters kritik rammer dem begge, selv om hun ikke eksplicit nævner Paul Ricœur. Og for den sags skyld kan man sige at det, som vi i gennemgangen af Charles Peirces videnskabsteori og semiotik kaldte hans optimistiske 'sten på sten'-perspektiv, også slår igennem i hans opfattelse af det menneskelige selv. For Peirce er der tilsyneladende ingen modsætning mellem det menneskelige subjekts tilegnelse af den kulturelle tradition og dets 'vækst' som et symbolsk tegn gennem mødet med den 'anden'. Peirce kunne således, på baggrund af de Peuters kritik af de narrative teorier, også læses organicistisk. Ifølge en sådan læsning ville hans position blive et argument for at dialogen mellem det innovative og det kritiske selv altid ville munde ud i en rationel syntese, der ikke bare ville genskabe subjektets værdimæssige enhed, men også ville berige både subjektet selv og den kulturelle kontekst, det var en del af i kraft af dets indhøstede livserfaringer.

En sådan læsning er absolut mulig, men det er ikke det, som interesserer her. I stedet vil jeg følge de Peuters indikation af et alternativ. Som redskab til at udfordre de monologiske og organicistiske identitetsteorier peger de Peuter på Mikhail Bakhtins dialogiske subjektsbegreb. På linje 
med de narrative konstruktivister flytter Bakhtin interessen i bestemmelse af subjektet bort fra den romantiske ideologis 'indre', essentielle subjekt til den sproglige eller diskursive konstruktion af identitet. Men hvor hovedparten af narrativisterne fokuserer på hvordan fortællingerne strukturerer subjektet som et homogent og selvbevidst centrum, der flytter Bakhtin interessen fra centret ud til subjektets grænse i mødet med den 'anden', og ud til de diskursive og dialogiske processer som konstruerer identiteten på tværs af denne grænse. Ifølge Jennifer de Peuter repræsenterer Bakhtin en dialogisk og decentreret position i opfattelsen af subjektet, hvor selvet desintegreres i en flerhed af stemmer uden nogen indbyrdes hierarkisk relation: »Selfhood is multivoiced « (op.cit. 39). Lad os se hvordan Bakhtin selv angriber beskrivelsen af det menneskelige subjekt, og lad os efterfølgende diskutere hvordan Bakhtins dialogisme lader sig kombinere med Peirce og narrativisterne.

\section{Subjektet hos Bakhtin}

Ligesom Peirce tager Bakhtin sit udgangspunkt for diskussionen af det menneskelige subjekt i menneskets forhold til dets omverden og til det som det ikke er, den 'anden': »From my own unique place only I-formyself constitute an $I$, whereas all others are others for me " Bakhtin I993, 46). Men idet dette 'jeg' eller 'selv' er relativt defineret i forhold til det, som det ikke er, udgør det ikke en stabil og uproblematisk position. Ligesom der i den sproglige kommunikation hos Bakhtin er et permanent spændingsforhold mellem centripetale og centrifugale kræfter, udspringer det menneskelige subjekt af en tilsvarende balance. Hvor de centripetale kræfter søger enhed, overensstemmelse og monolog, søger de centrifugale kræfter flerhed, forskellighed og heteroglossia. Michael Holquist beskriver subjektet hos Bakhtin som en dialogisk relation imellem et center og et 'ikke-center': »the self is an event with a structure [...] organized around the categories of space and time" (Holquist I990, 2I).

Især i de tidlige skrifter formulerer Bakhtin menneskets relation til den 'anden' som et dialogisk forhold mellem et 'selv' (the I-for-myself) og et 'ikke-selv-i-mig' (the not-I-in-me). Hvor det betragtende subjekts egen tid er » forever open and unfinished « og dets rumopfattelse altid udgør centrum for dets egen perception og væren i verden, dér er »the time in which we model others [...] perceived as closed and finished «, og »the space in which others are seen is never a significance-charged surrounding, but a neutral environment « (op.cit. 22). I kraft af disse kategorier bliver det muligt for Bakhtin at bestemme subjektet som et tidsligt og rumligt

\section{Litterær erfaring og dialogisme, E-bog 2006


bestemt møde mellem selvet og den 'anden'. For Bakhtin er det således et fænomenologisk grundvilkår, at jeg-for-mig-selv ikke har et fuldt billede af mig selv, men er afhængig af den 'andens' synsoverskud (Holquist I 990, 2I og 36 samt Bruhn og Lundquist I998, 48-49). Man kan sige at det menneskelige selv er usynligt eller tomt som det sproglige 'jeg', mens den anden er synlig for os, hvorfor det er gennem den andens blik at vi bliver synlige for os selv.

To be means to be for another, and through the other, for oneself. A person has no internal sovereign territory, he is wholly and always on the boundary; looking inside himself, he looks into the eyes of another or with the eyes of another (Bakhtin I984, 287).

'Jeg' har som subjekt et udsyn men intet syn på mig selv, mens den anden til gengæld har et syn på mig, som selvet i kraft af en dialogisk tilegnelse kan kombinere med sit eget udblik (der repræsenterer et »surplus of seeing « i forhold til den anden) med henblik på at konstruere en helhed. I det lille tekstfragment »Mennesket ved spejlet « siger Bakhtin:

Det er ikke mig, der indefra kigger på verden med mine egne øjne, men mig der kigger på mig selv med verdens øjne, med fremmede øjne; jeg er besat af en anden [...] Den anden rummer et overskud af betydning. Jeg kan ikke se mig selv udefra, jeg har ikke en tilgang til mit eget indre billede. Ud af mine øjne ser fremmede øjne (Bakhtin I998, 33).

Ved således at kombinere selvets billeder af sig selv og den anden konstruerer subjektet sig selv som en dialog mellem tre momenter: jeg-formig-selv, den-anden-for-mig og jeg-for-den-anden, dvs. det forestillede billede af selvet, som den anden måtte have, og som fungerer som selvets interpretant (Bruhn \& Lundquist I 998, 46). Eller formuleret med Michael Holquists ord: " a center, a not-center and the relation between them « (Holquist I990, 29). Anvender vi Peirces triadiske model på denne struktur, kunne det se således ud:

$$
\begin{gathered}
\text { jeg-for-mig-selv } \\
\text { center / ufinaliseret / nu }
\end{gathered}
$$

$\Delta$

den-anden-for-mig

ikke-center /

finaliseret / fortid jeg-for-den-anden

relation / fremtid

Det ureflekterede jeg-for-mig-selv har ikke nogen hverken tidslig eller rumlig afgrænsning, men lever i et evigt 'nu', og bliver kun bevidst om sig 
selv gennem konfrontationen med den anden, som for subjektet præsenterer sig som den-anden-for-mig. Den anden fremstår til gengæld som en finaliseret eller finaliserbar størrelse, der træder ind på non-egos plads i objektspositionen i tegnmodellen. Den 'anden' kan imidlertid anlægge et finaliserende syn på subjektet, som subjektet selv i anden omgang kan tilegne sig refleksivt som en interpretant af sig selv, hvorfor repræsentationen af subjektet selv som jeg-for-den-anden opstår som en fremtidig gestaltning på interpretantens position.

Det er hovedsageligt Bakhtins tidlige overvejelser om moral- og handlingsfilosofi (I9I9-2I) som tager sigte på at definere mennesket som et etisk-moralsk subjekt, som ligger til grund for den ovenstående fremstilling af hans subjektsbegreb, men også i hans senere forfatterskab kan man finde tilsvarende formuleringer. Således udtrykker han grundlæggende den samme opfattelse af det menneskelige subjekt som en dialogisk relation i kommentarerne til genudgivelsen af Dostojevskijbogen, som han skriver så sent som i I96I:

I am conscious of myself and become myself only while revealing myself for another, through another, and with the help of another.

$[\ldots]$

I cannot manage without another, I cannot become myself without another; I must find myself in another by finding another in myself (in mutual reflexion and mutual acceptance) (Bakhtin I984b, 287).

Mennesket er for Bakhtin kastet ud i verden i en Væren-som-begivenhed, som er præget af det givne og af de projekter, som subjektet er bærer af (Bruhn \& Lundquist 1998, 43). I temporal forstand bliver subjektet således til i en treenighed af selvets ureflekterede " nu ", den andens finaliserede datid og projekternes ufinaliserede fremtid. I essayet »Forfatter og helt i æestetisk aktivitet " beskriver Bakhtin denne relation som en dialog imellem ånd og sjæl, mellem værdicenter og erfaring. Sjælen udgør for Bakhtin »vores samlede erfaringsverden, således som den er blevet dannet fra vores fødsel til vores død ", eller »stedet hvor erfaringen bundfælder sig hinsides konkrete mål, ønsker og mening « og som sådan er usynlig for os selv (op.cit. 50). Heroverfor repræsenterer ånden »en aktiv del af mit konkrete liv, mine oplevelser, handlinger osv., således som de er udfoldet i min konkrete leven i Væren-som-begivenhed «(ibid.). Som Bruhn \& Lundquist gør opmærksom på, er den centrale erkendelse i dette skrift, at "når jeg gebærder mig i verden, møder jeg verden som et projekt, jeg lever i en rettethed mod fremtiden som indløsningsstedet af mål og mening « (ibid.).

Den dialogiske kombination af self og other betegner Bakhtin som et 
spørgsmål om at konstruere »the possible author of our own exterior « (Bakhtin I990, 33). Holquist døber denne proces authoring: "I author a unified version of the event of our joint existence from my unique place in it by means of combining the things I see which are different from [...] those you see (Holquist I990, 37). Denne authoring af subjektet som en kombination af self og other indebærer på sin side rent sprogligt at subjektets diskurs eller »i-tale-sættelse « bliver et amalgam af selvets nærvær og andre(s) stemmer. I denne forbindelse forekommer det slående at Peirce, i Colapietros udlægning, stort set formulerer den samme indsigt: »the subject is, among other things, a medium through which forces and persons other than the subject speak « (Colapietro I989, 38).

Der er imidlertid ikke tale om at denne authoring munder ud i et på nogen måde statisk eller stabilt / neutralt standpunkt: »A neutral position in relation to $I$ and another is impossible in the living image and in the ethical idea. They cannot be equated " (Bakhtin I984b, 296). Hvad der er tale om, er et dynamisk og levende forhold i permanent dialog. Til gengæld indebærer brugen af authoring-begrebet som metafor for subjektets identitetsmæssige positionering af sig selv i forhold til den anden en narrativisering af erfaringsbegrebet, som svarer til det, vi fandt $i$ Bruners beskrivelse af selvet som en tekst. Ifølge Bakhtin virker menneskets forudbestemte forventninger styrende for hvordan den erfaring tolkes, som subjektet indhøster i samspillet med verden. Og disse forventninger lejrer sig i narrative skematikker som mennesket tolker sig selv og sit eget liv i forhold til. Michael Holquist formulerer det således:

Stories are the means by which values are made coherent in particular situations. And this narrativity, this possibility of conceiving my beginning and end as a whole life, is always enacted in the time/space of the other (Holquist I990, 37).

Bakhtins forestilling om at det menneskelige subjekt etablerer sig som værdicenter, sådan som det er formuleret $i$ » Toward the Philosophy of the Act «, ligger i en vis forstand i forlængelse af Peirces idé om subjektets identitet som »a bundle of habits «. Men hvor Peirce relaterer disse semiotiske vaner og de bagvedliggende kulturelle værdisæt mere eller mindre uproblematisk til den individuelle livshistorie og den kulturelle tradition, dér søger Bakhtin at forankre de sproglige diskurser socialt og ideologisk: »Languages are philosophies - not abstract but concrete, social philosophies, penetrated by a system of values inseperable from living practice and class struggle « (Bakhtin I984a, 47I). Sprogets centrale betydning for subjektets identitetskonstruktion betyder således i anden omgang, at de 
samfundsmæssige magtforhold og spændinger, ifølge Bakhtin, også slår ned igennem subjektets identitetsstruktur. Subjektet bliver gennemstukket af forskellige heterogene diskurser som ikke nødvendigvis lader sig indordne i en harmonisk enhed, og som gør det nødvendigt at gentænke betingelserne for den narrative identitetskonstruktion. For hvis subjektet er liminalt defineret, dvs. hele tiden definerer sig selv i forhold til den grænse der markerer forholdet til den anden, så er der ikke tale om at subjektet blot kan støtte sig på en overordnet masterfortælling, der kan skabe orden og give mening. I stedet må subjektet hele tiden genskabe sin egen identitetshistorie, og det vil være nødvendigt hele tiden at anskue historien fra lige så mange perspektiver som der findes 'andre' i dets dialogiske horisont. Men inden vi går videre med denne diskussion, så lad os lige kaste et blik på Lotmans forståelse af subjektet, da det er ham, om nogen, der har tematiseret grænsen som den betydningsskabende semiotiske enhed.

\section{Subjektet hos Lotman}

For Lotman er den menneskelige bevidsthed bærer af de semiotiske processer og udgør derfor udgangspunktet for hans bestemmelse af subjektet. Subjektsbegrebet er hos Lotman endvidere både at forstå individuelt, som personlighed, og kollektivt, som en kulturel eller subkulturel formation (Lotman I990b I38), jf. semiosfærebegrebet (se s. 55).

Lotmans begreb om det menneskelige subjekt tager afsæt i tre fundamentale antagelser, som vi allerede tidligere har været inde på. Den første antagelse går ud på at den menneskelige bevidsthed er heterogen, idet den er sammensat af diskurser tilhørende henholdsvis det diskret-symbolske register og det kontinuert-ikoniske register. Oversættelserne, såvel mellem disse to registre i subjektets indre dialog som mellem forskellige subjekter i kommunikativ udveksling, udgør det fundament, som al ny betydningsdannelse og kreativ tænkning bliver til på baggrund af (ibid. 36-37). Og disse oversættelser er principielt af dialogisk karakter: »The elementary act of thinking is translation [...] [and] the elementary mechanism of translation is dialogue " (Lotman I990b, I43).

Den anden antagelse består i at Lotman, på linje med både Peirce og Bakhtin, mener at udgangspunktet for en beskrivelse af subjektets personlighed og kvalitative forandringsprocesser (dannelsesmæssige udvikling) skal findes i forholdet mellem subjektet og den anden. Såvel semiosfærens intersubjektive kulturelle rum som det individuelle subjekts personlighed bliver konstrueret i dialogen hen over de betydningsmæssige 
eller semiotiske grænser som skiller os fra de andre: »The boundary of the personality is a semiotic boundary "(Lotman I990b, I38). Og igen er det interaktionen hen over grænsen som er den primære, identitetsgivende dynamik.

Endelig mener Lotman, på linje med Wileys udlægning af Peirce, at det semiotiske subjekt, hvad enten det er individuelt (personlighed) eller kollektivt (kulturel identitet), konstruerer sig selv diskursivt gennem en selvrefleksiv dialog. Igennem selvrefleksionen medierer subjektet sine erfaringer, og vurderer de normer og værdier som hidtil har ligget til grund for dets selvforståelse. Lotmans tredje grundlæggende antagelse går derfor ud på at det er nødvendigt at tilføje en anden 'kanal' til Jakobsons traditionelle kommunikationsmodel (I-s/he systemet), nemlig det som Lotman kalder et 'jeg-jeg system' (I-I system). Denne kanal er nødvendig at tilføje, mener Lotman, hvis man sætter sig som mål at konstruere »a culture-model on a more abstract level «(Lotman I990b, 20). Det er typisk dér, at både individuel og kollektiv selvrefleksion foregår:

The I-s/he system allows one merely to transmit a constant quantity of information, whereas the I-I system qualitatively transforms the information, and this leads to a restructuring of the actual 'I' itself. In the first system the addresser transmits a message to another person, the addressee, but remains the same in the course of the act. In the second system, while communicating with him/herself, the addresser inwardly reconstructs his/her essence, since the essence of a personality may be thought of as an individual set of socially significant codes, and this set changes during the act of communication (Lotman I990b, 22).

De to kommunikative systemer er komplementære i den forstand at det ekstroverte system, som Lotman kalder I-s/he, cirkulerer information i de sociale processer, mens det introverte system, I-I systemet i Lotmans terminologi, kvalitativt bearbejder denne information som en erfaring, der bidrager til udviklingen af subjektet selv. De to systemer udgør således i denne stiliserede udgave to indbyrdes forbundne strenge, og forestiller vi os det ekstroverte system som en fortløbende kæde af uendelige semiotiske processer, danner de to parallelle systemer tilsammen et semiotisk netværk af social praksis og kulturel selvrefleksion. Således kan man sige at Lotman, på linje med Peirce, definerer subjektet som en semiotiskdialogisk størrelse, og at begge insisterer på at indtænke subjektet i en holistisk sammenhæng, det være sig Peirces overgribende semiosisbegreb eller Lotmans semiosfærebegreb. Ligesom Peirce understreger Lotman den åbne relation mellem individuelle og kollektive semiotiske processer, hvor det menneskelige subjekt bliver defineret gennem dets tilstedeværelse i den 
semiotiske interaktion. Sprog og semiosis bliver noget som mennesket er til stede i, og ikke bare noget som er inde $i$ mennesket:

The individual human intellect does not have a monopoly in the work of thinking [...] thought is within us, but we are within thought, just as language is something engendered by our minds and directly dependent on the mechanisms of the brain and we are with language (Lotman I990b, 273).

Skulle man pege på en forskel imellem Charles Peirce og Jurij Lotmans måde at begribe det menneskelige subjekt på semiotisk, kan man sige, at hvor Peirce med sine overvejelser af mere kosmologiske karakter mener at der er tale om evolutionær kontinuitet mellem naturens processer og den menneskelige kommunikation, dér præsenterer Lotman klart semiosfærens relation til Verdnadskys biosfærebegreb som en kognitiv metafor.

\section{Psykostrukturen som tegn}

En freudiansk orienteret, semiotisk udlægning af subjektet ville bestræbe sig på at forstå dettes psykodynamiske struktur som en mediering mellem indre begær efter driftstilfredsstillelse og ydre civilisatorisk tvang. Således konciperet ville subjektet kunne udlægges processuelt i det pragmatiske tegnbegrebs tredelte relation.

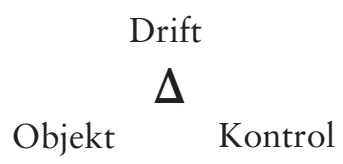

Subjektet forklares her som en relativt stabil, men på ingen måde statisk, balance mellem civilisatorisk kontrol og kropslige eller spontane driftimpulser. Den civilisatoriske tvang udmønter sig, i Freuds terminologi, i udviklingen af et overjeg, der over tid dannes som et sæt af vaner til at tackle spændingen mellem drift og civilisatorisk tvang. Anskuet fra subjektets position kunne man argumentere for at subjektet først bliver bevidst om sin egen drift, når driften konfronteres med omverdenens civilisatoriske tvang i form af udskydelse af den umiddelbare tilfredsstillelse. Igennem den civilisatoriske træning opøves subjektet $i$ at balancere egen drift i forhold til de krav der stilles af omverdenen, hvilket igen udmøntes $i$ en balance mellem overjegets normer og de kropsligt ubevidste drifter.

Idet vi relaterer de psykologiske begreber til Peirces kategorier, bliver det klart at der hos Freud er tale om at førsteheden repræsenterer et 
driftsorienteret lystprincip, der i udgangspunktet er udifferentieret og uden specifikt objekt. Andetheden repræsenterer driftens rettethed imod et specifikt objekt, men dermed også forhindringen af den umiddelbare driftstilfredsstillelse, hvilket opleves som en modstand. Socialiteten opleves som en række udefra formulerede krav og normer, der i udgangspunktet forhindrer driftstilfredsstillelsen, og som først bliver forståelige når de medieres af refleksion og formuleres som sprog. Det, som altså fra andethedens 'infantile' synsvinkel opleves som modstand og begrænsning, kan fra tredjehedens standpunkt erfares som social ansvarlighed og samhørighed. For Peirce erhverver mennesket kun sin identitet ved at erkende at det ikke lever i ophøjet adskilthed fra andre, men udgør en del af et samlet hele.

De psykologiske teorier indebærer, som antydet, et evolutionært aspekt i den forstand at de tre kategorier repræsenterer bestemte 'faser' i barnets udvikling mod voksenidentiteten. Denne forestilling ligger heller ikke Peirce helt fjernt, idet han opfatter evnen til handlen og kommunikation som en grundforudsætning for tilblivelsen af selvbevidsthed:

It is not simply as a sensing and desiring organism that the child is able to become conscious of itself as distinct from others; rather it is primarily as an acting and communicative organism that it achieves this level of consciousness. In other words, through refined capacities for acting and for communication, the child reaches the stage where self-consciousness becomes possible (Colapietro I989, 7I).

For Peirce er det menneskelige subjekt ikke, selv om det i visse passager kan lyde sådan, ren bevidsthed, men en størrelse som er fysisk/kropsligt til stede i den verden, hvormed det dialogerer. Kroppen er således ikke bare et hylster der omgiver den rene bevidsthed, den præger også dennes karakter på en grundlæggende måde: »Semiotic consciousness is incarnate consciousness " (op.cit. 39). Grunden til, at det er vigtigt at understrege dette, er at kroppen repræsenterer en forbindelse til de ubevidste og instinktive sider af vores væren, som komplementerer de bevidste og rationelle sider. Selv om Peirce skrev hovedparten af sine artikler før Freud offentliggjorde sine resultater om det ubevidste, og ikke formodes at have haft kendskab hertil, indgår begrebet om det ubevidste som et vigtigt element $\mathrm{i}$ hans teoridannelse. I en tekst fra 1905 skriver han således følgende:

The doctrine of Descartes, that the mind consists solely of that which directly asserts itself in unitary consciousness, modern scientific psychologists altogether reject. Swarming facts positively leave no doubt that vivid conscious- 
ness, subject to attention and control, embraces at any one moment a mere scrap of our psychical activity. Without attempting accuracy of statement demanding long explanations, and irrelevant to present purposes, three propositions may be laid down. (I) The obscure part of the mind is the principal part. (2) It acts with far more unerring accuracy than the rest. (3) It is almost infinitely more delicate in its sensibilities (CP 6.569).

I andre af Peirces skrifter finder vi en behandling af psykologien og den menneskelige subjektsdannelse, som knytter dette undersøgelsesområde an til hans tre overordnede kategorier (førstehed, andethed og tredjehed). Hermed indføres nogle følelsesmæssige og hændelsesorienterede aspekter af bevidstheden, som ikke har været bragt i fokus i den primært logisk orienterede behandling ovenfor. Disse aspekter vil imidlertid være vigtige når vi skal til at se på de æstetiske aspekter af den litterære reception nedenfor. I artiklen »Phaneroscopy or the Natural History of Concepts «, ligeledes fra I905, skriver Peirce: »The triad, feeling, volition, cognition, is usually regarded as a purely psychological division «(CP I.332). Følelse er, for Peirce, en ren kvalitativ førstehed, og som sådan er den ikke hverken begrænset eller knyttet til noget specifikt og determineret subjekt: »Feeling is a quality, but so far as there is mere feeling, the quality is not limited to any definite subject « (op.cit.). Følelsen er ubegrænset i tidslig og rumlig udstrækning, og som sådan en ren mulighed i modal forstand, for i det øjeblik den afgrænses, konfronteres den med en anden kvalitativ tilstand, en anden følelse. I dette sammenstød mellem noget allerede kendt og noget andet, opstår den afgrænsning eller modstand, som er forudsætningen for psykologisk 'villen'. » As for volition, I would [...] limit it to the momentary direct dyadic consciousness of an ego and a non-ego then and there present and reacting each upon the other" (CP I.334).

Peirce giver de psykologiske kategorier forskellig udformning i forskellige skrifter, men fælles for dem er at de alle indeholder den samme triadiske relation mellem modal mulighed, aktualitet og generalitet eller repræsentation:

The first is thought in its capacity as mere possibility; that is, mere mind capable of thinking, or a mere vague idea. The second is thought playing the role of a Secondness, or event. That is, it is of the general nature of experience or information. The third is thought in its role as governing Secondness. It brings the information into the mind, or determines the idea and gives it body. It is informing thought, or cognition. But take away the psychological or accidental human element, and in this genuine Thirdness we see the operation of a sign (CP I.537).

Vi skal vende tilbage til en mere udførlig behandling af disse aspekter i 
forbindelse med gennemgangen af Peirces opdeling af interpretanten i et emotionelt, energetisk og logisk aspekt nedenfor (se s. I34 ff.).

\section{Kritikken af psykosemiotikken: det radikalt decentrerede subjekt}

Som reaktion på den romantiske essentialisme, som dominerede humanvidenskabernes opfattelse af subjektivitet og identitet op til midten af det tyvende århundrede, har de strukturalistiske og poststrukturalistiske teoridannelser, som dominerede århundredets seneste årtier, bestræbt sig på at aflive det menneskelige subjekt på forskellig vis. Først ved at lade det overdeterminere af de sproglige strukturer (Barthes) og diskursive praksisser (Foucault), og siden ved at dekonstruere subjektiviteten i den isolerede sproglige ytrings altid åbne og til dels selvmodsigende betydningspotentialer (Derrida, de Man). Under indtryk af poststrukturalismens angreb på de romantiske forestillinger om et transcendent eller essentielt menneskeligt subjekt, har dele af Bakhtin-receptionen fokuseret på Bakhtins sprogfilosofiske overvejelser i den senere del af hans forfatterskab og kastet de mere fænomenologiske synspunkter, som dominerede mange af hans tidlige skrifter, ud med badevandet.

Et eksempel på en sådan Bakhtin-reception finder vi bl.a hos John Shotter og Michael Billing, der med deres titel »A Bakhtinian Psychology: From out of the heads of individuals and into the dialogues between them ", udtrykker deres forehavende meget præcist (Shotter \& Billing I998). Som påpeget af Shotter \& Billing flytter Bakhtin og Volosjinov fokus fra den individuelle psykologi til socialpsykologien, hvorefter de forankrer socialpsykologien i det dialogiske sociale samspil. Denne operation bygger de på to fundamentale antagelser om de psykologiske fænomeners karakter. For det første forudsætter de at vores mentale processer (tænkningen) er skabt med udgangspunkt i vores sprogligt baserede sociale praksis, hvorved de placerer sig helt på linje med Charles Peirces forståelse af subjektet som et tegn. Og for det andet mener de at den menneskelige tænkning, som al anden sprogligt baseret social praksis, må være dialogisk organiseret (op.cit. I4).

I modsætning til individualpsykologien, der ser talen som udtryk for indre processer, antager Bakhtin og Volosjinov at tænkningen er et aspekt af vores sproglige, sociale praksis. Og da talen altid er udspændt i et udsigelsesfelt mellem en afsender (subjekt) og en modtager (anden), så må menneskenes 'indre liv' udgøres af partikulære og konkrete sociale konstruktioner (op.cit. I 5). En dialogisk tilgang til psykologien skulle derfor, ifølge Shotter \& Billing, hellere beskæftige sig med de synlige og studerbare talehandlinger end med 'skjulte' indre kræfter. De diskursive ytringers konkrete betydning afhænger altid af en tre-enighed af dialogi- 
ske relationer: den intertekstuelle dialog med de forudgående ytringer om samme emne, den omgivende kontekst hvori ytringen finder sted og de formodede fremtidige reaktioner på ytringen. Derfor kan meningen med en ytring eller talehandling ikke søges alene i den ytrende persons indre psyke, men må analyseres i dens konkrete dialogiske kontekst.

På trods af at Shotter og Billing hævder at se en parallelitet i Bakhtins syn på de indre og ydre processer, antyder deres rekommendation af at flytte interessen fra hvad der foregår i det menneskelige indre til samspillet mellem folk i deres sociale praksis, at de anser de indre processer for ikke at have en dialogisk form, hvilket til gengæld antages at være gældende for de ydre. Som vi har set ovenfor, er den fænomenologisk baserede forestilling om selvet som en indre størrelse der definerer sig selv i en dialogisk relation imellem et jeg-for-mig-selv, et den-anden-for-mig og et jeg-for-den-anden imidlertid ikke Bakhtin fremmed. Og selv om udfoldelsen af denne tese tilhører hans tidlige forfatterskab, har vi også set at han gentager synspunktet næsten enslydende i sine kommentarer til genudgivelsen af Dostojevskij-bogen, som han skriver i I96I (Bakhtin I84, appendix II). Jeg ser derfor ingen grund til at følge Shotter \& Billing i deres forsøg på at afvise en semiotisk undersøgelse af subjektets indre dialogisme med Bakhtin ved hånden.

\section{Det dialogiske subjekt}

Jeg har i gennemgangen af de forskellige tilgange til undersøgelsen af subjektet som en semiotisk størrelse gjort mig til talsmand for et dialogisk og konstruktivistisk syn på selvet, der indebærer at subjektet konstruerer sig selv og sin egen identitet narrativt i relation til repræsentationen af den anden, samt til den refleksive forestilling om denne andens syn på subjektet selv. Processen tager form af en dialog mellem vanebaserede forestillinger og nyindhøstede erfaringer, hvori det temporale forhold mellem fortid, nutid og fremtid bidrager til at parcellere subjektet $\mathrm{i}$ en række indbyrdes dialogerende størrelser, og hvor repræsentationen af den anden udgør den fremmede modpart i subjektets mediering af erfaringer på baggrund af tilværelsens konstante flow af konkrete tildragelser. I det følgende vil jeg forsøge at præsentere en samlet model for repræsentationen af subjektets semiotiske processer, der sammentænker de præsenterede positioner med nyere bidrag på området. Her vil jeg først og fremmest trække på det arbejde med emnet, som i løbet af de seneste år har udviklet sig i Spanien.

Den spanske litteraturprofessor Manuel Ángel Vázquez Medel fra 
universitetet i Sevilla har i en årrække stået i spidsen for en gruppe af forskere, der har arbejdet med teorien om det, som de på spansk kalder el sujeto emplazado, på dansk: det situerede / engagerede subjekt (Vázquez Medel I997, 2003a og 2003b). I den spanske betegnelse spilles der på de to samtidige betydninger, som kan læses ind i verbet emplazar. Slår man op i ordbogen, betyder emplazar enten at 'stævne' nogen, eller at 'placere' nogen eller noget. I ordets stamme finder vi således to forskellige rødder, som Vázquez Medel spiller bevidst på (Vázquez Medel $2003 \mathrm{~b}, 26)$. Den ene af ordets betydninger kommer af plazo, som betyder 'frist', hvorved begrebet får betydning af 'stævning' i temporal/juridisk forstand eller ligefrem af 'kaldelse' i religiøs forstand. ${ }^{21}$ Den anden kommer af 'plaza', som betyder en 'plads' i rumlig forstand, hvorved begrebet el sujeto emplazado får betydning af at være 'situering' af subjektet, en eksistentiel 'kastethed'. Tilsammen giver de to udlægninger begrebet en kompleks betydning, henviser til at det menneskelige subjekt altid er emplazado i kraft af det, som Vázquez Medel kalder 'den trefoldige emergens': vores rumlige, tidslige og rent personlige forankring i et her, et nu og i et forhold til den anden. Mennesket er et semiotisk væsen der er drevet af en 'vilje til mening' (Vázquez Medel 2003a, I 2), og det er den andens tilsynekomst i subjektets horisont der udgør den dynamik, som gør det muligt for subjektet at erfare sig selv, og dermed tilskrive sig selv og sit eget liv mening. Subjektet er emplazado inden for en semiosfære, hvorigennem det bliver i stand til at tilskrive dets konkrete tidslige, rumlige og personlige placering en symbolsk værdi eller mening (ibid., 8), og hvorigennem subjektet udfordres til at påtage sig et etisk ansvar $\mathrm{i}$ forhold til den anden og den kontekst, som de fælles indgår i (op.cit.I3).

Det spanske forskningsprojekt er et friskt og inspirerende initiativ, ikke mindst fordi gruppen ikke har sat sig for at konstruere en sammenhængende og 'lukket' teori, men snarere forstår deres arbejde som åbningen af et forskningsfelt og som en invitation til at lade forskellige tilgange mødes og befrugte hinanden i et udogmatisk samspil. Beskrivelsen af subjektets 'topologi' bliver således forstået som en tværfaglig udfordring, der stiller krav om en åben kartografisk samvirken af semiotiske, pragmatiske og hermeneutiske tilgange.

Det, som Vázquez Medel kalder subjektets trefoldige emergens (tidsligt, rumligt og personligt), kommer direkte til udtryk i sprogets deixis-former. Igennem hele dette kapitel har jeg løbende taget udgangspunkt i det forhold at subjektet konstruerer sine erfaringer med verden narrativt, hvorved hele subjektets syn på sig selv og på verden bliver sprogligt medieret.

\footnotetext{
${ }^{21}$ Der er ikke nogen religiøs dimension knyttet til gruppens arbejde, men de religiøse konnotationer bruges til at antyde subjektets 'kaldelse' i etisk forstand.
} 
Narrativiseringen af erfaringsbegrebet tildeler således sproget en helt central funktion i subjektets selvkonstruktion. Sproget får det, som Bruner kalder en 'dobbeltkarakter', fordi det på én gang er menneskets privilegerede medium til at kommunikere om forhold i verden og udgør det redskab, hvormed vi konstruerer vores opfattelse af den samme verden. Og dermed også af os selv:

Language not only transmits, it creates or constitutes knowledge or 'reality'. Part of that reality is the stance that the language implies toward knowledge and reflection, and the generalized set of stances one negotiates creates in time a sense of one's self (Bruner I986, I32-33).

Sproget er således ingen uskyldig eller neutral instans, men afspejler altid et bestemt syn på verden. Også Bakhtin understreger det forhold, at subjektets diskurs altid skriver / taler sig ind i en bestemt sociokulturel sammenhæng, hvori bestemte magtfulde og autoritative diskurser hersker. Hver epoke, hver kultur og hver social sammenhæng har sin måde at forme de diskurser som indgår i dem, hvorfor der i enhver sammenhæng tales distinkt og genkendeligt: på arbejdet, iblandt vennerne, i familien osv. Ligegyldigt hvor et menneske vokser op og lever sit liv, vil der herske en række magtfulde institutioner, hvortil der knytter sig bestemte distinkte diskurser, som dette subjekt vil være nødt til at forholde sig til. Institutionerne kan være familiemæssige, uddannelsesmæssige, jobmæssige, kunstneriske, videnskabelige, journalistiske osv., og subjektet kan forholde sig imiterende, refererende, diskuterende eller ironisk parodierende til disse diskurser. Den enkeltes sprogbrug bliver således til i en permanent dialog med andres individuelle ytringer samt med de talegenrer, som er bestemmende for sammenhængen, og som, i større eller mindre grad, indoptages som en del af denne sprogbrug:

Our speech, that is, all our utterances (including creative works), is filled with other's words, varying degrees of otherness or varying degrees of 'our-ownness', varying degrees of awareness and detachment (Bakhtin I986, 89).

Subjektets sproglige authoring af sig selv bliver, i kraft af denne delvise assimilering af de samfundsmæssige diskurser, socialt og kulturelt overdetermineret. Sproget kommer som et indeks til at afspejle den konkrete historiske kontekst, hvoraf det udspringer, og subjektets ytringer vil altid forholde sig ideologisk stillingtagende til denne sammenhæng. Men samtidig vil subjektet altid kun kunne tage ordet i form af et kulturelt situeret og diskursivt konstrueret selv: 
The word in language is half someone else's. It becomes 'one's own' only when the speaker populates it with his own intention, his own accent [...] adapting it to his own semantic and expressive intention. Prior to this moment of appropriation the word does not exist in a neutral and impersonal language [...], but rather it exists in other people's mouths, in other people's contexts, serving other people's intentions: it is from there one must take the word and make it one's own [...] [But] expropriating it, forcing it to submit to one's own intentions and accents, is a difficult and complicated process (Bakhtin I98 I, 293-94).

Selve italesættelsen af subjektet bliver således gennemstukket af forskellige diskursive registre som gør, at subjektet altid vil konstruere sig i relation til (op imod / i forlængelse af) andre diskurser. Der vil således ikke være ét enkelt privilegeret udsigelsespunkt, hvorfra subjektet som helhed kan artikuleres, men i stedet vil helheden i subjektets selvopfattelse være henvist til at artikulere sig som en i princippet uendelig serie af situerede selver. Som Jennifer de Peuter formulerer det, bliver romantikkens autentiske selv i en dialogisk tilgang afløst af et 'mutable self', som er under permanent formulering og reformulering (de Peuter, I998, 42-43).

Den spanske psykologiprofessor Carlos Castilla del Pino har i artiklen "El sujeto como sistema " (»Subjektet som system «) forsøgt at tegne omridset af en psykologisk model, der på én gang kunne indeholde disse centrifugale og kontekstrelaterede subjektspositioner, og på den anden side medreflektere subjektets kontinuerte tilstedeværelse i form af erindring og selvkritik (Castilla del Pino 200I). Således drager han en skelnen mellem et intellektuelt subjekt, placeret i det præfrontale cortex, og en serie kropsligt materialiserede selver. Forholdet mellem de to er at subjektet garanterer den i Bakhtins forstand centripetale bevægelse, hvor en persons forskellige aktiviteter kan forstås som nogens handlinger (op.cit. 389), mens selvet skal forstås som »det instrumentelle billede med hvilket subjektet præsenterer sig i og med henblik på situationen; en mellemmand mellem subjektet og situationen « (op.cit. 399. Min oversættelse). ${ }^{22}$ Subjektet er således overordnet de situationsrelaterede selver i den forstand, at det er subjektet som efterfølgende evaluerer selvets ageren i den konkrete situation, og det er subjektet som både lagrer erindringen om erfaringen og genererer nye adækvate selver med henblik på fremtidige situationer. Subjektet er således unikt og kontinuert, om end ikke uforanderligt, idet subjektet hele tiden selv påvirkes af de selver det producerer, evaluerer og memorerer, mens selverne er situationelt artikulerede diskurser med narrativ struktur og hvis retoriske form har karakter af

\footnotetext{
${ }^{22}$ Den spanske tekst lyder således: »la imagen instrumental con la que el sujeto se presenta en y para la situación; un intermediario del sujeto para la situación«.
} 
argumenter (ibid., 400). Subjektet kan således ikke defineres med udgangspunkt i ét eller i et begrænset antal af dets selver, men selverne kan beskrives konkret på baggrund af deres optræden.

Ifølge Castilla del Pino konstruerer subjektet selvet 'proleptisk', dvs. forud for selve kommunikationssituationen, og det gør subjektet på baggrund af en hypotese om, hvilken type 'selv' det ville være adækvat at præsentere i forhold til den konkrete situation. Som Peirce har illustreret det i forbindelse med sin beskrivelse af abduktionsbegrebet, trækker hypotesedannelsen på en forudgående viden der spiller ind som en implicit præmis, og Castilla del Pino medgiver da også at subjektet i denne aktivitet dels trækker på det, han kalder »pragmatiske teorier om virkeligheden « (op.cit. 393), dels på nogle genremæssige kategoriseringer af selverne, som han i øvrigt ikke gør synderligt meget ud af (op.cit. 4OI). Hvad Castilla del Pino ikke siger noget om, er imidlertid hvordan den sociale sprogbrugs diskursive registre til dels determinerer subjektets valgmuligheder i konstruktionen af de adækvate selver. Ikke desto mindre finder jeg Castilla del Pinos skelnen mellem subjekt og selv frugtbar for den videre beskrivelse af subjektets erfaringsbearbejdning og identitetskonstruktion, fordi den giver et begrebsmæssigt redskab til at balancere dialogen mellem centrifugale og centripetale kræfter i subjektetkonstitutionen.

Ved at kombinere Castilla del Pinos forestilling om forholdet mellem subjekt og selv med på den ene side Wileys refleksioner over subjektets temporale dialog mellem fortid og fremtid og på den anden side Bakhtins overvejelser over subjektets diskursive dialogisme mellem self og other, opstår muligheden for at konceptualisere subjektets erfarings- og identitetsdannelse i tre niveauer. For det første har vi et direkte kommunikativt niveau, hvor subjektet etablerer en dialog med en konkret anden, der indtager pladsen som interpretant for subjektets ytringer, hvad enten de er udtrykt diskursivt eller i handling. Vi kan kalde dette niveau for det kommunikative niveau. På dette niveau skal vi forestille os semiosis som en ubrudt kæde af fortløbende, kommunikative processer, hvor subjektet engagerer sig i verden som en social praksis, men 'bag' subjektets ekstroverte tegngivning finder vi en kulturelt og diskursivt medieret selvrefleksion, der sikrer at subjektets tale eller handlen rettes retorisk mod den 'forventede' anden, dvs. hvor subjektet skaber sit eget billede af den anden på baggrund af de kulturelle og idiosynkratiske for-domme som subjektet besidder, og etablerer sig selv som et diskursivt selv med denne 'maske'. På dette niveau tjener subjektets erfaringer med den konkrete 'anden' som udgangspunkt for en dialog med det billede af den anden, som subjektet har etableret som skabelon for sin kommunikative eller retoriske strategi, hvorfor vi kan kalde dette niveau for det erfaringsdan- 
nende niveau. Og for det tredje har vi et niveau hvor et bagvedliggende subjekt med sin vilje til at skabe mening og sammenhæng insisterer på at mediere de forskellige diskursive selvers erfaringer i forhold til dets bundle of habits i form af narrativiserede erindringer og sæt af kulturelle værdier. Vi kan kalde dette rent selvrefleksive niveau for niveauet for egentlig subjektskonstruktion. Relaterer vi nu denne struktur det til den semiotiske trekantsmodel, får vi følgende model over subjektsdannelsen:

\section{Tegn}

Kritisk subjekt

Subjektskonstruktion

$\Delta$

Objekt Interpretant

Fortid Fremtid

Jeg-for-mig-selv

Innovative fokale selver

Erfaringsdannelse

\section{Tegn}

\begin{tabular}{ccl} 
& Objekt & Interpretant \\
& Non-ego / alteritet & Diskursive selver \\
Den anden for mig & Jeg-for-den-anden \\
& & Udtryk / handlen \\
Kommunikation & \multicolumn{2}{c}{$\begin{array}{c}\Delta \\
\text { Objekt }\end{array}$} \\
& \multicolumn{1}{c}{ Interpretant } \\
Livsverden & Den konkrete anden
\end{tabular}

Ligesom Peirce insisterer på at det er hele den treleddede relation mellem repræsentamen, objekt og interpretant som udgør tegnrelationen, således insisterer Castilla del Pino også på at det menneskelige subjekt består af den samlede relation mellem det kritiske subjekt og de situationelle selver, og at konstruktionen af hvert nyt selv efterlader subjektet forandret (op. cit. 292). Parallelt hermed kan vi sige at det dialogiske subjekt er at forstå som den samlede, treleddede relation mellem kommunikation, erfaringsdannelse og subjektskonstruktion, og at subjektet som sådan må anses for forandret for hver enkelt erfaringsdannende proces det gennemløber.

Som det fremgår af figuren, er personificeringen af subjektet i en række diskursivt konstruerede selver den eneste port til en interaktion med omverdenen. Dette indebærer på den ene side, at de fortællinger eller masker som subjektet kan bringe i anvendelse for at konstruere sin identitet, altid allerede vil være konkret situerede identiteter, som kun og i bedste fald kan være partielle i forhold til subjektets identitet. Dette aspekt er ikke 
medreflekteret hos Castilla del Pino, selv om han peger på selvernes mulige udvikling gennem interaktionen. Hos Castilla del Pino mangler ganske enkelt det niveau, hvor subjektet ser sig selv under den andens indflydelse. Det forhold, at de konstruerede selver er subjektets eneste port til interaktion med omverdenen, indebærer for det andet, at al virkelig dialogisk erfaringsdannelse må træde i kommunikativ interaktion med den anden for ikke at reproducere og bekræfte de for-domme, hvorpå det retoriske billede af denne anden, non-ego, er konstrueret. Som påvist af forskellige poststrukturalistiske teoridannelser har den vestlige kultur konstrueret billedet af sig selv gennem udgrænsningen af en række kulturelle 'andre' (orienten, kvinden, den homoseksuelle osv. osv.). Det er formentligt et alment antropologisk vilkår, at enhver kultur forsøger at skabe en indre sammenhæng ved at etablere sig selv som et 'vi' over for de 'andre' på baggrund af en række historisk og kulturelt betingede fordomme. Hvad der er vigtigt for mig at understrege med denne model er, at al virkelig erfaringsdannelse forudsætter en dialogisk interaktion med den anden, for at sikre at processen ikke går i selvsving i en monologisk og selvretfærdiggørende udgrænsning, ikke af den konkrete anden, men af det kulturelt determinerede og for-domsfulde billede af den anden, som danner det retoriske afsæt for det diskursive selvs udtryk. Men er der tale om en reel dialogisk interaktion med den anden må dette indebære at processens 'retning' også er reversibel: den konkrete anden udtrykker sig med sin respons med et tegn, og subjektets fortolkning heraf udgør interpretanten og så fremdeles, for at erfaringerne kan sætte sig igennem i dybden:

\section{Interpretant}

Kritisk subjekt

Subjektskonstruktion

$\Delta$

Objekt Tegn

Fortid Fremtid

Innovative fokale selver

Interpretant

Erfaringsdannelse

$\Delta$

Objekt

Non-ego / alteritet

Kommunikation

Tegn

Diskursive selver

Interpretant

$\Delta$

Objekt Tegn

Livsverden Den konkrete anden 
I kraft af den dialogiske interaktion, der installerer den anden som et selvstændigt subjekt eller 'jeg', bliver subjektet gjort til interpretant af den anden og den måde, hvorpå denne forholder sig til sin livsverden. Og det er denne levende erfaring som bliver konfronteret med stereotypbilledet, fordommen, som subjektet $i$ forvejen havde af den anden. Udtrykt $i$ Bakhtins terminologi kan man sige, at uden den konkrete kommunikative interaktion med den anden mister det diskursive selv sin dynamiske og erfaringskonstruerende funktion, og degenererer i stedet til blot at være en monologisk bekræftelse af de fordomme, der udgrænser alteriteten som stødende eller ligefrem truende. Udtrykt i Lotmans termer kan man sige at uden den konkrete dialogiske interaktion på tværs af grænsen, mister dette begreb sin funktion som semiosfærens betydningsgenererende zone, og degenererer til at være en demarkationslinje for autoritær udgrænsning. Jan Gustafsson går endog så vidt som til at tale om at den uendelige semiosis slår om i limited semiosis (Gustafsson 2003 samt arbejdspapir).

Når vi med Gustafsson taler om limited semiosis ved den monologiske og autoritære udgrænsning af den anden skal vi imidlertid huske på, at der er tale om to komplementære semiotiske systemer: den sociale praksis og den kulturelle selvrefleksion. Den monologiske udgrænsning kan betragtes som en begrænsning af den uendelige semiosis i subjektets kulturelle selvrefleksion, fordi det kommunikative niveau enten slet ikke aktualiseres (undersøgelser bekræfter således at mange xenofobe faktisk selv har meget få erfaringer med etnisk alteritet), eller fordi de indhøstede erfaringer ikke bearbejdes og derfor ikke kommer til at indgå i en dialogisk relation med subjektets forforståelse. Men omvendt er der langt fra tale om at den monologiske udgrænsning som social praksis udgør en begrænsning af semiosis. Tvært imod giver alle former for stigmatiserende, krænkende, rettighedsindskrænkende, frihedsbegrænsende eller voldelig praksis, der er udtryk for at en monologisk stereotypopfattelse har erstattet det kommunikative forhold til den konkrete anden, i allerhøjeste grad anledning til produktionen af nye interpretanter. Det kan derfor være hensigtsmæssigt at erindre sig den netværksstruktur af parallelt forbundne strenge, vi var inde på lå til grund for semiosfærens måde at fungere på i afsnittet om Lotman (se s. 55 ).

Fordelen ved modellen over det dialogiske subjekt er, efter min mening, at de identitetsmæssige og erfaringsmedierende processer kan forstås i dialogiske og semiotiske termer som svarer til de principper, som er gældende for den kommunikative handlen. Der er for Peirce ikke bare tale om at processerne 'ligner' hinanden, men om at både menneske og natur grundlæggende set er konstitueret af semiosis. Hvor det lille barn kan siges at starte sin erfaring med at driften konfronteres uformidlet med 
verden, dér består hele den civilisatoriske erfaring i det spænd som modellen åbner af komplicerede, indre dialogiske processer omkring kulturel og personlig identitet, mellem fortid og fremtid. Hvor subjektets fysiske drift er et begær rettet mod et objekt og reguleres af civilisatorisk kontrol, dér kan vi forstå subjektets semiotiske drift som en vilje til mening. Den semiotiske vilje til mening er i første omgang rettet mod forståelsen af den anden, men gennem assimileringen af den andens blik bliver mødet med den anden en kilde for subjektet til at tilskrive sig selv og sit eget liv sammenhæng og mening. Det er imidlertid kun på det kommunikative niveau at subjektet kan interagere direkte med verden i form af en virkelig anden, dvs. al konkret, ny viden og erfaring genereres her. Til gengæld vil den ny viden og erfaring udgøre det materiale som de indre dialogiske processer udspinder sig omkring. Forstået på den måde vil det menneskelige subjekt konstituere sig som et permanent flow af dialogiske relationer mellem spontan drift og civilisatorisk kontrol, mellem kulturelle værdier og nye erfaringer, mellem etablerede genrer og nye historier samt mellem subjektet selv og den omgivende verden. Anskuet på denne måde vil de indre og de ydre processer kunne forstås i de samme kategorier.

Peirce fandt, i det Colapietro kalder hans anden fase, en slags teleologisk bestemt kontinuitet i den måde, hvorpå tanker opstår og udvikles inden for den socialt-kulturelle enhed, der gjorde det muligt for ham at sammenligne den kulturelle enhed med en mind. I artiklen »What Pragmatism is " fra I905 udtrykker Peirce det immanente teleologiske mål (summum bonum) i sin kosmologi som " [a] process of evolution whereby the existent comes more and more to embody those generals which were [...] said to be destined, which is what we strive to express in calling them reasonable« (CP 5.433). Peirces evolutionære kosmologi forenes her med hans semiotik i forestillingen om den fremvoksende reasonableness, der grundlæggende må forstås som udkrystalliseringen af en række teleologisk bestemte semiotiske vaner eller regelmæssigheder. Det individuelle, menneskelige subjekt, forstået som et tegn, er derfor at betragte som en proces under stadig udvikling frem imod tilegnelsen af de overgribende ideer eller ideologiske forestillinger (generals), som vil være herskende på et givet tidspunkt. Og de erhvervede semiotiske vaner, den kulturelle tradition, vurderes af Peirce som en berigelse og som frigørende - ikke en begrænsning:

Some undisciplined young persons may have come to think of acquired human habits chiefly as constraints; and undoubtedly they all are so in a measure. But good habits are in much higher measure powers than they are limitations (MS 930, 3 I. Citeret efter Colapietro I989, I I 2). 
Selv om Peirces kosmologi således arbejder ud fra en idealmodel, hvor semiosis, såvel på individuelt plan som på samfundsmlæssigt plan, er teleologisk styret i retning af en overgribende enhed i form af en fremvoksende reasonableness, er der ikke tale om en harmonisk opfattelse af denne proces: » unity does not preclude mental or intrapersonal conflict « (op.cit. 88). Der er tale om en proces, hvori de indeholdte modsætninger bearbejdes og manipuleres af et aktivt og selvbevidst subjekt, der er i stand til både at udøve selvkritik og selvkontrol. Og dog er der alligevel et stykke vej fra Peirces holisme til Bakhtins dialogiske opfattelse af forholdet mellem sproglig diskurs og epistemologisk sand viden. Hvor der for Peirce er tale om en fremvoksende overgribende reasonableness, er der for Bakhtin tale om at de diskursive sammenhænge, som subjektet er kastet ud i, til dels determinerer dettes muligheder for erfaringsdannelse og konstruktion af egen identitet. Disse diskursive positioner er socialt og kulturelt betingede og kan være åbne over for en dialogisk relation med omverdenen, i hvilket tilfælde man kunne håbe på en fremvoksende reasonableness, men de kan lige såvel være autoritært monologiske og lukkede over for den givne kulturs konkrete anden, hvorved kommunikativ interaktion afløses af udgrænsning og konflikt.

\section{Det kulturelle subjekt}

I det ovenstående har jeg gentagne gange refereret til en skelnen mellem det individuelle og det kollektive niveau i den kulturelle identitetsdannelse, og postuleret en vis form for parallelitet i de semiotiske processer, der er tale om på de to niveauer. Inden vi går over til at samle op på subjektsbegrebet og relatere det til den litterære erfaringsdannelse, ville det derfor være på sin plads at præcisere hvad jeg mener med begreber som 'kollektiv identitet' og 'kultur'. Kulturbegrebet er imidlertid i sig selv et hyperkomplekst begreb at have med at gøre (Fink I988), og jeg skal derfor afstå fra at forsøge at redegøre for begrebets historie og mange mulige udlægninger, og her blot præcisere at jeg i denne sammenhæng støtter mig til en bred antropologisk og konstruktivistisk forståelse af begrebet 'kultur', der ligger i forlængelse af den måde Edmond Cros i El sujeto cultural definerer begrebet:

Kultur kan, blandt alle de forskellige måder at definere begrebet på, forstås som det ideologiske rum hvis objektive funktion består $\mathrm{i}$ at forankre et kollektiv i bevidstheden om sin egen identitet [...]. Faktisk eksisterer en kultur kun i det omfang den udskiller sig fra andre kulturer og dens grænser bliver 
markeret af et system af adskillende indekser, uafhængigt af hvilke distinktioner der anvendes eller hvilken typologi der er tale om (nationale, regionale eller klassemæssige kulturer mv.) (Cros 2003, I I. Min oversættelse). ${ }^{23}$

Med denne definition lægger Edmond Cros sig tæt op ad en forståelse af kulturbegrebet, som vi genfinder hos f.eks. Jurij Lotman, der også hæfter sig ved kulturens grænser som værende konstituerende for dens egenart. "Every culture begins by dividing the world into 'its own' internal space and 'their' external space" (Lotman I990b, I3 I). Denne grænsedragningsproces er for Lotman grundlæggende set en semiotisk praksis, hvorfor han karakteriserer en kultur ved de grænser dens semiosfære etablerer både indadtil og udadtil. Og selve grænsen forstår Lotman netop i diskursive kategorier som » the outer limit of a first-person form « (ibid.). Selv om man således ikke kan sætte lighedstegn mellem begreberne 'semiosfære' og 'kultur' hos Lotman, kan man sige at kulturen er konstitueret ved de grænser som drages i og af semiosfæren. Semiosfæren er således at forstå som kulturbegrebets semiotiske aspekt, kulturen forstået i dens egenskab af tegn- og betydningsproduktion.

Tager vi, som Edmond Cros gør det, udgangspunkt i Michel Foucaults forståelse af den diskursive praksis som værende en social praksis forankret historisk konkret i samtidens sociale institutioner, så kan man sige at Lotmans begreb om semiosfæren må anses for at være gennemstukket af forskellige diskurser og diskursordener, som det individuelle subjekt må lære at navigere igennem som led i udviklingen af sine sociale kompetencer. Lotman ekspliciterer ikke selv dette forhold, men taler dog om semiosfærens modsætningsfyldthed og indre grænser. For at understrege de sociale diskursers identitetsgivende karakter anvender Edmond Cros begrebet 'kollektive' eller 'transindividuelle' subjekter for de identitetsmæssige masker som knytter sig til hver af de etablerede diskurser. Begrebet om de kollektive eller transindividuelle subjekter henter Cros hos Lucien Goldmann, der knytter disse begreber til sin teori om det 'ikke-bevidste', dvs. det, som subjektet udtrykker uden selv at være bevidst om det (Cros I988, I0-I7). Der er ikke tale om en parallel til Freuds ubevidste, da det ikke-bevidste i Goldmans forstand ikke er fortrængt; snarere ville det ikke-bevidste kunne udlægges som den 'grund' subjektet er bærer af i semiotisk forstand, og som først bliver 'synlig' i det øjeblik den konfron-

\footnotetext{
${ }^{23}$ Den spanske tekst lyder således: "La cultura puede ser definida - entre tantas posibles definiciones - como el espacio ideológico cuya función objetiva consiste en enraizar una colectividad en la consciencia de su propia identidad [...]. La cultura, en efecto, sólo existe en la medida en que se diferencia de las otras y sus límites vienen señaladas por un sistema de indicios de diferenciación, cualesquiera que sean las divisiones y la tipología adoptadas (culturas nacionales, regionales, de clase, etc.) «.
} 
teres med alteriteten. De kollektive subjekter er altså at forstå som bestemte typer af historisk, kulturelt og socialt betingede forudsætningsindhold som knytter sig til de diskursordener som gennemstikker semiosfæren, og som det enkelte individuelle subjekt taler eller skriver sig ind i.

Idet det individuelle subjekt kun er i stand til at etablere sig som subjekt gennem sproget, dvs. ved at tage ordet, slår diskursen så at sige tilbage, hvorved det individuelle subjekt 'interpelleres ${ }^{24}$ af de socialt konstruerede diskurser. Sammenholder vi Cros' synspunkt med det sprogsyn vi har fundet hos f.eks. Bakhtin / Volosjinov, kan man sige at der er en høj grad af overensstemmelse i den forstand, at det netop er den diskursive anvendelse af sproget med al dens ideologiske indebyrd og kulturelle ballast, der er udgangspunktet for subjektets tilbliven og sprogets videreførelse i begge tilgange. Volosjinov siger det på følgende måde:

Language cannot properly be said to be handed down, it endures, but it endures as a continuous process of becoming. Individuals do not receive a ready-made language at all, rather, they enter upon the stream of verbal communication; indeed, only in this stream does their consciousness first begin to operate (Volosjinov I973, 8I).

Som Bakhtin formulerer det, tager subjektet ikke 'ordet' ud af sprogsystemet, men ud af »other people's mouths «, hvorfra man må gøre det til sit eget (Bakhtin I98I, 293-93). I forrige afsnit var vi inde på, at det individuelle subjekt må konstruere sig selv som en størrelse sammensat af forskellige diskursivt konstruerede selver der indgår i dialogisk interaktion med et bagvedliggende kritisk selv eller subjekt på den ene side, og med den konkrete 'anden' på den anden side. Med Cros' teori om de transindividuelle subjekter der optræder som diskursive 'stedfortrædere' for subjektet, kommer der et overindividuelt, kollektivt eller kulturelt niveau ind i billedet. Cros siger det på den måde at subjektet kun konstituerer sig som subjekt 'interdiskursivt':

Jeg betegner 'diskurs' som værende et transindividuelt subjekts diskursive egenart, hvilket fører mig til at definere helheden af et subjekts tilegnede praksisser som interdiskursivitet [...] et subjekt der, ligesom alle andre subjekter, har gennemløbet og fortsat gennemløber forskellige transindividuelle subjekter; således forstået udgør interdiskursiviteten subjektets kompetence, et begreb som jeg knytter til sprogbrugen og ikke til sprogsystemet (Cros 2003, I 5 , min oversættelse). ${ }^{25}$

\footnotetext{
${ }^{24}$ Begrebet 'interpellation' stammer fra Louis Althusser, som i Ideologi og ideologiske statsapparater anvender det om den måde, hvorpå ideologierne sætter sig igennem i den individuelle bevidsthed og gør denne til et subjekt (Althusser 1972, 57).

${ }^{25}$ Den spanske tekst lyder således: »Yo designo como discurso a la especificidad discursiva de
} 
Forestillingen om tilstedeværelsen af de kollektive subjekter som sociokulturelle mærker eller indekser af 'ikke-bevidsthed' i teksten, ligger til grund for hele Edmond Cros' sociokritiske teori og metode (Cros I988), men i sin seneste bog går Cros et skridt videre, idet han knytter forestillingen om flerheden af kollektive subjekter til begrebet om det 'kulturelle subjekt'. Det kulturelle subjekt er, ligesom de kollektive subjekter, diskursivt konstrueret og forudsætter tilstedeværelsen af disse kollektive subjekter og deres indhold af kulturel og social ikke-bevidsthed. Men hvor de kollektive subjekter er éndimensionelle i den forstand at de knytter sig til én diskursorden, dér refererer det kulturelle subjekt til en kompleks, heterogen og modsætningsfuld sammenhæng:

Hvor det transindividuelle subjekt er endimensionelt, refererer det kulturelle subjekt til et komplekst, heterogent og konfliktuelt rum, en helhed inden for hvilken den dominerende rolle er omskiftelig elementerne imellem og i hvis indre forskellige semiotisk-ideologiske udkast til en række transindividuelle subjekter, hvis antal og vigtighed afhænger af de enkelte individers maner, hele tiden bliver redistribueret (Cros 2003, 28, min oversættelse).

Det kulturelle subjekt er således en kategori, som er overordnet de diskursive, kollektive subjekter, og som til dels sætter sig igennem i dem. Cros trækker ikke selv parallellen, men jeg mener at det ville være oplagt at se en relation mellem Lotmans semiosfærebegreb og Cros' begreb om det kulturelle subjekt. Ligesom Lotmans semiosfære kan forstås som værende gennemskåret af forskellige og til dels indbyrdes modstridende og konfliktende diskurser, således er også det kulturelle subjekt en heterogen og diskursivt konstrueret helhed. For Cros indgår det som et kriterium i bestemmelsen af det kulturelle subjekt, at dette udtrykker sig diskursivt som et sådant (Cros 2003, I2), hvorfor man kunne sige at det kulturelle subjekt er semiosfærens diskursive konstruktion af en subjektivitet i form af et 'vi'. Som sådan fungerer det kulturelle subjekt som en kollektiv erindring, der garanterer en vis form for kontinuitet i de transindividuelle subjekters selvforståelse, og som dermed sikrer deres opretholdelse som værende de 'samme' i Ricœurs 'ipse'-forstand:

Kulturen fungerer som en kollektiv erindring der tjener som referenceramme, og den opleves følgelig officielt som en vogter af kontinuitet og en garant for

un sujeto transindividual, lo cual me lleva a definir como interdiscursividad el conjunto de las practices adquiridas [...] por un sujeto que, como todos los sujetos, ha atravesado y sigue atravesando varios y diversos sujetos transindividuales; esta interdiscursividad, así definida, constituye su competencia, noción que para mí atañe pues al habla y no a la lengua «. 
den troskab, det kollektive subjekt bør udvise over for det billede af sig selv, som det således modtager (Cros 2003, I I ). ${ }^{26}$

Et sted siger Edmond Cros at det kulturelle subjekt er stedfortræder for den anden (Cros 2003, 25), hvilket jeg vælger at udlægge således at det er det kulturelle subjekt, der leverer billederne af, eller fordommen om den anden forud for det konkrete møde med den anden. Det kulturelle subjekt bliver dermed det tegn, på hvis grund de diskursivt konstruerede kollektive subjekter baserer deres forventninger til den anden. Denne dialog mellem det kulturelle subjekt som den overordnede, integrative kategori, der sikrer kontinuiteten i den historiske repræsentation af de transindividuelle subjekter, og de transindividuelle subjekter som stedfortrædere eller masker for det individuelle subjekt i dettes kommunikative interaktion eller møde med den konkrete anden, gør det muligt at forestille sig en parallel struktur til modellen over dialogen mellem kommunikativ handlen, diskursiv erfaringsdannelse og kulturel identitetsdannelse på det individuelle plan. ${ }^{27}$

\footnotetext{
${ }^{26}$ Den spanske tekst lyder således: »La cultura funciona como una memoria colectiva que sirve de referencia, y por consiguiente, es vivida oficialmente como guardiana de continuidad y garante de la fidelidad que el sujeto colectivo debe observar para con la imagen de sí mismo que de este modo recibe".

${ }^{27}$ Det samme inversionsprincip hvor dialogismen vender tegnet til interpretant og interpretanten til tegn, som vi iagttog på niveauet for individuel identitetsdannelse, vil naturligvis også gøre sig gældende her (se s. 99).
} 


\section{Tegn}

Kulturelt subjekt

Identitetsdannelse:

$\Delta$

Objekt

Interpretant

Fortid Transindividuelle subjekter

Tegn

Erfaringsdannelse:

$\Delta$

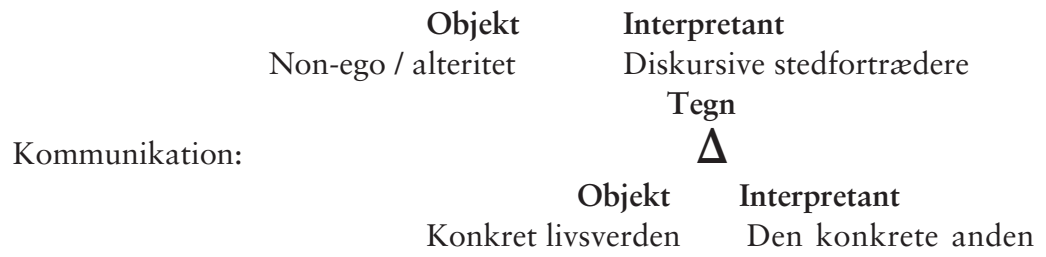

De transindividuelle subjekter er som 'stedfortrædere' for det individuelle subjekt i de diskursivt determinerede kommunikationsprocesser på én gang aktører i de diskursive og sociale praksisser og interpretanter af den kulturelle tradition og historie, der udgør 'grunden' for deres egen tilblivelse. I kraft af denne medierende rolle forstår Cros forholdet mellem det individuelle og det kulturelle subjekt således, at det individuelle subjekt kan have assimileret kulturen i større eller mindre omfang, men at det som individ ikke kan påvirke det kulturelle subjekt direkte (op.cit. I2). Til gengæld kan det individuelle subjekt udfordre de kollektive subjekters fordomme og stereotypforestillinger af den 'anden' ved at møde denne 'anden' som et 'du', dvs. ved at gå ind i en dialogisk interaktion på lige vilkår. Blokeres dialogen, cementeres i stedet semiosfærens grænsedannelser og der sker en autoritær og monologisk udgrænsning af den 'anden' qua det kulturelt formede stereotypbillede.

\section{Subjektets imaginære erfaringsdannelse}

Vi har tidligere været inde på, hvordan det menneskelige subjekt udvikler sin personlighed som en dialog mellem to instanser: på den ene side et 'dybere' selv, dvs. subjektet forstået som en kulturel vanedannelse, og på den anden side en i princippet uendelig række stemmer, der repræsenterer subjektet i lige så mange fremtidige positioner som 'innovative' selver. Dialogen mellem 'subjekt' og 'selv' er således udspændt i et erfaringsfelt mellem semiosfærens kulturelle vanedannelse, der selv artikulerer sig diskursivt som et kulturelt subjekt, og de erfaringer som subjektet gør sig 
i interaktion med omverdenen i form af forskellige, diskursivt konstruerede udsigelsespositioner. Det dynamiske element i denne dialog udspringer imidlertid primært af de nye erfaringer, som subjektet gør sig i interaktionen med sin omverden, og disse erfaringer kan karakteriseres som værende både aktuelle og rent 'potentielle'. Med potentielle, eller mulige, tildragelser menes her mentale repræsentationer i forståelsen imaginære, svarende til Jerome Bruners possible worlds.

For Peirce er det vigtigt på den ene side at skelne mellem en indre og en ydre verden, men samtidig også at tilkende både den indre, imaginære verden og den ydre, aktuelle verden en real status og dermed også en indflydelse på subjektets dialog med $\sin (\mathrm{om})$ verden.

Every sane person lives in a double world, the outer and the inner world, the world of percepts and the world of fancies. What chiefly keeps these from being mixed up together is (besides certain marks they bear) everybody's well knowing that fancies can be greatly modified by a certain non-muscular effort, while it is muscular effort alone [...] that can to any noticeable degree modify percepts. A man can be durably affected by his percepts and by his fancies. The way in which they affect him will be apt to depend upon his personal inborn disposition and upon his habits [...] (CP 5.487).

De imaginære tildragelser har således, ifølge Peirce, direkte indflydelse på menneskets kulturelle vanedannelse, og dermed på dannelsen og udviklingen af såvel den individuelle personlighed som den kollektive, kulturelle identitet. Når de ydre omstændigheder ikke tillader den nødvendige repetition af erfaringen, for at denne kan etablere sig som vane, tager den imaginære repetition over:

[E]very man exercises more or less control over himself by means of modifying his own habits; and the way in which he goes to work to bring this effect about in those cases in which circumstances will not permit him to practice reiterations of the desired kind of conduct in the outer world shows that he is virtually well-acquainted with the important principle that reiterations in the inner world - fancied reiterations - if well-intensified by direct effort, produce habits, just as do reiterations in the outer world; and these habits will have power to influence actual behavior in the outer world; especially, if each reiteration be accompanied by a peculiar strong effort that is usually likened to issuing a command to one's future self ( $\mathrm{CP} 5.487)$.

Ifølge Peirce er vores almindelige forestillingsverden bundet til praktiske erfaringer fra den ydre verden, og omvendt: vores handlinger i den praktiske verden er afhængige af vores operationer med mentale eller imaginære scenarier. Når en arkitekt vil bygge en bygning et bestemt sted, 
starter han således med at forestille sig en bestemt form i et givet landskab. Men hvor Peirces pragmatiske semiotik primært hæfter sig ved eksempler med en positiv og konstruktiv baggrund, har nyere neuropsykologisk forskning vist, at dagdrømme også, eller måske ligefrem primært, retter sig mod bearbejdningen af negativt ladede erfaringer (Miall I995, 292). Spørgsmålet er nu, om ikke det er den samme funktion fiktionslitteraturen indtager for både det skrivende og det læsende subjekt?

It may be assumed that people generally take up literary texts to read because they anticipate pleasure from the experience; and, no doubt, a number of aspects of a literary text may often be pleasurable [...]. At the same time it is apparent that many texts, and tragedies in particular, often deal at length with predominantly negative situations. Readers may be engaging with such experiences in order to allow a text to fulfil a similar function to that of the daydreams or dreams [...], that is, the text induces, whether explicitly or less consciously, the reader's memories of negative feelings and the self-concept concerns that these raise. But the constructive process of reading also places negative feelings in a critical context, allowing them to be brought into relation with other feelings and ideas so that the feelings at issue become better understood (op.cit. 293).

I overensstemmelse med Mialls aktuelle overvejelser mener Peirce at de imaginære verdener kan betragtes som et alment eksperimentarium for såvel subjektets kritiske selvrefleksion som for direkte handlen i den ydre verden. I en tekst fra I 893 går Peirce så langt som til at se den imaginære kalkule som selve grundlaget for den rationelle tænkning:

A fancied conjuncture leads us to fancy an appropriate line of behavior. Day-dreams are often spoken of as mere idleness; and so they would be, but for the remarkable fact that they go to form habits, by virtue of which when a similar real conjuncture arises we really behave in the manner we had dreamed of doing.

$[\ldots]$

Indeed, the whole business of ratiocination, and all that makes us intellectual beings, is performed in imagination (CP 6.286).

Jerome Bruner går så at sige i samme retning, men på en anden måde. I stedet for som Peirce at understrege de imaginære verdeners betydning for vores handlen i den aktuelle verden, peger Bruner på hvordan vores opfattelse af den aktuelle verden er formet af imaginære forestillinger og possible worlds. Den første possible world, barnet skal forholde sig til, er moderens tilstedeværelse som en bevidsthed med en række ønsker og 
forestillinger, hvad Bruner kalder en række 'konjunktive verdener'. I det hele taget er menneskets identitetsmæssige dannelse i mødet med den anden præget af menneskets åbenhed over for at kunne sætte sig ind i den andens bevidsthed, forstået som en flerhed af possible worlds. Den aktuelle verden, som er rammen om mødet med den anden bliver derved til en sammensat og konstrueret størrelse af forventninger og imaginære forestillinger, hvorved det skarpe skel mellem det aktuelle og det imaginære tenderer mod at blive udvisket.

Ikke desto mindre eksisterer der en slags litterær konvention mellem forfatter og læser, om at sproget i litterære tekster ikke skal forstås på baggrund af den samme form for referentialitet som den, der er gældende i anden sprogbrug. Sproget i litterære tekster henviser til fiktive eller imaginære universer, og ikke til konkret eksisterende verdener. Det står forfatteren frit for at iscenesætte de erfaringsprocesser, det interesserer ham at eksperimentere med på et givet tidspunkt, uden at tage hensyn til den aktuelle verdens betingelser, det være sig dens lovmæssigheder eller begrænsninger. Og læseren skal tilsvarende ikke interessere sig for om de skildrede begivenheder har en umiddelbar sandhedsværdi eller ej. At denne suspenderede reference så $\mathrm{i}$ anden omgang viser sig at blive reetableret i læserens hermeneutiske tilegnelse af teksten, er så en anden sag som jeg skal vende tilbage til nedenfor.

At referencen i litterære tekster tilsyneladende er umiddelbart suspenderet, betyder dog ikke, at der ikke eksisterer nogen relation imellem de fiktive universer og den aktuelle verden. Hvordan denne relation kan etableres, kan begribes ved hjælp af Bakhtins authoring-begreb. Authoring-begrebet handler, som vi har set ovenfor, dels om det almene forhold at subjektet opbygger sin egen identitet ved at etablere sig i en specifik (narrativ) relation i forhold til den anden, dels handler det om forfatterens iscenesættelse af et fiktivt subjekt $\mathrm{i}$ en imaginær verden. Forholdet mellem de to betydninger af begrebet kan udlægges sådan at den litterære authoring er et billede på subjektets almene betingelser for identitetsdannelse, hvorfor sproget i litterære tekster, med Bakhtins ord, kun beskæftiger sig med images of language, altså ikoniske repræsentationer af virkelig sprogbrug. De fiktive personers tale bliver ikoniske repræsentationer af virkelige subjekters diskurser til og om andre. Eller som Bakhtin siger det:

All forms involving a narrator or a posited author signify to one degree or another by their presence the author's freedom from a unitary and singular language, a freedom connected with the relativity of literary and language systems; such forms open up the possibility of never having to define oneself in language, the possibility of translating one's own intentions from one 
linguistic system to another, of fusing 'the language of truth' with 'the language of the everyday', of saying 'I am me' in someone else's language, and in my own language, 'I am other' (Bakhtin I98 I, 3 I 5 ).

For Bakhtin er forholdet mellem author eller 'autor' og den fiktive person i den moderne, polyfone roman et spejlbillede af den dialogiske proces, der ligger bag den almene subjektsdannelse. Forfatteren konstruerer sin egen subjektivitet igennem en sproglig 'i-diskurs-sætning', der afspejler den proces, hvorigennem ethvert menneske er henvist til at konstruere sin egen identitet med afsæt i forskellige diskursivt konstruerede selver eller udsigelsespositioner. Med Michael Holquists ord bliver romangenren dermed » an allegory for representing existence as the condition of authoring " (Holquist, I990, 30). Men der er naturligvis forskel på den authoring som alle mennesker hele tiden foretager for at konstruere og rekonstruere sig selv som selvbevidste subjekter, og så den authoring som fører til det, som vi forstår ved litterære kunstværker; ellers ville litteraturen bestå af lutter indre dialoger eller solipsistiske fremstillinger. Med Holquists ord består forskellen $\mathrm{i}$ » the ability of the artist in his or her text to treat other human subjects from the vantage point of transgredience, a privilege denied the rest of us who author only in lived experience " (op.cit. 32). Romanforfatteren må være i stand til at manipulere den fiktive person, som jo egentlig er en other, ikke bare som en anden, men som 'selv'. For Bakhtin er billedet på denne romanform først og fremmest Dostojevskij. I bogen Problems of Dostoevsky's Poetics (Bakhtin I984b) beskriver Bakhtin det nye ved Dostojevskijs poetik som et spørgsmål om, at forfatteren ikke er engageret $\mathrm{i}$ at beskrive en fiktiv person, men så at sige indefra konstruerer denne persons selvbevidsthed og udblik på verden som et 'selv':

What is most important to Dostoevsky is not how his hero appears in the world but first and foremost how the world appears to his hero, and how the hero appears to himself (Bakhtin I984b, 47).

Fremstillingen af den fiktive person i kraft af dennes måde at opfatte sin omverden på kan ifølge Bakhtin ikke sameksistere med en lukket og udvendig beskrivelse af personen, men indoptager i stedet karakteristiske elementer, der fratages deres karakter af en lukket udvendig beskrivelse. Personen bliver en åben struktur under konstruktion i permanent dialog med de andre personers mere lukkede vurderinger af ham eller hende (Bakhtin I984b, 50):

Thus the new artistic position of the author with regard to the hero in Dostoevsky's polyphonic novel is a fully realized and thoroughly consistent 
dialogic position, one that affirms the independence, internal freedom, unfinalizability, and indeterminacy of the hero. For the author the hero is not 'he' and not 'I' but a fully valid 'thou', that is, another and other autonomous 'I' (»thou art«) (op.cit. 63).

Ifølge Bakhtin bliver heltens egen opfattelse af sig selv hos Dostojevskij til en dialogisk relation mellem de tre kategorier vi allerede tidligere har stiftet bekendskab med, jeg-for-mig-selv, den-anden-for-mig og jeg-forden-anden. Og det er i denne dialogiske relation at teksten kan diskutere de moralske eller etiske aspekter af de skildrede erfaringer: » What results is a peculiar sort of mystery play, or rather, morality play, in which the actors are not whole people but rather the spiritual forces battling within them... « (op.cit. I984b, 2I7). Selve litteraturens egenart bliver at skabe sådanne images of persons: "Literature creates utterly specific images of people, where $I$ and another are combined in a special and unrepeatable way: $I$ in form of another, or another in form of $I$ (op.cit. 293-94).

Vender vi for et øjeblik tilbage til modellen over det dialogiske subjekt udfoldet ovenfor, kan man sige at litterære tekster - i de heldigste tilfælde - ansporer såvel forfatter som læser til at konstruere et kreativt selv, hvis imaginære erfaringer fra læseprocessen erstatter den kommunikative interaktion med en empirisk anden, hvorved de litterære erfaringer tilegnes som værende egne. Castilla del Pino skelner imellem to forskellige domæner for projektion af selver i subjektets intime selvrefleksion: imaginære og fantaserede selver (Castilla del Pino 200I, 295). Hvor de imaginære selver holder begge ben på jorden, og gør sig forestillinger om virkeligheden med henblik på efterfølgende at handle i forhold til den, dér vender de fantaserede selver ryggen til virkeligheden i en bestræbelse på at opnå en sublimeret driftstilfredsstillelse, som ikke kan indfris i virkeligheden. Jeg tror nu, at man med fordel kan sige at begge aspekter er involveret i den litterære diskurs' eksperimenteren med imaginære erfaringer, om end forskellige genrer accenturer de to aspekter forskelligt. Den socialrealistiske roman gør sig f.eks. forestillinger om en umiddelbart genkendelig virkelighed, som tilsyneladende kunne virke som øvelser der går ud på efterfølgende at kunne handle i forhold til denne virkelighed. Dermed accentuerer denne romanform et stærkt imaginært selv i Castilla del Pinos forstand. Heroverfor kan den romantiske eksotisme siges at søge en sublimeret drifttilfredsstillelse som ikke kan indfris i virkeligheden, hvorved den accentuerer et stærkt fantaseret selv i Castilla del Pinos forstand. Ikke desto mindre vil den realistiske roman, hvis den ellers er god og har potentiale for at fange sin læser, åbne en verden, hvor forfatteren/ læseren udlever en række erfaringer ved at gøre personernes passioner og 
lidelser til sine egne. Således fordrer læsningen/skrivningen af den realistiske roman også et element af et fantaseret selv. Og tilsvarende kan den romantiske eksotisme forstås som en indirekte kritik af I800-tallets profane utilitarisme, hvorfor selv det mest eskapistiske kærlighedsdigt kan siges at fordre et imaginært selv, der kritisk sammenholder den æstetiske erfaring med subjektets øvrige livsverdensbaserede erfaringer.

Litteraturens fiktive universer kan således udformes realistisk eller fantastisk, uden at dette i princippet har nogen fundamentalt forskellig indflydelse på den erfaringsdannelse, som læseren gennemløber i tilegnelsen af de i den imaginære verden udlevede erfaringer. Der er tale om en kreativ eller eksperimenterende manipulation af mødet med verden som en andethed eller 'alteritet', hvorigennem der gives form til det, som Holquist kalder »the chaos of lived experience" (Holquist I990, 3I). Harold Bloom går så langt som til at karakterisere universel litterær værdi som et spørgsmål om at værket repræsenterer en særlig fremmedhed, som er helt igennem ureducerbar til det kendte (Bloom I994). Igennem litteraturens fiktive universer og narrative forløb kan forfatteren således iscenesætte en række dilemmaer af æstetisk, etisk og/eller logisk karakter, der mimer subjektets interdiskursive dialog mellem selv og subjekt samt mellem individuel personlighed og semiosfærens kulturelle subjekt. Indholdsmæssigt eller tematisk er mulighederne legio for hvilke emneområder, der kan gøres til genstand for behandling, og de imaginære eksperimenter tager sigte på at generere erfaringer, der indgår som argumentative strukturer i dialog med andre teksters argumenter. Heri adskiller den litterære diskurs sig imidlertid ikke grundlæggende fra andre typer af diskurser, f.eks. den journalistiske.

Litteraturen adskiller sig i kraft af sin form, dvs. den måde hvorpå argumenterne bliver fremstillet, og den position som hhv. forfatteren selv, de fremstillede personer og for den sags skyld læseren tildeles i teksten. Det, at den litterære diskurs ofte arbejder med en åben struktur, en polysemisk semantik og/eller polyfon udsigelse, udfordrer læseren og tvinger ham eller hende til at skulle investere sig selv og tage stilling. Dermed mimer den litterære fremstilling subjektets position i den almindelige erfaringsdannelse og identitetsskabelse, hvor subjektet netop ofte stilles over for ikke bare at skulle tage stilling til en række klart fremstillede argumenter, men at skulle opstille og evt. revidere de præmisser, som »the chaos of lived experience « (Holquist ibid.) skal vurderes ud fra.

Begrebet unfinalizability er et centralt begreb i Bakhtins teori om den polyfone roman, der repræsenterer den åbenhed og uafgrænsethed som kendetegner subjektets selvforståelse over for andres 'finaliserede', dvs. lukkede og udvendige blik. Idet fremstillingen af den fiktive person 
tilknyttes selvets åbenhed, skaber forfatteren en triadisk struktur imellem personens åbne selvbevidsthed, omverdenens lukkede/udvendige blik på personen og den dialogiske relation imellem dem i form af en erfaringsdannelse. Også Dines Johansen anser forfatterens identifikation og dialogiske interaktion med den fiktive person for at være et fundamentalt træk ved den litterære erfaringsskabelse, idet han beskriver sammensmeltningen af selv og anden i den litterære skabelsesproces således:

Literature makes it possible for you to speak as if you were another or, rather, others. At first glance, it seems a trivial fact that the author is neither the narrator nor the protagonist; this is, however, the precondition for a less trivial fact, namely, an amalgation of self and other. It is this amalgation of self-asother and other-as-self that makes possible the emergence of what would otherwise never appear (Johansen 2002, 243).

Den litterære erfaring bliver, beskrevet på denne måde, en grænseerfaring, hvor positionerne self-as-other and other-as-self dialogeres. Den kreative skriveproces, forstået som en imaginær erfaringsdannelse af det fiktive møde mellem selv og den anden kan nu illustreres med nok en tillempet udgave af Peirces tegnbegreb:

\section{IMAGINÆR \\ Person som selv}

$\Delta$

EKSPERIMENT

Fiktivt møde med

den anden
ERFARING

Person som 'mig'

Dialogisk skrivning

Den kreative skriveproces udlægges her som interpretanten af en transgrederende identifikation med en fiktiv person i et imaginært møde med sin anden, der udmøntes i form af en erfaring. Rent formmæssigt kan skrivningen tage forskellige retninger, afhængig af hvilket erfaringsindhold det kreative subjekt intenderer at udtrykke. Som Jennifer de Peuter antyder, anvender mange narrative identitetsteorier en lineær fortællingsskabelon hentet ud af i 800-tallets realistiske roman, fordi de tenderer mod at forstå subjektet som en monologisk og modsætningsfri enhed. Anskuet som sådanne masterfortællinger ville de lineære fortællinger, skruet sammen omkring et fiktivt subjekt og med en klar intrige, ikke være epistemologisk holdbare repræsentationer af subjektets aktuelle vilkår for dannelse af kulturel identitet i postmoderniteten. Og faktisk går de Peuter skridtet videre, idet hun karakteriserer dem som uetiske, fordi de konstruerer subjektet som værende autonomt og uafhængigt af det 
menneskelige fællesskab: »Because the voices of the self populate multiple story-worlds, because self-stories are multi-voiced, [...] linear or modernist narrative form is also unsustainable as an ethical mode of self-intelligibility «(de Peuter I998, 40). Men hvor Jennifer de Peuter her nærmest får det til at se ud som om dem, som hun kalder de traditionelle narrative konstruktivister, opfatter fortællingerne som et redskab til at lukke subjektets relation til dets historiske og kulturelle kontekst, dér formulerer Jerome Bruner litteraturens funktion som værende stik den modsatte: »Literature subjunctivizes, makes strange, renders the obvious less so, the unknowable less so as well, matters of value more open to reason and intuition " (Bruner I986, I 59).

Det forhold, at fortællinger, såvel fiktive som historiske, ofte kan siges at have den funktion at tilskrive verden sammenhæng og mening for såvel det skrivende som for de læsende subjekter, behøver jo hverken at betyde, at subjektet kun søger bekræftelse for allerede eksisterende kulturelle fordomme eller kun søger at spejle sin egen historie selvbiografisk i disse fortællinger. Som vi netop har været inde på, kan subjektet anskues som en dialog mellem en kulturel vanedannelse og en række diskursivt konstruerede udsigelsespositioner, medieret gennem forskellige erfaringsprocesserende innovative selver, der sammenholder subjektes kulturelle vaner med den andens udefrakommende blik på de samme. Dermed kan også fortællinger af meget forskellig karakter, såvel lineære som fragmenterede, traditionelle som postmoderne, kanoniske som nybrydende, være absolut holdbare, hvis de forstås som imaginære eksperimentarier, som hver enkelt læser kan bruge til at konstruere partielle erfaringer med en mulig verden.

Hvad angår formaspektet, er det vigtigt at holde sig for øje, at den kreative skrivning altid udfolder sig i en dialog med den kulturelle vane eller tradition. Ligesom sproget for Bakhtin er gennemstukket af den andens ord, således er den litterære kreation også fanget i de litterære genrers sæt af normer og forventninger. Denne dialogiske relation indebærer, at formmæssig nyskabelse altid kun antager betydende karakter i kraft af at fremstå på baggrund af en kamp med eller mod traditionen, jf. Blooms agon (Bloom I 994). Det forekommer i den forbindelse interessant at Peirce tilsvarende forstår den filosofiske undersøgelse som en kombination af appropriation og articulation, altså » a respect for tradition and an openness to innovation «(Colapietro I989, 2). Man kan sige at den litterære forfatters aktivitet bevæger sig i samme spændingsfelt mellem tradition og fornyelse: respekt for traditionen i form af genresatte forventninger og etablerede litterære topoi, og brud på de traditionelle forventningsmønstre i en fornyende og kreativ skaben. Og man kan sige at 
læseren af litterære tekster står over for at skulle aktualisere disse erfaringseksperimenter som sine egne. Set i dette perspektiv bliver formspørgsmålet historiceret, hvorved det først og fremmest relateres til den konkrete litteraturhistoriske kontekst og først i anden omgang, medieret gennem læsererfaringen, kan relateres til det æstetiske, etiske og logiske eller epistemologiske indhold, som en given form måtte udtrykke.

Ikke desto mindre kan den tekstlige strategi determinere erfaringer af forskellig karakter. Der kan være tale om erfaringer, der har karakter af konservativ og monologisk bekræftelse af eksisterende kulturelle fordomme og stereotypforestillinger, som udgrænser alterniteten som truende, eller der kan være tale om erfaringer, som er dialogisk dannende for læseren. Desuden kan erfaringerne repræsentere primært æstetiske eller etiske udfordringer af læserens kulturelle kompetencer, eller de kan rumme en direkte logisk udfordring af læserens semiotiske kompetence. Som vi har været inde på ovenfor, karakteriserer Dines Johansen den litterære institution som værende multifunktionel, om end han i sin egen behandling bruger forholdsvis mange kræfter på at forstå de imaginære eksperimenter som etiske problemkomplekser: »Literary texts function as means to test conditions and consequences of a given morality within an imaginary world « (Johansen I998, 293). Det er naturligvis et meget væsentligt aspekt af litteraturens kulturelle dannelsesfunktion, men jeg mener det vil være frugtbart også at forstå litteraturens æstetiske oplevelseskvalitet og logiske argumentstruktur som ligeværdige dele af denne erfaringsdannelse.

Når vi arbejder med litteratur som en erfaringskategori, forekommer det rimeligt at skelne mellem litterære værker i deres to forskellige fremtrædelsesformer eller som to forskellige objekter for kritisk bearbejdning. Vi har i forrige kapitel været inde på, at hvor de litterære værker produceres som en kreativ reaktion på forfatterens fortolkning af sig selv og sin omverden, læses de, i kraft af deres skriftsproglige form, løsrevet fra deres oprindelige kontekst (se s. 62). Derfor må læseren, som et uundgåeligt grundvilkår for tekstlæsning, fortolke teksten på baggrund af sin egne erfaringer, som er forskellige, ikke bare fra forfatterens erfaringshorisont og kulturelle forforståelse, men også fra andre læseres erfaringshorisont. Vi kan derfor, med Victorino Tejeras terminologi, skelne imellem på den ene side the work-as-composed som en enestående og i den forstand stabil begivenhed, hvis oprindelige, historiske og kulturelle kontekst imidlertid er gået tabt i samme øjeblik, værket er færdiggjort, og på den anden side the work-as-received som en repeterbar hændelse, der til en vis grad er forskellig fra sig selv hver gang den gentages (Tejera I995, I24). 


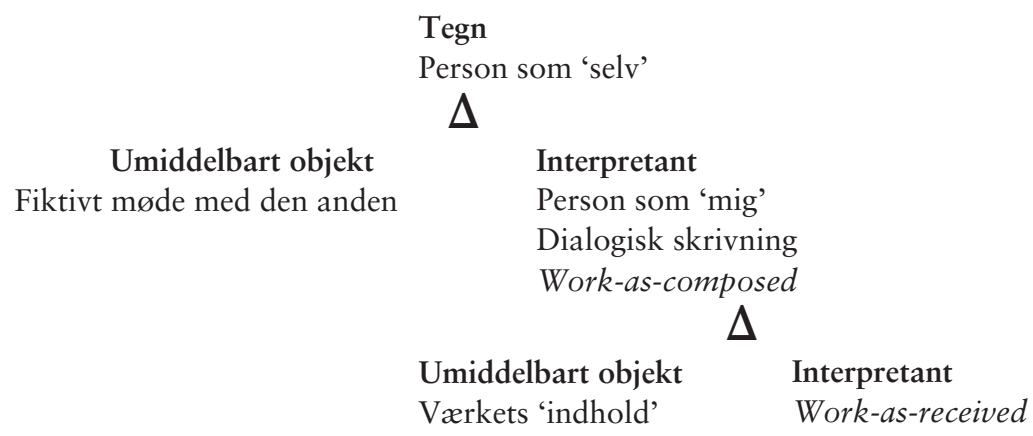

Svarende til disse to forskellige semiotiske processer finder vi to forskellige felter for litterære studier, som det kan være hensigtsmæssigt at holde ude fra hinanden, jf. Augusto Ponzios skelnen mellem »semiotica della scrittura « og » semiotica della interpretazione «(Ponzio I 990). ${ }^{28}$ På tilsvarende vis argumenterer Richard Johnson for at skelne mellem the-text-as-produced og the-text-as-read i sin model over det kulturelle kredsløb (Johnson I983/I995, 593). På baggrund af denne skelnen konstaterer Johnson at der er tale om tre forskellige 'momenter' i det kulturelle kredsløb, som til sig knytter tre forskellige teoretiske modeller for kulturstudierne: produktionsbaserede studier (Gramsci, Adorno, Benjamin), tekstbaserede studier (Saussure, tidlig Barthes, Lévi-Strauss) og receptionsbaserede studier, som ser på samspillet mellem tekster og fortolkningsprocesser $\mathrm{i}$ hverdagslivet. Et eksempel herpå kunne være Johnsons eget Centre for Contemporary Cultural Studies i Birmingham. Denne opstilling får Johnson til at pege på, at »there are some real incompatibilities between approaches ", og den deraf følgende opgave, som består i at »rethink each moment in the light of the others « med henblik på at »trace [...] the inner connections " (op.cit. 607). Johnson skyder imidlertid sig selv i foden og blokerer for dette positive og frugtbare forehavende ved at basere sin tilgang til teksten på den strukturelle tradition i stedet for at lade en pragmatisk baseret semiotik, med vægt på semiosens dialogiske proceskarakter, være det som skaber enhed og kompatibilitet analyseniveauerne imellem.

Med udgangspunkt i Alexander Zolkovskij og Jurij Ščeglov diskuterer også Lotman en model for den litterære kreation. Hvor Zolkovskij og Šceglov går ud fra en ren deduktionsmodel, der forudsætter at afsenderen i kommunikationsprocessen betjener sig af ren logisk deduktion i

${ }^{28}$ Se i den forbindelse også Jansen 1982. 
omsætningen af erfaringer til sproglig praksis, ${ }^{29}$ dér kritiserer Lotman denne model for at være for mekanisk. Han finder at den kunstneriske funktion er til stede lige fra starten i konciperingen af temaet (Lotman I 990b, 73) og foreslår i stedet en anden model, der bygger på en asymmetrisk relation imellem de kontinuerte eller non-diskrete diskurser (ikoniske og indeksikale) og de diskrete diskurser (sprogligt/symbolske). Lotman beskriver således forfatterens kreative skaben som en tilføjelse af betydning i skriveprocessens oversættelse af erfaringsmateriale fra ét semiotisk register til et andet.

Hvor den litterære tekst således skabes som en kreativ og transgredient interpretant af forfatterens authoring, præsenterer den sig for læseren som the-work-as-composed, et ikonisk tegn, åbent for læserens fortolkning. I de følgende kapitler skal vi nærmere se på, hvordan vi kan beskrive bevægelsen fra the-work-as-composed til the-work-as-received i semiotiske termer, idet vi skelner mellem de æstetiske, etiske og logiske aspekter af læserens erfaringsdannelse.

\footnotetext{
${ }^{29}$ For en tilsvarende skelnen mellem forskellige logiske operationer i den sproglige produktion og reception, se også Henning Andersen 1984.
} 


\section{III. ÆSTETISK ERFARINGSDANNELSE I LITTERÆRE TEKSTER}

I dette kapitel skal vi se på vilkårene for en semiotisk beskrivelse af den æstetiske erfaringsdannelse ${ }^{1}$ i den litterære praksis. Fokus ligger således først og fremmest på, hvordan vi kan foretage en semiotisk beskrivelse af fænomenet 'æstetisk erfaringsdannelse', og i mindre grad på en diskussion af, hvordan den æstetiske erfaring er blevet beskrevet inden for andre områder, såsom f.eks. den filosofiske æxtetik ${ }^{2}$ eller den neurofysiologiske kognitionsforskning. ${ }^{3}$ Disse discipliner kan imidlertid siges at udgøre en mere eller mindre implicit teoretisk ramme for fremstillingen, hvor den semiotiske beskrivelse må forholde sig til hhv. traditionen og fornyelsen. Sigtet er at kunne foretage en beskrivelse af den æstetiske erfaringsdannelse $\mathrm{i}$ en terminologi, der på én gang er $\mathrm{i}$ stand til at begribe både de semiotiske betingelser bag subjektets almene (selv)konstruktion (Kapitel II) og de andre relevante erfaringskategorier som beskrives i de efterfølgende kapitler. Da fremstillingens bærende interesse således snarere er alment semiotisk end specifik litterært-æstetisk, har jeg valgt at lade et antal anerkendte litteraturvidenskabelige teorier repræsentere nogle generelle principper, som vedrører fænomener knyttet til den æstetiske erfaring i litterære tekster. Disse principper vedrører forhold i teksten i sig selv, der så at sige ligger forud for enhver konkret aktualisering, hvorfor de, i Peirces terminologi, må diskuteres på niveauet for den umiddelbare interpretant, altså dér hvor teksten betragtes som værende et rent potentiale af betydning forud for enhver aktualisering. Netop fordi fremstillingens bærende interesse snarere er alment semiotisk end specifik litterært-æstetisk, gør kapitlet heller ikke krav på at være en gennemgang af alle æstetiske virkemidler i litterære tekster, men forsøger gennem nogle nedslag på udvalgte aspekter af den litterære æstetik at forklare disse aspekter i lyset af en pragmatisk orienteret semiotik.

Studier af den æstetiske erfaring i den litterære læsning baseret på Peirces semiotik er, ud fra mit kendskab, stadig relativt sparsomme. Dines Johansens Literary Discourse, der ellers på mange punkter er det

\footnotetext{
${ }^{1}$ Hvad angår en semiotisk forståelse af erfaringsbegrebet henviser jeg til Kapitel II (se s. 97). Dog vil jeg på dette sted tilføje, at det engelske begreb 'aesthetic experience' (spansk: experiencia estética) både omfatter det, vi på dansk karakteriserer som en 'erfaring' og som en 'oplevelse'. Netop på æstetikkens område er det vigtigt at vi bibeholder denne dobbelthed i begrebet.

${ }^{2}$ For en introduktion til den filosofiske æstetik, se f.eks. Raffnsøe I 996.

${ }^{3}$ For en introduktion til neuroæstetikken, se f.eks. Ramachandran \& Hirstein I999 eller Zeki I999.
} 
væsentligste og indtil videre mest overbevisende bidrag til litteraturstudierne ud fra en pragmatisk-semiotisk vinkel, er hovedsageligt koncentreret om litteraturens psykologiske, sociale og etisk-moralske funktioner. Både Sheriff og Tejera betegner den æstetiske erfaring som en rhematisk størrelse, dvs. som en polysemisk åbenhed eller kvalitativ førstehed, som de efterfølgende stiller op over for den kritiske diskurs forstået som dicente tegn og litteraturteorien som en argumentativ diskurs (Sheriff I 989 og Tejera I 995).${ }^{4}$ Andre, som bl.a. Umberto Eco, ser bort herfra og beskæftiger sig udelukkende med de rent logiske operationer i brugen af Peirce (Eco 1979/87). Men ingen af de nævnte behandlinger tager for alvor fat på diskussionen af, hvordan den æstetiske erfaring kan beskrives semiotisk og hvilken rolle den spiller i relation til det erfarende subjekt og dettes øvrige erfaringskategorier.

Dines Johansen peger på at æstetikken spiller en vigtig rolle for menneskets selvopfattelse, og at de æstetiske præferencer med hensyn til påklædning, stil, personlig fremtoning osv. er snævert knyttet til de kulturelle og personlige normer og værdier, som såvel den kulturelle identitet som den individuelle personlighed er bygget op omkring (Johansen 2002, 348). Den æstetiske erfaring udgør således en integreret del af vores måde at situere os selv i forhold til verden på og indgår derfor også i et intimt dialogisk samspil med vores stillingtagen til verden i mere etisk orienterede kategorier. Og på tilsvarende vis kan man sige at den æestetiske tilrettelægning af en litterær tekst udgør transformationspunktet mellem læserens konstitution som subjekt i læseprocessen og hans eller hendes stillingtagen til teksten, og/eller stillingtagen til sin egen livsverden på baggrund af de af teksten formidlede erfaringer. Det forekommer derfor logisk at behandle vilkårene for en semiotisk beskrivelse af tekstens æstetiske strategi netop på dette sted mellem diskussionen af subjektet som semiotisk begreb og den litterære tekst forstået som en model til generering af imaginære erfaringer af etisk karakter.

Kapitlet indledes med en kort præsentation af læseprocessen begrebsliggjort som en semiotisk proces, fremstillet i lyset af Charles Peirces tegnbegreb. I første omgang handler det blot om at bestemme den æstetiske erfaring som en interpretant af værket, mens beskrivelsen af processens kompleksitet vil blive yderligere udfoldet i det følgende afsnit. Derefter følger en gennemgang af begrebet om 'det æstetiske' hos Peirce. Den æstetiske erfaring udlægges som en dialog mellem forskellige interpretantniveauer, som efterfølgende diskuteres i forhold til tre litteraturteoretiske tilgange. Det drejer sig om Roman Jakobsons teori om tekstens parallel-

\footnotetext{
${ }^{4}$ For en kritik af Sheriffs definition af det æxtetiske tegn som rhematisk, se kapitel V (se s. 258 ).
} 
istiske strukturer, Paul Ricœurs teori om den poetiske metafor og Mikhail Bakhtins teori om den polyfone roman. Efter en summarisk præsentation af nogle hovedpunkter i hver af disse teorikomplekser, vil de blive diskuteret i lyset af den pragmatiske semiotiks begrebsinventar, og hvert afsnit vil blive illustreret med en eksemplarisk læsning. Endelig afsluttes kapitlet med en opsamling af nogle af den litterære teksts æstetiske karakteristika på niveauet for den umiddelbare interpretant.

\section{Læseprocessen som semiotisk proces}

Som vi har set det i behandlingen af subjektet i Kapitel II, kan det litterære værk forstås som en interpretant i forfatterens kreative skabelsesproces. Samtidig udgør teksten det tegn, der danner udgangspunkt for læserens fortolkning. Kreationsproces og læseproces kædes således sammen af teksten.

I en første, forsimplet udlægning af den litterære læsnings semiosis kan man sige at tegnets position indtages af selve det litterære værk, mens det umiddelbare objekts position vedrører det fiktive univers. Peirce siger således at »the object of the sentence Hamlet was insane is the Universe of Shakespeare's Creation so far as it is determined by Hamlet being a part of it « (CP 8.I78). Victorino Tejera formulerer det samme synspunkt ved at understrege, at det litterære tegns objekt er »characters and events put on exhibit " (Tejera I995, I22). Endelig er læserens æxtetiske oplevelse, med Tejeras ord, at forstå som interpretanten: »The aesthetic experience is the proximate constitutive interpretant of the work and its object « (ibid.). Forholder vi denne beskrivelse af den litterære semiosis til modellen over Peirces tegnbegreb, kunne en første model over litteraturlæsningen tage sig således ud:

\section{Tegn}

Det litterære værk

$\Delta$

\begin{tabular}{ll}
\multicolumn{1}{c}{ Objekt } & Interpretant \\
Et fiktivt univers af & Læserens æstetiske erfaring. \\
forløbsmæssig eller & (Oplevelser, reaktioner og forståelse \\
følelsemæssig karakter & af værket, som det er determineret af \\
& værkets strategi)
\end{tabular}

Den foreløbige udlægning af objektspositionen som »et fiktivt univers af forløbsmæssig eller følelsesmæssig karakter « skyldes bestræbelsen på at gøre modellen så vidtfavnende at den kan anvendes på både narrative og 
poetisk-lyriske tekster. Hvor Tejera udlægger læserens æstetiske oplevelse eller erfaring (experience) som interpretanten, kunne man tilføje at det handler om læserens oplevelser af, reaktioner på og forståelse af værket. Denne noget bredere formulering skyldes på den ene side en hypotese om at de erfaringer, som tematiseres af kunst og litteratur, ikke kun er af æstetisk karakter, men også kan være af etisk og/eller af logisk eller rent semiotisk karakter. På den anden side foregriber tilføjelsen en hypotese vedrørende selve karakteren af den æstetiske oplevelse, som vil blive udviklet i løbet af dette kapitel. Denne hypotese går ud på at den æstetiske oplevelse består af et modalt spændingsforhold mellem følelsesmæssige, hændelsesmæssige og logiske kvaliteter. I den forstand handler tilføjelsen altså om en mere nuanceret forståelse af selve den æstetiske erfaring.

Formuleringen om, at interpretanten i den litterære reception vedrører »læserens oplevelser af, reaktioner på og forståelse af værket som det er determineret af værkets strategi « indebærer at læserens erfaring på dette niveau må betragtes som resultatet af en dialogisk proces mellem tekstens strategi, forstået som en relativ determination af interpretanten, og læserens aktive deltagelse i betydningstilblivelsen. Umberto Eco anvender i bogen Lector en fábula begrebet om 'tekstens strategi' til at beskrive den måde, hvorpå det tekstlige forlæg til dels determinerer læserens abduktivthypoteseorienterede dialog med teksten (Eco I98I). ${ }^{5}$

\section{Tekstens æstetiske strategi}

På trods af at Umberto Eco med Lector en fábula sætter sig for at præsentere Charles Peirces semiotiske teori for et bredere europæisk publikum, er han på dette tidspunkt, dvs. omkring I980, fortsat stærkt influeret af Hjelmslevs tegnbegreb og hele den europæiske, semiologiske tradition. Dette giver sig udtryk i, at han i mange sammenhænge fortsat opererer med et binært tegnbegreb og med begreber som 'koder' og 'hyperkoder' ${ }^{6}$ Hans hensigt med teksten er dog at forbinde den europæiske tradition med en pragmatisk orienteret semiotik af peirceansk afstamning, og terminologien til trods mener jeg ikke der er nogen grundlæggende problemer $\mathrm{i}$ at sammenholde hans resultater med beskrivelsen af niveauet for den umiddelbare interpretant, som vi har udfoldet den indtil videre. Hans generelle sigte med bogen er således at foretage en

\footnotetext{
${ }_{5}^{5}$ Lector en fábula er udkommet i en noget anden version på engelsk under titlen The Role of the Reader. Da den oprindeligt italienske og den spanske udgave er identiske, henviser jeg i det følgende til den spanske.

${ }^{6}$ Jeg vil her blot henvise til Kapitel I, hvor strukturalismens kodebegreb blev diskuteret, og hvor Peirces semiotiske 'vane' blev foreslået som et alternativ, der netop indfører en diakron, historisk dimension i de symbolske tegns funktionsmåde (se s. 33).
} 
semiotisk beskrivelse af forholdet mellem teksten og den i teksten indskrevne læserposition, den såkaldte 'modellæser'.

Eco bruger strategibegrebet som en metafor til at karakterisere spillet mellem den litterære teksts form og læserens abduktive slutninger: ligesom en general i en krig må forsøge at forudse modstanderens reaktioner og indarbejde disse i sin egen strategi, således må realforfatteren skabe en modellæser, som modsvarer den anlagte strategi. Omvendt må reallæseren danne sig et billede af forfatteren alene ud fra den måde realforfatteren gestaltes i teksten som strategisk tilrettelægger, altså som modelforfatter. Eco tegner således billedet af en firleddet udsigelsesstruktur: realforfatter, modelforfatter, modellæser og reallæser, der grosso modo svarer til Dines Johansens fire udsigelsesmæssige kategorier: utterer/addresser - addressee/ interpreter (se s. 42).

De forskellige mulige tekststrategier lader sig ikke beskrive i en klar typologi, men tegner sig, ifølge Eco, som et gradueret kontinuum mellem to yderpoler: den lukkede og den åbne tekst. Disse to tekstlige strategier lader sig så kombinere med forskellige læserstrategier, hvis yderpunkter han beskriver som hhv. 'fortolkning' og 'brug'. For Eco består en fortolkning af en læsning som er i overensstemmelse med tekstens strategi, og denne læsning tager nødvendigvis form af en logisk refleksion, mens læserens umiddelbare oplevelse og spontane følelsesreaktion på teksten er kategoriseret under reallæserens individuelle brug (Eco I98 I, 85-87 og I 992, 29 og 39-4I). Den mest lukkede tekst kan således gennem en fri brug gøres til en radikalt åben tekst, men her er så også tale om en voldtægt af tekstens indskrevne strategi, og ikke om et samspil eller samarbejde mellem tekst og læser. For at reallæseren kan påtage sig rollen som modellæser i dette samarbejde, er det påkrævet at denne udfører sit filologiske hjemmearbejde, som består i at sætte sig ind i de for teksten gældende 'koder'.

Eco peger endvidere på det tilsyneladende paradoksale fænomen, at jo mere lukket tekstens strategi er, og desto fastere modellæseren er defineret, desto mere holder teksten over for en åben læsning. Til gengæld kan en åben tekst kun vanskeligt læses lukket. Rex Stouts krimier kan således læses som Kafka'ske tekster, men Processen kan ikke med udbytte læses som en kriminalroman. Proust kan læse en køreplan som et digt, men Prousts romaner kan ikke læses som køreplaner (Eco I98 I, 86-87). Den frie brugslæsning, hvor læserens egne koder og fortolkningsrammer indskiftes til erstatning for tekstens, må ifølge Eco ses som et udslag af den radikale subjektivisme, som modernismen bragte med sig. Den frie brug er således et moderne fænomen, dvs. at ældre tekster kan læses moderne, men det er svært at læse moderne tekster klassisk. Og ret beset 
er hele denne del af Ecos teori vendt polemisk som et argument imod de mest radikale dele af dekonstruktionen og læserresponsteorierne.

Eco beskriver seks forskellige niveauer i læserens fortolkningsmæssige interaktion med teksten, som kan danne baggrund for den videre konceptualisering af læseprocessen (Eco I98I, I03). De seks niveauer betegner forskellige aspekter af læserens deltagelse i betydningstilskrivelsen, men de skal ikke forstås som værende kronologisk ordnede eller på anden måde indbyrdes hierarkisk relaterede. Beskrivelsen er hos Eco udelukkende rettet mod narrative tekster, men kan, efter min mening, også med fordel anvendes på andre typer af tekster præget af det, Eco kalder en indholdståge (nebuloso de contenido). ${ }^{7}$

I. Tekstens lineære manifestation er det rent leksikalske udtryk, som møder læseren. Dette udtryk er traditionelt knyttet til et indhold, og Eco forsøger med sin beskrivelse at skildre hvorledes dette indhold normalt gives form. I visse tilfælde kan udtrykket være uden et sådant indhold (nonsensremser eller Alfonso Reyes lyddigte, 'jitanjáforas'), men det indtryk som teksten giver, vil alligevel oftest kunne knyttes til en form for hyperkodificeret indhold som f.eks. 'litteraritet' eller 'børnerim'.

2. Læseren konfronterer det sproglige udtryk med det, som Eco kalder læserens kodemæssige kapacitet, og som han beskrev med den labyrintiske Q-model i sin Tratado (se s. 37). Der er her tale om såvel den rent sproglige forståelse (ordforråd og syntaktisk sammenhæng tilhørende de sproglige koder), som om mere komplicerede fortolkningsmæssige slutninger af pragmatisk, ideologisk og intertekstuel karakter, der tager form af såkaldte 'hyperkodificeringer'. Begrebet 'hyperkodificering' betegner hos Eco en abduktiv slutning, som på baggrund af en tidligere kode i hypotetisk form fortolker en hændelse som en modificering af denne kode. Som et eksempel på en hyperkodificering nævner han Peirces beskrivelse af mødet med den tyrkiske guvernør (Eco I 977, 208. For en beskrivelse af hændelsen, se også Peirce I 994, I 55. .)

Hyperkodificeringen opererer i to retninger: hvor de almindelige koder tilskriver betydning til de minimale udtrykshelheder, ${ }^{8}$ dér regu-

\footnotetext{
${ }^{7}$ Eco anvender udtrykket nebuloso de contenido om kreative tekster med et komplekst og ureducerbart indhold, som bryder eller ændrer koden igennem selve skabelsesakten (læs: udfordrer læserens genrebestemte forventninger / semiotiske vaner gennem kreative nyskabelser) (Eco I977, 282-85).

${ }^{8}$ Eco bruger udtrykket expresiones mínimas. Dette kan ikke oversættes med »udtrykkets mindstenheder ", da disse ikke i sig selv er tilskrevet en betydning, selv om de er betydningsbærende.
} 
lerer hyperkodificeringen betydningstilskrivelsen i forhold til de større semantiske helheder, som f.eks. de retoriske eller ikonologiske koder. Når disse større enheder én gang er tillagt en betydning, vil de på den anden side virke tilbage på de mindre enheder, som dermed tilskrives en ny betydning. Hyperkodificeringen kan gennem social accept blive etableret som en konnotativ subkode, men oftest forbliver de hyperkodificerede elementer fluktuerende mellem koderne, dvs. i gråzonen mellem konvention og innovation. Som eksempler på hyperkodificeringer nævner Eco så forskellige fænomener som forståelsen af paralingvistikken, forskellige former for ideologisk konnotation, høflighedsformularer, ansigtsudtryk, de narrative regler formuleret af Propp, kunstkritikerens brug af despektive betegnelser som 'kitsch' eller 'déjàvu', den dårlige kunstners manierisme eller gentagelse af en succes og det intertekstuelle princip (Eco I977, 205-I2).

Læserens genreforventninger, som knytter sig til tekstens retoriske og stilistiske karakteristika, udgør for Eco en sådan hyperkodificering, mens beredskabet af intertekstuelle referencer reguleres af pragmatiske frames. Eco hierarkiserer disse intertekstuelle referencer i et system der går fra de mest omfattende præfabrikerede fabler over kendte motiver og situationer til den klassiske retoriks topoi. Endelig har modellæserens forudsatte ideologiske beredskab en afgørende indflydelse på læsningen.

3. Tekstens diskursive struktur relateres - mens den læses eller høres - til de udsigelsesmæssige betingelser, den fremsættes under. For mundtlige udsagn handler det om den umiddelbare situationelle konteksts indvirkning, mens det for skrevne tekster f.eks. er et spørgsmål om at bestemme genre og aktivere det nødvendige filologiske beredskab mht. sproglig kode etc. For alle kreative eller kunstneriske udtryk gælder imidlertid at det ekstratekstuelle arrangement, præsentationen af kunst som kunst, spiller en afgørende rolle. Bestemmelsen af tekstens genre er således knyttet til både punkt $2 \mathrm{og} 3$, første gang som et umiddelbart forventningsmønster, anden gang som et filologisk redskab.

4. Det næste niveau i læserens deltagelse i betydningstilskrivelsen handler om hvordan den diskursive struktur knyttes til et forestillet handlingsrum eller mulige verdener (mundos posibles). Eco definerer disse mulige verdener som »tilstande som læseren forudser «, dvs. som læserens abduktive slutninger omkring en fremtidig udvikling i det fiktive univers (Eco I98 I, I60 og I 8I). De mulige verdener består således for Eco af en kombination af objektive, tekstlige betingelser og subjektive 
læsertilskrivninger, hvori en central sammenholdsfaktor udgøres af nogle generelle narrative strukturer.

Som den første funktion på dette niveau nævner Eco nødvendigheden af, at læseren beslutter sig for et eller flere topics, der kan danne baggrund for læserens udledningen af de isotopier, som i hans terminologi præget af den strukturelle semantik udgør læserens konkrete valg blandt de sproglige elementers betydningsmuligheder (jf. Greimas I974). På dette niveau foretager læseren en første abduktiv hypotese om rummets karakter, der fungerer som styringsinstrument (relativ éntydiggørelse) i den videre læsning.

Læseren aktiverer således visse pragmatiske og/eller intertekstuelle frames, mens andre nedtones. Eksempelvis denoterer en kvinde, som nævnes i en tekst, et menneske af hunkøn, som, alt efter topic og frame, kan aktivere forskellige sociale, biologiske, kulturelle etc. karakteristika fra den encyklopædiske betydningslabyrint.

5. Eco hævder, at konstruktionen af en fabel er afgørende for udviklingen af dette fiktive rum - også for ikke-narrative tekster (Eco I98 I, kap. 6). Det gælder først og fremmest indlæsningen af et hypostaseret forløb: før - ændring - efter. Parallelt hermed forstår Eco aktantstrukturerne, som vi kender dem fra Propp og Greimas, som fundamentale elementer i læserens etablering af teksten som en mulig verden.

Parallelt med Wolfgang Iser ${ }^{9}$ mener Eco endvidere at læseren, i forbindelse med konstruktionen af tekstens mulige verden, nødvendigvis må 'låne' elementer fra den 'virkelige' verden, fordi en litterær tekst ikke kan beskrive alt, men må forudsætte visse og ofte centrale og omfattende dele af universet som givne. Derfor indeholder de mulige verdener altid en reference til læserens egen livsverden. Den mulige verden er således at betragte som et kulturelt konstrueret fænomen, men argumentet for at det er nødvendigt at låne elementer fra den virkelige verden (det vil aldrig være muligt at foretage en udtømmende beskrivelse af en virtuel verden) slår tilbage på den 'virkelige' verden selv (det er heller ikke muligt at foretage en udtømmende beskrivelse af den virkelige verden), hvorfor også denne teoretisk set må betragtes som værende kulturelt konstrueret (op.cit. I 87 og 202-3).

6. Som et sidste niveau i samspillet mellem læser og tekst nævner Eco de ideologiske strukturer, der forstås som en axiologisk tilskrivning af værdier til tekstens elementer (op.cit. 248-49).

\footnotetext{
${ }^{9}$ Jeg henviser til en nærmere omtale af Wolfgang Isers virkningsæstetik i kapitel IV, se s. I98.
} 
I Ecos beskrivelse etablerer læserens fortolkning sig i spændingsforholdet mellem det han kalder intenciones og extenciones. De ekstentionelle bevægelser vedrører spørgsmål, såsom hvilke individer der er involvereret, hvilken karakter det beskrevne univers har (realt eller fiktivt), hvilke handlingsmæssige forudsigelser vi som læsere kan konstruere osv. De intentionelle bevægelser vedrører spørgsmål, såsom hvilke egenskaber vi tilskriver de involverede personer, hvilke værdier vi kan tilskrive dem, og hvorvidt flere personer udfylder den samme rolle osv. På det intentionelle plan accepteres teksten som et fiktivt univers med egne lovmæssigheder og logikker, mens læseren på det ekstentionelle plan foretager de refleksioner, der sætter ham eller hende i stand til at forholde sig til dette univers. Refleksionerne på det ekstentionelle plan knytter således an til analysen på den dynamiske interpretants niveau i Peirces terminologi.

Ecos beskrivelse understreger elementet af intern kohærens i det narrative univers, der på én gang lukker universet som udgangspunkt for en identifikation og samtidig åbner det for læserens gisning i form af abduktive hypoteser om den videre handling. Modellen er således velegnet til at beskrive nogle centrale læseroperationer, der først og fremmest knytter sig til produktionen af en logisk interpretant. Imidlertid viser nyere resultater inden for den neurofysiologiske forskning, at de emotionelle og kognitive input til hjernen følger forskellige baner, og at de emotionelle inputs baner er op til 40 millisekunder hurtigere end de kognitive signaler til cortex (Mial I995, 282 og Damasio 2003, 60). Det betyder ifølge Miall, at de emotionelle input udgør en 'præattentiv mekanisme', som er delvist styrende for vores opmærksomhed, og som således har stor indflydelse på vores konstruktion af verden. Og for en læserorienteret litteraturteori betyder dette at tekstens emotionelle potentiale indgår som en uomgængelig faktor i analysen af læseprocessens logiske operationer.

Over for Ecos beskrivelse, med dens fokus på udkrystalliseringen af en logisk interpretant som tekstens 'mening', mener jeg derfor at det må være nødvendigt at skildre den modale flerhed i læserens dialogiske interaktion med teksten. På trods af at Eco anvender mange af Peirces termer, såsom interpretant- og abduktionsbegrebet, ${ }^{10}$ så er Ecos centrale teoretiske udgangspunkt, som nævnt, fortsat præget af den europæiske strukturalisme. Som en konsekvens heraf kunne et forbehold over for Ecos model bestå $i$ at han efter min mening overser relevansen af kategorier som oplevelse og følelsesmæssig reaktion i sin skelnen mellem 'fortolkning' og 'brug'.

\footnotetext{
${ }^{10}$ Angående Ecos brug af abduktionsbegrebet i litteraturstudierne, se Eco I984 samt I990/I992.
} 
For Eco består fortolkningen i en læsning der er i overensstemmelse med tekstens strategi, og denne tager for Eco nødvendigvis form af logiske argumenter, mens den umiddelbare oplevelse og spontane følelsesreaktion er kategoriseret som reallæserens individuelle brug af teksten (Eco I98I, 85-87 og I992, 39-4I). Men Eco overser at teksten i sin æstetiske strategi også kan operere med læserens følelsesmæssige oplevelse og spontante reaktioner, kategorier som hos Peirce kan beskrives ved hjælp af begreberne den 'emotionelle' og den 'energetiske' interpretant. Jeg er således ikke uenig i Ecos skelnen mellem fortolkning og brug i sig selv, men i hans snævre definition af tekstens strategi som eksklusivt udtryk for en logisk og argumentativ refleksion.

Eco har til gengæld fat i, at hvis tekstens æstetiske virkning ikke blot er en individuel og singulær begivenhed, men besidder en eller anden grad af intersubjektivitet, så må teksten have indskrevet en strategi for sin egen læsning. En strategi, der over for læseren antyder hvordan bl.a. vægtningen af de indgående modaliteter skal være, og som af kritikeren kan gøres til genstand for en semiotisk beskrivelse. Hans Robert Jauss formulerer det på denne måde: »[E]t litterært værk [...] disponerer på forhånd sit publikum ved hjælp af åbne og skjulte signaler, tegn man er fortrolig med, eller implicitte henvisninger til en ganske bestemt måde at opfatte teksten på " (Jauss I98 I , 62). Således kan man med en vis mening tale om den tekstlige strategi som en læservejledning, som teksten selv rummer: "Når man tilegner sig en tekst, [...] virkeliggør [man] bestemte anvisninger i en proces, hvor ens iagttagelser er styret; denne proces kan erkendes og beskrives tekstlingvistisk på grundlag af de motivationer som konstituerer den, og de signaler, som udløser den « (ibid.).

På den baggrund forekommer det hensigtsmæssigt at rette blikket mod de forskellige niveauer i Peirces interpretantkategori med henblik på at studere tekstens erfaringspotentiale nærmere. Den umiddelbare interpretant repræsenterer, som vi har været inde på tidligere, det betydningspotentiale en tekst har forud for en given aktualisering i en konkret læsning. Steen Jansen har karakteriseret dette som »noget i teksten, der sammen med læservirkeligheden bidrager til at der kan etableres et tekstunivers i en given læsesituation "(Jansen I982). I beskrivelsen af den umiddelbare interpretant, som den udfoldes i dette kapitel, vil jeg diskutere hvordan man kan foretage en semiotisk beskrivelse af den æstetiske erfaring som en dialog imellem tre aspekter: den emotionelle, den energetiske og den logiske interpretant. Hver af disse interpretanter udgør aspekter af læserens oplevelsesmæssige erfaring, sådan som den er indskrevet i tekstens implicitte læserposition, og vil derfor kunne beskrives med reference til forskellige litteraturvidenskabelige teoridannelser. 


\section{Den umiddelbare interpretant}

Studiet af den umiddelbare interpretant udgør første skridt i en receptionsorienteret, semiotisk beskæftigelse med litterære tekster. I Kapitel II var vi inde på, at receptionssemiotikken i en vis forstand består i en omvending af kreationssemiotikken (se s. I I6). Hvor kreationen består i en kreativ, sproglig formgivning af forfatterens erfaringer og imaginære forestillinger, består receptionen i læserens abduktive syntetisering af betydning på baggrund af dette ordmateriale. Tidligere i Kapitel II var vi inde på at kreationssemiotikken beskæftiger sig med hvordan forfattersubjektet iscenesætter et fiktivt univers som en authoring af sit eget forhold til sin omverden (se s. $85 \mathrm{ff}$.), hvorfor man kunne forvente at studiet af den umiddelbare interpretant ville beskæftige sig med at rekonstruere det indhold, som forfatteren oprindeligt intenderede at teksten skulle have. Så enkelt er det imidlertid ikke.

For at forklare hvorfor det ikke er så enkelt, kunne man se på den tilsyneladende diskrepans mellem to forskellige definitioner af den umiddelbare interpretant, som vi finder hos Peirce. På den ene side definerer han begrebet som betydningen forstået som en umiddelbar, dvs. uanalyseret og ureflekteret mulighed: » The Immediate Interpretant is the immediate pertinent possible effect in its unanalyzed primitive entirety « (citeret efter Johansen I993, I66). På den anden side definerer Peirce den samme instans som det 'korrekte' indhold af et tegn i sig selv: »the Immediate Interpretant, [....] is the interpretant as it is revealed in the right understanding of the Sign itself « (CP 4.536). Hvad er det, som er på færde her?

Baggrunden for denne tilsyneladende diskrepans kunne være, at den 'rette' eller 'rigtige' forståelse af et tegn altid kun kan være en mulighed. Idet tegnproduktion og tegnfortolkning er to forskellige, om end sammensvejsede, processer, indeholder den konkrete kommunikative aktivitet altid en transmission eller oversættelse mellem de kommunikerende subjekter der indebærer, at der tilføjes noget på vejen. De kommunikerende instanser er ikke neutrale beholdere for indholdet, men tilføjer selv ny substans til det kommunikerede, hvilket Peirce formulerede som et spørgsmål om at "symboler vokser « (CP 2.222). Samtidig må man imidlertid ikke være blind for at tegn, samtidig med at de vinder i betydning på vejen, også taber dele af deres indhold, idet de løsrives fra deres oprindelige kontekst. Dette fænomen er af nykritikken blevet formuleret som et opgør med den tidligere litteraturvidenskabs søgen efter forfatterens intention som 'løsningen' på litteraturens sande indhold. Ifølge nykritikken var denne intention netop en del af den betydning, som det litterære tegn havde tabt på vejen, og som det aldrig kan lykkes at rekonstruere, jf. Beardsleys begreb the intentional fallacy. Den verden, som teksten re- 
fererer til, er i første omgang forfatterens indre eller imaginære verden, og den er gået tabt i samme øjeblik skriveprocessen er overstået. Der hvor man i stedet kan søge efter en holdbar definition af tekstens betydning, er ifølge Umberto Eco enten i teksten selv forstået som et potentiale af mulige betydninger eller i den konkrete aktualisering af en betydning hos en empirisk læser (Eco I990/I992, I24 ff.; I995, 70 ff.). Dette er niveauerne for hhv. den umiddelbare og den dynamiske interpretant hos Peirce.

\section{Begrebet om det cestetiske hos Peirce}

Æstetikken er hos den senere Peirce beskrevet som en af de tre 'formelle' videnskaber. Som vi var inde på i Kapitel I, skelner Peirce mellem det han kalder de ikke-normative videnskaber, som er matematikken og fænomenologien, og så de normative videnskaber, som er æstetikken, etikken og logikken (se s. I 8). Vedrørende det 'normative' i de normative videnskaber siger Peirce: »I never use the word 'norm' in the sense of a precept, but only in that of a pattern which is copied, this being the original metaphor « (CP I.5 86). Det æstetiske består med andre ord for Peirce ikke i at fælde smagsdomme, lige så lidt som etikken består i at fælde moralske domme. Studiet af æstetikken er studiet af en både ontologisk og konceptuel formdannelse, mens studiet af etikken er studiet af en såvel personlig som kulturel habit-taking relateret til social handlen.

Hvad der imidlertid kan have interesse at kommentere her, er at æxtetikken, forstået som studiet af »those things whose ends are to embody qualities of feeling ", så at sige går forud for etikken, forstået som studiet af »those things whose end lie in action " (CP 5.I 29). Anvender vi denne indsigt på den ovenfor skildrede relation mellem de overordnede idealer, som subjektet bruger til at ordne og give enhed til det netværk af habits som regulerer vores etiske adfærd, vil vi se at den grundlæggende stillingtagen til idealet er præget af en forudgående æstetisk dom. For at vide hvad der er godt og rigtigt at gøre eller sige i hver af de situationer som subjektets diskursive selver finder sig selv involveret $\mathrm{i}$, er det med andre ord nødvendigt at tage stilling til hvad der i æstetisk forstand er 'godt' eller 'smukt'. Igen, ikke som en smagsdom, men som en stillingtagen til hvad der kan bibringe helheden enhed. Altså en formel dom, i dette tilfælde relateret til subjektets enhed som semiotisk størrelse.

Det er også interessant at studiet af logikken og semiotikken indbefatter æstetikken og etikken i Peirces videnskabsteoretiske paradigme. Dette indebærer, at den logiske beskrivelse af en tekst, dvs. dens rent argumentative opbygning, også indeholder etiske og æstetiske problemstillinger, men at de rent æstetiske aspekter hverken indeholder etiske eller logiske 
problemstillinger, ligesom de rent etiske aspekter kan rumme æstetiske, men ikke de logiske problemstillinger.

For Peirce kan den æstetiske oplevelse eller erfaring bestemmes som værende relateret til et spændingsforhold mellem førstehedens grænseløse kvalitet og tredjehedens reducerende abstraktion: I den femte af hans Lowell Lectures fra 1903 ekspliciterer han dette forhold således:

[An] object to be aesthetically good, must have a multitude of parts so related to one another as to impart a positive simple immediate quality to their totality; and whatever does this is, in so far, esthetically good, no matter what the particular quality of the total may be. If that quality be such as to nauseate us, to scare us, or otherwise to disturb us to the point of throwing us out of the mood of esthetic enjoyment, out of the mood of simply contemplating the embodiment of the quality [...] then the object remains none the less esthetically good, although people in our condition are incapacitated from a calm esthetic contemplation of it (CP 5.I32).

Det er vigtigt her igen at understrege, at det æstetiske for Peirce således intet har at gøre med det, som vi forstår ved 'skønhed' i traditionel forstand, men om formelle domme om formmæssig enhed. Denne reduktion af en mangfold til enhed er en almen semiotisk funktion, som Peirce bl.a. knytter til de almene begrebers funktion i sproget. I den meget centrale artikel, »On a New List of Categories « fra I868, definerede Peirce begrebernes rolle således: » The function of conceptions is to reduce the manifold of sensuos impressions to unity, and that the validity of a conception consists in the impossibility of reducing the content of consciousness to unity without the introduction of it " (CP I.545). Det er selve denne oplevelse af, at en flerhed glider sammen og danner en helhed, som har æstetisk kvalitet for Peirce.

Når vi taler om æstetisk kvalitet i kunstneriske udtryk har vi at gøre med komplekse tegn, hvor den æstetiske kvalitet udmønter sig i, at værkets mange delelementer glider sammen i en overordnet helhed. Peirce udtrykker det på den måde at store, klassiske værker har en sådan helhedskarakter, at alle dele fornemmes som en del af den samme flavour. I den tredje af hans Lowell Lectures fra I 903 skriver han:

A Firstness is exemplified in every quality of a total feeling. It is perfectly simple and without parts; and everything has its quality. Thus the tragedy of King Lear has its Firstness, its flavor sui generis. That wherein all such qualities agree is universal Firstness, the very being of Firstness. The word possibility fits it, except that possibility implies a relation to what exists, while universal Firstness is the mode of being itself (CP I.53I). 
Peirce anvender formentlig metaforen flavor for at understrege det umiddelbare i oplevelsen af denne æstetiske kvalitet. Det æstetiske er altså noget som opleves umiddelbart, noget man som læser eller tilskuer føler falder på plads. Men at det er en umiddelbar oplevelse betyder ikke, at der ikke er tale om en fortolkning, eller at der ikke fældes en 'dom'. Som det fremgår af artiklen »A Guess at the Riddle « fra I 887-88 mener Peirce, at også den umiddelbare perception er underlagt fortolkning, og at der dermed er tale om perceptuelle domme. I dette synspunkt foregriber han så at sige Jerome Bruners perfink-begreb, som jo netop også understreger enheden af perception, feeling og thinking (Bruner I986, 69). På baggrund af denne udlægning af Peirce er den æstetiske oplevelse ikke grundlæggende adskilt fra eller anderledes end det logiske eller videnskabelige ræsonnement - og dermed er den også semiotisk beskrivbar. Omkring I 890 skriver han således:

The work of a poet or a novelist is not so utterly different from that of the scientific man. The artist introduces a fiction; but it is not an arbitrary one; it exhibits affinities to which the mind accords a certain approval in pronouncing them beautiful, which if it is not exactly the same as saying that the synthesis is true, is something of the same general kind. The geometer draws a diagram, which if not exactly a fiction, is at least a creation, and by means of observation of that diagram he is able to synthesize and show relations between elements which before seemed to have no necessary connection (CP I.383).

Den æstetiske kvalitet er således noget, som er der eller ikke er der. De æstetiske elementer kan være til stede i større eller mindre omfang, men der kan ikke være tale om at noget er mere eller mindre æstetisk godt i sig selv. Dette kommer klart til udtryk i den femte af hans Lowell Lectures:

All there will be will be various esthetic qualities; that is, simple qualities of totalities not capable of full embodiment in the parts, which qualities may be more decided and strong in one case than in another. But the very reduction of the intensity may be an esthetic quality; nay, it will be so; and I am seriously inclined to doubt there being any distinction of pure esthetic betterness and worseness (CP 5.132).

Det æstetiske har således noget at gøre med forholdet mellem førstehedens udifferentierede mangfold og tredjehedens enhed i komplekse tegn. Det er noget af det, Peirce forsøger at beskrive med begrebet kalos i teksten "Esthetics, Ethics, and Logic " (CP 2.197). Vanskeligheden med at beskrive den æxtetiske kvalitet kommer til udtryk ved, at Peirce forsøger at beskrive førsteheden i nærmest poetiske vendinger. Det æstetiske er en førstehed, og dermed opleves den som frisk og ny hver gang. Som det hedder i »A Guess at the Riddle«: 
It must be fresh and new, for if old it is second to its former state. [...] Only, remember that every description of it must be false to it (CP I.357, for hele citatet se s. 20).

I stedet for at tale om objekter som værende i sig selv æstetiske, er det vigtigere at tale om, at betragteren kan anlægge et æstetisk syn på komplekse tegn, og at betragteren kan vurdere forholdet mellem tegnenes kvalitative og repræsentative sider. Den æstetiske oplevelse indtræffer, det er en hændelse som er tidsligt og rumligt afgrænset, og som derfor også finder sted i en konkret person. Som sådan er det en andethed. Men hændelsen er en fortolkning i den forstand at det betragtede objekt er et komplekst tegn, altså en tredjehed, som lader sig betragte på en sådan måde, at alle dets dele går sammen i en helhed som repræsenterer en eneste kvalitet, og som sådan er det en førstehed:

The esthetic Quality appears to me to be the total unanalyzable impression of a reasonableness that has expressed itself in a creation. It is a pure Feeling but a feeling that is the impress of a Reasonableness that Creates. It is the Firstness that truely belongs to a Thirdness in its achievement of Secondness (MS nr 3 Io, citeret fra Haley I988, 57).

Denne opfattelse af det æstetiske kunne man mistænke for at være præget af Peirces for- og samtid i form af normative romantiske forestillinger om det organiske værk mv., som ikke ville være holdbare for det 20. århundredes æstetiske udtryk. Der er imidlertid nok snarere tale om, at Peirces begreb om det æstetiske sætter nogle almene rammer for forståelsen af det æstetiske princip. Således tyder nyere neurofysiologiske forskningsresultater på at der eksisterer et dialogisk udvekslingsforhold mellem de udifferentierede, visuelle udtryk og formgenererende hypoteser i den menneskelige hjerne. Neuroæstetikken, der forsøger at forklare den æstetiske erfaring ud fra empirisk baseret hjerneforskning, opererer på den baggrund med en hypotese om at kunsten for så vidt blot gennemspiller hjernens almene, betydningsgenererende operationer i eksemplarisk form (Zeki I999, 79-80), og at disse kan sammenfattes i et begrænset katalog af 'universalier', gældende for alle kunstarterne. Således opstiller Ramachandran og Hirstein otte pricipper, som angiveligt skulle ligge under alle former for kunstnerisk eller æstetisk erfaring. Et af de vigtigste består i at identificere, isolere og gruppere de karakteristiske eller klassificerende træk ved et fænomen, der muliggør en karrikeret eller typemæssigt rendyrket fremstilling. Et andet består i at koncentrere opmærksomheden mod dette træk ved at bortrense uvedkommende 'støj'. Og et tredje består i en perceptuel gruppering eller sammenbinding af de karakteristi- 
ske træk (Ramachandran \& Hirstein I999). Selv om både Ramachandran \& Hirstein og Semir Zeki måske kan kritiseres for at universalisere bestemte træk fra såvel den præmoderne og højmoderne kunst (Cezanne, f.eks.), er det samtidig oplagt at de er på sporet af nogle centrale fysiologiske principper i den måde hvorpå mennesker, eller måske ligefrem alle biologiske organismer, forholder sig til form. ${ }^{11}$ Og her er det netop igen forholdet mellem de udifferentierede, visuelle indtryk og de formgenererende hypoteser i den menneskelige hjerne, som står centralt for undersøgelsen. Forestillingen er her at de formgenererende hypoteser fra cortex så at sige løbende dialogeres med den underliggende perception gennem det limbiske system:

Given the limited attentional ressources in the brain and limited neural space for competing representations, at every stage in processing there is generated a 'Look here, there is a clue to something potentially object-like' signal that produces limbic activation and draws your attention to that region (or feature), thereby facilitating the processing of those regions of features at earlier stage [...]. And what the artist tries to do, is to tease the system with as many of these 'potential object' clues as possible (Ramachandran \& Hirstein I999, 23).

Anskuet på denne måde kan den æstetiske oplevelse knyttes til oplevelsen af den åbne, ubestemmelige og ureducerbare betydningsmangfold i værker som yder læseren modstand, og som udfordrer dennes kreative evne til at skabe sammenhæng i kaos. Den teoretiske beskrivelse af dette æstetiske 'blik', måden hvorpå vi betragter samspillet mellem form og betydning $\mathrm{i}$ alt fra hverdagslivets objekter og begivenheder og til de kunstneriske udtryk, spænder således fra fx John Dewey og Roman Ingarden over Wolfgang Iser og receptionsæstetikken til den mest moderne neuroæstetik.

\section{Den emotionelle, energetiske og logiske interpretant}

Definitionen af den æstetiske oplevelse som en hændelse, hvori det kontemplerede objekts kvalitative og repræsentative sider smelter sammen til en enhed, bestemmer studiet af den æxtetiske oplevelse som studiet af det dialogiske forhold mellem en umiddelbar og en dynamisk interpretant. Hvor den umiddelbare interpretant betegner betingelserne eller mulighe-

\footnotetext{
${ }^{11}$ Dette gælder ikke mindst når Ramachandran \& Hirstein inddrager symmetriprincippet blandt de otte universelle principper. Empirisk forskning har vist, at symmetri udgør en generel biologisk / kropslig / seksuel attraktor for svaler (Anders Pape Møller, I992), og andre lignende undersøgelser tyder på at dette princip gælder alle levende organismer. Det kunne derfor være i kraft af vores organiske dragning mod symmetriens enhed og helhed, at forskellige æxtetiske strømninger kan udmønte deres særlige spil.
} 
derne for en betydningstilskrivning, dér repræsenterer den dynamiske interpretant den konkrete aktualisering. Disse begreber giver os et redskab til at undersøge betingelserne for denne hændelse i det Peirce betegner som en quasi-mind. I en tekst fra I 906 skriver Peirce:

I have already noted that a Sign has an Object and an Interpretant, the latter being that which the Sign produces in the Quasi-mind that is the Interpreter by determining the latter to a feeling, to an exertion, or to a Sign, which determination is the Interpretant ( $\mathrm{CP} 4.536)$.

Peirce anvender begrebet quasi-mind som en betegnelse for de almene betingelser for kommunikativ udveksling, der er betinget af de semiotiske processers dialogiske karakter: for at der kan være tale om semiosis, skal der være to quasi-minds, en afsender og en modtager, og det gælder alle processer lige fra naturens biosemiotik til den menneskelige tale og skrift. I det anførte citat definerer Peirce således interpretanten af et givet tegn som de følelser, den anstrengelse eller det nye tegn, som et givet tegn determinerer i modtageren, forstået som en almen forudsætning for kommunikativ udveksling. Som vi har været inde på i Kapitel I og II, er der i den litterære receptionssemiotik tale om at omvende den semiosis som lå til grund for forfatterens skriveproces. I kreationsprocessen blev tegnfunktionen bag det kreative subjekt bestemt som en mediering mellem et ego og et non-ego, mellem væren og hændelse i form af erfaring. Og, som vi så, anvendte Peirce begreberne feeling, volition og cognition som betegnelser for de mentale modalkategorier i beskrivelsen af den menneskelige psykologi (se s. 9I). I fortolkningsprocessen genfinder vi nu de samme kategorier udmøntet som en beskrivelse af forskellige aspekter af interpretanten. Det gælder begreberne den emotionelle, den energetiske og den logiske interpretant:

Now the problem of what the 'meaning' of an intellectual concept is can only be solved by the study of the interpretants, or proper significate effects, of signs. These we find to be of three general classes with some important subdivisions. The first proper significate effect of a sign is a feeling produced by it. This 'emotional interpretant', as I call it, may amount to much more than that feeling of recognition; and in some cases, it is the only proper significate effect that the sign produces. Thus, the performance of a piece of concerted music is a sign. It conveys, and is intended to convey, the composer's musical ideas; but these usually consist merely in a series of feelings. If a sign produces any further proper significate effect, it will do so through the mediation of the emotional interpretant, and such further effect will always involve an effort. I call it the energetic interpretant. The effort may be a muscular one, as it is in the case of the command to ground arms; but it is much more usually an exertion upon the Inner World, a mental effort. It never can be the meaning of 
an intellectual concept, since it is a single act, [while] such a concept is of a general nature. But what further kind of effect can there be? (CP 5. 475)

In advance of ascertaining the nature of this effect, it will be convenient to adopt a designation for it, and I will call it the logical interpretant (CP 5.476).

Peirce definerer i dette citat interpretantens tre almene aspekter som værende tilknyttet en følelsesmæssig tilstand, en anstrengelse og en logisk slutning. Inden for den logiske interpretant skelner Peirce endvidere mellem de første og de sidste logiske interpretanter. De første logiske interpretanter opstår som abduktive gisninger, når man første gang støder på noget overraskende, hvad enten det tilhører den aktuelle virkelighed eller et imaginært univers. Ikke alle tegn har sådanne logiske interpretanter, idet den logiske interpretant igangsætter en kæde af refleksioner af rationel karakter, der forsøger at etablere en generaliseret forestilling om den overraskende hændelse, der kan dække fremtidige tilfælde. Dette indebærer at den første logiske interpretant på den ene side involverer intellektuel begrebsdannelse og på den anden side refererer til et objekt, som endnu kun er af mulig eller potentiel karakter. Et sådant potentielt objekt kalder Peirce et would-be (CP 5.482). Den 'sidste' (ultimate) logiske interpretant består på sin side i en vanedannelse:

James [...] does not restrict the 'meaning', that is, the ultimate logical interpretant as I do, to a habit, but allows percepts, that is, complex feelings endowed with compulsiveness, to be such (CP 5.494).

Som både Josef Ransdell og Dines Johansen har anført, er der blandt Peirce-forskere fortsat diskussion om, hvordan man skal opfatte forholdet mellem Peirces forskellige trikotomier af interpretanter. Nogle, heriblandt Fitzgerald og Savan, mener at opdelingen i den emotionelle, den energetiske og den logiske interpretant er en underopdeling af den dynamiske interpretant, hvorved de er på linje med Victorino Tejera, der anvender begreberne til at skildre interpretanten som »the significate outcome of a sign ", dvs. de følelser teksten producerer hos læseren, dennes konkrete reaktioner og værkets betydning som et argument (Tejera 1995, 42). Dines Johansen anfører, at endnu andre mener at de to trikotomier nærmest er identiske (Johansen I993, I66). Dines Johansens eget bud er, at den emotionelle, energetiske og logiske interpretant udgør underkategorier til såvel den umiddelbare, den dynamiske og den finale interpretant, således at der inden for hver af de sidstnævnte kan skelnes mellem hver af de første (Johansen I993, I66). Sagt med andre ord har et tegns umiddelbare interpretant, dvs. tekstens umiddelbare betydningspotentiale, et 
emotionelt aspekt (de følelsesmæssige muligheder), et energetisk aspekt (mulighederne for konkrete reaktioner) og et logisk aspekt (mulighederne for begrebslig eller narrativ betydning). Tilsvarende vil man også på niveauet for både den dynamiske og finale interpretant kunne tale om emotionelle, energetiske og logiske aspekter. I det følgende vil jeg støtte mig til Dines Johansens udlægning.

Udlagt på denne måde vil begreberne emotionel, energetisk og logisk interpretant være tæt forbundne med de almene betingelser for den menneskelige kognition, som Peirce naturligvis beskriver i lyset af sine almene fænomenologiske kategorier. I »A Guess at the Riddle « beskriver Peirce betingelserne for menneskelig kognition ud fra en skelnen mellem begreberne immediate feeling, polar sense og synthetical consciuosness:

Here then, we have indubitably three radically different elements of consciousness, these and no more. And they are evidently connected with the ideas of one-two-three. Immediate feeling is the consciousness of the first; the polar sense is the consciousness of the second; and synthetical consciousness is the consciousness of a third or medium (CP I.382).

I det følgende har jeg koblet de tre kognitive begreber feeling, polar sense og synthetical consciousness til de tre interpretantbegreber (den emotionelle, den energetiske og den logiske interpretant), og med udgangspunkt i denne kobling har jeg foretaget en mere udfoldet beskrivelse af disse tre aspekter af den umiddelbare interpretant. Det følgende skema kan således opfattes som en diagrammatisk beskrivelse af de tre værensmodi, som læseren kan forsøge at bringe sammen til et hele i den æstetiske oplevelse. Jeg har brugt de betegnelser, som Peirce bruger om den menneskelige kognition, som ramme for en beskrivelse af forholdet mellem teksten som et materielt udtryk og den umiddelbare interpretant som et heraf determineret betydningspotentiale:

TEKST

\begin{tabular}{lll}
\hline Materiale & Hændelse & Form \\
Kvalitet & Reaktion & præsentation \\
Potentialitet & Aktualitet & Generalitet \\
Ubestemthed & Negation / Modsætning & Totalitet \\
Tone of conciousness & Oplevelse & Kognition \\
Quality of feeling & Polar sense & Logisk slutning \\
Umiddelbar bevidsthed & Direkte bevidsthed & Synt.bevidsthed \\
Emotionel interpretant & Energetisk interpretant & Logisk interpretant \\
\hline
\end{tabular}

DEN UMIDDELBARE INTERPRETANT 
Det rent emotionelle aspekt af den umiddelbare interpretant bestemmes i udgangspunktet af det sproglige materiales kvalitative karakter. Teksten benytter sig af et bestemt ordvalg og en given syntaks, der i kraft af de stilistiske signaler lægger en kvalitativ ramme omkring tekstens emotionelle ladning. Tekstens strategi kan på det emotionelle plan således i vid udstrækning aflæses ud fra ordmaterialets karakter og organisering, og ifølge D.S. Miall bekræfter den neurofysiologiske forsknings empiriske resultater den senere Mukarovskys hypotese om, at aktualisering af bestemte sproglige komponenter gennem f.eks. metrum, rim, inversioner eller metaforer (foregrounding hos Mukarovsky) evokerer følelser hos læseren (Miall I995, 283).

Som en modal førstehed er den emotionelle interpretant at betragte som et åbent mulighedsfelt, knyttet til den materielle form: » The first must be indeterminate, and the indeterminate first of anything is the material of which it is formed «(CP I.373). Ubestemtheden og uafgrænsetheden karakteriserer det kvalitative materiale i sig selv, som først træder i karakter idet det konfronteres med det, som det ikke er: »Indeterminacy is really a character of the first. But not indeterminacy of homogeneity. The first is full of life and variety. Yet that variety is only potential « (ibid.). Peirce ynder at forklare denne emotionelle kvalitet metaforisk eller synæstetisk: den uafgrænsede følelsesmæssige tilstand bliver sammenlignet med en duft, en smag eller en tone: "A quality of feeling, in itself, is no object and is attached to no object. It is a mere tone of consciousness " (CP 7.530). I temporal forstand er denne tone of consciousness knyttet til det uafgrænsede øjeblik, nuet, for ifølge Peirce er det uafgrænsede nu karakteriseret ved en form for umiddelbar bevidsthed, et rent nærvær præget af qualities of feeling: »Feelings [...] form the sum total of all which we have in immediate and instantaneous consciousness " (Peirce I992, 259). Den umiddelbare bevidsthed er betegnelsen for den bevidsthedstilstand, hvor vi egentlig ikke er bevidste om vores væren, men hvor vi bare er, og den kvalitative betegnelse for denne tilstand er følelse: »[T] he feeling is simply a quality of immediate consciuosness «(CP I.307).

Det energetiske aspekt af den umiddelbare interpretant er knyttet til de rammebetingelser, teksten sætter som mulighed for en aktualisering i læseakten. Selve den empiriske læsers læsning af teksten ville skulle analyseres som en dynamisk interpretant, men de rammer, som tekstens strategi lægger for en læsning, herunder tekstens retoriske, prosodiske og kompositionelle karakteristika, kan meningsfuldt begribes som energetiske aspekter af den umiddelbare interpretant. Den energetiske interpretant er som andethed knyttet til den indtrædende hændelse eller forandring, der fordrer en reaktion af modtageren. Hændelsen binder to tilstande 
sammen, et før og et efter, hvorfor den energetiske interpretant er en analytisk kategori for overgangen mellem én tilstand og en anden, forstået som et faktum:

The event is the existential junction of states (that is, of that which in existence corresponds to a statement about a given subject in representation) whose combination in one subject would violate the logical law of contradiction. The event, therefore, considered as a junction, is not a subject and does not inhere in a subject. What is it, then? Its mode of being is existential quasi-existence, or that approach to existence where contraries can be united in one subject (CP I.494).

Forstået som rent indtrædende hændelse og reaktion er den energetiske interpretant en modalkategori, dvs. en værensform der kun har sin berettigelse i at modstille de to tilstande i én hændelse uden at medtænke modtagerens mediering imellem de to, hvilket ville tage form af en tredjehed, en refleksion over sammenhæng og mening med forandringen:

Just as the first is not absolutely first if thought along with a second, so likewise to think the second in its perfection we must banish every third. [...] It meets us in such facts as another, relation, compulsion, effect, dependence, independence, negation, occurrence, reality, result (CP I.358, for hele citatet se S. 2I).

Hvor den emotionelle interpretant skal forstås som en modalkategori der involverer uafsluttethed, ubestemthed og et åbent potentiale af muligheder, der repræsenterer den energetiske interpretant en afgrænsning af førstehedens uafsluttethed i form af 'aktualitet', dvs. en realisering af et partielt udsnit af potentialet i tid og rum:

If I ask you what the actuality of an event consists in, you will tell me that it consists in its happening then and there. The specifications then and there involve all its relations to other existents. The actuality of the event seems to lie in its relations to the universe of existents [...]. We have a two-sided consciousness of effort and resistance, which seems to me to come tolerably near to a pure sense of actuality (CP I.24).

Når jeg på dette sted involverer aktualitetsbegrebet i beskrivelsen af den energetiske interpretant, skal det naturligvis understreges at vi stadig befinder os på niveauet for den umiddelbare interpretant, hvor det vi analyserer, er teksten i sig selv som æstetisk strategi, altså som et rent mulighedsfelt. Når det alligevel giver mening at bruge modalkategorien aktualitet i denne sammenhæng, er det fordi der vil være forskel på de 
elementer i en teksts strategiske inventar, der tager sigte på at give læseren en fornemmelse af åben ubestemthed, og de elementer der tager sigte på at overraske, provokere eller ligefrem chokere. Som modalkategori giver begreberne og den emotionelle og den energetiske interpretant os et analytisk redskab til den semiotiske beskrivelse af et væsentligt inventar af æstetiske virkemidler: ubestemthed over for overraskelse, følelse over for hændelse, kvalitet over for negation, indføling over for reaktion osv. Som modpol til det vi kunne kalde den emotionelle interpretants mindsteenhed, quality of feeling, karakteriserer Peirce den energetiske interpretant som det forhold, at oplevelsen af én quality of feeling modstilles en anden i form af en polar sense: »the polar sense is the sense of the difference between what was before and what is after a dividing instant, or the sense of an instant as having sides « (CP I.386). Endelig karakteriserer Peirce den modale oplevelsesform, hvorunder modtageren erfarer effekten af de energetiske interpretanter, som direct experience, hvilket jeg vælger at oversætte med direkte oplevelse:

Direct experience is neither certain nor uncertain, because it affirms nothing - it just is. There are delusions, hallucinations, dreams. But there is no mistake that such things really do appear, and direct experience means simply the appearance (CP I.I45).

Når jeg her vælger at oversætte det engelske experience med oplevelse og ikke med erfaring, er det fordi erfaringsbegrebet indbefatter refleksionen over hvilken betydning denne erfaring kan tillægges for det erfarende subjekt, og dette element ligger netop uden for den energetiske interpretant som 'just is'. I den forstand er den energetiske interpretant snævert knyttet til det uformidlede møde mellem ego og non-ego, der ligger til grund for subjektets erfaringsdannelse, og som Peirce karakteriserer som direkte bevidsthed (direct consciousness, CP I.325). Hvor den umiddelbare bevidsthed var betegnelsen for en bevidsthedstilstand, hvor vi ikke var bevidste om vores væren, dér kan den 'direkte bevidsthed' karakteriseres som en bevidsthedsform, der udspringer af, at vi bliver gjort opmærksomme på verden omkring os, ved at den trænger sig på, den overrasker os og evt. provokerer os og fremkalder en reaktion eller evt. blot en vilje dertil. Refleksionen over sammenhæng og betydning hører hjemme inden for den logiske interpretant.

Fra den emotionelle interpretants synsvinkel præsenterer teksten sig som et rent sprogligt materiale, og fra den energetiske interpretants synsvinkel præsenterer teksten sig som et givet hændelsesforløb, men fra den logiske interpretants synsvinkel fremtræder teksten som en narrativ 
eller argumentativ form. Den logiske interpretant forstår teksten som en symbolsk repræsentation, hvor den sproglige begrebsdannelse og de forskellige former for, i Ecos terminologi, hyperkodificeringer såsom diskursive registre og genreforventninger gør det muligt for læseren at konstruere en overgribende betydning, der sammenkæder tekstens mikrosegmenter, tegnene, til en helhed, teksten.

Freedom can only manifest itself in unlimited and uncontrolled variety and multiplicity; and thus the first becomes predominant in the ideas of measureless variety and multiplicity. It is the leading idea of Kant's 'manifold of sense'. But in Kant's synthetic unity the idea of Thirdness is predominant. It is an attained unity; and would better have been called totality [...] (CP I.302).

Ovenfor udlagde vi den emotionelle interpretant som en modalkategori, der involverede uafsluttethed, ubestemthed og et åbent potentiale af muligheder, og den energetiske interpretant som en tilnærmelsesvis afgrænsning af førstehedens uafsluttethed, en aktualitet. Heroverfor består den logiske interpretant i et generaliseret og dermed repetitivt betydningsindhold. Den logiske interpretant medierer mellem den emotionelle og den energetiske interpretant i den forstand, at det altid er kvalitativ forskel som er udgangspunktet for betydningstilskrivelse, også inden for auditive og visuelle udtryk (Ramachandran \& Hirstein I995, 25). Oplevelseskategorierne kvalitet og ændring/reaktion spiller således sammen i en repeterbar repræsentation eller tegnfunktion, på samme måde som materiale og hændelsessekvens tænkes sammen i en overgribende form. De modale kategorier 'potentialitet' og 'aktualitet' modsvares af det symbolske tegns 'generalitet', som kun udvikles gennem den semiotiske vanedannelse. Det er således i kraft af den semiotiske vanedannelse at de emotionelle interpretanters åbne ubestemthed og de energetiske interpretanters konsekvente negation og modsætning gives plads inden for en overgribende totalitet, der ikke blot rummer begge de modstridende principper, men sammenholder dem i en overgribende form. Og endelig medieres de følelsesmæssige kvaliteter og de overraskende sanseindtryk af den menneskelige kognitions vilje til at skabe sammenhæng og mening:

[T]hat element of cognition which is neither feeling nor the polar sense, is the consciousness of a process, and this in the form of the sense of learning, of acquiring, of mental growth is eminently characteristic of cognition $(\mathrm{CP}$ I.38I).

Menneskets evne til at erkende verden, til at omsætte sine umiddelbare oplevelser i konfrontationen med non-ego til erfaringer, der giver viden 
om verden, afhænger således af menneskets evne til at lade logiske interpretanter mediere mellem de emotionelle og de energetiske interpretanter. Peirce kalder også denne erkendelsesform, der er præget af helhedstænkning og logiske slutningsformer, for syntetisk bevidsthed:

[T] he highest kind of synthesis is what the mind is compelled to make neither by the inward attractions of the feelings or representations themselves, nor by a transcendental force of necessity, but in the interest of intelligibility that is, in the interest of the synthesizing 'I think' itself; and this it does by introducing an idea not contained in the data, which gives connections which they would not otherwise have had (CP I.383).

Selve det faktum, at de logiske interpretanter tilsyneladende er absolut dominerende i langt størsteparten af den menneskelige kommunikation, ændrer ikke ved det forhold, at de logiske interpretanter kun opstår som en mediering af emotionelle og energetiske interpretanter, og at det, som vi her har kaldt den æstetiske erfaring, netop består i at erkende disse modalkategoriers dialogiske samspil. Det æstetiske blik lader ikke tegnets udtryk forsvinde eller blive gennemsigtigt, men fokuserer i stedet på udtrykket, som på sin side danner udgangspunkt for produktionen af emotionelle og energetiske interpretanter.

\section{Den æstetiske erfaring i læseprocessen}

Vi går nu over til at se på hvordan den æstetiske erfaring kan beskrives $\mathrm{i}$ relation til den litterære praksis. Selv om fokus er rettet mod det litterære kunstværk, er målet med dette afsnit at forsøge at udlede nogle mere generelle principper for beskrivelsen af hele det æstetiske problemfelt. Fordelen ved en semiotisk begrebsliggørelse af den æstetiske kontemplation som et spil mellem modale kategorier er, at den ikke kun har gyldighed inden for det litterære felt, men er anvendelig inden for alle kunstarter, og således også forekommer velegnet til såkaldte interartstudier (se eksempelvis Hansen I996, I997a, I999a og I999b). På trods af denne interdisciplinære ambition gør fremstillingen dog ikke krav på at foretage en udtømmende beskrivelse af 'det æstetiske', men stiller sig som mål at samle en række forskellige karakteristika knyttet til den æstetiske erfaring inden for én og samme semiotiske beskrivelseslogik.

Den hypotese, som styrer den følgende fremstilling, er at vores æstetiske forholden os til verden korresponderer med nogle af de grundlæggende principper i den almene subjektsdannelse. Idet Peirce opfatter det menneskelige subjekt som et tegn, kunne man forestille sig, at det vi 
kalder den æstetiske erfaring kan beskrives som en udfordring af dette subjekt (os, læseren/betragteren) netop i dets egenskab af fortolkende subjekt, i dets egenskab af at være en interpretant. Man kan også sige, at vi i kraft af den æstetiske erfaring bliver opmærksomme på vores funktion som fortolkende subjekter. Forstået på denne måde kan det kunstneriske tegn karakteriseres ved at det gør opmærksom på sit eget udtryk (jf. Roman Jakobson), hvorved det determinerer en bestemt orkestrering af de emotionelle, energetiske og logiske interpretanter i det, vi kalder den æstetiske erfaring. Hvor den logiske interpretant vil være altdominerende i almindelig sprogbrug, dér vil de emotionelle og energetiske interpretanter gøre sig selv meget mere mærkbare og påtrængende i den æstetiske kontemplation.

Måden, hvorpå jeg vil udfolde denne hypotese, vil bestå i følgende. Udgangspunktet tages i tre anerkendte bidrag til beskrivelsen af æstetisk kvalitet i litterære tekster, bidrag som bygger på en processuel og læserorienteret tilgang, og på baggrund af denne beskrivelse vil jeg diskutere teorien om den æstetiske erfaring som et samspil af emotionelle, energetiske og logiske interpretanter hos Peirce. Gennemgangen vil falde i tre tempi ud fra Peirces tre centrale niveauer i studiet af tegnfunktionen: det morfosyntaktiske, det semantiske og det pragmatiske. Til illustration af den æstetiske funktion inden for det morfosyntaktiske niveau har jeg valgt at se på Roman Jakobsons parallelismebegreb. Til illustration af den æstetiske funktion på det semantiske niveau har jeg valgt at se på Paul Ricœurs beskrivelse af den poetiske metafor, og til at undersøge forholdet mellem tegn og interpretant, det pragmatiske niveau, vil jeg inddrage nogle aspekter af Bakhtins dialogismebegreb, sådan som det er udfoldet i relation til hans romanteori.

\section{Det morfosyntaktiske niveau: Roman Jakobsons parallelismer}

Som nævnt i Kapitel I kan man med udgangspunkt i Peirces opdeling af semiotikkens discipliner definere det morfosyntaktiske niveau som studiet af tegnet i sig selv (se s. I9). Studiet af den æstetiske funktion på niveauet for tegnet i sig selv har jeg valgt at behandle ud fra Roman Jakobsons teori om sprogets poetiske funktion. Efter en kort introduktion af Jakobsons teori vil jeg forsøge at diskutere den i lyset af en definition af den æstetiske oplevelse, forstået som et samspil mellem modale relationer. Afsnittet afsluttes med en eksemplarisk læsning af »Digt nr. 20 « fra Pablo Nerudas digtsamling Tyve kerlighedsdigte og en desperat sang.

Roman Jakobson er den vel nok fremmeste og internationalt set mest kendte repræsentant for Pragerskolens funktionalistiske strukturalisme, der ganske vist i udgangspunktet lod sig inspirere af Saussures binære 
tegnbegreb, men som i deres virke var optaget af betydningernes tilblivelse og spil i konkrete tekster samt i dialogen mellem kunstarterne. ${ }^{12}$

Roman Jakobson beskæftigede sig med æstetiske udtryk inden for en række forskellige semiotiske registre såsom litteratur, musik og maleri, men inden for litteraturstudierne knytter han det æstetiske udtryk til det, han kalder sprogets 'poetiske funktion'. Den poetiske funktion i en tekst, dens poeticitet, beskriver han som noget ureducerbart og unikt: "..the poetic function, poeticity, is [...] an element sui generis, one that cannot be mechanically reduced to other elements «(Jakobson I98I III, 750). Hos Jakobson finder vi endvidere dette unikke, ureducerbart ikoniske ved poesien beskrevet som en art selvrepræsentation:

Poeticity is present when the word is felt as a word and not a mere representation of the object being named or an outburst of emotion, when words and their composition, their meaning, $[\ldots]$ acquire a weight and value of their own instead of referring indifferently to reality (ibid.).

Teksten gør i kraft af sin egen form opmærksom på sig selv og sit eget udtryk. Poeticiteten er for Roman Jakobson endvidere en funktion der, med udgangspunkt i tekstens mangfold af dele, udfordrer læseren med henblik på at konstruere en helhed, som så efterfølgende virker tilbage på de andre tekstelementer og kun derigennem bestemmer helhedens karakter.

For the most part poeticity is only a part of a complex structure, but it is a part that necessarily transforms the other elements and determines with them the nature of the whole (ibid.).

Konkret består den poetiske funktion i at forskellige former for parallelismer (similaritet) i teksten påkalder sig læserens opmærksomhed. Parallelismernes system af ligheder etableres paradigmatisk og giver teksten et andet helhedspræg end den nærhedsbestemte betydning (kontiguitet), som er knyttet til tekstens lineære fremtræden. Sådanne parallelismer kan være til stede i alle former for tekster, og alle former for tekster kan således have en vis grad af poeticitet. Men poesi kan på sin side ifølge Jakobson karakteriseres ved, at denne poetiske funktion bliver ophøjet til diskursens centrale element. Poesi bliver således at forstå som det sprogligt æestetiske udtryk par exellence: »One may state that in poetry similarity is superimposed on contiguity, and hence equivalence is promoted to the constitutive device of the sequence" (op.cit. 92).

\footnotetext{
${ }^{12}$ På dansk udgør Karen Gammelgaards Tekstens mening (2003) en glimrende introduktion til Pragerskolens tænkning.
} 
Roman Jakobson opererer i sin sprogbeskrivelse med to akser, selektionsaksen og kombinationsaksen. Selektionsaksen er konstitueret på baggrund af ligheds- og forskelsrelationer, og den er som hos Saussure knyttet til sprogsystemets bagvedliggende struktur. Kombinationsaksen er konstitueret på baggrund af nærhedsprincippet og relaterer til diskursens konkrete brug. Dette forhold bliver ifølge Jakobson vendt om i kraft af sprogets poetiske funktion, der overfører lighedsprincippet fra selektionsaksen til at være det diskurskonstituerende princip på kombinationsaksen. Den poetiske funktion lader altså similarietets- eller ækvivalensprincippet være det styrende princip for diskursens formgivning:

The poetic function projects the principle of equivalence from the axis of selection into the axis of combination. Equivalence is promoted to the constitutive device of the sequence (op.cit. 27).

Selve parallelismebegrebet hos Jakobson er meget bredt og spænder over både morfologiske og syntaktiske gentagelsesstrukturer, men i virkeligheden også over rent semantiske relationer:

The interaction between syntactic, morphologic and lexical equivalences and discrepancies, the diverse kinds of semantic contiguities, similarities, synonymies and antonomies, finally the different types and functions of allegedly 'isolated lines', all such phenomena call for a systematic analysis indispensable for the comprehension and interpretation of the various grammatical contrivances in poetry (op.cit. 90-9I).

Tekstens form og tekstens semantiske betydning ${ }^{13}$ bliver med dette udgangspunkt uadskillelige dele af en helhed, ikke mindst fordi tekstens poetiske betydning i den grad bliver knyttet til sprogets konkrete materiale og formgivning. Derfor kan studiet af tekstens morfosyntaktiske karakteristika ikke siges at udgøre et rent formelt studium af tekstens form, adskilt fra tekstens 'indhold':

Such a crucial linguistic and poetic problem as parallelism can hardly be mastered by a scrutiny automatically restricted to the external form and excluding any discussion of grammatical and lexical meanings (ibid.).

Inden for den plastiske og figurative kunst genfinder vi stadig ifølge Jakobson den poetiske funktions parallelismer i de geometriske principper,

\footnotetext{
${ }^{13}$ Karen Gammelgaard vælger i sin gennemgang af Pragerskolens semiotik at bruge begreberne 'form' og 'betydning' som ækvivalente til Saussures signifiant og signifié, og jeg følger hende heri (Gammelgaard 2003, I 5 ).
} 
idet de udgør en beautiful necessity på linje med grammatikken i sproget:

The obligatory character of the grammatical processes and concepts constrains the poet to reckon with them; either he strives for symmetry and sticks to these simple, repeatable, diaphanous patterns, based on a binary principle, or he may cope with them, when longing for an 'organic chaos' (op.cit. 94).

Forsøger vi at relatere denne beskrivelse af parallelismernes betydning for tekstens poetiske funktion til de tre ovenfor behandlede interpretantaspekter, kan man sige at similaritetens åbne polysemiske betydningspotentiale ville tilhøre den emotionelle interpretant. I læseprocessen udfordres læseren af tekstens parallelistiske mønstre, som med deres repetitive rytme åbner paradigmatiske betydningsrelationer så at sige på tværs af tekstens lineære progression og lader ordmaterialet 'male' en grundstemning frem. Men tekstens parallelistiske strukturer har ikke kun betydning i kraft af deres repetitive konstans, men også i kraft af de brud, som teksten selv måtte etablere på disse mønstre. Hvis et rim eller en rytme er gennemgående hele vejen igennem et digt og pludseligt brydes, så vil dette brud fremstå som en markeret position i teksten. Et sådant brud ville kunne forstås som en energetisk interpretant i tekstens æestetiske strategi. Og endelig udgør den formbevidste læsning af teksten i sin helhed muligheden for at tilskrive forholdet mellem parallelistiske mønstre og markerede brud signifikans eller betydning, hvilket i Peirces terminologi ville være at forstå som logiske interpretanter i den æstetiske strategi.

UMIDDELBAR INTERPRETANT

$\begin{array}{lll}\text { Emotionel interpretant } & \begin{array}{l}\text { Energetisk interpretant } \\ \text { Similaritet }\end{array} & \begin{array}{l}\text { Logisk interpretant } \\ \text { Signifikans }\end{array}\end{array}$

Opstillet på denne måde kan Jakobsons teori om tekstens poetiske funktion beskrives som et modalt spændingsforhold mellem emotionelle, energetiske og logiske interpretanter inden for en peirceansk semiotisk ramme. Parallelismernes polysemiske spil på lighed og brud, knyttet til den konkrete sproglige formgivning, udfordrer læserens logiske mediering af teksten til en semantisk kohærent betydning.

\section{Pablo Nerudas "Digt nummer tyve " ${ }^{14}$}

I det følgende eksempel skal vi studere hvordan en poetisk tekst i kraft af et spil på parallelistiske strukturer kan orkestrere en dialog imellem emo-

\footnotetext{
${ }^{14}$ Dele af denne tekst har været tidligere været offentliggjort i Hansen I999c. 
tionelle, energetiske og logiske interpretanter, hvorved tekstens parallelistiske form og poetiske betydning bliver uadskillelige dele af en helhed. Teksten er »Digt nummer tyve « fra Nerudas (I904-I973) Veinte poemas de amor y una canción desesperada udgivet i I924 (i dansk oversættelse: Tyve kcerlighedsdigte og en fortvivlet sang). Samlingen er Nerudas anden digtsamling, som han publicerede i en alder af blot 20 år, og som øjeblikkeligt gav ham en enorm anerkendelse og popularitet. Samlingen består af en på én gang enkel og universel digtning inden for det, man kunne kalde en postromantisk tradition (Rovira Soler I 99 I, 27; Sicard I 98 I, 54) med et billedsprog ladet med naturens og universets elementer: natten, vinden, himmelrummet, stjernerne osv. Samlingens centralmotiv er om den unge mands første kærlighedserfaringer, både erotiske og sjælelige, og den efterfølgende ensomhedsoplevelse, som sådanne erfaringer efterlader.

I læsningen vil jeg fokusere på en enkelt verslinje for at studere, hvordan tekstens parallelistiske strukturer lader similaritetsprincippet gribe ind over nærhedsprincippet i form af en emotionel interpretant, samt hvordan bruddet på de samme parallelistiske strukturer bliver det betydningsbærende mærke (energetisk interpretant), som tvinger læseren til at skabe en overgibende poetiske betydning, som holder flere betydningslag åbne samtidigt (logisk interpretant). Verset, som jeg vil koncentrere læsningen om, er tekstens niende og lyder således: »Ella me quiso, a veces yo también la quería « (Hun elskede mig, og jeg til tider også hende). ${ }^{15}$

\section{Kærlighed og erindring}

»Digt nummer tyve « er, som hovedparten af samlingens digte, skrevet på alexandrinervers. Den spanske alexandriner er et fjortenstavelsesvers, som typisk falder i to halvvers med cæsur efter den syvende stavelse. Alexandrinerversets langsomme rytme og de mange accentuerede i'er evokerer den unge digters sentimentale stemning under den stjernebesatte chilenske himmel. Men når læseren når til tekstens niende vers, opstår der imidlertid et problem. Følger vi den prosodiske rytme, som alexandrineren foreskriver, bliver betydningen en anden »Ella me quiso, a veces / yo también la quería " (Hun elskede mig til tider, jeg elskede også hende). ${ }^{16}$ Tekstens metriske opbygning fungerer som en parallelistisk struktur der

\footnotetext{
${ }^{15}$ Oversættelserne støtter sig generelt på Gunnar Engberg Hansens gendigtning (Neruda I924/ 84), men i flere tilfælde har jeg følt behov for en mere tekstnær oversættelse med henblik på at kunne betone bestemte analystiske pointer. I disse tilfælde anføres, at oversættelsen er min egen. I dette tilfælde er der tale om en helt korrekt oversættelse af den spanske teksts grammatiske betydning.

${ }^{16}$ Denne iagttagelse skylder jeg en af mine tidligere studerende, Corina Roig, som i en opgave ved Odense Universitet for mere end Io år siden gjorde opmærksom på dette forhold.
} 
ansporer læseren til at respektere en cæsur efter syvende stavelse, hvorved det niende vers semantisk set splittes op i to modsatte betydninger: en grammatisk betydning byggende på tekstens syntaktiske nærhedsprincip og en prosodisk byggende på parallelismernes similaritetsprincip.

Betydningsspillet kompliceres yderligere af versets brug af aspekt i de to datider: præteritum (quiso, afsluttet handling) og imperfektum (quería, uafsluttet eller repetitiv handling). Generelt kan man sige, at den perfektive præteritumsform quiso betoner kærlighedsfølelsen som noget, der i dag er overstået, i modsætning til det imperfektive quería, der mere betoner kærligheden som en generel baggrund i fortiden. Men samtidig er præteritumsformen mere intens og insisterende end imperfektumsformen. Hvis vi forholder denne forskel $i$ intensitet til rækken af varierede gentagelser af det samme vers som man finder i teksten, vil vi se en bevægelse fra den stærkeste intensitet i starten af digtet til en højere grad af distance i digtets slutning. De følgende oversættelser med stærke accentueringer af aspektet er alle mine:

6. Yo la quise, y a veces ella también me quiso (»Jeg elskede hende dengang stærkt og intenst, og til tider elskede hun også mig lige så stærkt, men altså kun til tider «).

9. Ella me quiso, a veces yo también la quería (»Hun elskede mig dengang stærkt og intenst, og jeg elskede til tider også hende, men i dag føles dette måske knap så intenst / Til tider elskede hun mig stærkt og intenst og jeg elskede også hende, men i dag føles dette misforhold måske knap så intenst «).

23. Ya no la quiero, es cierto, pero cuánto la quise (»Nu elsker jeg hende ikke mere, det er vist, men hvor elskede jeg hende dog dengang! «)

27. Ya no la quiero, es cierto, pero tal vez la quiero. (»Nu elsker jeg hende ikke mere, det er vist, men måske elsker jeg hende, underforstået i erindringen «. Denne sidste betydning accentures af det efterfølgende vers: »Hvor er kærligheden kort og hvor er glemslen dog lang«).

Opsamlende kan vi altså konstatere, at de fire parallelismer beskriver en udvikling fra en intens og stærk kærlighedsoplevelse til en svagere erindret beskrivelse af denne kærlighed, som i nedskrivningsøjeblikket har mistet sin glød. Og det niende vers' to betydninger, den grammatiske og den prosodiske, diskuterer karakteren af dette kærlighedsforhold: var det et lige forhold mellem to jævnbyrdige, eller var der tale om at det lyriske jeg var den forsmåede part som ønskede at fastholde forholdet, men hvis bestræbelser var forgæves? 
Den selvreferentielle læsning

Teksten, og samlingen som helhed, er imidlertid andet og mere end blot en teenagers nostalgiske begrædelse af et kærlighedsforhold, som ikke længere er. Teksten rummer samtidig nogle dybere og mere modne refleksioner over poesiens karakter og funktion, hvor poesien, forstået som en intens men flygtig oplevelse, modstilles distancen i den skrevne tekst, og det er min hypotese at bruddet i vers ni anticiperer denne anden læsning som en følelsesmæssig eller førbevidst mekanisme.

I samlingens første halvdel skildres den autentiske kærlighedsoplevelse som værende knyttet til tavsheden og den fysiske kærlighed. Den er intens, flygtig og singulær. I »Digt nummer tretten « formuleres det på den måde, at det lyriske jeg dækker den elskedes krop med kys i stedet for ord, mens det lyriske jeg i »Digt nummer femten « understreger sammenhængen mellem den fysiske kærlighed og stilheden: "parece que un beso te cerrara la boca « (»og det synes som et kys så lukkede din mund «). Der skabes således en tematisk forbindelse mellem elementer som kysset, stilheden, nærheden og sanseligheden, men kærligheden indeholder samtidig et element af fravær fordi den tilhører fortiden: »Me gustas cuando callas porque estás como ausente « (»Din tavshed glæder mig fordi du synes langt borte «). Som det fremgår allerede af »Digt nummer et « er den evokerede kvinde ikke en kvinde af kød og blod, men en mental konstruktion: "Para sobrevivirme te forjé como un arma " (»For at overleve måtte jeg forme dig som et våben «. (Min oversættelse)). Der er altså forskel på nærhed (intimitet) og nærvær (eksistens), ligesom der er forskel på distance (ikke-intimitet) og fravær. Den umiddelbare, nære og intense kærlighedserfaring kan imidlertid kun afspejles delvis i den poetiske oplevelse, således som den er formidlet gennem ordet. Igen i »Digt nummer tretten « formuleres denne erfaring således:

Entre los labios y la voz, algo se va muriendo.

Algo con alas de pájaro, algo de angustia y de olvido.

Así como las redes no retienen el agua.

Muñeca mía, apenas quedan gotas templando.

Sin embargo, algo canta entre estas palabras fugaces.

Algo canta, algo sube hasta mi ávida boca.

(Mellem læber og stemme er der noget der dør Noget med fuglevinger, noget med angst og glemsel Som når fiskernes net ikke kan fange vandet Kun hænger, min skat, få skælvende dråber tilbage Og dog er der noget, der synger blandt disse flygtige ord Noget, der synger og stiger til min begærlige mund. (Min oversættelse)). 
»Ordet «, la palabra, optræder for første gang i samlingen i » Digt nummer fem «, men det kommer ikke til at udgøre en dominerende faktor før i samlingens anden halvdel. Ordet, forstået som poesiens materiale, er først og fremmest det talte eller det sungne ord, som i Nerudas univers har en næsten immateriel og åndelig eller sjælelig kvalitet, der kræver indføling og intuition. Ordet er lige så flygtigt som den fysiske, sanselige oplevelse, men hvor den erotiske kærlighedserfaring er en essentielt singulær begivenhed, består den poetiske oplevelse af en artificiel og dermed repetitiv følelse. Sanseligheden dominerer teksterne i samlingens første halvdel, og ordet dominerer teksterne i samlingens anden halvdel, mens skriften træder først ind på scenen $\mathrm{i}$ »Digt nummer tyve «, som vi beskæftiger os med her. Denne tekst indledes med versene:

Puedo escribir los versos más tristes esta noche.

Escribir, por ejemplo: »La noche está estrellada,

y tiritan, azules, los astros, a lo lejos «.

El viento de la noche gira en el cielo y canta.

(I nat kan jeg skrive de vemodigste vers

Skrive for eksempel: »Natten er stjerneklar

og de blå stjerner skælver i det fjerne."

Nattevinden drejer på himlen og synger. (Min oversættelse)).

Der er flere bemærkelsesværdige forhold i denne begyndelse på digtet. For det første er disse fire vers markeret som en indledning, adskilt fra resten af teksten i kraft af det assonantiske a-a-rim mellem vers to og fire, mens resten af teksten rimer på i-o eller o-i. For det andet er det, som nævnt, første gang i hele samlingen at skriveprocessen nævnes. Det sker fra den første verslinje og med en modal betoning af selve muligheden af at kunne (jf. puedo, »jeg kan«). For det tredje er det værd at bemærke den måde, hvorpå det lyriske jeg anvender vendingen por ejemplo (»for eksempel «), hvorved der antydes en høj grad af distance til det skrevne. Han kunne vælge at skrive disse vers eller nogle helt andre, og dog vælger han at skrive de smukkeste vers om et af samlingens centrale ledemotiver: natten. Natten, som alene i dette digt nævnes ti gange, kan forstås som en parallel til den fraværende andenperson, ganske vist ikke den konkrete kvinde som han elskede med i skumringstimen i samlingens første halvdel, men et poetiseret eller evokeret billede på denne kvindes fravær. I »Digt nummer femten « hedder det bl.a.: 
Eres como la noche, callada y constellada

Tu silencio es de estrella, tan lejano y sencillo

(Du er som natten med dens tavshed og stjerner

Din tavshed er som stjernen, så fjern og enkel. (Min oversættelse)).

Det lyriske jeg giver udtryk for at have opnået den distance til sit emne, som gør ham i stand til at skrive. Om det er kvinden, der er metafor for natten, eller omvendt, er svært at afgøre, og måske er det også ligegyldigt, da digtet som helhed kan læses som en metafor for poesiens medierende funktion mellem livserfaring og tekst. Nedskrivningen er poesiens slutpunkt, og derfor finder vi "Digt nummer tyve " placeret hvor vi gør, nemlig som det sidste af samlingens tyve digte og lige inden den afsluttende sang. Skriveprocessen indebærer at det lyriske jeg lægger afstand til den smertelige erindring om den tabte sanselighed og til universets elementer, dvs. til natten, himlen og den universelle stilhed. I groft forkortet udgave kan de tre centrale kategorier, den sansede erfaring, den evokerede poesi og den materielle skrift, opstilles i skematisk form:

\begin{tabular}{|l|l|l|l|l|l|l|}
\hline & Objekt & Udtryk & Attitude & Væren & Oplevelse & Modus \\
\hline $\begin{array}{l}\text { Sanset } \\
\text { erfaring }\end{array}$ & kys & stilhed & nærhed & fravær & $\begin{array}{l}\text { fysisk } \\
\text { sansning }\end{array}$ & $\begin{array}{l}\text { singulær og } \\
\text { flygtig }\end{array}$ \\
\hline $\begin{array}{l}\text { Evokeret } \\
\text { poesi }\end{array}$ & ord & poesi & $\begin{array}{l}\text { algo queda } \\
\text { (noget er } \\
\text { tilbage) }\end{array}$ & $\begin{array}{l}\text { evoka } \\
\text { tion }\end{array}$ & $\begin{array}{l}\text { sjælelig } \\
\text { følelse }\end{array}$ & $\begin{array}{l}\text { repetitiv og } \\
\text { flygtig }\end{array}$ \\
\hline $\begin{array}{l}\text { Materiel } \\
\text { skrift }\end{array}$ & digt & skrift & distance & $\begin{array}{l}\text { nær- } \\
\text { vær }\end{array}$ & forståelse & $\begin{array}{l}\text { repetitiv og } \\
\text { varig }\end{array}$ \\
\hline
\end{tabular}

Verset er det lyriske jegs balsambøsse, eller som det udtrykkes i vers fjorten: »Y el verso cae al alma como al pasto el rocío « (»Og verset falder på sjælen som duggen på engen «). Poesien opstår som en kvalitet mellem stilheden og skriften, der medierer mellem nærheden og distancen, mellem sansning og tekst, og denne kontekst giver vores detalje fornyet betydning. Lad os rekapitulere verset i dets to betydninger: »Ella me quiso, a veces yo también la quería « (»Hun elskede mig og jeg til tider også hende / Hun elskede mig til tider - jeg elskede også hende «). De to betydninger, som henholdsvis omvender og bekræfter forholdet mellem de to elskende, vil imidlertid kunne artikuleres samtidigt i kraft af en recitation som behersker cæsuren. I stedet for en modsætning mellem to forskellige betydninger opstår en modsætning mellem skriftens entydige, grammatiske betydning, determineret af kommaet, og den polysemiske eller poetiske betydning, der kunne opstå som en logisk-poetisk interpretant i selve recitationsakten, en kortvarig oplevelse som ville være lige så svigefuld og

\section{Litterær erfaring og dialogisme, E-bog 2006


flygtig som den forgangne kærlighed. Udlagt på denne måde ville alle samlingens flygtige elementer kunne læses som metaforer for den logiske interpretants momentane og skrøbelige mediering mellem emotionelle og energetiske interpretanter: stranden mellem hav og land, skumringen mellem dag og nat, vinden, fuglenes flugt, den fysiske kærlighedsakt samt forholdet mellem de to personer. Den poetiske kvalitet opstår i et intenst, men flygtigt øjeblik og har i det næste ladt sin tilhører tilbage som den forsmåede elsker, der må tage til takke med den skrevne teksts æstetiske fraværserfaringer. Poesien bliver, i det mindste efter "Digt nummer ni «, samlingens reelle omdrejningspunkt (Sicard I98I, 59). Eller som det er udtrykt af Carlos Santander:

Digtet bliver således den virkelige kærligheds rum, absolut, utilfredsstillende, ustabilt, men udtryk for den højeste kreative fylde. Den elskede er grundlæggende set forbindelsesled og forankringspunkt, omfavnelse og indramning, men hun udgør også selve sangens mulighed (Santander I97I, IO2. Min oversættelse). ${ }^{17}$

\section{Sangens semiotik}

Man kunne nu hævde at de analytiske procedurer, som er bragt i anvendelse, ikke adskiller sig afgørende fra strukturalismens standardprocedurer: Lidt tematisk analyse tilsættes symbolanalyse og en udsigelsesanalyse med selvreferentiel pointe. Og dog vil jeg mene at min læsning overskrider dette beskrivelsesinventar, først og fremmest fordi den rejser spørgsmålet om læserens æstetiske oplevelse af teksten som et semiotisk problem. Beskæftigelsen med forhold som modtagerens oplevelse af rytmisk puls i recitationen eller den urimelige flygtighed, hvormed vor rationelt trænede hjerner er i stand til at percipere poetisk kompleksitet og polysemi, er forhold som forudsætter en læserorienteret, pragmatisk og fænomenologisk baseret semiotik. Lad os blot erindre, hvordan Peirce selv skildrer førsteheden, dvs. den rene kvalitative mulighed, som udgør en forudsætning for såvel andethedens barske realitet som for tredjehedens logiske refleksion:

It cannot be articulately thought: assert it and it has already lost its characteristic innocence; [...] Only, remember that any description of it must be false to it (CP I.357, for hele citatet se s. 20).

Denne beskrivelse af forholdet mellem førsteheden som spontan erfaring

\footnotetext{
${ }^{17}$ Teksten lyder således på spansk: »El poema viene a ser así espacio del amor real, absoluto, insatisfactorio, precario, pero de la máxima plenitud creadora. La amada, esencialmente, es la atadura y el anclaje, el abrazo y el cerco, pero también, la posibilidad del canto«.
} 
og den umulige, sproglige artikulering af den, kunne udlægges som en særdeles præcis beskrivelse af forholdet mellem kærlighed og poesi hos Neruda, jf. billedet med fiskenettet, som ikke kan holde havets vand tilbage: »Kun hænger, min skat, få skælvende dråber tilbage «. Forskellige forskere, som har set denne relation mellem Peirces førstehed og en ideal litterær poeticitet i digtningen, har givet teorien forskellige applikationer. Således forsvarer Jørgen Dines Johansen at litteraturen er karakteriseret ved at være en ikonicitetsform, altså en semantisk førstehed i Peirces forstand (Johansen I996), mens John K. Sheriff mener at litterariteten skal forstås som et rhematisk træk ved det litterære tegn, altså en art pragmatisk førstehed (Sheriff I989). Endelig har jeg selv peget på at opstillingen af førsteheden som et uopnåeligt poetisk ideal, sådan som vi finder det hos bl.a. Pablo Neruda, er et fænomen som ligger til grund for både symbolisterne og den tidlige avantgarde (Hansen I997b). I min udlægning er der tale om at en række selvreferentielle, puristiske strømninger i starten af det 20. århundrede udpegede en almen fænomenologisk modalitet, den åbne mulighed, til at være selve kunstens essens, netop fordi denne modalitet bliver særlig synlig i den æstetiske kontemplation.

Pablo Neruda udtrykker i disse Tyve koerlighedsdigte på den ene side nødvendigheden af at skelne mellem kærligheden som en flygtig, førsproglig følelse og den poetiske erfaring formidlet af det levende ord. Og på den anden side understreger han forholdet mellem det levende ords kropslige rytme og skriftens materielle aftryk. Når det lyriske jeg samtidig i »Digt nummer 20 " understreger at han nu kan skrive de vemodigste vers, uden at de anfægter ham, så skabes den fortolkningsmæssig baggrund, hvorpå dialogen mellem det niende vers' syntaktiske entydighed og parallelistisk baserede polysemi udmøntes i en flygtig poetisk oplevelse, der i semiotisk forstand kan defineres som den logiske interpretants mediering af de emotionelle og de energetiske interpretanter. Helt centralt for denne analyse står naturligvis, at denne dialog kun opstår i den konkrete, æstetiske læse- eller lytteerfaring. Med Nerudas egen metafor kan vi sige, at forskellen på versets to betydninger er som forskellen mellem fiskenet og vand: I skriften hænger kun få skælvende dråber tilbage af selve den poetiske erfaring.

\section{Det semantiske niveau: Paul Ricœur og Paul Henle: metaforen}

Som nævnt i Kapitel I kan man med udgangspunkt i Peirces opdeling af semiotikkens discipliner definere semantikken som studiet af forholdet mellem tegnet og dets objekt (se s. I9). I det følgende vil jeg se på Paul Ricœurs og Paul Henles teorier om den poetiske metafors semantik. De to teorikomplekser vil blive kort introduceret, hvorefter de relateres til 
den overordnede beskrivelse af den æstetiske oplevelse som et samspil mellem modale relationer med Peirces begreber om den emotionelle, den energetiske og den logiske interpretant.

I løbet af det tyvende århundrede har en række forskellige litteraturteoretiske tilgange fokuseret på det poetiske udtryk som essensen af sprogets poetiske funktion, heriblandt ikke mindst forskellige strukturalistiske teorier under indflydelse af Roman Jakobson. Og inden for poesien er det nok metaforen, som har påkaldt sig den største opmærksomhed som den centrale æstetiske figur overhovedet. Det ville derfor forekomme mærkværdigt at skulle behandle det æstetiske princip i litterære tekster uden at komme ind på beskrivelsen af metaforen. Til dette formål har jeg blandt de mange forskellige teorier om metaforen valgt at se på Paul Ricœurs behandling af emnet i hans The Rule of Metaphor (1977), fordi han her anvender en fænomenologisk og hermeneutisk tilgang, der efter min mening lægger vægt på nogle af de samme aspekter af den æstetiske oplevelse, som en peirceansk semiotisk beskrivelse ville vægte.

Paul Ricœur foretager en veritabel tour de force igennem det tyvende århundredes metaforteorier, hvorfra han selektivt henter en række indsigter, som han sammensætter til sin egen beskrivelse af fænomenet. Det ville være for omfattende på dette sted at skulle komme ind på alle de teoridannelser som Ricœur lægger til grund for sin behandling, hvorfor jeg vil nøjes med at resumere nogle generelle træk i Ricœurs egne konklusioner, dog med særlig vægt på Paul Henles bidrag. Henle refererer selv eksplicit til Peirce, hvilket Ricœur kun gør i mindre omfang og mere kritisk.

Ricœurs fremstilling bygger på den såkaldte interaktionsteori, der forstår metaforens betydning som en interaktion mellem et focus og en frame, mellem ordet og den omgivende kontekst. Her trækker han på f.eks. I.A. Richards, Max Black og Monroe Beardsley. Ricœurs beskrivelse af metaforens betydningsdannelse i The Rule of Metaphor er binært formuleret, dvs. at han hele tiden beskriver metaforens semantiske ladning som en spænding mellem det 'bogstavelige' og det 'figurative', mellem det lukkede og det åbne, mellem kode og polysemi. Med Beardsleys begreber kan man opsummere dette spændingsforhold som en relation mellem to principper: 'kohærensprincippet' og 'plenitetsprincippet'. Men samtidig fastholder Ricœur i sin egen behandling af disse principper hele tiden en tredje position, idet han insisterer på læsningen som den fortolkning, der er i stand til at producere den poetiske betydning som en fusion af de to principper.

De to principper modvirker således ikke (i det mindste ikke kun) hinanden, men kan (også) samvirke eller komplementere hinanden (Ricœur 
I977, 96). Den ikke-reduktive læsning forstår Ricœur således som et samspil af to diskurser:

Interpretation is then a mode of discourse that functions at the intersection of two domains, metaphorical and speculative. It is a composite discourse, therefore, and as such cannot but feel the opposite pull of two, rival demands. On one side, interpretation seeks the clarity of the concept; on the other, it hopes to preserve the dynamism of meaning that the concept holds and pins down (Ricœur 1977, 303).

Det er i dette samspil af imaginær åbning og rationel lukning, at Ricœur tager sit udgangspunkt når han definerer sit begreb, den 'levende metafor':

Metaphor is living not only to the extent that it vivifies a constituted language. Metaphor is living by virtue of the fact, that it introduces the spark of imagination into 'thinking more' at the conceptual level (ibid.).

Fra Jean Cohen (Structure du langage poétique, Paris 1966) henter Ricœur begrebet 'pertinens' (Ricœur I977, I 5 I), der betegner den sammenhæng eller meningsfuldhed, som er krævet på sætningsplanet, for at en ytring opleves som meningsfuld. Således fungerer den semantiske impertinens også som et retorisk signal i den forstand, at når ordenes 'bogstavelige' betydning ikke giver mening på sætningsplan, så må læseren søge efter en anden og mere figurativ betydning. Svarende til bestemmelsen af de semantiske troper som figurer, der producerer deviation af den semantiske pertinens, kan fortolkningen forstås som en proces der søger reduction of deviation. I fortolkningsprocessen søger læseren med andre ord det begreb, som kan genetablere udsagnets sammenhængende eller kohærente mening. Men dermed har vi også sagt, at semantisk pertinens indebærer en betydningsmæssig reduktion af ordenes mulige betydninger: »words have actual meanings only in a sentence [...] lexical entities words in the dictionaries - have only potential meanings « (Ricœur I974, 99).

Forsøger vi at relatere denne beskrivelse af den poetiske metafors æstetiske funktion til de tre ovenfor behandlede interpretantaspekter, kan man sige at plenitetsprincippets åbne, polysemiske betydningspotentiale ville tilhøre den emotionelle interpretant, og tropernes retoriske afvigelse fra den normalsproglige norm ville udløse en energetisk interpretant $\mathrm{i}$ form af en undren, efterfulgt af en selektion i dette betydningspotentiale i form af en figurativ læsning. Den figurative læsning reetablerer den semantiske pertinens i kraft af kohærensprincippet, der svarer til det, Peirce ville kalde produktionen af en logisk interpretant. 
UMIDDELBAR INTERPRETANT

$\begin{array}{lll}\text { Emotionel interpretant } & \text { Energetisk interpretant } & \text { Logisk interpretant } \\ \text { Mulig betydning } & \text { Afvigelse } & \text { Semantisk pertinens }\end{array}$

Ricœurs udlægning af metaforens æstetiske funktion kan på denne baggrund beskrives som et modalt spændingsforhold mellem emotionelle, energetiske og logiske interpretanter, hvor udtrykkets polysemiske betydningspotentiale, bundet til den konkrete sproglige formgivning, yder modstand mod den logiske reduktion af teksten til en entydig semantisk kohærent betydning.

Paul Ricœur inddrager Peirces ikonbegreb i sin definition af metaforen, og heri er han inspireret af Paul Henle (Henle I958/72). Henle bygger i udgangspunktet på Peirces begreb om metaforen som et ikonisk tegn $\mathrm{i}$ modsætning til de ikke-metaforiske sproglige udtryk, der betragtes som konventionelle symboler. I udgangspunktet behandler Henle alle former for semantisk omstilling fra 'bogstavelig' til 'figurativ' betydning. Den bogstavelige betydning er for Henle umiddelbar, mens den figurative betydning af Henle betegnes som værende 'middelbar'. Ikonbegrebet bliver derefter introduceret for at karakterisere metaforen over for de andre troper, dvs. for at uddybe metaforens analoge karakter: » the essential role of the icon is to contain an internal duality that at the same time is overcome " (Ricœur I977, I89). Henle pointerer dog, at der ikke er tale om en billeddannelse, men om en rent sproglig funktion i den forstand, at vi ledes af den figurative diskurs til at tænke på noget gennem en betragtning af noget andet, som minder om det: » The icon is not presented, but is merely described « (ibid). Det hele foregår inden for sproget, som jo i Peirces terminologi er symbolsk. Henle analyserer metaforen ud fra to modaliteter i det semantiske forhold:

I. Først fungerer udtrykket 'bogstaveligt' (dvs. vanebaseret inden for den symbolske modalitet, hvor tegnet refererer til et objekt eller en situation).

2. Dernæst fungerer udtrykket ikonisk ved at udpege en anden, lignende situation.

Netop fordi den metaforiske repræsentation ikke er et billede, kan den trække på en række originale ligheder vedrørende kvalitet, struktur, lokalitet, situation eller følelse (ibid.). Derigennem har den ikoniske repræsentation evnen til at udbygge den parallelle, betydningsproducerende struktur. Det er heri at metaforen i Henles teori adskiller sig fra de andre 
troper, og det er på et andet niveau herved, at Henles metaforbegreb får en prædikativ karakter. Metaforen tilføjer intet nyt til beskrivelsen af verden, men alene til den måde verden opleves på (op.cit. 190).

Enheden i Henles metaforbegreb er syntagmet, forstået på den måde at produktionen af den metaforiske betydning forudsætter et helt udsagn hvor nogle ord skal forstås bogstaveligt og andre figurativt. Et enkelt isoleret ord kan aldrig være en metafor. Dermed definerer han metaforen som stående mellem på den ene side 'simile', hvor alle termer fastholder den bogstavelige betydning, og på den anden side 'allegorien', hvor alle termer skal forstås i spændet mellem to lige gyldige fortolkninger (ibid.).

In a metaphor some terms symbolize the icon and others symbolize what is iconized [...] some terms refer literally to one situation and figuratively to the second, while other terms refer literally only and refer to the second situation only (Henle I972, I8I).

Henles metaforbegreb indarbejder endvidere den logiske absurditet (jf. Monroe Beardsley) i den ikoniske teori i den forstand, at det er dét, som han kalder the semantic clash på niveauet for den bogstavelige mening, som tvinger læseren til at søge efter en figurativ betydning. Henle indoptager ikke bruddet som en del af metaforen: »However, metaphor is not quite the clash itself, but rather its resolution " (Ricœur I977, I90). Men søgningen efter den figurative betydning indebærer samtidig at læseren træffer et valg eller fælder en 'dom' over, hvilken af situationerne som er ikke-figurativ:

Where the clash of literal senses is felt, however, the problem is to discover which terms cannot be taken in a literal sense and what figurative sense may be attributed to them (Henle 1972, I83).

Hos Henle er fortolkningen beskrevet som en kreativ proces, hvor læseren på baggrund af en række kontekstuelle spor må slutte sig frem til, hvilken term som kan forstås bogstaveligt, og hvilken som må forstås figurativt. Læseren må udvikle den parallelitet, som bliver styrende for den ikoniske betydningstilskrivning. Hos Henle har vi således at gøre med en vekselvirkning mellem en ikonisk og en symbolsk modalitet i teksten, der støder sammen i læsningen som en begivenhed og tvinger læseren til en stillingtagen. The clash vil være at forstå som det energetiske aspekt af den umiddelbare interpretant i den forstand, at det er the clash der, som en hændelse i læseprocessen, udpeger ikonet og tvinger en anden læsemåde igennem hos læseren. The clash i sig selv aktualiseres naturligvis først som led i læsningen, dvs. på niveauet for den dynamiske interpretant, men det 
kan siges at være strategisk tilrettelagt $\mathrm{i}$ teksten som et led i dennes poetiske strategi, hvorfor det kan beskrives som et potentiale på niveauet for den umiddelbare interpretant.

Henles brug af Peirces ikonbegreb vil kunne forstås som en betegnelse for interpretantens emotionelle aspekt, idet valget af tekstens konkrete ordmateriale og 'tonalitet' er medvirkende til at selektere blandt de mulige associative lighedspunkter som kan skabes mellem de to situationer. Endelig vil symbolet være at forstå som den logiske interpretant, idet det er her, teksten tilskrives enhed og semantisk mening. Metaforen som sådan vil imidlertid nødvendigvis være at forstå som helheden af de tre niveauer, der fastholder den ikoniske åbenhed som en polysemi inden for rammerne af den symbolske diskurs.

Hvis man skulle forsøge at sammentænke indsigterne fra Ricœur og Henle kunne man sige at de begge behandler den poetiske metafor som en af de måder, hvorpå en tekst kan 'tvinge' sine læsere til at anlægge et æstetisk blik på teksten, og at de begge forsøger at skildre hvordan det æstetiske moment består $\mathrm{i}$ at fokusere på tegnets materiale og form, som derved 'fortykkes' og blokerer for læserens betydningsmæssige lukning af teksten. Således indebærer synliggørelsen af det sproglige materiales ikoniske åbenhed, at tekstens polysemiske potentialer ikke kan reduceres i den logiske interpretants konceptuelle mediering.

UMIDDELBAR INTERPRETANT

Emotionel interpretant

Ikonisk åbenhed
Energetisk interpretant

Semantisk clash
Logisk interpretant

Symbolsk polysemi

For Ricœur er det desuden afgørende at metaforen ikke alene henter sin betydningsmangfold ud fra tekstens kontekst, men at tekstens semantiske åbenhed tvinger læseren til selv at investere betydning, at tilskrive mening, hvorved den hermeneutiske fortolkning uundgåeligt kommer ind i billedet:

The difference between trivial metaphor and poetic metaphor is not that the one can be paraphrased and the other not, but that the paraphrase of the latter is without end. It is endless precisely because is can always spring back to life (Ricœur I977, I88).

Metaforen opnår herved en erkendelsesskabende eller kognitiv funktion, der går langt ud over de fleste andre behandlingers syn på metaforen som en rent stilistisk trope, hvis funktion hovedsageligt tjener til overfladisk udsmykning. 


\section{Rafael Albertis »Togstation Syd ${ }^{18}$}

Dette afsnit tager udgangspunkt i læsningen af halvanden verslinie fra digtet »Estación del sur «(» Togstation Syd «) skrevet af den spanske digter Rafael Alberti i 1926 og udgivet i digtsamlingen Cal y canto fra I929. ${ }^{19}$ Versene lyder således: "De versos llena, / pasa la mar sus hojas de bajeles « (»Rigt på vers / vender havet sine bådes blade«). Den metafor, som først falder i øjnene i disse vers, er »bådenes blade «, eller "sus hojas de bajeles «. Metaforen bygger på en kvalitativ lighed i form og farve mellem bådenes hvide sejl og de hvide papirblade i en bog, og metaforen understøttes af den rent lydlige parallelisme mellem udtrykkene "hojas de bajeles " og » hojas de papeles «, som betyder papirblade. I kraft af denne metafor ser læseren sejlbådenes hvide sejl, der, idet de glider over havets overflade, vender som siderne i en bog, fulde af poesi. Med denne metafor kaster teksten opmærksomheden hen på et selvreferentielt niveau i læsningen, der gør det oplagt at udvide metaforens fortolkningsramme og inddrage forfatterskabets og periodens øvrige poetiske diskurser. Rafael Alberti skrev mellem I924 og I926 tre digtsamlinger inden for en såkaldt 'neopopulær' poetik, hvor en serie canciones, udfolder et poetisk univers, hvis overgribende metaforiske skema kan beskrives med den nærmest historieløse mastertrope »poesien er en rejse«. Canciones-formen udgøres af korte, melodiske folkesange med hyppige gentagelser og strukturerende omkvæd.

Albertis første digtsamling Marinero en tierra (Sømand på land) var i I926, da Rafael Alberti nedskrev det her behandlede digt, stadig forfatterskabets vigtigste udgivelse, og i denne bog tildeles havet rollen som ledemotiv og som poesiens element par excellence. Det generelle billedske$\mathrm{ma}^{20}$ " poesien er en rejse " gives i Marinero en tierra en særlig udformning, som kan udmøntes i billedet "poesien er en undersøisk rejse". Sømanden på land, det lyriske jegs alter ego, drømmer sig nostalgisk tilbage til Albertis barndom ved Cádizbugten, og i denne poetiske drømmediskurs sejler han ud på havet i sin lille båd for at blive forenet med sin udkårne, sirenen på havets bund. I min ph.d.-afhandling (Hansen I996)

\footnotetext{
${ }^{18}$ Dele af dette afsnit har tidligere været offentliggjort i Hansen I997c.

${ }^{19}$ Rafael Alberti (Puerto de Santa María, Cádiz, I902-I999) var den sidste overlevende digter fra den såkaldte 27-generation i spansk litteratur. 27-generationen omfattede poeter som Federico García Lorca og nobelprisvinderen fra 1977, Vicente Aleixandre. Rafael Albertis forfatterskab i 20 'erne bevægede sig fra den tidlige puristiske essentialisme over en neobarok inspiration fra guldalderdigteren don Luis de Góngora til surrealismen i hans hovedværk Sobre los ángeles (Om englene) fra 1929. Sobre los ángeles er oversat til dansk af Per Sibast, Husets Forlag (I988). Cal y canto er imidlertid ikke oversat, og alle oversættelser er derfor mine egne. ${ }^{20}$ George Lakoff og Mark Johnson har i deres kognitive semantik introduceret teorien om de overgribende metaforiske billedskemaer der strukturerer sproget (Lakoff \& Johnson I989).
} 
har jeg udfoldet en allegorisk læsning af en række af de diagrammatiske relationer, som dette univers' elementer indgår i. Idet tuborgparentesen betegner selve diagrammets analogiske transskription, kan denne læsning udlægges som følger:

$\{$ hav : land :: poesi : prosaisk verden\}

\{sømand : hav :: lyrisk jeg : poetisk univers\}

\{båd : hav :: sprog : poesi $\}$

\{drøm : sømand :: inspiration : digter\}

\{sømand : sirene :: digter : muse\}

\{sirene : hav :: essens : poesi\}

Havets relation til landjorden ligner pr. analogi poesiens forhold til den prosaiske verden: Det er en verden for sig, som følger egne lovmæssigheder og principper. Sømanden på land står i et forhold til havet som element, der pr. analogi ligner det forhold, som digteren har til det poetiske univers: det er et forhold styret af trangen til at trænge ind $\mathrm{i}$ og lade sig integrere i dette univers. Båden står i en relation til havet, som pr. analogi ligner det forhold sproget har til poesien: det er det vehikel, med hvilket universet udforskes. Drømmen er for sømanden på land, hvad inspirationen er for digteren: Det er den faktor, som får ham til at se. Sømandens forhold til sirenen ligner digterens forhold til sin muse: Det er den skjulte, feminine kraft, som driver hans projekt. Og endelig er sirenens relation til havet analog til den rolle, som den poetiske essens spiller i forhold til den poetiske diskurs i Albertis tidlige, essentialistiske digtning: Det er den efterstræbte, nøgne sandhed som skjuler sig på bunden. Den store afstand imellem havisotopien og den selvreferentielle, poetiske isotopi betyder, at havuniverset får en stor selvstændighed, og den emotionelle interpretants åbenhed og polysemi får stor vægt. Men samtidig sikrer tilstedeværelsen af et overgribende billedskema, der organiserer teksten i en serie af parallelle diagrammer, at læseren bliver i stand til at reducere det semantiske clash mellem de for hinanden fremmede isotopier i en overgribende logisk interpretant.

I Albertis tredje digtsamling, Cal y canto, hvorfra det her læste citat er hentet, udsættes det maritime univers for en destruktiv omvending, hvorefter det overordnede billedskema " poesien er en rejse " appliceres avantgardistisk på den moderne verdens univers, som variationer over skemaet "poesien er den moderne massekulturs adspredelser «. Det poetiske univers skifter karakter, elementer fra den moderne storby gennemtrænger universet, og den nostalgiske tone erstattes med en ironisk distance, som svinger mellem en let munterhed som i »Estación del sur « og en bitter 
sarkasme i andre dele af samlingen. »Estación del sur « er imidlertid et af Cal y cantos allertidligste digte i kronologisk forstand, hvorfor angrebet på den neopopulære poetik og transformationen af den maritime motivkreds her kan ses i en meget tidlig fase. I »Estación del sur « er der ikke længere tale om at se båden som den nostalgiske sømands naturlige vehikel (den ene og eneste båd), men om en serie af forskellige både, der byder sig til som et optrin for læseren, ligesom de forskellige poetiske diskurser (den symbolistiske, den avantgardistiske, den klassiske, den neogongoristiske ${ }^{21}$ etc.) bød sig til for periodens digtere. Bådene i »Estación del sur " fastholder således deres allegoriske betydning, mens bådens eller den poetiske diskurs' rolle i forhold til resten af universet skifter.

Vi har således at gøre med to forskellige billeddannelser, svarende til hhv. Peirces billede (image) og diagram, men som her optræder indlejret i hinanden i det analyserede vers:

I. »hojas de bajeles « refererer til digtsamlingens hvide sider i kraft af en kvalitativ lighed i form og farve.

2. »bajeles «, bådene, refererer til periodens forskellige poetiske diskurser i kraft af et diagram funderet på analogi: \{både : hav :: sprog : poesi\}.

Vender vi tilbage til verset i sin helhed, vil vi imidlertid se, at der er nok et billede, eller 'hypoikon' i Peirces terminologi, på færde: »Rigt på vers / vender havet sine bådes blade «. Havet dynamiseres og antropomorfiseres, idet det er i stand til at vende sejlene/bladene, og samtidig udgør havet det element, som i sig rummer poesien. Havet er et urgammelt, traditionelt symbol - denne gang ikke i en Peirce'sk forstand, men i en traditionel litterær forstand (se eksempelvis Eco I984, I 56 ff.). Dette traditionelle betydningspotentiale beriger havet som poetisk element, idet det indsættes i tekstens og forfatterskabets umiddelbare kontekst. Herved reaktiveres havet som en levende metafor, der er i stand til at generere nye betydninger ud fra en dialog med tekstens øvrige metaforik.

I Albertis tidlige, neopopulære diskurs etableres en kvalitativ lighedsrelation mellem havet og poesien, som røber tilstedeværelsen af et Peirce'sk image. Havet beskrives som poesiens ideelle locus i kraft af en række

\footnotetext{
${ }^{21}$ Luís de Góngora y Argote (I56I-I627) var en af den spanske baroks mest bemærkelsesværdige digtere. Hans elaborerede kunstsprog delte samtiden i modstandere og tilhængere, men fra og med I700-tallet blev han betragtet som 'dunkel' og uforståelig. Han blev vakt til live igen af Mallarmé og symbolisterne i slutningen af det I9. århundrede, og i forbindelse med hans 300 års dødsdag i 1927 dyrkede en gruppe unge digtere med bl.a. Federico García Lorca og Rafael Alberti i spidsen en særlig form for 'neogongorisme', der kombinerede avantgardistiske formeksperimenter med barok tradition i Góngoras aftapning. Året 1927 kom til at lægge navn til hele generationen.
} 
kvalitative ligheder såsom skønhed, dybde, det ukendte og dragende osv. Men samtidig indlejres havet som en diagrammatisk metafor, idet der etableres en analogi mellem på den ene side havets overflade og havets dyb, og på den anden side poesiens formsprog og dens betydning. De to sider af den ikoniske betydning er sammenkædet på den måde, at havets skønhed er en visuel skønhed, der beror på at havbunden, set gennem det klare vand, fortegnes af havoverfladens bevægelser, hvilket gør den til en ukendt og dragende verden, samtidig med at poesiens skønhed er en semiotisk eller sprogligt formidlet skønhed, der beror på, at det poetiske sprog med sin ikoniske intention prætenderer at ophæve det arbitrære forhold mellem sprogets form og betydning. Det er med andre ord de to sider i diagrammets analogi (havets fysiske vandighed i relationen mellem overflade og havbund og tegnets betydningsrelation i forholdet mellem formsprog og betydning), som begrunder den relative forskel mellem elementerne i billedes kvalitative lighed.

Det kvalitative spring, der udløser den metaforiske læsning, er det, Haley kalder den indeksikale semantiske spænding i metaforens brud på konventionelle, eksistentielle eller konceptuelle grænser i sproget (Haley I988, Kapitel V og VI). I det analyserede eksempel involverer udtrykket »hojas de bajeles « et lettere brud med en konventionel semantisk grænse (skibe har normalt ingen blade), som igangsætter de ikoniske analogier for såvel »skibe « som for »blades « vedkommende, samtidig med at besjælingen af havet, " havet vender... osv. «, tilsvarende indebærer, at der brydes med det, som Haley kalder en eksistentiel grænse (havet er ubesjælet og kan ikke handle), hvorved havet metaforiseres. Det, som sætter selve den metaforiske proces i gang, er det, i Henles terminologi, semantiske clash imellem metaforens to betydningsområder, som i fremstillingen ovenfor er skildret som en energetisk interpretant.

Udtrykket "hojas" (blade), forstået som sider i en bog, er selv oprindeligt en metafor (blade sidder på træerne), men når »hojas «, forstået som papirblade, i den umiddelbare læsning af verset fungerer som en symbolsk eller vanebaseret betydning, er det fordi udtrykket gennem brug og over tid er blevet kodet som en symbolsk vane på linje med sprogets øvrige symboler i en Peirce'sk forstand. Denne i sig selv banale erkendelse antyder vigtigheden af at opretholde en klar skelnen mellem metaforen som et dynamisk og betydningsgenererende ikon og metaforen som vanebaseret skematik, dvs. som et Peirce'sk symbol (Factor I996, 229-35). På trods af deres metaforiske oprindelse er sådanne udtryk gennem deres udbredelse blevet lige så vanemæssigt kodet som alle andre sproglige udtryk. Den 'ægte' eller poetiske metafor er heroverfor ikke kodet, men indeholder en frisk og betydningsgenererende ikonicitet, netop fordi den 
i sig rummer den dialogiske interaktion mellem den emotionelle interpretants åbenhed, det semantiske clash der kommer til syne som en energetisk interpretant og endelig den logiske interpretants mediering af relationen imellem de to. Så snart metaforen bliver 'slidt', og der bliver tale om produktionen af en 'sidste' eller vanebaseret logisk interpretant, brydes den ikoniske åbenhed, og ordet opleves som henhørende til et andet semiotisk register.

Havbunden blev i Rafael Albertis tidlige, neopopulære poesi beskrevet som en skøn, dyb, ukendt og uopnåelig verden i stadig forandring, som beskueren drages imod, når den betragtes fra overfladen, og tilsvarende gør det poetiske formsprogs ubestemtheder og ureducerbarhed poesien selv til en dragende labyrint af skønhed, dybde, ukendthed etc. I Cal y canto, hvor »Estación del sur « er optrykt, er havbunden og dybet derimod udgrænsede størrelser, mens sirenerne sejler kapsejlads på havets glitrende overflade. Dette kan læses som en allegorisk og selvreferentiel beskrivelse af poetikkens udvikling i Spanien i slutningen af tyverne, hvor de neogongoristiske formeksperimenter blev gjort til selve poesiens formål, samtidig med at den poetiske diskurs blev tømt for indhold, forstået som introspektion eller transcendens. De to ikonicitetsformers dialogiske interaktion i det metaforiske udtryk giver således dette en særlig dynamik, der gør det i stand til at generere stadig nye betydninger i relation til sit objekt. Den vellykkede metafor er med andre ord ikke blot en retorisk leg med dekorativt sigte, men fastholder hele tiden en referentiel dimension i forhold til sit objekt. Og det er denne kognitive funktion, hvor metaforen udtrykker en erkendelse, der ikke kan udtrykkes på anden måde, som Ricœur kalder for 'metaforisk sandhed'. I Albertis vers er det havmetaforens forfatterskabsbundne reference til en æstetisk kontekst, der på den ene side ligger som en realitet uden for teksten, og på den anden inkluderer teksten selv og gør den selvreferentiel, der giver nyt liv til en række i princippet slidte eller banale metaforer: f.eks. poesien forstået som en rejse, havet set som poesi eller sejlene på havet set som hvide sider i en bog. I det øjeblik vi læser teksten i dialog med forfatterskabets og samtidens øvrige litteratur- og kunstproduktion, får billedet ny betydning som en beskrivelse af den intranscendente overfladeæstetik, som José Ortega y Gasset karakteriserede som 20'ernes 'afhumaniserede' kunst (Ortega y Gasset I925).

Den overfladeæstetik, som de citerede vers selvreferentielt skildrer i form af forskellige både eller poetiske diskurser på havets overflade, afspejler ganske præcist udtryksformens dominans i 27-generationens gongoristiske formeksperimenter. Hos Alberti er der tale om en glad og formbevidst poetik, der udgrænser mørket og dybet, det uigennemtrænge- 
lige og det transcendente. Ligesom Góngora, tager Rafael Alberti i en række af Cal y cantos digte afsæt i den omgivende realitet, og hæver den op til at være et poetisk ideal gennem metaforens lovprisende kraft. Og netop i denne selvreferentielle karakteristik ligger versets kognitive kraft eller metaforiske sandhed: Det udtrykker præcist og poetisk en poetik, som på én gang ligger forud for, og som samtidig kun eksisterer i kraft af versets egen poetiske funktion. Således knytter dette metaforiske udtryk an til en hel æstetisk strømning i tyvernes spanske kunst og kulturliv, som Ortega y Gasset betegnede som pueril, ludfisk og intranscendent.

\section{Det pragmatiske niveau:}

\section{Bakbtins polyfoni, kronotop og intertekstualitet}

Som nævnt i Kapitel I kan man med udgangspunkt i Peirces opdeling af semiotikkens discipliner definere pragmatikken som studiet af tegnet og dets interpretanter (se s. I9). Det pragmatiske problemfelt inden for de litterære studier er meget vidtfavnende, men jeg har i første omgang valgt at behandle det med udgangspunkt i Mikhail Bakhtins teori om romanens polyfone karakter og dialogiske relationer til andre tekster. Efter en kort introduktion til teorikomplekset vil jeg forsøge at diskutere den i lyset af den æxtetiske oplevelse som et samspil mellem modale relationer. Behandlingen af Bakhtins romanæstetik foregiver på ingen måde at være udtømmende, men skal forstås som en selektiv udvælgelse af elementer, der egner sig til at supplere teorien om den æstetiske erfaring som en dialogisk relation imellem emotionelle, energetiske og logiske aspekter af Peirces interpretantbegreb.

I Discourse in the Novel skelner Bakhtin mellem to former for dialogisme i tekster, intern og ekstern dialogisme. External dialogization er den kompositionelt markerede dialog mellem tekstens stemmer, mens begrebet internal dialogization dækker diskursens eget dialogiske forhold til andre diskurser, som indoptages, repræsenteres, besvares og parodieres eller på anden måde kommenteres. Det er især denne interne dialogisme, som vil blive gjort til genstand for behandling i dette afsnit, og det vil vi gøre ved at fokusere på tre forskellige aspekter af den:

Den polyfone relation mellem 'autor' og fremstillede personer.

Tekstens traditionsrelaterede dialog med de genrebestemte kronotoper.

Tekstens intertekstuelle dialog med andre tekster.

Den følgende fremstilling vil følge disse tre niveauer. På hvert niveau vil jeg kort introducere udvalgte aspekter af Bakhtins teori, som efterfølgende vil blive relateret til modellen for det æstetiske samspil mellem den 
emotionelle, den energetiske og den logiske interpretant, som den er udfoldet i det ovenstående.

\section{Dialogen mellem 'autor' og fiktiv person: polyfoni}

Nogle væsentlige træk af den dialogiske relation mellem 'autor' og fiktiv person er allerede ridset op i afsnittet »Subjektsdannelse og litteratur «. Til forskel fra den tidligere behandling har vi her at gøre med receptionssiden, hvor læseren aktivt deltager i skabelsen af det eller de fremstillede subjekters forhold til et fiktivt univers. Man kunne sikkert, og til dels med rette, indvende, at dialogen mellem 'autor' og fiktiv person skulle tilhøre det semantiske niveau, da der er tale om at analysere, hvordan teksten selv lægger en ramme omkring læserens konstruktion af et fiktivt univers. Men da læserens forhold til den eller de fremstillede personer reguleres gennem en kombination af identifikation og distance i tekstens måde at formidle det fremstillede stof på, bliver det udsigelsesmæssige aspekt involveret som et centralt element. Forholdet mellem identifikation og distance er i meget høj grad determineret af den måde, hvorpå 'autor' fokuserer eller fremstiller en given person, hvorfor spørgsmålet behandles her i forbindelse med det pragmatiske niveau.

Hvad angår definitionen af begrebet author skriver Bakhtin i essayet »Forms of Time and Cronotope in the Novel «, at det er nødvendigt at skelne klart mellem 'autor' som en implicit fortællerinstans og den empiriske forfatter. For Bakhtin er autor til stede $i$ teksten, hvorved han indfører en skelnen mellem denne tekstinterne instans og den empiriske forfatter, parallelt med begreberne om den implicitte fortæller eller 'model-forfatteren': »We find the author [...] as the creator of the work itself, although he is located outside the cronotopes represented in his work, he is as it were tangential to them. We meet him (that is, we sense his activity) most of all in the composition of the work « (Bakhtin I98I, 254). Og i Author and Hero in Aesthetic Activity skriver han:

The author is the bearer and sustainer of the intently active unity of a consummated whole (the whole of a hero and the whole of a work) which is transgredient to each and every one of its particular moments or constituent features (Bakhtin I990, I2).

I sin beskrivelse af Dostojevskijs poetik i Problems of Dostoevsky's Poetics lægger Bakhtin vægt på, at Dostojevskijs litterære personfremstilling ikke bliver stående ved en udvendig beskrivelse, der ville beskrive personen som en lukket (finalized) og statisk størrelse, men først og fremmest udfolder personens selvbevidsthed. Den fiktive person bliver 
fremstillet som et individuelt selv, der således på én gang oplever »[his] own inner unfinalizability « i dialog med »other people's words about him that might finalize and deaden him " (Bakhtin I984b, 59). "The cognizant and judging ' $I$ ', and the world as its object, are present there not in the singular but in the plural « (Bakhtin I984b, 99). Personen bliver således tendentielt en selvstændig og individuel størrelse, der taler fra sit eget distinkte udgangspunkt og i sin egen 'ret', og hvis karakteristika først træder i relief $\mathrm{i}$ konfrontationen med hans egne reaktioner over for andre personer og disses reaktioner over for ham. I denne udsigelsesstruktur mister 'autors' stemme sin olympiske autoritet og bliver blot én blandt andre stemmer i den polyfone tekst eller glider helt i baggrunden og lader sig kun mærke i kraft af værkets kompositionelle opbygning. For Bakhtin bliver romanens æstetiske særpræg derfor til et spørgsmål om, at sproget ikke bare er en repræsentation af en 'verden', men først og fremmest en ikonisk repræsentation af diskursiv praksis:

It is characteristic of all these phenomena (stylization of languages, parody and skaz $^{22}$ ) that the discourse in them not only represents, but is itself represented; social language in them (whether generic, professional or that of a literary trend) becomes the object of reprocessing, reformulation and artistic transformation that is free and oriented toward art (Bakhtin I98I, 336).

Forskellen på gengivelsen af andres tale i hverdagssproget og i litteraturen er således ifølge Bakhtin, at den kunstneriske repræsentation sikrer sprogets sociale repræsentativitet: "In an authentic novel there can be sensed behind each utterance the elemental force of social languages ", hvor begrebet social language skal forstås som » a concrete socio-linguistic belief system that defines a distinct identity for itself « (ibid.). Det er med andre ord det litterære værks balancerede fremstilling af personens individuelle selvstændighed og diskursens sociale repræsentativitet, som ligger bag Bakhtins forståelse af romanens kunstneriske egenart: »The image of such a language in a novel is the image assumed by a set of social beliefs, the image of a social ideologeme that has fused with its own discourse, with its own language " (op.cit. 357). Selv om det ikke er alle romaner som er polyfone, så er den åbenhed og eksperimenteren som denne sociale repræsentativitet indebærer, et fundamentalt og genredefinerende karaktertræk, som Bakhtin knytter sammen med det moderne. I Epic and Novel karakteriserer han romanen ved denne erfaringsorienterede fremtidsrettethed over for den klassiske epik:

\footnotetext{
${ }^{22}$ Hos Bakhtin repræsenterer begrebet 'skaz' den parodierede gengivelse af den andens tale. 
In ancient literature it is memory and not knowledge that serves as the source and power for the creative impulse. That is how it was, it is impossible to change it: the tradition of the past is sacred [...]. The novel, by contrast, is determined by experience, knowledge and practice (the future) (Bakhtin I98 I, I 5 ).

Ifølge Bakhtin bryder romanen som genre med den episke distance til sit stof og åbner den fiktive verden, som det man kunne kalde et 'emergent' univers, hvori subjekter interagerer og formes i dialog med deres omgivelser og de muligheder disse tilbyder. I denne forstand er romanen en moderne genre, fordi den modsvarer menneskets individuelle frisættelse fra traditionen og fokuserer på de dynamiske processer i den menneskelige erfaringsdannelse. Bakhtin siger således at romanens modernitet som genre bunder i det, han kalder en »eternal re-thinking and re-evaluating « (op.cit. 3 I). Og det er i denne romangenrens modernitet at 'autor' slipper sine personer fri og lader deres stemmer tale fra hvert deres udgangspunkt, og så at sige 'i egen ret' uden at autor lægger sin egen diskurs bedømmende og monologisk ned over dem. Det er så op til læseren selv at danne sig sin mening om den polyfone dialog, som udspiller sig i teksten.

Forholder vi denne udlægning af Bakhtins beskrivelse af forholdet mellem autor og fiktiv person i den polyfone roman til Peirces skelnen mellem den emotionelle, den energetiske og den logiske interpretant kunne man sige, at den emotionelle interpretant ville kunne dække læserens spontane identifikation med den fiktive persons udifferentierede selv som en åben og i princippet ubestemt (indeterminate) væren. Læserens møde med andre fiktive personers udvendige syn på personen, og til en vis grad også med autors udvendige og finaliserende beskrivelse af personen, ville kunne beskrives som en energetisk interpretant, der dementerer eller bekræfter bestemte sider af personens identitetsmæssige væren, forstået som det ovenfor beskrevne mulighedsfelt. Og endelig tvinger denne åbne udsigelsesstruktur som sagt læseren til at forholde sig aktivt fortolkende og stillingtagende til tekstens dialogiske orkestrering af stemmer for at tilskrive persontegningen helhed og mening i form af en logisk interpretant. Dette kunne i modelform tage sig således ud:

UMIDDELBAR INTERPRETANT

\begin{tabular}{lll|}
\hline Emotionel interpretant & Energetisk interpretant & Logisk interpretant \\
Ubegrænset 'selv' & Den 'anden' & Dialog \\
Ubestemthed / & Den 'andens' finaliserende ord & Helhedsbillede \\
Unfinalizability & & \\
\hline
\end{tabular}

Modellen illustrerer bl.a. at den aktivitet, som læseren forpligtes på i læsningen af polyfone romaner, kan udlægges parallelt med de semiotiske 
processer der ligger bag subjektets identitetskonstruktion. Såvel forfatter som læser identificerer sig til en vis grad med den fiktive person (jf. Bakhtins begreb sympathetic co-experience, Bakhtin I990, 8I ff.) og oplever til dels dennes identitetsmæssige tilbliven i mødet med tekstens 'anden' som sin egen erfaring. Der er imidlertid ikke bare tale om en empatisk indlevelse, hvor læseren oplever den fiktive persons selv som sit eget, men om en dialogisk relation, hvor personen på en gang ses udefra og indefra:

Aesthetic activity proper comes into effect with the moment of creative love for the content (the life) which has been co-experienced, i.e. of that love which brings forth an aesthetic form for the co-experienced life that is transgredient to that life (Bakhtin I990, 86).

Hvordan balancen mellem identifikation og distance falder ud, afhænger ganske af tekstens konkrete brug af effekter såsom ironi og parodiering som led i den energetiske interpretants finaliserende bestemmelse af personen, men personbeskrivelsens æstetiske spændingsrelation bibeholdes ved at personen konstant søger at undslippe dette finaliserende blik. I den polyfone personbeskrivelse vil den emotionelle interpretants ufinaliserbare betydningspotentiale hele tiden forsøge af modgå den 'andens' determinerende bestemmelse: "Dostoevsky's hero always seeks to destroy that framework of other people's words about him that might finalize and deaden him «(Bakhtin I984b, 59).

\section{Tekstens traditionsrelaterede dialog med de genrebestemte kronotoper}

Den totalitet eller orden, som læseren etablerer i læseprocessen i form af en logisk interpretant, det være sig læserens mediering af parallelismernes polysemiske spil på lighed og brud eller tendensen i retning af udkrystallisering af en semantisk polyfoni i den poetiske metafor, etableres ikke hver gang som en jomfruelig ny og ubesmittet orden, men etableres som ethvert andet tegn på en bestemt baggrund af tradition eller vane. Den æstetiske kvalitet i den kunstneriske oplevelse afhænger ganske vist af den nyhed og friskhed, som det kunstneriske tegn måtte skabe, men det er altid en nyhed og en friskhed i forhold til noget allerede eksisterende, $\mathrm{i}$ forhold til en vane. Vi har tidligere været inde på at det dialogiske forhold mellem selvet og den anden reguleres af en række vaner i subjektets individuelle og kulturelle identitetsdannelse. På dette sted kan vi nu udnytte denne indsigt til at sige, at disse vaner inden for den litterære reception bl.a. svarer til de genreforventninger der bestemmer læserens umiddelbare forforståelse af teksten. Ricœur kalder denne genreforvent- 
ning Mimesis I eller præfiguration, idet han præciserer at der er tale om " a preunderstanding of the world of action, its meaningful structures, its symbolic resources, and its temporal character " (Ricœur I984 I, 54).$^{23} \mathrm{I}$ de dagligdags processer, hvorigennem subjektet regenererer sig selv i en social og kulturel praksis, indgår de semiotiske vaner og diskursive talegenrer i et komplekst netværk med de kulturelt bestemte handlemønstre, der bestemmer hvilke kollektive subjekter individet skriver eller taler sig ind $\mathrm{i}$. I den litterære kreationsproces indgår de samme diskursive talegenrer på den ene side som grundlag for den mimetiske genskabelse, idet deres reartikulation inden for det kunstneriske tegn sikrer det element af genkendelighed, som gør læseren i stand til at situere det fiktive univers i forhold til sin egen verden (Dines Johansen I997). Og på den anden side overlejres kunstværket af de traditionsbetingede litterære genrer, som Bakhtin kalder secondary eller complex speech genres (Bakhtin I986, 62). Disse mere komplekse regelsæt for diskursiv produktion indoptager de primære og mere simple talegenrer og normer og mimer dem inden for rammerne af et fiktivt univers af en bestemt karakter.

Bakhtin analyserer disse sekundære eller litterære genrer i relation til deres universers 'kronotopiske' struktur. Kronotopbegrebet betegner fortællingens forankring $\mathrm{i}$ en indbyrdes forbundet tidslig (kronos) og rumlig (topos) struktur, og Bakhtin hævder at hver genre så at sige har sin egen karakteristiske kronotop. I dette kronotopbegreb bygger Bakhtin videre på Kants forestilling om at tid og rum er kognitive a priori kategorier, altså at de ligger til grund for eller 'forud for' enhver kognition, men hvor der for Kant er tale om transcendentale kategorier, er der for Bakhtin tale om en konkret situering af al diskursiv praksis (Bakhtin I98 I, 85 note 2). Parallelt med Paul Ricœurs forestilling om, at det kun er gennem fortællingen at mennesket kan begribe tiden, dvs. sammenknytte den fænomenologiske tidsoplevelse med den målelige, fremadskridende kronometri (se s. 76), påpeger Bakhtin at kronotopen materialiserer tiden i rummet ved at give den kød og blod: "Time becomes, in effect, palpable and visible; the chronotope make narrative events concrete, makes them take on flesh, causes blood to flow in their veins " (op.cit. 250). Bakhtins begreb om kronotopen er således udtryk for en forestilling om at tidslige og rumlige koordinater altid både ligger indskrevet i ethvert litterært værks struktur, og indlejret i læserens møde med kunstværket. Kronotopen er således altid til stede i den kunstneriske repræsentation af en verden, men relationerne imellem tid og sted varierer med de kendte generer.

Bakhtin beskriver kronotopen som »the organizing center for the fun-

${ }^{23}$ Ricœurs tre mimesis-niveauer er yderligere behandlet i Kapitel IV, se s. $204 \mathrm{ff.}$. 
damental narrative events of the novel « eller som »a centre for concretizing representation « (ibid.). Ikke overraskende mener Bakhtin at der inden for det enkelte værk kan optræde flere forskellige kronotoper, som kan indgå i et dialogisk spil med hinanden, og at også læseren og fortælleren derudover kan repræsentere egne kronotoper, som kan bringes i dialog med de kronotoper som konstrueres igennem tekstens univers. Dog understreger Bakhtin at læserens og fortællerens kronotoper er »outside the world represented, although not outside the work as a whole« (ibid., 252). Dette vælger jeg at forstå således, at kronotopen som tilhører tekstens fiktive univers er indskrevet i tekstens semantiske struktur, mens fortællerens og læserens kronotoper (og evt. andre intertekstuelt repræsenterede kronotoper) inddrages som pragmatiske elementer i læseprocessen: De er altså med i læsningen som begivenhed, men ikke repræsenteret i det fiktive univers.

I den litterære skriveproces er der imidlertid ikke bare tale om en reproduktion af normen eller genren, men om en aktiv og kreativ produktion af novelness, erkendelse og indsigt, hvor normen bliver den baggrund, som historien/teksten tager form på baggrund af. Fornyelsen tager i Bakhtins terminologi form af en forvridning (distortion) af den genreskabende kronotop. Betragtet ud fra et receptionssynspunkt må kendskabet til disse normer anses for at være indskrevet som en del af værkets forudsætningsindhold, dets 'strategi' med Ecos udtryk. Tekstens strategiske udfordring af læseren kan derfor beskrives som et spørgsmål om at bestemme tekstens specifikke kronotopiske udformning i dens præcise relation til den eller de generiske kronotoper, som teksten forudsættes at dialogere med. Tekstens specifikke kronotopiske struktur kommer i læsningen til at oscillere i et spændingsforhold mellem tradition og fornyelse. Skulle vi skildre den kronotopiske dialogs æstetiske funktion med Peirces tre modale aspekter af den umiddelbare interpretant, kunne det se således ud:

UMIDDELBAR INTERPRETANT

\begin{tabular}{lll}
\hline Emotionel interpretant & Energetisk interpretant & Logisk interpretant \\
Generisk kronotop & Forvridning & Specifik kronotop
\end{tabular}

Den generiske kronotop udgør det emotionelle udgangspunkt, hvorpå en fortælling lejrer sig; tænk blot på de følelsesmæssige forventninger der knytter sig til eventyrets traditionelle genreemblem: "Der var engang..." eller til ridderromanen som generisk kronotop for Cervantes' Don Quijote. Den generiske kronotop udgør således en umiddelbar og ureflekteret forventningshorisont for læseren, som teksten dialogerer med i læsepro- 
cessen. Hans Robert Jauss definerer i Litteraturhistorie som udfordring til litteraturvidenskaben forventningshorisonten som følger:

[D]et system af forventninger, som for det historiske øjeblik, hvor et værk fremkommer, kan udledes og objektivt beskrives ud fra genrens forforståelse, ud fra allerede kendte værkers form og tematik og ud fra modsætningen mellem digterisk og praktisk sprogbrug (Jauss I98I, 6I).

Ifølge Jauss spiller alle litterære værker sig selv op i forhold til en sådan forventningshorisont, men Jauss skelner dog mellem det, han kalder den 'kulinariske' kunst, som blot opfylder horisontens forventninger, og den egentlige kunst, som fordrer horisontændringer hos læseren.

Bakhtins kronotopbegreb, forstået som en tilsyneladende transhistorisk narrativ kategori, indeholder »the total matrix comprised by both the story and the plot « på den måde, at story (fablen) er den baggrund, hvorpå plottet (intrigen/fortællingen) tager form (Holquist I990, I I3). Figur/ grund-metaforen er udfoldet i Bakhtins tekst »Author and Hero in Aesthetic Activity « og bygger ifølge Holquist på Sjklovskijs forestilling om at tekstens litteraritet $»$ depends on readers perceiving precisely how the chronology is deformed « (op.cit. I I4-I 5). Sjklovskij adskiller de to elementer, idet han antager at fablens kronologi er transhistorisk og at fablen dermed udgør en konstant, mens plottet er variabelt. Heroverfor insisterer Bakhtin på at fabel og fortælling indgår i et dialogisk samspil, hvorigennem de gensidigt skaber hinanden som grund og figur. Denne position indebærer at også fablens kronologi bliver historisk variabel: »the chronological order of events is always interpreted in different ways at different times " (op.cit. I I6). Ifølge Bakhtin ville den samme fabel således blive konstrueret forskelligt til forskellige forskellige tider, hvilket indebærer at man kan spørge til, i hvilket omfang teksten 'betyder' det samme. Dette spørgsmål vil blive taget op i forbindelse med fortolkningsog referenceproblematikken i Kapitel IV. Det centrale i denne sammenhæng er imidlertid at læserens konstruktion af det kronotope rum forstået som en figur/grund-relation, involverer " a multitude of parts so related to one another as to impart a positive simple immediate quality to their totality « (CP 5.I32).

\section{Tekstens intertekstuelle dialog med andre tekster}

Som vi var inde på i Kapitel I er Bakhtins tegnbegreb pragmatisk i den forstand, at et tegn eller en tekst altid medtager andre forudgående tegn, eller andre tidligere tekster, der gør den samme problematik til en del af deres reference. Man kan således sige at Bakhtin udvikler den teoretiske 
forudsætning for intertekstualitetsbegrebet, som i Julia Kristevas udlægning har vundet almen anerkendelse, selv om han aldrig selv anvender termen (Todorov I984, 60). Hvad angår forhold som f.eks. genre, tematik, topoi og retorisk karakter, bygger litterære tekster altid videre på andre litterære tekster. Man kunne sige at tekster udgør de byggesten, som litterære tekster er konstrueret af. Tænk blot på, hvordan Cervantes i Don Quijote mimer en hel række andre litterære tekster og andre litterære genrer, og spiller dem dialogisk op imod hinanden: Ridderromanens middelalderlige idealisme modstilles den pikareske romans realisme, som så igen spilles op imod den pastorale romans neoplatoniske renæssanceidyl, der igen modstilles den byzantinske kærlighedsromans orientalsk inspirerede verdensbillede osv.

De intertekstuelle litterære referencer kan være eksplicitte, som når Don Quijote nævner Amadis af Gallien som en af sine yndlingsromaner, eller når præsten og barberen diskuterer nogle af Cervantes' egne litterære værker, som de finder i Don Quijotes bibliotek. Men de kan også ligge implicit i teksten som en mere eller mindre gennemskuelig mimen af genkendelige genre- eller værkspecifikke træk og således være afhængige af læserens litterære kompetencer. Hele dette kompleks af intertekstuelle relationer og netværk af betydninger i de litterære teksters kreation og reception er velbeskrevet og har nydt stor opmærksomhed i litteraturkritikken i de seneste 20 til 30 år. Men såvel den implicitte som den eksplicitte intertekstualitet refererer til det, som Bakhtin kalder secondary speech genres (Bakhtin I986, 62), altså genrer der i forvejen kun er mimetiske fremstillinger af anden sprogbrug. Der er derfor vigtigt at gøre opmærksom på at Bakhtins begreb om teksternes interne dialogisme også rummer teksternes dialogisk orkestrerede mimen af de primære talegenrer, den levende sprogbrug som social praksis. Det er jo i udgangspunktet dette forhold der ligger til grund til for, at vi i Kapitel I karakteriserede den litterære diskurs som værende af mimetisk karakter.

Den interne dialogisme kan komme til udtryk gennem en kombination af forskellige former for dialogeret heteroglossia, såsom direkte fortælling, skaz, stiliseret, semilitterær fortælling (breve, dagbog), litterær ikkekunstnerisk tale (retorisk monolog, moralprædiken etc.) og stiliseret individuel tale (Bakhtin I98 I, 262). Ifølge Bakhtin skal den polyfone romans 'stil' derfor i mindre grad findes i et stilistisk helhedspræg, der kan ses som autors fingeraftryk på teksten, end i den specifikke kombination af stilarter som dialogeres i teksten:

The stylistic uniqueness of the novel as a genre consists precisely in the combination of these subordinated, yet still relatively autonomous, unities $[\ldots]$ 
into a higher unity of the work as a whole: the style of the novel is to be found in the combination of its styles (ibid.).

Distancerende udsigelsesteknikker, såsom parodiering og stilisering, er ikke kun træk som vedrører den direkte parodiering af andre personers tale, men slår også ind i de litterære tekster, f.eks. i form at en farvning af både fortælleren og andre personers sprog. Resultatet af dette kalder Bakhtin hybride konstruktioner eller hybridizations, som han definerer som " an utterance that [has] two semantic and axiological belief systems " (op.cit. 304). Den komiske stil er grundlæggende præget af dette »varied play with the boundaries of speech types, languages and belief systems « (op.cit. 308), en indflydelse som ifølge Bakhtin kan føres direkte tilbage til Cervantes. Det er som om forfatteren ikke har et eget sprog, men kun opnår sin selvstændighed i spillet mellem de heteroglotte diskurser.

Fra Don Quijote kommer også spillet med en eksplicit fortæller (posited author): "a particular belief system belonging to someone else, a particular point of view on the world belonging to someone else, is used by the author $[. .$.$] to show the object of representation in a new light [. .$. and $[. .$.$] to illuminate in a new way the 'expected' literary horizon [...] «$ (op.cit. 3 I 2). Fortælleren benytter sig ikke nødvendigvis kun af ét sprog, men kan snart anvende ét, snart benytte sig af et andet til at udtrykke sig, og ved at overlade ordet til andre fortællere bliver fortællerens eget sprog blot til ét blandt flere. Ved siden af fortællernes sprog har vi så de repræsenterede personers sprog, som hver især repræsenterer forskellige belief systems, og endelig har vi muligheden for at indføje andre stemmer i kraft af andre genrer - digte, ordsprog og indlagte fortalte historier i historien osv. (op.cit. 320). Don Quijote nævnes som »the classic and purest model of the novel as a genre « der kombinerer de andre modeller i sig (op.cit. 324). Denne polyfoni af stemmer udgør en tekstintern dialogisme, som i princippet er lige så uudtømmelig for betydning som den poetiske metafor:

Authentic double-voicedness, although it generates novelistic prose dialogues, is not exhausted in these dialogues and remains in the discourse, in language, like a spring of dialogism that never runs dry (op.cit. 330).

Resultatet af de hybride konstruktioner er således ikke bare en modstilling af stilistisk forskellig sprogbrug, men en modstilling af forskellige synsvinkler på verden og i sidste instans af forskellige, evt. kolliderende ideologiske holdninger til verden:

In an intentional novelistic hybrid [...] the important activity is not only (in fact not so much) the mixing of linguistic forms - the markers of two 
languages and styles - as it is the collision between differing points of view on the world that are embedded in these forms (op.cit. 360).

Og ligesom den enkelte romans stilistiske særtræk skal findes i den kombination af stilarter, som dialogeres i teksten, således skal værket, stadig ifølge Bakhtin, vurderes indholdsmæssigt ud fra den arkitektoniske komposition af de ideologiske synspunkter som værket rummer. Selv bruger Bakhtin både arkitektur-metaforen og den musikalske 'orkestrerings-metafor' til at karakterisere dette forhold:

The novel orchestrates all its themes, the totality of the world of objects and ideas depicted and expressed in it, by means of the social diversity of speech types and by the differing individual voices that flourish under such conditions (op.cit. 263).

Skulle vi skildre den æstetiske funktion af den interne dialogisme mellem distinkte diskurser med Peirces tre modale aspekter af den umiddelbare interpretant, kunne det se således ud:

UMIDDELBAR INTERPRETANT

\begin{tabular}{lll|}
\hline Emotionel interpretant & Energetisk interpretant & Logisk interpretant \\
Heteroglossia & Sammenstød mellem synspunkter & 'Orkestrering'
\end{tabular}

Begrebet heteroglossia skal forstås som »another's speech in another's language, serving to express authorial intentions but in a refracted way «. Det er en doublevoiced discourse, som aldrig kan udtømmes tematisk i en analytisk diskurs (op.cit. 324-26). Hvor metaforen som trope bygger på en monologisk polysemi i relationen mellem tegn og objekt, repræsenterer Bakhtins heteroglotte polyfoni en ureducerbar potentialitet i udsigelsens stemmeføring på det pragmatiske plan. Hvor den poetiske metafor er polysemisk i semantisk forstand, er romanens dialogerede heteroglossia altså polyfont i pragmatisk forstand.

In the majority of poetic genres (poetic in the narrow sense) [...] the internal dialogization of discourse is not put to artistic use, it does not enter into the work's 'aesthetic object' [...] In the novel, however, this internal dialogization becomes one of the most fundamental aspects of prose style and undergoes a specific artistic elaboration (op.cit. 284).

Bakhtin knytter imidlertid denne forskel på polysemi og polyfoni til en skelnen mellem litterære hovedgenrer, således at den interne dialogisme især ses som værende bundet til romangenren, mens han mener at poesi principielt ikke kan være polyfonisk. I poesien er: 
[T] he entire event [polysemiens opståen] [...] played out between the word and its object; all of the play of the poetic symbol is in that space. A symbol cannot presuppose any fundamental relationship to another's word, to another's voice. The polysemi of the poetic symbol presupposes the unity of a voice with which it is identical, and it presupposes that such a voice is completely alone within its own discourse (op.cit. 328).

For Bakhtin er såvel tropens som det litterære symbols semantiske polysemi således principielt af monologisk karakter, dvs. båret frem af én stemme med én udsigelsesmæssig logik. Heroverfor er polyfonien dialogisk, dvs. knyttet til tilstedeværelsen af flere samtidige stemmers, sprogs eller talegenrers indbyrdes dialogeren, og denne form er for Bakhtin i særdeleshed knyttet til romanen som genre. Bakhtin illustrerer polyfonien ved at forestille sig, at et digt med den omtalte polysemi bliver trukket ind i en roman. I romanens double voiced word sker der det, at » in the space between the word and its object another's word, another's accent intrudes, a mantle of materiality is cast over the symbol « (op.cit. 329).

I stedet for at skelne så bastant mellem hovedgenrerne, som Bakhtin gør det, og dermed karakterisere hele det poetiske register som monologisk, kunne man skelne mellem forskellige stilarter forstået som diskursive praksisformer. Dette ville indebære, at man kunne tale om dialogiske (novellistiske) digte og poetiske (monologiske passager i) romaner. Dermed ville man også med fordel kunne skelne mellem forskellige typer af peirceanske førsteheder i det kunstneriske udtryk. Således viser brugen af metaforer i romaner at der også kan forekomme semantisk polysemi inden for denne genre, mens ironiske rolledigte viser at der også kan forekomme pragmatisk polyfoni i digte. Ligesom hos Ricœur er der imidlertid også i Bakhtins behandling af Dostojevskij tale om at det, der gør den polyfone tekst til et ikon med et uudtømmelig eller dialogisk indhold, er relationen tilbage til den sociale og kulturelle virkelighed:

Dostoevsky never created his idea-images out of nothing, he never made them $u p$ any more than a visual artist makes up the people he represents - he was able to hear or divine them in the reality at hand (Bakhtin I984b, 90).

Uden kendskab til eller fornemmelse for denne virkelighed vil læseren ikke være i stand til at aktualisere den polyfone romans æstetiske potentiale. Tekstens æstetiske potentiale består således ikke i en 'litteraritet' lukket omkring sig selv, men forudsætter som en del af den tekstlige strategi en åben, referentiel og diskuterende dialog med virkeligheden: 
It is characteristic that in Dostoevsky's works there are absolutely no separate thoughts, propositions or formulations such as maxims, sayings aphorisms which, when removed from their context and detached from their voice, would retain their semantic meaning in an impersonal form (op.cit. 95).

Set ud fra et æstetisk synspunkt er det Bakhtins store force, at han er i stand til at bryde den sædvanlige fordom om, at spørgsmålet om sproglig 'form' skiller de forskellige litterære genrer. Paul Valéry, og med ham en stor del af dette århundredes litterære kritik, skildrer poesien som 'uoversættelig' i modsætning til prosaen, dvs. at poesien er i besiddelse af en ureducerbar sproglig form, mens den litterære prosas sproglige form tenderer mod at forsvinde bag sprogets kommunikative mening, ligesom i ikke-litterær prosa:

In the practical and abstract uses of language that is specifically prose, the form is not preserved, does not outlive understanding, but dissolves in the light, for it has acted, it has made itself understood, it has lived [...] But the poem, on the contrary, does not die for having been of use; it is purposely made to be reborn from its ashes and perpetually to become what it has been [...] it tends to reproduce itself in its own form, it stimulates our minds to reconstruct it as it is (Paul Valéry, "Remarks on Poetry ", The Art of Poetry, citeret efter Justus Buchler I974).

Paul Valéry kan udlægges sådan, at i prosaen, som for den franske poet dækker såvel den hverdagssproglige praksis og teoretisk diskurs, det han kalder " practical and abstract uses of language «, dér begrænses forståelsen af sproget til produktionen af en logisk interpretant. Og over for disse primære talegenrer, udmærker poesien sig ved at »it tends to reproduce itself in its own form, it stimulates our minds to reconstruct it as it is ", dvs. at den logiske interpretant vedbliver at oscillere i dialogisk interaktion med de emotionelle og energetiske interpretanter.

Et problem ved Valérys synspunkt er, at han ikke skelner mellem det, Bakhtin kalder primære og sekundære talegenrer, hvorfor han kommer til at rubricere hele den ikke-poetiske, litterære prosa som værende ikkeæstetisk. Et andet problem er, at han forsøger at modstille forskellige typer af sprog i stedet for at modstille forskellige typer af reception eller lytten. Det han gør, er med andre ord at tage udgangspunkt i at spørge til, hvad det specifikt litterære eller poetiske er, i stedet for at se på hvordan vi læser eller lytter. Vi læser litterære tekster, såvel poesi som romaner, med et æstetisk blik, der tilskriver formen en betydning ud fra formens kvalitative og aktuelle samspil med en kontekst. Betragtet ud fra denne synsvinkel vil al litteratur være formmæssigt unik og umulig at oversætte 
uden at helt centrale karakteristika går tabt eller bliver ændret. Og det er først og fremmest Bakhtin, som med sit polyfonibegreb og teorien om autors orkestrering af romanens stemmer har leveret os argumentet herfor for romanens vedkommende.

\section{Manuel Vázquez Montalbáns »El premio«}

Den spanske forfatter Manuel Vázquez Montalbán (I939-2003) var, sammen med bl.a. Eduardo Mendoza, en af de centrale personer inden for den litterære strømning, som på spansk går under betegnelsen la nueva narrativa española (den nye spanske fortællekunst). Betegnelsen dækker roman- og novellekunstens opblomstring fra midt i I970'erne og frem til i dag og er bl.a. kendetegnet ved et opgør med tressernes elitære modernisme og en tilbagevenden til glæden ved at fortælle en god historie, ofte med et parodisk sideblik til kriminalgenren. Vázquez Montalbán er herhjemme nok mest kendt for sin serie om kriminaldetektiven Pepe Carvalho. Serien omfatter mere end tyve bind, af hvilke en hel række er oversat til dansk: Direktørens ensombed (1988), Sydhavet (1988), Mord $i$ centralkomiteen (1989), Fuglene i Bangkok (I990), Den groeske labyrint (I993), Olympisk sabotage (I994) og Buenos Aires-kvartetten (2002). El premio (Prisen) fra 1996 tilhører Carvalho-serien, men den ikke oversat til dansk.

Pepe Carvalho er som person en yderst sammensat figur. Han er tidligere kommunist og agent for CIA, og i romanernes 'nutid', der altså strækker sig fra midt i 70 'erne og frem til 2002, fungerer han som privatdetektiv med hjemstavn i Barcelona. Han er bosat i et eksklusivt villakvarter i byens udkant, hvor han tilbringer sin fritid med gastronomiske udfoldelser samt med i kaminen at brænde bøger fra sit omfattende privatbibliotek, ofte i selskab med sin veninde, den prostituerede Charo. Der er med andre ord tale om en politisk og ideologisk desillusioneret antihelt, for hvem alle mere transcendentale værdier, politiske idealer, personlig dyd, religiøs tro osv. har mistet deres mening, og som tilsyneladende kun værdsætter verdens mere konkrete goder: god mad og vin, spiritus i store mængder, fysisk kærlighed og den varme, som litteraturhistoriens hovedværker kan afgive under brændingen. Men personen er mere kompleks end som så, for samtidig er der tale om en person med en meget høj grad af personlig integritet, som gennemlever forskellige personlige kriser af mere eksistentiel karakter. Med sin kombination af kulturel dannelse og kras sarkasme fungerer figuren som en skarp kommentator af den sociale og politiske udvikling i det postfrankistiske Spanien, og hans attitude stemmer nøje overens med den dominerende stemning, der fulgte demokratiseringsprocessen efter Francos død, den såkaldte desencanto. Regi- 
mets strategi for en fredelig overgang til demokratisk styre indebar en række sociale og politiske kompromiser, herunder en stiltiende pagt om at de ansvarlige for regimets undertrykkelse ikke ville blive retsforfulgt, hvorfor det officielle Spanien gennemlevede en periode af kollektiv amnesi. Dette manglende opgør med regimets ansvarlige og fraværet af mere radikale reformer ledte til en udbredt skuffelse og desillusion blandt de tidligere modstandere af diktaturet, og alle mere vidtgående politiske og ideologiske drømme og idealer blev gradvist afløst af desillusion og kynisk beregnende pragmatisme. Ifølge den katalanske kritiker, Fernando Vals, kan alle Vázquez Montalbáns romaner læses som en dissidents mod denne pagt, som blev indgået for at glemme fortiden (Vals 2003, 47).

Handlingen i El premio udspiller sig omkring I995, hvor socialistpartiet PSOE med Felipe González i spidsen har siddet på regeringsmagten i mere end ıo år. På dette tidspunkt er den første desencanto for længe siden blevet afløst af socialisternes taburetklæberi, og regeringen rystes af den ene skandale efter den anden: Finansmanden Mario Conde tages i at bestikke regeringen, chefen for politikorpset Guardia Civil, Luis Roldán, stikker af med kassen og regeringen anklages for at have hyret lejemordere til at henrette formodede ETA- medlemmer i Baskerlandet, den såkaldte GAL-sag. Året efter, dvs. samtidig med at romanen udkom, tabte PSOE valget til det borgerlige Partido Popular, der med José María Aznar som regeringsleder sad på regeringsmagten indtil foråret 2004. Denne baggrund er vigtig at have in mente, da romanens handling udspiller sig som en travesti over rænkespillet i magtens korridorer, tilføjet nogle svære drag over nakken til den kulturelle og litterære elite.

I romanen tager rigmanden Lázaro Conesal, en fiktiv blanding af den skandaleramte Mario Conde og den italienske mediemagnat og nuværende ministerpræsident Silvio Berlusconi, initiativ til at indstifte en ny, spansk litteraturpris i eget navn. Hensigten er koldt og kynisk at købe kulturlivets anerkendelse og at få tilskrevet kulturel kapital til sit medieimperium ved at skænke en eksorbitant sum til vinderen af en romankonkurrence. Hele processen med udnævnelse af en jury, som i virkeligheden intet bestemmer, og selve festbanketten, hvor prisen skal tildeles, kan læses som en parodi på hvordan den borgerlige offentlighed i dag er degenereret til et repræsentativt medieshow. Til stede ved uddelingsceremonien finder vi en række kendte, virkelige personer, såsom politikerne Joaquín Leguina og Carmen Alborch, adelsmanden Jesús Aguirre og en række let gennemskuelige nøglefigurer for kendte forfattere og litterater, hvoraf den lettest genkendelige er nobelprisvinderen Camilo José Cela, i teksten blot kaldet el premio Nóbel. Også Pepe Carvalho er til stede med sit sarkastiske blik, der registrerer, farver og kommenterer alt, hvad der 
foregår. Conesal har nemlig hyret Carvalho til at overvåge banketten fordi han selv er blevet truet på livet. Men på trods af Carvalhos tilstedeværelse myrdes Conesal under middagen, og i bogens sidste del hjælper Carvalho politiet med at forhøre de inviterede gæster.

\section{Tekstens stemmer}

Romanen, som er fortalt i tredje person, begynder in medias res ved festbankettens start, hvor de inviterede ankommer til hotellet. Scenen, der indleder første kapitel, starter med en i flere henseender påfaldende passage, som jeg vælger at citere i sin helhed:

Det var ikke til at undgå, og blev heller ikke undgået af en stor del af de deltagende, at passere det filter af journalister, som var mere eller mindre specialiserede i litterære priser, og som strejfede omkring iblandt de etablerede kritikere og deres undersåtter, som var bidt på krogen, lokket af at kunne vise at de ikke var som de andre ved at deltage ved uddelingen af Venice-Fundación Lázaro Conesal Prisen, hundrede millioner pesetas, den største litterære pris i Europa, på trods af den foragt som de altid havde følt for sammenhængen mellem de mange penge og litteraturen, når man altså så bort fra de omkring tres procent af historiens største forfattere, der kom fra magtfulde, for ikke at sige oligarkiske, familier (Vázquez Montalbán I996, 9. Alle oversættelser er mine). ${ }^{24}$

Karakteristisk for passagen er ikke blot den ekstremt lange og komplicerede periode, men også de mange stemmer som taler i teksten på én gang. Fortællerstemmen er anonym, men alligevel klart markeret i kraft af den sarkastiske distance, som kommer til udtryk i udstillingen af de deltagendes hykleriske holdninger. Selv om det ikke er detektiven som fortæller, genkender den trænede Carvalho-læser detektivens stemme bag den sarkastiske tone, der ligger som en holdningsmæssig farvning af indholdet. Stemmen forholder sig fra allerførste linje kritisk og nedladende til den kulturelle elite og deres ambivalente forhold til mediernes flashlights. Dette antydes f.eks. gennem den indskudte sætning »Det var ikke til at undgå, og blev heller ikke undgået ", hvor den anonyme fortællerstemme

\footnotetext{
${ }^{24}$ Den spanske tekst lyder således: »Era inevitable, e inevitado por buena parte de los asistentes, pasar el filtro de periodistas más o menos especializados en premios literarios, merodeantes en torno a críticos y subcríticos establecidos que habían acudido al reclamo para gozar la sensación de que no eran como los demás y podían asistir a la concesión del Premio Venice-Fundación Lázaro Conesal, cien millones de pesetas, el más rico de la literatura europea, a pesar del desdén que siempre les había merecido la relación enter el mucho dinero y la literatura, obviando a un sesenta por ciento de los mejores escritores de la Historia, pertenecientes a familias potentadas, cuando no oligárquicas «.
} 
markerer sig med en selvstændig vurdering af de deltagendes fordækte intentioner. I den følgende passage toner en ny stemme imidlertid igennem i fortællerens diskurs, idet læseren for sig hører propaganda-sloganet »Venice-Fundación Lázaro Conesal Prisen, hundrede millioner pesetas, den største litterære pris i Europa « udbasuneret som i et tv-reklamespot, mens de inviterede gæster efterfølgende refereres parodisk for det synspunkt, at sammenhængen mellem penge og litteratur er foragtelig "når man altså så bort fra de omkring tres procent af historiens største forfattere, der kom fra magtfulde, for ikke at sige oligarkiske, familier «. Således hører læseren nede i tredjepersonsfortællerens diskurs lyden af tre forskellige stemmer, der dialogeres: Pepe Carvalhos ikonoklastiske sarkasme, Conesal-imperiets propagandaslogan og kulturelitens parodierede hykleri.

Hvor romanens første par sider er præget af fortællerens kompakte sprog, der i sig dialogerer en flerhed af stemmer, så er resten af det første kapitel karakteriseret ved, at et mylder af stemmer træder frem og taler direkte og selvstændigt, næsten uden præsentation fra fortællerens side. Læseren kastes direkte ud i at være vidne til en række samtaler mellem forskellige af de inviterede personer, og kun langsomt finder man ud af, at det drejer sig om brudstykker af konversationen ved bankettens forskellige borde. Dialogfragmenterne vælter rundt oven i hinanden, og persongalleriet flimrer. Først langt senere i romanen får læseren dokumenteret, at Carvalho under middagen går rundt imellem bordene, og at også denne del af det første kapitel kan læses med ham som synsvinkelbærer. Flimmeret af samtalefragmenter giver først mening, når vi læser det som udtryk for detektivens observationer, mens han slentrer rundt.

Det eneste tidspunkt, hvor læseren i løbet af det første 50 sider lange Kapitel I får et konkret hint om at Carvalho er tilstedeværende i salen, er imidlertid da teksten ganske kortvarigt skifter synsvinkelbærer, og vi følger en af gæsterne, af fortællerstemmen sarkastisk givet tilnavnet Terminator, ud på toilettet, hvor han i døren støder på en mandsperson, der beskrives som »en mand med et udseende mellem medfødt strenghed og livstræt skuffelse «. ${ }^{25}$ Fanger læseren ikke i første omgang denne reference til Carvalho, bliver den tydeliggjort, da manden selvironisk præsenterer sig selv som James Bond og i øvrigt afslører en overraskende dyb indsigt i produktionen af dyr single malt whisky. Men idet læseren genkender denne udefra beskrevne person som Carvalho, spaltes læserens oplevelse mellem en ydre og en indre beskrivelse af personen, for Carvalho er jo samtidig den, der farver fortællerens beretning, og som implicit

${ }^{25}$ På spansk: »un hombre de aspecto entre la severidad congénita y el desencanto histórico«. 
fungerer som den synsvinkelbærer, der fører os rundt blandt bordene. Gennem farvningen af fortællerens sprog får læseren indblik i Carvalhos måde at opleve begivenhederne på, men gennem de fiktive personers 'finaliserende' blik får læseren samtidig et udvendigt billede af samme person, hvorved self og other dialogeres i læserens æstetiske oplevelse af tekstens åbenhed.

Personernes konkrete sprogbrug bliver romanen igennem brugt til at karakterisere forskellige sociale miljøer, og stemmerne bliver dermed det konkrete 'kit', som får den fiktive handling til at afspejle en konkret, social og politisk kontekst. Det gælder f.eks. kritikerne Marga Segurola og Altamirano, som Carvalho karakteriserer ved, at de taler 'på vers', eller erhvervsfolkenes stemmer, som tenderer mod at forstå hele verden som en urskov eller som en krig (alles kamp mod alle og den stærkestes ret). Men det gælder også det slang, som den unge punk-lømmel Dios nos pille senere i romanen benytter sig af. Det samtidige madrilenske slang modstilles på den ene side det elaborerede kunstsprog, som tales inde på hotellet til middagen, og på den anden side Carvalhos erindring om tyve år gammelt madrilensk slang. Disse distinkte og genkendelige former for sprogbrug slår fra tid til anden over i en parodisk stilisering, som når Carmela, lømlens mor, må oversætte drengens tale til Carvalho, eller når Marga Segurola og Altamirano svinger sig højest op i deres semilitterære kitsch-sprog. Ikke desto mindre kan romanens æstetiske strategi beskrives som en orkestrering af ideologiske synspunkter og verdensanskuelser, som det bliver læserens rolle at dialogere.

Urskovskronotop og krimigenre

Efter det første kapitel, som hovedsageligt udgøres af de skildrede samtaler, vender Kapitel II tilbage til det tidspunkt nogle dage før festbanketten, hvor Conesal kontakter Carvalho i hans hjem. Således bliver handlingen temporalt splittet op i to forskellige typer af sekvenser, en fremadskridende, der handler om den aften festbanketten afholdes og hvor Conesal myrdes, og en anden tilbageskuende, hvor læseren får forhistorien fortalt. Denne tilbageskuende fortælling komplementeres senere i romanen af gæsternes vidneudsagn under forhøret, der følger oven på mordet.

Rummet, som præger de temporalt fremadskridende sekvenser, er begrænset og udgøres af hotellets spisesal, herretoilet og det rum, som senere bliver indrettet til forhørslokale. Spisesalen opdeles så igen hierarkisk i overensstemmelse med de sociale rum omkring forskellige borde, som samtidig antyder personernes placering på en social rangstige: "landets største formuer delte bord med de forfattere, som var udset til en 
skønne dag at modtage Cervantes-prisen [...] De endnu ikke anerkendte forfattere sad længere væk fra hovedbordet « (Vázquez Montalbán I996, $2 \mathrm{I}-22){ }^{26}$

Rummet, som præger de temporalt tilbageskuende sekvenser, er til gengæld præget af åbenhed og et væld af referencer til konkret genkendelige steder i Barcelona og Madrid. I Madrid ligger Hotel Palace f.eks. lige ved siden af Palacio del Congreso (s. 74), og i gå-afstand herfra finder vi Huertas-kvarteret med la calle del Prado, Echegaray og Espoz y Mina samt Plaza Santa Ana, som er en plads fuld af cervecerías og med et ArtDeco hotel ved navn Hotel Victoria (s. 75). I Madrid finder vi også El Café Gijón (s. 84) og kvarteret ved navn La Moraleja (s. I6I). Alt sammen spatiale indekser, der peger på et konkret socialt og historisk genkendeligt rum.

Disse to kronotopiske strukturer dialogeres i læseprocessen, således at læseren forstår handlingen i de temporalt fremadskridende sekvenser i lyset af begivenhederne i de tilbageskuende, men samtidig også forstår den sociale orden i de tilbageskuende sekvensers realistiske rum på baggrund af den stærkt hierarkiserede magtstruktur, som bliver tegnet op i de temporalt fremadskridende sekvenser. I tilgift overlejres dette konkrete, historiske rum i visse passager med en symbolsk dimension, idet de økonomisk stærkeste personer som nævnt bruger junglen som en metafor for det moderne spanske samfund: »la jungla de Madrid « (s. 74) og »la jungla capitalista « (s. I 67). Hermed understreger disse stemmer det synspunkt, at det senkapitalistiske samfund blot fungerer efter de samme lovmæssigheder, som samfundene har gjort siden tidernes morgen, nemlig jungleloven.

Dette ideologiske synspunkt synes at finde resonans i en scene hen imod slutningen af Kapitel II, hvor to unge kvindelige og politisk bevidste studerende opsøger Conesal for at lave et kritisk interview med ham, mens Carvalho lytter på. De to piger præsenteres i et seksualiseret sprog farvet af Carvalhos bevidsthed, der benytter sig af et metaforisk dyreskema som inddeler personerne i rovdyr og offerdyr. Pigerne præsenteres med ordene »blide som gazeller, men stive som pantere parate til at springe i halsen på finansmanden « (s. IOI) ${ }^{27}$ altså som rovdyr, men dog med offerdyrets ynde. Ud fra denne synsvinkel optræder Conesal i rollen som muligt offer, men umiddelbart forinden er Conesal selv blevet

\footnotetext{
${ }^{26}$ Den spanske tekst lyder således: »las primeras fortunas del país compartían mesas con los destinados a recibir algún día el premio Cervantes [...] Los escritores todavía no consagrados estaban más alejados de la mesa presidencial $[\ldots]$..

${ }^{27}$ Den spanske tekst lyder således: »tiernas como gacelas, pero rígidas como panteras dispuestas a saltar al cuello del financiero«.
} 
karakteriseret som »el Gran Tiburón «(den store haj). Man kunne derfor forvente, at mødet mellem de to parter i mindre grad bliver et møde mellem rovdyr og offerdyr, men snarere en kamp mellem to typer af rovdyr. Beskrivelsen af selve interviewet fortsætter den erotiserede sprogbrug og lader dermed læseren forstå, at det i Carvalhos øjne er Conesals fysiskerotiske magt og udstråling som $\mathrm{i}$ sidste ende besejrer pigerne, og forvandler dem til »to småfisk som nervøst bed sig selv i halen «(s. IO2). ${ }^{28}$ I tilfældet Conesal spiller økonomisk magt og fysisk seksuel udstråling sammen på en måde som gør, at pigerne ikke kan undgå at havne i offerrollen. Det metaforiske skema bag beskrivelsen bliver vendt: Pigerne der først blev præsenteret som rovdyr, bliver selv ædt, og urskovskronotopens ideologiske budskab træder frem: Æd de andre eller bliv selv ædt!

Som José Colmeiro påpeger i sin gennemgang af kriminalgenrens udvikling i Spanien, er Vázquez Montalbáns kriminalromaner skrevet i dialog med den 'sorte' kriminalroman (Colmeiro I 994), og fortællerstemmens kritisk-sarkastiske distance til den neoliberale ideologi, som kommer til udtryk i den sarkastiske brug af urskovskronotopen, giver da også stærke mindelser om den samfundsbeskrivelse, som man finder i den sorte kriminalroman. Begrebet den 'sorte' krimi kan man finde diskuteret hos Todorov, der skelner mellem kriminalgenrens to undergenrer, hhv. den 'klassiske' krimi (Arthur Conan Doyle og Agatha Christie) og den 'sorte' (Dashiell Hammet og Raymond Chandler). Todorov karakteriserer forskellen på de to som en strukturel forskel i forholdet mellem de to historier, som karakteriserer kriminalfortællingen som sådan: forbrydelsens historie og opklaringens historie (Todorov I988, I 59 ff.). Hvor den klassiske whodunit klart adskiller de to historier og oftest helt udelader den første for at fokusere eksklusivt på den anden, integrerer den amerikanske thriller de to historier til én, hvorved karakteren af læserens æstetiske oplevelse ændres. Fra at være en intellektuel nysgerrighed, knyttet til gådens løsning som i et puslespil, bliver det et spændingsmættet suspense, knyttet til det konkrete udfald af personernes handlinger. Men Todorov påpeger samtidig, at det for den klassiske krimi er et centralt genredefinerende træk at de to historier holdes adskilt, mens man ikke kan sige at det modsatte gælder for den sorte genre. Her varierer de strukturelle forhold mere, og det er i højere grad tematik og miljøbeskrivelse som udgør de genrespecifikke elementer: »violence, generally sordid crime, the amorality of the characters " (op.cit. I62).

José Colmeiro bygger videre på Todorovs distinktion, men applicerer samtidig Northrop Fryes skelnen mellem det 'romantiske' og det 'ironi-

${ }^{28}$ Den spanske tekst lyder således: "dos pescadillas que ya estaban mordiéndose la cola nerviosamente . 
ske', det 'komiske' og det 'tragiske', på de to undergenrer (Colmeiro I994, 65 ff.). Den klassiske krimi er ifølge Colmeiro romantisk fordi den henviser til hovedpersonens lighed med ridderskikkelsen fra middelalderens romancer og ridderromaner. Romanen giver et idealiseret portræt af en person, der handler ud fra en overordnet målsætning: opretholdelsen af den sociale orden. Og den er komisk fordi den henviser til den klassiske komediegenre, hvor handlingen altid ender godt. I den klassiske krimi ender historien altid med en opklaring, der sikrer den sociale ordens opretholdelse. Heroverfor kan den sorte genre, ifølge Colmeiro, karakteriseres ved at være ironisk og tragisk. Den er ironisk fordi hovedpersonen er en marginaliseret antihelt der bliver personligt involveret $i$ historien, og fordi det sociale miljø er realistisk skildret. Beskrivelsen trækker på paralleller til guldalderens pikareske romaner (antihelten, det groteske miljø, den kritiske synsvinkel), og det er svært at skelne de(t) gode fra de(t) onde. Og den er tragisk, fordi det inden for den sorte genre ikke er muligt at finde en egentlig 'lykkelig' slutning, idet kriminaliteten er en integreret del af den sociale orden. Den kan sammenlignes med de klassiske tragedier, hvor skæbnen ligeledes umuliggør den lykkelige slutning.

Colmeiros bearbejdning af de to undergenrer munder ud i en modstilling ud fra en række kriterier, som virker anvendelige til at beskrive de læserforventninger, Carvalho-serien trækker på, når den lægger sig op ad den sorte krimi: Det gælder forhold såsom hovedpersonens personlighed, detektivarbejdets karakter, forholdet mellem forbrydelse og samfund, handlingens slutning og historiens morale samt forholdet mellem æstetisk strategi og etisk stillingtagen i teksten (op.cit. 56 ff.). Den klassiske krimi er karakteriseret ved at hovedpersonen er en socialt velanset og usårlig superdetektiv, der konfronteres med en forbrydelse, som krænker samfundets harmoniske normalitet. Der er med andre ord tale om en klar skelnen mellem godt og ondt, og detektivens indsats for at reetablere den 'gode' orden har karakter af en intellektuel leg, som ikke involverer ham personligt. Slutningen er lykkelig i den forstand at forbryderen bliver fanget, og samfundets harmoni genoprettet. Og endelig kan man sige at selv om der altid er et etisk aspekt involveret i den klassiske krimis stillingtagen til godt og ondt, harmoni og uorden, så er det de æstetiske aspekter af forbryderens legen kispus med detektiven, som dominerer genren. Heroverfor er den sorte krimi karakteriseret ved at hovedpersonen er en marginaliseret antihelt, ofte fysisk stærk og med moralske skrupler. Han drives af et personligt æreskodeks og bliver direkte og personligt involveret i historien, hvor han gengælder vold med vold, og hvor han selv viser sig sårbar. I modsætning til den klassiske kriminalroman er der i den sorte genre ikke noget, som adskiller forbrydelsens princip fra samfundets 
måde at fungere på i almindelighed, snarere synes det som om forbryderen følger samfundets etablerede normer. Forholdet mellem godt og ondt relativiseres, og romanen kan derfor ikke ende 'godt', men må slutte mere åbent. Og hvad angår forholdet mellem de æstetiske og etiske dimensioner, vil kriminalgåden ofte tjene som en narrativ ramme for en social kritik med etisk sigte.

På en lang række punkter følger Carvalho-bøgerne den sorte kriminalromans genrekodeks. Pepe Carvalho er et godt billede på den desillusionerede antihelt, der ikke føler sig hjemme i samfundets øverste sfærer, men skruppelløst spiser den gode mad og nyder den gode spiritus. Generelt blander Carvalho-romanerne forbrydelsens og opklaringens historie, og kriminalintrigen udgør den narrative ramme omkring en skildring af det moderne Spaniens sociale og politiske udvikling, som har en udtalt kritisk brod. Carvalho-figurens dyrkelse af gastronomien og hans særhed med bogbrændingerne kan endvidere ses som en ironisk genskrivning af de 'tics' man finder hos den stereotype detektiv i den sorte genre. Men samtidig leger Carvalho-bøgerne med krimigenrens normer på forskellig måde. F.eks. er det ikke usædvanligt at kriminalintrigen suspenderes til fordel for lange passager, der handler om hovedpersonens personlige problemer og søgen efter identitet. Således bruges detektivens undersøgelser ofte som et billede på hovedpersonens søgen efter sit eget 'jeg', i en fremstilling der konstant skifter mellem forskellige litterære fremstillingsformer, og hvor tekstens strategi med de mange intertekstuelle referencer forudsætter en læser med højtudviklede kulturelle og litterære kompetencer.

Endelig må man sige at El premio i særdeleshed bryder med kriminalromanens genrekodeks i kraft af den udtalte selvreferentielle understrøm, der ligger gennem hele romanen. Igennem de diskussioner, som forfattere og litteraturkritikere fører ved prisuddelingen, bliver læseren stillet over for at skulle tage stilling til forskellige udlægninger af forskellige litterære genrers sociale egenart, og ikke mindst er det krimigenren der bliver taget op til debat. Samtidig betyder romanens slutning at der bindes en ironisk, selvreferentiel sløjfe på bogens handling, som snarere hører hjemme i den sprogskepticistiske ende af den postmoderne romantradition end i en kriminalroman. På hjemvejen i flyet på vej fra Madrid til Barcelona sætter Carvalho sig til at læse det manuskript, som vandt konkurrencen, og det viser sig at begynde med den selv samme passage som El premio starter med, og som vi citerede i starten af denne læsning. Romanen hedder Ourobouros, et navn som henviser til den mytologiske slange, der som symbol på den uendelige gentagelse, bider sig selv i halen. 
Den intertekstuelle dialog med litteraturteorien

Forholdet mellem litterær fiktion og 'virkelighed' bliver taget op gentagne gange i løbet af romanen, og de fiktive personers synspunkter på dette spørgsmål kan opsummeres i to positioner, som man kunne kalde en hhv. mimetisk og anti-mimetisk holdning. Inden for den mimetiske position, der ser en snæver afhængighedsrelation imellem virkelighed og kunst, finder vi igen to underpositioner. På den ene side finder vi Aristoteles' forestilling om, at kunsten efterligner virkeligheden, ironisk parafraseret af Carvalho: »kunsten efterligner virkeligheden « (op.cit. 258), og på den anden side vender kritikeren Altamirano denne position på hovedet, idet han på postmoderne vis ser det som et spørgsmål om at »livet efterligner litteraturen " (op.cit. I 38 ). ${ }^{29}$ Blandt de anti-mimetiske forestillinger om at fiktion og virkelighed er adskilte størrelser, finder vi ligeledes to positioner. Ifølge Conesal er den litterære fiktion en måde at slippe væk fra virkeligheden på: Det handler ikke om at litteraturen omskaber virkeligheden, men om at »den erstatter den med en anden, frit opfundet af forfatteren [...] Litteraturen er det eneste virkeligt pålidelige redskab til at bringe orden tilbage i virkeligheden uden at forringe den « (op.cit. 64). ${ }^{30}$ Heroverfor kan Carvalhos bogbrænding ses som udtryk for en skuffelse over at bøgerne netop ikke fremstiller verden, sådan som den virkelig er: »ikke engang Marlowe snakkede som Chandler. I det virkelige liv snakker privatdetektiverne som kvæghandlere « (op.cit. I 2I). ${ }^{31}$ Over for Conesal begrunder Carvalho desuden sine bogbrændinger med, at bøgerne »ikke har lært mig at leve lige så godt som Dem« (op.cit. I 89). Når Carvalho som en anden modreformatorisk inkvisitor dømmer bøger til bålet, er han først og fremmest ude efter at slå ned på fiktionslitteraturens idealiserende og romantiserende 'løgne'. Således var Pablo Nerudas Tyve koerlighedsdigte en af de første bøger han brændte (s. 23I), mens det af en af Vázquez Montalbáns tidligere bøger fremgår, at García Lorcas Digter $i$ New York er en af de få bøger, som har opnået amnesti hos detektiven, fordi det at brænde den ville være ligesom at henrette digteren for anden gang. ${ }^{32}$ Endelig bliver de to hovedpositioner (den mimetiske og den antimimetiske) aktualiseret $\mathrm{i}$ forhold til romanens overordnede æstetiske strategi, der netop er udspændt mellem den konkrete sociale og politisk

\footnotetext{
${ }^{29}$ På spansk: »el arte imita a la realidad « og »la vida imita a la literatura «.

${ }^{30}$ Den spanske tekst lyder således: »la literatura [...] no es que transforme la realidad, la sustituye por otra, según la real gana del escritor [...] La literatura es el único instrumento solvente de reordenar la realidad sin empeorarla ".

${ }^{31}$ Den spanske tekst lyder således: »ni siquiera Marlowe dialogaba como Chandler. En la vida real los detectives privados dialogamos como vendedores de ganado «.

${ }^{32}$ Det drejer sig om romanen El delantero centro fue asesinado al aterdecer (1988).
} 
engagerede kritik på den ene side og tekstens suspension af sig selv som ren og skær tekst i kraft af Ouroboros-slutningen på den anden.

Mere specifikt bliver kriminalgenren taget op til diskussion flere gange i løbet af romanen. I en samtale mellem æstetikerne Altamirano og Marga Segurola kæder førstnævnte krimigenren sammen med Fryes beskrivelse af det ironiske verdenssyn, hvilket kunne tyde på at han med begrebet 'krimigenren' refererer til den sorte krimi, jf. Colmeiros beskrivelse ovenfor. Men efterfølgende tilføjer han, at kriminalgenren efter hans mening er udtryk for en æstetisk degradering af litteraturen som kunstform: »de mest monotone og sløsede almindeligheder forvandles til elementer forlenet med en skæbnesvanger og mystisk betydning [...] det er den litterære logiks fornedrelse [...] avantgardistisk propaganda for politistaten i den forstand at den medvirker til at acceptere volden « (s. 5 I). ${ }^{33}$ Læsere med kendskab til teorien omkring kriminalromanens to undergenrer fornemmer her en diskrepans i den forstand at den sorte krimi, i hvert fald hos Todorov og Colmeiro, netop først og fremmest er kendetegnet ved dens tematiske indhold og samfundskritiske indstilling. Denne mistanke bestyrkes da Marga Segurola nogle sider længere fremme udtaler, at »med hensyn til krimien er jeg enig $i$ at det handler om en overføring af labyrintens mytologi i moderniseret form til storbyens labyrint « (op.cit. 57)..$^{34}$ Som begge citater viser, diskuterer de to kritikere den sorte kriminalromans æstetiske og etiske karakteristika på en måde, som afviger afgørende fra Colmeiros beskrivelse, idet de først og fremmest betragter den æstetisk, jf. henvisningen til labyrinten og den litterære gæld som herigennem etableres til f.eks. Kafka, Beckett, Perec og måske Borges som den allervigtigste. Men samtidig viser de også at de har misforstået den sorte krimis etiske side, idet de ser den som udtryk for en legitimering af volden og politistaten i stedet for at se den som udtryk for en social og politisk kritik.

Har læseren kendskab til Colmeiros bog, kan denne med andre ord se hvordan de to æsteter parodieres og udstilles ironisk. Dette indtryk forstærkes af at den forfatter, som kritikerne retter deres kritik imod er den fiktive person Sánchez Bolín, som i flere at Vázquez Montanbáns romaner optræder som hans eget alter ego. Det skulle altså med andre ord være Vázquez Montalbán selv, der angiveligt stod for den avantgardistiske

\footnotetext{
${ }^{33}$ Den spanske tekst lyder således: »trivielle las trivialidades más monótonas y descuidadas de la vida cotidiana se convierten en elementos de un significado misterioso y fatal [...] es la degradación de la lógica literaria [...] propaganda de vanguardia del estado policial, en la medida en que ayuda a aceptar la violencia «.

${ }^{34}$ Den spanske tekst lyder således: »En lo referente a lo policíaco sí que estoy de acuerdo con que se trate de una transposición de la mitología del laberinto, modernizada en relación con el laberinto urbano .
} 
propaganda for politistaten. Er det på den baggrund for langt ude at hæude at romanen etablerer en intertekstuel dialog med Colmeiros litteraturvidenskabelige afhandling, som udkom to år før El premio? Det mener jeg ikke det er, for det kan dokumenteres at Vázquez Montalbán har haft indgående kendskab til Colmeiros bog, til hvilken han bl.a. selv skrev forordet. Og denne implicitte intertekstuelle reference til Colmeiros bog antyder i hvor høj grad, Vázquez Montalbán forudsætter et udviklet litteraturteoretisk beredskab hos sine læsere, hvis disse skal være i stand til at fange alle de 'fremmede ord', som blander sig i tekstens encyklopædiske labyrint af betydninger, og indfri tekstens æstetiske strategi.

\section{Æstetiske træk ved den umiddelbare interpretant}

Ovenfor har jeg kort skitseret, hvordan tre anerkendte, litteraturteoretiske traditioner kunne bidrage til opstillingen af en generel semiotisk model over den æstetiske erfaring. På det morfosyntaktiske niveau blev Roman Jakobsons teori om sprogets poetiske funktion brugt som eksempel på, hvordan værkets formgivning kan tilskrives en betydningsmæssig dimension. På det semantiske niveau anvendte jeg Paul Ricœurs begreb om den levende metafor til at skildre det æstetiske spændingsforhold i den poetiske metafor, mens Mikhail Bakhtins polyfonibegreb og intertekstuelle dialogisme blev anvendt til at illustrere den pragmatiske side af den æstetiske erfaring. Fælles for alle tre tilfælde har været, at det særligt æstetiske har kunnet lade sig forklare som et modalt spændingsforhold imellem en potentiel åbenhed, en hændelsesmæssig aktualisering og en logisk betydningstilskrivelse. Og dette spændingsforhold er efterfølgende begrebsliggjort med Peirces skelnen mellem tre interpretantformer: den emotionelle, den energetiske og den logiske interpretant. Dette kan skildres i følgende skema:

\begin{tabular}{|l|l|l|l|}
\hline & $\begin{array}{l}\text { Emotionel inter- } \\
\text { pretant }\end{array}$ & $\begin{array}{l}\text { Energetisk inter- } \\
\text { pretant }\end{array}$ & Logisk interpretant \\
\hline Morfosyntaks & Similaritet & Brud & Signifikans \\
\hline Semantisk & $\begin{array}{l}\text { Mulig betydning } \\
\text { Ikonisk åbenhed }\end{array}$ & $\begin{array}{l}\text { Afvigelse } \\
\text { Semantisk clash }\end{array}$ & $\begin{array}{l}\text { Semantisk pertinens } \\
\text { Symbolsk polysemi }\end{array}$ \\
\hline Pragmatisk & $\begin{array}{l}\text { Unfinalizability } \\
\text { Generisk kronotop } \\
\text { Heteroglossia }\end{array}$ & $\begin{array}{l}\text { Den andens ord } \\
\text { Forvridning } \\
\text { Kollision }\end{array}$ & $\begin{array}{l}\text { Dialog } \\
\text { Specifik kronotop } \\
\text { Orkestrering }\end{array}$ \\
\hline
\end{tabular}


Den emotionelle interpretant er determineret af værkets form og materiale, der giver læseren en oplevelse: en følelse, en stemning osv. Materialet i et digt er ord, forstået simpelthen som ord; i et billede er der tale om former og farver, simpelthen som former og farver i sig selv. Den energetiske interpretant kan beskrives gennem de reaktioner, som sætter sig igennem med ubetinget nødvendighed, idet læseren konfronteres med værket som en provokation, mens den logiske interpretant, der kræver en mediering mellem værkets formaspekter og det repræsenterede fiktive univers, må indebære en form for logisk refleksion. Disse interpretantfunktioner udgør modalformer i den æstetiske reception, som på niveauet for den umiddelbare interpretant kan analyseres i det omfang man kan tale om en i værket indskrevet læsning. Det er det, vi med Umberto Ecos begreb har kaldt 'tekstens strategi'.

En sådan skildring af den æstetiske erfaring bygger på en fænomenologisk forståelse af æstetikken, hvor den æstetiske kvalitet i højere grad knyttes til en bestemt betragtningsmåde, et æstetisk blik, end den er knyttet til særlige karakteristika ved det betragtede objekt. Den spanske filosof José Ortega y Gasset er inde på det samme, når han beskriver den moderne kunstoplevelse med den kendte glasrude-metafor i Menneskets fordrivelse fra kunsten fra 1925 :

Læseren må forestille sig, at vi betragter en have gennem en glasrude [...] Eftersom genstanden for vores betragtning er haven, og vores blik er rettet imod den, vil vi ikke se ruden; blikket går lige igennem den. Jo finere glasset er, desto mindre vil vi lægge mærke til det. Men hvis vi gør os en anstrengelse, kan vi se bort fra haven og fæstne blikket på glasset. Så forsvinder haven for vores øjne, og det eneste der er tilbage er nogle diffuse farver, som forekommer at være klæbet til glasset (Ortega y Gasset 1987,53 . Min oversættelse). ${ }^{35}$

Ortegas beskrivelse af det æstetiske objekt som en relation mellem betragter og yderverdensobjekt er grundlæggende set fænomenologisk, idet æstetikken bliver forstået som en måde at betragte verden på. Philip Silver beskriver Ortegas fænomenologisk funderede kunstsyn således:

Kunsten består [for Ortega y Gasset, HLH] grundlæggende set i at gøre verden uvirkelig; det kunstneriske objekt er et nyt og idealt objekt, som hverken er af

\footnotetext{
${ }^{35}$ Den oprindelige tekst lyder således på spansk: »Imagínese el lector que estamos mirando un jardín a través del vidrio de una ventana [...] Como la meta de la visión es el jardín y hasta él va lanzado el rayo visual, no veremos el vidrio, pasará nuestra mirada a su través, sin percibirlo. Cuanto más puro sea el cristal menos lo veremos. Pero luego, haciendo un esfuerzo, podemos desentendernos del jardín y, retrayendo el rayo ocular, detenerlo en el vidrio. Entonces el jardín desaparece a nuestros ojos y de él solo vemos unas masas de color confusas que parecen pegadas al cristal .
} 
psykologisk eller fysisk karakter, og som et af sine karakteristika har at det tilintetgør virkeligheden (Silver I971, 377). ${ }^{36}$

Vinduesmetaforen for maleriet kan ifølge Ernst Gombrich føres tilbage til renæssance-teoretikeren Leon Battista Alberti. Alberti beskrev i Della Pittura (I435-36) maleriet som et vindue til den synlige verden, og Leonardo da Vinci beskrev, på baggrund af Albertis tekst, det tredimensionelle perspektiv som »nothing else than seeing a place behind a pane of glass, quite transparent, on the surface of which the objects behind the glas are to be drawn « (citeret efter Gombrich I960, 299).

Idet vinduesmetaforen hos såvel Alberti som hos Leonardo da Vinci er bundet til udviklingen af det tredimensionelle perspektiv, forekommer det oplagt, at Ortegas brug først og fremmest knytter sig til opgøret med perspektivismen som den mimetiske illusionismes forudsætning. Hos Ortega udmøntes vinduesmetaforen da også som en beskrivelse af, hvordan havens farver forvandles til en perspektivløs, todimensional masse, påklæbet glassets flade uden dybde og kontur, der giver mindelser om f.eks. kubismens bestræbelser på at ophæve perspektiv og dybde i maleriet. Eksemplet viser, hvordan en semiotisk begrebsliggørelse af den æstetiske kontemplation som et spil mellem modale kategorier kan fungere som teoretisk beskrivelsesramme for studierne af interartistiske relationer. Således skrev Jose Luiz Martinez fra internetdiskussionslisten Musikeion d. I3/4 I999 følgende med udgangspunkt i en, efter min mening, tilsvarende forståelse af det æstetiske hos Peirce:

I have worked on a hypothesis that there is a mode of aesthetical apprehension that consists in abstracting - by a conscious effort - the aspects of firstness out of the complex, which includes secondnesses and thirdnesses. As both secondness and thirdness have their qualities of firstness, it is clear that the firstnesses we experience are related to that sign universe. For instance, when we go to Madrid and look at the Guernica, we see a canvas painted by Picasso, signifying his ideas on an episode of the Spanish civil war. Yet, we can look at the colors, we can look at the forms and see just what they are, forgetting that it was painted by such and such individual in such and such historical circumstances. If you can't see the forms and the colors, and you only think of the man Picasso and the history of Spain and the dreadfulness of totalitarian systems, and, once again, you don't see the qualities, I doubt you are seeing any piece of art. You see at most an object, an indexical sign of human history. (Jose Luiz Martinez, Pontificia Universidade Catolica de São Paulo, http:// www.pucsp.br/pos/cos/rism/muskfram.htm. Mine fremhævninger).

\footnotetext{
${ }^{36}$ Den oprindelige tekst lyder således på spansk: »El arte es esencialmente irrealización; el objeto artístico es un nuevo objeto ideal que no es ni de carácter psicológico ni de carácter físico, y contiene, como uno de sus elementos, la trituración de la realidad «.
} 
Maurice Merleau-Ponty, som i særlig grad har beskæftiget sig med forholdet mellem synet, fremtrædelsen og malerkunsten, beskriver forholdet mellem synet og det sete som værende grundlæggende kropsligt. Sanser som synet, høre/tale- og følesansen er kødeligt funderede i en krop og som sådan til stede blandt de elementer, hvori der ses, tales eller føles. Der er derfor ikke tale om en entydig subjekt-objekt-relation, men om det som Merleau-Ponty kalder et reversibelt forhold. Uden i øvrigt at intendere en større gennemgang af Merleau-Pontys fænomenologi eller at argumentere for en sammentænkning af denne med Peirces kategorier, vil jeg blot pege på, hvorledes Merleau-Pontys beskrivelse af forholdet mellem det, han kalder 'betydning' og 'tale', forbilledligt udtrykker det, som jeg ville kalde den logiske interpretants dominans over de andre modaliteter i den ikkeæstetiske perception. Merleau-Ponty formulerer det således:

Ligesom der består et reversibelt forhold mellem den seende og det synlige, og ligesom det, vi kalder perception, opstår dér, hvor de to metamorfoser mødes, således består der en reversibel relation mellem talen og det, den betyder; betydningen er det, der til sidst forsegler, slutter, samler mangfoldigheden af fysiske, fysiologiske, lingvistiske momenter af udtaleakten, koncentrerer dem i én eneste handling, ligesom synet fuldender den æstesiologiske krop; og ligesom det synlige bemægtiger sig det blik, som netop har blotlagt det, og som tager del i det, således vælder betydningen tilbage over sine virkemidler, annekterer sig talen, som bliver videnskabsobjekt, foruddaterer sig selv ved en tilbagegribende bevægelse, som aldrig er helt forgæves, fordi talen allerede ved at åbne det nævneliges og sigeliges horisont tilstod, at den selv har sin plads her, fordi ingen talende taler uden på forhånd at gøre sig til tiltalt, $i$ det mindste af sig selv [...] (Merleau-Ponty I969, 278).

Kunst adskiller sig netop fra andre typer af tekster i aflæsningen, i det vi her har kaldt et æstetisk blik. Det særlige ved det æstetiske blik er, at det indbefatter spørgsmålet om form, dvs. at det intenderer en helhedsbetragtning af teksten (talen hos Merleau-Ponty), hvorved relationen mellem tekstens fænomenologiske modaliteter bliver central. Herved accentueres spændingen mellem de logiske interpretanters ordnende og enshedssøgende funktion på den ene side, og de kaotiske, spontane og irrationelle elementer, som tilhører de to andre modaliteter, på den anden.

Det æstetiske blik er således kendetegnet ved at være en bestemt måde, hvorpå læseren af en tekst eller betragteren af et objekt betragter denne tekst eller dette objekt. Et kunstværk kan være udformet på en sådan måde, at det i kraft af sin strategisk tilrettelagte formgivning (jf. Bakhtins arkitekturbegreb) tilskynder betragteren til at anlægge et æstetisk blik, men den æstetiske kontemplation kan nøjagtig lige så godt anvendes over for brugsobjekter (design) eller over for naturens former. Under alle 
omstændigheder opstår den æstetiske kvalitet altid først i den aktualiserede betragtning som en hændelse eller 'dom'. Det betyder at den æstetiske kvalitet således ikke er noget, som ligger i objektet i sig selv, men noget som indgår som et samspil af modaliteter i læserens eller betragterens erfaring. I den forstand, og kun i den forstand, kan man sige at den her beskrevne definition tilnærmer sig Kants beskrivelse af den æstetiske dom, som er karakteriseret ved det, Kant kalder 'subjektiv universalitet', dvs. at den på den ene side er subjektivt erfaret og på den anden side gør krav på at have universel gyldighed.

Det, at en læser af et litterært værk eller en betragter af et kunstværk anlægger et æstetisk blik, er naturligvis i vidt omfang styret af de genremæssige forventninger, som den litterære eller kunstneriske diskursorden determinerer. At et kunstnerisk objekt så alligevel ofte er tilrettelagt på en sådan måde, at det i særlig grad stimulerer denne betragtningsform og dermed vender betragterens opmærksomhed 'indad' mod objektets eller tegnets egen form, er en anden sag, som vi har diskuteret med afsæt i Umberto Ecos strategibegreb. Anskuet på denne måde kan den æstetiske strategi bag moderne kunstværker karakteriseres modalt ud fra deres vægtning af emotionelle, energetiske og logiske interpretanter. Kubismen og andre 'puristiske' avantgardestrømninger (suprematisme og til dels futurisme mv.) kan f.eks. siges at være kendetegnet ved at betone æstetiske aspekter knyttet til den emotionelle interpretants semiotiske register, mens dadaismen og surrealismen, med deres provokationer og grænseoverskridende æstetik, kan karakteriseres ved at betone aspekter knyttet til den energetiske interpretants semiotiske register (Hansen I996 og I997). 


\section{ETISK ERFARINGSDANNELSE I LITTERATUR}

Dette kapitel handler om, hvordan læsning af litterære tekster kan forstås som etiske eksperimenter med imaginære erfaringer. Den litterære erfaring er i Kapitel II blevet skildret som det kreative og læsende selvs møde med en imaginær 'anden', hvor selvets og den andens erfaringer udveksles dialogisk i form af omvendingen self as other og other as self (Bakhtin). Det forhold, at den imaginære erfaring i de bedste tilfælde kan spille den samme rolle som den direkte, kommunikative interaktion med den anden i subjektets identitetsdannelse, sætter det etiske spørgsmål som et centralt og uomgængeligt punkt på den litterære kritiks dagsorden, snævert knyttet til spørgsmålet om tekstens reference. Subjektets forhold til den anden er grundlæggende set et etisk spørgsmål, som i Peirces terminologi vedrører »those things whose end lie in action « (CP 5.I 29), altså de spørgsmål som vedrører subjektet handlen over for den anden. Også hos Bakhtin formuleres forholdet til den anden som et etisk spørgsmål, al den stund det altid indebærer en situering af subjektet historisk, kulturelt og holdningsmæssigt/ideologisk i forhold til en kontekst. Selve subjektets emplazamiento (Vázquez Medel) involverer med andre ord en uomgængelig etisk dimension.

Fra at den litterære teksts betydning i forudgående kapitel blev betragtet som et rent potentiale, knyttet til teksten i sig selv (den umiddelbare interpretant hos Peirce), bliver teksten i dette kapitel betragtet som en betydningsskabende handling. Læserens aktualisering af tekstens betydning gennem læseakten indebærer, at teksten gives reference til en konkret virkelighed, og at tekstens etiske og moralske dilemmaer diskuteres som vedkommende og aktuelle for den empiriske læser. Læsningen udmønter sig derfor i det, som Peirce ville kalde en dynamisk interpretant. En af den pragmatiske sprogvidenskabs mest grundlæggende præmisser består netop i den iagttagelse, at sprog først opnår konkret betydning når det betragtes som led i den kommunikative interaktion, hvor det opnår reference til en kontekst. Når det ikke bare handler om sprog i al almindelighed, men om litterære tekster, er man imidlertid nødt til at spørge: hvilken kontekst? Hvilken verden er det, vi læser teksten som havende reference til: den samfundsmæssige og kulturelle kontekst tilhørende tekstens kreationsproces, det korpus af samtidige og tidligere hypertekster som udgør tekstens kreationsmæssige 'grund' eller læserens samtidige samfundsmæssige og kulturelle kontekst? Den litterære tekst har en splittet reference til alle tre niveauer, og der knytter sig forskellige typer af overvejelser til hver af disse referentielle betydningslag. Ovenfor 
har vi allerede været inde på det æstetiske aspekt af tekstens genremæssige forankring og intertekstuelle relationer. I det følgende skal vi koncentrere os om hvordan den litterære teksts reference til dens fiktive univers altid opstår i dialog med referencen til dens oprindelige kontekst på den ene side og til læserens egen samtidige kontekst i den konkrete læseproces på den anden, og hvordan den etiske stillingtagen udgør et uomgængeligt moment i denne dialogiske relation.

\section{Fiktion mellem indekser og objekter}

Ifølge Peirce er der ingen kvalitativ forskel på sproget i litterære tekster, som henviser til en fiktiv verden, og tekster der henviser til en 'virkelig' verden, forstået som et univers knyttet til kropsliv livserfaring. Som tekster forstået, dvs. på niveauet for den umiddelbare interpretant i Peirces terminologi, henviser begge typer af tekster blot til rent mulige universer med reference til en almen, kulturel 'grund'. For at en tekst kan få en egentlig reference, skal den forankres i det, som Peirce kalder modtagerens collateral experience. I »The Critique of Arguments « fra I 892 påpeger Peirce således følgende:

It is requisite then, in order to show what we are talking or writing about, to put the hearer's or reader's mind into real, active connection with the concatenation of experience or of fiction with which we are dealing, and, further, to draw his attention to, and identify, a certain number of particular points in such concatenation. If there be a reader who cannot understand my writings, let me tell him that no straining of his mind will help him: his whole difficulty is that he has no personal experience of the world of problems of which I am talking, and he might as well close the book until such experience comes (CP 3.4I9).

I den konkrete kommunikationsproces forstår den empiriske læser den læste tekst på baggrund af sine egne semiotiske kompetencer (jf. Ecos encyklopædiske labyrint, se s. 38) og i forhold til sin personlige collateral expericence, hvilket tilføjer teksten en helt anderledes betydningsdimension. Som en dynamisk interpretant består tegnets betydning ikke alene i en reference til en 'grund', men også i en reference til et mere eller mindre konkret objekt. På dette semiotiske niveau lader forskellen mellem fiktive og ikke-fiktive tekster sig aflæse som en forskel på typen af indeksikale tegn indeholdt i teksten, samt karakteren af det univers disse indekser refererer til. Ifølge Peirce giver den 'virkelige' verden sig til kende i kraft af den fysiske og kropslige indvirkning den har på os og vi på den, mens der på beskrivelsesplanet stort set ingen forskel er: 
The real world cannot be distinguished from a fictitious world by any description. It has often been disputed whether Hamlet was mad or not. This exemplifies the necessity of indicating that the real world is meant, if it be meant. Now reality is altogether dynamic, not qualitative. It consists in forcefulness. Nothing but a dynamic sign can distinguish it from fiction. It is true that no language (so far as I know) has any particular form of speech to show that the real world is spoken of. But that is not necessary, since tones and looks are sufficient to show when the speaker is in earnest. These tones and looks act dynamically upon the listener, and cause him to attend to realities. They are, therefore, the indices of the real world (CP 2.337).

Det er således i kraft af de indeksikale, designative tegn at teksten præciserer "whether the universe of reality or what universe of fiction is referred to «(CP 8.368, note 23). Den fiktive tekst bliver, som vi har set i Kapitel II, til som led i en kreativ proces, hvor forfatteren, i kraft af en med Bakhtins ord 'transgredient' bevægelse, er i stand til at installere en fiktiv person i sit eget selvs position. Den fiktive person tilskrives sin identitet i kraft af sit møde med verden, alteriteten, og dette møde kan i et vist omfang læses som et billede på forfatterens eget møde med sin verden. Forfatterens materiale for konstruktion af den fiktive verden hentes ud af hans egen livsverden (såvel den fiktive som den aktuelle), og forfatterens egen samtid afsætter derfor spor, reagents, i den kreative skabelsesproces. Det er imidlertid vigtigt at understrege, at det ikke drejer sig om spor, der er direkte synlige i tekstens fiktive univers, men spor som først og fremmest henviser til den måde, hvorpå forfatteren har fortolket sin egen verden i kraft af den transgredience, som ligger bag den kreative proces. Dines Johansen formulerer det således:

[T] he source of the immediate object of a fictional text is not a dynamical object, but an author who on the basis of his experiences, i.e., by being himself influenced by dynamical objects, but also by other texts representing fictional universes, offers a certain vision that only exists by virtue of his text (Johansen I998, 286).

Konventionen om at fiktionsteksternes umiddelbare reference er suspenderet, får Dines Johansen til at konkludere, at der ikke er knyttet noget dynamisk objekt til fiktive tekster, kun et umiddelbart objekt (Johansen 2002, I I6). I modsætning hertil skelner Vincent Colapietro imellem tre forskellige former for dynamiske objekter hos Peirce, bestemt ud fra dennes tre grundlæggende værensmodaliteter: mulighed, aktualitet og generalitet, hvilket umiddelbart forekommer mere oplagt (Colapietro I989, I7). Colapietros skelnen løser den tilsyneladende selvmodsigelse hos Peirce, der består i at tegnet generelt er underlagt en dobbelt deter- 
mination (fra objet til repræsentamen og fra repræsentamen til interpretant), mens bestemte former for ikoniske tegn skaber deres eget objekt:

An Icon is a sign which refers to the Object that it denotes merely by virtue of characters of its own, and which it possesses, just the same, whether any such Object actually exists or not ( $\mathrm{CP}$ 2.247).

Det er således det dynamiske objekts karakter, som bestemmer forholdet mellem tegn og objekt. De aktuelle, dynamiske objekter determinerer tegnprocessen, som igen determinerer interpretanten, mens de mulige objekter (might-bes) omvendt genereres af tegnet selv, der i givet fald antager karakter af et ikon. Skulle vi relatere denne skelnen til modellerne udviklet i Kapitel II og III, ville det indebære en skelnen mellem en kreationsproces, hvor forfatterens livsverden, i sin karakter af dynamisk objekt for forfatterens tolkning af sig selv og sin omverden, determinerer den kreative skriveproces, mens den skrevne tekst i sig selv som et ikonisk tegn selv konstruerer sit dynamiske objekt, der tager form af et Peirceansk might-be:

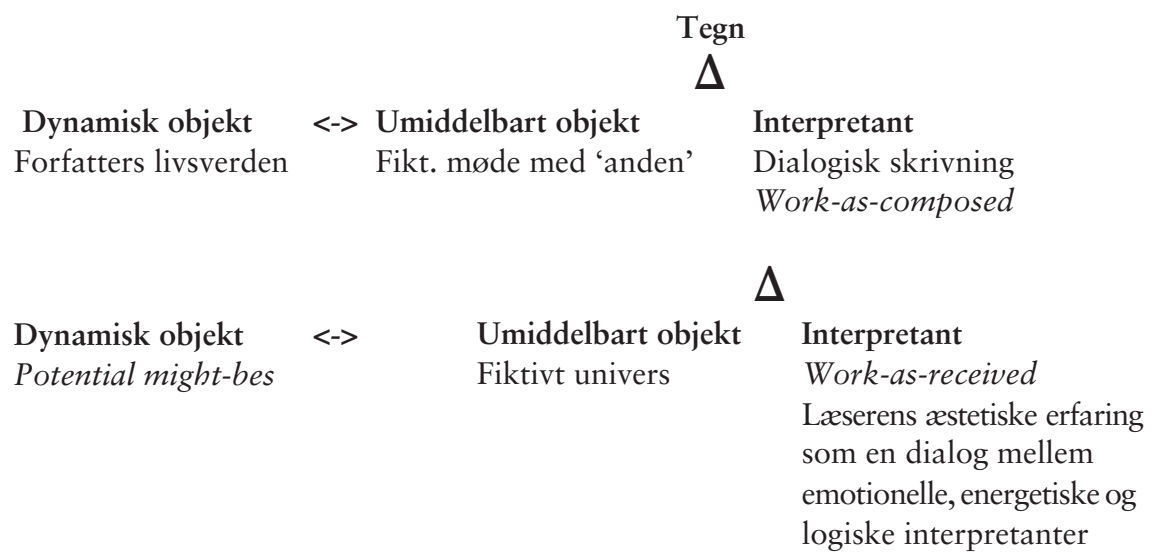

Betragter vi værket som en kreativ interpretant af forfatterens livsverdenbaserede erfaring, the work-as-composed, kan man sige at værket indeholder 'aftryk', eller i Peirces terminologi indeksikale 'reagents', der refererer til denne livsverden, bl.a. de mærker af ikke-bevidsthed, som Edmond Cros nævner (se s. IO3). Betragter vi omvendt værket som en betydning, der opstår i læserens møde med teksten, vil teksten skabe sit eget fiktive univers, og referencerne til en ekstratekstuel kontekst vil tage form af afledte indekser, i Peirces terminologi designations, idet de hovedsageligt refererer til positioner inden for tekstens eget univers. 
Det dynamiske objekt, tilknyttet den umiddelbare interpretant, er karakteriseret som et potentielt might be, dvs. det er skabt af tegnet selv, der dermed får karakter af et ikon. Derfor er der heller ikke nogen 'ægte' indekser der kan referere til objektet $\mathrm{i}$ kraft af en eksistentiel relation. Karakteren af det dynamiske objekt for det fiktive univers bevirker, at der opstår et "lack of access to additional sources of information concerning the states of affairs represented in the fictional text " (Johansen I998, 276). I stedet for ægte reagents, der forankrer universet i en fysisk verden, finder vi på niveauet for den umiddelbare interpretant en række designations, der peger på forhold inden for tekstens fiktive univers og kun indirekte tilbage på forfatterens historiske og kulturelle kontekst.

\section{Tekstens designative referencer}

At den primære reference i litterære tekster synes suspenderet og 'udsat', betyder naturligvis ikke, at der ikke eksisterer en relation imellem tekst og virkelighed. Både i fiktion og i virkeligheden konfronteres læseren med et heteroglot netværk af stemmer og diskurser, som denne skal tilskrive en dialogisk orden for at bringe mening ind i den pågældende verden. Og hvor romanen i skriveprocessen henter sit sprogligt-diskursive materiale ud af virkeligheden, dér vender værket tilbage til virkeligheden som nok en diskurs, materialiseret i form af en tekst, f.eks. en roman. Der er således ingen vandtætte skotter mellem fiktion og realitet; tværtimod eksisterer der en række forskellige relationer mellem de to instanser, som bl.a. Jørgen Dines Johansen har forsøgt at klarlægge.

Dines Johansen giver med begreberne 'kontinuitet', 'lighed', 'konventionalitet' og 'figurativitet' et bud på hvordan man kan skelne mellem fire forskellige former, som forholdet mellem fiktion og realitet kan antage (Johansen 1998 og 2002). Tekstens fiktive indekser kan være indlejret i en række ikke-fiktive indekser, altså henvisninger til historiske konkrete steder og hændelser, hvorved der opstår en relation af kontinuitet mellem fiktivt univers og livsverden. Lighedsrelationen mellem fiktion og verden vedrører ikke alene den konkrete lighed imellem elementer fra de to universer, men måske først og fremmest imellem måden hvorpå disse forhold omtales og beskrives. Vi er her ovre i noget der ligner Bakhtins genkendelige talegenrer i form af images of language (se s. 59). Det konventionelt bestemte forhold mellem fiktion og verden vedrører »the prepositional network which grounds action, reactions, emotions etc., " som, bortset fra særlige tilfælde, bør stemme overens med normer og værdier i verden uden for værket (op.cit. 279). Endelig handler Dines Johansens figurative relation mellem fiktion og realitet om, at teksten læses som en eller flere metaforer, der appliceres på læserens egen erfarede livsverden. 
Teksten fungerer her som en analog model for en hermeneutisk fortolkning, som man finder disse beskrevet hos f.eks. Max Black og Jurij Lotman (op.cit. 282). Max Black understreger, at analoge modeller netop er isomorfe med originalen, idet de udviser den samme "structure or patterns of relationships «(Black I962, 223). Der er altså ikke tale om en kvalitativ lighed som i skalamodellen, men om en rent relationel lighed

Dines Johansens beskrivelse af de fire former, som forholdet mellem fiktion og realitet kan antage, virker umiddelbart plausibelt og brugbart, men det havde dog været ønskeligt, om Dines Johansen, i det mindste i artiklen fra 1998, havde præciseret hvad det er for en kontekst, teksten etablerer en reference til. Refererer det, som Dines Johansen kalder »the historical universe ", til den samme kontekst som det, han kalder »our world of experience «? (jf. Johansen I998, 278). I den senere gennemgang i Literary Discourse placeres afsnittet omhandlende de fire typer referencer i et kapitel der omhandler mimesisbegrebet, hvorfor det ville være rimeligt at antage, at de fire beskrevne relationer mellem fiktionsteksterne og den historiske virkelighed primært vedrører referencen til tekstens oprindelige kontekst, men det står stadig ikke ganske klart. Desuden virker det som om der er nogle vigtige forskelle mellem de tre første af de nævnte former, og den sidste. Hvor de tre første former fungerer som indeksikale pegefingre, der peger tilbage på forfatterens samtidige kontekst, dér inddrager den sidste (også) den empiriske læsers nutidige verden som baggrund for den hermeneutiske fortolkning. Imidlertid vil tekstens oprindelige kontekst i de fleste tilfælde være mere eller mindre tabt for den empiriske læser, hvorfor denne vil være henvist til at skaffe sig viden om den tabte sammenhæng gennem andre tekster. I den konkrete læsning vil der imidlertid også altid blande sig forståelsesrammer og kulturelle indflydelser fra læserens egen samtidige kontekst, og det er i denne forstand spørgsmålet om tekstlig reference tilhører niveauet for den dynamiske interpretant, hvad enten det gælder referencer til tekstens oprindelige kontekst eller referencer til læserens samtidige kontekst.

\section{Udfyldningen af tekstens tomme pladser}

I The Act of Reading tager Wolfgang Iser spørgsmålet op om, hvordan læseren bidrager til skabelsen af den litterære teksts betydning i læseakten. Iser tager med sin virkningsæstetiske teori udgangspunkt $\mathrm{i}$ et dialogisk forhold mellem læseren og teksten. Fokus er på den indbyrdes interaktion mellem de to instanser, hvor teksten opfattes som et strategisk tilrettelagt forlæg og læserens aktivitet som et aesthetic response. Hans metode 
lægger således op til at analysere læserens interaktion med teksten, som den er bestemt af dennes strategiske tilrettelægning, og ikke den empiriske læsers mere eller mindre tilfældige fortolkningsarbejde, som ville falde ind under det, som Iser kalder receptionsæstetik: »A theory of response has its roots in the text; a theory of reception arises from a history of readers' judgements « (ibid.). Isers virkningsæstetik tager således sit udgangspunkt $i$ en bekrivelse af tekstens implicite læser, som Iser definerer som en tekstlig instans der »embodies all those predispositions necessary for a literary work to exercise its effect - predispositions laid down [...] by the text itself " (Iser I980, 34). Undersøgelsen handler om, hvordan tekstens æstetiske strategi er styrende for en mulig læsers dialogiske interaktion med teksten, hvor teksten opfattes som et betydningsmæssigt mulighedsfelt (jf. gennemgangen af Eco i Kapitel III), og i den forstand kan man sige at Isers virkningsæstetik hører hjemme på niveauet for den umiddelbare interpretant. Når jeg alligevel vælger at inddrage gennemgangen af Iser på dette sted, er det fordi Isers teori om læserens udfyldning af tekstens 'tomme pladser' samtidig beskriver den proces, hvorigennem den empiriske læser investerer sine egne erfaringer i tekstens betydning, hvorved tekstens erfaringer i anden omgang gøres åbne, tilgængelige og realistiske for samme læser.

Iser definerer relationen mellem læser og tekst som værende grundlæggende 'asymmetrisk', idet en vellykket kommunikation mellem tekst og læser forudsætter, at læseren løbende kompenserer for tekstens mangel på information gennem hypotesedannelser og hypotetiske slutninger (op.cit. I 66 ff.). Teksten be- og/eller afkræfter ikke som en normal dialogpartner rammerne for den kommunikative interaktion, hvorfor der opstår en ubalance i forholdet mellem tekst og læser: teksten kommer først og fremmest til at repræsentere en grundlæggende ubestemthed eller indeterminacy i Roman Ingardens forstand, som det altså er læserens opgave at kompensere for (op.cit. I67). Ifølge Wolfgang Iser skabes en litterær teksts fiktive univers $\mathrm{i}$ et samspil mellem tekstens negativt formulerede ramme og læserens udfyldning af dens 'tomme pladser' (Leerstellen eller blanks). Teksten selv bidrager med et begrænset sæt af informationer om det fiktive univers' tids- og rumlige koordinater samt om de personer, der indgår og deres handlinger, men universet gives fylde og personerne iklædes kød og blod ved, at læseren investerer viden og erfaringer hentet ud af sin egen livsverden i tekstens koordinatsystem.

For Iser udgør tekstens tomme pladser således en helt central betingelse for den litterære kommunikation, da det er dem, som etablerer dialogen eller udvekslingen mellem tekst og læser. Ifølge Iser er der tale om to forskellige typer af tomme pladser. På den ene side er der tomme pladser 
som udgøres af strukturelle mangler i tekstens opbygning, der fordrer læserens aktive kreativitet for at få skabt en tekstlig kohærens: »Blanks [...] designates a vacancy in the overall system of the text, the filling in of which brings about an interaction of textual patterns " (op.cit. 82). Man kan sige at den type tomme pladser organiserer forholdet mellem tema og horisont for læseren i udviklingen af tekstens narrative plot, eller som Iser formulerer det i Jakobsons terminologi: »they organize the syntagmatic axis of the reading " (op.cit. 2I2). Den anden type af tomme pladser vedrører læserens repertoire af livsverdensbaserede erfaringer, på baggrund af hvilke denne er i stand til at give det fiktive univers kraft og substans. Når normer og værdier fra dette repertoire indsættes i en anden kontekst gennem fiktionen, mister de muligvis deres gyldighed. De bliver negeret, og der opstår en tom plads, som læseren så at sige må udfylde på tekstens paradigmatiske akse. Iser selv opsummerer synspunktet således:

The function of the blanks is dual in nature: on the syntagmatic axis of reading they constitute the links between the perspective segments of the text; on the paradigmatic axis they constitute the links between negated norms and the reader's relation to the text. The intimate connection between the two functions is the basic condition that gives rise to the interaction between text and reader (op.cit. 216).

I læseprocessen konstrueres den litterære teksts narrative plot syntagmatisk på baggrund af de i teksten nedlagte tidslige og rumlige koordinater, svarende til Bakhtins kronotopiske struktur (for en beskrivelse af Bakhtins kronotopbegreb, se s. I69). Læseren reducerer tekstens elementer af ubestemthed og betydningsmæssig mangfoldighed til semantisk kohærente former, der løbende kombineres med læserens kreative udfyldning af de tomme pladser på det paradigmatiske plan. Således bidrager læseren med sine egne erfaringer som byggemateriale i den fiktive konstruktion. Det fiktive univers befolkes og møbleres med elementer og erfaringer taget ud af læserens egen, erfaringsbaserede vidensbank. Tekstens betydning kan på denne baggrund ikke forstås som en lukket mening, tvært imod rummer den et semantisk betydningspotentiale og et betydningsoverskud (excess of meaning), der udfordrer læserens "consistency-building habit, which underlies all comprehension« (op.cit. I 29).

The fulfilment, however, takes place not in the text, but in the reader, who must 'activate' the interplay of the correlates prestructured by the sequence of sentences. The sentences themselves, as statements and assertions, serve to point the way toward what is to come, and this in turn is prestructured by the actual content of the sentences. In brief, the sentences set in motion a process 
which will lead to the formation of the aesthetic object as a correlative in the mind of the reader (op.cit. I Io).

Læseren tilskriver teksten en semantisk kohærens ud fra en forventning om, at teksten skal kunne fremtræde som et meningsfuldt hele, men læseren har på intet tidspunkt et umiddelbart og direkte kontemplativt forhold til teksten i dens helhed. Tvært imod må tekstens objekt konstrueres processuelt i læsningen. Læsningen, forstået som en læsehandling, er derfor udspændt i tid, og læserens færd gennem teksten beskriver Iser som et 'wandering view-point', en position i permanent bevægelse fra start til slut. På et hvilket som helt givet tidspunkt er dette viewpoint altså placeret i et spænd mellem et konkret fokus, som Iser benævner et tema (theme), og den baggrund som det allerede læste udgør for forståelsen af dette tema. Iser kalder denne baggrund af det allerede læste for læsningens 'horisont' (ibid. I980, 97). Og læseren konstruerer tekstens kohærens i en dynamisk kombination af fremadrettede forventninger (protentions) og bagudrettede erindringer (retentions jf. Husserls terminologi):

The reader's position in the text is at the point of intersection between retention and protention. Each individual sentence correlate prefigures a particular horizon, but this is immediately transformed into the background for the next correlate and must therefore necessarily be modified. Since each sentence correlate aims at things to come, the prefigured horizon will offer a view which - however concrete it might be - must contain indeterminacies, and so arouse expectations as to the manner in which these are to be resolved (op.cit. III).

Læserens placering i spændingsfeltet mellem bagudrettet etablering af kohærens i forhold til det allerede læste og fremadrettede abduktive hypotesedannelser, giver læseren en oplevelse af at være direkte involveret i plottets tilblivelse. Desuden medvirker læserens kreative 'befolkning' eller 'indretning' af det fiktive univers med egne erfaringer til at styrke dennes engagement i de forhold, som udfoldes i det fiktive univers. Der etableres et dialogisk forhold mellem værkets fiktive verden og læserens ekstratekstuelle, livsverdensbaserede erfaringer:

The work and the world represented in it enter the real world and enrich it, and the real world enters the work and its world as part of the process of its creation, as well as part of its subsequent life, in a continual renewing of the work through the creative perception of listeners and readers (Bakhtin I98I, 254).

I læseprocessen opleves den indskrevne læserposition som et åbent mulighedsfelt, dvs. som et 'jeg' eller 'selv' (sameness, ifølge Ricœur), der 
optræder i dialogisk opposition til tekstens fiktive hændelser, som på sin side indtræder som andetheder (difference) som et 'du' / 'anden' medieret af 'mig'. Således vender vi tilbage til den semiotiske proces, hvorigennem subjektet etablerer sig som en fortolkning af sig selv i forhold til alteriteten, og læserens identifikation / udfyldning af de 'tomme pladser' bliver en inversion af forfatterens transgredience, som netop erstatter positionen for forfatterens 'selv' med en mere eller mindre fiktivt skabt person. Kreationsprocessens interpretantposition, den fiktive person set som forfatterens 'mig', person as $m e,{ }^{1}$ bliver i receptionsprocessen i første omgang vendt til en identifikation med den fiktive person som en selvstændigt 'selv' i form af positionen self as person, mens den i anden omgang, når teksten relateres til læserens egne livsverdensbaserede erfaringer, konverteres til me as person.

\section{Tegn \\ Person as' self'}

$\Delta$

\section{Umiddelbart objekt \\ 'Anden' \\ Umiddelbart objekt \\ Tekstens repræsentation af hændelser}

\section{Interpretant}

Person as ' $m e$ '

\section{$\Delta$}

Interpretant

'Self' as person

$\Delta$

\author{
Umiddelbart objekt \\ Læserens erfarede livsverden \\ Interpretant \\ 'Me' as person
}

Læseren lader sig således engagere i en kreativ udformning af fiktionen, som efterfølgende kan fortolkes som et billede på læserens egen verden. Dette kan tage form af, at læseren i egentlig forstand identificerer sig med personer eller positioner inden for det fiktive univers, og 'lever' det fiktive univers med de skildrede personer. Denne empatiske identifikation forudsætter, at læseren oplever et magic moment, hvor han eller hun opsluges af romanens fiktive univers. I dette magiske øjeblik sker der en indeksikal situering af læseren i tekstens kontekst. Teksten bliver som helhed til et ikon for læseren i den forstand, at tekstens karakter af et tegn der refererer til noget andet, træder i baggrunden, og ikonets egen form bliver objekt for den umiddelbare opmærksomhed. Peirce siger herom:

\footnotetext{
${ }^{1}$ Jeg undskylder for brugen af de engelske udtryk i denne serie af identifikationspositioner mellem læseren og den fiktive person, men en dansk oversættelse ville enten blive gumpetung eller ikke tillade den komplekse omvendingsrelation mellem de forskellige niveauer.
} 
Icons are so completely substituted for their objects as hardly to be distinguished from them [...] So in contemplating a painting, there is a moment when we lose the consciousness that it is not the thing, the distinction of the real and the copy disappears and it is for the moment a pure dream - not any particular existence, and yet not general. At that moment we are contemplating an icon (CP 3.362).

Samtidig med at den litterære tekst inviterer læseren til at træde over fiktionstærsklen og identificere sig med de fremstillede personer, involverer tekstens æstetiske strategi også en vis distance mellem den indskrevne læserposition og de fremstillede personer. Reallæseren må derfor følge tekstens strategiske dispositioner og tilegne sig teksten med en blanding af identifikation og distance. Distancen gør, at læseren, på trods af sin empatiske identifikation, er i stand til at bibeholde et udvendigt syn på teksten og tekstens personer og vurdere de erfaringer, som herigennem bliver formidlet. I kraft af denne balance mellem identifikation og distance, hvor læseren identificerer sig med den fiktive anden som et selv og tilegner sig dets erfaringer, bliver teksten til en genstand, hvorigennem læseren kan lære noget om sig selv og sin egen verden. Også i denne forstand er der tale om et ikon i Peices forstand:

A great distinguishing property of the icon is that by the direct observation of it other truths concerning its object can be discovered than those which suffice to determine its construction (CP 2.279).

En egentlig forståelse af teksten (appropriation) forudsætter at reallæseren situerer tekstens univers indeksikalt $\mathrm{i}$ forhold til sin egen erfarede livsverden, hvorved teksten opnår en slags »second-order truth-value « $\mathrm{i}$ forhold til læserens kontekst. Denne hermeneutiske operation forudsætter at der etableres en vis grad af genkendelighed mellem det fiktive univers og læserens historiske og kulturelle kontekst, men denne genkendelighed skulle imidlertid være sikret igennem læserens udfyldning af tekstens tomme pladser. Robert Scholes beskriver denne afledte eller sekundære reference som en dobbeltsidet relation af 'begribelse':

[B]ehind that world [det fiktive univers, HLH] or around it is our own phenomenal world, in which the fictional events reverberate. What we know from experience of love and lust, charity and hate, pleasure and pain, we bring to bear upon the fictional events [...] And what we find in fiction leaks out to colour our phenomenal world, to help us assign meaning, value and importance to the individual events and situations of our lives (Scholes I982, 32).

Den litterære tekst må på dette niveau forstås som et redskab for læseren, 
ikke blot til at betragte og forstå sin egen verden bedre, men simpelthen til at regenerere sig selv som et subjekt i verden. Værket forlenes med aktualitet $\mathrm{i}$ kraft af læserens kreative medvirken, og tekstens argumentative struktur bliver en model, dvs. et landkort eller en eksistentiel graf over læserens erfarede livsverden, hvor denne kan foretage eksperimenter og udføre slutninger i relation til sin egen erfarede livsverden. I kraft af den kulturelle konvention om 'det fiktive', er læseren imidlertid klar over, at den litterære teksts univers ikke må forveksles med virkeligheden, og at domme vedrørende sandt og falsk ikke umiddelbart er relevante her. Vi skal derfor forsøge at gå lidt tættere på, hvordan dialogen mellem tekst og læser, eller mellem fiktivt univers og erfaret livsverden, kan fremstilles teoretisk.

\section{Præfiguration, konfiguration og refiguration}

Tilsyneladende er den umiddelbare reference til en omgivende virkelighed suspenderet af fiktionskonventionen, men også kun tilsyneladende. Selv om vi som læsere godt ved at vi ikke kan spørge til begivenhedernes sandhedsværdi i et fiktivt univers, har vi alligevel en forventning om, at litteraturen skal kan sige os noget, som vi oplever som 'sandt'. Paul Ricœur taler i den forbindelse om en first-level og en second-level reference:

The literary work through the structure proper to it displays a world only under the condition that the reference of descriptive discourse is suspended. Or to put it in another way, discourse in the literary work sets out its denotation as a second-level denotation, by means of the suspension of the first-level denotation of discourse (Ricœur I977, 221).

Denne second-level reference eller denotation er en betydning som teksten får for den empiriske læser i forhold til hans egen verden, hvorved vi står over for spørgsmålet om læserens hermeneutiske forståelse af værket. Med artiklerne samlet i bogen Hermeneutics and the Human Sciences tager Paul Ricœur fat på en diskussion af såvel fiktionsteksternes umiddelbart suspenderede reference som af det mere grundlæggende fortolkningsproblem, tilknyttet skriftsproglige tekster som sådan. Han definerer en 'tekst' som "any discourse fixed by writing «, dvs. aktualiseret sprogbrug eller en slags parole i Saussures forstand (Ricœur I98 I, I45). Men til forskel fra den direkte, mundtlige dialog, kan forfatteren og læseren ikke forhandle sig tilrette om sprogets betydninger fordi de er adskilt i tid og rum: »the writing-reading relation is [...] not an instance of dialogue 
[...] The writer does not respond to the reader « (op.cit. I46). Herved opstår en dobbelt fraværssituation, hvor modtager ikke er til stede ved skrivningen, mens afsender ikke er til stede ved læsningen. For Ricœur har selve nedskrivningen, den grafiske udmøntning i skriftsprog, således en vigtig indvirkning på den måde sproget fungerer, som kan opsamles $\mathrm{i}$ følgende punkter (op.cit. I 47-49):

- Skriften udsætter tekstens referentielle forhold til en verden, forstået som »that about which (one) speaks".

- Skriften relativiserer forholdet mellem sproget og den subjektivitet, som det udtrykker.

- Skriften afbryder tekstens relation til en situationel kontekst.

- I stedet sættes teksten fri til at lade denne kontekst erstatte med forholdet til andre tekster, dvs. med en litterær 'kvasi-verden'.

- Skriften er således ikke uden reference, men den kræver en fortolkning.

Som et bud på en sådan fortolkning foreslår Ricœur at vende tilbage til Wilhelm Diltheys skelnen mellem explanation (forklaring) og understanding (forståelse), men i en omfortolket udgave. De to begreber repræsenterede for Dithey to typer af videnskabelig erkendelse, knyttet til hhv. natur- og humanvidenskaberne. For Dilthey var fortolkningen (interpretation) at forstå som en underafdeling eller 'provins' af 'understanding', og denne hele forståelse sås som et spørgsmål om at forstå en andens indre tanker og følelser, altså i tilfældet med fortolkningen af litterære tekster, at forstå forfatteren (op.cit. I 5I).

Ricœur omdefinerer nu disse begreber således at de ikke bare bliver mere tidssvarende, men også komplementære, i stedet for som hos Dilthey at være gensidigt udelukkende. Explanation forstår han i denne artikel fra I970 som en beskrivelse af tekstens betydning i sig selv. Ricœur tager ganske vist, påvirket af sin tid, udgangspunkt i den strukturalistiske teori og metode for beskrivelsen på dette niveau, men det er i denne forbindelse ikke afgørende. Det interessante er, at Ricœur understreger at der på niveauet for forklaring er tale om, at fiktionens suspension af tekstens referentialitet opretholdes og ligefrem forstærkes, og at teksten afkontekstualiseres (op.cit. I 53-I 58). Hvis en litterær tekst forudsætter som sandt, at der eksisterer 'orker', eller at man ved at tage en ring på sin finger kan blive usynlig, så er dette gældende som sandt for tekstens forklaring, også selv om der i teksten måtte indgå genkendelige referencer til vores livsverden.

Til gengæld er der på niveauet for fortolkning tale om »[to] lift the suspense [of referentiality] and fulfil the text in present speech « (op.cit. I 58 ). Ricœur gentænker her Diltheys definition af den litterære fortolk- 
ning og omformulerer den fra at være et spørgsmål om at forstå forfatterens intention til at være et spørgsmål om at læseren selv tilegner sig tekstens betydning i form af en Gadamersk appropriation: » that the interpretation of a text culminates in the self-interpretation of a subject who thenceforth understands himself better, understands himself differently, or simply begins to understand himself « (op.cit. I 58 ). At give teksten mening indebærer at læseren tilegner sig teksten, aktualiserer den i forhold til sin egen livsverden: »making one's own what was initially alien « (op.cit. I 59). Fortolkningen indebærer således, at læseren medierer den kulturelle og historiske distance mellem sig selv og teksten, samt læser teksten som redskab til at forstå sig selv og sin egen verden bedre, idet han/hun 'aktualiserer' teksten i læsningen. Læsningen bliver et event med "a present character: the realisation of the semantic possibilities of the text «. Læseren må rekontekstualisere teksten for at give den 'mening' (meaning overfor forklaringens sense), og den kontekst som teksten aktualiseres i forhold til er »the world of the reader " (ibid.). Dermed er vi ovre $i$ at undersøge det som Peirce kalder »the actual effect that it has upon me, its interpreter " (CP 8.3 I4), hvilket indebærer at vi er ovre i at undersøge litteraturens dynamiske interpretanter.

Beskrivelse / forklaring og fortolkning / tilegnelse spiller sammen på den måde, at den strukturelle analyse, med Ricœurs ord, er et skridt på vejen til at blotlægge den 'semantiske dybdestruktur' i teksten, som er det niveau tekstens aktualiserede 'mening' produceres på. Retorikken med 'dybdestruktur' og 'overflade' afspejler igen påvirkningen fra 70 'ernes tekstteori, men jeg finder det væsentligt her at holde fast i at tekstbeskrivelsen forholder sig til tekstens karakteristika i sig selv, mens fortolkningen aktualiserer en læsning i en bestemt kontekst. Ricœur anvender Aristoteles' fortolkningsbegreb (som han selv gør opmærksom på forveksler fortolkning med sprogbrugens semantiske dimension) til at sige at »interpretation is interpretation by language before being interpretation of language « (op.cit. I63). Denne udlægning af fortolkningsbegrebet er til dels objektivistisk (meningen ligger i teksten selv) og tenderer mod at udsætte læserens hermeneutiske tilegnelse af teksten til en senere fase, hvor det kun er den af tolkningsfællesskabet kanoniserede læsning, som tilegnes af det læsende subjekt. Ikke desto mindre er ideen om at teksten, forstået som sprogets diskursive manifestation i sig selv, (til dels) er styrende for sin egen fortolkning, det afsæt Ricœur bruger for at inddrage Peirces tegnbegreb som fortolkningsramme. Ricœur misforstår ganske vist Peirce, men det kan relativt enkelt bringes på benene.

Ricœur foreslår en Peirce-inspireret model over fortolkningsprocessen, som indsætter 'dybdesemantikken' på tegnets plads, teksten selv som 
objekt og fortolkningsfællesskabets serie af mulige fortolkninger som interpretant (ibid.). Dybdesemantikken er imidlertid i sig selv resultatet af en tekstbeskrivelse, hvorfor der umiddelbart må arbejdes med en fordobling af trekanstrukturen. Teksten refererer på tekstbeskrivelsens niveau til et fiktivt univers, der gives en speciel udlægning i form af den strukturelle teoris dybdesemantik. I fortolkningen læses denne dybdesemantik som tegn for noget andet, nemlig det som er tekstens egentlige 'mening'. Vi kan således illustrere Ricœurs applikation af Peirces tegnbegreb på den hermeneutiske tekstfortolkning med nedenstående model:

\begin{tabular}{|c|c|c|c|}
\hline Forklaring & \multicolumn{3}{|c|}{ Tekst } \\
\hline \multirow[t]{2}{*}{ Fortolkning } & $\begin{array}{r}\text { Umiddelbart objekt } \\
\text { Fiktivt univers }\end{array}$ & $\begin{array}{l}\text { Um } \\
\text { Dyb }\end{array}$ & $\begin{array}{l}\text { elbar interpretant } \\
\text { emantik }\end{array}$ \\
\hline & Umidd & & $\begin{array}{l}\text { Dynamisk interpretant } \\
\text { Fortolkningsfællesskabets } \\
\text { bud på fortolkning }\end{array}$ \\
\hline
\end{tabular}

Som antydet er Ricœurs udlægning af Peirce imidlertid ikke uden problemer. For det første mener Ricœur, at det kan være problematisk at anvende Peirces tegnbegreb på hele tekster. Der tager han ganske enkelt fejl. For det andet virker det bagvendt, at det objekt, som dybdesemantikken refererer til, skulle være teksten i sig selv. Hvis dybdesemantikken er det niveau som tekstens meaning bliver produceret på, må den referere til noget inden for den fortolkende instans' horisont, en slags erfaret livsverden eller lignende.

I artiklen »Metaphor and the Central Problem of Hermeneutics « anfører Ricœur at 'forklaringen' kan forstås som et svar på spørgsmålet hvad?, mens 'fortolkningen' må forstås som et svar på spørgsmålet om hvad? (Ricœur I98 I, I76). Spørgsmålet om, hvad der sker i en litterær tekst, kan besvares med en parafrase af handlingen, mens spørgsmålet om, hvad en roman handler om i f.eks. etisk eller eksistentiel forstand, er noget, som kun kan besvares på baggrund af en en tilegnelse af teksten, dvs. på baggrund af en læsning der bygger på vis livserfaring. Det giver os mulighed for at revidere Ricœurs udgave af den fordoblede trekant på følgende måde: 
Forklaring

\section{Umiddelbart objekt}

Fiktive personer og begivenheder

\section{TEGN}

Tekst

$\Delta$
Umiddelbar interpretant

Hvad? Kohærent univers

\section{$\Delta$ \\ Fortolkning

\author{
Umiddelbart objekt \\ Læserens livsverden som \\ fokuseret af teksten
} \\ Dynamisk interpretant \\ Om hvad? Tilegnelse}

Ifølge denne reviderede model har den litterære tekst en betydning, som på niveauet for forklaring udfoldes som et sammenhængende, fiktivt univers af narrativ eller sentimental karakter. I overensstemmelse med Isers beskrivelse af læserens kreative betydning for tilblivelsen af det fiktive univers, optræder dette ikke på objektspladsen ligesom i modellen ovenfor, men på interpretantpladsen. Kun gennem læserens udfyldning af tekstens tomme pladser og negative koordinater vedrørende personer og begivenheder befolkes det fiktive univers, som dog til en vis grad må siges at have en intersubjektiv karakter. At det kun til en vis grad er intersubjektivt skyldes, ud over de tomme pladser og åbne fortællemæssige strukturer, forekomsten af f.eks. billedsprog og symboler samt andre elementer af ubestemthed og polysemi som gør, at det altid vil være et åbent spørgsmål hvor forklaringen slutter og fortolkningen starter. Det som på ét tidspunkt regnes for en kanoniseret læsning, anses senere for at være udtryk for en naiv fejllæsning. Forholdet mellem forklaring og fortolkning kan således betragtes som en historisk og kulturel variabel, som afhænger af hvor et givet tolknings- eller forskningsfællesskab på et givet tidspunkt lægger grænsen for en intersubjektiv gyldig tekstbeskrivelse.

Sideløbende med at læseren deltager i konstruktionen af tekstens fiktive univers på niveauet for forklaring, tilegner denne sig tekstens mening i en hermeneutisk fortolkning, der sætter den i relation til læserens egen, livsverdensbaserede erfaringshorisont. Forholdet mellem det fiktive univers og dets tematikker og transformationer på den ene side og en af læseren erfaret livsverden på den anden, er til en vis grad også baseret på de relationer af kontinuitet, lighed, konvention og figurativitet, som vi ovenfor så Dines Johansen anvende til at konstruere tekstens forhold til en oprindelig kontekst. Selv om en del af tekstens designative indekser til den oprindelige kontekst stadig vil være virksomme for en senere læser (stednavne og landskabsbeskrivelser, f.eks.), er det nok på dette niveau den figurative læsning som er den vigtigste, og vi kan indtil videre sige, at 
teksten bliver en metafor på læserens erfarede livsverden. Ved at etablere en figurativ reference til egen livsverden kan læseren tage stilling til tekstens udsagn som værende sande eller falske for ham eller hende. Sprogets suspenderede reference til en kontekst og en verden genskabes i fortolkningen som denne 'metaforiske sandhed' (Ricœur I977).

For Ricœur er niveauerne for forklaring og fortolkning ikke tidsmæssigt forskudt, sådan at forklaringen ligger før fortolkningen. Tvært imod indgår de to elementer i et dialogisk samspil i læseprocessen, forstået som en proces over tid. Hvor forklaringen lægger en ramme for fortolkningen, dér virker fortolkningen tilbage på forklaringen og påvirker dermed den ramme, som udgør forudsætningen for dens egen tilblivelse. Således bliver dialogen mellem de to niveauer til en dynamik, ikke ulig det forhold vi skildrede mellem det kommunikative niveau og det erfaringsbearbejdende niveau i afsnittet om det dialogiske subjekt (se s. 93). På det kommunikative niveau er subjektet 'kastet' ud i at være deltager i den ubrudte kæde af semiotiske udvekslinger, som i en sideløbende selvrefleksiv proces bearbejdes som erfaringer, der hhv. kan bekræfte eller revidere subjektets socialt, kulturelt og historisk betingede forforståelse. Tilsvarende har vi med Iser skildret læseprocessen som en fortløbende dialog mellem et akuelt fokus (theme) og en fortolkningsramme bestående af det allerede læste (horizon), hvorfra læseren drager en række imaginære erfaringer, der i en tilsvarende refleksion af anden grad indgår i subjektets dialog med egne normer og værdier (se s. I98 ff.). Og ligesom subjektets diskursive praksis og kulturelle selvrefleksion udgør to parallelle og indbyrdes forbundne semiotiske systemer i semiosfærens netværk, således må ovenstående model over subjektets imaginære erfaringsdannelse i læsningen af litteratur forstås som en dynamisk model, hvor den fortløbende læsning, forstået som en dialog mellem fokus (theme) og baggrund (horizon), hele tiden driver nye umiddelbare interpretanter frem, som parallelt gøres til genstand for subjektets selvrefleksion. Selv om der altså ikke er tale om tidsligt adskilte processer, kan der således være en pointe $\mathrm{i}$ at holde dem ude fra hinanden i den teoretiske beskrivelse, netop for at kunne skelne mellem en vis grad af intersubjektiv betydning på niveauet for tekstens forklaring på den ene side og læserens hermeneutiske dialog med teksten på den anden.

I Time and Narrative forlader Ricœur den strukturalistisk inspirerede tro på muligheden af at blotlægge tekstens betydning i sig selv og anerkender den konkrete læseproces' afgørende betydning, da det er her betydningen aktualiseres $\mathrm{i}$ et sammenstød mellem tekstens og læserens horisonter (Ricœur I 988 III, I 59). Ikke desto mindre opretholder han en skelnen mellem de to niveauer som et analytisk redskab. Således skelner 
Ricœur nu mellem tre momenter i den litterære teksts kommunikative omløb, som han kalder 'præfiguration', 'konfiguration' og 'refiguration' eller simpelthen mimesis I, -2 og -3 (Ricœur I984 I, 54ff.). De tre niveauers indbyrdes relation kan skildres således:

I. Prefiguration (mimesisı). Tilhører tekstens tilblivelse som en kreativ handling.

Her har vi at gøre med de konceptuelle og narrative modeller, der ligger til grund for forfatterens måde at forstå sin egen livsverden, og som således også ligger til grund for hans repræsentation af personer og handling i skabelsen af teksten. Mimesis i kan bedst beskrives med Peirces ground-begreb, dvs. som den semiotiske 'grund' hvorpå forfatteren etablerer sin verdensanskuelse, og som danner grundlag for hans repræsentation af handling (Ricœur I984 I, 64). Man kunne også kalde det den genremæssige 'kode' eller den forforståelse, som en given tekst trækker på.

2. Konfiguration (mimesis2). Konstruktionen af teksten som diskursiv struktur.

I læserens konfiguration af teksten bliver denne konstrueret som en helhed. I narrative tekster har vi at gøre med forståelsen af fortællingen som en enhed, hvor en række hændelser ordnes til et forløb med begyndelse, midte og slutning. Denne 'i-intrige-sættelse' (emplotment) af begivenhederne indebærer, at fortællingen konstrueres som et forløb, der omformer en initialsituation til en slutsituation over en række episoder, og i denne formgivning indgår en stillingtagen til spørgsmål såsom hensigter og intentioner bag personernes handlinger, samt forholdet mellem forudsigelige årsager og rene tilfældigheder i begivenhedernes tilrettelæggelse. Læserens konfiguration af teksten syntetiserer således en række heterogene elementer: Den medierer mellem det, som går forud for fiktionen (præfigurationen), og det som følger efter (refigurationen); den bringer en række heterogene hændelser, faktorer og personer sammen til en handlingsmæssig helhed, og den medierer hændelsernes episodiske karakter med fortællingens temporale lukkethed (op.cit. 65 ff.). I denne syntetiserende bevægelse ser Ricœur en parallel til Kants begreb om dømmekraften og den kreative forestillingsevne. I Kants første Kritik er 'forståelsens' kategorier først skematiseret af den kreative forestillingsevne, fordi denne netop har en syntetiserende funktion, der medierer mellem det intellektuelle og det intuitive. Tilsvarende har fortællingens konfiguration en skematiserende funktion, fordi den medierer mellem fortællingens i intellektuel forstand tematiske helhed 
og dens intuitive præsentation af det heterogene materiale: personer og episoder, skæbne og tilfælde (op.cit. 68).

I Time and Narrative beskriver Ricœur niveauet for konfigurationen som » the kingdom of the as if " (op.cit. 64), hvorfor man kan sige, at dette niveau svarer til niveauet for 'forklaring' i hans tidligere tekster. Konfigurationsbegrebet indebærer at teksten skal forstås som en selvstændig beskrivelse af imaginære livsverdenserfaringer, som er frigjort fra forfatteren som empirisk person gennem en distancerings- eller objektiviseringsproces, og som først aktualiseres af en læser i læseprocessen. Jacob Dahl Rendtoff har opsummeret disse processer i en række punkter, som ligger til grund for nedenstående (Rendtorff, I998).

- Sproget anvendt som diskursiv hoendelse. Dette svarer nogenlunde til nedskrivningens effekt på sprogets kommunikative egenskaber, som den er gennemgået ovenfor.

- Voerket selvstondiggør sig fra forfatterens psykologi. Idet skriften fæstner sproget, løsrives værket fra den tid og det sted, som er knyttet til forfatterens nedskrivning af teksten. Det er nu ikke længere muligt at nå frem til forfatterens intention med værket.

- Tekstens verden. Selv om teksten har løsrevet sig fra forfatteren, præsenterer den sig som en projektion af en verden, et rum som indeholder en litterær og historisk selvfortolkning, som læseren kan bebo. Konfigurationen består $i$ at læseren, gennem en vis grad af empatisk identifikation, kan opleve de tekstligt formidlede erfaringer som sine egne, og dette niveau svarer således overens med niveauet 'Self as person' i modellen ovenfor.

- Den littercere tekst har et overskud af betydning. Forstået som en figurativ meddelelse rummer teksten et vist mål af ubestemthed, som gør, at den ligger åben for læserens fortolkninger, hvad enten det gælder tekstens poetiske eller narrative elementer. Idet vi parafraserer Dines Johansen, kan man sige, at teksten på paradoksal vis har et overskud af betydning i kraft af at den indeholder et underskud af information (Johansen I998, 276).

- Tekstens verden antyder et budskab, som ligger ud over tekstens umiddelbare indhold. Den litterære tekst interpellerer det læsende subjekt i form af en i teksten indskrevet læserposition og forbereder således en læsning, der henter sin betydning i dialog med den empiriske læsers livsverden. Dette sidste punkt danner bro til det næste niveau, den litterære refiguration... 
3. Refiguration (mimesis3): Den empiriske læsers tilegnelse af teksten. Dette niveau svarer til niveauet for fortolkning eller forståelse i Ricœurs tidligere tekster, som han nu mener repræsenterer »the intersection of the world of the text and the world of the hearer « (Ricœur I984 I, 7I). Ligesom tidligere erstatter Ricœur Diltheys begreb 'forståelse' med Gadamers 'tilegnelse' (appropiation/application), hvorved teorien åbner mulighed for at se refigurationen som en dialogisk relation mellem læserens udlægning af tekstens univers og hans eller hendes forståelse af sig selv og sin egen livsverden. I kraft af læserens identifikation med de fiktive personer kan denne bebo det fiktive univers som en selvstændig verden, jf. begrebet self as person ovenfor, hvilket giver læseren mulighed for at bearbejde elementer i sit forhold til sig selv og sin livsverden, som ikke lader sig beskrive i en rationelt forklarende diskurs, jf. også Bruners skelnen mellem den videnskabeligt-rationelle og den narrative vidensgenerering. Igen på baggrund af Rendtorff kan vi skelne mellem 4 aspekter af refigurationsprocessen:

- Brug og identifikation. Tilegnelsen af teksten forudsætter at læseren lader teksten 'tale' i sin egen livsverden, dvs. han skal lade teksten etablere en reference til hans egen umiddelbare kontekst. På dette niveau drejer det sig således ikke længere blot om at forstå en fiktiv person som et selvstændigt subjekt, men om at identificere sig med denne person for at tilegne sig dennes erfaringer (me as person). Der er ikke tale om blot og bart at reducere den fiktive verden til den kendte livsverden, men om at etablere en analog fortolkning baseret på en skematisering af relationer i såvel det fiktive univers som i forståelsen af egen livsverden (se også herfor Dines Johansen I998, 283). Således bliver læseren i udgangspunktet præsenteret for en partikulær og konkret virkelighed (om end fiktiv), hvorudaf han må drage et sæt af generelle principper.

- Forståelse og narrativ identitet. Som vi var inde på i slutningen af Kapitel II bruger vi de narrative strukturer til at indsætte den menneskelige eksistens i en sekventielt ordnet serie af tildragelser og åbner derigennem mulighed for at sammenkæde disse til meningsfulde helheder (se s. 76). Den litterære teksts objektiverende distance giver således subjektet mulighed for at reflektere over sin egen tilværelse og identitet. Det store antal litterære tekster, hvori der optræder personer som på den ene eller anden måde 'fortæller sig selv' forekommer i den forbindelse slående. Dette selvreferentielle eller metanarrative betydningslag vil blive taget op særskilt nedenfor i slutningen af Kapitel V. 
- Etik og fortcelling. Den litterære tekst behandler ofte emner såsom 'det gode' og 'det onde', 'det retfærdige' og 'det uretfærdige', og ofte sker dette i form af en kritik af den måde, hvorpå disse begreber udlægges i virkeligheden.

- Poetik og metafysik. Den litterære tekst kan også omhandle mere eksistentielle emner såsom spørgsmålet om 'sandheden' eller spørgsmål vedrørende vores ontologiske og metafysiske væren.

Helt parallelt med begreberne 'forklaring' og 'fortolkning' lader forholdet mellem 'konfiguration' og 'refiguration' sig relatere til niveauerne for kommunikativ udveksling og kulturel erfaringsbearbejdning i modellen over det dialogiske subjekt (se s. 98 ff.), hvorfor det også lader sig skildre i den dobbelte trekantsmodel. Modellen etablerer en dialogisk relation mellem den umiddelbare og den dynamiske interpretant, idet vi her relaterer den umiddelbare interpretant til Ricœurs begreb om 'konfiguration' og den dynamiske interpretant til hans begreb om tekstens 'refiguration'. De æstetiske eksperimenter, som forfatteren anstiller inden for den fiktive konfiguration, får således indflydelse på det, man kunne kalde læserens etiske filter, dvs. de kriterier denne bruger til at skelne godt fra skidt, og de er dermed heller ikke uden indflydelse på læserens vurdering af sig selv og 'det gode liv':

The thought experiments we conduct in the great laboratory of the imaginary are also explorations in the realm of good and evil. Transvaluing, even devaluing, is still evaluating. Moral judgement has not been abolished; it is rather subjected to the imaginative variations proper to fiction.

Because of these exercises in the dimension of fiction, the narrative can finally perform its functions of discovery and transformation with respect to the reader's feelings and actions, in the fase of the refiguration of action by the narrative (Ricœur I992, I64).

\section{Talen som 'ideologeme' og læserens etiske ansvarlighed}

Det litterære værk er skabt som en diskursiv handling gennem den kreative skriveproces, ganske vist en kunstnerisk elaboreret og artistisk tilrettelagt diskursiv handling, men som alle andre diskursive handlinger er også den litterære kreation dybt rodfæstet i det samfund og de sociale og kulturelle praksisser, som den udspringer af. Når læseren efterfølgende forsøger at rekonstruere tekstens relation til dens oprindelige kontekst, sådan som Bakhtin gør det i studiet af Rabelais' og Dostojevskijs romaner, så genvinder sproget dets sociale og ideologiske indebyrd, hvorved 
romanen kommer til at pege ud over sit eget fiktive univers og få en social og ideologisk betydning. Bakhtin ser, som vi har været inde på tidligere, den polyfone romans sprog som en stiliseret, ikonisk repræsentation af socialt og kulturelt forankrede talegenrer:

It is characteristic of all these phenomena (stylization of languages, parody and skaz) that the discourse in them not only represents, but is itself represented; social language in them (whether generic, professional or that of a literary trend) becomes the object of reprocessing, reformulation and artistic transformation that is free and oriented toward art (Bakhtin I98I, 336).

Som det fremgår af citatet understreger Bakhtin, at en stor del af romanens sprogbrug er karakteriseret ved både at repræsentere og at være repræsenteret. Dels repræsenterer skriften den spontane, levende tale, dels er den stiliserede tale i romanens dialoger, den parodierende sprogbrug og de fiktive personers gengiven af andre personers tale (den såkaldte skaz) genkendelig som 'type' og får derigennem en repræsentativ karakter. Skriften får således en dobbeltkarakter, idet den som symbol repræsenterer den levende tale, mens den som ikonisk tegn reprocesserer den sociale konteksts genkendelige diskurser. Det som den polyfone roman skildrer, er således ikke først og fremmest personer og handlinger, men diskursiv praksis: "Characteristic for the novel as a genre is not the image of a man in his own right, but precisely the image of a language" (op.cit. 336). Stiliseringen af talen til en historisk specifik og genkendelig diskurs er imidlertid ikke bare resultatet af en simpel reproduktion af en 'andens' tale, men resulatet af en særlig kunstnerisk repræsentation:

The speaking person and his discourse are not, in everyday speech, subject for artistic representation, but rather they are topics in the engaged transmission of practical information. For this reason everyday speech is not concerned with forms of representation, but only with forms of transmission (op.cit. 339).

Dines Johansen karakteriserer, som vi så i Kapitel I, den litterære diskurs som en grundlæggende mimetisk diskurs, og læserens forventning til en litterær tekst vil være, at den mimer de kollektive subjekters individualiserede 'masker' i interaktion i levende og socialt genkendelige diskurser. Forskellen på gengivelsen af andres tale i hverdagssproget og i litteraturen er således, at den artistisk gode repræsentation sikrer sprogets sociale repræsentativitet. Bakhtin siger herom: "In an authentic novel there can be sensed behind each utterance the elemental force of social languages " (op.cit. 356). Begrebet 'social language' skal her forstås som »a concrete sociolinguistic belief system that defines a distinct identity for itself « 
(ibid.). Til karakteristik af dette fænomen, at talen i den litterære diskurs altid bliver en ikonisk repræsentation af en socialt og ideologisk genkendelig diskurs, introducerer Bakhtin ideologeme-begrebet, som betegner diskursens sociale repræsentativitet, og som ligger bag Bakhtins forståelse af romanens kunstneriske egenart:

The image of such a language in a novel is the image assumed by a set of social beliefs, the image of a social ideologeme that has fused with its own discourse, with its own language (op.cit. 357).

Det er imidlertid vigtigt at understrege, at de fiktive personers tale, disse images of language, ikke er rene peirceanske images, altså billeder der ligner udelukkende i kraft af deres kvalitative egenskaber. De fiktive personers tale indgår i romanens orkestrering af dialogiserede diskurser, og kun i kraft af denne helhed kan de forbindes tilbage til en social kontekst:

The speech of the characters participates in the depicted dialogues within the work and does not enter directly into the ideological dialogue of contemporaneity, that is, into the real speech communication in which the work as a whole participates and is communicated (they participate in it only as elements of this whole) (Bakhtin I986, II6).

Der indtræder således en relationel lighed i forholdet mellem personernes tale, hvor social distinktion (høj vs lav), kønslig distinktion (kvinde vs mand), aldersmæssig distinktion (ung vs ældre) bidrager til at understrege lighedsrelationen i den kunstneriske repræsentation af en helhed. Og det er kun igennem denne repræsentation / repræsentativitet at den kunstneriske diskurs (romanen) forlenes med en ikonisk ureducerbarhed:

Thus double-voicedness in the novel, as distinct from doublevoicedness in rhetorical or other forms, always tends toward a double-languagedness as its own outside limit. Therefore novelistic doublevoicedness cannot be unfolded into logical contradictions or into purely dramatic contrasts (Bakhtin I98 I, 356).

Helt parallelt med Wolfgang Isers synspunkt mener også Bakhtin at de litterære tekster først opnår en konkret reference gennem den konkrete læsehandling, altså ved produktion af en dynamisk interpretant i Peirces terminologi. Teksternes indekser viser tilbage til deres oprindelige kontekst som konkrete og manifeste spor, som en læser, fortrolig med samtidens kulturelle semiosfære, umiddelbart kan forstå. Har vi at gøre med kulturelt eller historisk fjerntliggende tekster, kan en kritisk læser aktualisere de indeksikale referencer på baggrund af en tilegnet viden om 
sproglige, kulturelle og historiske forhold omkring tekstens tilblivelse. ${ }^{2}$ Bakhtin mener således selv at kunne aktualisere betydninger i f.eks. Rabelais' og Dostojevskijs tekster, som igennem en lang kritisk tradition har forblevet 'skjulte'.

To be understood he [Rabelais, HLH] requires an essential reconstruction of our entire artistic and ideological perception, the renunciation of many deeply rooted demands of literary taste, and the revision of many concepts. Above all, he requires an exploration in depth of a sphere as yet little and superficially studied, the tradition of folk humor (Bakhtin I984a, 3).

Samtidig anser Bakhtin det for at være essentielt at skelne mellem det han kalder the represented world og the world that creates the text (Bakhtin I98 I, 253). De to verdener tilhører to forskellige epistemologiske systemer, som må holdes ude fra hinanden for ikke at ende i Don Quijotes dilemma: "Når et menneske er i kunsten, er det ikke i livet, og omvendt « (Bakhtin I998, I3). Bakhtins to begreber vil svare til det vi har kaldt 'det fiktive univers' og en eller anden form for 'virkelighed' eller 'erfaret livsverden'. Her viser det sig imidlertid igen at være nødvendigt at skelne mellem tekstens kontekst og læserens kontekst, en skelnen som heller ikke er Bakhtin fremmed: " authors and the listeners or readers, may (and often are) located in different time-spaces, sometimes separated from each other by centuries and by great spatial distances, but nevertheless they are all located in a real, unitary and as yet incomplete historical world «(Bakhtin I98 I, 253).

Referencen til tekstens oprindelige kontekst blev behandlet ovenfor, og filologens arbejde hermed udgør en art 'tekst-arkæologi', der undersøger hvordan teksten er bærer af spor, reagents, der viser tilbage til den kulturelle formation, hvoraf den udspringer:

Out of the actual chronotopes of our world (which serve as the source of representation) emerge the reflected and created chronotopes of the world represented in the work (in the text) (ibid.).

Et eksempel på en sådan tekstarkæologisk tilgang finder vi hos Bakhtin, hvor han nævner tilsynekomsten af »the space of parlours and salons « $\mathrm{i}$ Stendhals og Balzacs romaner som udtryk for et epokalhistorisk træk:

\footnotetext{
${ }^{2}$ Den filologiske traditions krav til videnskabelighed retter sig mod de procedurer og metoder som litteraturkritikken anvender i (re)konstruktionen af den kontekst, som gør det muligt at tilskrive en given tekst konkret reference. Spørgsmålet om kravene til videnskabelighed i den litterære praksis vil blive behandlet nedenfor i Kapitel V.
} 
Here the graphically visible markers of historical time as well as of biographical and everyday time are concentrated and condensed; at the same time they are intertwined with each other in the tightest possible fashion, fused into unitary markers of the epoch. The epoch becomes not only graphically visible (space), but narratively visible (time) (Bakhtin I98 I, 247).

Salonernes sociale funktion i den historiske virkelighed i i 800-tallets Frankrig har naturligvis haft afgørende indflydelse på Stendhals og Balzacs litterære diskurser, men derfor kan der hverken sluttes at »those salons ... were 'the same' as in Balzac's novels. Nor are they the same as the meanings those salons have had in subsequent readings of Balzac's novels « (Holquist I990, I I 2). Alligevel kan et element som salonerne i Stendhals og Balzacs romaner bidrage til at situere den fiktive handling $\mathrm{i}$ en given kulturel og historisk kontekst i den forstand, at de repræsenterer et indeksikalt potentiale for læseren. På den umiddelbare interpretants niveau fungerer de som en slags afledte indekser, designations, hvis fortolkning afhænger af den aktuelle læsers forudgående viden om sociale institutioner i I 800-tallets Frankrig. Således nævner Dines Johansen at Flauberts Madame Bovary udspiller sig i den fiktive landsby YonvilleL'Abbaye, der geografisk er placeret præcist tyve kilometer fra Rouen mellem vejene til Abbeville og Beauvais. Disse indekser fungerer som designations. De bliver fortolket som indekser med en specifik reference, og deres gøren krav på at henvise til en 'virkelig', historisk verden bevirker, at det fiktive univers antager en hybrid karakter mellem fiktion og realitet. Læseren anspores således til at gestalte handlingen, som om den udspillede sig i Frankrig midt i det forrige århundrede.

Ved siden af den tekstarkæologiske tilgang finder vi forskellige virkningsæstetiske og hermeneutiske tilgange, der undersøger hvordan en bestemt litterær gengivelse af tid, rum og handling fortolkes ind i den kulturelle kontekst, som er læserens. Et andet aspekt af Bakhtins kronotopbegreb kan her tjene som eksempel. Som Holquist gør opmærksom på, kunne det virke som om Bakhtin modsiger sig selv, når han på én gang definerer kronotopbegrebet som en historisk specifik størrelse (parlourkronotopen) og som et slags transhistorisk ledemotiv (rejsekronotopen eller adventurekronotopen) der har været anvendt siden antikken (Holquist I990, I I 2-I3). ${ }^{3}$ Hertil svarer Holquists selv, at » the chronological order of events is always interpreted in different ways at different

\footnotetext{
${ }^{3}$ I Bakbtin og Don Quijote præsenterer Rigmor Kappel Schmidt en forenklet udlægning af Bakhtins kronotopbegreb, der gør det vældigt operativt. Hun skelner her mellem genregenererende kronotoper, som hun reducerer til tre (hverdagskronotopen, eventyrkronotopen og karnevalskronotopen) og det, som hun kalder 'delkronotoper', som hun reducerer til fire: vejen, mødet, flugten og tærsklen (Schmidt 2003, 74 ff.).
} 
times « (op.cit. I I 6). Den samme 'fabel' vil således blive læst forskelligt til forskellige tider:

[A]t different times and places authors and readers will be working with different sets of time/space coordinates, and thus the relationship between time and space - and therefore the relationship between a presumed chronology and its 'distortion' in any given narrative progression - will vary (op.cit. I 20).

Selv om vi bestræber os på at forstå the represented world med reference til tekstens egen kontekst, så er selve the represented world altså konstrueret på baggrund af en opfattelse ikke bare af tid og rum, men også værdier og normer, som er hentet ud af læserens historiske og kulturelle kontekst. Disse niveauer vil derfor aldrig kunne adskilles i en dialogisk forståelse af tekstlæsning. Det fiktive univers eksisterer som et potentiale $\mathrm{i}$ teksten (den umiddelbare interpretant), men betydningen aktualiseres $\mathrm{i}$ en konkret læsning, der tager form af en dynamisk interpretant. Med Ricœurs begreber kan man sige, at tekstens temporale distance til sin oprindelige kontekst bevirker, at tekstens reference i læsningen bliver splittet op imellem en hermeneutisk tilegnelse og læserens konstruktion af tekstens oprindelige kontekst. Det umiddelbare objekt i fiktive tekster ligger således udspændt mellem to repræsentationer på niveauet for tekstens kreation og for dens fortolkning.

Bakhtin knytter med sin dialogiske forståelse af de kommunikative processer derfor også an til den hermeneutiske fortolkningstradition. Michael Holquist karakteriserer Bakhtins dialogisme-opfattelse som en triadisk proces og ikke en dyadisk struktur, og det gør han i form af modellen » utterance, reply and the relation between them «. Her bliver det dialogiske til et spørgsmål om en fusion, eller et sammenstød, mellem to forskellige horisonter, altså et hermeneutisk problem, der modsvarer forholdet mellem læser, tekst og tilegnet betydning. Også for Bakhtin involverer al forståelse (understanding) således to subjekter (autor og læser) og to niveauer i tilegnelsen:

With explanation there is only one consciousness, one subject; with comprehension there are two consciousnesses and two subjects. There can be no dialogic relationship with an object, and therefore explanation has no dialogic aspects (Bakhtin I986, III).

Eller som Michael Holquist formulerer det i en udlægning af Bakhtins tekstforståelse:

[T] he 'text itself' is never, of course, itself; it is always a composite of what the author produced at one given time and in one given place, and the meanings 
that accrue to the formal features of that text in its latter appropriations at subsequent times (Holquist I990, I 2 I).

I Marxism and the Philosophy of Language skelner Volosjinov mellem begreberne tekstens meaning som en form for stabil mening i tegnet på den ene side, og på den anden tekstens theme som værende det, som forbindes med den konkrete læsning og som kræver en respons. Volosjinov definerer begrebet meaning som "all those properties of the sign that are reproducible, stable and subject to the process of identification ", mens begrebet theme defineres som: "The theme of an utterance is concrete as concrete as the historical instant to which the utterance belongs " (Volosjinov 1973, I00). Senere skelner Bakhtin i Discourse in the Novel mellem tekstens neutral meaning og actual sense på samme måde. På den baggrund foreslår Augusto Ponzio på at man kan relatere Bakhtin/ Volosjinovs terminologi til Peirces begreber for den umiddelbare og den dynamiske interpretant ved at sige, at begrebet meaning dækker Peirces forestilling om den umiddelbare interpretant mens Bakhtin/Volosjinovs theme svarer til den dynamiske interpretant (Ponzio I990, 258). Ligesom Peirces dynamiske interpretant forudsætter Volosjinovs theme nemlig en synsvinkel, et synspunkt, en kontekst og et forudsat svar. Det giver således, ud fra såvel Peirce som Bakhtin, god mening at betragte læsningen som en dialogisk proces mellem tekstens betydningspotentiale og læserens aktualisering af dele af dette potentiale i læseprocessen.

Især i sine tidlige skrifter er Bakhtin optaget af læserens hermeneutiske tilegnelse af de tekstligt formidlede erfaringer som en del af den æstetiske oplevelse. For Bakhtin udgør den indledende empatiske identifikation med tekstens anden udgangspunktet for denne bevægelse, som dog altid efterfølges af en modsatrettet bevægelse: »An essential moment (though not the only one) in aesthetic contemplation is empathizing into an individual object of seeing - seeing it from inside in its own essence " (Bakhtin I993, I4). Denne seen en person indefra indebærer en ideologisk udfordring og horisontudvidelse for læseren, at den fiktive person repræsenterer et konkret og genkendeligt syn på verden i kraft af talens ikoniske karakter af ideologeme. Men denne transgrediente oplevelse af at 'se med en andens øjne' modsvares af en modsatrettet bevægelse, hvor læseren etablerer en distance til det læste og forholder det til sine egne erfaringer med en livsverden. I Author and Hero... anvender Bakhtin begrebet consummation som betegnelse for læserens reaktualisering af tekstens erfaringer som sine egne, i noget som minder om Gadamers appropriation: 
Aesthetic activity proper actually begins at the point when we return into ourselves, when we return to our own place outside the suffering person, and start to form and consummate the material we derived from projecting ourselves into the other and experiencing him from within himself (Bakhtin I990, 26. Min fremhævelse).

Det er således læserens indlevelse i tekstens anden som et selv, der danner udgangspunkt for den efterfølgende indsigt, som udspringer af at forstå sit eget liv i lyset af denne andens erfaringer. Cirklen sluttes således når læseren, med Bakhtins formulering, 'vender tilbage til sig selv' og forstår disse erfaringer i kategorier, der hidrører fra dennes egen livsverden:

After looking at ourselves through the eyes of another, we always return - in life - into ourselves again, and the final, or as it were, recapitulative event takes place within ourselves in the categories of our own life (Bakhtin I990, I7).

Gennem en kombineret bevægelse af empati og identifikation med tekstens fiktive subjektspositioner (jeg som anden) på den ene side og distance til og 'objektivering' af den samme position på den anden side, gør læseren tekstens erfaringer til sine egne. Men på trods af det temporale adverbium i citatet ovenfor, "after looking...", understreger Bakhtin, at der ikke er tale om at disse to aspekter kan isoleres som temporale eller succesive momenter: »the moments of empathizing and of objectifying interpenetrate each other " (Bakhtin I993, I 5 ).

I bogens første kapitel har vi fæstet os ved hvordan »all real and integral understanding is actively responsive " (Bakhtin 1986, 69), hvormed Bakhtin mener, at forståelsen af et tegn eller en ytring, interpretanten i Peirces terminologi, altid kan forstås som det første skridt i retning af et svar. Som Bakhtin formulerer det: "[the word] cannot escape the profound influence of the answering word that it anticipates « (Bakhtin I98 I, 280). Derfor er subjektets tale eller diskursive praksis altid retorisk rettet mod den andens forventede reaktion og respons. Tilsvarende er den litterære tekst altid retorisk rettet mod læserens fortolkning, som i den forstand blot bliver at betragte som første led i et 'svar'.

For Bakhtin er subjektets identitet socialt konstrueret i kraft af subjektets relation til den anden (se s. 83). I Kapitel I har vi været inde på hvordan sprogets dialogiske karakter indlejrer sprogbrugerne i en historisk konkret, social, kulturel og ideologisk specifik kontekst, og Kapitel II har vi set hvorledes subjektet bruger det, som Bakhtin kalder den andens finaliserende blik på sig selv, til at danne sig et helt og kulturelt medieret billede af sig selv. Subjektets forventede eller forventelige svar på den andens ytringer bliver derfor til et spejl for subjektets selvidentitet, jf. 
også Ricœurs udlægning af subjektets selfconstancy som keeping one's word (se s. 78). Det er på baggrund af vores forudsigelighed i forhold til den anden, at vi forstår os selv som værende den samme.

Vi har også set at en given ytrings eller teksts betydning må forstås i dialogisk samspil med de ytringer eller tekster, som forud har taget det samme emne som sit objekt, men disse 'fremmede ord i objektet' er jo ikke i praksis knyttet til objektet som frit i luften svævende ideer; de er til stede som en (bag)grund i modtagerens bevidsthed:

[T] his contradictory environment of alien words is present to the speaker not in the object, but rather in the consciousness of the listener, as his apperceptive background, pregnant with responses and objections (Bakhtin I98I, 28I).

I det kommunikerende subjekts relation til modtageren smelter sprogets fortidsrettede og fremtidsrettede dialoger i praksis sammen i den forstand, at denne i sin forståelse og gennem sine svar samler dem i en stillingtagen til den måde, hvorpå sagsforholdet er blevet fremstillet af ytringen (hos Peirce, det umiddelbare objekt). I sin forståelse af ytringen pådrager modtageren sig således en etisk ansvarlighed, der for Bakhtin er knyttet til al form for social handlen på grund af subjektets og handlingens unikke og urepeterbare karakter.

Det forhold, at subjektet for Bakhtin grundlæggende set er defineret i relation til den anden, indebærer at subjektets 'væren til' altid er unik og urepeterbar, hvilket klarest kommer til udtryk i handlingens singulære karakter. Subjektet udtrykker sin unikke karakter netop gennem sine handlinger, fordi subjektet $\mathrm{i}$ handlingen må påtage sig ansvaret for sin egen væren-til: »I am actual and irreplaceable, and therefore must actualize my uniqueness. It is in relation to the whole actual unity that my unique ought arises from my unique place in Being " (Bakhtin I993, 4I). Derved bliver handlingen i bred forstand, hvilket for Bakhtin også involvere de diskursive handlinger at tale, skrive og læse, tilskrevet en etisk dimension, som han kalder answerability: »An answerable act or deed is precisely that act which is performed on the basis of an acknowledgement of my obligative (ought-to-be) uniqueness « (op.cit. 42). ${ }^{4}$

Bakhtins begreb om individets etiske ansvarlighed kan således i semiotisk forstand siges at være knyttet til den kommunikative handlen, men samtidig, eller måske netop derfor, er det også socialt forankret, fordi

\footnotetext{
${ }^{4}$ Det er bemærkelsesværdigt, at hvor Bakhtin karakteriserer det man kunne kalde diskursens etiske positionering af det ytrende subjekt i forhold til den anden som answerability, dér anvender Ricœur et andet begreb afledt af den dialogiske relation, nemlig 'responsibility' (Ricœur I992, I65).
} 
sproget af Bakhtin betragtes som et kommunikativt redskab, der er grundlæggende socialt i sit væsen. Og forstår vi den litterære diskurs som en diskursiv praksis på linje med anden social praksis, vil den litterære diskurs være underlagt princippet om answerability, såvel i forhold til dens konkrete læsere som i forhold til et publikum i al almindelighed.

I kraft af at de litterære tekster udfordrer læseren til at erfare sin egen livsverden set gennem en andens øjne, får de æstetisk formidlede erfaringer etisk konsekvens, og påvirker læserens opfattelse af sig selv som person. I det lille men yderst centrale fragment, Art and answerability, formulerer Bakhtin det således:

I have to answer with my own life for what I have experienced and understood in art, so everything I have experienced and understood would not remain ineffectual in my life (I990, I).

\section{Teksten som erindring, aktualiseret ikon og model til selvforståelse}

Også hos Jurij Lotman finder vi en beskrivelse af det vi har kaldt den litterære teksts splittede reference mellem det fiktive univers, tekstens oprindelige kontekst og tekstens betydning som orienteringsredskab i forhold til læserens egen samtid. Lotman kalder den funktion, hvor teksten $\mathrm{i}$ en vis forstand selv medbringer spor af sin oprindelige kontekst, for 'tekstens erindring'. Tekster, ikke bare historiske kildetekster, men også litterære tekster, repræsenterer en adgang til fortiden. Uden den tekstlige overlevering ville vi ikke have en kollektiv erindring om fortiden, og uden fortid, ingen historievidenskab:

A text has the capacity to preserve the memory of its previous contexts. Without this function, there could be no science of history, since the culture of preceding ages (and more broadly speaking its picture of life) inevitably comes down to us in fragments [...] [F]or the perceiver a text is always a metonymy of a reconstructed integral meaning, a discrete sign of a non-discrete essence. The sum of the contexts in which a given text acquires interpretation and which are in a way incorporated in it may be termed the text's memory. This meaning-space created by the text around itself enters into relationship with the cultural memory (tradition) already formed in the consciousness of the audience. As a result the text acquires semiotic life (Lotman I990b, I8).

Ifølge Lotman får teksten semiotisk liv i læsningen, gennem dialogen mellem to instanser: På den ene side det som han kalder 'tekstens erin- 
dring', altså den viden om f.eks. historiske, sociale og kulturelle forhold som det er nødvendigt for læseren at have for at kunne forstå den, og på den anden side det kulturelle subjekt, som udgør den grund et publikums læsning vil foregå på. Denne grund kalder Lotman »the cultural memory (tradition) already formed in the consciousness of the audience «. Det er altid en forudsætning for enhver form for vellykket kommunikation, at der foreligger et minimum af fælles kontekstuel forståelsesramme, og en tekst kan følgelig karakteriseres på baggrund af den forudsatte informationsmængde hos den intenderede modtager. Wolfgang Iser ville her tale om viden tilskrevet den implicitte læser.

Helt på linje med Iser er Lotman også godt klar over at forholdet mellem tekstens eksplicitering af dens eget vidensmæssige forudsætningsniveau og den indskrevne læserposition forholder sig anderledes i litterære tekster end i brugstekster, fordi »the memory-orientation becomes a signifying (i.e. free) artistic element which plays with the text " (Lotman op.cit. 65). Samtidig med at teksten indskriver læserpositionen gennem hele den udsigelsesmæssige strategi samt doseringen af kontekstuel viden, så virker den empiriske læsers kulturelle og litterære kompetencer tilbage på tekstens betydning i selve læseprocessen: »the play between the reader's real pragmatics and that imposed by the author is what constitutes the special experience of the literary work « (op.cit. 67). Før tekstens betydning aktualiseres i læsningen, eksisterer den for Lotman kun i form af et betydningspotentiale, ganske om hos Ricœur: » The text's first movement is its actualization: the text which exists in a state of potentiality (the book on a shelf, the as yet unstaged play, and so on) acquires reality in the consciousness of the addresser " (Lotman I 990b, 69). Dialogen mellem læsningens umiddelbare og dynamiske interpretant kan med Lotman karakteriseres som en dialog på grænsen mellem et kulturelt subjekt, dvs. en indskrevet kollektiv horisont af kulturelle normer og værdier, og den empiriske læseres individuelle bevidsthed: » The first semiotic transformation of the text takes place here on the boundary between the collective memory of culture and the individual consciousness " (op.cit. 69).

Som vi har været inde på reguleres den empiriske læsers balance mellem identifikation og distance i forhold til de fremstillede personer og begivenheder i læseprocessen bl.a. af tekstens udsigelsesmæssige strategi, hvorved læseren hele tiden bevæger sig mellem positionerne self as other og other as self. Som Iser endvidere var inde på, bidrager læserens 'møblering' eller 'indretning' af tekstens fiktive univers og udfyldning af dens tomme pladser til, at læseren til en vis grad oplever universet som bekendt og samtidig som noget fremmed, der skal opdages. Lotman formulerer dette i semiotiske termer som et spørgsmål om at teksten splittes, idet den overskrider 
grænsen fra at være en printet side til at være en litterær erfaring i den empiriske læsers krop og bevidsthed. Samtidig med at teksten som et ikonisk tegn transformeres til en del af læserens egen erfaringsdannelse i form af billeder, følelsesmæssige indtryk, aktuelle hændelser og abstrakte handlingsmønstre, bevarer den sin materielle karakter, hvorved den udgør en kilde til kontrol for læseren, der kan slå tilbage, kontrollere og om nødvendigt læse om igen. Som vi var inde på i Kapitel I, er der for Lotman tale om en principiel uoversættelighed imellem disse to niveauer, hvorfor læserens overførsel af information fra det ene register til det andet vil være udtryk for skabelsen af en ny, hybrid tekst (op.cit. 70).

Litterære tekster og kunst i det hele taget må ifølge Lotman forstås som 'secundary modelling systems', hvormed vi som læsere fortolker eller genfortolker vores livsverden (Lotman I 990b, 3 I). Selve oversættelsen af vores kropsligt og sanseligt erfarede livsverden til en kodebaseret sproglig diskurs indebærer en udvælgelse og værdimæssig kategorisering af de beskrevne elementer, som på sin side samtidig resulterer i en nok så sigende udgrænsning af andre elementer:

Any act of semiotic recognition must involve the separation of significant elements from insignificant ones in surrounding reality. Elements which, from the point of view of that modelling system, are not bearers of meaning, as it were do not exist (Lotman I99ob, 58).

Desuden kan plottet i narrative tekster fungerer som et filter som læseren kan anvende til at segmentere sit eget liv i en række narrativt konstruerede selver. Vi har alle behov for narrative modeller, med hvilke vi kan skelne mellem forskellige aspekter af vores livsverden, både historisk, socialt og kulturelt. Ved at segmentere vores liv i forhold til forskellige projekter bliver det muligt at tilskrive disse segmenter både en begyndelse med håb og ønsker, en midte med helte og skurke, hjælpere og modstandere, samt en slutning som kan være lykkelig eller tragisk. Og først i kraft af denne narrativt konstruerede orden bliver vi i stand til at tilskrive vores eksistens en mening:

Plot is a powerful means of making sense of life. Only when narrative forms came into being could people learn to distinguish the plot aspect of reality, that is, to divide the non-discrete flow of events into several discrete units, linking these units together by semantic interpretations, and organizing them into ordered chains by syntagmatic interpretations. The essence of plot lies in selecting the events, which are the discrete units of plot, then giving them meaning and a temporal or causal or some other ordering (Lotman I990b, I70). 
Læserens brug af teksten som model for forståelse af sin egen livsverden har formentligt at gøre med de forventninger, som er knyttet til litteraturen som selvstændig diskurs. Lotman er selv inde på at 'jeg-jeg-kanalen' aktiveres ved at nogle bestemte signaler markerer den som en litterær tekst (for en præsentation af 'jeg-jeg-kanalen', se s. 88). Disse signaler kan være af tekstekstern (omtale, distributionsform osv.) eller tekstintern (æstetiske virkemidler osv.) karakter. Signalerne får læseren til at rubricere teksten som tilhørende det litterært-kunstneriske register, hvorved de forventningsmønstre som er knyttet til dette register aktualiseres, herunder aktualiseringen af 'jeg-jeg-kanalen'.

Lotmans modelbegreb, der forstår de litterære tekster som modeller for subjektets dannelse og selvdannelse, lægger på den ene side vægt på teksternes narrative element, hvor udvælgelsen og den tidsmæssige sekventielle ordning af begivenheder spiller ind, men på den anden side rummer modelbegrebet også muligheden for at forklare hvordan litterære tekster kan bidrage til at oendre læserens personlighed ved at ændre subjektets personlige 'koder' (Lotman I990b, 29). Lotman nævner selv eksemplet med en læser af Anna Karenina der får at vide at Anna har kastet sig ud foran et tog som resultat af en ulykkelig kærlighedshistorie, og som bruger denne information som model til at forstå sin egen situation, ved at se sig selv som Anna:

If that reader instead of adding this information [about the suicide of Anna, $\mathrm{HLH}]$ to what she already has in her memory, comes to the conclusion "Anna Karenina is me" and starts changing her understanding of herself, her relationship with people and perhaps even her behaviour, then obviously she is using the novel not as a message like any other, but as a kind of code in her own process of selfcommunication (Lotman I990b, 30).

Lotman skelner her imellem tekstens betydning forstået som hhv. en 'meddelelse' og som 'kode'; to betydningsniveauer der står i indbyrdes dialog med hinanden. Teksten betydning forstået som en meddelelse hænger sammen med kommunikationen gennem $I-(s)$ he kanalen, hvor den litterære tekst udgør det forlæg, som læseren bruger til at udfolde et fiktivt univers som en fremmed verden, der kan udforskes af et subjekt. Gennem læserens identifikation med en romanperson (Anna) gives denne liv som en selvstændig person, der lever i Rusland i det forrige århundrede. Og gennem denne indlevelse lærer læseren noget af tekstens kontekstuelle informationer, som tilføjes det inventar af kulturelle kompetencer, som læseren besidder i forvejen. Tekstens betydning forstået som en kode hænger derimod sammen med 'jeg-jeg kanalen', hvor læserens identifikation med romanens hovedperson overskrider grænserne for det fiktive 
univers og lader romanen tale som en stemme i læserens livsverden. Det var den type læsning vi i afsnittet om Ricœur karakteriserede som refigurationen. Det autokommunikative betydningsniveau annullerer ikke $I$ (s)he-kanalens meddelelse, men bliver så at sige et ekstra betydningslag, som lægger sig ovenpå romanens fiktive univers. Kunst og litteratur kendetegnes således, ifølge Lotman, ved at kommunikere gennem begge kanaler samtidigt:

The aesthetic effect arises when the code is taken for the message and the message as a code, i.e. when a text is switched from one system of communication to another while the audience keeps awareness of both (Lotman I990b, 32).

Effekten af den refigurative eller autokommunikative læsning indebærer, at det subjekt, individuelt eller kollektivt, som deltager i processen, sætter sine vanemæssige kulturelle koder til diskussion, hvorved den litterære erfaring kan bidrage til at ændre disse (op.cit. 29).

\section{Referencen i dialogisk forståelse}

Forfatterens livsverden udgør den kontekst, som teksten i første omgang henter sin betydning fra i skriveprocessen, og som i læsningen i et vist omfang kan rekonstrueres gennem en tekstarkæologisk tilgang. Bakhtin hæfter sig særligt ved den måde hvorpå Dostojevskij lader sine fiktive personer repræsentere tidens ideer:

Dostoevsky never created his idea-images out of nothing, he never » made them up « any more than a visual artist makes up the people he represents - he was able to hear or divine them in the reality at hand (Bakhtin I984b, 90).

Den kontekst hvorfra forfatteren henter de ideer, som udgør materialet for hans skrivning, er hans historisk konkrete samtid som derfor også, eller måske især, indbefatter en litterær horisont: »the contemporaneity from which the author observes includes, first and foremost, the realm of literature [...] The realm of literature and more broadly of culture [...] constitutes the indispensable context of a literary work [...] « (Bakhtin I98 I, 255). Således udgør forfatterens tekstlige og kulturelt bestemte tilgang til sin egen samtid, eller i tilfælde af at der er tale om historiske værker samtidens syn på den behandlede periode, et vigtigt udgangspunkt for forståelsen af værkets reference.

Det litterære værk opstår således som en kreativ interpretant af 
forfatterens livserfaringer, men det fiktive univers er samtidig et tekstligt konstrukt, som læseren kun har adgang til igennem sproget. Dette univers, lad os kalde det den repræsenterede kronotop, udgør et potentiale for fortolkning med visse indeksikale relationer tilbage til forfatterens kulturelle og historiske kontekst, hvori teksten blev til. Selve realiseringen af dette univers afhænger imidlertid af den konkrete læsers kulturelle kompetencer. Den umiddelbare interpretant af teksten kan følgelig betegnes som den 'medierede kronotop'.

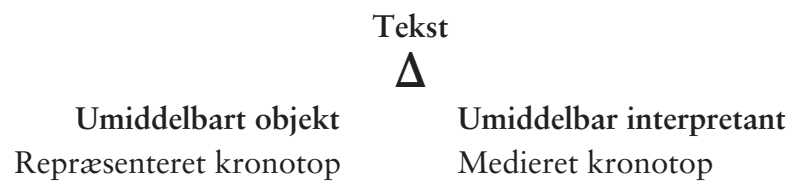

Den repræsenterede kronotop skal her forstås som et sæt af tids- og rumlige koordinater determineret af teksten, som først får karakter af et muligt, kohærent univers i kraft af læserens kreative udfyldning af tomme pladser i form af en medieret kronotop. Bakhtin anvender ikke selv begrebet 'medieret kronotop', men her repræsenterer den medieringen af den af teksten determinerede betydning og en i læsningen realiseret mening. Ifølge en interessant passage hos Holquist, kan Bakhtins kronotopbegreb imidlertid forstås som et dialogisk mødested for tre i sig selv statiske eller monologiserede tilgange. For det første tekstens interne tid/rum-struktur i sig selv, som den ville kunne udlægges i en formalistisk tilgang, for det andet tekstens tid/rum-struktur som værende determineret af forfatterens historisk-kulturelle forståelse af tid/rum-forhold, som den ville blive udlagt i en vulgærmarxistisk tilgang (Holquist nævner Pereverzevs analyser af Gogol), og for det tredje tekstens tid-rumstruktur determineret af læserens historisk-kulturelle forståelse af tid-rumforhold, som den ville kunne udlægges af den mest radikale læser-responsteori (Holquist, I4 I). De tre tilgange Holquist nævner kan siges at svare til de tre typer af referencer til en 'verden', som vi har ridset op ovenfor: forfatterens livsverden, det fiktive univers og læserens livsverden. Jeg vil ikke gå ind i en nærmere kritik af Holquists kommentar, men blot understrege, at den foreslåede skelnen mellem den 'repræsenterede' kronotop og den 'medierede' kronotop efter min mening tilgodeser denne uklarhed i Bakhtins kronotopbegreb, ikke mindst hvis vi forstår 'repræsenterede' kronotop som den litterære teksts umiddelbare objekt, determineret af et dynamisk objekt i form af forfatterens livsverden, og den 'medierede' kronotop som den umiddelbare interpretant, medieret af læserens livserfaring. 
Den medierede kronotop udgør et betydningspotentiale, der fungerer som dialogpartner for den empiriske læser, for hvem den antager karakter af det Jerome Bruner kalder en 'virtuel' tekst:

The virtual text becomes a story of its own, its very strangeness only a contrast with the reader's sense of the ordinary. The fictional landscape, finally, must be given a 'reality' of its own - the ontological step (Bruner I986, 37).

Den virtuelle tekst formes under indtryk af den empiriske læseres kompetence, men tilskrives en fiktiv ontologi og selvstændighed. Og det er denne virtuelle tekst, som danner udgangspunkt for læserens tilegnelse af værket i form af en dynamisk interpretant. Den empiriske læsers aktualisering af værket sker under indtryk af hans/hendes litterære kompetence og forventninger, herunder hans/hendes forståelse af tid- og rumforhold, som er farvet af egne kulturelle værdier og normer. I det omfang læseren forsøger at danne sig et billede af forfatterens historiske og kulturelle kontekst som fortolkningsramme for læsningen af teksten, vil den nødvendige information i langt de fleste tilfælde kun være tilgængelig for læseren i form af andre tekster. Her bliver den empiriske læsers litterære kompetence og kulturelle dannelse af afgørende betydning for den konkrete udformning af den virtuelle tekst. Den virtuelle tekst fungerer, med Lotmans udtryk, som en analog model, på baggrund af hvilken læseren bliver i stand til at iværksætte en række 'eksperimenter' med forskellige typer af erfaringer, som læseren efterfølgende anvender til at etablere en 'jeg-jeg' refleksion der involverer hans/hendes egne narrative modeller for selvforståelse. Tekstens medierede kronotop bliver dermed omformet til at fungere som en model eller et kognitivt skema for læserens forståelse af sig selv i forhold til sin egen livsverden:

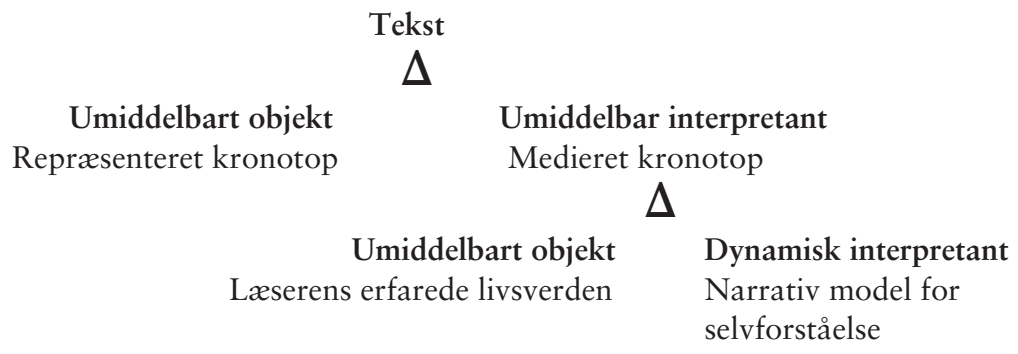

Forholdet mellem de to betydningsniveauer er dialogisk, hvilket vil sige at der går påvirkningslinjer og afhængighedsrelationer begge veje. Læseren kan ikke konstruere den umiddelbare interpretant uden at læse teksten, dvs. uden så at sige at gå gennem den dynamiske interpretant. Men 
samtidig fungerer tekstbeskrivelsen på niveauet for den umiddelbare interpretant som dokumentation for holdbarheden af den dynamiske interpretants fortolkninger. Selv om de i praksis er uadskillelige, er det derfor alligevel vigtigt at forsøge at holde de to niveauer adskilt, ikke mindst i den kritiske og metodebevidste diskurs. Et givet værk vil, anskuet på denne måde, altid udmønte sig i nye dynamiske interpretanter for hver ny læsning, hvori læserne tilegner sig teksten i relation til deres beholdninger af personlige og kulturelle erfaringer. I fortolkningen, forstået som en dynamisk interpretant, aktualiseres således blot et begrænset udsnit af den umiddelbare interpretants betydningspotentiale. Og læsningen antager på dette betydningsniveau karakter af en allegorese. Ricœur siger herom, med et citat fra Jauss, i Time and Narrative:

Allegorization occurs whenever we attempt »to translate the meaning of a text in its first context into another context, which amounts to saying: to give it a new signification which goes beyond the horizon of meaning delimited by the intentionality of the text in its original context (Ricœur I98 5 III, I76-77).

Læserens allegoriske fortolkning af værket tager form af det Peirce kalder diagrammatiske ræsonnementer, hvor relationen imellem elementer i værket, efter en abduktiv hypotese om hvorledes relationen kan etableres, deduceres til at ækvivalere relationen imellem elementer i læserens livsverden (allegori: struktur $=$ struktur). Læserens konstruktion af den virtuelle tekst med en fastlagt kronotopisk struktur af temporale, spatiale og modale/aktantielle relationer svarer til tegningen af diagrammet (landkortet eller grafen). Jerome Bruner mener ligefrem at læseren selv til en vis grad medbringer noget af det materiale, som den virtuelle teksts strukturelle skelet formes over:

As our readers read, as they begin to construct a virtual text of their own, it is as if they were embarking on a journey without maps - and yet, they posses a stock of maps that might give hints, and besides, they know a lot about journeys and about mapmaking (Bruner 1986,36$)$.

I udformningen af den virtuelle tekst som et diagrammatisk ikon udfører læseren en række abduktive og/eller syntetiske refleksioner, der efterfølgende komplementeres med en serie analytiske refleksioner, ${ }^{5}$ som kan beeller afkræfte den virtuelle teksts egnethed som eksistentielt diagram for læseren. Den virtuelle teksts diagram bliver konstrueret syntetisk under

\footnotetext{
${ }^{5}$ Peirce skelner mellem syntetisk og analytisk ræsonneren i den forstand at "analytical reasoning depends upon associations of similarity, synthetical reasoning upon associations of contiguity « (CP 6.595).
} 
hensyntagen til værkbegrebets imperativ, som forpligter læseren på at konstruere en logisk og relativ modsigelsesfri helhed af tekstens elementer i form af en logisk interpretant, mens de kreative abuktioner spiller ind som hypoteser til, hvordan teksten kan bringes i dialog med læserens erfarede livsverden.

Læseren konstruerer således den virtuelle tekst som et ikonisk tegn, ikke som en skalamodel af sin egen livsverden, men som en analog version af de forskellige måder, hvorpå vi kulturelt set kategoriserer, modelliserer og diskurssætter vores livsverden (Johansen 2002, 432). Og idet omridset af den virtuelle tekst er etableret som en diagrammatisk model, kan læseren forsøge sig med egne eksperimenter af deduktiv karakter efter devisen: »forudsætter jeg at dette skulle oversættes til min verden, ville det betyde..." Disse hypoteser afprøves dels ud fra deres udsigelseskraft i relation til værket/andre værker af samme forfatter/periode osv., dels ud fra deres forklaringskraft i forhold til læserens erfarede livsverden. Peirce er selv inde på at den analytiske eller deduktivt diagrammatiske tænkning især anvendes ved det han kalder 'imaginære objekter':

Deduction, or analytical reasoning, is, as I have shown in my »Theory of Probable Reasoning " a reasoning in which the conclusion follows (necessarily, or probably) from the state of things expressed in the premises, in contradistinction to scientific or synthetical, reasoning, which is a reasoning in which the conclusion follows probably and approximately from the premises, owing to the conditions under which the latter have been observed, or otherwise ascertained [...] Deduction is really a matter of perception and of experimentation, just as induction and hypothetic inference are; only, the perception and experimentation are concerned with imaginary objects instead of with real ones (Peirce, CP 6.595, I893).

Når vi forstår litteraturen og kunsten funktionelt som en kilde til selverkendelse og identitetsudvikling, bliver det klart at den litterære aktivitet i virkeligheden blot mimer det som vi alle uafladeligt gør, når vi igen og igen revurderer forholdet mellem vore eksistentielle idealer som en æstetisk dimension og vore handlingsmæssige forskrifter som etiske retningslinjer.

Such being his [mans] condition, he often foresees that a special occasion is going to arise; thereupon, a certain gathering of his forces will begin to work and this working of his being will cause him to consider how he will act, and in accordance with his disposition, such as it now is, he is led to form a resolution as to how he will act upon that occasion. This resolution is of the nature of a plan; or, as one might almost say, a diagram (CP I.592, I903). 
Den virtuelle tekst, selve diagrammet, kan forstås som en argumentativ struktur, hvorindenfor tekstens enkelte elementer, herunder de fiktive personers diskurser, tilskrives deres betydning i kraft af deres placering inden for denne helhed. Dines Johansen siger herom: »[I]t is not the literal fictional universe that is compared to and interpreted in the light of our life-world, it is the interpretation of it in abstract statements about forces and conflicts in the outer or inner world « (Johansen I998, 28I). Disse "abstract statements about forces and conflicts « udlægger Dines Johansen selv i Literary Discourse som kæder af logiske argumenter med en nærmest syllogistisk struktur (Johansen 2002, 390). Nu er de færreste litterære værker jo direkte syllogistisk opbyggede rent kompositorisk, hvorfor det kan være nødvendigt for læseren at bidrage aktivt til konstruktionen af tekstens argumentative struktur (op.cit. 368). Det kan foregå på følgende måde: Den traditionelle syllogisme er opbygget med to præmisser og en deraf følgende konklusion. Første præmis har en almen karakter, mens anden præmis og konklusionen som følger deraf er af mere konkret karakter. I litterære tekster vil man imidlertid ofte se, at den første, almene præmis kun ligger implicit som en ideologisk position determineret af den kulturelle og historiske kontekst, hvor de samtidige læsere forudsættes spontant at opfatte forholdene på en given måde, jf. Edmonds Cros’ begreb om det ikke-bevidste (se s. I03). Eller sagt på en anden måde, litterære teksters konkrete udmøntning af forhold og hændelser i et fiktivt univers kan forstås som den konkrete præmis i et argument, hvor det er op til læseren at finde den førstepræmis, der gør det muligt at drage en konklusion. Retorisk kalder Aristoteles det syllogistiske argument, hvor en af præmisserne eller konklusionen er udeladt, for et 'enthymem': "Enthymemet bygger på få utsagn, ofte færre enn i primærsyllogismen. For dersom en av dem er velkjent, er det unødvendig å fremsette den, tilhøreren kan selv lægge den til« (citeret fra Eide, Kittang og Aarseth, 1987, 49). Læsningen af det litterære værk som et enthymem stiller dermed læseren over for den opgave at konstruere den udeladte, almene præmis, som efterfølgende gør ham/hende i stand til at vurdere tekstens argumentative struktur i forhold til egen livserfaring. Er der tale om tekster løsrevet fra deres historiske og/eller kulturelle kontekst, kan opstillingen af disse præmisser imidlertid vise sig at være en kompliceret opgave, og de udgør ofte en kilde til fejlfortolkning, et forhold som Bakhtin netop gør opmærksom på $\mathrm{i}$ indledningen til sin læsning af Rabelais (Bakhtin 1984, 3).

I læserens tilegnelse af teksten refererer teksten således ikke længere kun til sin egen samtid, men tilskrives, som vi har set, en ikonisk-diagrammatisk reference til læserens verden. Den dynamiske interpretants 
umiddelbare objekt er imidlertid ikke bare læserens 'virkelige' verden, men læserens erfarede livsverden. Forskellen er, som Jerome Bruner har været inde på, at den erfarede livsverden er læserens konstruerede og narrativiserede billede af sin egen historie og kulturelle kontekst. Dette billede virker nu selekterende og med Peirces ord 'determinerende' ind på genereringen af den dynamiske interpretant, altså på den empiriske læseres hermeneutiske tilegnelse af teksten. Men i det omfang vi som læsere er i stand til at læse forskellige tekster som værende reelt forskellige og ikke bare indlæser det kulturelle subjekts fordomme om og om igen, må vi sige at teksten kan repræsentere den anden, og at de litterære erfaringer i de lykkeligste tilfælde kan gøre det ud for den direkte interaktion med den anden i subjektets dannelsesproces. I den forstand kan tekster give anledning til konstruktionen af nye selver og en dialogisk erkendelse af nye typer af erfaringer, hvor den anden erkendes som værende et selv, og hvor læseren oplever at se sig selv igennem denne anden. Denne type erfaringer kan få afgørende indflydelse på det læsende subjekt, al den stund tilegnelsen af alteriteten som et selv kan fremprovokere vigtige skred i subjektets vurdering af både sig selv og den anden samt af de dertil knyttede handlingsstrategier, også uden for den imaginære verden.

Således smelter sprogets fortidsrettede og fremtidsrettede dialoger i praksis sammen i subjektets forhold til den anden, idet denne, i sin forståelse og gennem sit svar, pådrager sig en etisk ansvarlighed, der vælder tilbage over subjektet selv. I kraft af de litterære teksters omvending af forholdet mellem selv og anden bliver den æstetiske udfordring af læseren vendt til en etisk erfaring, der vedrører læserens opfattelse af sig selv som person. Således bliver cirklen sluttet: læserens fortolkningsaktivitet munder ud i en imaginær erfaringsbearbejdning, som i en vis forstand kan forstås som en omvending af forfatterens kreative skaben. Lotman formulerer det således: "The reader repeats this process in the opposite direction, passing from the text to the intention « (Lotman I990b, 78), men han tilføjer umiddelbart efter, at der også på læsersiden er tale om en kreativ proces, hvilket jo så involverer asymmetri: »their relationship to the text is asymmetrical «. Hvor teksten for forfatteren udgør en proces i konstant udvikling, møder læseren den som en afsluttet struktur. Men som sagt er teksten, set fra læserens synspunkt, ikke kun en meddelelse, men også en 'kode' for selvforståelse: »(the reader brings) his or her own personality, his or her own cultural memory, codes and associations, to bear on the text " (op.cit. 79), og de er altid forskellige fra forfatterens. Der er derfor ikke tale om, at læseren rekonstruerer forfatterens oprindelige erfaringer eller intention med teksten. De erfaringer, som læseren høster af teksten, er læserens egne erfaringer al den stund de genereres i dialog med 
læserens personlige identitetsstruktur og det bagvedliggende kulturelle subjekt, i Peirces ord forstået som a bundle of acquiered habits. Eller som Dines Johansen udtrykker det: »literature is, perhaps even first and foremost, imaginary experiments with experiences«(Johansen 2002, 43 I).

\section{Antonio Muñoz Molinas »Sefarad «}

Antonio Muñoz Molina (født I956) har med Sefarad (200I, dansk oversættelse 2003) skabt sit til dato mest komplekse, polyfone og etisk engagerede værk. Forfatteren er herhjemme kendt for romaner såsom Vinteren $i$ Lissabon (1992), Den polske rytter (1996), og Fuldmåne (2000), og vi genfinder en række af forfatterskabets store temaer i Sefa$\mathrm{rad}$, om end i en anden iklædning: forholdet mellem erindring og fantasi, mellem fiktion og historie samt mellem fortælling og konstruktion af kulturel identitet. Nedenfor skal vi i Kapitel V vende tilbage til en læsning af hans roman Mørkets fyrste fra 1989 i forbindelse med gennemgangen af metafiktionen. ${ }^{6}$

Ordet sefarad er den hebraiske betegnelse, som den jødiske befolkning på den iberiske halvø brugte om deres land, inden de blev landsforvist af det katolske regentpar Isabel af Kastillien og Fernando af Aragon i I 492. Og som titlen antyder, tager bogen afsæt i eksileringsproblematikken som det gennemgående tema for bogens sytten kapitler. Hvert kapitel fortæller sin egen historie, men historierne er alligevel snævert sammenhængende ikke bare tematisk, men også gennem et netværk af genkommende personer og referencer, som inviterer læseren til selv at etablere de ofte kun antydede sammenhænge. Fortællingerne blander en række fiktive personer med kendte, historiske skikkelser (bl.a. Primo Levi, Willi Münzenberg, Jean Améry, Franz Kafka og Victor Klemperer) i en kollage, der placerer sig mellem romanskrivning og historiefortælling, og med en eksplicit fortæller der hele tiden skifter identitet og leger kispus med læseren gennem skiftende udsigelsespositioner og en labyrint af intertekstuelle referencer.

Det konkrete udgangspunkt for mange af historierne udgøres af jødernes diaspora i det 20. århundredes Centraleuropa, hærget af totalitære regimer, og romanen synes at spørge til hvad det var der gjorde, at ingen gjorde noget for at forhindre holocaust. Ikke engang ofrene selv, som ofte forholdt sig passivt afventende, og accepterede deres skæbne ligesom

\footnotetext{
${ }^{6}$ En læsning af Sefarad ligger også til grund for artiklen »Etisk ansvar i den moderne spanske roman. Tilfældet Antonio Muñoz Molina «, in: Schwartz Lausten og Verstraete Hansen: Engagement i litteratur (Hansen, under udgivelse).
} 
Kafkas K i Processen - paralyserede af deres pludselige identitet som paria. Men vi finder også fortællinger der tager deres udgangspunkt i Spaniens traditionalistiske regime i 50'erne eller i forfatterens eget privilegerede forfattermiljø i I990'ernes Europa - sågar København lægger navn til et af kapitlerne.

I det følgende vil jeg se på hvordan dette værks komplekse strategi ikke bare udfordrer læseren æstetisk, men netop i kraft af det dialogiske forhold mellem autor og personer, mellem selv og anden samt mellem tekst og læser også kaster læseren ud i en etisk stillingtagen.

\section{Tekstens stemmer som ideologemer}

Alle bogens sytten fortællinger er fortalt af forskellige, eksplicitte fortællere i første person. Hver af disse fortællere giver hver af historierne dens eget sproglige og følelsesmæssige udgangspunkt i den måde, hvorpå fortællerne situerer sig selv i forhold til det fortalte, og det fortalte $\mathrm{i}$ forhold til deres egen livsverden. I den første historie møder vi f.eks. den arbejdsløse familiefar fra Madrid, der kæmper for at fastholde sin faderautoritet og sin egen selvrespekt i en moderne verden, der er løbet fra ham. Selv er han født og opvokset i en by i provinsen med klare lighedstræk med Úbeda, Muñoz Molinas egen fødeby, og fortællingen starter med fra første linje at etablere et diskursivt kollektivt subjekt, der indbefatter alle de 'eksilerede' tilflyttere i Madrid fra denne provinsby:

Vi har skabt os et liv langt fra vores lille by, men vi kan ikke vænne os til at være væk fra den, og vi elsker at dyrke vores længsel efter den når vi ikke har været hjemme et stykke tid, og nu og da overdrive vores dialekt når vi taler sammen, og bruge lokale ord og vendinger som vi har samlet på i årenes løb, og som vores børn knap forstår selvom de har hørt dem så mange gange (Muñoz Molina 2003, 9). ${ }^{7}$

Ved at modstille det traditionelle provinsliv, der prægede fortællerens barndom, med metropolens urbane modernitet, udfolder fortællingen et tema, som er genkendeligt fra andre af Muñoz Molinas romaner: den nostalgiske længsel efter en svunden tid. Men i Sefarad kombineres den nostalgiske længel med et kritisk blik, der både retter sig imod de nærmest præmoderne livsformers klaustrofobiske traditionalisme og mod på de

\footnotetext{
${ }^{7}$ Den spanske tekst lyder således: »Nos hemos hecho la vida lejos de nuestra pequeña ciudad, pero no nos acostumbramos a estar ausentes de ella, y nos gusta cultivar su nostalgia cuando llevamos ya algún tiempo sin volver, y exagerar a veces nuestro acento, cuando hablamos entre nosotros, y el uso de las palabras y expresiones vernáculas que hemos ido atesorando con los años, y que nuestros hijos, habiéndolas escuchado tanto, apenas comprenden« (Muñoz Molina 200I, I2).
} 
tabserfaringer, som den moderne individualisering fører med sig: ensomhed, angst og den enkeltes kamp for overlevelse.

Store dele af fortællingen, i særdeleshed de dele der handler om de gode gamle dage i provinsen, er imidlertid ikke fortalt af denne jeg-fortæller selv, men af sekretæren for den forening, hvori tilflytterne til storbyen mødes, Godino. Passagerne med Godinos indlagte fortællinger er ikke altid grafisk klart markerede, men Godinos sprog er til gengæld genkendeligt med dets salvesesfulde tone, der blander udtryk hentet fra en religiøstkirkelig diskurs ind $\mathrm{i}$ beskrivelsen af lokalområdets kulinariske og kulturelle egenart. Igennem denne til tider næste umærkelige glidning fra fortællerens diskurs over i Godinos fortællinger fornemmer læseren hvor stærk en rolle Godinos lokalpatriotiske ideologi spiller for fortællerens bestræbelser på at fastholde den selvrespekt, som hele tiden truer med at smuldre mellem fingrene i et samfund, som tilsyneladende ikke kan finde anvendelse for ham. Mellem fortællerens beretninger fra sin hverdag og Godinos fortællinger om det fortidige provinsliv etableres noget man i Edmond Cros' terminologi kunne kalde et regionalt, kulturelt subjekt (se s. IO2 ff.). Men dette kulturelle subjekt slår sprækker, for Godino lyver, og fortælleren identificerer sig i øvrigt heller ikke helhjertet med den ideologiske position, som Godino repræsenterer.

Hvis man kun læser denne ene fortælling, får man som læser kun et spinkelt hint om Godinos ideologiske glorificering af alt hvad der har med hjemstavnen og fortiden at gøre: i starten af fortællingen nævner han deres barndoms skomager fra landsbyen, Mateo Zapatón, som han omtaler som havende "trukket sig tilbage til hovedstaden og hoffet " (spansk: retirado en la Villa y Corte) (op.cit. I4), mens fortælleren selv i slutningen af kapitlet beretter hvordan han møder Mateo Zapatón på en plads i Madrids hårdeste narkokvarter Chueca, hvor han står senil og sølle, og tilsyneladende hverken aner hvor eller hvem han er. Her bliver de adelige associationer i Godinos beskrivelse bitterligt dementeret af den socialrealistiske skildring.

Læser man imidlertid hele bogen grundigt, ${ }^{8}$ vil læseren bemærke hvordan det omtalte netværk af genkommende personer og referencer dementerer Godinos idylliske udlægning af provinsbyens lokalhistorie. Således bliver f.eks. Godinos historie om byens lokale musikgeni dementeret. I Godinos udgave opgav bysbarnet Gregorio E. Puga en glorværdig international komponistkarriere for at hellige sig stillingen som direktør for det lokale orkester (op.cit. I 5). Men i Kapitel 8, "Olympia «, får vi en anden udlægning af denne historie, fortalt af en af Pugas provinsielle

\footnotetext{
${ }^{8}$ I et interview har forfatteren selv givet udtryk for at bogen forudsætter en læser, der ikke bare læser bogen en enkelt gang, men studerer den grundigt (Hansen \& Alzaga 2003).
} 
kolleger. Han fortæller historien om, hvordan Puga havde spildt sit ellers glimrende talent på grund af alkoholisme og var gået i hundene (op.cit I 63-64). Hvis læseren ellers er opmærksom nok, kan han altså allerede fra bogens første kapitel læse autors advarsel om, at de fortællende stemmer ikke er neutrale og pålidelige, men taler ud fra bestemte sociale og ideologiske positioner.

I andre fortællinger møder vi andre fortællere, datteren af la pasionaria, ${ }^{9}$ den gamle psykolog der som ung mand deltog i La legión azul, det regiment Franco sendte til østfronten for at hjælpe Hitler mod kommunisterne, og en række fortællere som har en påfaldende lighed med den empiriske forfatter selv. Således møder vi allerede i Kapitel 2, »København ", den internationalt anerkendte forfatter, der i starten af I990'erne er på besøg i Danmark og deltager i en middag arrangeret af forfatterforeningen, og denne eksplicitte fortæller med Muñoz Molinas ansigt dukker op igen i fortællinger som »Berghof « (Kapitel 9), »Du er « (Kapitel I 5 ), "Narva " (Kapitel I 5) samt i det sidste og afsluttende Kapitel I7, der har givet titel til bogen. Der er imidlertid hverken nogen klar afgrænsning mellem de ovenfor nævnte fortællere og forfatterens selvbillede eller nogen klar identitet mellem dette selvportræt og den empiriske forfatter. F.eks. er der på den ene side en række detaljer, der knytter den arbejdsløse stakkel fra Kapitel I sammen med forfatterens egne erindringer fra Úbeda, mens der på den anden side er en række modsigelser mellem de forskellige figurer, hvormed autor beskriver sig selv som fortæller. Muñoz Molina selv har ganske vist bekendt at han faktisk deltog i den beskrevne middag i København, og at det var en samtale han førte under denne middag, som kom til at danne udgangspunkt for den første fortælling han skrev til denne bog, ${ }^{10}$ men det ændrer ikke ved at den litterære fremstilling af dette selvportræt til dels er fiktionaliseret. Således anføres det f.eks. i kapitlet »Du er", at hans hjemby er Mágina, dvs. en fiktiv repræsentation af en andalusisk provinsby, der ganske vist har ligheder med Úbeda, men som stammer fra hans egne romanuniverser i Beatus ille (I986) og Den polske rytter (I 99I). Først i det afsluttende kapitel, »Sefarad «, træder forfatterfiguren åbent frem og refererer til Úbeda som sin barndoms hjemby (op.cit. 544).

I denne bog optræder autor først og fremmest som en indsamler af stemmer, deriblandt hans egen stiliserede og fiktionaliserede fortæller-

\footnotetext{
${ }^{9}$ La pasionaria, Dolores Ibárruri (I 895-1989), var en kvindelig kommunistisk leder fra Asturien, som blev symbol på den antifascistiske kamp under den spanske borgerkrig, og som efter krigen gik i eksil i Sovjetunionen.

${ }^{10}$ Dette blev fortalt i samme interview som ovenfor, men er ikke medtaget i den publicerede version i Hansen \& Alzaga 2003.
} 
stemme, som han lader dialogere i en polyfon komposition, som det er op til læseren at mediere. Hver stemme taler ud fra sit eget kulturelle, ideologiske standpunkt og i sin egen ret som et ubegrænset selv, men samtidig gør talens repræsentative karakter hver af disse stemmer til et historisk og kulturelt genkendeligt ideologeme. Nogle af stemmerne stiliseres i en sådan grad, at de bliver monologiske stedfortrædere for en række kollektive kulturelle subjekter. Klarest kommer dette måske frem i Kapitel I 2, "Sheherazade «, hvor la pasionarias datter ikke bare forsvarer Stalin og Sovjetunionen mod den ondsindede vestlige propaganda, men ligefrem føler medlidenhed med den gamle mand hun mødte på hans 70 års fødselsdag i I949, og forklarer hvordan han var udsat for et jødisk komplot (op.cit. 372). Men det gælder også den ovenfor nævnte provinsbo i Madrid fra romanens første kapitel eller den frankistiske legionær, der i Kapitel 4, "Ganske tyst ", fortæller hvordan han under nazisternes offensiv forelskede sig i en ung jødisk pige i Rusland. I visse tilfælde etableres den, i Bakhtins terminologi, 'eksterne' dialog mellem disse selvfremstillende subjektspositioner og autors stiliserede forfatterstemme som i f.eks. "Narva ", men andre gange optræder disse stemmer blot side om side, hvorfor deres 'interne' dialogiske mediering afhænger af læseren konstruktion af en overgribende logisk interpretant.

\section{Fiktion, historie og opfattelsen af Europa}

I en afsluttende note erklærer forfatteren, at han selv har digtet meget lidt til i de historier han fortæller, og at de stemmer han lader tale, er stemmer han enten selv har hørt og gemt i sin erindring eller nogle han har fundet $\mathrm{i}$ andre bøger - fortrinsvis i en række biografiske fremstillinger af de i Sefarad optrædende historiske personer. Denne afsluttende erklæring bryder med læserens genreforventning til romanformen om at skulle deltage i opbygningen af et fiktivt eller imaginært univers. Og der er også andre indicier på, at vi ikke har med en helt normal roman at gøre. F.eks. udfordrer manglen på en samlet protagonist og fraværet af et samlet plot romangenrens kronotopiske karakteristika. Hvad er der da på færde, og hvorfor kalder autor selv bogen for en novela de novelas i undertitlen?

Den danske oversættelse af undertitlen, » roman-roman «, giver ikke megen mening, men udtrykket novela de novelas kan meningsfuldt oversættes til noget i retning af »en roman om romaner « eller "en roman sammensat af romaner ". Autor udlægger selv romanbegrebet som en livsfortælling: således er Kapitel I I af autor givet en titel, som stammer fra et citat af den spanske, realistiske I 800-talsforfatter Benito Pérez Galdós' (I843-I920): »Hvor mennesket end går, bærer det sin egen roman med 
sig « ${ }^{11}$ Og i den afsluttende fortælling reflekterer autors fiktionaliserede alter ego over romangenrens relation til den historiske virkelighed og de fortællinger, der knytter sig til de personer, som befolker og befolkede virkeligheden. I en passage, hvor fortælleren står på en kirkegård i New York og betragter digteren Federico García Lorcas fars gravsten, kommenterer han som følger:

Hvordan kan man være så indbildsk og letsindig at digte når der er så mange liv der fortjente at blive fortalt, for hvert eneste af dem er en roman, et netværk af forgreninger der fører til andre romaner og andre liv (op.cit. 382 ). ${ }^{12}$

Vi kan med andre ord forstå undertitlen på den måde, at det, vi som læsere har foran os, er en tekst, som inden for en samlet ramme sammenstiller alle disse levede historier, som hver af disse virkelige personer bærer med sig. Men hvordan kan dette i sig selv blive til en roman? Netop ved sin sammenstykkede karakter bryder teksten jo med vores vanemæssige genreforventninger til romanen som en udviklingshistorie, der koncentrerer sig om et individs, eller i kollektivromanen om en bestemt, afgrænset gruppe af personers, udvikling over tid.

Jeg tror at Bakhtins kronotopbegreb kan komme til hjælp her. For selv om Sefarad er sammensat af sytten forskellige historier med et varieret og meget stort persongalleri, så er alle fortællingerne komponeret over en ensartet kronotopisk struktur: eksilet. Alle fortællingerne handler om udgrænsningen af individet fra det etablerede fællesskab, hvilket vil sige at de bygger på en rumlig struktur med en grænse mellem 'inde' og 'ude' og en temporal struktur, der betoner forvandlingen eller stigmatiseringen af individet med et 'før' og et 'efter'. Eller sagt på en anden måde: Alle fortællingerne handler om, hvordan semiosfærens grænsedragninger påvirker individet og om individets oplevelse af den vold, som ofte er en konsekvens af at det kulturelle subjekt sættes igennem som en monologisk og autoritær diskurs uden en åben og kommunikativ dialog med den reelle anden. Inden for denne overordnede kronotopiske struktur udfolder teksten en række ledemotiver såsom natten, togrejsen eller værelset hvor individet kan finde fred, som alle bidrager til at give teksten en helhed så at sige på tværs af de kronotopiske elementer, som normalt karakteriserer romanen: protagonisten og handlingstråden.

\footnotetext{
${ }^{11}$ I den spanske udgave giver overskriften kun begyndelsen af citatet, "Doquiera el hobre va ", men citatet i dets helhed og reference til Galdos' Fortunata y Jacinta gives i slutningen af Kapitel 2 (Muñoz Molina 200I, 70).

${ }^{12}$ Den spanske tekst lyder således: „Cómo atreverse a la vana frivolidad de inventar, habiendo tantas vidas que merecieron ser contadas, cada una de ellas una novela, una malla de ramificaciones que conducen a otras novelas y otras vidas" (Muñoz Molina 200I, 569).
} 
Bogen er som sagt gennemstukket af intertekstuelle referencer, både til de mange mere eller mindre selvbiografiske fremstillinger som Muñoz Molina bekender sin gæld til, men også til andre fiktionstekster. Det er imidlertid bemærkelsesværdigt at det eneste navn, der refereres til i næsten alle fortællingerne, er Franz Kafka, og det på trods af at Kafka ikke optræder som person i nogen af dem. Han optræder kun som reference, men som sådan er han også signifikant.

Kafka-referencerne forankrer to af bogens centrale ledemotiver litterært: ofret som passivt tager sin skæbne på sig spejles i Kafkas person $\mathrm{K}$ fra Processen, mens den marginaliserede persons pludselige erkendelse af at hans eller hendes identitet ikke er noget ham eller hende iboende, men i sidste ende er noget som beror på den andens blik, finder sin litterære forankring i Kafkas »Forvandlingen «. I stedet for Kafkas mand, der en morgen ser sig forvandlet til et kæmpe insekt, møder vi i Sefarad en række personer, der i kraft af en racelov, en grænsedragning eller en lægelig diagnose fra den ene dag til den anden ser deres liv forandret, og deres identitet forvandlet. Men ud over denne litterære forankring af Sefarads ledemotiver får Kafka-referencerne betydning ved at afløse forfatterskabets tidligere centrale reference til den argentinske forfatter Jorge Luis Borges. Muñoz Molinas roman, Beltenebros fra I 989 kan læses som et selvreferentielt opgør med hans tidlige poetik eller romanteori, der dominerede hans firserproduktion og som begyndelsen på en romanskrivning, der tager skriftens referentielle dimension og forfatterens etiske ansvar alvorligt. ${ }^{13}$ I det tidlige forfatterskab, hvor Muñoz Molina var stærkt optaget af litteraturens formsprog og af selve repræsentationsproblemet, samt i første del af Beltenebros, var det altså de intertekstuelle referencer til Borges som dominerede, mens referencerne til Kafka dominerer her i Sefarad, som kan siges at være kulminationen på hans senere, mere etisk orienterede periode. Ud over at forankre de nævnte ledemotiver i Sefarad litterært, får referencerne til Kafka således en form for dialogisk betydning i kraft af deres negativt definerede relation til Borges. Forskellen på Muñoz Molinas tidlige og hans senere forfatterskab kan ikke beskrives som en forskel mellem hverken selvreferentialitet og realisme, ironi og engagement eller mellem fiktion og historie, for som Lawrence Rich påpeger, kan vi finde både metafiktion, ironi, engagement, fiktion og historisk repræsentation i såvel det tidlige som det senere forfatterskab (Rich I999). Jeg mener forskellen først og fremmest har noget at gøre med den måde, hvorpå autor tager ansvar for at knytte sit stof til sin livsverden og forpligte sin læser på en stillingtagen hertil.

Sefarad handler som sagt for størsteparten af fortællingernes vedkom-

${ }^{13}$ Se læsningen af denne roman, som afslutter Kapitel V. 
mende om Centraleuropa i mellemkrigstiden, og som sådan etablerer teksten en dialog med det billede af Europa, som har været dominerende i Spanien i mange år. Med det frankistiske regime ved magten fra 1936 til I978 oplevede Spanien en retraditionalisering af samfundet, der rullede stort set alle de sociale, kulturelle og politiske tiltag i retning af et moderne samfund tilbage, som Spanien havde gennemført i starten af det 20. århundrede. På den baggrund har Europa for mange spaniere først og fremmest repræsenteret kvaliteter såsom vestlig modernitet og demokratisk tradition. Det gælder for så vidt både perioden før og efter at Spanien blev optaget som medlem af De Europæiske Fællesskaber i I986. I perioden inden medlemskabet fremstod Europa som det forjættede land, og i perioden efter optagelsen har Spanien inden for en enkelt menneskealder gennemført en forceret moderniseringsproces, der har gjort at Spanien i dag i visse henseender og inden for visse sektorer hører til blandt Europas og verdens mest avancerede samfund. Men samtidig er der andre sektorer, som forbliver tilbagestående, knyttet til en præindustriel produktionsform og en traditionel kultur. Spanien har med andre ord også på dette spørgsmål udviklet sig til at være et modsætningsfyldt og polariseret samfund.

Læser vi Sefarad med afsæt i denne kulturelle horisont, kan Muñoz Molinas roman forstås som et forsøg på at vise en anden side af den europæiske moderniseringsproces end det idealbillede, som har været fremherskende i den spanske offentlighed. Ved at fokusere på jødernes situation i den europæiske historie, på holocaust og på udryddelseslejrene, gør Muñoz Molina på den ene side opmærksom på, at udryddelseslejrene også er en del af den moderne europæiske kulturhistorie, og på den anden side at antisemitismen kan siges at forbinde de mørkeste sider af Spaniens og Europas historiske tradition. Som Zygmunt Bauman påpeger, kan de nazistiske udryddelseslejre forstås som bagsiden af den industrieltbureakratiske rationalitet, som kendetegner det moderne samfund: »Hver eneste 'ingrediens' i Holocaust [...] var normal [...] i betydningen fuldstændig overensstemmende med alt, hvad vi ved om vores civilisation, dens ånd, dens prioriteringer, dens verdensbillede« (Bauman 200I, 26). Med et citat af teologen Richard Rubenstein karakteriserer Bauman dødslejrenes verden og det samfund den giver anledning til, som "natsiden af den jødisk-kristne civilisation " (op.cit. 27), et udtryk der ligger meget tæt på Muñoz Molinas »Europas store nat [...] gennemkrydset af lange uheldsvangre tog « (Muñoz Molina, op.cit. 34). Når Bauman gør opmærksom på at »ingen af de samfundsmæssige omstændigheder der gjorde Auschwitz mulig, for alvor er forsvundet « (Bauman, op.cit. 30), følger Muñoz Molina op ved at etablere en parallel mellem forfølgelsen af jøderne i 30 'erne og 40'erne og de mange druknede illegale emigranter, 
som i dag skyller op på Andalusiens kyster. Og hvor anonymiseringen og den psykologiske usynliggørelse af ofrene, ifølge Bauman, var en forudsætning for den rationelt bureaukratiske Endlösung (Bauman 200I, 48), dér kan Muñoz Molinas novela de novelas endeligt læses som et forsøg på at synliggøre hvert enkelt af disse ofre, give hvert enkelt af disse mennesker en historie, en fortid og et håb for en fremtid, kort og godt en stemme, og dermed gøre deres skæbner til en vedkommende udfordring for læseren at tage stilling til.

\section{Læserens ansvarlighed og teksten som etisk erfaring}

Muñoz Molina har altid været velbevandret i litteraturteorien, og ikke mindst receptionsæstetikken har haft hans bevågenhed (Rich I994). Det er derfor ikke overraskende, at autor i Sefarad er særdeles opmærksom på læserens rolle i tilblivelsen af tekstens betydning. Romanen tilbyder som tekstlig struktur kun et kaotisk netværk af løst sammenvævede historier, hvorfor det er læserens opgave at følge ledemotiverne og skabe de tematiske sammenhænge, der gør de mange interne henvisninger og intertekstuelle referencer meningsfulde.

Læseren af Sefarad er imidlertid ikke bare indtænkt i tekstens æstetiske strategi, men bliver direkte tiltalt og udfordret i kraft af det pronominale spil på udsigelsespositioner, som teksten orkestrerer. Forholdet mellem tekstens 'du' og 'jeg' bliver hele tiden byttet rundt, f.eks. når ordet skifter, og fortælleren bliver den tiltalte for andre indlagte fortællere, eller når henvendelsen i andenperson bare står fuldstændig åben som et anonymt 'du'. I disse tilfælde overlades det til læseren at tolke referencen, der både kan være en henvendelse til en ukendt andenperson, et selvrefleksivt mærke der markerer fortællerens, eller ligefrem autors, dialog med sit eget kritiske selv, eller det kan være en direkte henvendelse til læseren. »Og hvad ville du så gøre hvis du vidste ...« (op.cit. 50). Et andet eksempel kunne være Kapitel 3, »Den der venter «. Det er et kapitel der holder den stærkt markerede andenpersonsposition åben fra start til slut, som opruller næsten hele bogens galleri af fiktive og virkelige personer i en veritabel tour de force, og som samtidig indirekte involverer læseren gennem hentydningen til dennes kreative rolle som den, der skal forestille sig og sætte sig i den andens sted. Kapitlet indledes således:

Du ved det, eller du burde i hvert fald forestille dig det, du har set hvad der skete de andre meget tæt på, naboer der forsvinder, eller som har måttet flygte, eller som er blevet som om der ikke var nogen fare på færde, som om truslen ikke gjaldt dem (ibid.). ${ }^{14}$

${ }^{14}$ Den spanske tekst lyder således: »Tú lo sabes, o al menos deberías imaginarlo, has visto lo que 
I kraft af denne kombination af en anonym, men stærkt markeret andenpersonsposition $i$ en tekst med et permanent skiftende persongalleri, ser læseren sig nærmest tvunget ind i en identifikation, ikke med de konkrete personer som i denne kalejdoskopiske fremstilling kun bliver forbigående referencepunkter, men med de grusomme erfaringer, som udgør selve tekstens stof. Således understreger både udsigelsesstrukturen og tekstens insisterende tone bogens etiske appel og retoriske anliggende, og Bakhtins karakteristik af romangenrens answerability synes at blive trukket helt frem på tekstens overflade.

I efterskriftet til Dostojevskij-bogen skriver Bakhtin: »Literature creates utterly specific images of people, where $I$ and another are combined in a special and unrepeatable way: $I$ in form of another, or another in form of I« (Bakhtin I984b, 293-94). Denne transgrediente identifikation og omvending af forholdet mellem selv og anden er et konstant træk i romanen, som også lægges til grund for nogle af de eksplicitte overvejelser over den sociale konstruktion af kulturel identitet. Hvis vores identitet er socialt konstrueret igennem mødet med den anden og denne andens syn på os, så vil mødet med den autoritære anden, der afhumaniserer os og mærker os som udstødte, også ændre den, vi troede vi var. Vi bliver fremmede for os selv:

Du tror du ved hvem du er, og pludselig er du blevet til det som andre vil se i dig, og gradvist bliver du mere og mere fremmed for dig selv, og din egen skygge er spionerne der følger i hælene på dig, og i dine øjne ser du blikket hos dem der anklager dig, dem der skifter fortov for ikke at hilse på dig og skæver til dig med sænket hoved når de går forbi dig (op.cit. 57-58). ${ }^{15}$

Autor lader således til at eksperimentere med Bakhtins udsagn om, at romangenren åbner fiktive universer for transgredient identifikation: »the possibility of ... saying 'I am me' in someone else's language, and in my own language, 'I am other'" (Bakhtin I98 I, 3 I 5). Men i en vis forstand kan man sige at Muñoz Molina går et skridt videre end Bakhtin, idet han lader autor understrege, at disse grusomme erfaringer, som teksten opruller, netop ikke er fiktion. Ved i det ovenfor behandlede Kapitel 3, »Den

les ocurría a otros muy cerca de tí, vecinos que desaparecen, o que han tenido que huir, o que se han quedado como si no hubiera ningún peligro, como si la amenaza no fuera con ellos" (2003, 7I).

${ }^{15}$ Den spanske tekst lyder således: »Crees saber quién eres y resulta de pronto que te has convertido en lo que otros quieren ver en tí, y poco a poco vas siendo más extraño a ti mismo, y tu propia sombra es el espía que te sigue los pasos, y en tus ojos ves la mirada de quienes te acusan, quienes se cambian de acera para no saludarte y te miran de soslayo y con la cabeza baja al cruzarse contigo « (200I, 83). 
der venter ", hele tiden at indflette kursiverede passager fra Margarete Buber-Neumanns, Victor Klemperers og Jevgenija Ginzburgs selvbiografiske forlæg, understeges det over for læseren, at dette netop ikke er fiktion, men ægte, levede erfaringer.

Autors direkte henvendelser til den empiriske læser behøver ikke være henvendelser $\mathrm{i}$ anden person, men tager fra tid til anden form af åbne spørgsmål, der så at sige orkestreres i en retorisk strategi. F.eks. stiller autor i kapitlet »København « tre spørgsmål der involverer læseren som en direkte dialogpartner, der afkræves et svar som ingen ville kunne svare på med andet end en gysen:

- »Hvordan var det mon at ankomme til en tysk eller polsk banegård i en kreaturvogn [...]« (op.cit. 34) (spansk: Cómo sería llegar [...]).

- »Hvordan var det mon at sidde i toget og nærme sig en grænsestation og ikke vide om man ville blive afvist [...]« (op.cit. 37) (spansk: Cómo sería acercarse $[. .]$.$) .$

- »Hvordan er det mon at nå ind til kysten af et ukendt land midt om natten, hoppe i vandet fra en båd i hvilken man har krydset havet i mørke [...]" (op.cit. 38) (spansk: Cómo será llegar[...]).

Spørgsmålene opbygger med anaforisk konsekvens en parallelistisk forbindelse mellem jødeforfølgelsen og Den Europæiske Unions indvandrerpolitik, hvis aktualitet understreges af skiftet i verbaltid fra datid til nutid (fra konditionalis til futurum på spansk), hvorved kompositionel form og verbaltid gøres til integrerede dele af den retoriske strategi. Derved dekonstruerer teksten den åbenlyse modsætning mellem fortidens totalitære regimer med deres manglende respekt for det enkelte individ og samtidens demokratiske Europa gennem de glimtvise paralleller til det senmoderne og europæiske Spanien, hvor ligene af illegale afrikanske emigranter flyder i land på de andalusiske og kanariske kyster. Vi kan få øje på barbariet i den nazistiske holocaust, men kan vi sige os fri for ikke også selv at reproducere den sociale marginalisering som udgangspunkt for opretholdelsen af den skrøbelige 'normalitet', synes autor at spørge? Vi kan tage afstand fra historiens Hitler, men hvor snævert er egentlig forholdet mellem modernitet og totalitarisme? Spanien har i mange år, både under Francos diktatur og i perioden frem til optagelsen i De Europæiske Fællesskaber, kigget langt efter det demokratiske Europa, men hvori adskiller det 20. århundredes europæiske regimer sig egentligt fra I 500-tallets religiøse intolerance, der mundede ud i Spaniens uddrivelse af både jøder og maurere? Sådanne spørgsmål ligger under fortællingernes overflade og vidner om forfatterens udviklede bevidsthed om litteraturens etiske ansvar. 
Copyright (C) Museum Tusculanums Forlag 2006

Litterær erfaring og dialogisme, E-bog 2006 ISBN-13: 9788763506205

ISBN-10: 87-635-0620-3 


\section{LITTERATUR OG LOGISK ERFARINGSDANNELSE}

Dette kapitel skal samle op på spørgsmålet om logisk erfaringsdannelse i den litterære praksis. Det vil jeg gøre ved på den ene side at rejse diskussionen om de betingelser, hvorunder vi mener at kunne sige noget 'sandt' om den litterære diskurs i kraft af de tilgrænsende diskursive praksisformer inden for kritik og litteraturvidenskab, og på den anden side ved at se på hvordan den litterære diskurs diskuterer sin egen diskursive egenart i form af metafiktion.

Alene det første af disse emner er imidlertid stort nok til i sig selv at kunne fylde adskillige disputatser, hvorfor jeg fra starten vil præcisere, at den tilgang til spørgsmålet, som vil blive anlagt her, i store træk er determineret af den måde, hvorpå resten af bogen er bygget op. Den logiske erfaringsdannelse indgår naturligvis på alle niveauer i den litterære praksis og har derfor også indgået som et aspekt $\mathrm{i}$ de forudgående kapitler. I Kapitel II behandlede vi den logiske erfaring i form af den vilje til at skabe mening og sammenhæng, som etablerer subjektet som en centripetal dynamik i permanent dialog med en række diskursivt konstruerede selver på den ene side og et bagvedliggende kulturelt subjekt, som tegner omridset af det 'ikke-bevidste' eller kulturelt vanebetingede på den anden. I Kapitel III blev den logiske erfaringsdannelse inddraget i form af den logiske interpretants dialog med tekstens emotionelle og energetiske betydningspotentialer i tekstens æstetiske strategi. Og i Kapitel IV blev den logiske erfaringsdannelse bl.a. inddraget som det læsende subjekts evne til at udfylde tekstens tomme pladser og skabe det fiktive univers som en kohærent, mulig verden, samt til at etablere den argumentstruktur, der udgør et konstituerende element i læserens konstruktion af den virtuelle tekst, og som igen danner udgangspunkt for læserens hermeneutiske tilegnelse af teksten som en diagrammatisk model. Jeg ser ingen grund til at repetere disse aspekter af den logiske erfaringsdannelse yderligere. I stedet vil jeg benytte det afsluttende kapitel til at rejse en diskussion af, hvordan man kan begribe den dialogisk-semiotiske tradition og de anvendte peirceanske begreber, som har været et gennemgående struktureringsprincip for bogens fremstillingslogik, inden for en overordnet videnskabsteoretisk ramme. I den forstand kan man sige, at dette kapitel udgør den samme type selvrefleksion, som har indgået som et integreret element i flere af de øvrige kapitler, nu blot møntet på bogens fremstilling som helhed. 
Som nævnt i indledningen er bogen bygget op omkring to sideløbende kompositionsprincipper: på den ene side behandles de æstetiske, etiske og logiske aspekter af litteraturlæsningen i hvert sit kapitel, og på den anden side skelnes mellem tre forskellige epistemologiske vidensniveauer, som Peirce benævner den umiddelbare, den dynamiske og den finale interpretant. I Kapitel III kombinerede jeg behandlingen af den æstetiske erfaringsdannelse med niveauet for den umiddelbare interpretant hos Peirce, hvor teksten fremstår som et rent betydningspotentiale i sig selv. Og i Kapitel IV kombinerede jeg beskrivelsen af den etiske erfaringsdannelse med niveauet for den dynamiske interpretant, hvor teksten fremstår som aktualiseret betydning, determineret af læsehandlingen, og hvor teksten får tilskrevet en konkret reference til en kontekst. Kombinationen af disse to principper betyder nu, at det vil være naturligt i dette kapitel at kombinere behandlingen af den logiske erfaringsdannelse i den litterære praksis med det betydningsniveau, som Peirce har karakteriseret som den finale interpretant.

Den finale interpretant er for Peirce et grænsebegreb, en stabilitet i betydningsdannelsen, som kollektive subjekter udvikler som en vane over tid. For videnskabelige forskningsfællesskaber er det ligefrem noget man bevidst efterstræber, idet det kan betragtes som det tætteste man kommer på 'sand' viden i positiv forstand. Selv om den finale interpretant aldrig nås $\mathrm{i}$ ultimativ forstand, er tendensen i retning af at udkrystallisere en final interpretant partielt til stede i den måde vi etablerer intersubjektive 'vaner' i den litterære praksis. Bogens kompositionsprincip indebærer altså på den ene side, at de sider af den logiske interpretant, som tilhører niveauet for den umiddelbare og den dynamiske interpretant, allerede er blevet behandlet i Kapitel III og IV, samt at de aspekter af den finale interpretant som ikke vedrører tekstens logiske betydningsniveau, kun vil blive sporadisk behandlet nedenfor.

\section{Fra individuel læsning til litterær offentlighed}

Ved overgangen fra Kapitel III til Kapitel IV blev den 'afkontekstualiserede' tekst bragt i forbindelse med en kontekst, ganske vist ikke den oprindelige kulturelle og historiske kontekst, men læserens rekonstruktion af en sådan, samt hans eller hendes kulturelt konstruerede billede af sin egen livsverden. Rekontekstualiseringen af teksten betød, at den fiktive tekst genvandt en reference til en verden, og at det blev muligt at tage stilling til tekstens sandhedsværdi for læseren i form af en analog eller diagrammatisk læsning. Men da denne betydning bliver til på baggrund 
af en dialog med materiale fra læserens personlige erfaringshorisont, kan den kun have egentlig sandhedsværdi inden for rammerne af den enkelte læsning og for den individuelle læser. Nu gælder imidlertid det samme for den enkelte læsers fortolkning af en litterær tekst, som der gælder for forståelsen af en enkeltstående kommunikativ ytring: de foregår ikke i et kontekstfrit vakuum. Ligesom den enkelte ytring nødvendigvis må forstås ind i semiosfærens overgribende, holistiske og dog modsætningsfyldte labyrint af diskursive praksisformer (se herfor Kapitel I), således forsøger den enkelte læser også at forstå sin egen læsning i forhold til en diskuterende offentlighed.

I kapitel III var vi inde på, at den æstetiske erfaring opstod som en subjektiv 'dom', som det enkelte subjekt ikke desto mindre oplevede som havende universel gyldighed. Og i Kapitel IV har vi set, at læserens konstruktion af den virtuelle tekst som et diagrammatisk tegn involverer læserens erfaringsmateriale som kontekstuel baggrund for læsningen og desuden også ofte forudsætter læserens tilføjelse af nogle overordnede ideologiske eller filosofiske betragtninger som implicitte argumenter i tekstens enthymemiske, retoriske struktur. I begge tilfælde vil den enkelte læsers erfaring med teksten være præget af hans eller hendes egne subjektive betydningstilskrivninger, så for at kunne vurdere validiteten af såvel de æxtetiske erfaringer som af det hermeneutiske fortolkningsarbejde vil den enkelte være tilbøjelig til at konfrontere sine egne erfaringer med andre læseres ditto: familiens, venners, kollegers, anmeldelser osv. Man diskuterer, og man forholder sig til det dagsaktuelle anmelderi og den professionelle litteraturhistorieskrivning i en bestræbelse på at sætte sin egen umiddelbare forståelse af teksten (den subjektive 'brugslæsning' ifølge Umberto Eco) i spil med andres læsninger, for derigennem at nå frem til en forståelse med en mere eller mindre intersubjektiv eller almen gyldighed. Det er i semiotisk forstand den samme vilje til mening der får det menneskelige subjekt til at insistere på at mediere de forskellige diskursive selvers erfaringer i forhold til dets narrativiserede erindringer og sæt af kulturelle værdier (se s. 94), som driver den enkelte læser i retning af at relatere sin læsning til en overgribende cominterpretant eller commens, der kan give betydningen en vis kulturel eller ligefrem social stabilitet (se s. 4I og 59). Morten Kyndrup taler i den forbindelse ligefrem om kunstens civilisatoriske effekt, idet den æstetiske dom, her forstået i Kants forstand som en smagsdom, baner en passage fra 'jeg' til 'vi' (Kyndrup 2003, 72). Anvender vi terminologien fra Kapitel II kunne vi sige at kunsten udgør et medium, hvorigennem det individuelle subjekt ikke bare baner en passage til et kollektivt subjekt, men ved at bane denne passage aktivt deltager $\mathrm{i}$ konstruktionen eller opretholdelsen af dette kollektive subjekt. 
I pragmatisk forstand kompenserer denne bestræbelse på at relatere den enkelte læsning til en intersubjektiv forståelse af tekstens betydning i form af en cominterpretant til en vis grad for den manglende forhandling om samtalebetingelserne, som sproget mister ved overgang fra almindelig samtale til dialogen mellem tekst og læser. Bevægelsen frem mod en final, logisk interpretant består således i en stadig højere grad af generalisering af de forudsætninger af kontekstuel, intertekstuel og kulturel karakter, som lægges til grund for læsningen. I sidste instans fører denne systematiske eksplicitering af fortolkningens forudsætninger over i en litteraturvidenskabelig praksis, hvor spørgsmålet om argumentation og dokumentation for den lødige læsning samt den teoretiske afklaring af læsningens betingelser står som nogle af de diskursregulerende idealer.

Vi kan således skelne mellem tendenser i retning af vanedannelse på forskellige niveauer i den litterære praksis, ikke kun på niveauet for den logiske interpretant, men også på læsningens emotionelle og energetiske betydningsniveauer. Det giver således god mening at forstå den indflydelse, som forskellige aktuelle modestrømninger og konjunkturelle smagsfællesskaber kan have på hvilke værker, såvel kritikken som det læsende publikum vurderer positivt på et givet tidspunkt, som udtryk for et emotionelt aspekt $\mathrm{i}$ dannelsen af en final interpretant. De subkulturelle smagsfællesskaber opstår, når bestemte sociale, kulturelle, etniske eller på anden måde distinkte grupper forsøger at konstruere sig selv som et kollektivt subjekt over for det brede flertal som en anden. Denne afgrænsning fra resten af samfundet indebærer en markant gruppedannelse og et intensivt identitetsarbejde i gruppen. Dette identitetsarbejde understøttes evt. af forskellige former for 'afvigende' social adfærd, men udtrykkes sædvanligvis også gennem stil og smag. Dette forhold kender vi fra historiske fænomener såsom hippier, rockere, punkere samt en række mere aktuelle fænomener, som ikke skal behandles yderligere her. I dag er denne form for identitetssøgen gennem æstetiske udtryk imidlertid ikke blot noget som gælder for subkulturelle gruppedannelser, men også gældende for den måde store dele af befolkningen i de senmoderne samfund forsøger at konstruere sig selv som identitetsbærende subjekter (Henrik Kaare Nielsen, 200I). I vores bestræbelser på at konstruere os selv som identitetsbærende subjekter i en stadig mere frisat modernitet, betjener vi os af en række tegnsystemer, der bl.a. inkluderer måden at klæde os og de ting vi omgiver os med som forbrugere, herunder diverse former for kulturprodukter. Således indgår den enkeltes præferencer inden for musik, film, tv-udsendelser og computerspil i et mix med den personlige kanon af foretrukne litterære værker (nyudgivne, tidligere og oversatte), hvorved det enkelte subjekt definerer sig med en æstetisk accentu- 
eret ipse-identitet (Ricœur I992) i forhold til forskellige socialt og kulturelt betydende smagsfællesskaber. Den således personligt sammensatte kanon af kulturprodukter indgår som en central del af den enkelte læsers kulturelle horisont, som udgør den semiotiske grund, en given læsning vil blive til på baggrund af. Inden for disse smagsfællesskaber vil der, i kraft af denne intersubjektive referenceramme, være tilbøjelighed til at fælde de samme smagsdomme og derigennem bekræfte smagsfællesskaberne som identitetsgivende kollektive subjekter. Dannelsen af disse smagsfællesskaber afhænger ofte af helt ekstralitterære faktorer såsom f.eks. politiske forhold (González del Valle I993, 38-39) eller andre bevægelser inden for det kulturelle felt, men kan i kraft af deres overvejende æxtetiske udgangspunkt karakteriseres som temporalt og spatialt afgrænsede tendenser til dannelse af emotionelle, finale interpretanter, da de først og fremmest bidrager til at give subjektet følelsen af at være sig.

\section{Kanon og kulturel selvrefleksion}

Ligesom vi ovenfor betegnede de litterært-æstetiske smagsfællesskaber som 'emotionelle' finale interpretanter, kan udkrystalliseringen over tid af en række paradigmatiske værker og forfatterskaber i en kollektiv litterær kanon ses som udtryk for et 'energetisk' aspekt i tendensen mod at etablere vaner (dannelse af finale interpretanter) i den litterære praksis. Den energetiske interpretant er hos Peirce defineret som den konkrete effekt, der er resultatet af en given kommunikationsproces, og kanondannelsen kan i dette lys forstås som en kollektiv vanedannelse med hensyn til hvordan og hvor meget litterære værker læses og bruges, såvel i uddannelsessystemet som inden for en række kulturelle institutioner.

I antikken betød det latinske ord canon (fra græsk: kanón) regel eller norm og anvendtes, ifølge Carsten Sestofts begrebshistoriske gennemgang, i normativ forstand, dvs. som betegnelse for en liste af kanoniske tragedieforfattere, digtere og talere, der var egnede til undervisningsbrug (Sestoft I998, 59). Sådanne lister finder vi helt tilbage i Alexandria i det 3. århundrede før Kristus. I middelalderen anvendtes ordet hovedsageligt om det etablerede udvalg af de hellige skrifter, en betydning som stadig opføres som den første i det Spanske Akademis ordbog over det spanske sprog. Og med renæssancen opstod den klassiske kanon af antikke tekster. Med udspaltningen af det kunstneriske område som et selvstændigt socialt felt og udviklingen af den litterære diskursorden fra omkring I 800 var vejen banet for for alvor at applicere kanonbegrebet på litteraturen, hvilket da også skete allerede fra midt i I 700-tallet i Tyskland. 
Ikke desto mindre skal vi helt op i det 20. århundrede før vi møder begrebet udbredt med den betydning, som vi bruger i dag: Dvs. som en listning af nationallitteraturens eller en kulturel sfæres store, klassiske værker, der emblematisk tegner konturerne af et givet kulturelt fællesskabs selvopfattelse - værker der betragtes som særligt egnede til, eller ligefrem obligatoriske for, undervisningen. Specielt er brugen af begrebet eksploderet fra 1990 og frem, efter at debatten om revision eller fastholdelse af den klassiske kanon blev igangsat i USA under indtryk af kritikken fra forskellige poststrukturalistiske strømninger, der kritiserede den dominerende kanon for at fungere som et selvgivent, lukket og ekslusivt paradigme. Elaine Showalter skriver f.eks.:

Feministiske kritikere accepterer ikke det synspunkt, at kanon reflekterer historiens og eftertidens objektive værdidomme, men ser den i stedet som et kulturbundent, politisk konstrukt. I praksis har 'eftertiden' betydet en gruppe af mænd, hvis adgang til udgivelse og kritik gjorde det muligt for dem at gennemtvinge deres syn på 'litteratur' og at definere en gruppe af 'tidløse' klassikere (Showalter: The New Feminist Criticism, I985, citeret efter Sestoft I998, 60).

For Harold Bloom er den vestlige Kanon (med stort K) en grundpille i den vestlige kulturs selvforståelse, og alternativet til en fast kanon er for Bloom det rene kaos: uden en kanon ville det ikke være muligt at fastholde et universelt kvalitetskriterium, der kan udskille de væsentlige værker fra ligegyldighederne. Bloom føler sig så provokeret af kanonrevisionisternes kritik, at han forsvarer den vestlige Kanons ideologiske værdifrihed og rent æstetiske vurderingskriterier.

Nothing is so essential to the Western Canon as its principles of selectivity, which are elitist only to the extent that they are founded upon severely artistic criteria. Those who oppose the Canon insist that there is always an ideology involved in canon formation; indeed, they go further and speak of the ideology of canon formation (Bloom I994, 22).

Bloom mener ikke at det giver mening at skelne mellem de nationale litteraturer inden for det, han kalder 'den vestlige verden'. Den vestlige verden har én litterær kanon, som alene bygger på litterær kvalitet. Det er derfor nærmest pinsomt at være vidne til hvordan de 26 forfattere som Bloom inkluderer i sin kanon på baggrund af sådanne rent æstetiske valg fordeler sig på sprogligt og nationalt definerede områder: det engelske sprog er repræsenteret ved Chaucer, Shakespeare, Milton, Johnson, Wordsworth, Dickens, Austin, Whitman, Dickenson, Woolf, Eliot, Joyce 
og Beckett, fransk ved Montaigne, Molière og Proust, spansk ved Cervantes, Borges og Neruda, tysk ved Goethe, Freud og Kafka, italiensk ved Dante, russisk ved Tolstoj, portugisisk ved Pessoa og hele det nordiske område ved Ibsen. Alt i alt kommer altså halvdelen af Blooms kanoniserede forfattere i hele den vestlige kanon fra det engelsksprogede område, og af disse den absolutte hovedpart fra England med Shakespeare som den absolutte hovedfigur ("Shakespeare is the secular canon «, ibid. 24). Man kunne på den baggrund mene, at Blooms påståede universalisme afslører sig selv som værende lige så ideologisk rodfæstet som den feminisme han kritiserer, blot med et andet udgangspunkt.

De nationale kanoner som Bloom vender sig imod, bidrog til etableringen af forskellige nationale semiosfærer baseret på bestemte regionale sprog, der blev kastet op til at være nationalsprog. Med sin beskrivelse af den vestlige kanon argumenter Bloom imidlertid for, at litteraturen altid har opereret med en bredere referenceramme end de nationale sprog og kulturer, og at kanon altså tilhører en hel kulturkreds. Men det ændrer intet ved at Bloom med sin modstand mod at udvide og diversificere den litterære kanon samtidig kan forstås som et forsvar for et bestemt dannelsesideal og en bestemt litteraturopfattelse, tilhørende den modernistiske epoke. Og det ændrer intet ved at Blooms eget bud på en ikkenational vestlig kanon på trods af hans eksplicitte intention er underlagt et sproglig og nationalkulturel bias.

Bloom lancerede sit bud på den vestlige kanon på et tidspunkt, hvor forskellige poststrukturalistiske strømninger inden for litteraturkritikken havde bestræbt sig på at dekonstruere de traditionelle værdihierarkier op igennem I970'erne og I980'erne. Den 'hvide' kanon blev dekonstrueret af de sorte, mændenes kanon af kvinderne, den heteroseksuelle af bøsser og lesbiske, den koloniale af de postkoloniale samfund osv. Udtrykt i semiotiske termer udgør Blooms beskrivelse af den litterære kanon et bidrag til det, Lotman karakteriserer som semiosfærens kulturelle selvbeskrivelse.

The stage of self-description is a necessary response to the threat of too much diversity within the semiosphere: the system might lose its unity and definition, and disintegrate. Whether we have in mind language, politics or culture, the mechanism is the same: one part of the semiosphere (as a rule one which is part of its nuclear structure) in the process of self-description creates its own grammar [...] Then it strives to extend these norms over the whole of the semiosphere. A partial grammar of one cultural dialect becomes the metalanguage of description for culture as such (Lotman I990b, I28).

Den kulturelle selvbeskrivelse er ifølge Lotman en defensiv centripetal 
reaktion på en truende centrifugal aktivitet, som iværksættes i et forsøg på at holde sammen på semiosfæren på tværs af dens grænser. Lotman beskriver semiosfæren som værende organiseret omkring en kerne med de nationale sprog i centrum, hvilket betyder at semiosfæren som overbegreb må være sammensat af forskellige delsemiosfærer, organiseret omkring disse sprog. Den defensive centripetale reaktion på for meget diversitet iværksættes typisk fra et af disse kerneområder, der etablerer sin egen norm (grammatik), som efterfølgende opkastes til at være gældende for helheden. Blooms bud på den vestlige kanon kan forstås som et forsøg på at etablere en sådan norm, dvs. reetablere et værdihierarki for den vestlige verdens kulturelle semiosfære som helhed, om end afsættet tages i den engelsksprogede litteratur.

For Lotman danner den tekstligt formidlede forestilling om fortiden, hvad enten den formidles i narrativ eller systematisk form, baggrund for dén kulturelle tradition, som et givet subjekt, kollektivt eller individuelt, bygger sin personlighed eller kulturelle identitet op omkring: »Tradition is always a system of texts preserved in the memory of the given culture or subculture or personality (Lotman I990b, 70). Traditionen og forestillingen om fortiden er imidlertid for Lotman ikke en statisk beholdning af kanoniske tekster, men en aktiv partner i dialogen med subjektets samtidige erfaring om de vilkår som skal gælde for fremtiden:

Texts which form part of 'tradition' are not for their part inert ones: when they come into the context of 'contemporaneity' they 'come to life' revealing their previously concealed meaning-potential. So the picture we have before us is that of organic interaction, of a dialogue, in the course of which each of the participants transforms the other and are themselves transformed under the action of the other [...] (Lotman I990b, 7I).

Traditionen formidles til nutiden i form af en 'organisk interaktion' eller dialog med overleverede tekster, siger Lotman. I semiotisk forstand består kanon altså ikke af en liste af obligatoriske værker, men er et led i en kulturel vanedannelse over tid, hvor både tekster og deres læsninger 'kanoniseres' som privilegerede måder at se og forstå verden inden for forskellige og ofte modstridende eller konfliktende sektorer af den kulturelle semiosfære. Kanonbegrebet er således mere en funktionel kategori end det er en essentiel størrelse: kanon består af de tekster som et givet fællesskab på et givet tidspunkt anvender til at konstruere nogle kulturelle eller identitetsmæssige grænser inden for semiosfærens rammer. Det er en dynamisk proces i konstant udvikling, hvor forskellige kanoner konkurrerer, hvor kanoniserede forfattere glider ud, nye kommer til og gamle marginaliserede forfatterskaber rehabiliteres og reintroduceres i kanon. 
Det er på den baggrund vigtigt at humaniora sikrer en levende adgang til forståelse af denne proces i form af genskrivninger af litteraturhistorierne, ikke bare den nationale, men også den regionale og den internationale litteraturhistorie, og diskuterer denne i forhold til globaliseringens kulturhistorie.

Blooms liste over kanoniske forfattere udgør ikke en final interpretant i sig selv, men ingen vil vel bestride, at de forfattere, som figurerer på den, er væsentlige forfattere. Den finale interpretant eksisterer altså tendentielt som en implicit bagtekst, der udkrystalliserer sig over tid i et kompliceret samspil mellem litteraturkritik, litteraturhistorieskrivning, læsevaner, kommercielt marked og undervisningspraksis. Men Bloom har med sit udspil sat diskussionen af kriterierne for litterær kvalitet på dagsordenen, og har dermed stimuleret den demokratiske proces, som leder frem imod udkrystalliseringen af en final interpretant som en tendens, og det er positivt.

Et andet eksempel på, at kanonbeskrivelse kan anvendes som en defensiv centripetal reaktion på en truende centrifugal aktivitet, er den kanondiskussion, som regeringen bestående af Venstre og Konservative lancerede med støtte fra Dansk Folkeparti i 2004. På forslag af et udvalg med Jørn Lund som formand vedtog undervisningsministeriet en liste med I 4 forfatterskaber plus folkeviserne, som eleverne i den danske folkeskole skal stifte bekendtskab med. Dertil kommer en liste over forfatterskaber, som kanonudvalget anbefaler, at eleverne møder i skolen, og en anden liste over forfatterskaber, som anbefales til gymnasierne. Det eksplicitte argument for at iværksætte initiativet var, at dansk kultur og danske værdier er truet af globalisering, indvandring, it-revolution osv., samt en forestilling om, at skoleelevernes obligatoriske læsning af bestemte forfatterskaber ville kunne ændre noget ved det. Den implicitte præmis bag initiativet var en udløber af regeringens såkaldte værdikamp, der blæser til samling omkring en højrenational revanchistisk offensiv mod en række stereotype fjendebilleder, såsom kulturradikalismen, 68-generationen og venstrefløjen i al almindelighed. Denne side af baggrunden blev klar, da kulturminister Brian Mikkelsen umiddelbart efter foreslog en anden kanon for film, billedkunst og design mm., for at igangsætte en diskussion om den danske kulturarv. Ved at møde den usikkerhed, som brede dele af den danske befolkning føler over for de tiltagende globaliseringsprocesser, med kravet om en revitalisering af de nationale 'værdier' og koble denne kampagne sammen med hetzen mod det stigmatiserede stereotypbillede af de 'antinationale', har regeringen skabt en offensiv ideologisk platform, som oppositionen ikke har kunnet dæmme op over for. Som sådan har kanondiskussionen været en del af en effektiv politisk 
strategi. Men det er også hvad det er; et bidrag til etableringen af en kulturel kanon forstået semiotisk som udkrystalliseringen af en energetisk final interpretant er det imidlertid ikke.

Det er uomtvisteligt at kanondannelse, forstået som udkrystalliseringen af en final interpretant over tid, udgør en forudsætning for etableringen af de fortolkningsfællesskaber, som igen udgør en forudsætning for konstruktionen af kulturel identitet. Nationallitteraturen og den nationale, litterære kanon har været en forudsætning for konstruktionen af de nationale fællesskaber vi kender i dag, og kanondannelse er involveret i ethvert forsøg på national eller subkulturel identitetskonstruktion, hvad enten det foregår lokalt, nationalt eller globalt. Men at forestille sig, at et lovpligtigt påbud til skolerne om et bestemt læsepensum eller en liste med særligt betydningsfulde værker inden for kulturministeriets ressortområde kan ændre noget ved forholdet mellem de globale, regionale, nationale og lokale paradigmer i den kulturelle identitetsdannelse, er noget ganske andet. Udkrystalliseringen af kanon er en dialogisk proces som over tid tenderer mod at etablere en form for konsensus, eller cominterpretant, mens regeringens kanonudspil er et autoritært og monologisk diktat, der først og fremmest vil blive forstået som udelukkelse af dem, der ikke er taget med.

At kanondannelsen forstået som en tendens til at etablere en final energetisk interpretant foregår som en dialogisk og i den forstand demokratisk proces over tid, betyder imidlertid ikke, at den ikke er snævert relateret til magtfulde interesser. Derfor må processen studeres i dens diskursive interaktion med de sociale institutioner og de dertil knyttede praksisformer: litterær kritik, udgivelsesvirksomhed samt undervisning og uddannelse (González del Valle I993, 30). Studiet af et givet kulturelt fællesskabs kanon samt diskussion heraf giver et godt billede af denne kulturs bestræbelse på at konstruere et kulturelt subjekt med en specifik identitet. Og det gælder også Mikkelsen og Tørnæs' mere xenofobisk begrundede initiativer. I diskussionen af lovforslagene interagerer forskellige interesser og forskellige dagsordener: forfattere, kritikere, undervisere, læsere, politikere og folk professionelt beskæftiget med markedet bag litteraturproduktion og -distribution. Selv om de elektroniske medier og den udbredte adgang til internettet har ændret styringsmulighederne afgørende, er det fortsat sådan, at etableringen af en samlet eller bare dominerende kanon sker gennem et samvirke af forskellige systemer: det kommercielle system, uddannelsessystemet og den kulturelle offentlighed som et overgribende system. Det kommercielle system omfatter forskellige typer af hitlister, reklamer, bogklubber og filmatisering, mens uddannelsessystemets bidrag til kanondannelsen f.eks. består i etableringen af 
ensartede curricula med mere eller mindre obligatoriske pensumlister. Endelig omfatter den kulturelle offentlighed pressens anmelderi og tildeling af forskellige former for priser og stipendier samt denne luftige størrelse, som af Bourdieu er blevet døbt 'kulturel kapital'. At der ikke er vandtætte skotter imellem disse institutioner og deres forskellige praksisformer ses bl.a. af hvor stor betydning de komercielle priser har for bogsalget. Det gælder f.eks. priser som Goncourt-prisen i Frankrig, Man Booker-prisen i England, Pulitzer-prisen i USA og f.eks. Premio Planeta i Spanien. Omvendt finder man også ofte, at det er en relativt snæver gruppe af etablerede forlag, der trækker de prestigefulde priser hjem og som står som udgivere af de kanoniserede værker.

\section{Litteratur og videnskabelig erkendelse}

Indtil videre har vi alene beskæftiget os med den litterære kritik og udviklingen af den litteraturvidenskabelige teori som et led i bestræbelsen på at etablere en cominterpretant i relation til den litterære diskurs, dvs. en form for intersubjektiv vane eller final interpretant i forståelsen af de litterære værker. Det er imidlertid min opfattelse, at skønlitteratur, litterær kritik og litteraturteori må betragtes som tilhørende tre forskellige diskursive registre, hvorfor forholdet er lidt mere kompliceret end som så. Idet der er tale om tre forskellige diskurser, retter hver diskurs sig tendentielt mod etableringen af en final interpretant i form af en 'vane' inden for sit eget domæne, en vane eller regelmæssighed, som ikke desto mindre hele tiden bliver ændret, brudt og skifter retning i kraft af de dialogiske processer de gennemløber. Den litterære diskurs i Kapitel I og II blev defineret som er en mimetisk diskurs, der etablerer sig som interpretant i forfatterens fortolkning af de diskurser som karakteriserer hans forhold til sin livsverden, hvorimod den litterære kritik og litteraturteorien udgør metadiskurser i den forstand, at de bestræber sig på at hæve generaliseringsniveauet i den litterært-mimetiske diskurs. Den litterære kritik etablerer sig som en primært logisk interpretant af den litterære diskurs, og litteraturteorien etablerer sig som en primært logisk interpretant af såvel den litterære diskurs som af litteraturkritikken. Den litterære diskurs er en diskurs, der som et af sine karakteristika har en høj grad af poeticitet og som derfor kan siges bl.a. at være konstrueret med sigte på at udvirke en æstetisk erfaring hos læseren, mens de kritiske og teoretiske diskurser er konstrueret med henblik på at beskrive, analysere eller fortolke denne dialog i rationelle termer. Det betyder ikke, at der ikke kan være æstetisk erfaring knyttet til læsningen af kritiske eller teoretiske 
tekster, men at det er den logiske, rationelle udlægning af de æstetiske og etiske erfaringsniveauer, som udgør den centrale del af de diskursregulerende principper for disse diskursordener.

Hvad angår forholdet mellem den kritiske og den teoretiske diskurs kan man kortfattet sige, at den litterære kritik bidrager til dannelsen af 'vaner' i forståelsen af bestemte værker og forfatterskaber gennem udkrystalliseringen af alment accepterede og kanoniserede læsninger, dog uden universel gyldighed, mens litteraturteorien bidrager til dannelsen af 'vaner' i litteraturkritikken i form af at generere accepterede litteraturvidenskabelige tilgange og metoder.

Set over tid etablerer skønlitteraturen selv et netværk af genrer og undergenrer, der spiller en vigtig rolle for såvel den fremtidige skabelse af nye værker som for forståelsen af det enkelte værk i den konkrete læsning. På den ene side betyder forfatternes kamp med traditionen (Blooms agon), at de skriver deres tekster op imod andre tekster og forfatterskaber, jf. Blooms begreb anxiety of influence (Bloom I973), hvorved forfatterne selv fremskriver en form for kanondannelse. På dette niveau er der ikke tale om en autoritativ liste af mastertekster, men om at teksterne etablerer deres egen intertekstuelle påvirkningshistorie. Hvert nyt bidrag bliver således til i en dialog mellem tradition og fornyelse. På den anden side udgør genreforventningerne en vigtig del af den baggrund, hvorpå den enkelte læser fortolker et værk. I semiotisk forstand bliver den litterært-kulturelle offentlighed at forstå som den grund, som læseren foretager sin umiddelbare fortolkning på baggrund af. Som Alistair Fowler formulerer det, er der i hver historisk periode simpelt hen kun et begrænset antal af 'aktive' litterære genrer, som den litterære offentlighed kan forholde sig til (refereret af Harold Bloom, I994, 2I).

Hvis det første skridt i bevægelsen frem mod at etablere en final interpretant i den litterære praksis består i, at der såvel i kreationsprocessen som i receptionsprocessen spontant udskiller sig bestemte kanoner og dominerende genreforventninger, så består det andet skridt $\mathrm{i}$ at den analytisk-kritiske diskurs bestræber sig på at generalisere de forudsætninger, som lægges til grund for læsningen. Den litterære kritik baserer nødvendigvis sine domme på nogle stærke læsninger af en afgrænset række kanoniserede forfatterskaber, der således kommer til at udgøre rygraden i forskellige inddelinger, kategoriseringer og periodiseringer af forfatterskaber, stilretninger og genrer, samt for den sags skyld i hele den narrative konstruktion af litteraturhistorien. Som en analytisk diskurs skriver den enkelte læsning sig ind i kæden af andre diskursive ytringer, som kendetegner et givet forskningsfællesskabs kritiske tradition.

Endelig er litteraturteorien karakteriseret ved at gøre forholdet mellem 
den litterære diskurs og den kritiske diskurs til sin genstand. Den litteraturteoretiske diskursorden tenderer således mod at diskutere de principper, som litteraturkritikken baserer sine læsninger på, i forhold til almene filosofiske og semiotiske principper for erkendelse og viden. Tredje skridt i bevægelsen frem mod etableringen af en final interpretant i den litterære praksis består således i at formalisere og eksplicitere den teoretiske baggrund for læsningen med henblik på at etablere et intersubjektivt eller sammenligneligt udgangspunkt for fremtidige læsninger. Den grund som den kritiske læsning bliver til på baggrund af, er således det, som kendetegner eller samler forskningsfællesskabet til et fællesskab, dvs. en vis enighed om bestemte teoretiske eller epistemologiske princippers gyldighed. Derfor er det altid vigtigt at afklare, hvori de teoretiske forudsætninger for en given læsning består. Og ligesom det menneskelige subjekt i kraft af sin selvkritik og selvkontrol er i stand til at lære af sine erfaringer med henblik på at revidere og berige sin æstetiske, etiske og logiske kompetence, således bør også et forskningsfællesskab eller kollektivt subjekt altid være åbent over for at blotlægge, hvad nye kritiske indsigter indebærer for forskningsfællesskabets teoretiske tradition.

Peirce forstod den videnskabelige forskningsproces som en fremadskridende akkumulation af viden om verden, men han satte i høj grad spørgsmålstegn ved den positivistiske opfattelse af 'sand' viden: »Den mening, som alle forskere er skæbnebestemt til i sidste ende at blive enige om, er, hvad vi mener med sandhed, og det objekt, der repræsenteres i denne overbevisning er det virkelige " (Peirce 1994, 206). For Peirce eksisterer der således ikke en ultimativ 'sandhed', og den videnskabelige erkendelse kan kun tilnærmes via en 'asymptotisk' ${ }^{1}$ bevægelse, som en semiotisk eller intersubjektiv vane i de videnskabelige forskningsfællesskabers arbejde. Man kan sige at sådanne vaner f.eks. opstår inden for litteraturvidenskaben som periodisk kanoniserede læsninger i de store værkers kritikhistorie. Men da de humane videnskabers sandhedsideal er et andet end det, som gælder inden for naturvidenskaben, vil disse vaner være lettere at bryde i den videnskabelige praksis. Således kan man betragte den litteraturvidenskabelige praksis som en række fortløbende tekstlæsninger, hvorigennem tidligere læsninger be- og/eller afkræftes dialogisk. Hver ny læsning indeholder ud over den originale tekst også de tilkomne sekundærtekster i form af kritikken. Den forskellige grund som hver ny læsning etablerer sig på, fokuserer det samme litterære univers på en ny måde. Der er med andre ord tale om, at man kan foretage uendeligt mange læsninger af den samme tekst, hvilket dog ikke betyder, at alle

\footnotetext{
${ }^{1}$ Betegnelsen er Keld Gall Jørgensens ( 1994,24$)$ og refererer til geometrien, hvor en asymptote er en kurve som nærmer sig, men aldrig falder sammen med en ret linje.
} 
læsninger er lige 'korrekte'. Hvilke logiske kriterier vi kan etablere for at afvise en læsning som ukorrekt, eller for at skelne mellem stærkere eller svagere læsninger, vender vi tilbage til nedenfor. På dette sted er det blot vigtigt at slå fast, at så længe vi taler om en videnskabelig praksis, må man kunne forudsætte et kendskab til kritikken og kritikhistorien. Dette indebærer på sin side, at de tidligere læsninger af værket, eller i det mindste fragmenter heraf, må indgå som elementer i det nye makrotegn. Således bliver dialogen med kritikhistorien en integreret del af den videnskabelige beskæftigelse med litteraturen.

I modsætning til forskellige tekstimmanente teorier som f.eks. strukturalismen, ${ }^{2}$ opfatter Peirce ikke betydningen som en i tegnet immanent liggende størrelse, hvorfor den heller ikke kan bestemmes 'objektivt', men kun kan tilnærmes intersubjektivt. Den Peirce'ske litteraturmodel indebærer derfor en relativisering af strukturalismens objektivitetsideal. Sheriff formulerer relativismen i Peirces semiotik således: »Subjectivity and relativism, then, are inevitable [...] But this subjectivity is very limited and circumscribed, virtually lost as it is exercised. Relativism does not mean that there is no truth, but that truth is not outside and above time, place and history " (Sheriff I989, 95-96).

På trods af dette opgør med objektivismen er Peirces semiotik altså ikke relativistisk i dekonstruktiv forstand. ${ }^{3}$ Peirce, der som nævnt var både naturvidenskabsmand og begrebsrealist, konstruerede sin semiotiske teori i en bestræbelse på at blive klogere på verden. Og består verden af tekster, så for at blive klogere på disse tekster. For Peirce indebærer enhver ny læsning, så længe vi bevæger os inden for en videnskabelig praksis, at forskningsfællesskabets samlede viden om det dynamiske objekt øges. Og dette indebærer i anden omgang, at en videnskabelig omgang med tekster må medreflektere forskningsfællesskabets tradition i behandlingen af disse tekster, samt gøre sin egen stilling klar i forhold hertil.

En af de teoretikere som har anvendt Peirces semiotik til at beskrive relationen mellem litteraturen, litteraturkritikken og litteraturteorien, er netop John K. Sheriff. Han drager for sin part en skelnen mellem de tre diskursive niveauer i den litterære praksis ved at se på den måde, hvorpå de repræsenterer deres objekt for en interpretant:

\footnotetext{
${ }^{2}$ Som repræsentanter for den strukturalistiske tradition kunne man pege på en tendens gående fra Saussure over Hjelmslev (I943) og Svend Johansen (I949) frem til Greimas (I974).

${ }^{3}$ Se bl.a. Ecos opgør med Derridas dekonstruktive læsning af Peirce (Eco I $990 / 92$ kap. 4.6), Anne Marie Dinesens »Derrida og Peirce (Dinesen I 994) samt Sheriffs kritik af Derridas Peirceforståelse (Sheriff I $989,57-58,89$ og I 27).
} 
Literary art, criticism, and theory are all symbolic, but their difference in character consists precisely in whether they represent their objects as signs of possibility, fact or reason [...]. [Literary theory] represents its objects as general signs, as conventions, rules, laws (Sheriff I989, I24).

Sheriffs knytter efterfølgende de tre diskursers måde at repræsentere den litterære tekst (som hhv. en mulig verden, et aktuelt faktum eller en generel regel) til Peirces betegnelser for interpretantens relation til repræsentamenet, dvs. begreberne rhem, dicent tegn og argument. Relaterer vi Sheriffs måde at kategorisere de tre diskurser til den anvendte trekantsmodel, kunne det se således ud:

\section{Tekst}

Rhem \{

$\Delta$

$\begin{aligned} \text { Objekt } & \text { Interpretant } \\ \text { Teksten som en } & \text { Brugslæsning } \\ \text { mulig verden } & \end{aligned}$

Dicent tegn \{

$\Delta$

Objekt Interpretant

Teksten som et Kritisk læsning aktuelt faktum

Argument \{

\begin{aligned} & \multicolumn{2}{c}{$\Delta$} \\ & Objekt Interpretant \\ & $\begin{array}{r}\text { Teksten som en } \\ \text { generel regel }\end{array}$ Litteraturteori \end{aligned}

Skematiseringen ekspliciterer hvordan den teoretiske diskurs nødvendigvis må indoptage såvel den æstetisk-litterære som den analytisk-kritiske diskurs i sit genstandsfelt (tegnpositionen), da det jo er på baggrund af disse tekster og deres læsninger, teorien forsøger at generalisere et udsagn, der antages at have gyldighed som en generel regel. Resultatet af den kritiske læsning bliver således selv underlagt en fortolkning, der ser det som et lovmæssigt betinget tegn, et symbolsk argument, for en mere generel udvikling. På baggrund af den teoretiske refleksion bliver interpretanten således i stand til at fremskrive prognoser om en fremtidig udvikling.

Dines Johansen påpeger imidlertid at det er et problem når Sheriff anvender begreberne rhem, dicent-tegn og argument til at skildre de tre niveauer i den videnskabelige litteraturreception, fordi de litterære værker selv også fungerer som argumenter i den almindelige brugslæsning (Johansen I996). Det har vi været inde på i forbindelse med forståelsen af litterære værker som diagrammatiske modeller for læserens selvforståelse 
i forrige kapitel. Mit alternativ til Sheriffs karakteristik vil derfor være at forstå den litteraturvidenskabelige praksis som en kollektiv bestræbelse inden for et forskningsfællesskab frem imod udkrystalliseringen af en final interpretant, forstået som en vane i dette forskningsfællesskabs arbejde. Fordelen ved denne terminologi er på den ene side, at den kan operere med tekstens argumentstruktur på alle niveauer (betydningspotentiale, aktualiseret mening og kritisk bedømmelse), og at den på den anden side åbner muligheden for at forstå den litterære praksis som bestående af dialogiske interaktioner på alle tekstlæsningens niveauer. For at komplementere ovenstående model har vi derfor behov for at erstatte Sheriffs overordnede kategoriseringsprincip (rhem, dicent tegn, argument) med de interpretantniveauer, som har struktureret hele denne fremstilling (umiddelbar, dynamisk og final interpretant).

\section{Tekst}

$\Delta$

Umiddelbart objekt

Repræsenteret kronotop

Umiddelbart objekt

Læserens erfarede livsverden

Umiddelbart objekt

Teksten som et aktuelt faktum

Umiddelbart objekt

Teksten som en generel regel
Dynamisk interpretant

Narrativ model for selvforståelse

$\Delta$

I. finale interpretant

Kritisk læsning

$\Delta$

2. finale interpretant

Litteraturteori

Såvel brugslæsningen som den kritiske læsning består i at mediere dialogen mellem den umiddelbare og den dynamiske interpretant i form af en semiotisk vane. Forstået på denne måde består forskellen mellem en kritik med videnskabelig ambition og en 'brugslæsning' (Ecos begreb) i, at den kritiske læsning må redegøre fyldestgørende for denne dialog og for det teoretiske grundlag, som den udfolder sig på. Den kritiske diskurs må med andre ord forholde sig systematisk til tekstens morfosyntaktiske, semantiske og pragmatiske egenart, relatere denne til tekstens oprindelige kontekst og tradition samt endelig reflektere over sit eget teoretiske grundlag for at gøre dette. Dog kan heller ikke den litterære kritiker unddrage sig det hermeneutiske problem, men må også være bevidst om historiciteten i kritikhistoriens forskellige læsninger, inklusive sin egen. 
Hver ny læsning bliver til i en intertekstuel dialog med traditionen på den ene side og med samtiden på den anden, hvorved kæden af fortløbende interpretanter aktualiseres som en del af tegnet selv, mens den teoretiske refleksion hvormed læsningen metodisk set angribes, udgør den grund, hvorpå den kritiske læsning etableres. Den kritiske læsning stræber således mod at indgå i en reflekteret kæde af successive læsninger, hvorigennem konturen af en final interpretant tendentielt vil opstå over tid inden for et givet forskningsfællesskabs kontinuerte samarbejde. Den teoretiske tradition som teoriudviklingen knytter an til, bliver dermed at forstå som den finale interpretants grund.

\section{Kriterier for videnskabelighed}

Som nævnt i Kapitel I udtænkte Peirce sin semiotiske teori som led i en generel videnskabsteori. For Peirce var der ingen grundlæggende forskel mellem naturvidenskaberne og humanvidenskaberne, netop fordi han stillede sig på semiotikkens grund. Han problematiserede empirismen primært inden for naturvidenskaberne og foreslog som alternativ en dynamisk og selvreflekterende semiotisk teori, der også har gyldighed inden for humanvidenskaberne. Jeg har på den baggrund bogen igennem argumenteret for at litteraturvidenskaben kan forstås som en videnskabelig praksis og gjort dette som om det var et indiskutabelt faktum. Men det er ikke tilfældet. Faktisk har Mikhail Bakhtin, som er en anden af de vigtige inspirationskilder bag denne fremstilling, gjort sig til talsmand for det stik modsatte synspunkt. Det må derfor være på sin plads at runde fremstillingen af med nogle generelle betragtninger over de kriterier for videnskabelighed, som ligger til grund for denne bog og kort ridse op, hvordan de forholder sig til hhv. Peirces og Bakhtins standpunkter.

For Bakhtin er der på den ene side tale om en grundlæggende overensstemmelse mellem natur- og humanvidenskabernes videnskabshistoriske udvikling i den forstand at de begge er resultatet af en åndshistorisk udvikling, der tager sin begyndelse med renæssancen (Todorov I984, I 5 ). Men samtidig er der også tale om en grundlæggende forskel hvad angår det studerede objekt og de anvendte metoder. Med hensyn til det første mener Bakhtin, og med ham både Volosjinov og Medvedev, at teksten som genstand eller objekt for en undersøgelse adskiller sig grundlæggende fra naturvidenskabens objekter, idet tekster eller litterære værker er udtryk for en subjektiv intention. Den litterære fortolkning er således snarere et subjekt-subjekt-forhold, end det er et subjekt-objekt-forhold:

The human sciences are the sciences of man in his specificity, and not the sciences of a voiceless thing and a natural phenomenon. Man, in his human 
specificity, is always expressing himself (speaking), that is always creating a text (though it may remain in potentia). Where human being is studied outside of the text and independently of it, we are no longer dealing with the human sciences [...] (P.N. Medvedev: Formalism and Formalists I934, citeret fra Todorov I984, I7).

Humanvidenskabernes subjekt-subjekt-relation betyder, at forholdet mellem de to instanser antager en dialogisk karakter i stedet for naturvidenskabens monologiske diskurs:

The transcription of thinking in the human sciences is always the transcription of a special kind of dialogue: the complex interrelations between the text (the object of study and reflection) and the created framing context (questioning, refuting, and so forth) in which the scholar's cognizing and evaluating thought takes place. This is the meeting of two texts - of the ready-made and the reactive text being created - and consequently, the meeting of two subjects and two authors [...] The text is not a thing, and therefore the second consciousness, the consciousness of the perceiver, can in no way be eliminated or neutralized (Bakhtin I986, I06-I07).

Med denne skelnen mellem tegn og ting, mellem subjekt og objekt, lægger Bakhtin sig op ad nogle af de videnskabsteoretiske positioner, vi kender fra det sene I 800-tal, f.eks. Wilhelm Diltheys skelnen mellem natur- og åndsvidenskaberne og Wilhelm Windelbands skelnen mellem de 'nomotetiske' og de 'idiografiske' videnskaber. For Dilthey havde naturvidenskaberne til formål at give en ydre årsagsforklaring, at 'forklare', mens åndsvidenskaberne havde til formål at 'forstå', hvilket for Dilthey involverede en form for indføling og respekt for det subjektive element $i$ genstanden (Kapitel IV, se s. 205). Ifølge Windelband havde de nomotetiske videnskaber som målsætning at erkende det generelle eller at kortlægge generelle lovmæssigheder, mens de idiografiske videnskaber satte sig som mål at forstå det enkeltstående tilfælde. Man kan også sige, at den eksperimentelt funderede naturvidenskab retter sig mod universer, hvor 'sandheden' er en regel, der kan give anledning til systematisk gentagelse. Den hypotetiske abduktion verificeres eller falsificeres derfor ved videnskabelige eksperimenter gennem deduktion. Heroverfor beskæftiger humaniora sig typisk med forhold (begivenheder, tekster), hvor 'sandheden' består i en singulær fortolkning (abduktion), som ikke er entydig. Vurderingskriteriet er her argumentets 'styrke' og ikke dets sandhed. For de idiografiske videnskaber bliver verifikationsproblemet således til et spørgsmål om argumentets 'gyldighed' (Eco I992, 26I og Kjørup I996, 95 ff.).

For både Dilthey og Windelband adskiller verifikationsprocedurerne inden for humanvidenskaberne sig radikalt fra verifikationsprocedurerne 
inden for naturvidenskaberne, og Bakhtin synes at være enig i dette synspunkt. I og med at en læsning af en litterær tekst ikke kan siges at være 'sand' eller 'falsk', men snarere udfolder en dialog med tekstens synspunkt, adskiller litteraturstudierne sig fra naturvidenskaberne, hvor man mener at kunne bekræfte eller falsificere ved brug af eksperimentelle metoder. I de litterære studier kan man kun tale om forskellige grader af styrke eller sandsynlighed. Samme synspunkt forfægtes af f.eks. Paul Ricœur og Umberto Eco: Paul Ricœur bruger begrebet sandsynlighed (probability) for den gode læsning, mens Umberto Eco vælger at tale om stærkere eller svagere læsninger. Denne terminologiske forskel forskyder i Ecos tilfælde læsningens sigte fra en indskrevet intention til et samspil mellem tekstens strategi og læserens kreativitet, men synspunktet er i bund og grund det samme.

Betragter vi teksten som et subjekt, som læseren dialogerer med, er der i princippet ingen forskel på den litterære tekst og den kritiske tekst; alt hvad vi har at gøre med er tekster, og forholdet mellem den litterære tekst og kritikken er snarere at betragte som en intertekstuel end en metatekstuel relation. Tekster er bare tekster - der eksisterer simpelthen ingen epistemologisk position, hvorfra en kritisk tekst som metatekst kan hente autoritet til at udsige noget andet eller noget mere sandt end det, som den litterære tekst selv siger. Dette synspunkt som dele af Bakhtin-receptionen har tilskrevet Bakhtin op gennem firserne og halvfemserne, kan genfindes i den kritik, som har udviklet sig under påvirkning af Derridas og Paul de Mans dekonstruktion.

Hvori består da forskellen mellem en videnskabelig praksis og en ligegyldig plapren, når vi har med humaniora og med litteratur at gøre? For Bakhtin er humanvidenskaberne grundlæggende optaget af mødet med den anden, og når vi taler om tekstlæsning har vi at gøre med mødet med tekstens anden, hvor teksten antager karakter af et subjekt. Humanistens opgave bliver således ifølge Bakhtin at forstå og formidle den andens position, dog uden helt at opgive sin egen. I en sammenligning med naturvidenskabens akkuratesse i den empiriske dokumentation siger Bakhtin: "In the human sciences, accuracy consists in overcoming the other's strangeness without assimilating it wholly to oneself « (Bakhtin: Concerning methodology in the human sciences 1975, citeret efter Todorov I984, 24). For Bakhtin er humanioras beskæftigelse med tekster og historie således legitimeret gennem det formål at forstå. Men det er vigtigt at bemærke at der er en erkendelsesinteresse involveret, hvilket netop antydes ved at Bakhtin sammenligner denne forståelse med naturvidenskabens akkuratesse. Hvor det for naturvidenskaberne er den nøjagtige måling som borger for resultatets validitet, dér er det inden for 
humanvidenskaberne og tekstlæsningen det reflekterede forhold mellem selv og anden som det handler om. Der er her tale om en treleddet dynamisk relation, der modsvarer Bakhtins dialogiske subjektsbegreb. Den humanistiske forsker må stræbe efter at forstå den 'anden', indleve sig i den 'andens' (tekstens) udsigelsesposition og verdensforståelse, men samtidig må han fastholde en distance qua sin position som forsker, og han må medreflektere de teoretiske betingelser, som denne aktivitet udfolder sig på. Hvad enten Bakhtin beskæftiger sig med sprogfilosofi, litteraturkritik eller videnskabsteori, er det denne betydningens grundlæggende dialogiske karakter, der optager ham. For hvis betydningen altid opstår dialogisk, vil ingen diskurser, heller ikke den kritiske, kunne unddrage sig dette vilkår. Selv naturvidenskabsmanden indgår i det objekt, han undersøger, på samme måde som modtageren af en sætning indgår i denne sætnings kommunikative proces:

The experimenter constitutes part of the experimental system (in microphysics). One might say, likewise, that the person who participates in understanding constitutes part of the understood utterance (Bakhtin I986, I23).

Bakhtins videnskabsteoretiske position opløser således den dualistiske skelnen imellem et aktivt og iagttagende subject, og et passivt og beskrivbart objekt: »The observer has no position outside the observed world, and his observation enters as a constituent part into the observed object « (Bakhtin I986, I 26). Men hvad der måske i denne sammenhæng er endnu vigtigere at understrege er, at den videnskabelige undersøgelse for Bakhtin bliver en dialogisk proces, der bedst beskrives i billedet af samtalen: "Research becomes inquiry and conversation, that is dialogue [...] We put questions to ourselves and we organize observation or experiment in such a way as to obtain an answer " (Bakhtin I986, II4). Denne samtalemetafor for den videnskabelige forskning genfinder man helt identisk hos Peirce: "Successful research [...] is conversation with nature « (CP 6.568). Også for Peirce opløser den dualistiske subjekt-objektrelation sig $\mathrm{i}$ en treleddet relation imellem subjektet, objektet og relationen imellem dem, forstået som en interpretant. Det betragtende subjekt udgør selv en del af det betragtede objekt, fordi objektet defineres og afgrænses af den menneskelige bevidsthed. Men denne formelle lighed til trods, forbinder Bakhtin, som vi har set det hele vejen igennem denne fremstilling, al diskursiv aktivitet med et værdiladet synspunkt på verden på en måde som i udgangspunktet er Peirce fremmed, men som efter min mening ikke er uforenelig med hans pragmatisk orienterede semiotik.

Forskellen på den litterære tekst, litteraturkritikken og litteraturteorien 
er ikke en relation imellem en tekst og en videnskabelig metatekst, men en relation imellem tre forskellige diskursive registre. Den videnskabelige diskurs er ikke en værdineutral eller objektiv metadiskurs med en privilegeret adgang til sandheden, men en diskursorden som tager den litterære diskurs som sit objekt, og i hvis diskursregulerende elementer vi finder en række mere eller mindre formaliserede eller formaliserbare krav. Det gælder f.eks. kravet om at tidligere prægnante læsninger af den samme litterære tekst må indgå som en del af det studerede objekt, kravet om at kunne dokumentere læsningen empirisk i teksten, kravet om at analysens argumentative struktur skal være holdbar og endelig kravet om at medreflektere de teoretiske positioner, som udgør forudsætningen for læsningens tilblivelse.

Kravet om at tidligere læsninger må indgå som en del af det studerede objekt, hænger på den ene side sammen med Peirces forestilling om videnskabens kumulative funktion, det som vi tidligere har kaldt et 'stenpå-sten'-perspektiv. Idet Peirce forstår videnskaben som en mere eller mindre organiseret aktivitet, eller i hvert fald som en ubrudt kæde af dialogiske undersøgelser som over tid vil etablere vaner der tendentielt nærmer sig en beskrivelse af det dynamiske objekt, så forekommer det logisk at forudsætte kendskabet til de forudgående led i kæden for at kunne fortsætte forskningsfællesskabets opbygning af viden om verden. I dag ved vi imidlertid, at ingen videnskab er rent kumulativ, fordi nye resultater altid vil give anledning til en revurdering af de tidligere. Og som Kirsten Hastrup påpeger, er den humanistiske forskning markant mindre kumulativ end den naturvidenskabelige, fordi humaniora hele tiden er tvunget til at gå kritisk tilbage og spørge til traditionen (Hastrup I999, 37). Der behøver således ikke være tale om egentlige paradigmeskift (Kuhn), før man inden for humanvidenskaberne kan tale om at den semiotiske kæde brydes og tendensen til dannelse af en final interpretant om ikke bliver brudt, så i det mindste må starte fra et nyt udgangspunkt. Kravet om at tidligere læsninger af den samme tekst må indgå i kritikken, kan således ud fra denne præmis præciseres til et spørgsmål om, at andre læsninger, der stiller sig på det samme teoretiske standpunkt, må indgå, og at dette krav vedrører redeligheden af den kritiske diskurs.

På den anden side giver kravet om, at bestemte tidligere læsninger må inddrages, god mening ud fra Bakhtins forestilling om, at en given diskurs altid vil stå i et dobbelt dialogisk forhold til andre diskurser vedrørende det samme objekt: dels det, som andre diskurser tidligere har sagt om det samme emne, dels det, som en fremtidig modtager af denne diskurs formodes at ville mene om det her sagte. Hvor den første dialog kan siges at være en bagudrettet, intertekstuel relation til - i dette tilfælde - andre 
læsninger af den samme tekst, kan den anden dialog siges at være en fremadrettet, retorisk relation til den grund, hvorpå denne tekst skal fortolkes. Kravet bliver i denne sammenhæng først og fremmest til et krav om klarhed. Ethvert argument diskuterer med et tidligere argument, og hvis det tidligere argument ikke ekspliciteres, svækkes det aktuelle arguments klarhed og udsigelseskraft.

Kravet om at den kritiske diskurs skal kunne dokumentere læsningen empirisk i teksten, hænger sammen med den dialogiske relation, som jeg bogen igennem har forsøgt at beskrive mellem teksten i sig selv forstået som et åbent mulighedsfelt af betydning på den ene side (umiddelbar interpretant) og læserens aktualisering af værket på den anden (dynamisk interpretant). Her står vi over for det paradoksale forhold, at selvom den umiddelbare interpretant kun opstår i kraft af læserens aktualisering af værket i form af en dynamisk interpretant, udgør teksten i sig selv dog det empiriske materiale, som forskeren må forholde sig til som kontrolmateriale for sine abduktive gisninger. Fortolkningen er læserens dialog med teksten der tager form af, at denne stiller spørgsmål i form af hypoteser, som teksten 'svarer' på ved at bekræfte eller dementere de opstillede hypoteser. Kritikerens rolle bliver så at skulle beskrive tekstens strategiske manøvrer og at skulle føre 'beviset' igennem med empiriske fakta. Kritikeren får dermed tildelt rollen som detektiv i den kriminalintrige, der altid har forfatteren som forbryder (Hutcheon I980, 3 I).

Udfoldelsen af den kritiske dialog med teksten og kritikerens dokumentation for sit detektivarbejde stiller krav om samarbejde mellem hermeneutiske og positivistiske tilgange, og flere af de anførte teoretikere har i den forbindelse forsøgt at opstille nogle kriterier for hvordan vi vurderer hvad der er stærke, gode eller blot sandsynlige læsninger. Således nævner Paul Ricœur at antallet af træk i teksten, som en given læsning kan redegøre for, samt den kvalitative sammenhængskraft mellem de træk som inddrages, udgør de kriterier der er afgørende for læsningens troværdighed (Ricœur 1974, I04). Umberto Eco argumenterer på sin side for, at en hvilken som helst litterær tekst kan læses på uendeligt mange gyldige måder, hvilket imidlertid ikke betyder, at alle læsninger er lige gyldige. Og idet han fortsætter detektiv-allegorien, anfører han tre kriterier for et indiciums holdbarhed (Eco I 992, 99): forholdet må ikke kunne forklares mere enkelt eller 'økonomisk', det skal pege på en enkelt årsag eller i det mindste en begrænset række af årsager, og det skal kunne indgå i et system med andre indicier, der peger på det samme (Eco I992, 99 og 1995,54$)$.

Ved at udlægge litteraturvidenskabens erkendelsesinteresse som en dialog mellem læseren og det analyserede materiale, hvor kritikeren stiller 
spørgsmål og lader materialet hhv. be- eller afkræfte de opstillede hypoteser, samt ved at anskue litteraturvidenskabens metoder til dokumentation for de opstillede hypoteser som en kombination af hermeneutiske og positivistiske tilgange, bliver det pludseligt slet ikke så problematisk at hævde, at der er sammenhæng mellem de verifikationsprocedurer som anvendes i hhv. tekstfortolkning og inden for naturvidenskaberne. F.eks. omtaler Føllesdal m.fl. hermeneutik som »hypotetisk-deduktiv metode anvendt på meningsfuldt materiale «, dvs. på tekster i bredeste forstand (Føllesdal I997, 89 ff.).

\section{Metafiktion som diskursregulerende selvreference}

Jeg vil i dette afsnit afslutte behandlingen af betingelserne for logisk erfaringsdannelse i den litterære praksis ved at se på, hvordan den litterære diskurs selv diskuterer sin egen egenart i form af metafiktion. I Kapitel I diskuterede vi fiktionslitteratur som en selvstændig diskursiv praksis, tilknyttet sin egen diskursorden og adskilt fra øvrige diskursive praksisformer gennem de særlige konventioner eller vaner, som knytter sig til den. Som alle andre diskursive praksisformer etablerer de litterære tekster en interdiskursiv dialog med de elementer som regulerer den underliggende diskursorden, og set i det lys kan den litterære selvreference forstås som udtryk for, at den litterære diskurs har behov for at tematisere sin egenart som diskursiv praksis. På den baggrund kan metafiktionens funktion inden for rammerne af den litterære diskurs forstås som en 'diskursregulerende selvreference'.

Brugen af 'meta'-betegnelsen i metafiktionsbegrebet indeholder, efter min mening, en arv fra Louis Hjelmslevs begreb om 'metasproget', som han definerede som sprog, hvis indholdsplan også er sprog (Hjelmslev I943, IOI). Hvor metasprog altså er sprog der omhandler sprog, er metafiktion fiktion der omhandler det at læse eller skrive fiktion. Tilsyneladende. Men så enkelt er det desværre ikke! For de Hjelmslevske undertoner har foranlediget mange teoretikere til at tage afsæt i den strukturelle lingvistiks sprogfilosofiske problemstillinger når de skal behandle spørgsmålet om den litterære diskurs' selvreference, og Hjelmslevs skelnen mellem denotationssprog, konnotationssprog og metasprog har tilføjet diskussionen et problematisk objektivistisk eller scientistisk betydningslag. Hjelmslev skelner nemlig mellem to sprogklasser: de værdineutrale videnskabssprog, metasprogene, og ikke-videnskabelige objektsprog. Denne objektivisme indebærer, at man inden for denne tradition typisk spørger til, hvad noget er: Hvad er et participium, hvad er en nexusforbindelse og 
i forlængelse heraf, hvad er litteratur, hvad er fiktion? Og hvad er metafiktion? Som om der var nogle strukturelle forhold $i$ sproget, som skulle adskille fiktive tekster fra ikke fiktive. Det er der imidlertid, som vi tidligere har været inde på, ikke (se s. I94 ff.). Der er ingen sproglig forskel på en replik taget fra en roman og en anden taget fra livet på gaden. Der er forskel på hvordan vi loeser eller fortolker sproget alt efter hvilken kontekst det indgår i, og her bliver den litterære konvention, det diskursive register, en magtfuld indikator på hvordan litteratur skal forstås og relateres til verden.

Roman Jakobson anlægger med sin teori om sprogets funktioner en mere kommunikativ tilgang end Hjelmslev, selv om han arver noget af terminologien. For ham er den metasproglige funktion én af sprogets seks funktioner, som hver især er knyttet til kommunikationsmodellens seks centrale faktorer: den 'emotive' funktion er knyttet til afsenderen, den 'poetiske' funktion er knyttet til meddelelsen, den 'konative' funktion er knyttet til modtageren, den 'referentielle' funktion er knyttet til konteksten, den 'fatiske' funktion til kontakten og endelig er den 'metasproglige' funktion defineret som sprog, der vedrører selve den sproglige kode (Jakobson I98 I III, I 8 ff.).

Jakobsons definition af den metasproglige funktion ligger formentlig bag Gerald Princes skelnen mellem den trivielle litterære selvreference, "any and all passages referring to that narrative or its constituent parts ", og så det han kalder de metanarrative komponenter, som »explicitly refer to its code " (Currie I995, 58). Selv om Princes kodebegreb giver associationer til Hjelmslevs strukturalisme, så understreger han, at den litterære selvreference skal forstås som en diskursregulerende instans, der diskuterer de betingelser, ud fra hvilke den litterære diskurs fungerer som selvstændig diskurs.

Gerald Princes definition ligger også tæt op ad Mark Curries forståelse af metafiktionen. Han forstår det metafiktive element som »a borderline discourse, as a kind of writing which places itself on the border between fiction and criticism, and which takes that border as its subject " (Currie, 2). For Currie er der tale om, at metafiktionen som en sådan grænsediskurs omhandler »the artificiality of its constructions and a fixation with the relationship between language and the world « (ibid.). En sætning som kan findes næsten ord for ord hos Patricia Waugh, der mener at metafiktionen »draws attention to its status as an artefact in order to pose questions about the relationship between fiction and reality « (Waugh, 2). Begge peger de altså på, at metafiktionen ekspliciterer litteraturens konstruktkarakter og tematiserer forholdet mellem sprog og verden. Man kunne dog godt rejse en diskussion om hvorvidt metafiktion i virkelighe- 
den kan forstås som en grænsediskurs i Mark Curries forstand, al den stund den diskursregulerende selvreference har været en integreret del af selve den litterære diskurs lige så længe denne har eksisteret som sådan. De metafiktionelle elementer i f.eks. Don Quijote er jo anerkendt af alle, og i Narcissistic Narrative påpeger Linda Hutcheon, hvordan man kan finde metafiktionelle elementer helt tilbage til Homers tekster. Desuden kunne man også spørge til rimeligheden af at tale om en grænsediskurs. Som vi var inde på i Kapitel I, er forfatterens poetiske frihed i forhold til tekstens reference og læserens kontemplative forhold til teksten netop noget af det som adskiller litteratur og litteraturkritik, forstået som sociale praksisformer, også selv om distinktionen de sidste tyve år har været under angreb fra begge sider, jf. den postmoderne metafiktions diskussion af litteratur og dekonstruktionens fokus på den litterære kvalitet i de kritiske læsninger. Man kunne derfor med rimelighed spørge om det at distinktionen har været under angreb så længe, ikke snarere er udtryk for det diskursive registers styrke? Er det ikke netop fordi den litterærtkunstneriske praksis og den litteraturvidenskabeligt-kritiske praksis er klart adskilte som sociale praksisformer, at spillet på at nedbryde dem bliver interessant?

I Narcissistic Narrative skelner Linda Hutcheon mellem to former for mimesis i romanen: mimesis of product, som består i forfatterens skabelse af et fiktivt univers, og mimesis of process, som er litteraturens mimen af dens egen tilblivelse i form af metafiktion (Hutcheon I980, kap. 2). Ifølge Hutcheon har metafiktionen altid været en integreret del af den litterære praksis, idet denne tilbage fra klassikken og frem har integreret mimesis of product med mimesis of process. Adskillelsen af de to processer lokaliserer Hutcheon i forbindelse med fremkomsten af I 800 -tallets realistiske roman, eller rettere sagt forsteningen af romangenren i lyset af denne romanform. De øgede krav til læserens kompetencer, som ligger indskrevet i såvel den modernistiske som i den postmodernistiske æstetiske kanon, aktualiserer behovet for mimesis of process i den forstand, at de øgede krav til læsernes kompetencer giver et øget behov for at regulere læsernes bevidsthed om egen praksis.

Linda Hutcheons definition af metafiktionen som mimisis of process lægger op til at forstå metafiktionen som en dynamisk og funktionel diskursiv kategori (et svar på sprøgsmålet: hvad er det metafiktionen $g \varnothing r$ ?). Men på trods heraf kaster Linda Hutcheon sig ud i en kategorisering af fire forskellige slags metafiktion, hvor hun skelner mellem 'diegetisk-meta' og 'sprog-meta', og mellem 'åbenlys' og 'implicit' selvreference (Hutcheon I 980, 2 I ff.). I stedet for at følge logikken i sin egen funktionelt orienterede definition knytter hun an til den formalistiske traditions spørgen til, 
hvad metafiktionen er for en størrelse. Spørgsmålet er imidlertid om Hutcheons fire forskellige typer af metafiktion netop ikke kan gøre det samme i funktionel forstand, lige såvel om to 'ens' typer selvreference kan gøre noget forskelligt, alt afhængig af hvad det er for en historisk og kulturel kontekst vi bringer teksterne i dialogisk samspil med. Efter min mening hidrører Hutcheons klassifikationsiver fra hendes erklærede arv fra Saussures lingvistik og det tegnbegreb som ligger bag hele den europæiske semiologi, spændende fra Saussure over Hjelmslev til Jakobson.

Den måde jeg i det følgende vil forsøge at diskutere metafiktionen på, forstår den, på linje med Hutcheon, som en integreret del af den litterære praksis og dermed som et fænomen som er lige så gammelt som litteraturen selv. Den diskursregulerende selvreference tematiserer den litterære kommunikation som en diskursiv praksis, idet den etablerer en dialog mellem på den ene side periodens og kulturens genreforventninger til hvordan forholdet mellem kunst og verden generelt konciperes, og på den anden side læserens måde at forstå værket. Denne funktion er ikke kun passiv eller reaktiv, forstået på den måde at de selvreferentielle litterære tekster afspejler forskellige perioders eller kulturers epistemologiske tilgang til forholdet mellem tekster og verden, hvilket naturligvis også er tilfældet nogle gange, men andre gange er der tale om en kreativt skabende position, hvor litteraturen er med til at skabe nye måder at se og forstå både litteratur og forholdet mellem litteratur og verden på. Derfor bliver det afgørende at forstå den diskursregulerende selvreference i relation til den forudsætningshorisont, der er gældende ved værkets tilblivelse og læsning, hvorfor en dialog med litteraturhistorien og/eller idéhistorien bliver vigtigere end opstillingen af nok så mange forskellige klassifikationssystemer af forskellige slags 'meta-'. Det interessante er med andre ord ikke først og fremmest hvordan den diskursregulerende kommentar betyder, men hvad den betyder i forhold til den måde tekster bliver læst og sat i forhold til deres læseres erfaring og livsverden.

I dette afsnit vil metafiktionen blive diskuteret i forlængelse af den dialogisk-semiotisk tradition, som udgør rammen om hele denne bog. Det er en tradition som netop beskæftiger sig mere med hvad litteraturen $g ø r$ end hvad den er, og undersøgelsen vil derfor også forsøge at tilnærme sig hvad det er, selvreferencen $g ø r$ inden for rammerne af litteraturens generelle funktioner, eller måske snarere hvad er det vi gør med litteraturen, og hvilken rolle den litterære selvreference spiller i den forbindelse. Jurij Lotman betegner denne funktion, hvor kunsten så at sige spejler sine egne mimetiske funktioner med henblik på at blotlægge deres semiotiske karakter, som »ikonisk retorik «: 
In these cases [when there is a double replication, when a replica is made of the replica, HLH] the object and its representation are so glaringly not equivalent, and the transformation of the representation in the process of replication is so obvious, that attention is naturally drawn to the mechanism whereby the replica is made, and the semiotic process becomes a conscious one rather than a spontaneous one (Lotman I990b, 55).

Den diskursregulerende selvreference etablerer således en dialog mellem betragteren og det semiotiske register som ligger til grund for selve værket, samt den diskursorden det tilhører. Denne dialog involverer nødvendigvis både de genrebestemte forventninger om hvordan forholdet mellem kunst og verden generelt konciperes i værkets historiske og kulturelle samtid, og på den anden side læserens kulturelle og historiske forudsætninger for at indgå i denne dialog. I Kapitel I refererede vi Dines Johansens Habermas-baserede diskursbegreb, bestående af fem træk som oftest, men ikke nødvendigvis alle sammen på en gang, indgår i den mimetiske diskurs: fiktionalitet, poeticitet, eksemplaritet, poetisk frihed og kontemplativitet (Johansen 2002, 97). Eferfølgende talte vi med udgangspunkt i en Fairclough-baseret forståelse af diskursbegrebet, om tre elementer der regulerer den litterære diskursorden: æstetik, fiktion og dannelse. Det er disse tre diskursregulerende elementer der nedenfor vil blive strukturerende for den videre gennemgang.

\section{Selvreferencen og det æstetiske}

I behandlingen af den mimetiske diskurs' karakteristika knytter Dines Johansen med sin brug af Jakobsons poeticitetsbegreb an til en formalistisk tilgang til spørgsmålet, som ikke nødvendigvis er den mest hensigtsmæssige. Ved at reformulere problemstillingen og se på hvad det er teksterne gør, eller hvad det er vi som læsere gør med teksterne, kunne man fokusere på den æstetiske erfaring, der opstår hos læseren i mødet med teksten. I forlængelse heraf kunne man spørge til, om selvreferencen i sig selv har en æstetisk funktion, og i givet fald i hvilken henseende den har det, og om hvordan den diskursregulerende selvreference bidrager til at opretholde og/eller udvikle den litterære diskurs i æstetisk forstand? Derfor udgør det fænomenologiske æstetikbegreb en mere frugtbar måde at diskutere selvreferencens æstetiske funktion end det formalistiske. Som vi har været inde på i Kapitel III forsøger det fænomenologiske æstetikbegreb at begribe den æstetiske oplevelse på baggrund af kategorier, såsom det erfarede objekts åbenhed, ureducerbarhed eller ubestemthed, spændende fra f.eks. John Dewey og Roman Ingarden til Wolfgang Iser. Det æstetiske er i denne tradition knyttet til blikket der ser, dvs. til måden hvorpå vi betragter samspillet mellem form og betydning i alt fra hver- 
dagslivets objekter og begivenheder og til de kunstneriske udtryk, men dybden eller karakteren af denne dialog kan forberedes gennem det kunstneriske værks strategi. Et eksempel herpå kunne være nedenstående inversionsfigur taget fra Umberto Eco (Eco 1992, 23I).

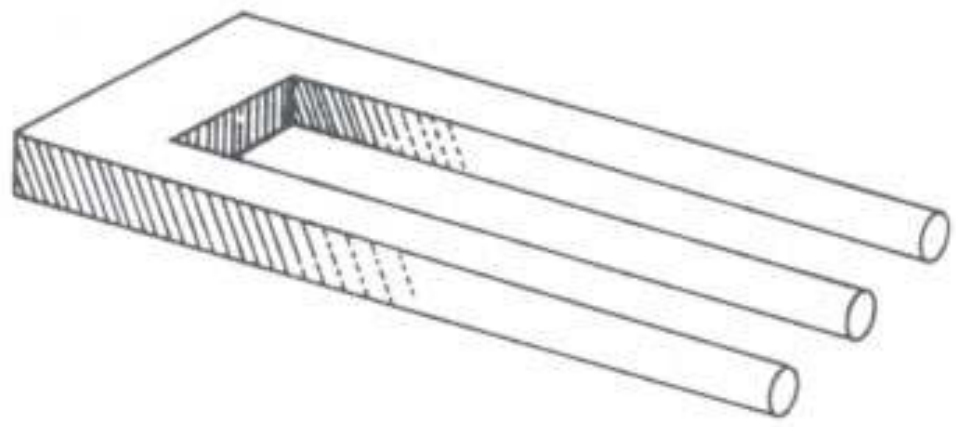

Figuren er hos Eco anvendt som et eksempel på en mulig-umulig verden, dvs. en imaginær verden der bygger på ontologisk umulige principper, men figuren illustrerer samtidig på glimrende vis, hvordan den grafiske fremstilling tvinger betragterens blik til at svinge frem og tilbage mellem to modstridende helhedsforståelser af figuren, hvilket skaber et grænseområde eller spændingsfelt af åben ubestemthed i midten af figuren, som af betragten kun momentant kan erfares som tilhørende begge ender af figuren på en gang. I denne momentane oplevelse af ureducerbar åbenhed indgår et element af æstetisk erfaring.

Det æstetiske udtryks ureducerbarhed og ubestemthed bliver af Uffe Hansen kædet sammen med det ubevidste og med drømmen (Hansen I98I). Kunstens og litteraturens 'ubestemtheder' giver os, ifølge Uffe Hansen, æxtetisk tilfredsstillelse, fordi de medierer mellem to forskellige slags psykiske processer, primærprocestænkningen og sekundærprocestænkningen. I modsætning til den rationelle sekundærprocestænkning er primærprocestænkningen, ifølge Freud, karakteriseret ved at acceptere ambivalenser og ved erkende forskellighed og direkte modsætninger samtidig. Primærprocestænkningen ville med andre ord ikke have problemer med at acceptere en figur som den ovenstående. Primærprocestænkningen er hos Freud knyttet til det ubevidste og til lystprincippet, hvorfor kunstens momentvise erkendelse af denne sanselige og ucensurerede åbenhed er kilde til lyst og tilfredsstillelse. Heroverfor er sekundærpro- 
cestænkningen styret af realitetsprincippet, der i vores normale virke griber ind over for primærprocestænkningens kaotiske materiale og ordner det i kronologiske og systematiske serier. Sekundærprocestænkningen opererer kognitivt i enten/eller, figur/grund osv. og ville kun kunne begribe en figur som den ovenstående som værende enten en tobenet eller en trebenet figur.

Oversætter vi Freuds psykologiske terminologi til semiotiske termer, kan vi med Umberto Eco sige at det handler om en forskel mellem to diskursordener, som har udspillet sig i den vestlige kulturhistorie siden antikken: den rationelle og den hermetiske. I Fortolkningens groenser beskriver Eco de tre principper som siden antikken, dvs. fra Platon og Aristoteles og fremad, har ligget til grund for den vestlige, rationelle diskurs, dvs. for den 'modus ponens', som udgør fundamentet for vores logiske erfaringsdannelse og normale årsagsforklaringer (Eco 1992, 49 og I995, 33). De tre principper er:

- Identitetsprincippet $(\mathrm{A}=\mathrm{A})$.

- Princippet om modsigelsesfrihed (A kan ikke være A og ikke-A samtidigt).

- Princippet om den udelukkede tredje: A er enten sand eller A er falsk, en tredje mulighed gives ikke.

Det rationelt fremsættende udsagn, som bruges til at affirmere vores sande viden om verden, forudsætter modus ponens. I den forstand er modus ponens et grænsebegreb: inden for denne modus eksisterer orden, mening, rationalitet, men bryder vi principperne hersker der kaos, mulighed for uendelige kæder af fortolkninger og uendelige forskydninger af sandhedsbegrebet.

Antikken havde imidlertid også en anden diskursorden der ikke byggede på den rationelle modus, men på apeion, det uendelige (Eco I995, 35), og som udmøntes i Hermes-myten. Hermes var halvt gud, halvt menneske og repræsenterede derfor mediationen mellem himmel og jord, mellem det hellige og det profane. Ifølge den hermetiske tradition er sandheden flydende og uendelig, den skal tydes i skrifterne, og tolkningerne er mangfoldige. Siden renæssancen er denne diskurs imidlertid blevet stadig mere marginaliseret, og er i dag begrænset til kun at udfolde sig i de de såkaldt 'okkulte videnskaber' samt i særligt æstetiske tekster, som vi henregner til kunst og litteratur.

Når Gorm Larsen skriver at »metafiktion er konstrueret omkring et logisk paradoks ", trækker han på det forhold, at metafiktionens selvreference muliggør et brud med modus ponens'- principper (Larsen 200I, 
5I). Gorm Larsen anfører som eksempel på den enkle selvreference Epimedes udsagn: »Alle kretere lyver «. Er sætningen sand lyver Epimedes, hvorfor sætningen må være falsk. Er sætningen falsk har Epimedes ret og dementerer sætningen osv. Den samme absurde forskydning af en sandhed finder vi i sætningen: »Denne sætning er falsk «. Selvspejlingen bryder med alle de tre logiske principper som ifølge Eco ligger til grund for modus ponens, hvorved der etableres en infinit regres af betydningsudskydelse. Et genkommende litterært symbol for denne funktion er labyrinten som billede på den infinitte regres og de uendelige mulige og umulige verdener. Dette billede, som Eco selv har anvendt som metafor for den uendelige semiosis, finder vi også som et centralt ledemotiv i Jorge Luis Borges forfatterskab. Man kan med Hutcheon sige, at »the metafictions of Jorge Luis Borges [...] stand as allegories of this, the reading (as well as writing) side of poiesis" (Hutcheon 1987,5 ).

\section{Jorge Luis Borges' fortcellinger}

Borges' fortællinger er gode til at illustrere den diskursregulerende selvreferences æstetiske funktion, fordi de stort set alle sammen bryder flere af modus ponens tre principper på én gang. Fortællingen »Pierre Menard, forfatter til don Quijote «, der er skrevet som et litteraturkritisk essay, tematiserer forholdet mellem værket som skrift og værket som læsning. Den fiktive person, Pierre Menard, er en samtidig forfatter, som midt i det tyvende århundrede sætter sig for at ville skabe et stykke af Cervantes' Don Quijote. Der skulle ikke være tale om en genskrivning af Don Quijote, men om at skabe den fra grunden, ord for ord identisk med den første. Det paradoksale er nu at selv om de to tekster, Cervantes' originale og Menards genskabelse, er fuldstændig ens, vurderer den eksplicitte fortæller at Menards tekst er umådeligt meget rigere end Cervantes' oprindelige tekst, fordi den indeholder alle de referencer som historien mellem det I7. og det 20. århundrede har gjort mulige: romantikkens og Nietzsches indflydelse på teksten osv. osv. Paradokset opstår således når både identitetsprincippet og princippet om modsigelsesfrihed brydes, når A ikke længere bare kun er $\mathrm{A}$, men også ikke-A, når bogen er den samme bog, men dog en anden og rigere bog.

Tilsyneladende er Mark Curries borderline-begreb velegnet til at beskrive det, som her er på færde. Fortællingen er skrevet inden for den litterære kritiks diskursive register, indeholdende en komplet bibliografisk fortegnelse over den fiktive forfatters udgivelser samt utallige overvejelser over den litterære påvirkningshistorie osv., og samtidig tematiserer fortællingen en central litteraturteoretisk problematik omkring forholdet mellem værk og læsning, hvor forfatter og læser bliver hinandens for- 
doblinger, hvilket bringer spejlingens princip ind i teksten (Lourdes Royano I993, 96). Og dette er, ifølge Borges, netop det som kendetegner Cervantes' egen teknik: »Cervantes nyder at sammenblande det objektive med det subjektive, læserens verden med bogens «, skriver han i » Magias parciales del Quijote « (Borges I985 III, 58). Med Curries begreber kan man sige, at fortællingen gør grænsefladen mellem fiktion, kritik og litteraturteori til sin genstand, hvorved den tilsyneladende dekonstruerer distinktionerne imellem de forskellige diskursive registre. Men nok også kun tilsyneladende. Måske er tematiseringen af grænsen netop det som klargør diskursen, det som får den litterære diskurs til at fremstå klart i sin egen ret?

Mit forbehold hænger sammen med forståelsen af det æstetiske hos Borges, samt med fortolkningen af hans syn på forholdet mellem kunst og verden, og i disse spørgsmål vil jeg støtte mig på Arturo Echavarrías læsninger af Borges forfatterskab (Echavarría I 983). For Borges hænger forfatterens og læserens aktivitet sammen som to uadskillelige, kreative og dog modsatrettede og forskellige processer, tilknyttet den sprogligt litterære kommunikation. Tilsammen danner de forudsætnigen for det, som Borges selv kalder for 'el hecho estético' eller 'den æstetiske begivenhed'. Den æstetiske begivenhed er ikke et fysisk objekt sådan som bogen, men forbundet med processerne at skrive og at læse. I introduktionen til sine poetiske skrifter definerer Borges denne begivenhed som et thrill, dvs. »den fysiske forandring som hver ny læsning fremkalder «, her citeret efter Echavarría (Echavarría I983, 40).

Echavarrías hovedhypotese er nu, at metafysikken hos Borges er underordnet æstetikken (op.cit. I 5). Det betyder, at den æstetiske begivenhed, som for Borges har en sanselig, processuel og momentan karakter, en glimtvis indsigt i det erfarede objekts uendelige åbenhed og æstetiske ubestemthed, bliver selve det hovedmotiv, der styrer hans skrivning. Og vejen til at fremstille dette motiv går igennem de labyrintiske, intertekstuelle spil, spejlingerne og den infinitte regres samt de logiske paradokser med deres sære, mulige-umulige universer. Ifølge Echevarría skriver Borges altså først og fremmmest litteratur med et æstetisk sigte, og i dette forehavende mimer han forskellige filosofiske, kritiske og teoretiske diskurser inden for grænserne af den litterære tekst. I den forstand bliver det metafysiske underordnet æstetikken hos Borges.

For det andet indebærer Echavarrías hypotese om, at metafysikken hos Borges er underordnet æstetikken, at Borges' skepticisme ikke skal læses i relation til hans ontologi, men i relation til hans epistemologi (op.cit. 46). Det som Borges sætter spørgsmålstegn ved er, med andre ord, ikke verdens ontologiske status i sig selv, men litteraturens og kunstens evne 
til at formidle det, som vi normalt kalder 'sand' viden om verden. Det er nemlig ikke litteraturens opgave. For Borges er enhver forfatter også en læser, men enhver læser er også i en vis forstand forfatter. Og hvis den æstetiske begivenhed er udgangspunkt for denne proces hos hhv. forfatter og læser, kunne tekstens diskursregulerende selvreferencer tjene til at klargøre læserens bevidsthed herom. Det gør de i en vis forstand også, men problemet er nu bare at Borges inddrager disse diskursregulerende selvreferencer som led i sin æstetiske strategi, idet det netop er selvreferencernes spejlingseffekter og paradoksale brud på modus ponens' logiske principper, som bliver en af hovedvejene til at beskrive den æstetiske begivenhed.

Labyrinten og den uendelige regres bliver for Borges emblematiske billeder på værkets radikale åbenhed, og i teksterne fremstiller han begrebet om det uendelige som et frygteligt og tragisk vilkår der afhumaniserer mennesket, idet det fratager mennesket døden. Borges’ måske kendteste fortælling »Babelsbiblioteket " kan illustrere dette. I dette gotiske og groteske bibliotek henslæber bibliotekarerne deres liv i en bestræbelse på at finde bøgernes bog, der kan forklare bibliotekets paradoksale struktur. Biblioteket er nemlig på én gang både uendeligt og afgrænset. På den ene side består det af et endeligt antal bøger, idet ingen bøger er ens, mens alle bøger har et ensartet antal sider med et ensartet antal linjer og kombinerer alle alfabetets tegn på alle tænkelige måder. Når der ikke er nogen dubletter, giver dette et endeligt, om end meget stort antal bøger. Men på den anden side hævder fortælleren, at biblioteket er uendeligt! Paradokset består i, at de bøger, bibliotekarerne konsulterer, er nye eller forskellige hver gang, også selv om de skulle få fat i den samme bog. Det, som fortællingen således tematiserer, er igen forholdet mellem epistemologi og ontologi, mellem læsning og 'væren'.

Man kan også sige, at det handler om tiden. Det litterære værk fremstilles allegorisk som et uudtømmeligt potentiale af betydning, og selve læseakten forstås som en aktualisering af en del af dette potentiale. Når bibliotekarerne i babelsbiblioteket efter mange år vender tilbage til den samme bog, er den ikke længere den samme, for de har selv forandret sig med tiden. Menneskets bundethed til tidens gang, og dermed også menneskets dødelighed, modstilles i fortællinger som » Den udødelige «, » Tløn, Uqbar, Tertius Orbit «, »Aleffen « det grænseløses og det uendeliges princip som noget grusomt og inhumant. Kun i kraft af vores dødelighed er vi i stand til at tilskrive tilværelsen betydning, for hvis vi levede uendeligt længe, ville alt godt og ondt udligne sig, som det hedder i »Den udødelige «. Enhver moralsk distinktion ville blive ligegyldig, og menneskets liv ville blive meningsløst. Tilsvarende er det kun den enkelte læsers ak- 
tuelle læsning der kan tilskrive et litterært værk en konkret betydning, selv om værket i sig selv rummer et betydningspotentiale, som er uendeligt.

Ved at behandle litteraturen litterært dekonstruerer Borges den rationelle diskurs om litteraturen, altså kritikken, og et af hovedredskaberne i denne operation er den litterære selvreference. Men det betyder ikke at

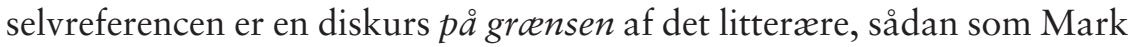
Curries borderline-begreb antyder. Tværtimod er det den litterære selvreference, som hos Borges sætter den æstetiske dagsorden - det er den som bryder med modus ponens' rationelle principper og som åbner tekstens æxtetiske ubestemtheder. Og det er selvreferencen der kaster læserens opmærksomhed tilbage på hans egen brug af teksten som register for en anden type erkendelse end den rationelt videnskabelige, hvorved den antager en diskursregulerende funktion.

Den diskursregulerende selvreference hos Borges tager form af en dialogisk interaktion med diskursfragmenter tilhørende andre diskursordener, ofte en litteraturkritisk diskurs præget af detaljeret, filologisk eksakthed og krævende, klassiske referencer samt citater på forskellige sprog, heriblandt latin. Og lige så ofte modsvares denne filologiske eksakthed af fortællerens svigtende hukommelse og 'menneskelige' usikkerhed. Under alle omstændigheder er det den litterære teksts mimen af de litteraturkritiske eller ligefrem filosofiske diskurser, som sætter den selvreferentielle spejling i stand, altså en i Faircloughs terminologi interdiskursiv funktion, der gør læseren opmærksom på selve læseprocessens æstetiske karakter.

\section{Fiktion og selvreference}

Det andet diskursregulerende element bag den litterære diskursorden var spørgsmålet om fiktionaliteten, som blev behandlet i Kapitel IV. Det vigtige, når vi skal se på hvad det er litteraturen gør, er at den litterære diskursorden suspenderer læserens forventning om at finde en reference til den fysisk eksisterende verden, hvorved tekstens reference, objektet i Peirces terminologi, erstattes med et muligt objekt, eller »a possible world « (Hutcheon I 987, 9). Begrebet 'mulig verden' refererer til en række teorier af formel, logisk karakter, som har været diskuteret i relation til litteraturteorien (se f.eks. Eco I982, 2 I 5 ff.; Larsen 2002). Den litterære fiktion, forstået som en mulig verden, er en verden som er kulturelt skabt på baggrund af sprog. Den må overholde visse love, og den er 'møbleret' eller indrettet med personer som (evt.) gennemløber en udvikling. Det er således læserens opgave at udfylde de tomme huller mellem tekstens fragmenter (Iser) og konstruere det fiktive univers som en sammenhængende mulig verden på baggrund af tekstens anvisninger og de genremæs- 
sige eller kronotopiske forventninger (Bakhtin). Men denne komplicerede operation skal være etableret som en kulturel konvention eller vane, knyttet til den litterære diskursorden og internaliseret af læseren for at operationen lykkes. Lad os se på hvordan Cervantes’ Don Quijote, som en af verdenslitteraturens første romaner, er med til at etablere denne konvention i form af en interdiskursiv dialog.

\section{Cervantes' »Don Quijote"}

I Ordene og Tingene foreslår Michel Foucault en læsning af Don Quijote, der udlægger romanen som en dialog imellem to epistemologiske modeller: på den ene side det middelalderlige lighedsepisteme, der ikke ligger langt fra det som Umberto Eco har kaldt den hermetiske diskursorden (Eco I990/I992, 47ff.), og på den anden side det klassisk-rationalistiske episteme, som etableres fra og med Descartes. Ifølge denne læsning skulle Ridderen af den sørgelige skikkelse repræsentere lighedsepistemet, som dominerede indtil slutningen af det $\mathrm{x} 6$. århundrede. Lad os kort studere hvordan lighedsrelationen ligger til grund for den måde som Don Quijote fortolker sin omverden. I den følgende passage er den sindsforvirrede adelsmand på vej til at afslutte sin første dag som omvandrende ridder, da han nærmer sig en kro:

Han nærmede sig kroen, der for ham lignede en borg, og holdt Rozinante an lidt fra den, mens han ventede på, at en dværg skulle komme til syne mellem murtinderne for at give tegn til en trompeter om, at der kom en ridder til borgen [...] Netop da skete det tilfældigvis, at en svinehyrde blæste i sit horn som signal til grisene om at samle sig, for han var ved at drive nogle svin, ja, sådan kaldes de altså uden forlov, ud fra nogle stubmarker, og straks forestillede Don Quijote sig, hvad han ønskede at høre, nemlig at en dværg blæste signal om hans komme [...] (Cervantes I998b, 42).

Don Quijote tager afsæt i nogle begrænsede ligheder mellem virkeligheden (svinehyrdens horn) og den tekstlige genrenorm (det I6. århundredes ridderroman), på baggrund af hvilke han foretager en fortolkning af helheden, der følger det middelalderlige lighedsepisteme. Lighedsepistemet bliver dermed dialogisk parodieret i mødet med et klassisk-rationelt episteme, som repræsenteres af et netværk af andre stemmer og fortællere, heriblandt hovedfortælleren, der i dette uddrag kommer eksplicit frem i undskyldningen for udtrykket »svin «. Men hvad er det for en type tolkning som er på færde i det såkaldte lighedepisteme? Er det en fri associationskæde baseret på nogle få ligheder, således som Foucault hævder?

I en anden scene, denne gang fra første bogs Kapitel I6, sniger kropigen Maritornes sig om natten ind i det værelse, som Don Quijote og Sancho 
deler med en muldyrdriver, for at tilbyde sidstnævnte sine ydelser. På trods af hendes stygge fremtræden tager Don Quijote hende imidlertid for at være borgherrens dydige og yndige datter, der forelsket opsøger ham:

Og den stakkels ridders forblændelse var så stor, at hverken når han rørte hende eller lugtede til hendes ånde eller andre ting, som hang ved den gode pige, blev han revet ud af sin vildfarelse, og det var ellers lugte, der kunne få enhver anden end en mulddyrdriver til at kaste op; snarere troede han at han holdt skønhedens gudinde i sine arme (Cervantes I998b, I 57).

For Don Quijote betyder genrekonventionerne mere end de konkrete, taktile og olfaktiske erfaringer af kropslig karakter, som pigen giver anledning til. Episoden viser således hvordan Don Quijote forvalter lighedsepistemet: der er ikke tale om en fri associationsrække på baggrund af en sanselig lighed, men om at den tekstlige tradition fortolkes autoritært og dogmatisk, også selv om udlægningen måtte stride imod de mest elementære erfaringer. Som Rigmor Kappel Schmidt formulerer det, er don Quijotes menneskesyn unuanceret og forankret i den litteratur han har læst, idet han ikke lytter, men blot befæster sin generelle fejltolkning monologisk (Schmidt 2003, 35). Og som vi var inde på i Kapitel II, træder subjektets stereotypbilleder af den anden i aktion som monologisk reduktive skabeloner, når der ikke er tale om en åben dialogisk interaktion med den anden. Samtidig viser episoden imidlertid også hvordan Don Quijotes position bliver parodieret og udstillet gennem mødet med det rationelt-empiriske episteme, der tilsyneladende udgør den dialogiske modpol til lighedsepistemet, og som, ud over at omfatte en konsensus mellem fortælleren og den intenderede læser også tæller en række 'fornuftige' fiktive personer: bl.a. præsten og barberen.

Don Quijotes autoritært deduktive måde at forholde sig til verden på kan forstås som en parodieret fremstilling af den dogmatiske middelalderlige bibeleksegese, hvor de hellige teksters autoritet stod som den øverste kilde til erhvervelse af kundskab om verden. I sin værdifulde monografi om Don Quijote fra I 986 tolker E.C. Riley netop romanen som en dialog mellem en række forskellige diskursordener, som hver især repræsenterer det epistemologiske skift ved renæssancens afslutning (Riley I986, I $67 \mathrm{ff}$.). Riley peger således på dialogen mellem de poetiske og historiografiske diskurser, mellem den religiøse tro og den videnskabelige sandhed, mellem ridderromanerne og den moderne roman i form af Don Quijote selv osv. Men ligesom Foucault bliver han i 1986 stående ved registreringen af de binære oppositioner og ser ikke at dialogen er dobbeltsidet og involverer mindst tre forskellige diskursordener. I introduktionen til nyudgivelsen af Don Quijote fra forlaget Crítica i 1998 læser Riley 
imidlertid romanen som en litteraturteoretisk eller metalitterær reflektion over den moderne roman som genre (Riley I998, CXIX ff.).

Den tredje diskurs, som vi kan føje til middelalderens religiøst-autoritære diskurs tilknyttet bibeleksegesen og den rationelt-empiriske diskurs tilknyttet historieskrivningen samt den begyndende eksperimentelle videnskab, er netop den litterært-kunstneriske diskurs. Ligesom middelalderens religiøst-autoritære lighedsepisteme bliver parodieret ved at blive konfronteret med den rationelt-empiriske diskurs, således bliver denne parodieret, idet romanen gennem et helt system af selvreferencer og forskellige interdiskursive dialoger suspenderer selve de logisk-rationelle årsagssammenhænge. I kraft af romanens parodiske interdiskursivitet og intertekstuelle genredialoger udkrystalliserer der sig en egentlig diskursregulerende selvreference, der så at sige sigter på at opdrage det samtidige publikum til at reflektere over, hvad det er litteraturen formår med sine mulige umulige verdener. Den parodiske interdiskursivitet mellem historiografi og fiktion optræder i koncentreret form i romanens første kapitel, men gentages med jævne mellemrum gennem hele romanen i spillet på forskellige fortællere samt deres baggrund og troværdighed, mens den parodierede interdiskursivitet mellem litteratur og litterær kritik f.eks. tager form at samtalerne mellem præsten og barberen om hvilke bøger de skal brænde, eller mellem Don Quijote selv og kanniken i første bogs kapitel 48-50 om litteraturens karakter. Samtidig orkestrerer romanen en række genredialoger mellem f.eks. ridderromanen og den pikareske roman eller mellem den pikareske roman og den pastorale roman, som alle bidrager til at sætte fokus på litteraturens konstruktkarakter for læseren, samt til at parodiere de enkelte genrer i lyset af de andre.

Det første skridt til at erkende denne tredje dimension i romanen går efter min mening ud på at forstå, at Don Quijote ikke først og fremmest drager ud for at læse verden som en åben bog, sådan som Foucault og mange med ham mener. Han drager ud på eventyr for at skrive verden. Hans ambition er at bidrage til skabelsen af den litterære fiktion og således overtage forfatterens rolle, ikke læserens, hvilket romanen gør klart fra det første kapitel. Således siges det om hidalgoen Alonso Quijano, som vor tapre ridder muligvis hed inden han helt mistede forstanden, at han havde denne trang til at digte videre på ridderromanernes fiktive universer:

[T]it fik han lyst til at gribe pennen og helt bogstaveligt tilføje den slutning, der blev lovet; og han ville uden tvivl have gjort det, og endda være sluppet godt fra det, hvis større og mere vedholdende overvejelser ikke havde bremset det (Cervantes I998b, 34). 
Et andet indicium på at Don Quijotes aktivitet skal læses som en kreativ skriven og ikke som en læsen eller tolken af allerede givne tegn, består i at vores ridder allerede på sit første togt forestiller sig, hvordan hans historie vil blive fortalt af en fremtidig forfatter. Han forestiller sig endog dennes måde at fortælle på:

- Hvem kan tvivle på, at i de kommende tider, når den sandfærdige historie om mine navnkundige bedrifter ser dagens lys, vil den vismand, der beretter om dem, vælge at beskrive det således, når han skal fortælle om første gang jeg drog ud: "Næppe havde den rødblonde Apollon spredt sin smukke hårpragts gyldne lokker ud over den vide, udstrakte jord [...] «(Cervantes I998b, 4I).

Læg mærke til at teksten er fuld af det, som Bakhtin ville kalde 'fremmede ord' (alien words), dvs. tekstfragmenter som i kraft af deres stilistiske egenart etablerer dialogiske relationer mellem flere forskellige diskurser: inde i fortællerens beretning optræder Don Quijotes tale, som på sin side præsenterer os for det stiliserede billede af en fremtidig imaginær fortæller. Og ud af dennes mund kommer Don Quijotes stemme i en parodieret version, der illuderer hvordan den ville lyde i en fremtidig bog:

Så udbrød han igen, som om han virkelig var forelsket: „Oh prinsesse Dulzinea, mit tryllebundne hjertes herskerinde! Stor er den krænkelse, I har tilføjet mig ved at sende mig bort og vise jeres misbilligelse, idet I med ubøjelig ihærdighed har befalet, at jeg ikke må vise mig for jeres skønne åsyn « (Cervantes I998b, 4I-42).

På dette sted løber Rigmor Kappel Schmidts ellers udmærkede og meget roste oversættelse ind i et sprogligt problem, for hvordan skal man i dansk oversættelse gengive de diskursmarkører, der markerer Don Quijotes parodierede tale som værende et billede på ridderromanernes sprogbrug, et image of language i Bakhtin'sk forstand? Lad os lige et øjeblik studere hvorledes disse diskursmarkører fungerer i den originale spanske tekst. Her lyder den samme passage således:

Luego volvía diciendo, como si verdaderamente fuera enamorado: »-iOh princesa Dulcinea, señora deste cautivo corazón! Mucho agravio me habedes fecho en despedirme y reprocharme con el riguroso afincamiento de mandarme no parecer ante la vuestra fermosura" (Cervantes i 998a, 47-48).

Brugen af ' $\mathrm{f}$ ' i stedet for ' $\mathrm{h}$ ' $\mathrm{i}$ ord som fecho og fermosura, med sært bøjede verber (habedes) og ord der ikke længere var i brug på de Cervantes' tid (afincamiento), er stilistiske diskursmarkører, der signalerer at her 
tales der med en sprogbrug der ikke hører til i 'virkeligheden', men i et fiktivt, litterært univers. Således bliver de også til et galskabens mærke i teksten, som markerer at Don Quijote ikke kan skelne mellem fiktion og 'virkelighed', og som optræder hver gang han træder i aktion som omvandrende ridder. Men det er værd at bemærke, at den parodierede stemme er modelleret over de bøger Don Quijote har læst og således ikke er et idiosynkratisk træk ved den gale herremand:

Oven i det hældte han yderligere tøjerier af sig, der alle blev holdt i den stil, han havde lært af sine bøger, idet han efterlignede deres sprog så godt han kunne (Cervantes I998b, 42).

Stemmen med den arkaiske stil, markeret med 'f' i stedet for ' $h$ ', kommer ud af munden på Don Quijote, men tilhører den fremtidige fortæller som Don Quijote forestiller sig skal nedskrive hans eventyr. Det vil sige, at den arkaiske stil bliver et fiktionsmærke i teksten. Forholdet mellem den historiografiske diskursordens sandhedssøgen og den litterære diskursordens fiktion er i det hele taget et vigtigt tema lige fra første kapitel hvor fortælleren diskuterer navnet på romanens hovedperson med sig selv på følgende måde:

Det siges, at hans tilnavn var Quixada eller Quesada, men her er der nogen uenighed blandt de forfattere, der skriver om ham, skønt velbegrundede formodninger peger på, at han hed Quexana. Men det betyder ikke så meget for vores fortælling; det må være tilstrækkeligt at beretningen om han ikke afviger en tøddel fra sandheden (Cervantes I998b, 33).

Henvisningen til de forskellige forfattere, »som skriver om ham «, efterligner den historiografiske diskurs, der sætter sig for at vurdere forskellige historiske kilders troværdighed, hvorved der opstår en diskursivt betinget dobbelttydighed af ordet 'historie'. Dette forhold kompliceres naturligvis blot yderligere efter romanens niende kapitel, hvor udsigelsesstrukturen mangedobles med introduktionen af den arabiske historieskriver Cide Hamete Benengeli, som angiveligt har forfattet det oprindelige manuskript, oversætteren som oversætter det til kastilliansk fra arabisk, udgiverens der selv optræder som en anden fortæller og siden hen en hel række af eksplicitte fortællere, der tager ordet for at fortælle både deres egen og andres historier. Effekten af denne eksplosion af indlagte historier er, at den indledningsvist mimede historiografiske diskurs bliver parodieret, og denne effekt forstærkes kun af de mange intertekstuelle referencer og genrepasticher, hvor personer hentet ud af ridderromaner dialogerer med pikareske figurer eller stiliserede doncellaer og ædle hyrder fra 
pastoralromanerne eller med mystiske maurerkvinder fra de byzantinske kærlighedsromancer. Hertil kommer forekomsten af den egentlige selvreference, hvor romanen i slutningen af den første bog nævner Cervantes' egen novelle » Rinconete y Cortadillo «, og hvor Cervantes' navn optræder $i$ en samtale om ridderromanerne imellem præsten og kannikken (kapitlerne 47 og 48 i første del).

Det ambivalente og dialogiske forhold mellem den historiske sandhed og den gode historie bidrager til at relativisere det empirisk-rationelle årsag-virkningsparadigme, og dette bliver endegyldigt parodieret $\mathrm{i}$ romanens anden del, hvor romanens første del optræder som en bog personerne, som Don Quijote møder, har læst. I anden del optræder Don Quijote således på en gang som hovedperson i en ridderroman og som hovedperson i Cide Hamete Benengelis beretning, og Don Quijote beklager sig endog selv over eksistensen af en virkeligt eksisterende forfalskning i form af den apokryfe anden del af romanen, skrevet af Avellaneda og udgivet nogle få år før Cervantes udgav anden del af Don Quijote. Det går endog så vidt, at Don Quijote på et tidspunkt møder en person, som hævder at have mødt denne anden Don Quijote i kød og blod. Her går princippet om den udelukkede tredje endegyldigt i sort.

Opsummerende kan man sige, at lighedsepistemet bliver parodieret $\mathrm{i}$ dialog med det rationelt-empiriske vidensparadigme, mens et af dettes epistemes centrale diskurser bliver parodieret gennem romanens interdiskursive dialoger, dens komplicerede udsigelsesstruktur og dens leg med overblændinger af forskellige virkelighedsplaner og mulige og umulige verdener. Romanens tredje betydningsniveau bliver således at forstå den diskursregulerende selvreference, der tager sigte på at lære samtidens læsende publikum at respektere den litterære diskursordens fiktionelle frihed (Dines Johansens license og kontemplativitet) over for modreformationens dogmatiske bibeleksegeser.

\section{Dannelse: teksten som model i læserens identitetskonstruktion}

I denne sidste del skal vi se på hvordan den litterære selvreference kan have en diskursregulerende funktion i forhold til læserens forståelse af tekstens 'eksemplaritet' (Dines Johansen), eller det man også kunne kalde tekstens dannelsesmæssige potentiale i etisk forstand. I Kapitel II har vi været grundigt inde på den semiotiske beskrivelse af betingelserne for subjektets identitetskonstruktion. Synspunktet var her, at det menneskelige subjekt måtte forstås som en sprogligt konstrueret stabilitet eller 'vane', udspændt temporalt mellem en erindret fortid og en forestillet fremtid, spatialt mellem selvet og den anden og kulturelt mellem det kulturelle subjekts stereotype forventningshorisont og det individuelle subjekts egne 
kommunikative erfaringer. Erfaringsmaterialet som indgår i denne konstruktion, er af både imaginær og narrativ karakter, i den forstand at den litterære diskursorden forudsætter, at det læsende subjekt tilegner sig tekstens mulige erfaringer som sine egne og relaterer dem til sin egen aktuelle livsverden som en slags kognitiv model. Der er altså ikke bare tale om, at læseren forudsættes at identificere sig med personerne i et fiktivt univers, men også om at fastholde en distance og derved forstå sig selv gennem forståelsen af tekstens anden. Lad os se hvordan en litterær teksts diskursregulerende selvreferencer så at sige instruerer eller vejleder sine læsere om denne komplicerede operation.

\section{Antonio Muñoz Molinas »Beltenebros"}

Den roman som skal illustrere de metafiktive elementers dialog med den litterære diskurs' dannelsesmæssige funktion, er Antonio Muñoz Molinas Beltenebros, eller Mørkets herre som den hedder i dansk oversættelse. Beltenebros udkom forste gang i 1989 , på et tidspunkt hvor den spanske demokratiseringsproces var gennemført, og hvor socialistpartiet PSOE havde siddet ved magten i en årrække. Som vi allerede har været inde på, kan bogen siges at markere en overgang mellem forfatterskabets tidlige, formorienterede periode og en mere etisk stillingtagende fase (se s. 239). Romanen er fortalt i første person, og handlingen udspiller sig i den spanske efterkrigstid, hvilket jo naturligvis refererer til tiden efter borgerkrigen I936-39.

Hovedpersonen og førstepersonsfortælleren ved navn Darman er en tidligere kaptajn i den republikanske hær, som en hemmelig organisation af eksilspaniere sender fra London til Madrid i starten af tresserne for at likvidere en formodet forræder. Ofret, som hedder Andrade, fornemmer truslen og flygter, hjulpet af sin veninde, den unge Rebeca. Til Darmans store overraskelse ligner den unge Rebeca på en prik en anden Rebeca, som Darman lærte at kende tyve år tidligere, og som han blev dybt forgabt i. I jagten på Andrade gennem et labyrintisk og tåget Madrid bliver Darman konfronteret med en uendelig serie af spejlinger og dobbeltgængere, og han begynder at tvivle både på Andrades skyld og på sin egen identitet. Med temaer såsom 'jeg og den anden' og 'forræderen og helten' bliver referencerne til Borges forfatterskab manifeste, og der knyttes an til hele den postmoderne og dekonstruktive tradition, hvor tegnets reference hele tiden udsættes i nye forskydninger. Imidlertid sker der på et tidspunkt det, at sagen går hen og bliver meget personlig for Darman, fordi alle disse spejlinger får ham til at forbinde denne sag med en anden sag, som udspillede sig tyve år tidligere. I denne anden sag likviderede Darman en anden formodet forræder, en mand ved navn Walter, som var gift med 
den Rebeca, som han havde forelsket sig i. Walter-sagen har i de tyve år, som er gået siden da, udgjort en permanent kilde til eksistentielt ubehag for Darman, hvilket har gjort, at han har fortrængt hele sin fortid. I romanens slutning opdager Darman imidlertid, at alle disse spejlinger og gentagelsesstrukturer hverken har at gøre med en umulig gentagelse af historien med stort $\mathrm{H}$ eller med hans egne subjektive fantasier, men at der drejer sig om en nøje tilrettelagt strategi, udarbejdet af en af hans ekskombatanter, en mand ved navn Valdivia, som nu er chef for det frankistiske politi. I bogens sidste scene overvinder Darman Valdivia, som også kalder sig Beltenebros, mørkets herre og ondskabens inkarnation.

Historien bliver fortalt med tilbageblik, hvilket tillader fortælleren at kommentere sin situation sådan som den var på det tidspunkt, da hovedintrigen udspillede sig i I960'erne: "Jeg var ligesom ham « siger fortælleren om sig selv, når han sammenligner sig med skurken, den senere Beltenebros (Muñoz Molina I 989, I 23). Men selv om historien er fortalt med denne temporale forskydning, så udtaler personen Darman gentagne gange, at han ikke ønsker at huske. Der kan således iagttages en interessant udvikling i hovedpersonens måde at være på fra det tidspunkt hvor handlingen starter, og han ikke ønsker at huske, og til det tidspunkt hvor han fortæller historien efter sin hukommelse. Personen gennemgår en udvikling, hvor han genvinder hukommelsen. En tilsvarende udvikling finder vi i den måde de labyrintiske spejlinger i bogens start blokerer for at tilskrive sproget enhver reference eller stabil betydning, og så den åbenbaring som afsløringen af skurken udvirker, hvor sproget pludselig får en meget konkret reference til det spanske samfund og historie. Og med den konkrete reference får det også en kritisk brod i social og politisk forstand. Det, kan man sige, er den erfaring, som den implicitte fortæller sigter på at kommunikere til sine læsere gennem sin strategiske tilrettelægning af teksten, for ved at forføre læseren til at se verden med personens øjne, trækkes læseren gennem den samme erfaringsproces som hovedpersonen, og ledes dermed til at drage sine egne konklusioner.

En selvreferentiel læsning ville etablere en allegori mellem kriminalhistorien med Darman i detektivens rolle og læseakten, hvor læseren indtager detektivens plads (Hutcheon I980; Eco \& Sebeok 1983; Colmeiro 1994, 74; Rich 1999, 66). Darman analyserer den verden, som omgiver ham, og han tolker tingenes tilstand som indekser eller spor, der kræver en rekonstekstualisering, ganske som læseren står over for at skulle udfylde alle tekstens tomme pladser. For at kunne forbinde alle de løsrevne og fragmenterede spor han finder, må Darman opdigte historier. Han begynder simpelt hen igen og igen at forestille sig, hvad det er som er sket forud for hans tilstedeværelse, hvorved han allerede som 'person' 
påtager sig sin senere rolle som fortæller, men i allegorisk forstand påtager han sig også læserens rolle.

Vi har allerede konstateret at Antonio Muñoz Molina, ligesom mange andre af nutidens forfattere, er en forfatter med en høj grad af litteraturteoretisk ballast, og at den teoretiske diskussion om læserens aktive rolle i den litterære praksis er et genkommende motiv i hans tekster. Det ser man f.eks. i novellen »Den besatte« (»La poseída ", Muñoz Molina I993). I denne historie opfinder hovedpersonen en romantisk kærlighedshistorie helt ude af trit med virkeligheden, mens han sidder og betragter en ung, kvindelig narkoman, der venter på sin pusher. Hovedpersonen, der selv er en anonym kontormand, indtager sin formiddagskaffe på den bar, hvor pigen sidder og venter, og det er hovedpersonens manglende erfaringer fra livet på gaden, som fører til den grove fejltagelse. Når Darman i Beltenebros også lader sig føre bag lyset, er det ikke fordi han mangler livserfaringer, men på grund af at han ikke kan eller ikke vil huske. Generobringen af erindringen, som er forudsætningen for at besejre Beltenebros, finder sted i romanens sidste kapitler og beskrives symbolsk som en slags genfødsel. For at komme hen til den nedlagte biograf hvor det endelige opgør finder sted, må Darman passere gennem en underjordisk tunnel. Tunnelen, som er mørk og fugtig og fyldt med rotter, fører ham direkte til verdens underliv, »el vientre del mundo " (Muñoz Molina I989, 2 I I), men tunnelen beskrives samtidig som en passage mellem fortid og nutid, idet fortælleren siger at »således forenedes fortid og nutid som to steder forbundet af en tunnel « (Muñoz Molina 1989, I64-65).

I kraft af passagen gennem tunnelen genvinder Darman sine kropslige sanser, følesansen og lugtesansen, og pludselig kan han også navigere igennem den mørklagte biograf i kraft af sin hukommelse, for han har været der før. Den endelige omvending, der giver ham sejren over mørkets fyrste, indtræder da han husker Valdivias navn. Idet han råber Valdivias navn af sine lungers fulde kraft, beviser han, at han har genvundet hukommelsen, at han ved hvem hans modstander er, og hvem der er ansvarlig for alle de bedrageriske spejlinger, han blev udsat for i romanens start. Men samtidig tilbageerobrer han også ordets magt, idet han med navnet som indeks, deiktisk udpeger forræderen. Herigennem genvinder sproget sin reference til verden, og de bedrageriske og labyrintiske spejlinger bryder sammen.

Beltenebros er en åben roman, der rummer mange mulige læsninger. På et plan er det en fiktiv fortælling om de historiske hændelser i den spanske efterkrigstid, og som sådan er romanen velresearchet og informativ. På et andet plan er det historien om et subjekts identitetsdannelse og forhold til sin egen fortid. På et tredje plan diskuterer den forholdet mellem sproget 
og dets reference i lyset af den dekonstruktive teori og den efterfølgende pragmatiske vending, og endelig kan alle disse udlægninger samles i en allegorisk læsning, der overfører perspektivet fra det individuelle subjekt til en allegori for den kollektive identitetsdannelse. Den erfaringsproces som Darman gennemløber, og som læseren qua fortællerens strategi gennemløber parallelt, overføres eksemplarisk på det læsende publikum i Spanien i slutningen af I 980 'erne i kraft af en selvreferentiel læsning, der inddrager læserens egen livsverden som den erfaringsbaggrund romanens erfaringer tilegnes på baggrund af.

\section{Tekst}

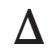

Umiddelbart objekt

Personer og begivenheder i Spanien i I960'erne
Umiddelbar interpretant

Erindring og glemsel

hos Darman

$\Delta$

Dynamisk interpretant

Kollektiv erindring og glemsel i slutningen af firserne i Spanien

I denne læsning foretager læseren en centripetal eller rekonstruktiv læsning, der fokuserer på forholdet mellem erindring og glemsel hos Darman, og applicerer denne relation som en model for den kollektive identitetsdannelse i Spanien i læserens samtid. Hvis subjektets identitetskonstruktion, hvad enten vi snakker individuelle eller kollektive subjekter, kan forstås som en narrativ proces, der forbinder den umiddelbare nutid med en erindret fortid og en forestillet fremtid, så må man sige, at denne relation er brudt sammen i Darmans tilfælde. Som person i romanen er Darman ude af stand til at huske, fordi hans erindringer er blokeret af nogle traumatiske begivenheder, og hans nutid bliver derfor en nærmest fiktiv eller labyrintisk ikke-tid og ikke-sted. Heroverfor genvinder Darman som fortæller af historien en ny identitet simpelt hen ved at fortælle historien. Og ligesom romanfiguren Darman er afhængig af at genvinde hukommelsen for at kunne reorientere sig i sin egen verden, således postulerer teksten i denne allegoriske læsning, at det spanske læsende publikum også er afhængigt af igen at skabe et kulturelt subjekt med en kollektiv erindring for at kunne udvikle en kulturel identitet i tiden efter Francoregimet. Efter Francos død opstod der nærmest det man kunne kalde officielt kollektivt amnesi hvad angik den politiske fortid, fordi de magthavende politikere mente, at det var den eneste måde, man kunne iværksætte en fredelig demokratiseringsproces på. Ingen skulle drages til ansvar, og 
derfor skulle intet huskes. Det er således min påstand, at teksten skal læses i dialogisk samspil med transitionsperiodens kulturelle subjekt, præget af amnesi og ansvarsforflygtigelse. Man kan sige, at det er den præmis, jeg tilføjer romanens enthymemiske struktur (se s. 23I).

At teksten i kraft af sin egen strategi peger på en sådan læsning ses af, at personen Darman nærmest fungerer som en maske i den forstand, at han lider af en personlig identitetskrise, som ikke hører hans egen tid til. Personen Darman lever i I 960'ernes dramatiske begivenheder, men fortælleren Darman antyder igennem det billedsprog han anvender, muligheden for en anden og mere allegorisk eller metafiktiv læsning. Og denne læsning har klar affinitet til det spanske publikums livsverden anno i 989.

Selve hovedpersonen inviterer som litterært motiv læseren til at forstå ham som nok et tilfælde blandt mange andre: den typiske, eksilerede spanier med mere end tyve år på bagen i udlandet, den politisk bevidste patriot, der længes nostalgisk efter sit tabte fædreland. Men det er ikke det, som er tilfældet. Det er ikke manglen på et fædreland, som er årsagen til Darmans krise, og endnu mindre den nostalgiske længsel efter en tabt fortid. Fortiden forekommer ham tvært imod så vederstyggelig og fyldt med så mange traumatiske oplevelser, at han har foretrukket at glemme alt om den. Det, som virkeligt går ham på, udtrykkes til gengæld oftest gennem det anvendte billedsprog. I første kapitel beskriver fortælleren f.eks. hvordan Darman levede i perioden op til de begivenheder, som udgør romanens centrale historie. Hans liv var delt imellem den trygge men intetsigende tilværelse som antikvar i England, og så hans mange rejser som hemmelig kurer for modstandsbevægelsen. Og dette rejseliv beskrives med lufthavnenes og hotellernes anonyme rum som en spatial metafor:

Sandt at sige tilbragte jeg på den tid halvdelen af mit liv i lufthavne, og eftersom hverken tid eller rum er helt virkelige sådanne steder, vidste jeg sjældent nøjagtig, hvor jeg befandt mig. Jeg levede i en varm og bestandig følelse af provisorium og landflygtighed, af ophævet tid og venten uden mål (Muñoz Molina I992, I2-I3). ${ }^{4}$

Læg mærke til hvordan fortælleren understreger, at hovedpersonens følelse af hjemløshed har rod $\mathrm{i}$ hans nuværende livsform med de mange rejser og de rum som omgiver ham, og ikke i hans eksil. Tilsvarende siger han at »nogen gange troede jeg, ligesom munkene, at jeg længtes nostalgisk efter en verden uden for, som i virkeligheden ikke vedkom mig «

\footnotetext{
${ }^{4}$ Den spanske tekst lyder således: »Es verdad que entoces me pasaba la mitad de la vida en los aeropuertos, y como en ellos ni el tiempo ni el espacio son del todo reales, casi nunca sabía exactamente dónde estaba y vivía bajo una tibia y perpetua sensación de provicionalidad y destierro, de tiempo cancelado y espera sin motivo" (Muñoz Molina I989, I3).
} 
(Muñoz Molina I989, I4). Personen Darman føler sig eksileret og fremmedgjort, men ikke fordi han er politisk forfulgt og landflygtig. Der er noget andet galt, og igen er det et billede som bringer os på sporet. I en scene fra bogens start, hvor Darman venter på sin kontaktperson i Firenzes lufthavn, forklarer fortælleren følgende:

Jeg var kommet med to på hinanden følgende fly fra Paris og Milano, og jeg vidste ikke, om mit ur viste italiensk tid, og havde ingen holdepunkter for at kunne forsyne det skyggelandskab, som omgav lufthavnen, med et lands eksakte navn. Kun den ugidelige søvnighed og kulden forekom mig at være sikre kendetegn på dette sted, hvor hver erindring bestandigt skulle glide bort, som regnen fra hangarernes bliktage (Muñoz Molina I992, I4)..$^{5}$

Det virker påtrængende vigtigt for fortælleren at understrege, hvordan lufthavnens anonyme arkitektur suspenderer alle tidslige og kulturelle referencer for personen. Darman var på dette tidspunkt dødtræt og halvsyg og på nippet til at tabe enhver form for jordforbindelse, et forhold som medvirker til at forklare hvorfor han i den grad lod sig forføre af de mange labyrintiske forviklinger, men citatet indeholder også noget mere i den forstand, at det antyder hvorfor de anonyme omgivelser har denne effekt på vores hovedperson. Med billedet af »dette sted, hvor hver erindring bestandigt skulle glide bort, som regnen fra hangarernes bliktage « forbinder fortælleren rummets anonymitet med hovedpersonens mangel på hukommelse. Billedet af regnen, der preller af på bliktaget, fremmaner et metaforisk skema, ifølge hvilket regn og erindring sidestilles. Regnens væde er under normale omstændigheder en forudsætning for jordens frugtbarhed, hvorfor bliktagets skærmen af for regnen må antages at medføre ufrugtbarhed og manglende 'vækst'. Ved at etablere en metaforisk relation mellem regn og erindring konstruerer teksten en forestilling om at de sidstnævnte kan udgøre forudsætningen for en 'vækst', hvorved teksten trækker på traditionelle romantiske forestillinger om hvordan den individuelle personlighed, eller den kollektive kulturelle identitet, vokser organisk, gødet af erindringen. Således kommer billedet af lufthavnen til at blive et emblem for det senmoderne samfund, hvor de menneskelige erfaringer ikke 'slår rod' i en bestemt historisk og geografisk kontekst, kulturelt medieret gennem den kollektive erindring. Og denne emblematiske brug af lufthavnen som billede på den senmoderne globalisering bliver

\footnotetext{
${ }^{5}$ Den spanske tekst lyder således: »Yo venía en dos vuelos sucesivos de París y de Milán, y no sabía si la hora que señalaba mi reloj era la hora de Italia ni tenía razones para otorgar al paisaje de sombras que circundaba el aeropuerto el nombre exacto de un país: sólo la perezosa somnolencia y el frío me parecieron atributos indudables de aquel lugar sobre el que toda memoria resbalaría siempre como la lluvia sobre las planchas onduladas de los cobertizos « (Muñoz Molina I989, I5).
} 
fortsat $\mathrm{i}$ en anden af forfatterens romaner, Carlota Feinberg (Muñoz Molina I999). Her er det lufthavnen i Pittsburgh, der danner ramme omkring de heteroglotte diskurser og sprogets hybridisering.

Læst på denne måde antyder billedet af lufthavnen, at Darmans krise er relateret til det senmoderne subjekts identitetskrise og intet har at gøre med det modernistiske subjekts typiske situation. Bogen handler således ikke om det politisk engagerede subjekts krise, men om de, med Jenaro Talens ord, 'indholdstømte', fragmenterede subjekter, som er resultatet af en kultur bygget på simulacra og fragmenteret af globaliseringens hybride diskurser (Talens 2000). Bogen handler om de stabile kulturelle værdiers sammenbrud og kan således siges snarere at tematisere de højere mellemlags aktuelle identitetskrise ved det 20. århundredes slutning end den politisk eksilerede spaniers situation i I960'erne. I den forstand overfører Muñoz Molina det indholdstømte subjekts identitetsproblematik fra sin egen samtid til romanens hovedperson, der som en maske bærer den i en tid, som er den fremmed. Men netop i kraft af denne operation lykkes det forfatteren at antyde en løsning på problemet. For fortælleren Darman lykkes faktisk med at skrive sig igennem krisen og at genvinde den erindring, som danner udgangspunkt for at etablere subjektet som en stabilitet eller 'vane' i de dialogiske processer. Eller som Jenaro Talens formulerer det: "Erindringen [...] er den mekanisme som gør det muligt at opretholde en vis enhed, uden hvilken selvet ville opløse sig i en mængde enkeltstående og uafhængige indtryk « (Talens op.cit., 28. Egen oversættelse).

I et essay med titlen »Fortidens ansigt « (»La cara del pasado «), altså kort tid efter udgivelsen af romanen, skrev Antonio Muñoz Molina at »den spanske hukommelse er et minefelt hvor ingen tør begive sin ind " (Muñoz Molina 1995, 69). I essayet fortæller han om, hvordan han i dagens avis har set fotografiet af en spansk modstandsmand, som blev henrettet af det frankistiske politi tilbage i I 962, og hvordan avisen i I 990 blot bekræfter dommen over ham fordi, som han ironisk siger, »det tjener alle bedst at de døde forbliver skyldige, så bødlerne kan bevare deres uskyld « (op.cit. 7I). Og han fortsætter: »Bødlernes mareridt ville være, hvis de døde genopstod sammen med alle de forfulgte, de fængslede og alle dem som ikke har efterladt sig navne eller sat mærke i vores erindring « (op.cit. 70). I hvilken anden verden end i fiktionslitteraturens kan det ske, kunne man spørge?

Beltenebros er på mange leder ikke Muñoz Molinas mest vellykkede roman, men den er interessant på den måde, at det er en roman, hvor han i allegorisk form tager sin egen tidligere skrivemåde op til revision, og hvor han gør sig klart, hvad det er for et etisk ansvar som påhviler den 
skønlitterære forfatter. Og det er samtidig klart, at denne etiske betydningsdimension kun træder klart frem, når vi foretager den læsning, der stiller skarpt på den diskursregulerende selvreference. Selvreferencen trækker en parallel mellem hovedpersonens detektivrolle og læserens egne hypotetiske abduktioner, og hovedpersonens hukommelsestab stiller dermed spørgsmålstegn ved læserens eget forhold til relationen mellem fortid og samtid, skyld og ansvar eller for den sags skyld mellem magt og mening, fiktion og historie. 
Copyright (C) Museum Tusculanums Forlag 2006

Litterær erfaring og dialogisme, E-bog 2006 ISBN-13: 9788763506205

ISBN-10: 87-635-0620-3 


\section{GLOBALISERING, FREMMEDSPROG OG LITTERATUR}

I forrige kapitel er det gentagne gange blevet påpeget, at den kritiske diskurs løbende bør diskuterer sine egne teoretiske præmisser, hvis det skal give mening at tale om produktion af 'videnskabelig' erkendelse i litteraturstudierne. Eller - udtrykt i semiotiske termer - at den kritiske diskurs bevidst må medreflektere den grund, hvorpå læsningen bliver til. Kun ved at sikre et afklaret forhold mellem forskellige læsningers teoretiske præmisser kan der etableres en frugtbar dialog mellem tradition og fornyelse samt mellem de mange forskellige og fuldt legitime tilgange, som i dag beriger forskningsfeltet. Dette krav om teoretisk metarefleksion fordrer imidlertid også, at fagets udøvere fra tid til anden tager vores egen faglighed op til revision i lyset af den generelle samfundsmæssige udvikling. Kun ved at diskutere vores faglighed specifikt i lyset af humanioras generelle udfordringer, bliver vi i stand til at sætte den teoretiske metarefleksion i perspektiv og give den konkret mening.

Selv om den finale interpretant aldrig nås i endelig form, men kun kan spores som en processuel tendens, f.eks. i form af bestemte forskningsfællesskabers etablering omkring bestemte 'vaner', er det en virkelig, virkende og vigtig del af de diskursive praksisformer, der udspinder sig omkring den litterære diskursorden. Derfor afsluttes bogen med dette kapitel, hvor jeg vil forsøge at give en diagnose af det forskningsfællesskabs udvikling, som denne bog skriver sig ind i: de litterære discipliner på universiteternes fremmedsprogsuddannelser. Dermed håber jeg at min tilgang til de litterære studier kan indgå som et indlæg i den fortløbende dialog om vores genstandsfelt på fremmedsprogene og i litteraturfaget som sådan, og at jeg kan bidrage til udviklingen af dette forskningsfællesskabs løbende refleksion og selvrefleksion.

Det nu hedengangne Humanistiske Forskningsråd pegede i sin strategiplan for perioden 2003-2007 på den øgede globalisering som en af hovedudfordringerne for de humanistiske videnskaber i den kommende tid, og det er nok svært at være uenig deri. I de udviklede vestlige samfund nedtoner globaliseringen nationalstaternes traditionelle rolle, samtidig med at de kulturelle identiteter sættes i skred i en række flerkulturelle og multietniske kultursammenstød. Den øgede geografiske mobilitet og økonomiske globalisering lader således en forceret moderniseringsproces skylle hen over kloden, hvilket øger det samfundsmæssige behov for fremmedsproglige kvalifikationer og interkulturelle kompetencer. Derfor indtager 
fremmedsprogsstudierne efter min mening en nøgleposition i humanioras svar på de udfordringer, den øgede globalisering stiller de vestlige samfund overfor. Og inden for fremmedsprogsstudierne udgør den litterære dimensions fokus på æstetiske, etiske, logiske og hermeneutiske problemstillinger et meget værdifuldt aspekt af det, man kunne kalde en specifikt humanistisk måde at anskue de interkulturelle problemstillinger på.

Imidlertid står fremmedsprogsstudierne netop i disse år i et vadested mellem forskellige videnskabelige paradigmer og måden hvorpå fagene og de enkelte discipliner vælger at positionere sig i forhold til disse paradigmer kan få afgørende indflydelse på hvordan både fremmedsprogsstudierne og humaniora som sådan kan tackle denne udfordring i fremtiden. Med dette afsluttende afsnit ønsker jeg derfor at bidrage til diskussionen om de specifikke udfordringer, som den øgede globalisering stiller litteraturstudierne på universiteternes fremmedsprogsfag overfor.

\section{Globalisering af semiosfæren ${ }^{1}$}

Globalisering har om noget været årtusindskiftets buzzword. Den øgede globalisering har været brugt som argument for alt mellem himmel og jord, lige fra skærpet indvandrerkontrol og nedsættelse af priserne på alkohol og cigaretter til implementeringen af et bredsbåndsnet eller omlægning af de videregående uddannelser. På trods af begrebets mange forskellige og til tider ligefrem modsætningsfyldte betydninger er der imidlertid ingen grund til at betvivle det reelle $i$, at den nye økonomiske og politiske verdensorden efter østblokkens sammenbrud, it-teknologiens revolutionering af de menneskelige kommunikationsformer samt den øgede internationale mobilitet har betydet en reorganisering af de økonomiske og politiske magtstrukturer i verden og har sat en ny kulturel dagsorden. Selv om dette ikke er stedet for at gå ind i en dybere diskussion af globaliseringsbegrebet, vil jeg i det følgende uddybe to forskellige aspekter af globaliseringen, som jeg mener humaniora i almindelighed og fremmedsprogsfagene i særdeleshed må tage som udgangspunkt for deres overvejelser om fremtidens udfordringer. Det drejer sig om globalisering forstået som øget global dominans, og globalisering forstået som en forceret moderniseringsproces på globalt plan.

Forstået som en centraliseret, ideologisk, politisk og økonomisk dominansrelation kan den aktuelle globaliseringsproces ikke siges at være

\footnotetext{
${ }^{1}$ Dele af nedenstående afsnit har været præsenteret som en key-note forelæsning på en konference for American Society of Geolinguistics i oktober 2003 og er under udgivelse i tidsskriftet Geolinguistics.
} 
udtryk for noget revolutionerende nyt. Dominansforholdets konkrete former har skiftet hen over århundrederne og sågar inden for de seneste årtier; de midler hvormed dominansen sættes igennem og graden af lokal autonomi har f.eks. ændret sig helt afgørende, og dog er selve dominansrelationen ikke ny. ${ }^{2}$ Den samme proces kan ikke bare genfindes bag den imperialisme, som førte til det 20. århundredes to verdenskrige, men også bag så forskellige politiske begivenheder som etableringen af det romerske imperium, Karl den Stores dominans i den europæiske middelalder eller det spanske verdensimperium i det I 5. og I6. århundrede. Anskuet på denne måde kan den spanske kolonialisering af Amerika betragtes som et eksempel på, hvordan udbredelse af den dominerende magts sprog og opretholdelse af en politisk dominans altid er gået hånd i hånd. Således skrev den spanske grammaticus Antonio de Nebrija i året I 492 den første grammatik over det spanske sprog. I 492 var også året hvor de katolske regenter, Isabel af Castilien og Fernando af Aragonien, erobrede Granada fra maurerne og dermed samlede den iberiske halvø under kristen ledelse. Det var året hvor jøderne blev udvist, og det var året hvor Columbus 'opdagede' Amerika. I introduktionen til værket, som retorisk er rettet til dronningen, redegør Nebrija for den nytte, som hans grammatik kunne gøre. Efter at have forklaret at den grammatiske beskrivelse var nødvendig for standardiseringen og bevarelsen af det kastilianske sprog, anfører han følgende argument:

Den tredje nytte man kunne drage af mit arbejde kunne være dette at der [...] efter at Deres Højhed har underlagt sig mange barbariske folkeslag og nationer med mange forskellige sprog, måtte være behov for at disse [de underkastede folk, HLH] pålægges de forordninger som den sejrende pålægger den besejrede, heriblandt vores sprog; og her er det så at mit arbejde kunne være en hjælp, ligesom vi i dag studerer den latinske grammatisk for at tilegne os latin (Nebrija I492. Optrykt i Abellán I986, 22-23. Min oversættelse). ${ }^{3}$

Klarere kan sammenhængen mellem grammatisk sprogbeskrivelse, kul-

\footnotetext{
${ }^{2}$ Man kan sige at denne tilgang til globaliseringen svarer til det som Diana Crane ville kalde kulturimperialismemodellen (Crane 2002, 7). Denne model tager afsæt i marxismens analyse af kapitalismens internationale fremtræden i form af imperialisme, men den traditionelle, politisk baserede imperialisme er ifølge Crane i dag erstattet af en mediebaseret kapitalisme baseret på markedsfunktionen.

${ }^{3}$ Den originale spanske tekst lyder således: »El tercero provecho de este mi trabajo puede ser aquel que [...] después que vuestra Alteza metiese debajo de su yugo muchos pueblos bárbaros y naciones de peregrinas lenguas, y con el vencimiento aqullos tendrían necesidad de recibir las leyes que el vencedor pone al vencido y con ella nuestra lengua; entonces por esta mi Arte podrían venir en el conocimiento de ella, como ahora nosotros aprendemos el arte de la gramática latina para aprender el latín«.
} 
turelt hegemoni og politisk imperiedannelse vel næppe udtrykkes. Naturligvis er der uendeligt mange forskelle mellem den form for dominans Spanien udøvede for 500 år siden og den rolle som USA i dag indtager i den internationale verdensorden, og mit ærinde er på ingen måde at underbetone dette eller at hævde at der er tale om én og den samme ting. Ikke desto mindre mener jeg, at Nebrijas introduktion til dronning Isabel af Castilien er et godt eksempel på, hvordan udbredelsen af den dominante stormagts sprog nødvendigvis må indgå som et redskab i opretholdelsen af den økonomiske, politiske og ideologiske hegemoni.

Man kan ikke slet og ret at sætte lighedstegn mellem sprog og kultur. Selv om der er mange berøringspunkter imellem de to fænomener, er sprog et fænomen der dækker meget mere end kultur, og vice versa. Ikke desto mindre er jeg meget enig med Umberto Eco, når han, med et citat af V.V. Ivanov, hævder, at forskellige sprog skaber forskellige måder at se verden på, og at sproglig mangfoldighed således nødvendigvis må betragtes som en form for kulturel rigdom på samme måde som vi betragter biologisk variation som en naturlig ressource:

Ethvert sprog udgør en bestemt repræsentation af universet, et semiotisk system til forståelse af verden, og hvis vi havde 4000 forskellige måder hvorpå vi kunne beskrive verden, ville dette gøre verden til et rigere sted. Vi burde tage os af sprogenes overlevelse på sammen måde som vi engagerer os i miljøspørgsmål. (V.V. Ivanov, Reconstructing the Past, I992, 4. Citeret fra Eco I993, 363. Min oversættelse). ${ }^{4}$

Ifølge Jurij Lotman består alle kommunikative processer af oversættelser mellem forskellige semiotiske systemer, forskellige sprog, diskursive registre og mellem forskellige subjekter med en forskellig kulturel baggrund, og al ny meningsproduktion som måtte berige vores verden, hidrører fra disse oversættelser hen over semiosfærens asymmetriske grænseflader. Som nævnt i Kapitel I definerer Lotman semiosfæren i kraft af en analogi til V.I. Vernadskijs biosfærebegreb, hvilket kunne få én til at tro, at der blot var tale om én stor global og overgribende semiosfære. Men Lotman mener samtidig, at semiosfæren er organiseret omkring et centrum, der defineres af den givne kulturs stærkeste og bedst strukturerede semiotiske system, typisk det naturlige sprog. Derved bliver semiosfærebegrebet underopdelt i en række lokale, men indbyrdes dialogiserende semiosfærer, der hver især er organiseret omkring de naturlige sprog og de selvbeskri-

\footnotetext{
${ }^{4}$ Den italienske tekst lyder således: »Ogni lingua constituisce un certo modello dell'universo, un sistema semiotico di comprensione del mondo, e se abbiamo 4000 modi diversi de descrivere il mondo, questo ci rende più ricchi. Dovremo preoccuparci della preservazione delle lingue così como ci preoccupiamo dell'ecologia «.
} 
velser af sproglig og kulturel art, som måtte være aktuelle for en given kultur. Man kunne derfor spørge, hvilken indflydelse de forstærkede globaliseringsprocesser måtte forventes at have på denne komplekse interaktion mellem de forskellige sprogligt definerede dele af semiosfæren? Hvad betyder det, at de traditionelle koloniale eller imperialistiske styreformer skiftes ud til fordel for langt mere raffinerede ideologiske dominansrelationer, som oftest kanaliseres gennem medierne, og som sættes igennem i kraft af det økonomiske pres som de frie markedskræfter lægger på de pågældende kulturer? Og hvad betyder det, at denne udvikling destabiliserer forholdet mellem centre og periferi, idet de sociale og kulturelle modsætninger slår igennem såvel i centrene som i periferien?

I sin introduktion til antologien Streams of Cultural Capital argumenterer David Palumbo-Liu for, at der er ved at vokse en global medieskabt kultur frem, båret af de veluddannede og bemidlede mellemlag, som knytter an til de samme livsstilsmæssige trends på tværs af nationale og kulturelle grænser (Palumbo-Liu I997). Denne globale kultur, som udgør rammen for den kulturelle kapitals (Bourdieu) internationale flow, skal hverken forstås som en permanent eller homogen størrelse, idet de kulturelle billeder som konstituerer den, tillægges forskellig betydning i relation til den kulturelle kontekst, som de tolkes ind i. Og dog udgør den et element af sameness (Ricœur), som går på tværs af semiosfærens nationale og sproglige grænsedragninger.

Hans Ulrich Gumbrecht sætter spørgsmålstegn ved hvorvidt kategorierne selv og anden kan fungere som holdbare analytiske kategorier i en situation, hvor disse positioner bliver ustabile på grund af at den øgede globalisering og fremvæksten af en hybrid verdenskultur (Gumbrecht I997, 253). I modsætning til Gumbrecht mener jeg ikke at fremvæksten af en hybrid verdenskultur underminerer kategorierne selv og anden som analytiske begreber, men relationen imellem dem bliver naturligvis anderledes. Når den anden mister sin radikale eller kategoriske andethed, bliver selvets position i et vist omfang svækket, men subjektets vilje til mening, dets semiotiske begær efter at forstå den anden, indebærer, at subjektet altid vil konstruere sin kulturelle og personlige identitet ved at spejle sig i billedet af den anden. Subjektet vil derfor fortsat konstruere sin personlige og kulturelle identitet relativt i kraft af den række af diskursivt konstruerede selver, som vi har beskrevet i afsnittet om det dialogiske subjekt (se s. 93 ff.).

Karen Risager anlægger et i denne sammenhæng interessant perspektiv på forholdet mellem sprog og kulturer, idet hun trækker på Michael Agars begreb om 'sprogkulturer' (Risager 2004, 27). For Agar er sprogkulturen den del af en given kultur, som er specifikt knyttet til denne kul- 
turs dominerende sprog, eller måske bedre formuleret, de kulturelle dimensioner af et givet sprog. Begrebet sprogkultur giver derfor Risager mulighed for at løsrive sprogbegrebet fra den nationale ramme, hvori det traditionelt har været studeret, for, som hun fastslår, sprog er hverken territorialt eller nationalt afgrænsede. Ethvert geografisk område er således præget af en mængde forskellige sproglige praksisformer, spændende fra forskellige dia- og sociolekter inden for samme sprog over forskellen mellem første og andetsprog inden for samme sprog til brugen af andre sprog (fremmedsprog), hvor man igen kan skelne mellem brugere af dette som hhv. første, andet og tredje sprog. Sprog breder sig gennem forskellige sociale netværk hen over statsgrænser, i forskellige kulturelle kontekster og på tværs af forskellige diskursivt konstruerede fællesskaber, men de bringer elementer af sprogkulturerne med sig. Derfor vedbliver den sproglige mediering af de transnationale diskurser at være et centralt omdrejningspunkt i studiet af de kulturelle konsekvenser, som globaliseringen af semiosfæren bringer med sig. Men på trods af nationalstaternes ændrede økonomiske og politiske funktion i globaliseringens æra, vedbliver de med at spille en rolle som identifikationspunkter for produktionen af kulturelle subjekter (Cros), også selv om det enkelte individ i stadig højere grad vil se sig henvist til selvstændigt at skulle 'vælge' mellem forskellige kollektive subjektspositioner, nogle globale, andre lokale eller nationale, i konstruktionen af sin egen kulturelle identitet.

Fremvæksten af den globale, mediebårne kultur får også Hans Ulrich Gumbrecht til at udlægge traditionelle analytiske kategorier som hegemoni- og dominansbegrebet som værende utidssvarende. Hvis det virkelig er den rå, økonomiske magt og dominans som er bestemmende for cirkulationen af den kulturelle kapital, hvorfor ser vi så ikke tysk og japansk kultur repræsenteret i det transnationale flow af kulturprodukter på en position, som svarer til deres økonomiske magt, spørger han retorisk. Spørgsmålet har brodden vendt mod de dele af kulturanalysen, som stadig lader sig inspirere af marxismens politisk orienterede terminologi, og det må opfattes som værende rent retorisk, for det er mange år siden at selv de mest dogmatiske positioner inden for marxismen anerkendte den kulturelle overbygnings relative autonomi i forhold til den økonomiske 'basis'. Over tid vil karakteren af de økonomiske relationer lægge rammerne for hvilken retning udviklingen inden for det kulturelle felt vil tage, og det økonomiske styrkeforhold vil blive afgørende for hvilke sprogkulturer, som vil blive de dominerende. Den i økonomisk og teknologisk forstand dominerende kulturs sprog vil tendere mod at overtage stadig større domæner fra de oprindelige sprog, og iblandt disse vil den centripetale tendens blive yderligere styrket, dvs. dialekter, sociolekter og 
minoritetssprog vil tendere mod at forsvinde. Og med indflydelsen fra de nye teknologier og mediernes dominans i hverdagsbilledet, vil denne tendens blive voldsomt forstærket. Snarere end at underkende magtrelationen og ignorere den afgørende indflydelse den økonomiske magt har på udviklingen af diskursfællesskaber og sprogkulturer, ligger løsningen efter min mening $i$ at anerkende kompleksiteten $i$ analysen af de konkrete fremtrædelsesformer. Med den øgede globalisering multipliceres kulturmøderne på tværs af semiosfærens mange forskellige grænsedragninger, og i kraft af det selvrefleksive og 'dialogiske' videnskabsparadigme som i dag dominerer humaniora, kompliceres forholdet mellem forsker og genstandsfelt, mellem subjekt og objekt, til at være en hyperkompleks relation (Caro Almela 2003).

Det globaliserede videnssamfund reducerer afstandene i tid og rum og øger antallet af kulturmøder på tværs af semiosfærens grænser. Det stiller os over for mindst to forskellige eller ligefrem modsatrettede dynamikker hvad angår sprogenes udbredelse og semiosfærens fremtidige organisering. På den ene side finder vi en centripetal dynamik, der indebærer at magtblokkens hegemoniske diskurser sætter sig igennem som en monologisk envejskommunikation der tendentielt set truer med at udradere alle semiosfærens betydningsproducerende grænser. I dag udgøres magtblokken entydigt af USA, men dette lederskab kan i fremtiden blive udfordret af den kinesisk eller spansktalende del af verden. På den anden side finder vi en centrifugal dynamik, der tager næring fra de lokale kulturmøder, der omsættes i en levende og engageret oversættelse af kulturelle indsigter og repræsentationsmodeller hen over den samme semiosfæres grænser. Hvor den centripetale dynamik indebærer en semiotisk forarmelse af den globale semiosfære, indebærer den centrifugale dynamik muligheden for berigelse af den globale semiosfære under forudsætning af at de intensiverede kulturmøder omsættes i en levende og engageret oversættelse af kulturelle forståelsesmodeller hen over semiosfærens grænser. Derfor afhænger muligheden for at udnytte de øgede globaliseringstendenser til at styrke komplekse netværksdannelser på tværs af sproglige og kulturelle skel, til at sikre udbredelsen af det hybridiserede og multikulturelle samfund, i høj grad af de enkelte borgeres beredskab af fremmedsproglige kompetencer og af deres kulturelle åbenhed over for at fungere som kulturelle oversættere eller mediatorer mellem semiosfærens sproglige og kulturelle grænser.

Hermed har vi imidlertid nærmet os det andet aspekt ved globaliseringsbegrebet, nemlig spørgsmålet om hvordan de øgede globaliseringsprocesser kan forstås som en bølge af moderniseringsprocesser der skyller hen over kloden i en situation, hvor senkapitalismens reguleringsmekanis- 
mer har overskredet de nationale statsgrænser. ${ }^{5}$ Betragtet som en forceret moderniseringsproces vil den øgede globalisering munde ud i en serie kulturelle konflikter, når traditionelle og i økonomisk forstand tilbagestående regioner i de vestlige lande, eller hele traditionalistisk indrettede samfund, pludselig ser sig konfronteret med erfaringer knyttet til den avancerede modernitet. Det gælder f.eks. tendenser i retning af sekularisering af de religiøse institutioner, demokratisering af de politiske processer og individualisering af den enkeltes livsperspektiv, for blot at nævne nogle få af de mest centrale elementer. Denne proces opleves modsætningsfyldt af de involverede parter, på én gang som et tab af traditionelle fællesskabsværdier og som øget individuel frihed. Den øgede økonomiske globalisering styrker den internationale handel og kommunikation, ligesom den rent formelt set skaber mulighed for at udbrede de demokratiske styreformer og for at øge den folkelige mobilitet. Men samtidig følges den økonomiske globalisering og de dominerende magters militære dominans på verdensplan ikke op med politiske redskaber, der kan sikre denne udvikling. Derfor skaber globaliseringen modstand mod det, som opleves som den økonomiske og politiske magts hegemoniske diskurser, og denne modstand vil altid være sprogligt artikuleret. Derfor stiller de seneste årtiers øgede globalisering krav til de moderne samfund om et forbedret sprogligt beredskab og øget kulturel indsigt.

Forholdet mellem sprog og kulturer er et emne som er tungt af 'fremmede ord', og som er belastet med mange, stærkt ideologisk prægede opfattelser. De forskellige nationalistiske ideologier naturaliserer typisk de nationale sprog som noget der er vokset organisk sammen med de nationale folk, og de trækker således ofte stærkt på en romantisk sprogforståelse, der sætter sprog lig med kultur. Desuden stipulerer nationalismen, at den nationale identitet er vigtigere, dybere 'rodfæstet' eller endog hævet over andre former for kulturel identitet såsom køn, klasse, fag eller politisk orientering. Men de nationale sprog er lige så meget et resultat af I 800-tallet socialpolitiske konstruktion af nationalstaterne, som de politiske institutioner er det (Fleischman 2000, Wilken 200I). Således hævder Karl W. Deutch at antallet af nationalsprog under påvirkning af natio-

\footnotetext{
${ }^{5}$ Denne måde at betragte de kulturelle konsekvenser af globaliseringsprocessen svarer delvist til Diana Cranes såkaldte netværksmodel (Crane 2002, 7). Ifølge Crane tager globaliseringsprocesserne ikke blot form af en monologiseret envejskommunikation fra de dominerende centre til den dominerede periferi, men åbner også muligheden for en dialogisk interaktion på kryds og tværs. Således bliver periferiens regioner styrket af de netværkslignende kommunikationsprocesser, de dominerede kulturer hybridiseres og centrene tenderer mod at forsvinde i processen. Der er imidlertid en anden del af moderniseringshypotesen som ikke stemmer overens med Cranes netværksmodel, og det bliver klart når man medreflekterer de forskellige nationalistiske og fundamentalistiske gruppers måde at arbejde på, som også anvender sig af netværksmodeller (f.eks. forskellige fascistiske mindretalsgrupper i Europa samt Al Queda i den arabiske sprogkultur).
} 
nalromantikken voksede hurtigere mellem I 800 og I900, end på noget andet tidspunkt i de forudgående ti århundreder, og mellem I900 og 1937 voksede antallet af europæiske standardsprog mere end i de forudgående tusinde år (Wilken op.cit. I77). Ikke desto mindre anvender forskellige nationalistiske bevægelser de nationale sprog og de nationale grænsedragninger som ideologiske argumenter mod de af globaliseringens konsekvenser, som har at gøre med øget migration og kulturel 'forurening'. Selv om ingen af de nordiske sprog eller kulturer reelt er under pres, har de fremmedfjendske holdninger haft stor indflydelse på den kulturelle offentlighed og de har siden årtusindeskiftet reelt sat dagsordenen for den politiske debat i landet. Forsvaret af de 'danske værdier' er blevet et nationalt anliggende, som ingen politiske partier reelt i dag er i stand til at lægge afstand til. Men ideen om de oprindelige danske værdier er en romantisk ideologisk konstruktion, der bygger på forestillingen om en kulturel jomfruelighed hvor det danske er dansk i sin essens. Denne essentialistiske opfattelse af den nationale identitet vil typisk bygge på forskellige stereotypopfattelser af den anden, som imidlertid blokerer for at vi får øje på den konkrete anden, der står lige foran os.

Med den øgede globalisering forstærkes mødet mellem forskellige kulturer på alle niveauer i samfundet, og de kompetencer, som gør subjektet i stand til at kunne kommunikere med den konkrete anden, dvs. at 'oversætte' hen over semiosfærens grænser, bliver stadig vigtigere. Mødet mellem forskellige kulturer kan tage form af samkvem på tværs af de etablerede grænser, det kan bestå i ændringer af de bestående grænser som ved udvidelsen af EU, eller det kan vedrøre forholdet mellem indvandrere og 'indfødte' inden for de etablerede grænser. I alle tilfælde udgør en høj fremmedsproglig kompetence og en udviklet kulturel indsigt den måske vigtigste forudsætning for et positivt udfald af dette kulturmøde. Den sproglige kompetence og det indgående kendskab til den kulturelle anden udtrykker respekt for det anderledes og signalerer den tolerance og åbenhed, som er en forudsætning for en vellykket kommunikation. Og som sådan er det en uomgængelig produktionsressource i et globaliseret videnssamfund, for hvis den kommunikative interaktion med den konkrete anden blokeres, træder det kulturelle subjekts stereotypiserede fordomme mod den anden i den konkrete andens sted, og i stedet for et interkulturelt møde får vi en xenofobisk konfrontation og udgrænsning. Det er med andre ord ikke nok, at vi som danskere kan klare os på vores bedste skoleengelsk, og det er slet ikke tilfredsstillende at den danske horisont på det litterære og kulturelle område stadig er sprogligt begrænset til en hovedsageligt engelsksproget kanon, krydret med lidt tysk og fransk når det går højt. I takt med den øgede globalisering opstår der 
inden for alle samfundslivets områder et behov for personer, der kan kombinere en bred vifte af fremmedsprog på højt niveau med almene humanistiske kompetencer såsom indsigt i historiske og kulturelle forhold samt evnen til kritisk tænkning og kreativ kommunikation.

Efter d. II. september $200 \mathrm{I}$ har kultursammenstødet for alvor overtaget den kolde krigs rolle som sikkerhedspolitisk hovedspørgsmål. Hvor det under den kolde krig var politisk-ideologiske modsætninger, som kunne ryste den globale stabilitet og true vores sikkerhed på egen grund, dér er det i dag manglen på interkulturel forståelse og respekt for andres standpunkter, som udgør den vigtigste trussel. Naturligvis ligger der som altid også økonomiske interesser bag de kulturelle konflikter, men brudfladen, for nu at sige det på denne måde, har skiftet karakter. I 2002 udråbte Samuel P. Huntington ligefrem det 2I. århundrede til at være begyndelsen til »de muslimske kriges tidsalder « i et interview i Die Zeit. ${ }^{6}$ Fra tidligt i det tyvende århundrede at handle om det nationale spørgsmål, gled brudfladen i anden halvdel af det tyvende århundrede i retning af ideologiske konflikter i forbindelse med den kolde krig, og efter østblokkens sammenbrud er det så de kulturelle modsætninger der, ifølge Huntington, står i centrum. Uden nødvendigvis at skulle tage Huntington på ordet, eller for den sags skyld overtage hans problematiske kulturbegreb, er der ingen tvivl om, at kulturelle konflikter allerede nu sætter den politiske dagsorden i de fleste vestlige lande, og at de vil komme til at gøre det en rum tid fremover. Hvis vi ikke i den situation insisterer på vigtigheden af en sproglig-kulturel dimension i et humanistisk svar på den øgede globalisering, risikerer vi fra universiteternes side blot at gentage de politologiske og økonomiske globaliseringsteoriers blinde plet. Det er vigtigt at de aktuelle tendenser til øget økonomisk globalisering modsvares af et reelt globalt udsyn og en øget interkulturel forståelse, og at vi ikke bare lader en snæversynet anglofon provinsialisme herske.

\section{Krisen på fremmedsprogsstudierne}

Fremmedsprogsfagene på universiteterne står imidlertid i en paradoksal situation i disse år, forstået på den måde at vi, på trods af et stigende samfundsmæssigt behov for fremmedsproglige kompetencer, oplever vigende søgning og permanente økonomiske nedskæringer. Baggrunden herfor er naturligvis kompleks og skal både findes i forhold som er generelle for de videregående uddannelser og for humaniora som helhed, og i forhold som er specifikke for fremmedsprogsuddannelserne.

\footnotetext{
${ }^{6}$ Interviewet er optrykt i Politiken d. 7/9 2002.
} 
Krisen for fremmedsprogene er på den ene side en konsekvens af en ændring som har sat sig igennem for de videregående uddannelsessystemer som sådan på internationalt plan. I World Yearbook of Education for $200 \mathrm{I}$ beskriver Andreas Kazamias hvordan universiteternes rolle er under forandring. Fra at være institutioner som skulle sikre varetagelsen af den nationale kulturarv, der igen skulle udgøre grundlaget for den almene dannelse af samfundets individer til ansvarlige borgere, er der i løbet af de seneste årtier sket en glidning i retning af, at universiteterne skal være institutioner, der kan producere specialiseret viden og forsyne samfundet med brugbare eller kompetente kandidater. Det nøglebegreb som Kazamias bruger til at karakterisere udviklingen er 'intrumentalisering' af vidensbegrebet:

[The idea of the university] is changing from one whose main ingredient has been the English and US concept of 'liberal education', the German Bildung $[\ldots]$ to one where the main ingredients are 'instrumental rationality' and what the postmodernist French thinker Lyotard has called performativity (Kazamias 200I, 2).

Denne ændring i opfattelsen af universiteternes rolle spiller en kolossal stor rolle for den måde humaniora betragtes på inden for uddannelsessystemet, og for tilskrivningen af 'kulturel kapital' til den humanistiske viden generelt. Instrumentaliseringen af vidensbegrebet og udskiftningen af dannelsesbegrebet med et handlingsorienteret kompetencebegreb lægger op til, at alle studieelementer fremover skal indeholde en anvendelighedsdimension, som netop typisk ikke findes inden for de humanistiske erkendelsesfag, og som historisk set har været i decideret modstrid med de kulturelt æstetiske fag. Og denne generelle tendens til devaluering af humanioras kulturelle kapital rammer sprogfagene på en særlig måde.

Den instrumentelle rationalitet, som ifølge Kazamias har afløst det klassiske dannelsesideal, giver sig inden for fremmedsprogsområdet udtryk i, at det omgivende samfund i stadig højere grad anlægger et instrumentelt sprogsyn på vores genstandsområde. Det instrumentelle sprogsyn betragter sproget som et neutralt kommunikationsredskab som, i modsætning til f.eks. Jurij Lotmans opfattelse af sprogene som asymmetriske semiotiske systemer, muliggør den restløse og gnidningsfri oversættelse af et identisk indhold fra en tekst til en anden. Og med afsæt i et sådant gennemsigtigt og symmetrisk sprogbegreb fremstår det som en fuldstændig uproblematisk løsning på behovet for international kommunikation at lade det engelske sprog fungere som globaliseringsalderens kulturelle lommeregner.

Selv om det instrumentelle sprogbegreb står i modsætning til stort set 
alle gældende videnskabelige sprogteorier (funktionalistiske, kognitive, semiotiske mv.), fremføres den instrumentelle holdning til sprogindlæringen og til brugen af fremmedsprog vedholdende fra politisk hold, samt af stærke kræfter inden for erhvervslivet, f.eks. af Dansk Industri. Men også inden for akademiske cirkler er det en stadig mere accepteret holdning, og her taler vi ikke kun om natur- og samfundsvidenskaberne, men også om kræfter inden for humaniora selv. Hvis de økonomiske og politologiske globaliseringsteorier kan kritiseres for at have en blind plet hvad angår det kulturelle spørgsmål, kan man sige at humaniora er i gang med at reproducere denne blinde plet hvad angår sammenhængen mellem sprog og kultur. Og hvad værre er, jeg tror at vi på sprogfagene selv har et ansvar for at det forholder sig sådan. Instrumentalisterne, for nu at kalde dem sådan, har nemlig fat i den lange ende, når de kritiserer den humanistiske holdning til forholdet mellem sprog og kultur for at være ladet med romantisk arvegods: forestillinger om at det nationale sprog er organisk sammenvokset med den nationale kultur, at vi mister vores egenart hvis vi ikke beskytter vores nationale sprog osv. Og de har ret i den forstand, at disse ideologiske holdninger er vidt udbredt, nok ikke blandt folk som beskæftiger sig professionelt med sprog, men bredt i befolkningen, og de ligger bag mange behjertede forsøg på at lave en protektionistisk sprogpolitik. Sprogfagenes ansvar i den forbindelse består i ikke tilstrækkeligt kraftigt at have ført et alternativt sprogsyn frem i offentligheden, et sprogsyn som, i overensstemmelse med de gældende sprogvidenskabelige teorier, peger på, at sprog er det materiale som vi konstruerer vores forhold til verden igennem, og at sprog ikke er symmetriske og gennemsigtige transmissionssystemer, men asymmetriske og betydningsgenererende dynamikker knyttet til oversættelser hen over de betydningsgenererende grænser.

Men krisen for fremmedsprogsuddanelserne har også en dimension, som hænger sammen med fagene selv og deres egen selvforståelse. I løbet af det tyvende århundrede har filologien mistet sin kraft som overgribende videnskabsteoretisk paradigme, uden at nogen anden samlet opfattelse af sprogfagenes genstandsområde har taget dets plads. I stedet har vi oplevet en omfattende fagspecifik teoretisering af sprogfagene, der følgelig er blevet splittet op i en række specialiserede delaspekter: lingvistikken, historien, antropologien, litteraturvidenskaben, film- og medievidenskaben osv. Hver af disse specialiserede discipliner har tilføjet sprogstudierne værdifuld viden og frugtbare teoretiske indsigter, men udviklingen har samtidig betydet, at den vigtige sammenhæng imellem disciplinerne til dels er gået fløjten. Vi må derfor nok erkende, at der gennem en årrække har været problemer med at få uddannelserne til at fremstå som sammenhæn- 
gende helheder, der kombinerer de konkrete sproglige kvalifikationer med et solidt sæt af mere almene kompetencer. For at uddybe dette vil det nok være på sin plads at tage et kort blik på fagenes historiske udvikling.

\section{Sprogfagenes selvforståelse og videnskabelige paradigmer ${ }^{7}$}

De moderne fremmedsprogs stærke placering inden for det humanistiske hovedområdes fagudbud er opstået som konsekvens af det tyvende århundredes behov for at udbygge landets uddannelsesmæssige infrastruktur. I starten af det tyvende århundrede indførtes en særlig skoleembedseksamen for gymnasieskolen, som udpegede fremmedsprogene som en del af det alment dannende grundlag for den præuniversitære ungdomsuddannelse, og siden da er fremmedsprogene på universiteterne blevet udbygget i takt med gymnasieskolens vækst. Hvad angår sprogfagenes indholdsmæssige opbygning og faglige sammensætning, kan man sige, at de grundlæggende har været præget af den nationalfilologiske tradition. Nationalfilologien udvikledes i løbet af det nittende århundrede i snæver sammenhæng med primært den tyske nationalromantik, og det er i høj grad de nationalfilologiske forestillinger om sammenhængen mellem sprog, litteratur og nationalkultur, der har dannet baggrund for udviklingen af sprogfagenes faglige profil op igennem det tyvende århundrede, om end der hen imod århundredets slutning er blevet tilføjet en samfundsfaglig dimension. I deres nuværende form tager sprogfagene sigte på at studere nationalsprogene og de dertil knyttede litteraturer i deres samspil med samfundsmæssige, kulturelle og historiske forhold.

Indholdet af ordet filologi har gennem historien ændret sig i takt med de tider, hvori filologien har eksisteret. Det første behov for en egentlig filologisk tekstkritik opstod med den græske indflydelse på den romerske kultur (Høyrup I995, 38) og har kunnet registreres i snart sagt alle perioders åndsliv lige siden, idet behovet for oversættelse og formidling af den åndshistoriske tradition nødvendiggør vedligeholdelsen og udviklingen af en metodisk reflekteret tekstkritik. Det gjaldt f.eks. paladsskolen ved Karl den Stores hof i Aachen, hvor det klassiske curriculum blev taget op, og som dannede baggrund for den karolinske renæssance (op.cit. 52 ff.). Det gjaldt den såkaldte tolvte-århundrede-renæssance, som førte til oprettelsen af katedralskolerne, og det gjaldt renæssancehumanismen, som i det fjortende og femtende århundrede skabte behov for nye

\footnotetext{
${ }^{7}$ Dele af det følgende afsnit har tidligere været publiceret i Hansen (2002) som forfattet af undertegnede og Viggo Hjørnager Pedersen.
} 
kommenterede tekstudgivelser af de klassiske tekster (op.cit. 97). Men den udgave af filologien, som i særlig høj grad kom til at præge den måde fremmedsprogsuddannelserne blev tænkt, var som sagt i 800-tallets nationale filologi, der opstod i forlængelse af den neohumanisme, som igen lå bag Humboldts universitetsreform af I 809. Som påvist af bl.a. Lene Schøsler overtog nationalfilologierne den klassiske filologis tekstkritiske metoder, men anvendte dem fejlagtigt på de middelaldertekster, som man som led i det nationale opbygningsprojekt antog måtte ligge til grund for en given nationalkarakter (Schøsler, 200I). På trods af dette grundlæggende ideologiske udspring er det den dag i dag nationalfilologiens særlige blanding af positivisme, historicisme og hermeneutik, som ligger bag hvad man normalt forstår ved ordet filologi.

Søger man under opslaget 'filologi' i forskellige encyklopædier og leksika fra det tyvende århundrede, finder man en række forskellige og meget tidstypiske definitioner af hvad ordet betyder og hvordan filologien er blevet praktiseret. Hvad angår indholdsdefinitionerne mener Den Store Danske Encyklopæedi (I996), at begrebet dækker over »flere videnskabsgrene, som beskæftiger sig med studiet af en kulturs sprog og litteratur «. Brockhaus' Die Encyklopädie (I998) skriver, at ordet betyder »die Wissenschaft der Deutung von Texten, i.w.S. die wissenschaftliche Erforschung der geistigen Entwicklung und Eigenart eines Volkes oder einer Kultur aufgrund seiner Sprache und Literatur «. Hagerups leksikon ( I949) mener, at der er tale om »et Sprogstudium, der har til Maal at trænge ind i den Kultur og det Aandsliv, som den sproglige Overlevering er Udtryk for med Centrum i den nøjagtige Forstaaelse af de overleverede Tekster «, mens Espasa-Calpes Enciclopedia Universal Ilustrada (I924) mener at filologi er »den videnskab der beskæftiger sig med kendskabet til et folks åndelige karakter, eller en gruppe af folkeslag, således som denne kommer til udtryk i sproget og i den såvel ældre som nyere litteratur «. ${ }^{8}$

Af alle fremstillingerne fremgår, at filologi omhandler studiet af sprog og litteratur, altså beskæftigelsen med tekster i et specielt ærinde, nemlig med henblik på at forstå den kultur som ligger bag, kommer til udtryk gennem eller udgøres af disse tekster. Går vi et skridt nærmere på de konkrete formuleringer, vil vi imidlertid se en række forskelle definitionerne imellem som i vid udstrækning har at gøre med forståelsen af hvad 'kultur' er. Hagerups formulering om at studiets formål er at »trænge ind i« det åndsliv, som teksten kan læses som et udtryk for, afslører en essentialistisk tro på, at sprog og tekster er gennemsyrede af en bestemt

\footnotetext{
${ }^{8}$ Originalteksten lyder således: »la ciencia que tiene como objeto el conocimiento del carácter espiritual de un pueblo o de un grupo de pueblos tal como aquel se refleja en la lengua y en la literatura antigua o moderna «.
} 
nationalånd eller tidsånd, en opfattelse vi genfinder i Espasa Calpes romantiske begreb om »et folks åndelige karakter «. Heroverfor finder vi Den Store Danske Encyklopcedis formulering om, at filologien er »studiet af en kulturs sprog og litteratur «. Her udtrykkes en kulturopfattelse, der forstår 'kultur' som værende konstitueret af bl.a. sprog og litteratur. Og hvor Hagerups formulering om, at studiets formål er at "genskabe den nøjagtige Forstaaelse « afslører en forestilling om at videnskabsmanden gennem det filologiske studium kan "genskabe « den tabte betydning, som forfatteren i sin tid tillagde teksten, der foruddiskonterer Den Store Danskes mere neutrale formulering om, at filologien »beskæftiger sig med studiet af en kulturs sprog og litteratur ", ikke hvad det er for en betydning, vi i dag er i stand til at læse ud af de historiske tekster. Endelig står Den Store Danskes understregning af at filologien udgøres af "flere videnskabsgrene" over for Espasa-Calpes opfattelse af, at filologien er en enhedsvidenskab med egne metoder, der holdes sammen af filologiens specifikke mål: »Filologien bliver udelukkende til en videnskab i det omfang den anvender den lingvistiske og litterære forskning som karakteriserer den som redskab eller instrument til at udforske dette eller hint folkeslags karakter eller ånd, eller for den sags skyld en gruppe af folkeslag «. ${ }^{9}$

Disse forskellige og hver især tidstypiske formuleringer afspejler hvorledes nationalfilologiens forestilling om sig selv som en enhedsvidenskab op igennem det tyvende århundrede har veget pladsen for en forståelse af filologien som et mødested for flere discipliner. Desuden har nationalfilologiens meget ideologiske forestillinger om sprogets og kulturens forankring i en national ånd mistet deres gyldighed, og filologien har dermed også mistet sin kraft som et overgribende videnskabsteoretisk paradigme for humaniora. Men på trods heraf har den filologiske uddannelsesskabelon fortsat domineret opbygningen af sprogfagene i det tyvende århundredes sidste halvdel. Således fastholdt man f.eks. denne skabelon som grundlag, da man midt i tresserne institutionaliserede de eksisterende fremmedsprogsuddannelser i et antal institutter (Engelsk, Germansk og Romansk), og i øvrigt også da man etablerede en række nye sprogfag, som endnu ikke var eller aldrig blev en del af gymnasieskolens fagudbud (spansk, italiensk, portugisisk mv.). Det eksterne behov for at kunne levere gymnasielærere i engelsk, tysk, fransk, russisk og siden hen også spansk og italiensk har således legitimeret uddannelsernes eksistens op igennem århundredet, uden at noget andet videnskabeligt paradigme har overtaget opgaven med at definere sammenhængen mellem de fagligheder,

\footnotetext{
${ }^{9}$ Originalteksten lyder således: »La Filología sólo y únicamente llega a ser una ciencia por el hecho de utilizar la investigación lingüística y literaria, propia de ella, como medio o instrumento para conocer el carácter o espíritu de este o aquel pueblo o complejo de pueblos «.
} 
som indgik i disse uddannelser, og uden at den romantiske forestilling om en essentiel forbindelse mellem sprog, litteratur, historie og kultur er blevet erstattet af et andet helhedssyn på forholdet mellem sprog og kulturer. I stedet blev filologiernes discipliner hver især præget af den teoretisering, som fandt sted inden for de komparative videnskaber såsom historievidenskab, sprogvidenskab, sammenlignende litteraturvidenskab, antropologi og medievidenskab.

Som påpeget af Børtnes var historievidenskaben den første til at bryde med den filologiske enhedsvidenskab, idet Rankes spørgsmål til »wie es eigentlich gewesen " gjorde op med filologiens orientering mod tekstforståelsen og satte sig for at rekonstruere den ekstra-tekstlige begivenhedssekvens (Børtnes, 2002). Snart efter fulgte sprogvidenskaben under indtryk af Saussures synkrone beskrivelse af relationerne i sprogsystemet, og i I 920 'erne og I930'erne ser vi, hvordan formalismen vinder frem inden for litteraturstudierne med fokuseringen på, hvad der er det særligt litterære i litteraturen. Denne fragmentering af den filologiske faglighed er kun blevet yderligere tilspidset af, at samfundsfaglige, kulturanalytiske og medievidenskabelige problemstillinger siden sidst i I960'erne er indgået som helt naturlige, særfaglige problemstillinger i fremmedsprogenes genstandsområde. Filologiens oprindelige ambition om at være en enhedsvidenskab med klart definerede målsætninger og metoder desintegrerede $i$ en række specialdiscipliner, hvis eneste fællesnævner var, at de beskæftigede sig med et givent sprog. Til gengæld blev hvert enkelt sprogfag at betragte som et minifakultet af sammensatte fagligheder, som de trods alt små fag ikke kunne forsvare at opretholde hver for sig. Resultatet blev de fleste steder, at den enkelte videnskabelige medarbejder måtte vælge at specialisere sig inden for sin egen lille niche, hvorved sammenhængen i såvel forskning som undervisning blev truet.

Fra slutningen af I980'erne har der imidlertid været tegn på, at en alternativ tendens er under udvikling inden for humanvidenskaberne, der kunne pege frem imod et nyt videnskabeligt paradigme. Allerede I970'ernes marxistisk inspirerede interesse for at forstå sprog og litteratur i en historisk og samfundsmæssig sammenhæng banede vejen for et bredere tekstbegreb og en begyndende vending mod pragmatisk kommunikationsteori, som igen fremmede tværfagligt samarbejde og teoretisk eksperimenteren. I firserne slog forskellige poststrukturalistiske strømninger igennem sammen med en fornyet æstetisk interesse for litteraturen, men fra midtfirserne og frem er det kulturstudierne som har overtaget den samlende funktion for humaniora, således at de traditionelle Geisteswissenschaften som sådan er blevet begrebet i form af Kulturwissenschaften, som det er blevet formuleret af bl.a. Bernd Henningsen (Henningsen I 997, I 4). Dette 
perspektiv har sat sig igennem på filologiens område på flere måder. Inden for mediævistikken har centrale kræfter f.eks. arbejdet på at redefinere disciplinen på et på én gang materialistisk og konstruktivistisk grundlag under betegnelsen New Philology (Nichols I 990), ligesom kulturstudierne er blevet diskuteret som et samlende perspektiv for fremmedssprogsfagene som helhed (Grabes 1996 og 2002, Hansen 2001 og 2002, Sørensen 2002).

Desuden har vi inden for de sidste ti til femten år oplevet nogle afgørende skift i de dominerende videnskabelige paradigmer inden for de tre discipliner, som traditionelt har haft størst indflydelse inden for sprogfagenes genstandsområde: lingvistikken, litteraturvidenskaben samt historie og kulturstudierne. Det drejer sig for det første om den pragmatiske vending inden for sprogvidenskaben, som ikke kun ser det som lingvistikkens opgave at beskæftige sig med sprogsystemet, men også med sproget som det bruges i de kommunikative processer. Det drejer sig om forskellige former for funktionelle tilgange, der spændende lige fra analysen af talesprog til kritisk diskursanalyse, der knytter sproget an til spørgsmålet om magt og sociale institutioner. Det drejer sig for det andet om den sproglige vending inden for kultur- og samfundsvidenskaberne. Sproget er ifølge denne opfattelse det materiale eller den prisme vi forstår virkeligheden igennem, hvorfor vores forhold til virkeligheden ses som sprogligt konstrueret. Og sproget er ikke uskyldigt. Det er bærer af en række begreber, som igen er præget af kultur og historie. Og endelig gælder det den kulturelle vending inden for litteraturvidenskaben, hvor dekonstruktionen og forskellige poststrukturalistiske positioner fra slutfirserne og frem har mistet terræn til kulturstudierne, der har været på fremmarch i I990'erne. Forestillingen om tekstens autonomi har siden nykritikken holdt sig levende gennem strukturalismen og dekonstruktionen, mens der i dag er langt større opmærksomhed omkring den historiske og kulturelle forankring af teksterne. Disse tre parallelle 'vendinger' har været på vej i en længere årrække, men er først begyndt at sætte sig igennem som et egentligt paradigme til afløsning af det strukturalistiske-poststrukturalistiske paradigme i løbet af I990'erne, hvorved muligheden for at reetablere et fælles objekt for den filologiske stræben atter bliver realistisk.

Andetsteds har jeg argumenteret for, at disse tre videnskabsteoretiske 'vendinger' hænger sammen med et generelt videnskabsteoretisk paradigmeskift inden for humanvidenskaberne, som jeg har kaldt for 'dialogisk' (Hansen 2002b). Ifølge Foucault er det moderne videnskabsteoretiske paradigme, som har domineret størsteparten af det 20. århundrede, kendetegnet ved, at det rettede den videnskabelige erkendelsesinteresse mod beskrivelsen af de strukturer, som man antog regulerede den men- 
neskelige aktivitet bag om ryggen på de sociale agenter. Det gælder f.eks. de økonomiske relationer, der regulerer vores arbejdsliv, de biologiske vilkår der styrer vores livsprocesser og de grammatiske strukturer som styrer vores sproglige kommunikation (Foucault I 999, 262 ff.). Men det gælder også forestillingen om de dybdepsykologiske strukturer (det ubevidste mv.), som man antog regulerede vores psykiske liv. Dette moderne epistemologisk paradigme indebar, at videnskaben måtte sætte spørgsmålstegn ved tingenes positive fremtræden, der ikke længere kunne tale for sig selv, men kun kunne erkendes, når de blev betragtet i relation til det system, som kunne forklare deres funktion. For sprogets vedkommende indebar dette, at oplysningstidens encyklopædiske vidensbegreb, der byggede på en uproblematisk og logisk relation mellem ordet og dets reference, måtte erstattes af et sprogbegreb med en arbitrær relation mellem ordet og dets reference. Sprogets funktion kunne nu kun forklares gennem en kortlægning af sprogsystemet, grammatikken. Heroverfor indebærer det, som jeg har kaldt det dialogiske skifte i det videnskabelige paradigme, at erkendelsesinteressen for humanvidenskaberne igen vender sig mod forståelsen af de levende processer og i stigende grad engagerer sig i undersøgelsen af det menneskelige subjekt som en handlende størrelse (agency) i de kulturelle processer. Inden for humaniora indebærer dette, at forskere på ny vender sig mod de levende diskursive processer som kilden til viden om verden. Ikke i form af den monologiske diskurs som dominerede det encyklopædiske oplysningsprojekt og som leverede det rationelle redskab for en autoritær og entydig repræsentation af sandheden, men i form af en åben, dialogisk og ufinaliserbar semiosis, i kraft af hvilken vi ikke bare repræsenterer verden, men også konstruerer vores egen tilstedeværelse i den. Derfor indebærer det dialogiske paradigme også, som vi har set det ovenfor, at det binære subjekt-objekt-forhold dekonstrueres, idet det undersøgende subjekt i kraft af den teoretiske selvrefleksion bliver bevidst om sin egen rolle i konstruktionen af det objekt, som gøres til genstand for undersøgelsen (Gumbrecht I997, 250). Det menneskelige ego står ikke længere overfor non-ego som klart afgrænsede kategorier, men medieres af den tegnmæssige repræsentation af dette forhold i form af en interpretant. Eller sagt på en anden måde: menneskets forhold til den verden, som omgiver det, er sprogligt-diskursivt konstrueret.

De tre simultane paradigmeskift inden for sprogfagenes discipliner tillader i dag en tilbagevenden til teksten som et fælles tværfagligt genstandsområde for sprogfagene, og jeg har andetsteds argumenteret for at betegne denne tilbagevenden til det filologiske udgangspunkt på baggrund af en teoretisk reflekteret relation imellem sprog, kultur og historie for en 
'ny kulturfilologi' (Hansen 200I, 2002b og under udgivelse). Jeg er imidlertid ikke ene om at argumentere for en en tilbagevenden til filologibegrebet, og blandt fortalerne herfor er argumenterne for projektet mangfoldige. Således argumenterer Paul de Man i 1986 for en tilbagevenden til filologien fordi det netop er den sproglige detalje, som i en dekonstruktiv sammenhæng kan udløse det betydningsmæssige brud, der får de etablerede læsninger til at skride (de Man I986), mens Jan Ziolkowski omkring I 990 citerer Roman Jakobson for at filologi kan forstås som »the art of reading slowly « (Ziolkowski I 990, 6). Helge Jordheim argumenterer mere end et tiår senere for en tilbagevendenden til filologibegrebet for at genskabe humanioras tradition for en tekstlæsning, der medreflekterer det kulturelle kompleks i tekstforståelsen (Jordheim 200 I), og lægger sig i den forbindelse i forlængelse dels af den ny filologi inden for mediævistikken (se f.eks. Nichols I990) dels af aktuelle tendenser inden for kulturstudierne (se f.eks. Grabes I 996 og 2002).

For mit eget vedkommende har jeg foreslået at bruge filologibegrebet for at understrege, at vi må insistere på et meget højt niveau af sproglige kompetencer, og at vi må fastholde et analytisk fokus på behandlingen af tekster i relation til deres historiske og kulturelle kontekster. En ny kulturfilologi må endvidere definere sit genstandsområde som helheden af de flerstemmige og dialogiserede diskurser, som karakteriserer vidensproduktionen og vidensdistributionen i det globaliserede informationssamfunds semiosfære. Og en sådan kulturfilologi må udvikle de tværfaglige tilgange til vores genstandsfelt med henblik på at kombinere et meget højt sprogligt niveau hos vores kandidater med en høj grad af bevidsthed om oversættelsens betydning som kulturelt parameter samt en veludviklet bevidsthed om egen rolle som interkulturel mediator (Hansen 2004).

Spørgsmålet, som står tilbage, er så blot hvilke udfordringer en sådan tværfaglig redefinering af sprogfagenes genstandsområde repræsenterer for litteraturstudierne, og hvordan den her i bogen præsenterede semiotiske teori er i stand til at hjælpe os med at tackle disse udfordringer.

\section{Litteraturstudierne på fremmedsprogene}

Uddannelsesinstitutionerne i Danmark er under omformning. Det virker som om den herskende neoliberale ideologi sætter lighedstegn mellem samfundets almene interesser og samfundets økonomisk vækst (læs: erhvervslivets indtjening), som uden videre er blevet knæsat som højeste mål for samfundsmæssig udvikling. Samtidig indebærer den samme ideologiske retnings blinde tiltro til, at markedskræfterne ikke bare udgør det 
mest effektive, men også det mest demokratiske redskab til at regulere snart sagt alt mellem himmel og jord, herunder også uddannelsesplanlægningen og samfundets kulturelle udvikling, at alle landets uddannelsesinstitutioner for tiden er kastet ud i en omfattende transformationsproces. Og universitetssektoren med dem. Den instrumentalisering af universiteterne og de videregående uddannelsesinstitutioner, som vi beskrev ovenfor, indebærer, at disse institutioner skifter karakter: det traditionelle humanistiske dannelsesindhold omfortolkes som erhvervsrettede kompetencer og institutionernes mål defineres i kvantificerbare kategorier, der forsøges at gøres sammenlignelige på tværs af, eller på trods af forskelle i faglig substans. På undervisningssiden gøres 'produktionen' op i studieårsværk efter de studerendes aflagte eksamener, og på forskningssiden arbejde man på at indføre evalueringssystemer og benchmarking, der kvantificerer 'produktet' i antal internationalt anerkendte publikationer. Der er tale om det, som populært kaldes 'djøfficering' af institutionerne, et udtryk som dækker over en rationelt bureaukratisk effektivitetsmaksimering. Som afslutning på dette kapitels refleksion og selvrefleksion omkring fremmedsprogenes genstandsfelt og litteraturfagets metoder, ønsker jeg at give udtryk for, at denne udvikling ikke bare er uheldig, men direkte farlig for humanioras egenart og faglighed. Det er for mig at se en påtrængende opgave at argumentere for, at vores kandidaters traditionelle humanistiske kompetencer er mere værdifulde end nogen sinde før for det omgivende samfund.

I sin analyse af holocaust påpeger Zygmunt Bauman at moderniteten, forstået som en Weber'sk rationel-bureaukratisk effektivitetsmaksimering, ikke står i modsætning til Holocaust, men snarere udgør en af de nødvendige forudsætninger for at dette industrielt tilrettelagte folkemord kunne blive til noget (Bauman 200I). Bauman fastslår desuden at ingen af de samfundsmæssige omstændigheder der førte til katastrofen, for alvor er forsvundet, og han går endog så langt som til at påstå, at »den instrumentelle rationalitets regler i enestående grad er ude af stand til at hindre sådanne fænomener « (ibid., 38). Mit ærinde med at anføre dette er naturligvis ikke at påstå, at et nyt Holocaust er umiddelbart forestående og ej heller at forsøge at score billige points på en sammenligning af den seneste universitetsreform med et massemord. Det skal snarere forstås som en bekymring for hvor den rationelt bureaukratiske effektivitetsmaksimering fører vores uddannelsessystemer hen, hvis ikke der bliver taget stilling til udviklingen såvel etisk som politisk. I I998 skrev Birgitte Simonsen og Lars Ulriksen, at man fra politisk hold ikke havde noget klart billede af, hvor man ville hen med de brede (dvs. ikke professionsorienterede) længerevarende videregående uddannelser, der manglede en 
målsætning (Simonsen \& Ulriksen I 998, 33). I foråret 2003 gennemførte regeringen en ny universitetsreform, og universitetsuddannelserne er i dag under omformning, men overvejelserne over, hvordan vi skal definere humanioras overordnede målsætning i spændet mellem almen dannelse, brede samfundsmæssige interesser og mere snævre erhvervsmæssige behov for arbejdskraft, er stadig alt for svage. F.eks. er flere fremmedsprogsfag ved at forsvinde fordi de bliver 'urentable', uden at nogen egentlig har taget en politisk beslutning om, hvorvidt dette er ønskeligt eller ej. Tilsvarende er litteraturfaget mange steder under omdefinering som bredere kulturstudier, ligeledes uden at det har været genstand for en politisk prioritering. 'Markedskræfterne' gør deres arbejde i det anonyme. Det er måske nok givet, at disse fag ikke fortsat skal eksistere i den udgave, vi har kendt dem, men det er til gengæld også meget vigtigt, at vi får taget en debat om, hvordan de så skal se ud, eller hvad det er, som skal erstatte dem. Og det er i den forbindelse af afgørende betydning at vi sikrer, at humanistisk indsigt og forståelse ikke bliver smidt ud med badevandet.

Nærværende bog skal ses som et forsøg på at rejse denne diskussion så at sige indefra fagligheden selv. Ikke sådan at forstå, at jeg mener at have leveret svaret $\mathrm{i}$ bestemt form singularis på de udfordringer, litteraturfaget på fremmedsprogsstudierne står overfor. Tvært imod tror jeg det er vigtigt at søge forskellige løsninger i forskellige traditioner og på forskellig måde - en entydig og 'monologisk' tilgang til problemerne ville selv udgøre en del af problemet. Men når dette er sagt, er det mit håb, at bogen kan bidrage til videre refleksion over, hvordan vi angriber tre helt fundamentale udfordringer, som vi bliver nødt til at forholde os til. Det gælder bl.a. spørgsmål såsom:

- Hvordan kan vi i litteraturstudierne på fremmedsprogsuddannelserne eksplicitere fagets betydning for udviklingen af de interkulturelle kompetencer, som udgør en så vigtig del af humanioras generelle svar på den globale udfordring?

- Hvordan sikrer vi at det stof, som vi præsenterer vores studerende for, reelt bidrager til at åbne de studerendes kulturelle og historiske horisont, og samtidig modsvarer masseuniversitetets behov for formalisering og metodegørelse?

- Hvordan styrker vi den tværfaglige tilgang til det fælles studieobjekt, teksten, og hvad indebærer dette for de litterære discipliners traditionelle selvforståelse? 


\section{Humanioras interkulturelle udfordring}

Den aktuelle hovedudfordring for humaniora består i et problemkompleks af øget økonomisk globalisering, den nye informationsteknologis omkalfatring af vidensbegrebet og af markedet for kulturprodukter. Det er i sig selv en ordentlig mundfuld. Men humanioras måske allerstørste problem består $\mathrm{i}$, at det er de færreste uden for de humanistiske fakulteter, som i dag har forståelse for, at humaniora bør spille en central rolle i løsningen af de udfordringer, som det globaliserede videnssamfund stiller os overfor.

I sin åbningstale til folketinget i 2004 udpegede statsminister Anders Fogh Rasmussen netop globaliseringen til at være den største aktuelle udfordring for det danske samfund, og løsningen ligger for regeringen i at satse på forskning og viden. Eller som han formulerer det: vejen fra forskning til forretning skal være kortere, nemmere og hurtigere, og målet er som nævnt at etablere Danmark som et førende videnssamfund. I den gældende politiske diskurs betyder ordet 'globalisering' tab af arbejdspladser til udlandet, mens 'forskning' betyder oparbejdelse af viden, der sigter på eller kan udvirke økonomisk vækst, dvs. naturvidenskabelig og medicinsk viden, der let kan omsættes i teknologisk innovation og kommercialiseres økonomisk. »Vejen fra tanke til faktura skal gøres kortere", som det slagordsagtigt hedder i regeringens jargon.

At begrebet 'forskning' af centrale og toneangivende kræfter opfattes som oparbejdelse af viden, der umiddelbart kan omsættes i kommerciel virksomhed, ses bl.a. af det nyetablerede Strategiske Forskningsråds første rapport med titlen »Forskning der nytter «. Alene titlen antyder at den forskning som ikke falder inden for rådets beskrivelse ikke er nyttig, eller ligefrem er unyttig. I rapporten hedder det, at Det Strategiske Forskningsråds opgave er at fremme forståelsen mellem forskningsverden og samfund, og rådet fremfører det synspunkt, at forskningen ikke bidrager tilstrækkeligt til den økonomiske innovation. Man spørger derfor til hvordan universiteterne med deres vidensproduktion kan bidrage mere direkte til at skabe innovation og vækst. Når man læser videre bliver det imidlertid snart meget tydeligt, at 'samfund' skal forstås som det private erhvervsliv, og at 'nytte' skal forstås som forretning. Der er ikke i sig selv noget galt $i$ at fremme sammenhængen mellem forskning og erhvervsliv, men det er forkert at identificere samfundet med erhverslivet, og det er forkert at identificere begrebet samfundsnytte med kommerciel interesse. Resultatet er derfor forudsigeligt i den forstand, at Det Strategiske Forskningsråd udpeger tre områder, som skal have omgående og markant udvidede ressourcer, nemlig fødevare-sundhed, energi-miljø samt nanoteknologi, bioteknologi og IT. Igen må vi sige at der ikke er noget i vejen 
med at prioritere disse områder, men det er forkert, hvis man samtidig reducerer det vidensbegreb, der ligger til grund for begrebet om det globaliserede videnssamfund, til denne type instrumentel og kommercialiserbar viden. Og det ligner det man er ved at gøre.

I et nummer af Campus, Aarhus Universitets interne blad fra efteråret 2004, tager Helge Sander til orde for at forsvare regeringen imod anklagerne for at prioritere naturvidenskab, teknik og medicin på humanioras og samfundsvidenskabs bekostning. Han skriver således:

Selvfølgelig har vi ikke glemt humaniora og samfundsvidenskab! Det er meget væsentlige områder når vi skal forkorte vejen fra tanke til faktura. Det er ikke nok at opfinde verdens ottende vidunder, hvis man ikke kan give produktet den rigtige indpakning og få det solgt (Sander 2004).

Humaniora er aktuelt havnet i en klemme, fordi den instrumentelle rationalitet tenderer mod at reducere den klassiske dannelse til overflødig 'indpakning'. Det er derfor humanioras eget ansvar at redefinere sig selv i lyset af det globaliserede videnssamfunds udfordringer og at gentænke dannelsesidealet i forhold til det omgivende samfunds behov.

I en artikel fra 1995 tager Hans Ulrich Gumbrecht udviklingen i humanioras sociale funktion som kulturel dannelsesfaktor op med udgangspunkt i litteraturstudierne (Gumbrecht 1995). Ifølge Gumbrecht skulle baggrunden for litteraturstudiernes vigtighed og prioritering i det akademiske landskab i det I9. århundrede findes i det borgerlige dannelsesideal, hvor det var litteraturens rolle at fungere som formidler imellem det han kalder »institutionalized normative expectations about society and recurrent forms of experience in everyday social life « (Gumbrecht I995, 7). Litteraturkritikken bidrog med andre ord til at udvikle nye normative billeder af 'det gode samfund' ved at udlede de etiske værdier af de litterære tekster og relatere disse til det enkelte individs livsverdensbaserede erfaringer (op.cit. 8). Heroverfor påpeger Gumbrecht, at litteraturkritikken i det 2I. århundrede kunne reintegrere dannelsesidealet i sin sociale funktion, men nu med et kritisk potentiale, idet litteraturkritikken kunne bidrage til at "make part of our active experience those cultures and literatures that had been kept in the background under the traditional hegemony of eurocentric values and paradigms « (op.cit. 24 og 25).

Min pointe burde på dette punkt være rimeligt klar: I det 19. århundrede gjaldt det om at udvikle og stabilisere de nationale kulturer i forlængelse af de nydefinerede nationalstater, og samfundets krav og forventning til humaniora var at bidrage til at udvikle den almene dannelse på baggrund af det klassiske, borgerlige dannelsesideal. I dag er det nationale paradigme under ombrydning, og det globaliserede videnssamfund stiller 
krav om, at det enkelte individ kan orientere sig i såvel en lokal som en global kontekst samt forholde sig til de kulturmøder og -konflikter, som udspringer heraf. Således kan vi oversætte det borgerlige dannelsesideal fra det I9. århundredes nationale opbygning til det 2I. århundredes globaliserede samfund til et krav om, at det enkelte individ skal kunne udvikle de interkulturelle kompetencer. Det er på ingen måde nyt, at samfundet formulerer krav til humaniora, sådan som man nogen gange kan få indtryk af, når man må lægge øre til de forfaldsfortællinger, der florerer på mange humanistiske fakulteter og institutter i dag. Men omvendt er det også oplagt, at hverken den siddende regering eller den socialdemokratiske opposition har blik for den interkulturelle udfordring, som globaliseringen stiller vores samfund overfor. Det er derfor uddannelsesinstitutionernes eget ansvar at eksplicitere dette nye dannelsesideal og at møde den udfordring den tiltagende globalisering stiller samdfundet over for ved at øge kandidaternes fremmedsproglige beredskab og kendskab til den kulturelle anden (se også Hansen 2002 og 2002b).

Al virkelig interkulturel kommunikation, forstået som en dialog mellem lige parter, forudsætter højt udviklede sproglige kvalifikationer og dybtgående indsigt i forholdet mellem diskursfællesskaber og sprogkulturer, historisk og aktuelt, hen over semiosfærens grænser. Fremmedsprogsfagene på universiteternes humanistiske fakulteter står således med en enestående mulighed for at udvikle et humanistisk svar på globaliseringens udfordringer. Kun ved at prioritere sammenhængen mellem sprog, kultur, samfund og historie bliver vi i stand til reelt at vise den respekt for den kulturelle andens ret til at være menneske på egne og lige betingelser, som er nødvendig for at kommunikationen lykkes, og kun derved kan vi dæmme op overfor modernitetens tendens til, i effektiviseringens og den instrumentelle logiks navn, at udgrænse den anden som et 'ressourcespild'.

Ifølge den humanistiske tradition må kulturel indsigt og interkulturel forståelse bygge på sproglig kunnen og historisk viden, ellers er der ikke tale om forståelse. Den slags interkulturel kompetence jeg taler for her, er altså grundlæggende anderledes end den type interkulturel kommunikation, som har været praktiseret på militærakademier og handelshøjskoler som en instrumentel disciplin, opbygget omkring nationale stereotyper: »vis aldrig dine fodsåler til en araber, spørg altid til en hispanics familie, osv. « Forskellen ligger først og fremmest i det kulturbegreb, som bringes i anvendelse. Som Claus Altmayer formulerer det:

Cultures do not stand about each other like erratic blocks, but penetrate and influence each other in many different ways; they are unilaterally or multilaterally dependent on each other, whereas such cultural positions [the 'original' 
cultural perspective, HLH] must be considered as mainly a symptom of political and economic power relations (Altmayer I997, 8). ${ }^{10}$

For at kunne gøre de komplekse dialogiske processer i det interkulturelle møde til genstand for analyse, vil det være nødvendigt, at vores kandidater kan samle en række forskellige kompetencer, såsom veludviklede fremmedsproglige færdigheder, dybtgående historisk og kulturel indsigt, træning i kritisk og analytisk tænkning og kendskab til betingelserne for hermeneutisk fortolkning. I sit bidrag til Changing Philologies påpeger Susan Bassnett imidlertid, hvordan udviklingen faktisk går den modsatte vej. I sin karakteristik af de angloamerikanske uddannelsessystemer peger hun på, hvordan disse, under indtryk af en blind modernistisk fremskridtstro, nedprioriterer fremmedsprog og historieundervisning i en farlig cocktail af » monolingualism and amnesia «: » Why bother with other languages when English is taking over the globe? Why bother with history when what matters is improving the present for the future? « (Bassnett 2002, I5).

Den tilgang til studiet af de litterære tekster, som har præget denne fremstilling, har taget udgangspunkt $\mathrm{i}$ at betragte den litterære diskurs som en form for social praksis og har derfor forsøgt at medreflektere litteraturens samfundsmæssige og sociale funktioner. Litteraturens materiale er sproget, og litteraturen er derfor i en vis forstand bundet både til det sprog den er skabt på og til den kulturelle og historiske kontekst, som den udspringer af. I samtiden spiller de litterære tekster en rolle for konstruktionen af en kollektiv erindring, og litteraturen udgør samtidig den prisme, hvorigennem det moderne menneske kan betragte sig selv med den andens øjne og gøre den fiktive andens erfaringer til sine egne, såvel individuelt som kollektivt. De litterære erfaringer er blevet gjort til genstand for et bredt anlagt felt af analysemetoder, der ikke alene tager sigte på at studere litteraturen som et socialantropologisk eksperimentarium, men som også forsøger at inddrage teksternes æstetiske form og karakteristika i helheden af erfaringer. Derved inddrages betydningen af vores kandidaters æstetiske kompetencer, forståt som en skærpet bevidsthed om samspillet mellem sproglig form og betydningsdannelse. Det er en kompetence, som vil være relevant langt uden for det gode selskab af traditionelle litterater, f.eks. i forbindelse med forskellige former for oversættelsesvirksomhed og kulturformidling i bred forstand.

Den komplekse relation mellem diskursfællesskaber og sprogkulturer,

\footnotetext{
${ }^{10}$ Den originale tekst lyder således på tysk: »Kulturen stehen einander nicht wie erratische Blöcke gegenüber, sondern durchdringen und beeinflussen sich auf höchst vielfältige Weise gegenseitig, sind einseitig oder wechselseitig voneinander abhängig, wobei solche kulturellen Beziehungen [» ursprüngliche « kulturelle Perspektive, HLH] meist eine Folgeerscheinung politischer und ökonomischer Machtverhältnisse sind «.
} 
mellem individuelle, kollektive og kulturelle subjekter, gør, at det i fremtiden vil være nødvendigt, at frigøre sprogstudierne fra den entydige binding til studiet af de europæiske moderstater, for til gengæld at fokusere mere på den sproglige konstruktion af kulturelle identiteter i lokale eller transnationale sammenhænge. Nationalstaternes rammesætning af sprogene skal ikke opgives, for de udgør fortsat et orienteringspunkt for konstruktionen af kulturelle subjekter, men et blandt flere. Derfor må sprogstudierne tilføjes andre relevante dimensioner, som f.eks. det regionale eller det transnationale perspektiv. For mange spaniere udgør den lokale eller regionale identitet (katalansk, baskisk, gallicisk eller andalusisk) et afgørende udgangspunkt for egen selvforståelse, ligesom Den Europæiske Union for mange udgør en stadig vigtigere dimension i den internationale selvforståelse. Som en uundgåelig følge heraf vil fagenes genstandsområde blive yderligere fragmenteret, og spørgsmålet er nu hvordan vi sikrer den didaktiske operationaliserbarhed af et stofområde, der truer med at overskride enhver grænsedragning af såvel ontologisk som teoretisk-disciplinær karakter?

\section{Opgøret med tekstens autonomi \\ og 'metodegørelsen' af kontekstrelationen}

I rektorforeningens nyligt udgivne rapport om sprogpolitik på de danske universiteter fastslås det som et generelt træk ved udviklingen af uddannelsessystemet, at »tekstanalysen og dens teoridannelser i udstrakt grad har erstattet den tidligere nationale litteraturhistorie som danskfaglig selvforståelse « (Lauridsen 2003, 3). Det tror jeg er en korrekt analyse, og jeg tror at det er en karakteristik, vi kunne udbrede til også at være gældende for fremmedsprogenes fagligheder på universitetsniveau. Baggrunden herfor skal findes i nykritikkens sejrsgang gennem den vestlige verdens uddannelsesinstitutioner fra godt og vel midt $i$ det tyvende århundrede og frem. I en gennemgang af nykritikkens historie inden for litteraturvidenskaben i USA påpeger Wlad Godzich, hvordan denne strømning vandt massivt frem, fordi dens teoretiske forudsætning om tekstens autonomi var velegnet til at møde masseuniversitetets krav (Godzich I998, 25 ff.). Inden for en europæisk kontekst blev det i høj grad strukturalismen, som fra I940'erne og frem kom til at spille denne rolle inden for en række forskellige fag såsom sprogvidenskab, litteraturvidenskab, historie og antropologi, fag som alle igen kan siges at have haft en mere eller mindre identisk aflægger inden for sprogfagene. I en litterær sammenhæng finder vi denne diskussion tematiseret af bl.a. Eric Auerbach, som i indledningen til den posthumt udgivne Literatursprache und Publikum in der lateinischen Spätantike und im Mittelalter (I958) så at 
sige gør sit filologiske testamente op og under overskriften »Om hensigt og metode « diskuterer forholdet mellem den dannede filologiske indsigt og metodegørelsen af litteraturfaget (Auerbach 200I).

Auerbach er imod nykritikkens og formalismens 'metodegørelse' af litteraturfaget og plæderer i stedet for, at den individuelle forsker skal finde sin egen 'ansats' til stoffet, dvs. den vinkel som for ham åbner teksten for en historisk og kulturel indsigt og perspektivering. Hans position er sympatisk og hans argumenter stimulerende, men han henvender sig til den klassisk dannede forsker, der kun har meget lidt til fælles med de studerende, som i vore dage befolker fremmedsprogsinstitutterne. Filologiens massive dannelsesideal, der forudsatte en livslang beskæftigelse med sprog, litteratur og historie, var ikke velegnet som forudsætning for et uddannelsessystem, der som det danske firedoblede studenterbestanden mellem I960 og I970, og som i I970'erne fortsatte væksten med et øget optag på 50 \% mellem I970 og I978 (Simonsen og Ulriksen I998, 2I). Det øgede optag indebar at universiteterne optog stadig flere studerende fra befolkningslag, der ikke havde fordums dannelsesmæssige ballast, og nykritikkens og strukturalismens metodegørelse af litteraturlæsningen repræsenterede tilsyneladende en løsning på det problem. Forestillingen om tekstens autonomi var grundlaget for en 'demokratisk' pædagogisk tilgang til litteraturstudierne, idet den gjorde det muligt for studerende, rekrutteret fra bredere befolkningslag og med mindre kulturel ballast, at deltage på lige fod med den kulturelle elites børn. Den formalistiske tilgang gjorde det simpelthen muligt at sætte de historiske, kulturelle og biografiske referencer i parentes og fokusere på det metodiske i analysen af teksten i sig selv (Godzich I998, 26). I løbet af I980'erne udvikledes disse fagligheder teoretisk i form af diverse poststrukturalistiske og dekonstruktive retninger, uden at den oprindelige disciplinopsplitning på noget tidspunkt er blevet afgørende udfordret. Uden på nogen måde at ville stille spørgsmålstegn ved formalismens og strukturalismens værdifulde erkendelsesmæssige bidrag til humanvidenskaberne, kan man sige, at humanioras teoretisering og sprogfagenes efterfølgende faglige fragmentering i en række uafhængige discipliner modsvarer kravene fra et uddannelsessystem, hvor masseuniversitetet stiller krav om klart afgrænselige og pædagogisk operationaliserbare fagligheder. Men hvordan skal vi kombinere opgøret med forestillingen om den autonome tekst og den postkoloniale udvidelse af sprogfagenes genstandsområde uden at stofmængden bliver uoverkommelig, og den forudsatte vidensmængde urealistisk? Hvordan sikrer vi at humanioras interkulturelle kompetencer ikke 'instrumentaliseres' i den 'metodegørelse', som følger udviklingen af masseuniversitetet? 
Bogen igennem har jeg forsøgt at gøre den hermeneutiske relation mellem teksten i sig selv og læserens dialog med de historisk-kulturelle kontekster (tekstens oprindelige og læserens egen) til genstand for metodisk refleksion. Charles Peirces pragmatisk, semiotiske begrebsinventar repræsenterer efter min mening en brugbar metodisk ramme (givetvis blandt flere), der kan ordne nogle af de centrale analytiske operationer inden for et overskueligt 'system', uden at dette nødvendigvis reducerer genstandområdets kompleksitet. Genstandsområdet er kolossalt, og stofmængden er uoverkommelig, hvis vi forestiller os at de studerende både skal have overblik over helheden og dybtgående indsigt i sprog, kultur og historie. I stedet for dette klassiske ideal må vi nok i fremtiden slå os til tåls med eksemplariske nedslag i stoffet, der så til gengæld må bruges som afsæt for indlæringen af teoretisk generaliserbare indsigter. Eksempelvis må det indgående studium af et enkelt latinamerikansk lands litteratur, eller måske blot et enkelt forfatterskab her indenfor, skulle gøre det ud for det empiriske udgangspunkt for udviklingen af de interkulturelle færdigheder, som efterfølgende vil gøre den studerende i stand til selv at gøre sig bekendt med »those cultures and literatures that had been kept in the background under the traditional hegemony of eurocentric values and paradigms « (Gumbrecht, I995, 25).

Denne måde at anskue forholdet mellem indlæring af viden og opbygning af kompetencer hos de studerende stiller store krav til, at vores undervisning faktisk leverer nogle redskaber, som kan løfte læringsprocessen ud over den konkrete empiris horisont. I denne bog har jeg valgt at tage udgangspunkt i et alment tegnbegreb for at teoretisere den dialogiske relation imellem forskellige instanser i ensartede kategorier. Det gælder forholdet mellem selv og anden, mellem identitet og erfaring (individuelt som kollektivt) samt mellem teksten og den kulturelle semiosfære. Det er mit håb dermed at bidrage til at give studierne det påkrævede teoretiske løft, men samtidig er det vigtigt at advare mod at opfatte denne teoretiske rammekonstruktion som en overordnet 'masterteori', der gør krav på at kunne begribe fremmedsprogenes genstandsområde i sin helhed. Kravet på en enkelt 'masterteori' ville indebære en indsnævring af den mangfold af teoretiske tilgange, som i dag udgør en positiv mulighed for vores fags udvikling. I stedet vil jeg pege på vigtigheden af at udvikle et åbent felt af teoretiske tilgange og tværfaglige initiativer med udgangspunkt i fagenes konkrete problemstillinger.

\section{Faglighed og tværfaglighed}

På trods af de store og umiskendelige forskelle mellem de konkrete fagligheder som er udsprunget af fremmedsprogsstudiernes discipliner, har 
de til en vis grad et fælles studieobjekt i teksterne. Tekster, i ordets bredeste forstand, er filologiens genstand, og de moderne fremmedsprogsstudier ville kunne drage fordel af dette forhold i den forstand at tekster, forstået som diskursive praksisformer, tilbyder sig som et oplagt felt for tværfaglig eksperimenteren og fagudvikling. I stedet for først og fremmest at spørge til de litterære teksters formelle egenskaber, kan vi undersøge, hvad det er de litterære tekster gør, og det udgør da også allerede en væsentlig del af den anvendte praksis. Litterære tekster har, som alle andre tekster, både sociale, politiske, kulturelle og æstetiske funktioner, og det er i studiet af det konkrete dialogiske samspil af disse funktioner, at lingvister, litterater, historikere, medieforskere og kulturanalytikere vil kunne mødes i et frugtbart tværfagligt samarbejde (Hansen, 2004).

It-revolutionen og de visuelle mediers overvældende indflydelse udgør, sammen med den relative devaluering af litteraturen inden for det kulturelle felt, en af de helt store udfordringer, som litteraturfagene nødvendigvis må forholde sig til i fremtiden. Det litterære felt er ganske enkelt ikke længere udstyret med den 'kulturelle kapital' som tidligere, og som akademisk disciplin står litteraturfaget over for at miste den selvfølgelige autoritet, som det tidligere var forlenet med. Mange steder overtager de bredere kulturstudier ressourcer og årsværk fra den traditionelle litteraturvidenskab, og ikke uden grund. Hvor den 'store' litteratur udgjorde en væsentlig del af det stof som de 'forestillede fællesskaber' om nationen blev bygget op omkring i perioden fra romantikken og frem til midt i det 20. århundrede, dér er litteraturens sociale funktion i dag i udpræget grad på en gang individualiseret og internationaliseret (Navajas 2002, 3I). Skellet mellem den 'gode', men smalle litteratur og den brede triviallitteratur med de store oplag er i opløsning, og de fortællinger, som bruges til kulturel selvspejling og individuel identitetskonstruktion af det brede publikum, kendes i dag fra film og udkommer i elektronisk og eventuel interaktiv form. Det betyder imidlertid ikke, at litteraturvidenskabens specialiserede fagligheder er blevet uaktuelle, tvært imod har mange af litteraturvidenskabens tilgange vist sig at være uundværlige redskaber i de bredere kulturanalytiske studier. Men det betyder at litteraturfaget seriøst må overveje sin stilling og argumentere offensivt for sin eksistensberettigelse i forhold til de nye og anderledes definerede genstandsområder som vores studier står overfor (Boisen \& Schwartz Lausten, 2004).

Enhver videnskabelig nyudvikling, og her snakker vi ikke kun paradigmeskift i Kuhns forstand, vil have tværfaglig karakter alene af den grund, at det er den konkrete virkelighed, der som et 'dynamisk objekt' presser sig på for den videnskabelige erkendelse. Og ofte må man som forsker erkende de etablerede discipliners kognitive begrænsninger. Bån- 
dene til de dominerende videnskabelige traditioner og 'skoler' må løsnes for at kunne angribe det fælles genstandsfelt med andre teoretiske og metodologiske perspektiver, end vanen foreskriver, og nye teorier og nye metoder må udvikles som led i den tværfaglige praksis. Hvis fremmedsprogsfagene, og herunder også litteraterne på fremmedsprogsfagene, ønsker at tage de udfordringer op, som det globaliserede og elektroniske videnssamfund stiller humaniora overfor, samt ønsker at kunne levere kandidater med gode fremmedsproglige kvalifikationer og udviklede humanistiske, interkulturelle kompetencer, så haster det med at få dette tværfaglige samarbejde op at stå. Mange steder har fagspecialiseringen imidlertid allerede fjernet sig så meget fra den traditionelle filologis helhedssyn, at det forekommer umuligt at forestille sig, at den enkelte forsker skulle kunne overskue hele det komplekse felt af relevante discipliner og tilgange. Vi kan med andre ord ikke i udgangspunktet forvente, at tværfagligheden fra den ene dag til den anden vil udvikle sig som brede kompetencer hos den enkelte forsker, men må i stedet satse på at udvikle tværfagligheden som et samarbejde mellem specialister inden for hver deres felt. Derfor er det vigtigt, at vi så at sige inde fra hver af disciplinerne diskuterer hvordan vores faglighed kan begribes i relation til en helhedsforståelse af fremmedsprogenes genstandsområde, og dette gælder ikke mindst litteraturfaget.

Med denne bog har jeg forsøgt at gentænke litteraturstudiet på en måde, som åbner faget for en dialog med sprogfagenes øvrige discipliner; ikke ved som en glad amatør selv at gøre mig klog på både lingvistik, historie, samfundsforhold og visuelle medier, men ved inde fra litteraturfaget at etablere nogle åbninger, som kan muliggøre en dialog med de andre discipliner. Jeg har allerede nævnt at dét at betragte den litterære diskurs som en form for social praksis, hvorigennem det moderne subjekt konstruerer sin kulturelle identitet såvel individuelt som kollektivt, åbner for at medreflektere litteraturens samfundsmæssige og sociale funktioner. Og hele diskussionen om referenceproblematikken samt spørgsmålet om den litterære praksis' etiske erfaringskonstruktion trækker i den samme retning. Desuden håber jeg, at det teoretiske udgangspunkt i det pragmatiske tegnbegreb, gør det muligt at etablere en dialog med den pragmatiske sprogvidenskab og sociolingvistikken samt med antropologisk anlagte kulturstudier med et bredere sigte. Endelig er det mit håb at min semiotiske udlægning af det æstetiske 'blik' som en dialogisk relation mellem forskellige modale interpretantaspekter vil kunne invitere til en dialog med discipliner engageret $i$ analysen af visuelle udtryk og andre medier (se f.eks. Hansen I996, I997a og b, I998 samt r999a og b). 


\section{LITTERATURLISTE}

Abellán, José Luís (red.): Los españoles vistos por sí mismos. Madrid, Turner, I986.

Alberti, Rafael: Cal y canto. Hans Lauge Hansen (red.). Madrid, Libro Nuevo, 2002.

Alberti, Rafael: Obra completa. Poesía bd I-III, Madrid, Aguilar, I988.

Alonso, Amado: Poesía y estilo de Pablo Neruda. Buenos Aires, Sudamericana, Araya, I954.

Althusser, Louis: Ideologi og ideologiske statsapparater. Århus, Kurasje, I972. Altmayer, Claus: »Zum Kulturbegriff des Faches Deutsch als Fremdsprache». In Zeitschrift für Interkulturellen Fremdsprachenunterricht, 2,2. I997.

Andacht, Fernando: "Steps Toward a Sociosemiotic Analysis of Myth «, European Journal for Semiotic Studies, 7 (I,2), I995.

Andersen, Henning: »Language Structure and Semiotic Processes «. København, Apilku, I984.

Auerbach, Eric: »Om hensigt og metode«. Kultur og klasse 92, $200 \mathrm{I}$.

- " - "Philology and Weltliteratur «. The Centennial Review I3, I969.

Bakhtin, Mikhail: Dialogic Imagination. Austin, University of Texas Press, I98 I.

- " - Rabelais and his World. Bloomington, Indiana University Press, I984a.

- " - Problems of Dostoevsky's Poetics. London, University of Minnesota Press, I984b.

- " - Speech Genres and Other Late Essays. Austin, University of Texas Press, I 986 .

- " - Art and Answerability. Austin, University of Texas Press, I990.

- " - Towards a Philosophy of the Act. Austin, University of Texas Press, I993.

- " - »Mennesket ved spejlet«. Kultur og Klasse nr. 86, I998.

Barthes, Roland: "The Death of the Author «. Image, Music, Text. London, I 977. Bassnett, Susan: »Translation, Culture and History «. In: Hansen (red.): Changing Philologies, København, Museum Tusculanums Forlag, 2002.

Bauman, Zygmunt: »Sociologien efter Holocaust «. In: Modernitet og Holocaust. København, Hans Reitzels Forlag, 200I.

Bell, \& Gardiner (red.): Bakhtin and the Human Sciences. London, Sage, I998. Black, Max: Models and Metaphors. Ithaca, Cornell University Press, I962.

Bloom, Harold: The Anxiety of Influence. New York, Oxford University Press, I973.

- " - The Western Canon. Kent, Macmillan, I994.

Boisen, Jørn \& Schwartz Lausten, Pia: »The Study of Literature - What does it matter and why? «In: Hansen (red.): Disciplines and Interdisciplinarity in Foreign Language Studies. København, Museum Tusculanums Forlag, 2004 . 
Borges, Jorge Luis: Prosa completa, bind I-IV. Barcelona, Editorial Bruguera, 1985

Bruhn, Jørgen \& Lundquist, Jan: »Arkitektoniske momenter «. Kultur og Klasse nr. 86, I998.

Bruner, Jerome: Actual Minds, Possible Worlds. Cambridge \& London, Harvard University Press, I986.

Buchler, Justus: The main of light. On the concept of poetry. New York, I974. Bundgaard, Egholm \& Skov (red.): Kognitiv semiotik. København, Haase, 2003. Bürger, Peter: Theory of the Avant-Garde. Minneapolis, University of Minnesota Press, I984.

Børtnes, Jostein: »Lotman, Bakhtin, and the Problem of a Semiotics of Culture «. In: Hansen (red.): Changing Philologies, 2002.

Cairns, Jo: »Religious perspectives on values, culture and education«. In: Cairns, Lawton \& Gardener: Values, Culture and Education, London, Sage $200 \mathrm{I}$.

Caro Almela, Antonio: »El paradigma de complejdad como salida de la crisis de la Posmodernidad «. Discurso I6/I7, Sevilla, 2003.

Cascardi, Anthony: The Subject of Modernity. Cambridge University Press, I 992. Castilla del Pino, Carlos: »El sujeto como sistema «. In: M. Hermosilla Álvarez \& A. Pulgarín Cuadrado (red.): Identidades culturales, Universidad de Córdoba, 2001 .

Cervantes, Miguel de: Den sindrige ridder Don Quixote de la Mancha, Centrum I998a. Originaludgave på spansk: El ingenioso hidalgo Don Quijote de la Mancha. Barcelona, Crítica, I998b.

Christensen, Otto \& Meyer, Siri (red.): The Modern Subject. Bergen, Center for europeiske kulturstudier, I996.

Colapietro, Vincent: Peirce's Approach to the Self. A Semiotic Perspective on Human Subjectivity. New York, I989.

Colapietro \& Olshewsky (red): Peirce's Doctrine of Signs. Berlin/New York, Mouton de Gruyter, I996.

Collin, Finn og Køppe, Simo: Humanistisk videnskabsteori. København, Danmarks Radio, I995.

Colmeiro, José F.: La novela policíaca española. Teoría e história crítica. Barcelona, Anthropos, I994.

Crane, Diana: »Culture and Globalization «, in Crane, Kawashima \& Kawasaki (red.): Global Culture. Media, Arts, Policy and Globalization. New York, Routledge, 2002.

Cros, Edmond: Theory and Practice of Sociocriticism. Minneapolis, University of Minnesota Press, I988.

- " - El sujeto cultural. Medellín, Fondo Editorial Universidad EAFIT, 2003.

Currie, Mark (red.): Metafiction. London and New York, Longman, I995.

Damasio, Antonio: Looking for Spinoza. Hartcourt, 2003.

de Man, Paul: »Return to Philology«. The Resistance to Theory. University of Minnesota Press, I986.

Dinesen, Anne Marie: C.S. Peirce - fanomenologi, semiotik og logik. NSU, I99 I. - " - Grundbog i semiotik. København, Akademisk Forlag, I994. 
Echavarría, Arturo: Lengua y literatura de Borges, Barcelona, Ariel, I983. Eco, Umberto: Tratado de semiótica general. Barcelona, Lumen, I977/9I.

- " - Lector en fábula. Barcelona, Lumen, I98I.

- " - The Role of the Reader. Bloomington, Indiana University Press, I984.

- " - Semiotics and the Philosophy of Language. Bloomington, Indiana University Press, I984.

- " - Los limites de la interpretación. Barcelona, Lumen, I990/I992.

- " - La Ricerca della lingua perfecta, Laterza, Rom, I993.

- " - Six Walks in the Fictional Woods. Cambridge, Harvard University Press, I994.

- " - Fortolkning og overfortolkning. Systime, I995.

- " - Seis paseos por los bosques narrativos. Barcelona, Lumen, I996.

Edwards, Jorge: »El joven Neruda: Los poemas del amor compartido«. Revista Iberoamericana, I68-I69, University of Pittsburgh, I994.

Eide, Kittang og Aarseth: Europeisk litteraturteori fra antikken til I900. Oslo, Universitetsforlaget, I987.

Emerson, Caryl: »The Outer Word and Inner Speech: Bakhtin, Vygotsky, and the Internalization of Language «. Critical Inquiry I9, I983.

Emmeche, Claus: "Modeling life: a note on the semiotics of emergence and computation in artificial and natural living systems. In Sebeok \& Sebeok (red.): Biosemiotics. The Semiotic Web, Mouton de Gruyter, Berlin and New York, I992.

Factor, R. Lance: »Peirce's definition of metaphor and its consequences «.

Peirce Doctrine of Signs. Berlin \& New York, Mouton de Guyter, 1996.

Fairclough, Norman: Discourse and Social Change. Cambridge, I992.

Fink, Hans: »Et hyperkomplekst begreb «. In: Hauge, Hans \& Horstbøll, Henrik (red.): Kulturbegrebets kulturhistorie, Aarhus Universitetsforlag, I998.

Fleischmann, Suzanne: »Methodologies and Ideologies in Historical Linguistics: On Working with Older Languages«. In: Herring, Reenen \& Schøsler (red.): Textual Parameters in Older Languages. Benjamins, Amsterdam / Philadelphia, 2000.

Foucault, Michel: Ordene og tingene. Spektrum I999. Originalversion I966.

- " - »Hvad er en forfatter? " Passepartout nr. 22, 2003. Oversat fra »Qu'estce qu'un auteur? «, Dits et écrits, Paris, Gallimard, I969.

Føllesdal, Walløe og Elster: Moderne videnskabsteori. København, Politiken, I997.

Gammelgaard, Karen: Tekstens mening - en introduktion til Pragerskolen. Roskilde Universitetsforlag, 2003.

Gemzøe, A., Knudsen, B.T. \& Larsen, G.: Metafiktion-selvrefleksionens retorik. Medusa, 200I.

Godzich, Wlad: Teoría literaria y crítica de la cultura. Frónesis, Cátedra. Madrid, I998.

Gombrich, E.H.: Art and Illusion. A Study in the Psychology of Pictorial Representation. Washington, I960.

González del Valle, Luis T.: El canon. Madrid, Huerga y Fierro, I993. 
Grabes, Herbert: »The Cultural Turn of Philology «. In: Hansen (red.): Changing Philologies, 2002.

Grabes, Herbert: »Literaturwissenchaft, Kulturwissenschaft - Anglistik «. Anglia I I4, 3, I996.

Greimas, Algirdas Julien: Strukturel semantik. Odense, Borgen, I974.

Gumbrecht, Hans Ulrich: »The Future of Literary Studies «. New Literary History 26,3. Baltimore, I995.

- " - Epilogue: Untenable positions«. Palumbo-Liu \& Gumbrecht (red.):

Streams of Cultural Capital. Transnational Cultural Studies, Stanford University Press, I997.

Gustafsson, Jan: »Frontera, diálogo y exclusión«. In: Actas, La Frontera, Mexico 2003 (under udgivelse).

- " - »Sign, Translation and Boundaries (Towards a semiotics of culture) «.

In Gustafsson \& Blasco (red.): Boundaries and Encounters. Interculturality in Theory and Practice. København, Handelshøjskolen 2004 (under udgivelse).

Haley, Michael Cabot: The Semeiosis of Poetic Metaphor. Bloomington, Indiana University Press, I988.

Hansen, Hans Lauge: Tegn, tekst og tolkning. København, Akademisk Forlag, I995.

- " - Ikoniciteten(s) spreekker. En læsning af Rafael Albertis »Cal y canto«. Ph.d.-afhandling, Københavns Universitet, 1996.

- " - »La superposición metafórica entre ensalzamiento eufórico y degradación crítica en Rafael Alberti y Maruja Mallo «. In: Hansen og Jensen (red.): La metáfora en la poesía hispánica (I885-1936), Sevilla, Alfar, I997a.

- " - »Modalidad en la semiótica de Peirce y estética de vanguardia «. Discurso. Revista internacional de semiótica y teoría literaria, nr. II. Sevilla, I997b.

- " - »Poetisk metafor som ikonicitet hos Charles Sanders Peirce«. In: Carsten

Hansen (red.): Metaforer $i$ kultur og samfund. Københavns Universitet, I997c.

- " - »Diálogo entre meninas. Arte y literatura como metáforas espaciotemporales en Velázquez y Buero Vallejo". Sociocriticism, nr. 22, I-2, Montpellier, 1998.

- " - »El texto visual. Una lectura de Cenicitas de Salvador Dalí«. Etudes Romanes, nr. 44, I999a.

- " - "Sol Electrocutado. Rafael Alberti y la pintura de la escuela de París «. Actas del XIII Congreso Internacional de La Asociación Internacional de Hispanistas, vol. IV, Madrid, Castalia, I999b.

- " - „En skælvende dråbe i fiskerens net. Den poetiske oplevelse mellem kærlighed, poesi og skrift i Pablo Nerudas Tyve Karlighedsdigte ". Anne Sejten og Erik Svendsen (red.): Detaljen. Tekstanalysen og dens graenser, bind I, Roskilde Universitetsforlag, I999c.

- " - »Semiotik «. In: Fibiger, Lütken og Mølgård (red.): Litteraturens tilgange, København, Gads Forlag, 200I. 
- " - »For en ny kulturfilologi I \& II «. To netartikler tilgængelige på http://www.staff.hum.ku.dk/lauha/IDENTITE/ Debatforum/ 200 I.

- " - (red.): Changing Philologies, København, Museum Tusculanums Forlag, 2002.

- " - »A Change of Paradigm in Language Studies «. In: Hansen (red.): Changing Philologies, 2002b.

- " - "Subjektskonstruktion og erfaringsbearbejdning som dialogisk process i litteratur «. In: Møller Andersen \& Lundquist: Smuthuller - perspektiver $i$ dansk Bakhtin-forskning. København, Politisk Revy, 2003.

- " - »Towards a New Philology of Culture«. In: Jensen (red.): The Object of Study in the Humanities, Museum Tusculanums Forlag, 2004.

- " - »Recuerdo e imaginación en Beltenebros de Antonio Muñoz Molina «. In: Cifuentes (red.): Sintomas en la prosa hispana contemporánea, Odense Universitetsforlag, 2004.

- " - »Globalization of the Semiosfere «. In: Ashley \& Finke (red.): Geolinguistics, New York. Under udgivelse.

- " - Disciplines and Interdisciplinarity in Foreign Language Studies. København, Museum Tusculanums Forlags Forlag, 2004.

- " - » La tradición española y la otra cara de la modernidad europea «. Actas del X Simposio Internacional de la Asociación Andaluza de Semiótica, Granada. Under udgivelse.

- " - »Etisk ansvar i den moderne spanske roman. Tilfældet Antonio Muñoz Molina «. In: Pia Schwartz Lausten \& Lisbeth Verstraete Hansen (red.): Engagement i litteratur, København, Museum Tusculanums Forlag, under udgivelse.

Hansen, Hans Lauge og Alzaga, Angel: »Nyd eksilet«. Interview med Antonio Muñoz Molina. Bøger, Weekendavisen 43, 24-30. oktober, 2003.

Hansen, Uffe. "Die Unvermeidliche Inkohärenz des Kunstwerks«. Text \& Kontekst, I98I.

Hastrup, Kirsten: Viljen til viden. København, Gyldendal, 1999.

Hauge, Hans: »Kanon og kapital «, Passage 30, I998.

Hausman, Carl R.: »Peirce's and the interaction view of metaphor «. In:

Colapietro \& Olshewsky (red.): Peirce Doctrine of Signs. Berlin \& New York, Mouton de Guyter, I996.

Helleland, Einar Phil: Metafiction. Engelsk Institut, Københavns Universitet, I999.

Henningsen, Bernd: »Das Ende des Humboldt-Kosmos. Die Kulturwissenschaften und die neue Oberflächenstruktur der Wissenschaft«. In: Henningsen \& Schröder (red.): Vom Ende der Humboldt-Kosmen. Baden-Baden, Nomos Verlagsgesellschaft, I997.

Hjelmslev, Louis: Omkring sprogteoriens grundloeggelse. København, Akademisk Forlag, I943.

Hoffmeyer, Jesper: »Semiotic Emergence ", Revue de la pensée d'aujourd'hui, vol. 25-7, No 6. Internetartikel, tilgængelig på Arisbe: http://members.door.net/arisbe/ar-main.htm 
- " - En snegl på vejen: Betydningens naturhistorie. København, Rosinante, I993.

- " - »The global Semiosphere«. In: Irmengard Rauch and Gerald F. Carr (red.): Semiotics Around the World. Proceedings of the Fifth Congress of the International Association for Semiotic Studies. Berkeley 1994. Berlin/ New York, Mouton de Gruyter, 1997.

Holquist, Michael: Dialogism. Bakhtin and his World. London, Routledge, I990. Holmgaard, Jørgen: Teoriens topik. Aalborg, Medusa, I997.

Hutcheon, Linda: Narcissistic Narrative - The Metafictional Paradox. Waterloo, Wilfrid Laurier University Press, I980.

- " - »Metafictional implications for novelistic reference«. In: Whiteside \& Issacharoffs (red.): On Referring in Literature, Bloominton, Indiana University Press, I987.

Høyrup, Jens: As Regards the Humanities. Prepints and reprints, nr. I. Roskilde Universitetscenter, I995.

Iser, Wolfgang: The Act of Reading. Baltimore \& London, Johns Hopkins University Press, I980.

Jakobson, Roman: »Et blik på semiotikkens udvikling «. Elementer, funktioner og strukturer i sproget. Nyt Nordisk Forlag, København, 1979. Oprindeligt I974.

- " - Selected Writings. New York, Mouton de Gruyter, I98I.

Jansen, Steen: »Tekst - læsning - virkelighed «. In: Jansen, Kjær, Olrik og Pedersen (red.): Tekst og Virkelighed. København, Akademisk Forlag, I982. Jappy, Anthony: »On the neglect of Peirce's views on metaphor in current theories of iconicity «. Peirce's Doctrine of Signs. Berlin \& New York, Mouton de Guyter, 1996.

Jauss, Hans Robert: » Litteraturhistorie som udfordring til litteraturvidenskaben «. In: Olsen \& Kelstrup (red.): Vaerk og lceser, København, Borgens Forlag, I98 I. Johansen, Jørgen Dines: Dialogic Semiosis: An Essay on Signs and Meaning. Bloomington, Indiana University Press, I 993.

- " - »Ikonicitet i litteratur «. Kultur og Klasse 78, nr. 2, I995.

- " - »Arguments about Icons «. In Colapietro \& Olshewsky (red.): Peirce's Doctrine of Signs. Berlin \& New York, Mouton de Gruyter, I996.

- " - "Analogy and Fable in Poetry and Fiction ", RS.SI. Recherches Semiotic. Semiotic Inquiry, vol I 7, nr I, 2,3. Canadian Semiotic Association, I997. - " - »Lighedens figurationer «. In: Per Krogh Hansen \& Jørgen Holmgaard (red.): Billedsprog, Aalborg, Medusa, I997b.

- " - "A Semiotic Mapping of the Study of Literature", Sign Systems Studies, vol 26, Tartu, I998.

- " - Literary Discourse. A Semiotic-Pragmatic Approach to Literature. Toronto \& London, University of Toronto Press, 2002.

Johansen, J.D. \& Larsen, S.E. Tegn i brug. Amanda, I 994.

Johansen, Svend: »La notion de signe dans la glossématique et dans l'estetique «.

Travaux du Cercle Linguistique de Copenhague, vol 5. I949. 
Johnson, Richard: "What is Cultural Studies Anyway «(I983). Munns \& Rajan (red.): A Cultural Studies Reader, London \& New York, I995.

Jordheim, Helge: Lesningens vitenskap - Uttkast til en ny filologi. Universitetsforlaget, Oslo, 200I.

Jørgensen, Keld Gall: Semiotik, En introduktion. København, Gyldendal, I994.

Kazamias, Andreas: »Globalization and educational cultures in late modernity: the Agamemnon syndrome". Cairns, Lawton and Gardner (ed.s): Values Culture and Education. World Yearbook of Education 200I. London, Kogan Page, 200I.

Kjørup, Søren: Menneskevidenskaberne. Problemer og traditioner i humanioras videnskabsteori. Roskilde Universitetsforlag, I996.

Kyndrup, Morten: »Kunstværk, dom, subjektivitet «. Passepartout 22, 2003.

Køppe, Simo: »Virkeligheden er narrativ «. Kritik I3 I, I998.

Lakoff, George \& Johnson, Mark: More than Cool Reason: a field guide to poetic metaphor. Chicago, University of Chicago Press, I989.

Larsen, Gorm: »Lille metafiktionsstudie. Om udsigelse og subjekt i metafiktion «. In: Gemzøe, Knudsen \& Larsen (red.): Metafiktion - selvrefleksionens retorik, 2001.

Larsen, Svend Erik: »The Rational and the Impossible. A Pound of Flesh «. In: Bessière \& André (red.): Multiculturalisme et Identité en Littérature et en Art, 2002.

Lauridsen, Karen, M.: Sprogpolitik på de danske universiteter. Internetartikel på adressen:

http://www.rks.dk/sider/internationalt/Sprogpol.pdf

Lotman, Juri M.: »Der Begriff Text «. Die Struktur Literarischer Texte, München, I972.

- " - »Tre texter om konstens semiotik «, Asplin \& Lundberg (red.): Tecken och tydning.

Stockholm, I976.

- " - »Über die Semiosfäre«. Zeitschrift für semiotik, I 2/4, I990a.

- " - Universe of the Mind. Bloominton \& Indianapolis, Indiana University Press, I990b.

Loyola, Hernán: Ser y morir en Pablo Neruda. Santiago, Editora Santiago, I 967. - " - »Neruda I924-26: las manos de la noche «. Atenea 470, Universidad de Concepción, Chile, I994.

Marty, Robert: "76 definitions of the Sign by C.S. Peirce «. Internetartikel på Arisbe: http://members.door.net/arisbe/menu/library/rsources/rsources.htm

Merleau-Ponty, Maurice: »Synligt-usynligt «, Tegn, Udvalgte Essays. København, Rhodos, I969.

- " - »Kunstneren og filosoffen«. In: Jørgen Dehs (red.): Æstetiske teorier, Odense Universtetsforlag, I984.

Miall, David S.: »Anticipation and feeling in literary response«. Poetics nr. 23, I995. Også tilgængelig i netversion på:

http://www.ualberta.ca/ dmiall/reading/NEUROLIT.htm

Morris, Charles. Foundations of the Theory of Signs. Chicago \& London, I 938. 
Muñoz Molina, Antonio: Beltenebros. Madrid, I989. Dansk oversættelse: Mørkets herre. Husets Forlag, I992.

- " - Nada del otro mundo. Madrid, Espasa-Calpe, I993.

- " - La apariencias. Marid, Alfaguara, I995.

- " - Sefarad. Madrid, Alfaguara, 200I. Dansk oversættelse, København, Gyldendal, 2003.

Navajas, Gozalo: »El Übermensch caído en Antonio Muñoz Molina: La paradoja de la verdad reconstituida «. Revista de estudios hispánicos nr. 28, I994.

- " - Más allá de la posmodernisdad. Estética de la nueva novela y cine españoles. Barcelona, EUB I996.

- " - La narrativa española en la era global. Barcelona, EUB, 2002.

Nebrija, Antonio de: »Prólogo a la Gramática de la lengua Castellana «. I 492.

In: Abellán (red.): Los españoles vistos por si mismos. I986.

Neruda, Pablo: Obras Completas. Bd I. Buenos Aires, Losada, I957/I 967.

- " - Tyve kcerlighedsdigte og en fortvivlet sang. Oversættelse ved Gunnar

Engberg Hansen, Brøndum, I984.

Nichols, Stephen: »Philology in a Manuscript Culture «. Speculum nr. 65, I, I990.

Nielsen, Henrik Kaare: Kritisk Teori og Samtidsanalyse. Århus Universitetsforlag, 2001 .

Nøjgaard, Morten. Det littercere voerk. Odense Universitetsforlag, I995.

Ortega y Gasset, José: La deshumanización del arte. Madrid, Espasa-Calpe, I 987. Palumbo-Liu, David: »Introduction. Unhabituated Habituses «. In: Palumbo-Liu \& Gumbrecht (red.): Streams of Cultural Capital. Transnational Cultural Studies, Stanford University Press, I997.

Pape Møller, Anders: »Female swallow preference for symmetrical male sexual ornaments «. Nature nr. 357, Maj I992.

Peirce, Charles S. Collected Papers. Harvard I93 I-I958. På CD-Rom, Folio Bound Views, I994.

- " - »Prolegomena for an Apology to Pragmaticism«. In: Carolyn Eisele (red.): The New Elements of Mathematics, The Hague, I976.

- " - Semiotic and Significs: the correspondence between Charles S. Peirce and Lady Welby. Bloominton \& London, Indiana University Press, I977.

- " - Mursten og mørtel til en metafysik. Peder Voetmann Christiansen (red). Roskilde, I988.

- " - The Essential Peirce, vol I og II, Bloomington, Indiana University Press, I992 og I998.

- " - Semiotik og pragmatisme. København, Gyldendal, I994.

Perriam, Christopher: »Metaphorican machismo: Neruda’s Love Poetry «. Forum for Modern Language Studies, nr. 24, I. University of St. Andrews, Scottish Academic Press, I988.

Peuter, Jennifer de: »The dialogics of Narrative Identity «. In: Bell \& Gardiner (red): Bakhtin and the Human Sciences, London, Sage I998.

Ponzio, Augusto: Man as a Sign. Berlin \& New York, Mouton de Gruyter, I990.

- " - El juego del comunicar. Entre literatura y filosofía. Valencia, Eutopías, I995. 
- " - La revolución bajtiniana. Frónesis / Cátedra, Universidad de Valencia, I998.

Pozuelo Yvancos, José María: »Realidad, ficción y semiótica de la cultura «. In:

Romera Castillo, Guitiérrez Carbajo y García-Page (red.): La novela histórica a finales del Siglo XX. Madrid, Visor Libros, I996.

Prince, Gerald: »Metanarrative signs«. In: Gemzøe m.fl. (red.): Metafiktion selvrefleksionens retorik, $200 \mathrm{I}$.

Rafnsøe, Sverre: Filosofisk cestetik. Jagten på den svigefulde sandhed fra Baumgarten og Kant til Heidegger og Adorno. København, Museum Tusculanums Forlag, 1996.

Ramachandran, V.S. \& Hirstein, W.: » The Science of Art. A Neurological Theory of Aesthetic Experience". Journal of Consciousness Studies nr. 6, 6-7, I999. Rendtorff, Jacob Dahl: »Det sårede cogito - Paul Ricœurs Subjektshermeneutik «. Fortcelling og fortolkning - videnskabsteoretisk set. Danmarks Universitetsforlag, 1998.

Rich, Lawrence: »Antonio Muñoz Molina’s Beatus Ille and Beltenebros: Conventions of Reading in the Postmodern Anti-detective Novel «. Romance Language Annual nr. 6. West Lafayette, I994.

- " - The Narrative of Antonio Muñoz Molina. New York, Peter Lang, I999.

Ricœur, Paul: »Metaphor and the Main Problem of Hermeneutics ", New Literary History nr.6, I974.

- " - The Rule of Metaphor. Toronto University Press, I977.

- " - Hermeneutics and the Human Sciences. Cambridge University Press, I98I.

- " - Time and Narrative. Bind I-III. Chicago \& London, University of Chicago Press, 1984-88.

- " - Oneself as another. Chicago \& London, University of Chicago Press, I992.

Riley, Edward C.: Don Quijote, London, Allen and Unwin, 1986.

- " - »Cervantes: teoría literaria «. In: Cervantes Don Quijote de la Mancha. Barcelona, Crítica, 1998.

Rovira Soler, José Carlos: Para leer a Pablo Neruda. Madrid, Palas Atena, I991.

Royano Guitérrez, Lourdes: »Pierre Menard, autor del Quijote: La recepción de Borges «. Anthropos nr. I42-43, 1993.

Santander, Carlos: "Amor y temporalidad en Veinte poemas de amor y una canción desesperada «. Anales de la Universidad de Chile nr. 157-160, Santiago de Chile, I97I.

Schmidt, Rigmor Kappel: Bakbtin og Don Quijote. København, Gyldendal, 2003.

Scholes, Robert: Semiotics and Interpretation. New Haven, I982.

Sheriff, John K.: The Fate of Meaning. Charles Peirce, Structuralism and Literature, Princeton, I989.

Sestoft, Carsten: »Nogle historiske noter om kanon «. Passage nr. 30, I998.

Shotter, John \& Michael Billing: »A Bakhtinian Psychology: From out of the Heads of Individuals and into the Dialogues Between Them «. Bell \& Gardiner (red.): Bakbtin and the Human Sciences. London, Sage, 1998. 
Sicard, Alain: El pensamiento poético de Pablo Neruda, Madrid, Gredos, I98I. Silver, Philip: »La estética de Ortega y la generación de 1927“. Revista de Filología Hispánica nr. 20 bd. II, I97I.

Simonsen, Birgitte \& Ulriksen, Lars: Universitetsstudier i krise. Roskilde Universitetsforlag, I998.

Stjernfelt, Frederik. »The Diagrammatic Process of Interpretation as Generalized Deduction and Semiotic Epistemology «. Almen semiotik nr. I4, Aarhus, I998. Sørensen, Gert: »National Philology in a Globalised World «. In: Hansen (red.): Changing Philologies, 2002.

Talens, Genaro: El sujeto vacío. Madrid, Cátedra, 2000.

Tejera, Victorino. Literature, Criticism, and the Theory of Signs. Amsterdam \& Philadelphia, John Benjamins, I995.

Todorov, Tzvetan: Mikhail Bakbtin. The Dialogical Principle. Manchester University Press, I984.

- " - »The typology of detective fiction «. In: Lodge (red.): Modern Criticism and Theory, New York, 1995.

Vals, Fernando: La realidad inventada. Análisis crítico de la novela española actual. Barcelona, Crítica, 2003.

Vázquez Medel, Manuel Ángel: »Del escenario especial al emplazamiento«. Internetartikel fra 1997 på adressen: www.cica.es/aliens/gttcus/vazquezz.html - " - »Prolegómenos para una Teoría del Emplazamiento«. Discurso nr. I6/17. Sevilla, 2003 .

Vázquez Medel, Acosta Romero, Browne Satori \& Silva Echeto (red.): Teoría del Emplazamiento. Aplicaciones e implicaciones. Sevilla, Alfar, 2003.

Vázquez Montalbán, Manuel: El premio, Madrid, Planeta, I996.

Vice, Sue: Introducing Bakhtin. Manchester, Manchester University Press, I997. Volosjinov, V.N.: Marxism and the Philosophy of Language. London \& New York, Seminar Press, I973.

Waugh, Patricia: Metafiction. London \& New York. Routledge, I984.

Wiley, Norbert. The Semiotic Self. Oxford, Polity Press, I994.

Wilken, Lisanne: Enhed i Mangfoldighed? Aarhus Universitetsforlag, 200I.

Wolde, Ellen van: »Relating European structuralist semiotics to American Peircean semeiotic «. In: Colapietro \& Olshewsky (red.): Peirces's Doctrines of Signs, Berlin \& New York, 1996.

Zeki, Semir: »Art and the Brain«. Journal of Consciousness Studies nr. 6, 6-7, I999.

Ziolkowsky, Jan (red.): On Philology. University Park and London, the Pennsylvania State University Press, I990. 